\title{
O circuito das roupas A Corte, o consumo e a moda (Rio de Janeiro, 1840-1889)
}

\author{
Joana Monteleone
}

Tese apresentada ao Programa de PósGraduação em História Econômica do Departamento de História da Faculdade de Filosofia, Letras e Ciências Humanas da Universidade de São Paulo, para a obtenção do título de Doutor em Ciências.

Orientadora:

Profa. Dra. Vera Lúcia Amaral Ferlini 
Para Haroldo, Helena e Francisco 


\section{Agradecimentos}

$\mathrm{N}$

a realização dos muitos anos que durou essa pesquisa contei com a contribuição de várias pessoas. Em primeiro lugar, sou profundamente grata à professora Vera Ferlini, que acreditou no projeto, na pesquisa e na minha capacidade como historiadora desde o mestrado. Foi ao longo de conversas, almoços e livros que nossa amizade começou e, ao longo desses anos, se aprofundou.

Agradeço às professoras Heloísa Barbuy e Ana Lucia Duarte Lana as observações feitas na qualificação desse trabalho. No mestrado, ao estudar a cozinha e os alimentos importados, contei leituras críticas de Leila Algranti e Raquel Glezer. Ambas me deram pistas de que eu deveria continuar e aprofundar a pesquisa. Por esta razão, ao perceber que a principal mercadoria que chegava pelo porto do Rio eram tecidos escolhi estudar, no doutorado, o circuito das roupas na corte do século XIX.

Gostaria de agradecer aos meus amigos historiadores, Ana Paula Megiani, Lucília Siqueira, Maria Luíza Ferreira de Oliveira e Pedro Puntoni. Ao longo dos últimos anos, falamos de livros, sonhos, filhos, história e política. E foi sempre bom. Em conversas infinitas, fiquei mais confiante para tocar para frente projetos, fazer muitos livros e continuar a fazer pesquisas. A Eunice Ostrensky e Plínio Junqueira Smith, filósofos e amigos que moram no meu coração e que, partir de agora, possam me receber na mesa principal dos almoços e jantares deliciosos e inesquecíveis.

Ao Leopoldo Waizbort e à Tamara, amigos que emprestaram livros e discutiram muitas das ideias presentes neste trabalho. À Rosane Pavam, que me acompanha desde 
os tempos do Jornal da Tarde, com livros, sorvetes e longos almoços. À Liana Amaral, primeira leitora curiosa desse trabalho.

Às amigas e vizinhas da SPQ: Andrea e Edgar, Lígia e Fernando, Ana e João. Nas tarde de fim de semana, dividimos pipocas, filmes e mojitos. E foi uma delícia.

Aos amigos da CNV, Vitor Sion, Felipe Amorim e Rodolfo Machado e Lucas Figueredo. Nossa nova pesquisa deixou mais leve os últimos dias de doutorado. E à Mariana Berutto, que me acolheu em Belo Horizonte, e compartilha comiga muitos gostos em comum, além de um monte de crianças.

Ao pessoal da Entrelinhas, que está distante no dia a dia, mas perto no coração: Flávia Toscano, Mariana Carvalho, Roberto Cosso, Rita Camacho. Um beijo à Maria da Glória e aos pequenos Pedro e Gabriel. E também gostaria de mencionar duas amigas do dia a dia da redação, Marina Terra e Luka Franca, que durante longos almoços e reuniões, sempre mantiveram o bom humor.

Ao Ruy Braga e à Aline, que com pizzas nos domingos à noite, ouviram pacientemente sobre a lenta evolução desta tese e conversaram sobre política, livros e universidade.

A todos da Alameda, que me ajudaram a fazer a editora nas tarde em que eu precisava assistir aulas, fazer pesquisa ou escrever: Vitor Donofrio, João Paulo Putini, Leidiane Cavalcanti, Camila Pereira, Denis Leal, Tiago Tadeu, Ramana Medrado. Um beijo enorme e todo especial à Danuza Valim, que sem a ajuda inestimável teria sido impossível seguir em frente com a editora. E também à Patrícia, ao Bruno, à Natalia e à Manuela, colegas na Cátedra Jaime Cortesão.

Aos meus pais, Zélia Heringer de Moraes e Roque Monteleone, que sempre cuidaram de minha educação, me ensinaram a importância dos livros e da pesquisa e souberam ser interlocutores interessados sempre eu precisava. As palavras são poucas 
agradecer tanto amor. Aos meus avós, Domingos Aimone e Maria de Lourdes Monteleone, sempre queridos. À minha irmã Teresa, seu marido Beto e minha sobrinha Maria. Aos meus primos, Guri e Gorete, e à minha sobrinha e Katarina. Às minhas tias Zilma e Edna.

Um agradecimento ao José Sereza, meu sogro, que sempre esteve presente para brincar com a Helena e o Francisco. E à minha querida cunhada Cínthia e seu marido Diógenes, cumprades no melhor sentido da palavra, que várias vezes seguraram a onda de cinco crianças brincando por horas. Aos agora não tão pequenos Ana Beatriz, Vinícius e Laís, sobrinhos de sonho, pipoca e travessuras.

Gostaria ainda de agradecer a Helena, minha filha que, no meio da loucura que é uma mãe elaborar uma tese, cresceu e se tornou uma pessoa legal, delicada, gentil atenciosa, divertida e inteligente. Ainda temos muito para caminhar juntas. Ao Francisco, meu filho, que agora joga futebol, faz judô e circo e sempre defende o que é justo. E claro, às tarde que assistimos juntos à série de Star Wars e brincamos de soldadinho - dois hobbies compartilhados.

E finalmente ao Haroldo Ceravolo Sereza. Que me ajudou a terminar esse projeto e começou muitos outros. 
Resumo

Na hierarquia social da corte imperial brasileira de d. Pedro II (1841-1889), vestirse adequadamente revelava riqueza, poder e influência. Desta maneira, uma parcela da nobreza e também de fazendeiros e negociantes enriquecidos pelos negócios do café passou a gastar parte de suas fortunas com roupas e assessórios importados. Esta tese mapeia quais eram os principais tecidos que entravam no país pelo porto do Rio de Janeiro, de que maneira esses tecidos eram transformados em roupa e, finalmente, vendidos na rua do Ouvidor. Assim, ao estudar o consumo de roupas no Rio de Janeiro imperial, podemos perceber como se caracterizava o nascente capitalismo nacional, dentro das transformações globais ocorridas durante a Revolução Industrial. 


\begin{abstract}
In the social hierarchy of the Brazilian imperial court of d. Pedro II (1841-1889), dress codes would reveal wealth, power and influence. Thus, a part of the local nobility, and farmers and merchants enriched by coffee trade, began to spend part of their fortunes buying imported clothes and other fashion goods. This study maps which were the main fabrics entering the country through the port of Rio de Janeiro, how these fabrics were made into cloths and ultimately sold on the streets of the rua do Ouvidor. Therefore, it shows how the consumption of clothes in imperial Rio de Janeiro could characterize the national nascent capitalism and its relation with the global transformations promoted by the Industrial Revolution.
\end{abstract}

\title{
Résumé
}

Dans la hiérarchie sociale de la cour brésilienne, sous l'Empire de Don Pedro II (1841-1889), les vêtements révèlent la richesse, le pouvoir et l'influence des courtisans. Ainsi, les gens de la noblesse, les grands propriétaires agricoles et les commerçants enrichis du café ont commencé à consacrer une partie de leur fortune à l'achat de vêtements importés. Cette thèse a pour objectif de mettre en lumière l'arrivage des principaux tissus qui entraient dans le pays par le port de Rio de Janeiro et les processus de transformation des étoffes en vêtements, avant leur vente dans la Rua do Ouvidor, dans le centre de la capitale brésilienne. L'étude de l'usage de vêtements à Rio de Janeiro permet ainsi de bien comprendre ce moment de naissance du capitalisme national, et les transformations globales liées a la Révolution Industrielle.

PALAVRAS-CHAVE:

Brasil Imperial - moda - consumo - economia - Rio de Janeiro - Corte 


\section{Sumário}

Introdução 10

I. O Rio de Janeiro abre o leque do consumo 20

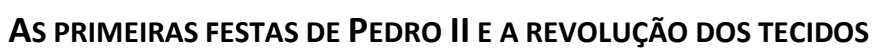

A MODA, O COMÉRCIO E UM NOVO SÉCULO TRANSFORMAM A VIDA CARIOCA

OS TECIDOS IMPORTADOS FAZEM AS ROUPAS NA CORTE

II. Dos tecidos às roupas 67

COSTUREIRAS E LAVADEIRAS: O CUIDADO COM AS ROUPAS E O PROBLEMA DO TRABALHO FEMININO LIGADO À FEITURA DAS ROUPAS

A HISTÓRIA DAS MÁQUINAS DE COSTURA NO RIO DE JANEIRO: UM ANÚNCIO BRASILEIRO VENDE UMA

MÁQUINA DE COSTURA AMERICANA

A HISTÓRIA DA MÁQUINA DE COSTURA FORA DA AQUI

III. As mulheres no espelho: silhueta feminina e consumo no século XIX

VESTIDOS DE TODAS AS CORES PARA TODAS AS OCASIÕES

CALÇAS PARA MULHERES: GÊNERO E SOCIEDADE NO SÉCULO XIX

IV. Os homens no espelho: novas roupas para dândis barões e militares 196

POR TODO O SÉCULO, DÂNDIS EM PRETO

OS BARÕES, A POLÍTICA E AS CASACAS 
V. Viver e mostrar-se em sociedade: o comércio, os acessórios de moda e as festas na corte

OS ENCANTOS DO CONSUMO NUMA NOVA CIDADE

UMA RUA VOLTADA PARA O COMÉRCIO DE LUXO

“LuVAS de PelicA, CAMURÇA E CASTOR. TeMOS PARES PARA tOdos OS GOSTOS E DE TODOS OS PREÇOS" 290

Consideracões finais 315

Fontes, livros de memória, relatos de viagem e romances 318

Referências bibliográficas 324

Pequeno dicionário histórico de tecidos 333 


\section{Introdução}

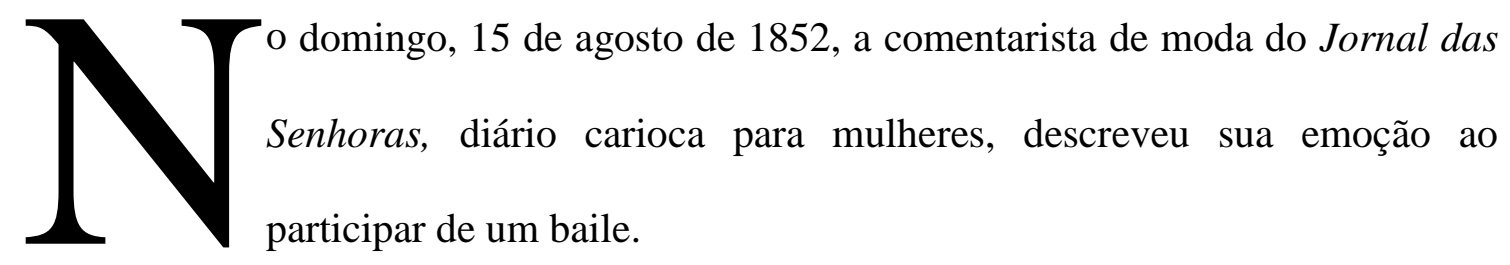

Um baile! Um baile de primeira ordem é muito interessante para nós. $\mathrm{Eu}$, pelo menos, fanática como sou por tudo quanto é divertir-me, não o circunscrevo à noite somente da função: divido-o em ter partes cheias de novidades e prazer. A primeira, é quando escolho as fazendas, tomo as medidas, compro os enfeites, os adereços e as joias. Que esperanças! A segunda, depois que todos esses objetos chegamme da casa da modista no dia aprazado e espargem-se por sobre o meu toucador e sobre o meu divã, para daí a instantes principiar a fazer meu toilette. Que alegria! A terceira é quando recebo os cortejos, os convites para as quadrilhas, esse feixe de palavrinhas galvanizadas de ouro e prata, tão bonitas que me faz pena ficarem ferro tão depressa! Valsar, valsar muito e conversar muito. Que saudosa retirada! ${ }^{1}$

Mas um baile no império brasileiro de d. Pedro II significava mais que emoções do dançar da valsa e suspiros de moças casadoiras. Num baile, ganhava-se um ministério, costurava-se uma aliança, pagavam-se favores e arrumavam-se casamentos. Numa reunião social, comprovava-se possuir capital econômico e simbólico para participar do poder político e econômico do império. Para além das roupas e da moda, estavam em jogo política e economia. Da mesma forma, nos passeios pela rua do

${ }^{1}$ Jornal das Senhoras, 15 de agosto de 1852 . O jornal encontra-se digitalizado, em $p d f$, no site da Biblioteca Nacional, <http://www.bn.br>. Consulta em 21/09/2013. 
Ouvidor, sabia-se da última moda de Paris, mas também os nomes do próximo ministério de d. Pedro II.

Dentro dos padrões da etiqueta real, as festas da corte evidenciavam as diferenças de nível, as distinções, permitiam provas de favorecimento ou desagrado. Como apontou Norbert Elias, a etiqueta tinha uma função simbólica de grande importância na estrutura dessa sociedade e dessa forma de governo. ${ }^{2}$ O império de d. Pedro II, longe de ser a corte de Luis XIV, no entanto, viu o Brasil assumir novos papeis na divisão internacional da produção de riquezas. No rodar das saias dos bailes, os valores imperiais se misturavam a novos conceitos próprios da lógica capitalista, como os de consumo e de acumulação. Nessa corte tropical, mesmo os elementos simbólicos podiam ser medidos em moeda e patrimônio. Nela, o dinheiro dava "prestígio e poder, glória e grandeza". 3

Qual o peso dessa sociedade de corte? Segundo o censo de 1872, viviam no Rio de Janeiro 226.033 pessoas livres. Ao longo de todo o império foram distribuídos cerca de 1.200 títulos de nobreza, sendo que uma mesma pessoa podia ganhar dois ou mais títulos ao longo da vida. Se contarmos as profissões ligadas à administração da corte, os negociantes sem título, alguns profissionais liberais e uns poucos herdeiros sem títulos, podemos dizer que a elite na corte não passava de $1 \%$ a $2 \%$ da população. Essa pequena parte da população carioca representava o que seria a "boa sociedade" da cidade, segundo o Jornal das Modas ${ }^{4}$. Do ponto de vista econômico, essa era a parcela que comprava as mercadorias que desciam dos navios do porto e eram revendidas na rua do Ouvidor. Os vestidos feitos de sedas importadas, os chapéus vindos da Alemanha, os sapatos e bengalas ingleses simbolizavam riqueza e poder aquisitivo da elite imperial.

\footnotetext{
${ }^{2}$ Norbert Elias. A sociedade de corte. Trad. port. Rio de Janeiro: Jorge Zahar, 2001, p. 102.

${ }^{3}$ Raymundo Faoro. Machado de Assis: a pirâmide e o trapézio. São Paulo: Globo, 2001, p. 268.

${ }^{4}$ Jornal das Modas, 13 de julho de 1854.
} 
O vestuário, elemento fundamental de distinção dessa sociedade, estimulava na capital do país novos ramos de negócios. Capitais e técnicas industriais estavam por trás de intensa circulação de novos bens de consumo. Para essa elite, as roupas, além de luxuosas, deveriam estar de acordo com os novos padrões de modernidade europeus. Dessa forma, a moda no século XIX surgiu como objeto privilegiado para a pesquisa. A moda, na sociedade burguesa recém formada, expunha novas hierarquias sociais, antecipando vontades e tendências culturais, trazendo valores e estilos que dialogavam com os velhos padrões do Antigo Regime, mas que, a pouco e pouco, impunham nova estética e novas etiquetas. ${ }^{5} \mathrm{O}$ movimento ocorrido no Brasil seguiu um padrão mundial: ao longo do século XIX, vestir-se adequadamente adquiriu cada vez mais importância social. Como em todas as cortes da Europa, a moda distinguiria as famílias mais ricas, mostraria quem estava mais perto do poder ou quem teria mais dinheiro. ${ }^{6}$

Com a chegada da família real portuguesa no Brasil e a abertura dos portos, em 1808, as importações de tecidos ingleses aumentaram, enquanto os tecidos de Portugal e da Índia perdiam mercado. ${ }^{7}$ As roupas se modificaram com o tempo, tanto ao sabor dos gostos como em decorrência da abundância dos novos tecidos que eram comercializados a partir do porto do Rio de Janeiro ${ }^{8}$.

$\mathrm{Na}$ dianteira das mercadorias que inundaram o mundo após a Revolução Industrial, estavam os tecidos. Os carregamentos do produto espalhavam-se pelo mundo, juntando países distantes num comércio intenso. Lãs inglesas saíam de

\footnotetext{
5 "Na sociedade democrática do século XIX, quando os desejos de prestígios se avolumam e crescem as necessidades de distinção e liderança, a moda encontrará recursos infinitos de torná-los visíveis." Gilda de Mello e Souza. O espírito das roupas. São Paulo: Companhia das Letras, 1987, p. 25.

${ }^{6}$ Cf. Thorstein Veblen. Teoria da classe ociosa. Trad. port. São Paulo: Abril Cultural, 1993.

${ }^{7}$ José Jobson de A. Arruda. O Brasil no comércio colonial. São Paulo: Ática, 1980, p. 190.

${ }^{8}$ Ver as tabelas no Anexo do livro de Richard Graham, Grã-Bretanha e o início da modernização no Brasil (1850-1914). Trad. port. São Paulo: Brasiliense, 1973, p. 344-345.
} 
Liverpool para o Rio de Janeiro, Boston ou Lisboa; ${ }^{9}$ sedas francesas chegavam às costureiras cubanas, nova-iorquinas e cariocas, chapéus belgas eram vendidos na Venezuela e Argentina. A intensificação das relações comerciais com a Europa e com os Estados Unidos foi uma constante ao longo de todo o oitocentos e contribuiu decisivamente para espalhar modas, ideias e mercadorias.

Num império tropical como o brasileiro essas mercadorias simbolizavam para muitos a chegada de modernidade ao país. Novos ventos que modificavam antigas maneiras de viver, com a permanência do trabalho escravo. O mundo das costuras era repleto de escravas, mucamas que ajudavam as senhoras a se trocarem e a cuidarem das roupas. Ter habilidade como costureira era tão desejável quanto ser uma excelente cozinheira - e os jornais estavam repletos de anúncios procurando escravas costureiras. Baronesas e mucamas que faziam parte do mesmo mundo, no qual a escravidão integrava-se às novidades do capitalismo.

Tem-se como razoável situar a explosão da produção inglesa de tecidos entre as décadas de 1790 e $1820 .{ }^{10}$ Mas apenas após a década de 1830 ficou claro, em testemunhos literários, jornalísticos ou artísticos - como, por exemplo, na Comédia Humana de Balzac -, que a sociedade havia passado e ainda estava no meio de uma transformação sem precedentes, na qual o dinheiro e a produção de mercadorias atingiriam um novo patamar. Assim, muitas vezes por meio do estudo do vestuário, ou das tendências das roupas, foi possível analisar as relações e mudanças econômicas do período.

\footnotetext{
${ }^{9}$ Richard Graham. Grã-Bretanha e o início da modernização no Brasil. Op. cit., p. 13.

10 'O que significa a frase 'a Revolução Industrial explodiu'? Significa que a certa altura da década de 1780, e pela primeira vez na história da humanidade, foram retirados os grilhões do poder produtivo das sociedades humanas, que daí por diante se tornaram capazes da multiplicação rápida, constante, e até o presente ilimitada, de homens, mercadorias e serviços. Este fato é hoje tecnicamente conhecido pelos economistas como a "partida para o conhecimento autossustentável'”. Eric Hobsbawm. A era das revoluções. 1789-1848. Trad. port. São Paulo: Paz e Terra, 1996, p. 44.
} 
No Segundo Reinado, as modistas da cidade escolhiam figurinos, modelos, retratos, óleos importados, jornais e revistas de Paris, que ajudariam as brasileiras a definirem a roupa mais adequada para os salões da corte de D. Pedro II. Após os bailes ou as reuniões, as roupas das damas eram comentadas e discutidas por jornalistas no Jornal das Senhoras ou na Gazeta de Notícias. O que estava em jogo, por trás dos comentários aparentemente inócuos e bastante descritivos, eram os sinais de prestígio político e indicação de boa fortuna.

No Brasil, a partir de meados do século XIX, a corte podia gastar suas fortunas tivessem sido elas conquistadas a partir da produção ou negociação de café no mercado internacional, ou no tráfico legal ou ilegal de escravos - em artigos de luxo importados da Europa. O país tornou-se importante mercado consumidor para os produtos de luxo produzidos no Velho Continente. Segundo dados do Annual statement of the trade of the United Kingdom with foreign countries and British possessions (Londres, 18531909) ${ }^{11}$, cerca de $68 \%$ das exportações do Reino Unido para o Brasil, entre os anos de 1850 e 1869, eram de algodão, lã, linho e sedas e, em menor escala, outros tecidos. Se juntarmos esses dados às exportações de vestimentas prontas, chega-se à conclusão de que mais de $70 \%$ do que a os britânicos exportavam ao Brasil estava relacionado ao mundo das roupas.

O Rio de Janeiro foi o local escolhido para o estudo dessas relações econômicas e sociais, provocadas pela moda no século XIX. A capital do Império, ao longo do período, transformou-se na cidade mais cosmopolita do país, para onde afluiriam mercadorias, viajantes e novas ideias. Os costumes coloniais modificaram-se lenta, mas cotidianamente. Pelo porto carioca, chegaram carregamentos de tafetás, sedas, musselines, rendas holandesas, gorgurão, flanelas, lãs, botões de madrepérolas, guarda-

\footnotetext{
${ }^{11}$ Ver as tabelas no Anexo do livro de Richard Graham, Grã-Bretanha e o início da modernização no Brasil (1850-1914). Op. cit., p. 344-345.
} 
chuvas, leques, luvas e muitos outros artigos do vestuário feminino e masculino: mercadorias que abasteciam lojas e ateliês de costura, revendidos às costureiras e alfaiates da cidade, que faziam os vestidos, fraques, chapéus ou sapatos consumidos pela sociedade carioca.

Para a elaboração da tese, foi utilizada documentação variada. A primeira série documental que me chamou atenção foram as tabelas da Estatística do comércio marítimo do Brasil do exercício de 1871-1872. A partir delas, foi possível recuperar as mercadorias que eram vendidas tanto no Rio como no resto do império. Os dados indicam os preços dos bens e suas quantidades, bem como os principais países exportadores.

As tabelas deram as primeiras pistas sobre o volume dos tecidos que chegavam à cidade e sua importância para o comércio mundial. A partir de sua análise, percebi que muito do conhecimento sobre a nomenclatura e a utilização os tecidos antigos havia se perdido. Elaborei, para isso, um "Pequeno dicionário histórico de tecidos antigo", reproduzido como anexo. Nesse dicionário, elenquei também tecidos do século XX, pensando em sua utilização para além desse trabalho.

Se as tabelas de importação foram o ponto de partido da tese, para se recuperar o caráter simbólico das roupas usadas diariamente foram utilizados outros tipos de fontes: artigos de jornal, propagandas no Almanaque Laemmert, romances e relatos de viagem. A iconografia teve importância vital para a pesquisa. Teria sido impossível falar de moda na corte sem mostrar quem eram as mulheres vestidas com os tecidos que chegavam ao Rio ou quem foram os homens que se vestiam de casaca preta nas reuniões sociais. Procurei principalmente por imagens de mulheres e homens brasileiros em museus e acervos particulares e públicos do país. Essas imagens nos contam como a corte gostava de se ver retratada, em pinturas ou fotos que os mostravam iguais, ou pelo 
menos bem parecidos, a seus pares europeus. Muitos dos retratistas faziam também trabalhos para casas de nobre da Europa.

Ao elaborar a pesquisa iconográfica, fiz questão de mostrar telas a óleo, mais do que fotografias. A questão se colocou a partir de uma apresentação de parte da pesquisa num congresso da Anpuh, em que um colega historiador questionou-me do por que de as roupas do século XIX serem "apenas pretas e brancas". Ora, ele pensava em fotografias, imagens que ficam em nosso inconsciente quando pensamos em uma época "antiga". As roupas não eram pretas e brancas. Pelo contrário. Os quadros (e as descrições dos romances) mostram a variedade de cores usadas cotidianamente. Percebi, e quis mostrar com a pesquisa de imagens, que essas cores não eram aleatórias ou fruto de gosto pessoal: tinham simbolismo específico e representavam também a aplicação na indústria têxtil das descobertas químicas de pigmentos sintéticos. Os retratos mostrados nesta pesquisa são fundamentais para a análise, da mesma forma que as tabelas.

Algumas histórias ligadas à evolução das técnicas de produção no século XIX também tiveram de ser recuperadas, como foi o caso da máquina de costura, para a devida compreensão do circuito econômico que ligava a produção de tecido ao baile imperial. São poucos os livros que dão contam das mudanças nas maneiras de se fazer roupas no período, portanto foi difícil encontrar documentos e histórias que relatassem e recuperassem essas transformações. Como a máquina de costura foi desenvolvida nos Estados Unidos, contar essa história ajudou-me a descobrir a importância dos pequenos ateliês de moda no Rio. O século XIX foi um período cheio de inovações tecnológicas e científicas e fiz questões que essas inovações também transparecessem nesta pesquisa sobre moda.

Quando necessário, sempre busquei fazer comparações com o que estava ocorrendo fora do país, na Europa ou nos Estados Unidos. Da mesma maneira que 
chegavam tecidos pelo porto do Rio, vindos da Inglaterra ou da França, quis enfatizar que novas ideias e novos comportamentos também estavam em intensa circulação. $\mathrm{O}$ que ocorria em exposições universais em Paris, Berlim ou Viena tinha eco nas vitrines da rua do Ouvidor, e um escritor como Joaquim Manuel da Macedo sabia descrever o que era ser um flâneur no Rio de Janeiro. Mercadorias, ideias e viajantes - estrangeiros que chegavam aqui ou brasileiros que iam para foram - mudaram a maneira de se comportar ou até mesmo de comprar.

O marco inicial desse trabalho é a maioridade de D. Pedro II, em 1840, com destaque para sua coroação, em 1841. As festas duraram alguns dias e encerraram-se em 24 de julho, com um grande baile no paço. D. Pedro apareceu com suas roupas majestáticas, imbuídas de significado político. Pelas próximas quase cinco décadas, d. Pedro II seria imperador do Brasil, dando o tom austero para corte, já que era avesso a festas e cerimônias. Ainda assim, a corte viveu como a capital do império brasileiro e as festas e cerimônias tinham lugar em outras casas para além do paço. Vestir-se bem e adequadamente acabou por se tornar um requisito fundamental para que se soubesse circular com desenvoltura pela complicada política de corte. Mas o vestir-se também pressupunha o conhecimento de um novo código de conduta que estava se estabelecendo, o da moda, ou melhor, o de "estar na moda". Durante as festas, estar “decentemente" vestido era requisito para visitar o salão do banquete e a varanda onde d. Pedro II havia acenado para o público.

Entre a coroação de d. Pedro II, em 1841, e o Baile da Ilha Fiscal, em 9 de novembro de 1889, poucos dias antes da proclamação de República, passaram-se quase cinquenta anos, em que o Rio de Janeiro modificou-se profundamente e a sociedade da corte se estabeleceu, assim como o Estado brasileiro se estruturou. O café, as estradas, a 
moda, os impostos, os jornais e os escritores, o sorvete, os hotéis e primeiros paquetes inicialmente novidades, tornaram-se fatos corriqueiros, do cotidiano.

No primeiro capítulo, intitulado "Um mundo de tecidos", apresenta-se o quadro geral das importações de tecido no Rio de Janeiro - das guerras comerciais da Inglaterra na Índia à sua repercussão no Brasil. Enfoca-se o surgimento da moda na sociedade industrial, de suas primeiras acepções em português à ideia corrente de consumo e de moda, com o surgimento de jornais dedicados às mulheres e às roupas. Também são analisados quadros estatísticos de meados do oitocentos que trazem a quantidade e variedade de tecidos que desembarcavam nos portos cariocas.

O segundo capítulo, "Dos tecidos às roupas", trata de como os tecidos que chegaram ao país se transformaram em roupas. Dessa forma, procurou-se mostrar como se dava o cuidado diário com a roupa; como se faziam, remendavam e lavavam as roupas em casa. A "revolução das máquinas de costura" mostra a importância do equipamento para a confecção e mudanças em estilos e roupas ao longo do século. Afinal foi a máquina de costura que possibilitou que a moda mudasse com mais constância. Nesse capítulo, foi analisado de que maneira o trabalho com a moda e com as roupas transformaram o papel da mulher na sociedade no século.

Trabalhando com romances brasileiros e estrangeiros do século XIX, vemos como aparecem no Brasil as figuras das senhoras de crinolina e do "dândi”. Dois capítulos mostrarão o significado social de vestir-se na moda, viver na corte e exibir-se nos salões no Império: o capítulo três, "As mulheres no espelho: silhueta feminina e consumo no século XIX", e "Os homens no espelho: novas roupas para dândis, barões e militares", capítulo quarto.

Finalmente, no último capítulo, "Viver e mostrar-se em sociedade: o comércio, os acessórios de moda e das festas na corte", a ênfase recai sobre os lugares onde se 
podiam comprar roupas e acessórios de moda. A rua, no século XIX, tornou-se vitrine da crescente produção de bens de consumo ligados ao vestuário. No Rio de Janeiro, em especial, a rua do Ouvidor faz o papel de centro elegante da cidade, com lojas de produtos importados, arrumados em vitrines cuidadosamente pensadas. Essa nova "arrumação" urbana estimulava e era estimulada por uma nova atitude da sociedade: as mulheres passaram a sair de casa tanto para usufruir da cidade, em confeitarias e sorveterias e restaurantes, como para fazer compras. No século XIX, uma série de inovações tecnológicas garantiu a produção em massa de itens antes utilizados apenas por poucas pessoas. Luvas, chapéus, lenços, relógios, sapatos, guarda-chuvas, bengalas, bolsinhas faziam parte do guarda-roupa antes do século XIX.

Busquei, ao longo desse trabalho demonstrar como esses dois processos interligaram-se, o capitalismo ascendente criando novos produtos e circuitos econômicos e a sociedade de corte brasileira alimentando, com a busca de signos de nobreza e tradição, o comércio internacional. O luxo e o dinheiro supriam a falta de tradição e história de comendadores, barões, viscondes, condes e duques. Essa nobreza, fruto da riqueza do café, não se pautava pelos ideais de honra e cavalaria, mas pelos novos símbolos burgueses de prestígio, essencialmente a riqueza material, expressa visualmente no vestuário. Por meio de um vestido, de uma cauda maior ou menor, de um babado mais ou menos marcado, de uma cor bem escolhida, de um colar ou de uma pulseira, podia-se, ao primeiro olhar treinado nas artes da corte, supor se uma mulher era filha de um nobre carioca, acostumada aos salões, ou uma fazendeira paulista tímida diante do ritmo frenético da rua do Ouvidor. A vestimenta foi, assim, fator de dinamização e modernização econômica na capital e, ao mesmo tempo, arma poderosa para as distinções sociais. 


\section{CAPÍTULO I. \\ O Rio de Janeiro \\ abre o leque do consumo}

Assim, não é, pois, mais indiferente desprezar ou adotar as fugidias prescrições da moda, pois mens agitat molem: o espírito de um homem advinha-se pela maneira como porta sua bengala. [...] Como a roupa é o mais enérgico de todos os símbolos, a Revolução foi também uma questão de moda, um debate entre seda e lã.

Honoré de Balzac ${ }^{1}$

\section{As primeiras festas de Pedro II e a revolução dos tecidos}

s 11 horas da manhã do dia 18 de julho de 1841 , D. Pedro II, com então 15
anos, seguiu para Capela Imperial no Rio de Janeiro para ser coroado
imperador do Brasil. A cerimônia durou o dia inteiro com seu rituais de sagração carregados de pompa e ostentação e a presença maciça da corte ornamentada com os mais ricos trajes jamais vistos num país tropical. Da coroação seguiu-se para o banquete oficial da cerimônia, marcado para seis da tarde, acompanhado por duas "ricas bandas de música" ${ }^{2}$. Às oito horas da noite, findo o serviço de mesa para 96 talheres, foi aberta a varanda e o paço imperial para quem estivesse decentemente vestido.

\footnotetext{
${ }^{1}$ Honoré de Balzac. "Tratado da vida elegante". In: Manual do dândi, a vida com estilo. Tomaz Tadeu (org). Trad. port. Belo Horizonte: Autêntica, 2009, p. 47.

${ }^{2}$ Jornal do Commercio, 20 de julho de 1841, p. 1 e 2.
} 
Dizem que mais de 12 mil pessoas passaram pelo paço neste dia e foram necessários mais alguns dias para dar conta de tamanha visitação. Estavam programadas também outras atividades: um dia para receber as felicitações; a noite das iluminações; a visita ao Teatro de São Pedro de Alcantara, o baile da coroação. ${ }^{3}$ D. Pedro era jovem, ainda que tímido, e nas décadas seguintes a corte viu renascer na cidade uma profusão de bailes, festas e folguedos.

D. Pedro II estava vestido para se tornar imperador. Um imperador tropical, diferente de seus pares europeus, mas ainda um imperador. A cerimônia de coroação foi pensada para destacar o poder real de um império que, ainda jovem, estava se consolidando. $\mathrm{O}$ imperador vestia uma roupa especialmente pensada para se destacar: o manto verde, com ramos de cacau e tabaco, a murça feita com penas de galo-da-serra ${ }^{4}, o$ cetro de dois metros e meio de altura, com o símbolo dos Bragança, a coroa de ouro. A corte estava em festa, vestida com suas melhores roupas, os cabelos arrumados por cabeleireiros franceses. ${ }^{5}$ A corte brasileira seguia o mesmo cuidado que o protocolo real determinava para essa ocasião. A coroação de d. Pedro II era uma tentativa de marcar a entrada do país na modernidade, no rol de países importantes, e para isso nada seria economizado. $^{6}$

\footnotetext{
${ }^{3}$ Jornal do Commercio, 20 de julho de 1841.

${ }^{4}$ Lilia Mortiz Schwarcz conta que a murça de galo-da-serra havia sido encomendada por um comerciante a um grupo de índios tirió e tornou-se roupa fundamental dos imperadores brasileiros. Mais de 50 anos depois, ela foi substituída por uma feita de penas de papo de tucano. Lilia Moritz Schwarcz. As barbas do imperador. D. Pedro II, um monarca nos trópicos. São Paulo: Companhia das Letras, 1998, p. 82.

${ }^{5}$ Lilia Moritz Schwarcz. As barbas do imperador. D. Pedro II, um monarca nos trópicos. São Paulo: Companhia das Letras, 1998, p. 81.

${ }^{6}$ Lilia Moritz Schwarcz. As barbas do imperador. D. Pedro II, um monarca nos trópicos. São Paulo: Companhia das Letras, 1998, p. 80-84.
} 


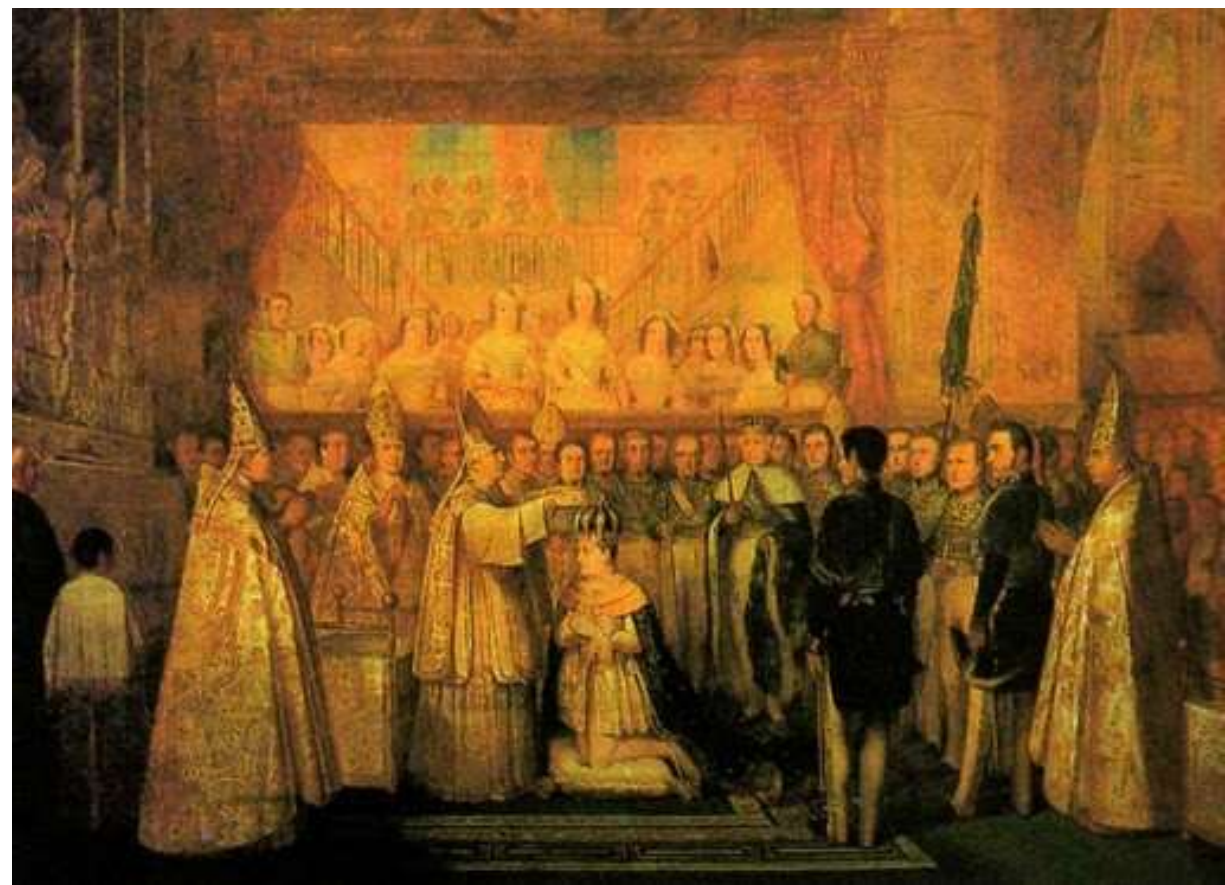

"O ato de coroação de d. Pedro II", por François René Moreaux, $1842^{7}$

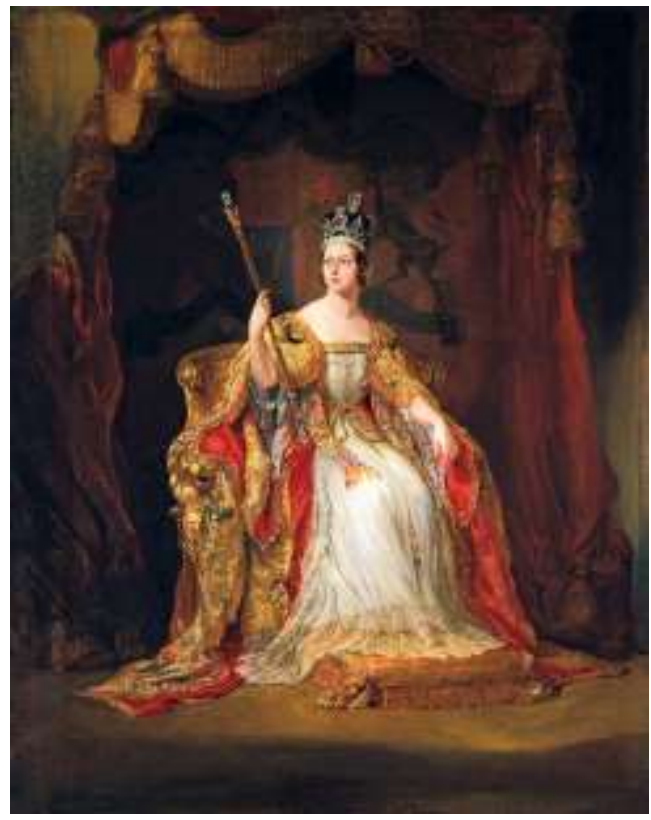

“A coroação da Rainha Vitória”, quadro de George Hayter $(21,5 x 105,5 \mathrm{~cm})^{8}$

Poucos anos antes, em junho de 1838, a rainha Vitória, da Inglaterra, também fora coroada bastante jovem, aos 18 anos. Da mesma maneira que d. Pedro II, sua coroação significava um apaziguamento das tensões de governo e da corte. Dessa maneira, a

${ }^{7}$ Lilia Moritz Schwarcz. As barbas do imperador. D. Pedro II, um monarca nos trópicos. São Paulo: Companhia das Letras, 1998, Caderno de imagens.

${ }^{8}$ O quadro "A coroação da Rainha Vitória", um óleo sobre tela de 21,5x10,5 cm) foi reproduzido do livro Christopher Hibbert, Queen Victoria: a personal history. Nova York, Peguin, 1997. 
rainha Vitória usou um vestido de seda branca, com todo aparato que cercava o cargo: a coroa, o cetro, o manto. ${ }^{9}$

Tanto a cerimônia de coroação de d. Pedro II como a da rainha Vitória faziam um elo com o passado de coroações reais do Antigo Regime. Os símbolos reais estavam mais do que aparentes, a cerimônia possuía um significado religioso, ambos os monarcas imbuíam-se desse espírito para governar. Contudo, tanto a monarquia da rainha Vitória como a de d. Pedro II, com o passar dos anos, "aburguesaram-se". Norbert Elias, em A sociedade de corte, vai dizer que "o tipo de modelos conceituais voltados para a realidade que têm influência sobre o comportamento humano difere de acordo com a estrutura da própria realidade. Por conseguinte, a realidade dos cortesãos é diferente da dos profissionais burgueses". ${ }^{10}$

D. Pedro e a rainha Vitória, da mesma maneira que Luis Felipe I, da França, tornaram-se monarcas burgueses no rastro das agitações políticas do começo do século XIX. Portanto, as roupas que usaram ao longo de seus reinados refletiam um tempo cada vez mais "burguês", uma aristocracia que se transformava e perdia os símbolos do Antigo Regime. “A adoção de casacas, sobrecasacas, cartolas e outros acessórios do guarda-roupa do cidadão comum era a principal forma pela qual d. Pedro buscava promover, tanto no Brasil quanto no exterior, a imagem de imperador-cidadão."11

A corte de d. Pedro II vai seguir seu exemplo e, ainda que jovem e desejosa de ostentar antigos símbolos da monarquia ${ }^{12}$, passou a consumir de maneira crescente os símbolos da burguesia. Em termos de roupas, isso se traduzia em cartolas, guarda-

\footnotetext{
${ }^{9}$ Vitória narrou sua própria coroação e o texto é bastante conhecido. Recolhi as informações de um site no dia 3/12/2012, depois do comentário da professora Anna Lanna sobre o problema da coroação de d. Pedro II. O site é o <http://www.londononline.co.uk/monarchy/Victoria/>.

${ }^{10}$ Norbert Elias. A sociedade de corte. Trad. port. Rio de Janeiro; Jorge Zahar, 2001, p. 109.

${ }^{11}$ Marcelo de Araújo. Dom Pedro II e moda masculina na época vitoriana. São Paulo: Estação da Letras e Cores, 2012, p. 24.

${ }^{12}$ Sobre a juventude e honra nas cortes, ver páginas 112/113 de Norbert Elias. A sociedade de corte. Trad. port. Rio de Janeiro; Jorge Zahar, 2001.
} 
chuvas, crinolinas, chapéus e tecidos de qualidade, como a seda e o gorgurão. Em atitudes, vemos a proliferação de teatros, saraus, festas e reuniões. Se d. Pedro II tornava-se cada vez mais um imperador vitoriano, sua corte lhe seguia o exemplo e tornava-se uma corte vitoriana e burguesa.

A vida mundana na corte de d. Pedro II pode ser grosseiramente separada em duas épocas distintas: a primeira que vai de 1841 a meados das décadas de 1860 e 1970, terminando com a guerra do Paraguai; a segunda, de 1870 ao baile da Ilha Fiscal, em 1889, que marcaria o fim do bailes imperiais. O primeiro período sendo muito mais animado que o segundo, quando o imperador envelheceu e se retraiu, isolando-se de festividades na corte, em Petrópolis. ${ }^{13}$ Mas, quando o imperador brasileiro ainda era jovem, as reuniões, sociedades ou clubes reuniam-se com frequência, dando espaço para a sociedade do Rio de Janeiro mostrar-se elegante, bem trajada, adequada ao novo império tropical que se formava. Depois, no segundo período, o hábito de reuniões de sociedade permaneceu em alguns salões do Rio, como o salão da marquesa de Abrantes.

No início da década de 1820 , os panos usados para fazer as roupas que as cariocas costuravam provinham de diferentes portos ao redor do mundo. A moda ditava os vestidos império, com cintura alta, marcada logo abaixo do busto, e o corpo solto. Musseline, seda, algodão fino, cambraia eram os mais usados. Os vestidos império, de gaze ou musseline, não precisavam de muito pano e se adaptavam bem ao calor dos trópicos. Desembarcados no porto e revendidos em mercados, em lojas na rua do Ouvidor ou por mascates ambulantes, os tecidos provinham de vários países, mas a Índia portuguesa era uma das maiores fornecedoras. Mas, as coisas estavam mudando rapidamente nesse período e os mercados, no espaço de tempo de uma geração, foram inundados de lãs, lãs frias ou algodões vindos da Inglaterra.

\footnotetext{
${ }^{13}$ Wanderley Pinho. Salões e damas do segundo império. São Paulo: Livraria Martins Editora, 1970.
} 


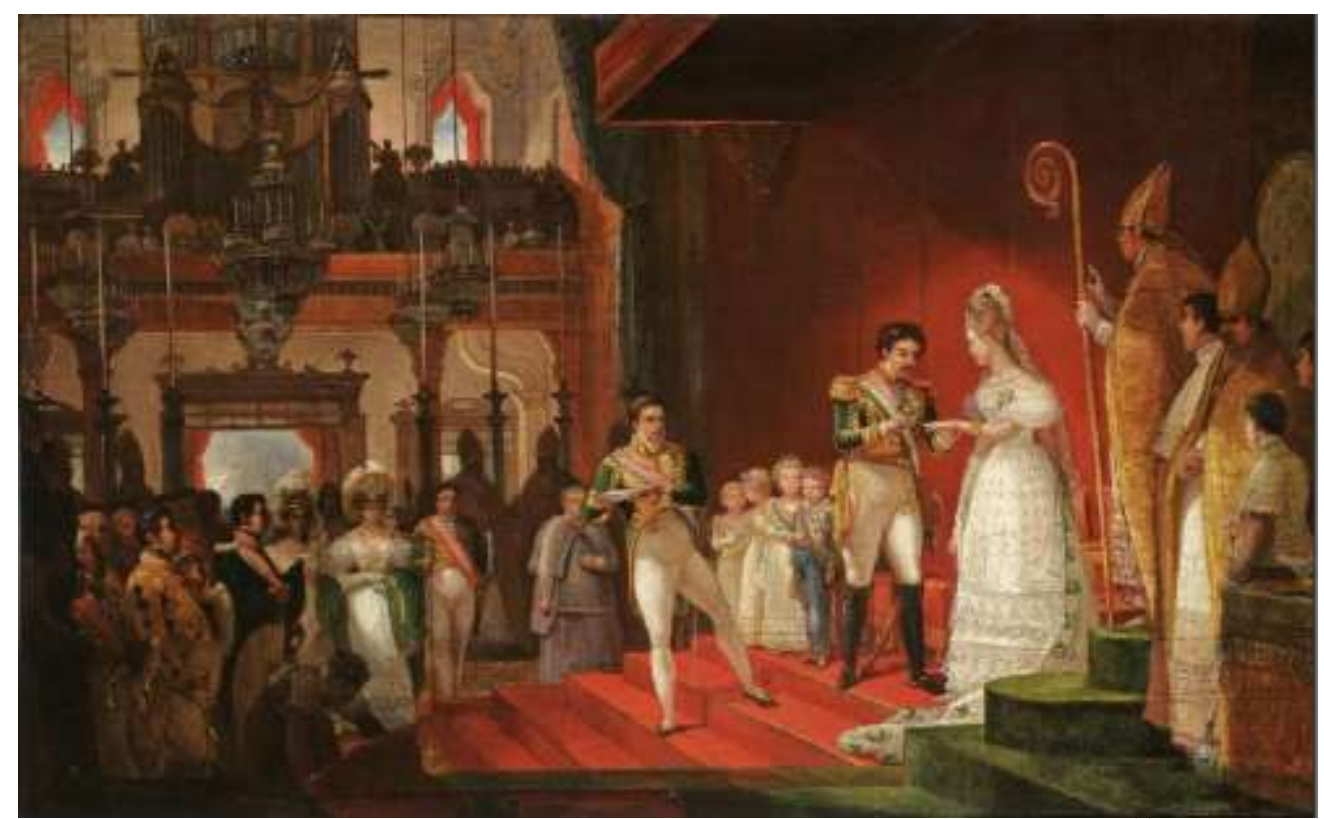

"O casamento de d. Pedro I e d. Amélia", de Debret, c., $1829^{14}$

No quadro redescoberto recentemente de Debret sobre o casamento de d. Pedro I e d. Amélia, vemos a noiva com um vestido império branco, com detalhes em verde, uma coroa de pedras preciosas, pulseiras, colar e brincos também em tons de verde (seriam esmeraldas?) e uma mantilha de renda branca, bordada com flores verde, presa num coque acima da cabeça. D. Pedro I, de uniforme de gala também verde, coloca o anel no dedo da noiva, que segura com a outra mão a luva que havia acabado de tirar. As vestimentas no quadro estão de acordo com a moda europeia, ressaltando o evento de um império recém-independente - por isso a ênfase no verde, tanto nos detalhes do vestido como na casaca de d. Pedro I e seus convidados.

A extraordinária expansão comercial inglesa no começo do século XIX afetou o mundo todo. Na verdade, essa expansão passou a cumprir duas funções essenciais: ao

\footnotetext{
${ }^{14}$ Julio Bandeira e Pedro Correa do Lago. Debret e o Brasil. Obra completa. Rio de Janeiro: Capivara, 2008, p. 98 . È um óleo sobre tela de $45 \times 72,3 \mathrm{~cm}$.
} 
mesmo tempo em que reorganizava a produção interna de tecidos por meio das inovações no maquinário, desorganizava a confecção de tecidos feitos fora da Inglaterra. Num exemplo objetivo, ao mesmo tempo em que a Inglaterra conquistou a Índia politicamente, transformando um concorrente comercial importante em fornecedor de matéria-prima, o algodão fiado, o país internamente reorganizou as maneiras de produzir tecidos e conquistou novos mercados, como o Brasil, por meio de acordos políticos ou guerras.

Até o começo do século XIX, muitos tecidos encontrados no mercado carioca vinham da Índia, principalmente das cidades colonizadas pelos portugueses, Goa, Diu e Damão ${ }^{15}$, de onde chegavam caros panos coloridos e estampados. Vinham também peças mais baratas, vendidas para uma população que não possuía meios de adquirir tecidos mais elaborados, ou então destinadas à vestimenta dos escravos.

Das três cidades, Goa foi a mais importante e concentrava o grosso das exportações indianas para Portugal. Navios carregados de produtos de luxo - tecidos e seda, em especial - saíam de seu porto em direção a uma escala em Luanda e outra em Salvador, antes de aportarem em Lisboa com o estoque quase vazio - razão de um aumento de impostos por parte da metrópole no fim do século XVIII. ${ }^{16}$ Depois da abertura dos portos, os navios saíam de Goa diretamente para o Rio de Janeiro, onde os tecidos eram totalmente revendidos, enfraquecendo ainda mais o comércio direto com Portugal.

As cidades de Diu e Damão, no norte da costa ocidental indiana, eram portos menores, escolhidos por Portugal para escoarem uma produção de menor valor, sobretudo tecidos baratos de algodão, reexportados para Moçambique em troca de,

\footnotetext{
${ }^{15}$ Goa, Diu e Damão são as três cidades mais importantes na Índia para o comércio português, ainda que distantes geograficamente umas das outras. Ver mapa.

${ }^{16}$ Ver item III do capítulo III, do livro de José Jobson de Arruda. O Brasil no comércio colonial. São Paulo: Ática, 1980, p. 279 a 317.
} 
principalmente, marfim, âmbar, ouro e escravos. A Índia sempre havia sido um tradicional fornecedor de produtos para a Europa, exportando não apenas seda ou algodão, mas também aço de excepcional qualidade e açúcar, tabaco, anil e papoula ${ }^{17}$.

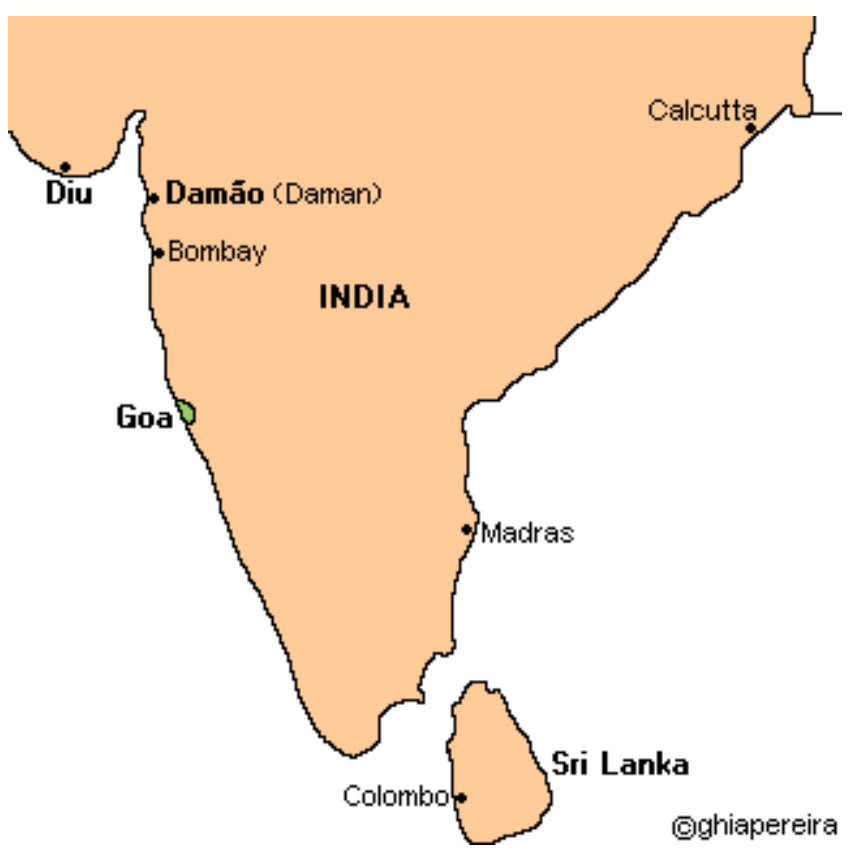

Fernand Braudel, em Civilização material, economia e capitalismo, explica o sistema de fabricação de tecidos na Índia, do adiantamento feito pelo mercador ao tecelão à venda do tecido para companhias de comércio europeias. Diferente da Europa no mesmo período, em que produção têxtil era vertical, ou seja, um mesmo empreendimento (geralmente familiar) controlava da feitura do fio à venda do tecido final. No sistema indiano, as diferentes etapas do processo eram feitas por diversos grupos ou, nas palavras do historiador francês, "um trabalho que na Holanda um só homem realizaria passa aqui [na Índia] pelas mãos de quatro". ${ }^{18}$

\footnotetext{
${ }^{17}$ Fernand Braudel. Civilização material, economia e capitalismo. Trad. port. Vol. 3 "O tempo do mundo". São Paulo: Martins Fontes, 1996, p. 465-470.

${ }^{18}$ Fernand Braudel. Civilização material, economia e capitalismo. Trad. port. Vol. 3, "O tempo do mundo". São Paulo: Martins Fontes, 1996, p. 468.
} 
Ao longo de muito tempo, as companhias europeias de comércio tentaram organizar a produção indiana em vão. $\mathrm{O}$ antigo sistema de extrema especialização do artesão estava enraizado na cultura indiana e, ainda assim, conseguia atender à crescente demanda europeia por tecidos até o começo do século XIX, quando as tecelagens inglesas, transformadas pela Revolução Industrial, começaram a produzir de maneira crescente, inundando, ao longo do século, o mercado mundial.

Braudel menciona vários fatores para a diminuição da produção têxtil. Todos tiveram seu papel, mas foi um fator político importante que transformou a florescente economia indiana: a conquista inglesa em meados do século XVIII. Devassada por disputas internas, a Índia passava por sérios problemas políticos ao longo de todo século XVIII; problemas esses que iriam afetar profundamente a produção e o comércio mundial de tecidos no século XIX. A tentativa inglesa de dominação do território indiano acentuou-se conforme a Revolução Industrial ganhava espaço e alguns fatos episódicos, no final do século XVIII, ajudaram a consolidar essa conquista inglesa.

Dessa maneira, quando o século XIX começou, a Índia encontrava-se sob recente domínio da Inglaterra, que, por sua vez, tentava escoar uma crescente produção de tecidos, resultado direto da Revolução Industrial. Friederich Engels, em A situação da classe trabalhadora na Inglaterra, explicou as etapas da revolução técnica que foram necessárias para que a Revolução Industrial acontecesse. Primeiro foi criada uma máquina chamada Jenny, construída em 1764 por um tecelão chamado James Hargreaves, em Lancashire, no norte da Inglaterra. ${ }^{19}$

Alice Canabrava, em seu trabalho clássico sobre a produção algodoeira em São Paulo dizia que: "Tanto pelo volume da produção, como pela importância de suas exportações, a Inglaterra desfrutava indiscutível liderança no campo da indústria têxtil

\footnotetext{
${ }^{19}$ Friederich Engels. A situação da classe trabalhadora na Inglaterra. Trad. port. São Paulo: Boitempo Editorial, 2007, p. 50-51.
} 
europeia. Existiam, em 1861, [...] cerca de três mil fábricas de tecidos, as quais possuíam 11.250.000 fusos e davam trabalho a cerca de 600.000 operários."20

Em meados dos anos 1860, o consumo europeu de algodão para a produção têxtil parecia não ter fim. Alice Canabrava recuperou uma frase do relatório apresentado ao imperador d.Pedro II por Julio Constancio Villeneuve sobre a Exposição Universal de 1867: “O algodão seria um gênero tão indispensável à Inglaterra como o próprio pão". ${ }^{21}$ Fora da Inglaterra, as fábricas para fazer tecidos também não paravam e mostram a importência dessa indústria para a economia. Na França 5.600.000 fusos em funcionamento, com 379.700 operários, em 1860; nos Estados Germânicos, 310 fábricas de fiação e 940 tecelagens, empregando 74.663 operários. ${ }^{22}$

Friederich Engles, em A situação da classe trabalhadora na Inglaterra ${ }^{23}$, vai dar os números da evolução da indústria do algodão na Inglaterra. No texto, ainda que mais tarde ele reconheça que os números podem não estar exatos, dão a dimensão da necessidade inglesa de algodão para seus teares:

Nos anos de 1171-1774, importava-se em média, anualmente, menos de 5 milhões de libras de algodão bruto; em 1841, 528 milhões; e, em 1844, pelo menos 600 milhões. [..] Nesse mesmo ano, operavam na indústria do algodão mais de 8 milhões de fusos, 110 mil teares mecânicos e 250 mil manuais, sem contar os fusos dos teares de corrente e, segundo os cálculos de McCulloch, viviam nos três reinos,

\footnotetext{
${ }^{20}$ Ver especialmente a análise feita sobre a produção inglesa de Alice Canabrava no primeiro capítulo ("A influência inglesa") de $O$ desenvolvimento da cultura do algodão na província de São Paulo (1861-1875). São Paulo, Edusp/Anpuh, 2 a edição, p. 75-87.

${ }^{21}$ Ver a nota 7 do primeiro capítulo de Alice Canabrava, "A influência inglesa". O desenvolvimento da cultura do algodão na província de São Paulo (1861-1875). São Paulo, Edusp/Anpuh, 2a edição, p. 79.

${ }^{22}$ Alice Canabrava, "A influência inglesa". In: $O$ desenvolvimento da cultura do algodão na província de São Paulo (1861-1875). São Paulo, Edusp/Anpuh, $2^{a}$ edição, p. 76.

${ }^{23}$ Friederich Engels, A situação da classe trabalhadora na Inglaterra. Trad. port. São Paulo: Boitempo, 2007, p. 51. No final do século XIX, Engels sabia que seus números não estavam exatos, mas que corresponderiam a grosso modo à necessidade da indústria de algodão da época.
} 
direta ou indiretamente ligados a este ramo, quase 1,5 milhão de pessoas, das quais 220 mil trabalhavam em fábricas; nestas, a força utilizada era de 33 mil cavalos-vapor e 11 mil cavalos de força hidráulica. Hoje essas cifras estão superadas e podemos admitir tranquilamente que, em 1845, o número de máquinas - assim como o de operários - e a potência gerada por elas ultrapassam em pelo menos a metade os valores de $1834 .^{24}$

No ano da Guerra de Secessão, nos Estados Unidos, em 1861, as fábricas de tecido da Europa consumiram 990 milhões de quilos de algodão, 750 milhões dos quais vindos dos Estados Unidos. O ano anterior havia sido de superprodução, adquirida pelos industriais europeus antes do começo das hostilidades entre ianques e confederados. ${ }^{25}$ Na França, sob a regência de Napoleão III e sua mulher, Eugênia de Montijo, a produção de tecidos atingiu seu ápice com a importação de 684.594 fardos. ${ }^{26}$

Dessa forma, os resultados da Revolução Industrial inglesa cedo se fizeram notar no Brasil, pois toda essa produção precisava de consumidores. O Brasil foi um dos lugares para onde se escoou parte da produção têxtil europeia. Essa quantidade de tecidos que passou a entrar pelo porto do Rio modificou o cotidiano das brasileiras. As moças e senhoras daqui, acostumadas com os estampados vestidos indianos, tiveram de se adaptar aos novos tempos, comprando tecidos ingleses em mercados e lojas locais. Mais ou menos na mesma época em que Engels contabilizou a produção fabril inglesa (período em que foi escrito o livro), isto é, meados da década de 1830, os portos cariocas estavam recebendo uma enorme quantidade de tecidos ingleses. Podemos perceber que, nesta época, os produtos ingleses, principalmente os têxteis, estavam

\footnotetext{
${ }^{24}$ Friederich Engels, A situação da classe trabalhadora na Inglaterra. Trad. port. São Paulo: Boitempo, 2007, p. 51.

${ }^{25}$ Alice Canabrava, "A influência inglesa". In: O desenvolvimento da cultura do algodão na província de São Paulo (1861-1875). São Paulo, Edusp/Anpuh, 2a edição, p. 76 e 77.

${ }^{26}$ Alice Canabrava "A influência inglesa". In: $O$ desenvolvimento da cultura do algodão na província de São Paulo (1861-1875). São Paulo, Edusp/Anpuh, 2ª edição, p. 77.
} 
plenamente incorporados ao cotidiano dos cariocas, tendo superado em muito a produção indiana.

No Brasil, essa diminuição de tecidos indianos à venda foi notável. "O comércio da Ásia tem um peso considerável; representa, em 1796, 16,5\%, e, em 1797, 27,3\%; daí para frente diminui sempre, sem deixar de ter significado", afirmou José Jobson de Arruda $^{27}$. Dessa forma, em 1808, ano da abertura dos portos, esse percentual ficou em cerca de 3,2\% - sendo que em 1801 havia sido de $15 \%$ e em 1805 foi de $10 \%$. O ano de 1808, naturalmente, foi significativo para as importações brasileiras em geral e de tecidos em particular.

Mas os números exatos escondem uma realidade que, ao longo do século XIX, afetou de forma profunda o cotidiano de mulheres como a dona-de-casa retratada por Debret. Os negócios envolvendo a compra e venda de tecidos tinham uma importância econômica significativa para os indivíduos e uma profunda relação no dia a dia das pessoas - eram locados no penhor, herdados ou remendados. Marx escreveu O Capital enquanto passava por maus bocados para sustentar a família. O casaco que aparece repetidas vezes no livro possuía uma proximidade cotidiana com a vida do filósofo que hoje pouco nos damos conta. Da mesma maneira que o vestido estampado na gravura de Debret - as mercadorias possuíam uma materialidade cotidiana. Ou melhor, quando os tecidos indianos diminuíram no mercado, as cores, estampas e padrões dos vestidos e roupas também mudaram. Os tecidos ingleses eram diferentes, mais pretos, cinzas ou azuis. A moda mudava por causa de um problema econômico, o surto industrial, e somente depois da descoberta de pigmento sintéticos, em meados do século, que as cores e estampas voltaram aos tecidos que chegavam ao porto carioca.

\footnotetext{
${ }^{27}$ José Jobson de Arruda. O Brasil no comércio colonial. São Paulo: Ática, 1980, p. 190.
} 
Participação percentual dos produtos na importação do Brasil (Rio de Janeiro) ${ }^{28}$

\begin{tabular}{|c|c|c|c|c|c|c|}
\hline Datas & $\begin{array}{r}\text { Mantimentos } \\
\%\end{array}$ & $\begin{array}{r}\text { Lanifícios } \\
\%\end{array}$ & $\begin{array}{r}\text { Linifícios } \\
\%\end{array}$ & $\begin{array}{r}\text { Sedas } \\
\%\end{array}$ & $\begin{array}{r}\text { Produtos das } \\
\text { fábricas } \\
\% \\
\end{array}$ & $\begin{array}{r}\text { Produtos da } \\
\text { Ásia } \\
\% \\
\end{array}$ \\
\hline 1796 & 15,2 & 11,7 & 20,4 & 2,7 & 29,4 & 9,9 \\
\hline 1797 & 11,7 & 17,4 & 10,4 & 1,6 & 33.7 & 14,9 \\
\hline 1798 & 12,0 & 13,4 & 8,7 & 1,2 & 42,2 & 13,9 \\
\hline 1799 & 10,3 & 18,0 & 10,6 & 1,8 & 36,4 & 12,4 \\
\hline 1800 & 9,6 & 15,4 & 11,4 & 2,0 & 39,5 & 12,3 \\
\hline 1801 & 10,7 & 13,0 & 10,7 & 1,3 & 36,9 & 15,0 \\
\hline 1802 & 10,00 & 16,00 & 9,8 & 1,6 & 37,2 & 11,1 \\
\hline 1803 & 17,1 & 2,3 & 8,9 & 5,6 & 40,5 & 10,3 \\
\hline 1804 & 20,7 & 14,6 & 6,2 & 2,9 & 32,5 & 10,2 \\
\hline 1805 & 21,8 & 15,4 & 9,0 & 2,2 & 25,2 & 10,1 \\
\hline 1806 & 28,2 & 14,5 & 11,8 & 2,8 & 18,3 & 8,7 \\
\hline 1807 & 30,6 & 14,5 & 15,9 & 2,1 & 15,4 & 6,7 \\
\hline 1808 & 26,4 & 3,2 & 32,4 & 3,1 & 16,9 & 3,2 \\
\hline 1809 & 18,7 & 1,7 & 25,5 & 4,9 & 16,3 & 6,8 \\
\hline 1810 & 36,9 & 0,9 & 17,9 & 3,9 & 16,7 & 2,8 \\
\hline 1811 & 26,9 & 0,4 & 19,1 & 4,1 & 19,0 & 8,5 \\
\hline Total & 16,1 & 13,4 & 11,6 & 2,3 & 32,3 & 11,2 \\
\hline
\end{tabular}

Fonte: Tabela 18, O Brasil no comércio colonial, de José Jobson de Arruda, p. 179.

\section{A moda, o comércio e um novo século transformam a vida carioca}

Em meados do século XVIII, o escritor inglês Daniel Defoe (1660-1731) observou um fenômeno novo e o descreveu em seu último livro, The complete english tradesman. Espantado, Defoe fala de uma nova atitude em seu tempo: “certas damas, e também pessoas de grande pompa, têm tomado as suas carruagens e passado uma tarde

\footnotetext{
${ }^{28}$ José Jobson de Arruda. O Brasil no comércio colonial. São Paulo: Ática, 1980, p. 179.
} 
inteira em Ludgate Street, ou em Covent Garden, apenas para divertir-se indo de uma a outra loja, para olhar as sedas, tagarelar e zombar dos comerciantes, não tendo tanto como a menor ocasião, muito menos intenção de comprar qualquer coisa". ${ }^{29}$

No mesmo período em que Daniel Defoe escreveu seu romance, em Portugal a palavra moda ganhava uma definição, um verbete no dicionário, que ainda era ambíguo e misturava os dois tempos: das roupas feitas para durar e da novidades constantemente renovadas. O dicionário de Rapahel Bluteau, editado em Lisboa entre 1712 e 1724, vem com uma longa definição, reproduzida abaixo:

Moda: o modo de trajar, falar ou fazer qualquer coisa conforme o costume novamente introduzido. Antigamente não havia modos no trajo como nem ainda hoje as há em todo o Levante. Parece razoável a continuação desta uniformidade no vestir, porque os vestidos se fizeram para cobrir o corpo, e como todos os corpos humanos, em todo o tempo são na figura os mesmos, é muito para estranhar a prodigiosa mudança de vestiduras, que umas às outras continuamente se seguem. E assim os inventores das modas, não são a gente mais sisuda da República; ordinariamente são mulheres e moços do Norte incitados por mercadores e artífices que não tem outro fim que a própria conveniência. Esta perpetua a variedade de ornatos não deixa de ter perniciosas consequências; os que a não seguem parecem ridículos, os que com ela se conformam, desperdiçam patrimônios. Os antigos, como sempre seguiam no vestir o mesmo estilo, sendo ricos, tinham quantidade de vestidos sobressalentes. No livro I das Epift. Horácio, se vê que no seu guarda-roupa tinha. Lucullo cinco mil chamydes, que entre romanos era um sago ou jaleca militar; desta abundância se pode julgar o mais. Quando o vestido é cômodo para o uso do corpo, descente para a qualidade e bom contra as injúrias do tempo; o inventar outro parece loucura, que bizarria. Aquiles Estaco

\footnotetext{
${ }^{29}$ Daniel Defoe, The complete english tradesman. Nova York: Penguin, 1983, p. 312.
} 
dá a entender que no seu tempo os romanos introduziram, novas modas do vestir. ${ }^{30}$

O texto é interessante para percebemos as sutilezas da palavra moda, que ainda vencia resistências em Portugal do setecentos. Trocar constantemente de roupas era considerado uma extravagância, um hábito de pessoas do "norte", jovens inconsequentes que não viam o bom senso de boas roupas duradouras. Mas esta era uma definição que estava para mudar e, ao longo do século XVIII, a noção de moda, ou mesmo de estar na moda, se transformou radicalmente.

Cerca de um século mais tarde, em 1813, o dicionário Moraes \& Silva, de Antonio Moraes Silva, publicava a seguinte definição: "moda: o uso correto e adotado de vestir, trajar em certas maneiras, gostos, estudos e exercício". ${ }^{31}$ Sucinto, o dicionarista já revelava o uso mais amplo e contemporâneo para a palavra, que vinha ligada às roupas e às maneiras de se portar em sociedade. A moda tornava-se lentamente senhora de corações e mentes, caminhando lado a lado da revolução industrial e da ascensão da burguesia. E por isso, quando chegamos ao Brasil século XIX, a moda já havia tomado os rapazes e moças da elite carioca.

Em A pata da gazela, José de Alencar, descreve Horácio de Almeida, um dândi, um leão $o^{32}$ da sociedade carioca. Horácio, antes de se apaixonar, preocupava-se unicamente em se vestir bem e apresentar uma boa figura em sociedade; visitava, inclusive, alfaiates da rua do Ouvidor cotidianamente. Alencar identifica seu leão como

\footnotetext{
${ }^{30}$ Dicionário de Rapahel Bluteau, verbete "moda". O dicionário está online, no site do IEB, www.ieb.usp.br.

${ }^{31}$ Moraes\&Silva, de Antonio Moares Silva. $2^{\mathrm{a}}$ Ed. Lisboa: Typographia Lacerdina, 1813, verbete moda. O dicionário de Moares e Silva também está no site do IEB, www.ieb.usp.br.

${ }^{32}$ José de Alencar. A pata da gazela. São Paulo: Saraiva, 1954, p. 11. A citação em que o escritor chama seu personagem de" leão" é a seguinte: "Horácio de Almeida, o nosso leão, voltou a casa à hora do costume, quatro da tarde".
} 
um "príncipe da moda". Já entendia, portanto, o significado da moda para a sociedade carioca da época.

Vestir-se elegantemente, ou simplesmente, estar à moda, era algo que se aprendia e se ensinava. Para isso, um novo veículo de comunicação, o jornal, cumpria um papel fundamental. Jornais feitos para senhoras e suas filhas, para avós e netas eram editados na corte e tinham como mote principal ensinar a boa sociedade a vestir-se. Reproduziam-se e comentavam-se gravuras francesas, falava-se dos bailes e reuniões galantes das famílias abastadas; das moças que se vestiam para danças e casar; das melhores costureiras e dos melhores alfaiates do Rio de Janeiro.

Escritos em primeiro lugar por jornalistas homens, como o redator do Jornal das Modas, de 1839 a 1842, e mais tarde por senhoras, esses jornais representavam a emancipação feminina de diversas maneiras. Em primeiro lugar, incentivavam as damas a saírem de casa para fazerem compras (sempre acompanhadas por uma escrava ou um filho), andarem pela cidade, frequentarem confeitarias e docerias, aparecerem em jantares, ampliando o círculo de sociabilidade para além da família patriarcal. Em segundo lugar, as jornalistas mulheres que escreviam folhas semanais, como o Jornal das Senhoras (1852-1855), se no início eram consideradas um escândalo para a sociedade, depois de um tempo apareciam como exemplos de profissões em que as mulheres poderiam atuar legitimamente fora do lar.

Em 12 de janeiro de 1839, o semanário carioca Jornal das Modas, que saía aos sábados, deu uma definição de moda que permaneceu atual ao longo do século XIX:

Há certas coisas que desafiam a inteligência para dar uma solução segura e esclarecida: a moda é, sem dúvida, uma delas. De que servem chapéus de certa cor, vestidos deste feitio, casacas à inglesa, à francesa, etc.? É uma pergunta simples, que muitas vezes acode ao espírito, porém, aparece logo uma resposta que desvanece a 
indiferença e excita o pensamento: o gosto, os desejos; e é a seguinte: “- Ora, se é moda!". Bem disse um escritor que a moda é hoje um dos piores tiranos.

A cada número do jornal, uma gravura era descrita e comentada pelo editor. E a cada gravura comentada, uma profusão de detalhes ligados ao se vestir bem aparecia em destaque. No mesmo dia da reflexão acima, são comentados os trajes de duas senhoras. “A que está toda vestida em cor-de-rosa tem um chapéu de Escócia tingido, o que na realidade é muito belo". ${ }^{33}$ Os acessórios, como os chapéus, apareciam em destaque nos comentários do editor - bem como nas tabelas de importação e eram itens essenciais para se "andar na moda".

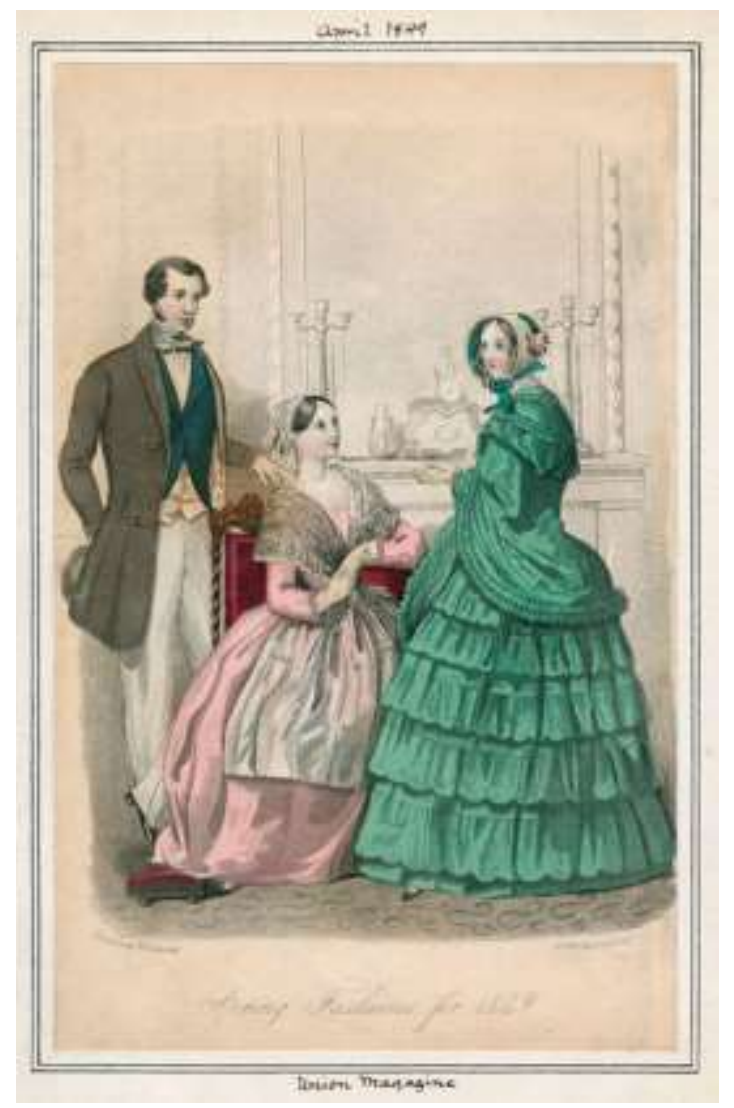

Exemplo de gravura de moda no século XIX usada no Jornal das Modas ${ }^{34}$

${ }^{33}$ Jornal das modas. Ano I, vol I, 12 de janeiro de 1839, p. 2.

${ }^{34}$ Jornal das modas. Ano I, vol I, 12 de janeiro de 1839, p. 1. 
Mas a moda era uma palavra nova e passava por múltiplos significados e associações ao longo do século. Moda era uma ideia recente para brasileiros, mas também para os franceses. O poeta francês Charles Baudelaire (1821-1867) associou moda à novidade e à arte. Para ele, a moda passava necessariamente, pela definição do moderno, de um novo moderno, de um moderno ligado a um novo século. Em um de seus textos sobre arte, intitulado $O$ pintor da vida moderna, arte e moda fundem-se para dar uma ideia de tempo diferente, em que o efêmero predominaria. Num texto que faz parte da mesma série, intitulado $O$ elogio da maquiagem, a moda viria ligada à velocidade, à fotografia, ao instantâneo, ao artifício, à vida na cidade. ${ }^{35}$ Por isso Baudelaire elogia o pintor impressionista Éduard Manet, por sua nova maneira de pintar, ou Félix Tournachon, fotógrafo conhecido por Nadar, por sua nova maneira de retratar a sociedade aliada à tecnologia. Moda e cidade, moda e velocidade, moda e arte passam a andar juntas numa ligação que perdura até os dias de hoje. ${ }^{36}$

Até o século XVIII, na França principalmente, a moda estava associada à aristocracia e aos privilégios das corporações de ofício que regulamentavam alfaiates e costureiras. "Assembleias anuais das corporações determinam, após longas deliberações, as mudanças que serão introduzidas na moda. Por mais ponderados que fossem seus decretos, aliás rigorosamente observados, incidiam apenas em questões de detalhe, de modo que a transformação da moda era extremamente lenta. Apenas um acontecimento significativo, como o casamento de um soberano com uma princesa estrangeira, podia resultar em modificações bruscas das formas adotadas no intuito de

\footnotetext{
35 "O pintor da vida moderna" e "O elogio da maquiagem" são textos jornalísticos de Baudelaire, escritos em 1859 e publicados em 1863 no jornal Le Figaro. Nos textos, Baudelaire explica suas ideias sobre a arte. Para ele, a arte seria o artifício, a fugacidade, o efêmero. A cidade, portanto, seria o lugar do artifício por excelência; lugar efêmero, dos prazeres, da modernidade e da rapidez. Por isso, em as Flores do mal, ele fala das prostitutas, da bebida, dos perfumes, da maquiagem: objetos artificiais.

${ }^{36}$ A ligação ente moda e arte é antiga, e no Brasil foi reforçada pelo estudo pioneiro de Gilda de Mello e Souza, O espírito das roupas (São Paulo: Companhia das Letras, 1987).
} 
harmonizá-las aos hábitos ou ao gosto da nova rainha." ${ }^{37}$ A moda seria, portanto, antes de mais nada um privilégio da corte e, como tal, inacessível ao resto da população.

Para Daniel Roche, a moda, esse "mundo encantado de códigos", teria nascido em algum momento em meados do século XVII, quando uma indústria do luxo se estabelece em Paris. É dessa indústria que saem as principais criações de moda do século e explica porque Paris tornou-se por muito tempo a capital mundial das novas tendências. ${ }^{38}$ E é por isso também que, ao longo do século XIX, a França vai se tornar a principal exportadora de roupas pontas para o Brasil.

Foi apenas com a Revolução Industrial que a troca constante de vestimentas por um estrato muito maior da população tornou-se corrente e o termo moda adquiriu uma conotação mais semelhante à que temos hoje. Foi, afinal, a Revolução Industrial que deu uma dimensão econômica mais profunda à moda.

Mas a moda também tinha outra dimensão, mais prática e ligada à economia. Filha da Revolução Industrial, a moda percorre o século XIX dando impulso à intensa fabricação de tecidos iniciada no final do século XVIII. Mais tecidos ingleses, como vimos, significava mais e constantes mudanças no vestuário tanto feminino, quanto masculino, ao longo do século. A entrada desses tecidos pelo porto do Rio do Janeiro, de certa forma muito peculiar, ditava a moda usada pelas ruas da cidade. Cores, padronagens, tipos de tecido eram importados para depois serem transformados em roupas em ateliês de costura, alfaiates ou nas casas, por costureiras ou donas de casa habilidosas. Entender essas importações e o que elas significavam em termos de possibilidade de se transformarem em roupa é essencial para se compreender uma espécie de "economia da moda carioca" do século XIX.

\footnotetext{
${ }^{37}$ Didier Grumbach. Histórias da moda. Trad. port. São Paulo: Cosac \& Naify, 2009, p. 16.

${ }^{38}$ Daniel Roche. A cultura das aparências. Trad. port. São Paulo, Senac, 2007, p. 57a 75. Ver também, do mesmo autor, $O$ povo de Paris. São Paulo: Edusp, 2004, principalmente a segunda parte, "Morar e consumir", p. 143 a 266.
} 


\section{Os tecidos importados fazem as roupas na corte}

Quando os tecidos ingleses começaram a chegar ao porto do Rio de Janeiro, no início dos anos 1830, a moda pedia saias ligeiramente bufantes, cinturas altas e mangas rente ao corpo, com pequeninos detalhes frisados no punho. Os vestidos império, que causaram furor logo após a Revolução Francesa, durante o governo de Napoleão Bonaparte, já estavam se transformando. De túnicas soltas, inspiradas em vestes gregas da antiguidade, de musselina branca esvoaçante, com decotes profundos, os vestidos se modificavam, adquiriam babados, adornos e volumes no redor dos pés como podemos perceber na gravura de Debret reproduzida abaixo. O pintor capturou uma cena de casamento entre negros nesse mesmo período. A noiva estava vestida de branco, mas o vestido império já não era o mesmo: tinha babados rente aos pés e cores e rendas fortes no corpete. As damas também se vestiam de maneira semelhante, com mangas curtas já um pouco bufantes, presas rente ao braço. 


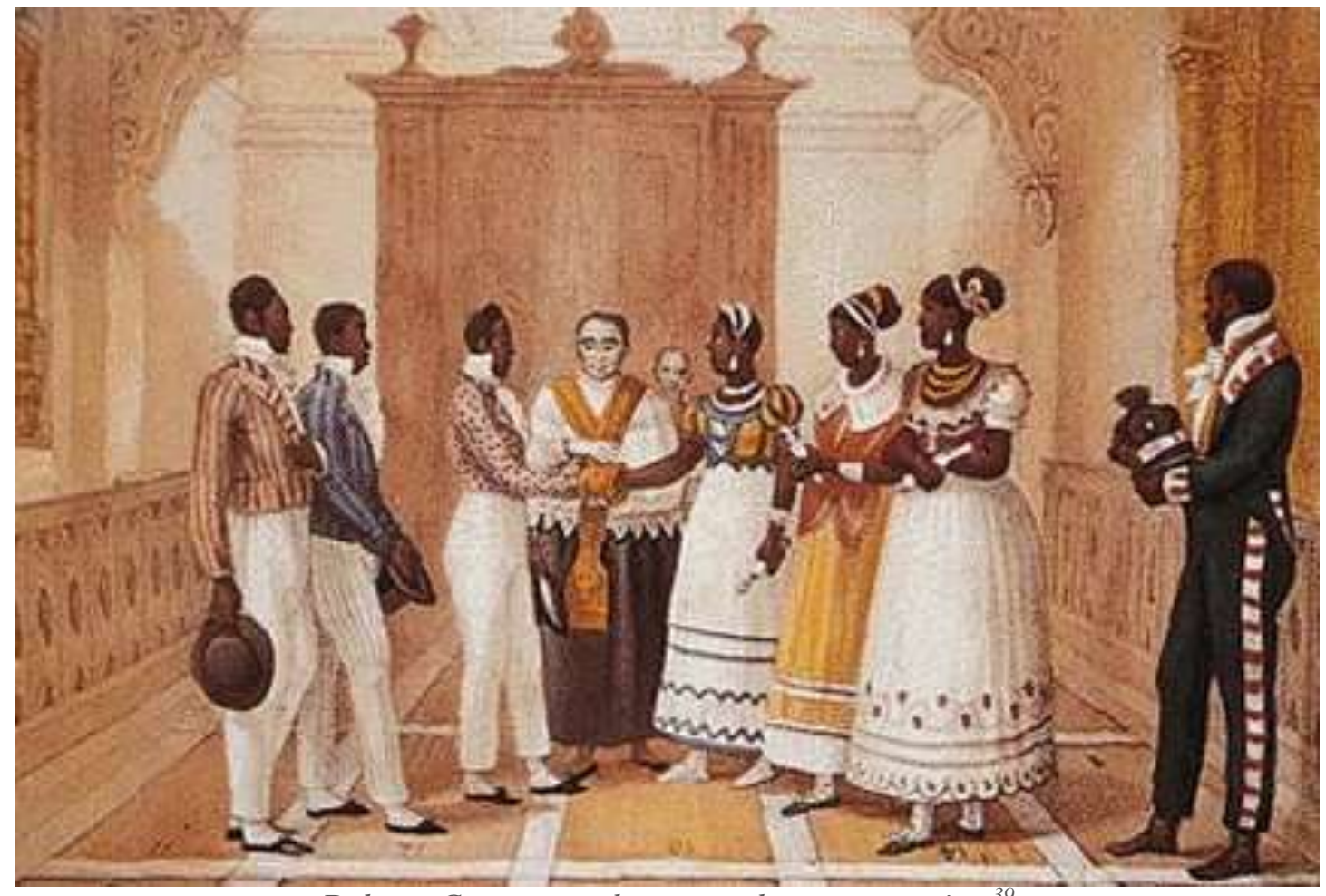

Debret: Casamento de negros de uma casa rica. ${ }^{39}$

Em outra imagem, uma família sai para igreja. A mulher vestia também um vestido branco com babados ao final, mangas curtas bufantes e o cabelo enfeitado com um pente coberto por uma renda escura. O Rio seguia a moda europeia e, em especial, a parisiense. Ambas as gravuras mostram uma mudança na moda e cuidado com vestir e apresentar-se em público que não era usual apenas alguns anos antes.

${ }^{39}$ Esta imagem faz parte do grande catálogo feito por Julio Bandeira e Pedro Correa do Lago. Debret e o Brasil. Obra completa. Rio de Janeiro: Capivara, 2008, p. 163. Atenção aos detalhes como os sapatos dos escravos, que não costumavam usar esse tipo acessório. 


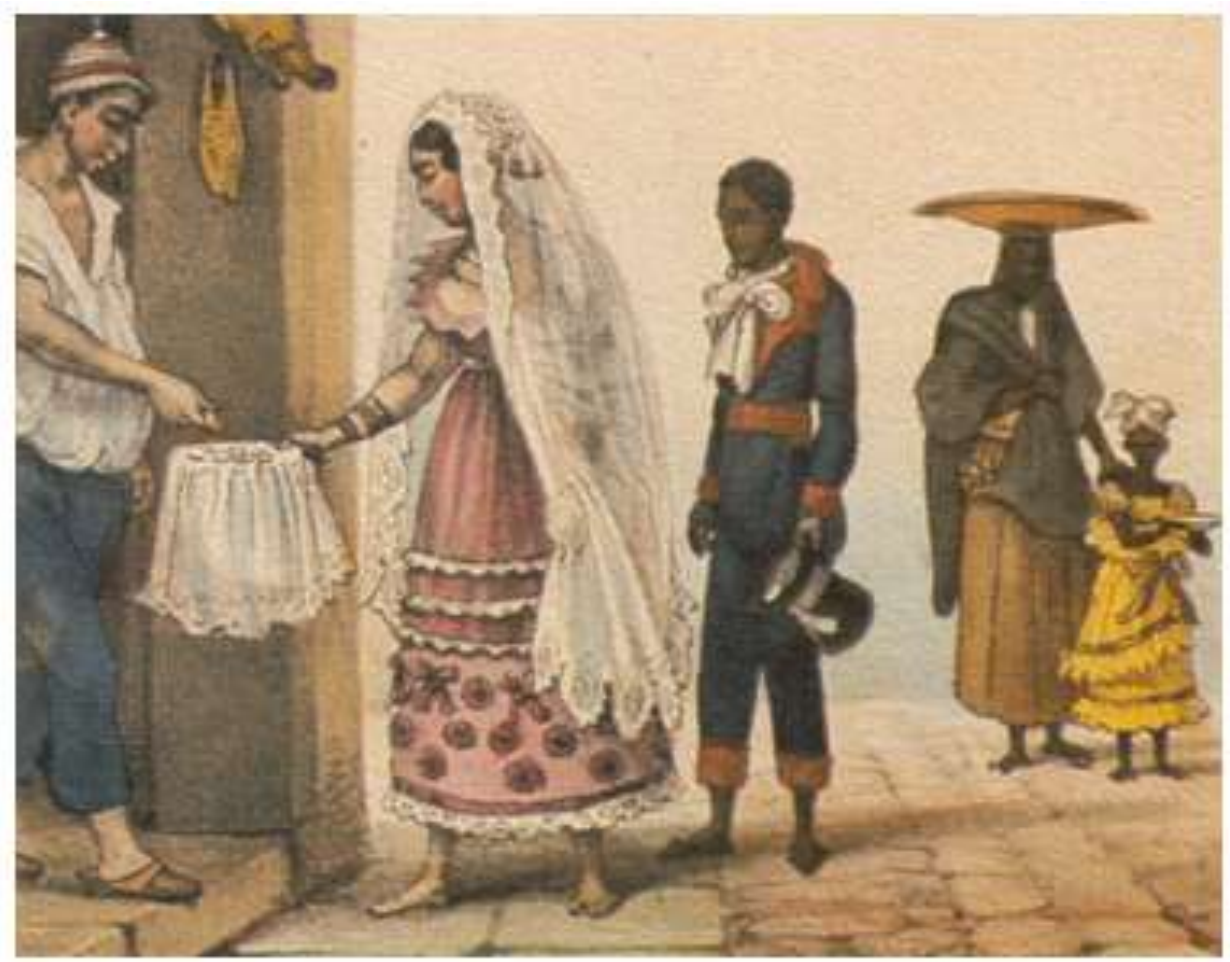

"Voto de uma missa pedida como esmola": dama de classe em 1826 usando vestido rosa e uma mantilha de renda ${ }^{40}$

No Rio de Janeiro, nas primeiras décadas do século XIX, as mulheres escondiamse atrás de mantilhas à oriental e mostravam-se pouco à rua. As exceções eram eventos religiosos, como missas, procissões ou promessas, como vemos na gravura de Debret. O cronista Luís Edmundo enxergou na cidade antes da chegada da família real portuguesa o atraso de uma cidadela ou de uma aldeia perdida no mundo, com hábitos estranhos, ruas mal calçadas, casarões caindo aos pedaços. "A cidade, na alvorada do século XIX, é o que tinha sido duzentos anos atrás: uma estrumeira." ${ }^{, 41}$

Com a chegada da família real, chegou também, para a maioria dos cronistas, a civilização europeia. Quando desembarcaram, as nobres lisboetas, em seus vestidos império, foram olhadas com admiração e espanto pelas cariocas locais, relatam

\footnotetext{
40 Julio Bandeira e Pedro Correa do Lago. Debret e o Brasil. Obra completa. Rio de Janeiro: Capivara, 2008, p. 160.

${ }^{41}$ Luis Edmundo. O Rio de Janeiro do meu tempo. Rio de Janeiro: Imprensa Oficial, 1938, vol. 1, p. 19.
} 
diferentes cronistas. Dois estrangeiros, Daniel Parrisch Kidder e James Cooley Fletcher, como tantos outros observaram que:

Com a chegada do príncipe-regente, abriram-se os portos. (...) Introduziram-se as modas europeias. Da reclusão e restrições do isolamento, o povo emergiu nas cerimônias festivas da Corte, cujas recepções e festas de gala atraíam multidões de toda a parte. $\mathrm{Na}$ sociedade misturada que a capital então ostentava, espanou-se o pó do retraimento, desapareceram antiquados costumes, novas idéias e formas de viver foram adotadas, propagando-se de círculo em círculo e de cidade em cidade. ${ }^{42}$

Desta forma, quando Maria Graham aportou ao Brasil, em meados da década de 1820, ela também descreveu a simplicidade elegante da corte no Rio de Janeiro, onde as damas usavam "sedas lisas, musselinas e cambraias", ainda que bastante decotadas ${ }^{43}$. Sua presença causou comoção e as cariocas não tardaram a imitar-lhe um hábito europeu, o de usar um chapéu. Diz a inglesa que ao fim de uma semana, o inusitado objeto que portava na cabeça foi "copiado em cinquenta cores diferentes". 44 Aqui o costume era usar mantilhas com coques altos e pentes à espanhola segurando os longos cabelos. $^{45}$

Mas a moda que chegava aos portos cariocas no século XIX vinha, sobretudo, em forma de tecidos e não de roupas prontas, ainda que chegasse uma imensa variedade de assessórios pelos paquetes ordinários. O historiador Richard Graham, em Grã-Bretanha

${ }^{42}$ Daniel Parrisch Kidder e James Cooley Fletcher. O Brasil e os brasileiros. Trad. port. São Paulo: Nacional, 1941, p. 70.

${ }^{43}$ Maria Graham. Diário de uma viagem ao Brasil e de uma estada nesse país durante parte dos anos de 1821, 1822, 1823. Trad. port. São Paulo, Companhia Editora Nacional, 1956, p. 117.

${ }^{44}$ Idem, p. 132.

${ }^{45}$ Luís Edmundo. Recordações do Rio Antigo. Rio de Janeiro: Biblioteca do Exército, 1950, p. 19. 
e o início da modernização do Brasil $^{46}$, elencou o número das exportações inglesas de tecidos entre 1850 e 1909. Entre 1850-1854, veio da Inglaterra um total de 8.689.288 libras de tecidos de algodão; 1.859.432 libras de lãs; 1.024 .063 de linhos; 112.947 libras de sedas, totalizando o montante de 11.685.730 libras ou cerca de 72,55\% do total de todos os produtos exportados para o Brasil - o que incluía produtos alimentícios, produtos de borracha, de barro, joias, prata, armas, drogas e remédios, couro, maquinaria, carvão de pedra, produtos químicos, equipamentos ferroviários, entre outros. As roupas prontas, dentro desse universo de coisas que chegaram aos portos brasileiros, representavam apenas $1,45 \%$ do total das exportações inglesas no período. E, mesmo no final do império, entre 1885 e 1889, a percentagem de roupas prontas vindas da Inglaterra permaneceu na casa dos $1,29 \%$ das exportações inglesas para o Brasil.

Por isso, quando chegavam, vestidos prontos do estrangeiro eram notícia importante dos jornais que cobriam a moda e as lojas cariocas; e o mesmo ocorria com os cortes de fazendas das mais variadas cores.

O armazém de Wallerstein e Masset recebeu pelo último paquete estes fascinadores vestidos de escomilha bordados de palha, também os de acrophone, gaze, e os de cassa de seda, que efetivamente são uma grande novidade. É preciso vê-los, assim como toda a variedade de primorosas fazendas que lhes chegarão, para admirar a perfeição do trabalho e o apurado capricho desses artefactos franceses. [...]

Os cortes de seda - Médicis, Dubarry, Albanie, Pomone, Esmeralda, Bosphore, Pérolas do Brasil, Montpensier, Val d’or, são inimitáveis e lindíssimos. [...]

As guarnições que receberão de joias de esmalte, trabalhado sobre aço, são o primor da arte: as pulseiras, os alfinetes, e as correntes de

${ }^{46}$ Richard Graham. Grã Bretanha e o início da modernização no Brasil. 1850-1914. Trad. port. São Paulo: Brasiliense, 1973, apêndice C. 
relógio encerrarão uma galanteria e delicadeza de trabalho a toda prova! [... $]^{47}$

$\mathrm{O}$ artigo era assinado por Christina, uma jornalista carioca, que tinha uma coluna semanal de comentários sobre a moda. Seu texto nos dá pistas importantes de como se vestir com elegância na época. Como se pode ver no texto acima, os tecidos mais valorizados eram franceses, coloridos e de seda, para as toilettes de grande baile. Rendas, luvas, veludos, tiaras, joias de esmaltes eram os complementos ideais. E se os tecidos fossem comprados no armazém do Wallerstein, melhor - sinal de distinção da dama. $^{48}$

Entretanto, se os tecidos franceses eram mais valorizados, as mercadorias inglesas de algodão mais numerosas, indicando a profusão desses tecidos entre a população, provavelmente usados para roupas do cotidiano e de diferentes classes sociais.

Tabela de exportações de tecidos e vestuário $(1850-1889)^{49}$

\begin{tabular}{|l|r|r|r|r|r|r|r|r|}
\hline $\begin{array}{l}\text { Ano/ } \\
\text { mercadoria }\end{array}$ & $1850-1854$ & $1855-1859$ & $1860-1864$ & $1865-1869$ & $1870-1874$ & $1875-1879$ & $1880-1884$ & $1885-1889$ \\
\hline $\begin{array}{l}\text { Tecidos de } \\
\text { algodão }\end{array}$ & 8.689 .288 & 10.305 .183 & 12.886 .034 & 17.010 .971 & 15.624 .589 & 14.739 .775 & 15.751 .779 & $\begin{array}{r}13.970 .172 \\
\text { Libras }\end{array}$ \\
\hline Lã & 1.859 .432 & 2.053 .246 & 1.418 .931 & 2.563 .818 & 2.210 .090 & 2.082 .015 & 1.578 .747 & 1.571 .894 \\
\hline Linhos & 1.024 .063 & 1.246 .526 & 1.203 .832 & 1.970 .607 & 1259.871 & 842.980 & 617.608 & 493.984 \\
\hline Sedas & 112.947 & 178.450 & 102.014 & 67.789 & 181.263 & 74.832 & 46.844 & ------- \\
\hline Vestuário & 234.409 & 300.083 & 324.490 & 594.287 & 499.959 & 334.837 & 417.197 & 383.327 \\
\hline
\end{tabular}

${ }^{47}$ Jornal das Senhoras, 2 de maio de 1852, p. 19.

${ }^{48}$ As assinaturas do Jornal das Senhoras podiam ser feitas no próprio armazém de Wallerstein, que ficava na rua do Ouvidor, 70 ou nas lojas de Desmarais, rua do Ouvidor, 86, e Mongis, rua do Ouvidor, 87. Também se podia assinar o semanário na gráfica que o imprimia, a Typographia de Santos e Silva Junior, na rua da Carioca, 32.

${ }^{49}$ Richard Graham. Grã Bretanha e o início da modernização no Brasil. 1850-1914. Trad. port. São Paulo: Brasiliense, 1973, apêndice C. 
Como vimos, ao longo do século XIX, a moda passava pela comercialização dos tecidos, muito mais do que pela produção em escala industrial de roupas, que era feita em casa ou em modistas e alfaiates. Ao longo do século, ocorreu uma passagem sutil, mas irreversível, em direção à industrialização das roupas, que começou com a abertura de ateliês de costura, comandados por costureiras especialistas, e alfaiates. Por fim, grandes lojas de varejo ou grandes ateliês passaram a vender roupas prontas ou semiprontas feitas por pequenas costureiras free-lancers. Dessa forma, veremos que a máquina de costura teve um papel primordial nessa mudança, uma vez que, conforme se popularizaram, uma mão-de-obra feminina especializada foi se formando e abastecendo o mercado de roupas prontas ou semiprontas.

Esse movimento de transformação de tecidos em roupas prontas de certa maneira começou em Paris, nas primeiras décadas do século XIX. O escritor Émile Zola, em seu romance $O$ paraíso das damas, descreveu um mundo comercial que girava em torno da compra e venda de tecidos. O protagonista do livro não era uma personagem, mas uma loja, um magazine - e uma nova maneira de vender. A fachada da grande loja, que dava para a praça Gaillon e continuava ao longo da rue Michodière e da rue Neuve SaintAugustin, impressionava os passantes. Nas vitrines, composições delicadas dos mais diversos tecidos e das mais diferentes cores, despencavam em cascatas. Na primeira cena, Denise, a pobre moça do interior, que chega à Paris com os irmãos, via admirada o poder daquela loja:

Enquadrando a soleira da porta, pendiam, em faixas estreitas, tiras de peles para adornar vestidos: o cinza fino das costas dos esquilos, a neve pura do ventre dos cisnes, os pelos de coelho, do falso arminho, e da falsa marta. Além disso, em estojos dispostos em mesa à entrada, junto de uma pilha de cortes avulsos, acumulavam-se acessórios anunciados por um nada: luvas e xales de lã tricotados, toucas, coletes, 
todo um mostruário de inverno em cores vivas, tricotadas, estampadas, matizadas, listradas ou salpicadas de um vermelho sangrento. [...] Era uma exposição gigante de feira livre, a loja parecia estar explodindo e lançando todo o excesso para a rua. ${ }^{50}$

Ao longo do romance, Denise vai se tornar vendedora e conhecer todos os segredos de uma nova modalidade de venda capitalista, uma loja que não media esforços para seduzir as mulheres com uma infinidade de produtos, dispostos com os variados preços. Luvas, chapéus, mantôs, roupinhas para crianças, lenços e bengalas para homens. Tudo se achava na loja. A cada liquidação semestral, o magazine apostava todas suas fichas. E, a cada liquidação, a loja se tornava mais forte e mais rica. Tanto Denise aprende a se comportar nesse mundo capitalista que, ao longo dos anos, galga posições de prestígio rapidamente dentro da loja até assumir a de gerente de vendas da seção feminina. Nos anos em que estava lutando para aprender a vender, a seção de Denise foi a que a mais mudou na loja - de tecidos e assessórios, passou a vender também roupas semiprontas, ajustadas de acordo com o corpo de cada cliente. ${ }^{51}$

Desde o século XVIII, os tecidos, assim como aconteceria com as roupas um século mais tarde, eram regulados pelas estações do ano. No verão europeu, estampas pequenas, com flores miúdas, tons pastéis. No inverno, veludos e lãs, em tons cinza, preto, azul, bordô. Um dos maiores costureiros ingleses de todos os tempos, Gaston Worth, resumiu no trecho citado abaixo o que deveria ser usado por cada mulher nos tempos de Luís XIV. As proibições e deveres no uso dos tecidos pelas mulheres ainda estavam ligados às diferentes leis suntuárias do século XVIII, mas a permanência do que deveria ou não ser usado foi impressionante e perdurou ao longo do século XIX, mesmo quando os vestidos prontos já dominavam a moda.

\footnotetext{
${ }^{50}$ Émile Zola. O paraíso das damas. Trad. port. São Paulo: Estação Liberdade, 2007, p. 33.

${ }^{51}$ Émile Zola. O paraíso das damas. Trad. port. São Paulo: Estação Liberdade, 2007.
} 
Os tecidos eram classificados segundo as estações: para o inverno, veludos, cetins, ratinas $^{52}$, percal $^{53}$; para o verão, tafetás ${ }^{54}$; para o outono e a primavera, os percais leves. Até as rendas variavam de acordo com as estações. O ponto inglês, embora não fosse mais quente que as malinas ${ }^{55}$, já não podia aparecer antes das festas de Longchamp. As peles eram usadas a partir do dia de Todos os Santos; na Páscoa, abandonavam-se os regalos, sendo proibido retomá-los mesmo que nevasse. Assim que uma mulher chegava aos 40 anos, já não podia se apresentar na corte sem um coque coberto por uma renda preta. $^{56}$

No Brasil, as modas seguiam o que se usava em Paris ou na Inglaterra. E, na Inglaterra ou em Paris, o hábito de se mudar de tecido e, consequentemente, de roupas conforme a estação do ano começou primeiramente com as mudanças de tecidos. Esse foi o padrão que ficou estabelecido para as lojas, costureiras e alfaiates desde o fim do século XVIII. As mudanças sazonais da moda, magas maiores ou menores, estampas, babados, foram apenas um passo que pareceu perfeitamente natural, dadas das mudanças que já vinham ocorrendo com os tecidos. Os armazéns e lojas de fazendas anunciavam a grande variedade de tecidos, para todas as estações, como podemos ver abaixo, num anúncio de 1861, publicado no Almanaque Laemmert. ${ }^{57}$

\footnotetext{
${ }^{52}$ Ratina: tecido felpudo de lã. Em francês, "ratine". Ver "Dicionário de tecidos antigos" no apêndice desta tese.

${ }^{53}$ Percal: tecido hoje usado em roupas de cama, extremamente macio, feito com fio penteado de algodão.

${ }^{54}$ Tafetá é um tecido brilhante e nobre fabricado com fios de seda. É aplicado na confecção de roupas mais finas e no revestimento de acessórios femininos.

${ }^{55}$ Malina é uma renda trabalhada, muito fina, feita na Bélgica.

${ }^{56}$ Gaston Worth. La couture et la confection dês vêtements de femmes. Paris: Chaix, 1895. Tradução minha.

57 Almanaque Laemmert, 1861. 〈http://brazil.crl.edu/bsd/bsd/almanak/al1861/00001428.html>. Pesquisado em 16/12/2011.
} 


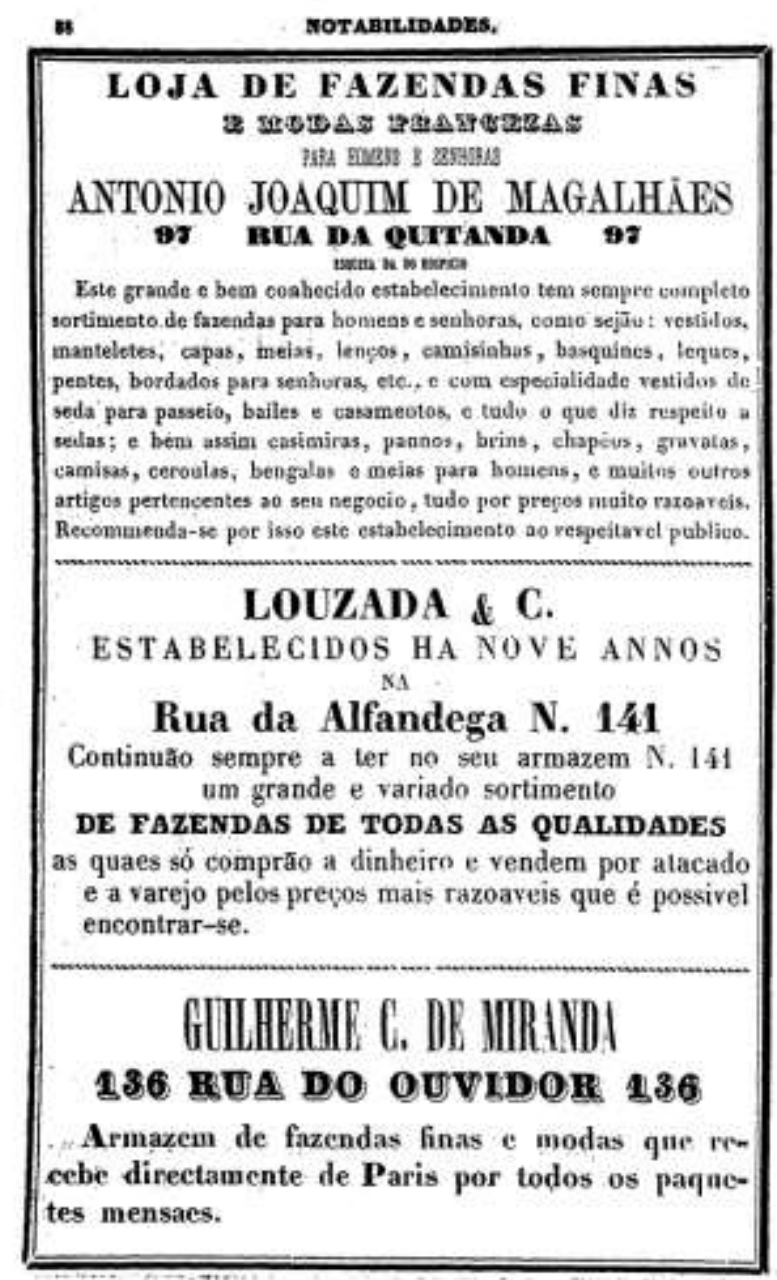

Anúncio de fazendas de 1861 no Almaque Laemmert

O historiador brasileiro Wanderley Pinho indicou a década de 1860 como aquela em que as brasileiras começaram a vestir os figurinos de acordo com a estação daqui, dos trópicos - e não seguir à risca o que se usava na Europa, numa total inversão de estações. Mas, mesmo na Europa, a ideia de ter estações para roupas era recente e estava se difundindo aos poucos. "Cerca de 1860", diz Pinho, “é que começam a respeitar-se as estações, desobedecendo um pouco a anterior imitação absoluta". 59

\footnotetext{
${ }^{58}$ Didier Grumbach. Histórias da moda. Trad. port. São Paulo: Cosac e Naify, 2009, p. 15-19.

${ }^{59}$ Wanderley Pinho. Salões e damas do segundo império. São Paulo: Livraria Martins Editora, 1970.
} 
Christina, a jornalista carioca do Jornal da Moda, mencionou diferentes tecidos que chegavam ao porto do Rio de Janeiro: "Os cortes de seda - Médicis, Dubarry, Albanie, Pomone, Esmeralda, Bosphore, Pérolas do Brasil, Montpensier, Val d’Or, são inimitáveis e lindíssimos. [...]". ${ }^{60}$ Se a moda nessa época passava pelas mudanças de tecidos era, portanto, a variedade de tecidos que chegavam ao porto do Rio de Janeiro que dava a dimensão de como esses panos eram usados no dia-a-dia.

Nos volumes do Estatística do comércio marítimo do Brasil do exercício de 1871$1872^{61}$ pode-se constatar os diferentes tipos de tecidos que chegam ao país no período: algodão, lã, linho e sedas. E também os principais países exportadores, parceiros comerciais importantes do Brasil no período: Grã-Bretanha, Alemanha, França, Estados Unidos, Itália, Portugal, Argentina e Paraguai.

Pelas estatísticas do comércio marítimo, podemos perceber o movimento do capitalismo mundial. Chegavam ao Rio de Janeiro, dentro de todo o rol de mercadorias elencadas, principalmente tecidos, vindos da Grã-Bretenha em plena Revolução Industrial. De todos os tecidos importados, o algodão era de longe o mais utilizado no cotidiano, em diferentes formas. Do algodão em fio simples e trapos importou-se, em 1870-1873, 61.765 quilos que valiam 59:469\$000 contos de réis. Nenhum outro país conseguiu chegar nem perto desses algodões ingleses, o segundo colocado sendo a Alemanha, com 2.606 quilos a um valor de 1:815\$000 contos de réis. ${ }^{62}$

A Grã-Bretanha aparece em primeiro lugar em quase todas as tabelas de importação de tecidos. Desta maneira, vieram para o Rio de Janeiro em 1872-73, 255.057 mil quilos de algodão em caroço ou em rama, o equivalente a 532:199\$000

${ }^{60}$ Jornal das Senhoras, domingo, 2 de maio de 1852, p. 19.

${ }^{61}$ Mapa geral das mercadorias importadas e despachadas para consumo anos de 1871-1872, p. 17 (ver o arquivo no site http://memoria.nemesis.org.br/. Acesso em 20 de agosto de 2010).Rio de Janeiro, Typografia Nacional, 1878.

${ }^{62}$ Mapa geral das mercadorias importadas e despachadas para consumo anos de 1871-1872, p. 17 (ver o arquivo no site <http://memoria.nemesis.org.br/>. Acesso em 20 de agosto de 2010). 
contos de réis, o que nos dá uma pista de que, provavelmente, esse algodão foi processado por aqui mesmo. Ainda no item algodão, vieram 6.280.111 quilos ou 9.336.325\$000 contos de réis de panos de algodão cru, curado e lavrado, principal item para a confecção de roupas dos mais variados tipos. ${ }^{63}$

\begin{tabular}{|l|r|r|}
\hline \multicolumn{3}{|l|}{ Tecido } \\
\hline Algodão em caroço, rama, etc. \\
\hline País & Quant. (Kg) & Valor \\
\hline Alemanha & 4.496 & $8: 844 \$ 000$ \\
\hline Bélgica & 411 & $822 \$ 000$ \\
\hline Confed. Argentina & 947 & $1: 894 \$ 000$ \\
\hline Estados Orientais & 800 & $1: 000 \$ 000$ \\
\hline Estados Unidos & 40 & $81 \$ 000$ \\
\hline França & 20.954 & $40: 451 \$ 000$ \\
\hline Grã-Bretanha & 255.057 & $532: 199 \$ 000$ \\
\hline Portugal & 2.941 & $5: 744 \$ 000$ \\
\hline Países indeterminados & 2548 & $5: 060 \$ 000$ \\
\hline Total & 288.194 & \\
\hline
\end{tabular}

Vieram para o país alguns itens de decoração feitos com algodão, como tapetes, oleados e alcatifas. A quantidade total era de 123.363 quilos, oriundos principalmente da Grã-Bretanha. Esses mesmo itens de decoração aparecem com diferentes tipos de fios, como algodões, linhos e lãs. A maior quantidade vinda para o Brasil era de linho, 48.636 quilos, importados majoritariamente da Grã-Bretanha (mais de 40 mil quilos). A quantidade de tapetes em lã é de 39.778 quilos, com a maioria da produção também vinda da Grã-Bretanha, mais de 33 mil quilos. Os tapetes e similares de algodão somaram 34.948 quilos.

${ }^{63}$ Mapa geral das mercadorias importadas e despachadas para consumo anos de 1871-1872, p. 17 (ver o arquivo no site <http://memoria.nemesis.org.br/>. Acesso em 20 de agosto de 2010). 


\begin{tabular}{|l|r|r|}
\hline \multicolumn{3}{|l|}{ Tecido } \\
\hline Alcatifas, tapetes e oleados de algodão. \\
\hline País & Quant. $(\mathrm{Kg})$ & Valor \\
\hline Alemanha & 8.806 & $12: 918 \$ 000$ \\
\hline Bélgica & 4.798 & $7: 987 \$ 000$ \\
\hline Estados Orientais & 180 & $285 \$ 000$ \\
\hline Estados Unidos & 755 & $881 \$ 000$ \\
\hline França & 6.869 & $8: 222 \$ 000$ \\
\hline Grã-Bretanha & 13.540 & $18: 038 \$ 000$ \\
\hline Total & 34.948 & \\
\hline
\end{tabular}

\begin{tabular}{|r|r|r|}
\hline \multicolumn{3}{|l|}{ Tecido } \\
\hline Alcatifas, tapetes, e oleados de linho \\
\hline País & $\begin{array}{r}\text { Quant. } \\
(\mathrm{Kg})\end{array}$ & Valor \\
\hline Alemanha & 730 & $817 \$ 000$ \\
\hline Bélgica & 242 & $161 \$ 000$ \\
\hline Estados Orientais & 50 & $83 \$ 000$ \\
\hline Estados Unidos & 435 & $415 \$ 000$ \\
\hline França & 2.744 & $2: 671 \$ 000$ \\
\hline Grã-Bretanha & 44.435 & $31: 804 \$ 000$ \\
\hline Total & 48.636 & \\
\hline
\end{tabular}




\begin{tabular}{|l|r|r|}
\hline Tecido \\
\hline Alcatifas, tapetes e oleados de lã & \\
\hline País & $\begin{array}{r}\text { Quant. } \\
(\mathrm{Kg})\end{array}$ & Valor \\
\hline Alemanha & 1.006 & $2.815 \$ 000$ \\
\hline Bélgica & 840 & $2: 658 \$ 000$ \\
\hline Confed. Argentina & 130 & $520 \$ 000$ \\
\hline Estados Orientais & 291 & $904 \$ 000$ \\
\hline França & 2.889 & $11: 238 \$ 000$ \\
\hline Grã-Bretanha & 33.997 & $112: 210 \$ 000$ \\
\hline Portugal & 122 & $488 \$ 000$ \\
\hline Países indeterminados & 503 & $5: 476 \$ 000$ \\
\hline Total & 39.778 & \\
\hline
\end{tabular}

Ao longo de todo o século XIX, tanto a musselina, como suas irmãs, a cassa, o filó ou o barége, reinaram como os tecidos mais utilizados tanto na produção de roupas como em outros itens de decoração. Todos são uma espécie de tecido de algodão muito fino e transparente. ${ }^{64}$ Podiam ser usados como cortinas ou mosqueteiros, como vemos na descrição de Theodor von Leithold e Ludwig von Rango, que estiveram no Rio em 1819: "Contra esses insetos usam-se mosquiteiros, cortinas de musselina verde ou de gaze, em que eles conseguem às vezes penetrar por algum buraco, tornando-se, então, nesse recinto fechado ainda mas irritantes $[\ldots . .]^{\prime 6}{ }^{65}$

Mas também eram muito usados em como parte de "roupas de baixo", adornos para espartilhos, corpetes, roupões, saias e saiotes. Algumas vezes, esse tipo de roupa podia ser usada como um vestimenta informal, dentro de casa, em que visitas mais íntimas podiam ser recebidas para um chá. Machado de Assis descreveu uma roupa desse tipo em A mão e a luva: "O roupão - de musselina branca - finamente bordado,

\footnotetext{
${ }^{64}$ Ver o "Pequeno dicionário de tecidos antigos" em anexo.

${ }^{65}$ Theodor von; Leithold e Ludwig von. Rango. O Rio de Janeiro visto por dois prussianos em 1819. Trad. port. São Paulo, Companha Editora Nacional, 1966. p. 39
} 
não deixava ver toda a graça do talhe [...]. Todo o colo ia coberto até o pescoço onde o roupão era preso por um pequeno broche de safira. Um botão, do mesmo mineral, fechava em cada pulso as mangas estreitas e lisas, que rematavam em folhos de renda". 66

Nas tabelas de importação, o barege, a musselina, a cassa e o filó aparecem com valores significativos, ainda que a quantidade de quilos não seja especificada, talvez por serem tecidos muito finos. A Grã-Bretanha aparece novamente em primeiro lugar, com quase 2,9 mil contos de réis. Para termos uma ideia de quanto isso representava no cotidiano do século XIX, podemos ver o exemplo de quanto custava um carro completo e novo, com seis cavalos, em 1876: cerca de 1:800\$000. ${ }^{67}$ Assim, a quantidade de musselina e equivalentes que chegou ao Rio de Janeiro no período podia comprar cerca de 1.609 carros. Ou podemos também fazer outra comparação e ver o quanto isso valia em escravos. Em Areias, interior paulista, um escravo, homem, em 1870, valia 1:846\$000. Desta forma, o valor de cerca de 80 escravos podiam comprar a totalidade de musselina, barege, cassa e filó exportada para o Brasil pela Alemanha no período, ou seja, 148:947\$000. ${ }^{68}$

\footnotetext{
${ }^{66}$ Joaquim Maria Machado de Assis. A Mão e a Luva (1874). São Paulo, Editora Cultrix, 1960. p. 191.

${ }^{67}$ Maria Luzia Ferreira de Oliveira recuperou o inventário de Antonio Joaquim da Silva no seu livro Entre a casa e o armazém. São Paulo: Alameda Casa Editorial, 2005, p. 47.

${ }^{68}$ Para um estudo sobre o preço dos escravos, ver o livro de José Flávio Motta, Escravos daqui, dali e de mais além: o tráfico interno de cativos na expansão cafeeira paulista. São Paulo: Alameda Casa Editorial, 2012, p. 189.
} 


\begin{tabular}{|l|l|r|}
\hline \multicolumn{3}{|l|}{ Tecido } \\
\hline Bareges, musselinas, cassas, filós, etc. \\
\hline País & Quant. (Kg) & Valor \\
\hline Alemanha & & $148: 947 \$ 000$ \\
\hline Bélgica & & $33: 025 \$ 000$ \\
\hline Confed. Argentina & & $7: 789 \$ 000$ \\
\hline Estados Orientais & & $4: 900 \$ 000$ \\
\hline Estados Unidos & & $13: 877 \$ 000$ \\
\hline França & & $587: 013 \$ 000$ \\
\hline Grã-Bretanha & & $2.896: 252 \$ 000$ \\
\hline Itália & & $1: 926 \$ 000$ \\
\hline Paraguai & & $467 \$ 000$ \\
\hline Portugal & & $1: 806 \$ 000$ \\
\hline Países indeterminados & & $76: 145 \$ 000$ \\
\hline Total & & $4.451: 757 \$ 000$ \\
\hline
\end{tabular}

Chegaram também da Grã-Bretanha itens como 10.390 quilos de belbutes, belbutinas, bombasinas de algodão, valendo 41:580\$000 contos de réis. Belbutes e belbutines eram uma espécie de tecido de algodão aveludado usado em vestidos, camisas, forros de coletes ou roupas de baixo, algumas vezes como um ornamento, outras como tecido para uma roupa completa. ${ }^{69}$

Assim, o belbute apareceu em vários inventários do século XVIII, como no de José Ayres Gomes, inconfidente, em 1791, e nos dá a ideia de sua riqueza na época. Ele possuía: "Fraque de baetão cor-de-rosa seca forrado de baeta azul. Casaca de chita amarela com sua veste sem mangas, tudo forrado de tafetá verde. Veste de belbute branco, e outra de fustão branco. Calção de pano amarelo, com ligas de galão de ouro. 6 camisas, quatro de bretanha e duas de linho [...]". ${ }^{70}$ Já no começo do século XIX, John Luccock observava, no sul, que os homens usavam um poncho "[...] frequentemente

\footnotetext{
${ }^{69}$ Ver "Pequeno dicionário de tecidos antigos" no anexo desta tese.

${ }^{70}$ Autos da Devassa da Inconfidência Mineira (1789-1791). vol. V, Rio de Janeiro: Ministério da Educação/ Biblioteca Nacional, 1936. p. 481
} 
orlado de belbute à volta toda e forrado de baeta de tonalidade alegre; quando de algodão, enfeitam-no com franjas de cores variegadas, entretecidas com a própria peça, e é artigo de manufatura sul-americana". ${ }^{71}$

Já as bombasinas, ou bombazines como são conhecidos hoje em dia, são uma espécie de tecido de veludo de seda ou algodão com sulcos muito profundos na camada de uso no sentido da teia. É um tipo de tecido bastante resistente, de amplo uso, tanto no vestuário masculino como no feminino e também na decoração da casa. ${ }^{72}$

\begin{tabular}{|l|r|r|}
\hline Tecido \\
\hline Bareges, belbutinas, bombasinas do algodão \\
\hline País & Quant. $(\mathrm{Kg})$ & Valor \\
\hline Alemanha & 1.936 & $4: 625 \$ 000$ \\
\hline Estados Orientais & 4.820 & $5: 499 \$ 000$ \\
\hline França & 321 & $918 \$ 000$ \\
\hline Grã-Bretanha & 10.390 & $41: 580 \$ 000$ \\
\hline $\begin{array}{l}\text { Países } \\
\text { indeterminados }\end{array}$ & 1577 & $3: 345 \$ 000$ \\
\hline Total & 19.044 & \\
\hline
\end{tabular}

Foram importados também brins, cassinetas, castores e metins da Grã-Bretanha num total de 1.610.607 quilos, que valiam 224:907\$000 contos de réis. O brim, tecido mais pesado, podia ser usado em calças, paletós, aventais ou roupas de trabalho. ${ }^{73}$

Brim era um tecido antigo, conhecido e usado largamente pelo menos desde o começo do século XVIII. O Dicionário Raphael Bluteau dá como definiçãa de brim o seguinte texto: "Pano de linho cru, fabricado em Hamburgo, e os há de duas castas; uns são muito tapados e fortes e servem para velas menores dos navios, como Joanetes,

\footnotetext{
${ }^{71}$ John Luccock. Notas sobre o Rio de Janeiro e partes meridionais do Brasil (1808-1818). Trad. port. São Paulo, Belo Horizonte, EDUSP/ Itatiaia Editora, 1975. p. 127.

${ }^{72}$ Ver "Pequeno dicionário de tecidos antigos" no anexo desta tese.

${ }^{73}$ Ver "Pequeno dicionário de tecidos antigos" no anexo desta tese.
} 
Cutelos e etc. os outros são estreitos, e de várias cores, e servem para forros de vestidos. Vide tomo 2 do vocabulário". ${ }^{74}$ A outra definição dizia que brim era o mesmo que "lençaria, da qual há muitas castas. Brim ordinário, brim fino, largo, grosso, curado e etc". 75

A ideia de que o brim era um tecido fabricado primordialmente em Hamburgo, na Alemanha, era corrente no século XIX. Por isso, em 1881, Aluísio Azevedo, em $O$ mulato, descreve um personagem da seguinte maneira: "Viam-se [...] capitalistas [...] por debaixo do chapéu de pelo [...]. Calça de brim de Hamburgo". ${ }^{76}$ Para os brasileiros, especialmente os do Rio de Janeiro, ser de Hamburgo era uma espécie de propaganda de um bom produto, conhecido e fabricado há tempos por uma cidade industrial. Ser capitalista também contava como propaganda, já que a indumentária que os empresários passaram a usar remetiam às cidades industrializadas da Europa.

As cassinetas, castores e metins ${ }^{77}$ eram tecidos mais finos - o metim uma espécie de algodão cardado usado para forros de vestidos, e as cassinetas, tecido fino e leve, geralmente usado para vestidos, saias e camisas. Os castores eram usados basicamente em chapéus de várias espécies.

\footnotetext{
${ }^{74}$ Dicionário Rapahel Bulteau: <http://www.ieb.usp.br/catalogo_eletronico/>, consulta 11/12/2012.

${ }^{75}$ Dicionário Raphael Bluteau: 〈http://www.ieb.usp.br/catalogo eletronico/>, consulta 11/12/2012.

${ }^{76}$ Aluísio. Azevedo. O Mulato. São Paulo, Martins Editora/ Instituto Nacional do Livro/ MEC, 1975. p. 34.

${ }^{77}$ Ver "Pequeno dicionário de tecidos antigos", no anexo desta tese.
} 


\begin{tabular}{|l|r|r|}
\hline \multicolumn{3}{|l|}{ Tecido } \\
\hline Brins, cassinetas, castores, metins, etc. \\
\hline País & Quant. & Valor \\
\hline Alemanha & 113.645 & $224: 907 \$ 000$ \\
\hline Bélgica & 73.393 & $153: 186 \$ 000$ \\
\hline China & 181 & $592 \$ 000$ \\
\hline Confed. Argentina & 1.590 & $3: 475 \$ 000$ \\
\hline Estados Orientais & 7.881 & $15: 770 \$ 000$ \\
\hline Estados Unidos & 51.407 & $104: 348 \$ 000$ \\
\hline França & 150.537 & $327: 756 \$ 000$ \\
\hline Grã-Bretanha & 1.200 .109 & $2.476: 599 \$ 000$ \\
\hline Portugal & 1.963 & $3: 946 \$ 000$ \\
\hline Países indeterminados & 9.901 & $39: 472 \$ 000$ \\
\hline Total & 1.610 .607 & \\
\hline
\end{tabular}

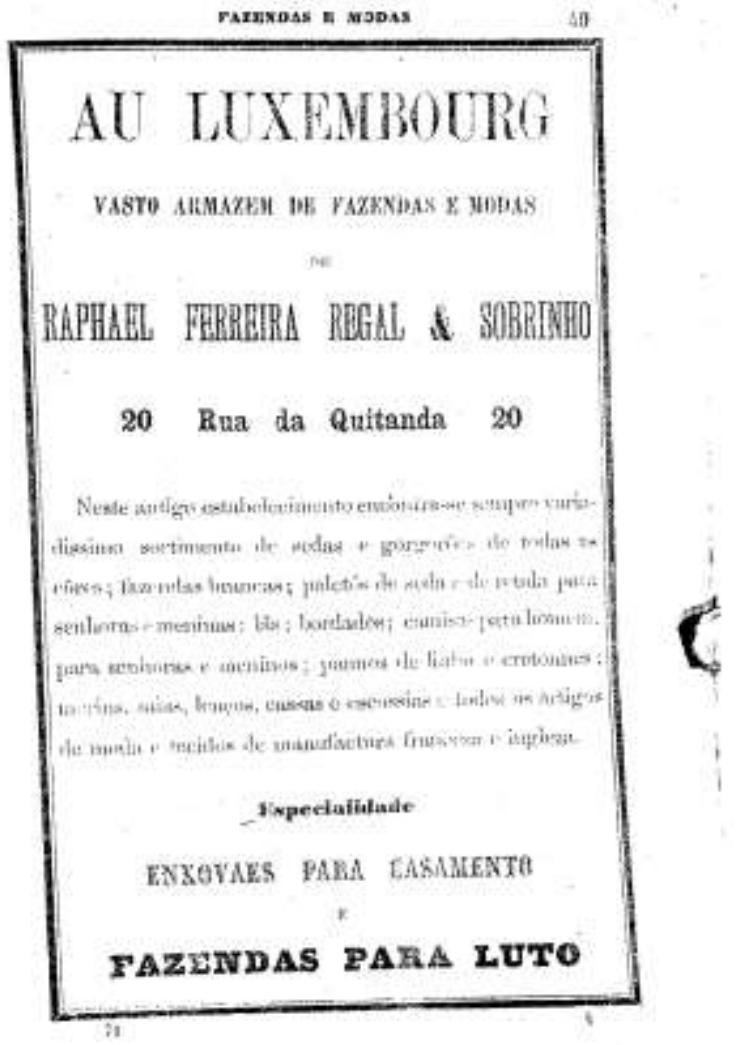

Anúncio do Almanaque Laemmert em $1871^{78}$

${ }^{78}$ Consultado em 26/01/2012, <http://brazil.crl.edu/bsd/bsd/almanak/al1871/00001303.html〉. 
Na rua da Quitanda, 20, Raphael Ferreira Regal vendia na sua loja Au Luxemburg um "variadissimo sortimento de sedas e gorgurões de todas as cores, fazendas brancas, paletós de seda e da renda para senhoras e meninas; lãs, bordados, camisas para homens, para senhoras e para meninos, panos de linho e cretones, morins, saias, lenços, cassas e escoceses e todos os artigos de moda e tecidos de manufatura francesa e inglesas." ${ }^{, 79}$ Não era uma loja na rua no Ouvidor, portanto devia vender produtos mais em conta - destacam-se os itens para o vestuário do cotidiano. Ao seu lado estava a loja de Norberto José da Silva Coelho, A figura risonha, no 26, com a miscelânia de artigos característica da primeira metade do século XIX, "miudezas de armarinho, modas, fazendas e ferragens".

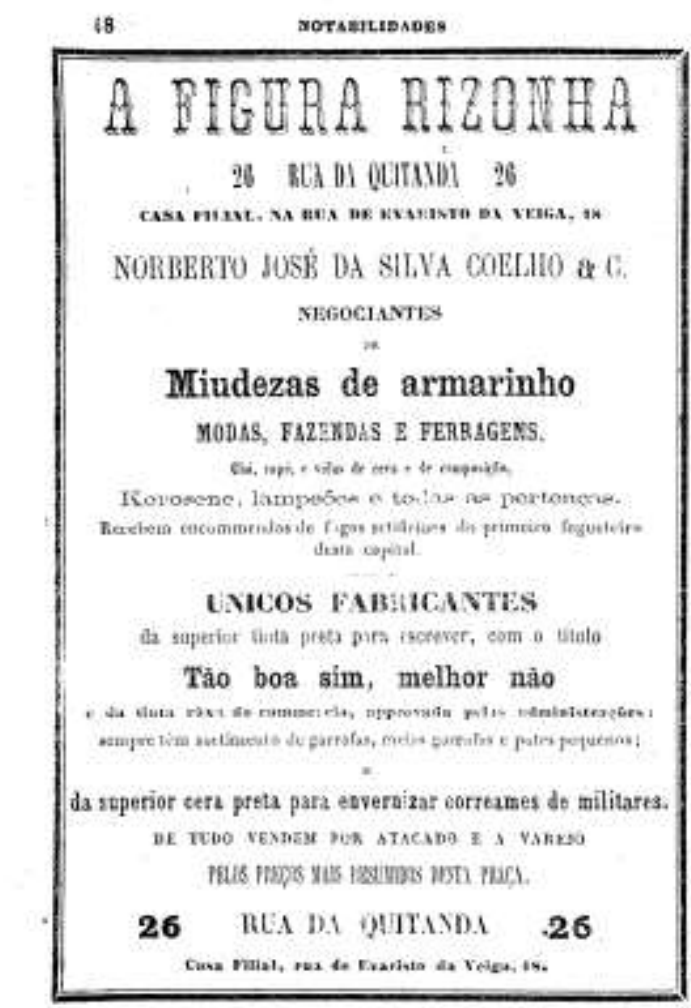

Almanaque Laemmert 1871, seção de Notabilidades ${ }^{80}$.

\footnotetext{
${ }^{79}$ Consultado em 26/01/2012, <http://brazil.crl.edu/bsd/bsd/almanak/al1871/00001303.html .

${ }^{80}$ Almanaque Laemmert, 1871, 〈http://brazil.crl.edu/bsd/bsd/almanak/al1871/00001302.html〉, consulta em 26/12/2012.
} 
Os tecidos de algodão eram um dos principais produtos da revolução industrial inglesa. Isso se traduzia numa produção excepcional. Alice Canabrava, para o mesmo período, dá os números da produção de tecidos na Inglaterra. "Em 1861, existiam [na Inglaterra] 3.000 fábricas de tecidos, as quais possuíam 11.250 fusos e davam trabalho a cerca de 600.000 operários". ${ }^{81}$ A Inglaterra, portanto, era a maior exportadora de tecidos do mundo, com cerca de 2,8 bilhões jardas de tecido de algodão, que saíam de seus portos para abastecer, justamente, mercados como o brasileiro. Saíam também dos portos ingleses outros produtos, como o fio simples e o fio torcido de algodão. Por isso, se pode entender que, entre 1871 e 1872, chegaram ao porto do Rio, 288.194 quilos de algodão em caroço e rama, uma quantidade que certamente era processada aqui.

\begin{tabular}{|l|r|r|}
\hline Tecido \\
\hline Algodão em caroço, rama, etc. \\
\hline País & Quant. $(\mathrm{Kg})$ & Valor \\
\hline Alemanha & 4.496 & $8: 844 \$ 000$ \\
\hline Bélgica & 411 & $822 \$ 000$ \\
\hline Confed. Argentina & 947 & $1: 894 \$ 000$ \\
\hline Estados Orientais & 800 & $1: 000 \$ 000$ \\
\hline Estados Unidos & 40 & $81 \$ 000$ \\
\hline França & 20.954 & $40: 451 \$ 000$ \\
\hline Grã-Bretanha & 255.057 & $532: 199 \$ 000$ \\
\hline Portugal & 2.941 & $5: 744 \$ 000$ \\
\hline Países indeterminados & 2548 & $5: 060 \$ 000$ \\
\hline Total & 288.194 & \\
\hline
\end{tabular}

A quantidade e, de certa forma, a variedade de tecidos importados nos dá a ideia não apenas do mercado do Rio de Janeiro, que também reexportava uma parte para outras regiões do Brasil, mas também da quantidade de roupas usadas no século XIX.

${ }^{81}$ Alice Canabrava. O desenvolvimento da cultura do algodão na província de São Paulo (18611875). São Paulo: Edusp, 2011, p. 75. 


\begin{tabular}{|l|l|r|}
\hline \multicolumn{3}{|l|}{ Tecido } \\
\hline Obras de algodão não especificadas \\
\hline País & Quant. $(\mathrm{Kg})$ & Valor \\
\hline Alemanha & & $52: 304 \$ 000$ \\
\hline Bélgica & & $9: 473 \$ 000$ \\
\hline Confed. Argentina & & $544 \$ 000$ \\
\hline Estados Orientais & & $8: 078 \$ 000$ \\
\hline Estados Unidos & & $821 \$ 000$ \\
\hline França & & $120: 535 \$ 000$ \\
\hline Grã-Bretanha & & $95: 352 \$ 000$ \\
\hline Italia & & $1: 882 \$ 000$ \\
\hline Portugal & & $2: 879 \$ 000$ \\
\hline Países indeterminados & & $6: 295 \$ 000$ \\
\hline Total & \\
\hline
\end{tabular}

Não chegaram aos portos cariocas apenas algodão. ${ }^{82}$ Nos navios que desembarcavam suas mercadorias, vieram também linhos, sedas e lãs, conforme a classificação que o fiscal usou para taxar esses produtos nos Mapas Estatísticos. Entre os linhos, 88.510 quilos também vieram sem tratamento, em "bruto" ou "asseado" ou "restelado", que provavelmente seriam trabalhados aqui. Mais uma vez, a Grã-Bretanha, com mais da metade da produção, 42.164 quilos, liderava os países exportadores, seguido pela França, com 19.832 quilos. Ainda assim, o linho francês valia mais do que o inglês, 32:967\$000 réis.

${ }^{82}$ Mapa geral das mercadorias importadas e despachadas para consumo anos de 1871-1872, $\mathrm{p}$. 17 (ver o arquivo no site http://memoria.nemesis.org.br/. Acesso em 20 de agosto de 2010). 


\begin{tabular}{|l|r|r|}
\hline Tecido \\
\hline Linho em bruto, assedado, restelado, etc. \\
\hline País & Quant. $(\mathrm{Kg})$ & Valor \\
\hline Alemanha & 458 & $298 \$ 000$ \\
\hline Confed. Argentina & 1.026 & $298 \$ 000$ \\
\hline Estados Orientais & 1.037 & $52 \$ 000$ \\
\hline Estados Unidos & 6.420 & $321 \$ 000$ \\
\hline França & 19.832 & $32: 967 \$ 000$ \\
\hline Grã-Bretanha & 42.164 & $24: 702 \$ 000$ \\
\hline Hespanha & 16 & $8 \$ 000$ \\
\hline Itália & 8.029 & $1: 745 \$ 000$ \\
\hline Paraguai & 184 & $9 \$ 000$ \\
\hline Portugal & 9.197 & $9: 534 \$ 000$ \\
\hline Países indeterminados & 147 & $12 \$ 000$ \\
\hline Total & 88.510 & \\
\hline
\end{tabular}

Chegaram também linhas e linho em fio torcido, para abastecer a grande quantidade de armarinhos, casas de bordados e armazéns que vendiam produtos para as costuras de casa e de pequenos ateliês. Na tabela abaixo, vemos que foram 59.447 quilos, a maioria, mais uma vez, da Grã-Bretanha, 29.567 quilos.

\begin{tabular}{|c|c|c|}
\hline Tecido & & \\
\hline $\begin{array}{l}\text { Linho em fio torcido o } \\
\text { qualidade }\end{array}$ & as de qu & quer \\
\hline País & $\begin{array}{r}\text { Quant. } \\
(\mathrm{Kg})\end{array}$ & Valor \\
\hline Alemanha & 6.036 & $6: 029 \$ 000$ \\
\hline Bélgica & 3.904 & $7: 797 \$ 000$ \\
\hline Confed. Argentina & 4 & $2 \$ 000$ \\
\hline Estados Orientais & 172 & $344 \$ 000$ \\
\hline França & 15.448 & $10: 886 \$ 000$ \\
\hline Grã-Bretanha & 29.567 & $35: 374 \$ 000$ \\
\hline Paraguai & 2 & $1 \$ 000$ \\
\hline Portugal & 4.312 & $8: 403 \$ 000$ \\
\hline Países indeterminados & 2 & $3 \$ 000$ \\
\hline Total & 59.447 & \\
\hline
\end{tabular}




\begin{tabular}{|l|r|r|}
\hline Tecido \\
\hline Aniagem, canhamaço, tecidos crus de fio de estopa \\
\hline País & $\begin{array}{r}\text { Quant. } \\
(\mathrm{Kg})\end{array}$ & Valor \\
\hline Alemanha & 374.775 & $224: 697 \$ 000$ \\
\hline Bélgica & 93 & $56 \$ 000$ \\
\hline Estados Orientais & 43.699 & $26: 220 \$ 000$ \\
\hline Estados Unidos & 25 & $15 \$ 000$ \\
\hline França & 145.051 & $95: 106 \$ 000$ \\
\hline Grã-Bretanha & 4.061 .439 & $2453: 869 \$ 000$ \\
\hline Portugal & 790 & $474 \$ 000$ \\
\hline Suécia & 5.110 & $3: 066 \$ 000$ \\
\hline Países indeterminados & 19.949 & $14: 487 \$ 000$ \\
\hline Total & 4.650 .931 & \\
\hline
\end{tabular}

O linho, por exemplo, como se percebe pela tabela abaixo, era usado em meias, luvas, gravatas e ligas e vinha de países como Alemanha, a Grã-Bretanha, a Itália e, principalmente nesse caso, a França. A lã era usada para os mesmos fins - meias, luvas, gravatas e ligas - e vinha principalmente da Inglaterra.

Não fazia muitos anos que a chegada da família real portuguesa ao Rio de Janeiro havia mudado a maneira com que seus habitantes se vestiam - cerca de 30 anos apenas. “Apesar do calor [...] a gente do povo [...] usa uns casacos pesados e felpudos. O mesmo fazem as mulheres, que ainda se cobrem de véus pretos [...]. De outro modo. Vestem-se elas, brasileiras e portuguesas, de sedas e tafetás; enquanto que as negras e mulatas usam tecidos grosseiros de lã em cor preta" ${ }^{\$ 3}$, disseram dois viajantes no início do século. Os tecidos que começavam a ser importados, transformavam-se em casacos como os descritos pelos dois viajantes estrangeiros em 1819. Em algumas décadas, as mudanças na maneira de se fabricar e vender tecidos na Inglaterra modificaram de maneira substancial o modo de se vestir no Brasil. Mas a Grã-Bretanha não era o único país a tentar vender tecidos no Brasil.

83 Theodor von Leithold e Ludwig von Rango. O Rio de Janeiro visto por dois prussianos em 1819. Trad. port. São Paulo: Companha Editora Nacional, 1966. p. 28. 
Por isso, no jogo do comércio mundial do período, outras nações tinham uma participação significativa. O Paraguai, nos anos de 1845-1849, aparece várias vezes como um exportador menor, mas sempre presente - foram 20 quilos de algodões em fios simples; 50 quilos em panos de algodão cru, curado e lavrado; 386 quilos de morins, madapoleões, bretanhas, riscadinhos e chitas; 184 quilos em linho em bruto, asseado, restelado; 6 quilos em baetas, baetilhas, baetões e flanelas em peças e, surpreendentemente, já que era um produto sofisticado, $400 \$ 000$ réis em rendas em peças e cortes. Esses números poderiam significar um contrabando de tecidos? Um tipo de reexportação? Ainda não foi possível descobrir. ${ }^{84}$

A França também era uma exportadora de tecidos significativa - e aparece nas balanças comerciais em segundo ou terceiro lugares do todo. O que chama a atenção, contudo, é a importância francesa em produtos como rendas, cujas exportações em totalizaram 33.387\$000 contos de réis, enquanto a Grã-Bretanha exportou 6:397\$000 contos de réis. Nos acessórios, como veremos mais a frente, a França competia com a Inglaterra quase que de igual para igual - muitos acessórios franceses valendo mais dos que inglesas, principalmente nos produtos femininos.

Roupas prontas, de todas as espécies, eram poucas as que chegavam por aqui. A França era a maior exportadora de roupas prontas, com 1.406:280\$000 réis em roupas prontas de algodão, 78:037\$000 em roupas de seda, 192:494\$000 em roupas de linho, 281:446\$000 em roupas de lã. No total, foram 1.958:257\$000 contos de réis de roupas prontas que entraram legalmente pelo porto do Rio de Janeiro entre 1871/72. Para se ter uma ideia, esse montante equivalia ao valor de mais de 1.000 casas na região do

\footnotetext{
${ }^{84}$ Mapa geral das mercadorias importadas e despachadas para consumo anos de 1845-1849, p. 17 (ver o arquivo no site <http://memoria.nemesis.org.br/>. Acesso em 27/08/2012).
} 
Carandiru e Morro de Santana, em São Paulo, em $1881^{85}$, ou cerca de 830 escravos, vendidos no interior paulista em $1878 .^{86}$

\begin{tabular}{|l|r|r|}
\hline \multicolumn{2}{|l|}{ Tecido } \\
\hline Roupas diversas de algodão & Vuant. (Kg) \\
\hline País & & $105: 330 \$ 000$ \\
\hline Alemanha & & $39: 275 \$ 000$ \\
\hline Bélgica & & $12: 616 \$ 000$ \\
\hline Confed. Argentina & & $30: 165 \$ 000$ \\
\hline Estados Orientais & & $60 \$ 000$ \\
\hline Estados Unidos & & $1.406: 280 \$ 000$ \\
\hline França & & $707: 326 \$ 000$ \\
\hline Grã-Bretanha & & $195 \$ 000$ \\
\hline Espanha & & $7: 502 \$ 000$ \\
\hline Itália & & $604 \$ 000$ \\
\hline Paraguai & & $4: 436 \$ 000$ \\
\hline Portugal & $24 \$ 000$ \\
\hline Suécia & & $64: 664 \$ 000$ \\
\hline Países indeterminados & & \\
\hline Total & \\
\hline
\end{tabular}

\begin{tabular}{|c|c|c|}
\hline \multirow{2}{*}{\multicolumn{3}{|c|}{$\begin{array}{l}\text { Tecido } \\
\text { Roupa de seda diversa. }\end{array}$}} \\
\hline & & \\
\hline País & $\begin{array}{r}\text { Quant. } \\
(\mathrm{Kg})\end{array}$ & Valor \\
\hline Alemanha & & $2: 356 \$ 000$ \\
\hline Bélgica & & $210 \$ 000$ \\
\hline Confed. Argentina & & $500 \$ 000$ \\
\hline Estados Orientais & & $1: 655 \$ 000$ \\
\hline França & & $78: 037 \$ 000$ \\
\hline Grã-Bretanha & & $45: 058 \$ 000$ \\
\hline Portugal & & $12: 042 \$ 000$ \\
\hline Países indeterminados & & $4: 979 \$ 000$ \\
\hline Total & & \\
\hline
\end{tabular}

${ }^{85}$ Maria Luzia Ferreira de Oliveira. Entre a casa e o armazém. São Paulo: Alameda Casa Editorial, 2005, p. 325.

${ }^{86}$ José Flávio Motta. Escravos daqui, dali e de mais além: o tráfico interno de cativos na expansão cafeeira paulista. São Paulo: Alameda Casa Editorial, 2012, p. 255. 


\begin{tabular}{|l|r|r|}
\hline \multicolumn{2}{|l|}{ Tecido } \\
\hline Roupas de linho & $\begin{array}{r}\text { Quant. } \\
(\mathrm{Kg})\end{array}$ & Valor \\
\hline País & & $4: 821 \$ 000$ \\
\hline Alemanha & & $1: 540 \$ 000$ \\
\hline Bélgica & & $3: 508 \$ 000$ \\
\hline Estados Orientais & & $192: 494 \$ 000$ \\
\hline França & & $110: 573 \$ 000$ \\
\hline Grã-Bretanha & & $585 \$ 000$ \\
\hline Itália & & $240 \$ 000$ \\
\hline Paraguai & & $3: 479 \$ 000$ \\
\hline Portugal & $9 \$ 000$ \\
\hline Suécia & & $8: 393 \$ 000$ \\
\hline Países indeterminados & & \\
\hline Total & & \\
\hline
\end{tabular}

\begin{tabular}{|l|r|r|}
\hline \multicolumn{2}{|l|}{ Tecido } & $\begin{array}{r}\text { Quant. } \\
(\mathrm{Kg})\end{array}$ \\
\hline País & & $114: 453 \$ 000$ \\
\hline Alemanha & & $9: 636 \$ 000$ \\
\hline Bélgica & & $4: 970 \$ 000$ \\
\hline Confed. Argentina & & $14: 698 \$ 000$ \\
\hline Estados Orientais & & $281: 446 \$ 000$ \\
\hline França & & $157: 190 \$ 000$ \\
\hline Grã-Bretanha & & $194 \$ 000$ \\
\hline Itália & & $83 \$ 000$ \\
\hline Paraguai & & $2: 105 \$ 000$ \\
\hline Portugal & & $41: 472 \$ 000$ \\
\hline Países indeterminados & & \\
\hline Total & & \\
\hline
\end{tabular}

Ao longo do século XVIII e do início do século XIX, a França desenvolveu um complexo sistema de ateliês e pequenas confecções de roupas prontas, por isso a maior quantidade de roupas prontas ter vindo de lá. Daniel Roche vai explicar o fenômeno dizendo que a França desenvolveu "uma indústria de roupa de luxo, concentrada em Paris, com uma tradição, clientes e grande interesses em jogo. Para sobreviver, ela 
precisava manter um fluxo de roupas novas e, para expandir, necessitava acelerar a frequência com que eram substituídas." ${ }^{87}$

Desta forma, a indústria de roupas prontas se expandiu conforme mudanças e práticas desenvolvidas a partir da revolução industrial. Michelle Perrot vai mostrar como, no século XIX, essa indústria de moda, feita em casa e em ateliês conheceu uma expansão considerável - ainda mais depois da popularização da máquina de costura a partir de 1860, como veremos. "Esse fenômeno", escreve a historiadora, "está ligado ao desenvolvimento da indústria de vestuário em série, a confecção, e responde ao lugar real e simbólico do vestuário de roupa branca, grande forma de consumo do século XIX. Muito racionalizada, essa indústria associava fabricação em domicílio das peças, com uma intensa divisão do trabalho, e montagem em ateliês de centros urbanos. ${ }^{88}$

Assim, as recentes significações sociais e que roupas passaram a ter, as diferentes técnicas produtivas e o desenvolvimento capitalista constituíram um novo circuito, o circuito das roupas. Era um negócio transnacional, cheio de detalhes e padrões, que iriam reconfigurar o comércio e o consumo de produtos no império brasileiro.

${ }^{87}$ Daniel Roche A cultura das aparências: uma história da indumentária. Trad. port. São Paulo: Senac, 2007, p. 57.

${ }^{88}$ Michelle Perrot. As mulheres ou os silêncios da história. Trad. port. Bauru : Edusc, 2005, p. 233-234. 


\section{CAPÍTULO II. Dos tecidos às roupas}

Estavam nisto, quando a costureira chegou à casa da baronesa. Não sei se disse que isto se passava em casa de uma baronesa, que tinha a modista ao pé de si, para não andar atrás dela. Chegou a costureira, pegou do pano, pegou da agulha, pegou da linha, enfiou a linha na agulha, e entrou a coser. Uma e outra iam andando orgulhosas, pelo pano adiante, que era a melhor das sedas, entre os dedos da costureira, ágeis como os galgos de Diana-para dar a isto uma cor poética. E dizia a agulha: - Então, senhora linha, ainda teima no que dizia há pouco? Não repara que esta distinta costureira só se importa comigo; eu é que vou aqui entre os dedos dela, unidinha a eles, furando abaixo e acima...

Machado de Assis ${ }^{1}$

\section{Costureiras e lavadeiras: o cuidado com as roupas e o problema do trabalho feminino ligado à feitura das roupas}

Ao longo de todo o século XIX, costurar em casa era muito comum. Esperava-se que as mulheres soubessem cuidar da roupa da casa, que incluía um sem número de remendos, recosturas e transformações. E isso significava um treinamento desde a infância. Nas famílias mais abastadas, não era incomum contratar-se, entre os diversos criados da casa, uma costureira para cuidar das roupas da família. Era um fenômeno que fazia parte da cultura ocidental e, no Brasil, costurar, lavar e cuidar das roupas era dos mais importantes afazeres domésticos. Mesmo em famílias remediadas, os cuidados com a roupa tomavam grande parte do tempo dos afazeres domésticos. Sandra Lauderdale Graham, em Proteção e obediência, seu estudo sobre patrões e criadas, diz

\footnotetext{
${ }^{1}$ Joaquim Maria Machado de Assis. "Um apólogo". Para gostar de ler: contos. São Paulo: Ática, 1984, p. 59.
} 
quanto ganhava uma costureira de família, além de evidenciar um hábito comum nas famílias cariocas: a presença de costureiras residentes e livres.

Uma costureira que morasse na casa esperava receber em torno de 18 dólares para coser à mão e à maquina, enquanto uma lavadeira portuguesa pedia cerca de 14 dólares por seus serviços. Uma doméstica, assim como uma mulher que 'lave, carregue água, venda doces na rua', ganhava entre oito e nove dólares. Para amamentar bebês, as donas de casa pagavam às amas de leite os salários mais altos de todos: 20 dólares por mês, além de casa e comida. $^{2}$

A historiadora recupera os preços de criadas de costura para mostrar como as costureiras faziam parte da criadagem doméstica de uma casa abastada. O cuidar das roupas implicava num sem-número de atividades diárias bastante extenuantes: lavar, secar, passar, engomar, costurar, remendar, que eram tão importantes para o cotidiano de uma casa quanto a constante feitura de alimentos para as mais diversas refeições.

As profissões de cozinheira e costureira misturavam-se muitas vezes. Machado de Assis, em Memórias póstumas de Brás Cubas, escreveu sobre uma viúva pobre, que não apenas fazia doces para sobreviver, mas entregava costuras: "Fazia doces, que era o seu ofício, mas cozia também, de dia e de noite, com afinco, para três ou quatro lojas [...]. A filha [...] levando-a consigo, quando tinha de entregar costuras". 3

Muitas mulheres da corte possuíam mucamas, que cuidavam de suas joias, cabelos, banhos, que as acompanhavam em compras na cidade ou nos banhos de mar recomendados pelos médicos e que cuidavam de suas roupas. Eram as mucamas que

\footnotetext{
${ }^{2}$ Sandra Lauderdale Graham. Proteção e obediência. Criadas e patrões no Rio de Janeiro. 18601910. Trad. port. São Paulo: Companhia das Letras, 1988, p. 27. Na época em que publicou seu livro, Sandra Graham fez uma atualização monetária da seguinte maneira: "Durante o século XIX e parte do século XX, a moeda brasileira era o mil-réis, grafado $1 \$ 000$. O conto, correspondente a mil mil-réis, era grafado 1:000\$000. Entre 1860 e 1910, a cotação do mil-réis relatava à moeda americana variou de 0,55 dólar no ponto mais alto (1863-1875) a 0,15 dólar no ponto mais baixo (1898-1899); em 1910, o mil-réis valia 0,33 dólar." (p. 9).

${ }^{3}$ Joaquim Maria Machado de Assis. Memórias póstumas de Brás Cubas. São Paulo: Editora Ática, s.d. p. 99.
} 
fechavam os fechos dos broches de ouro, amarravam as correntes, davam corda nos relógios de bolso, apertavam os laços dos espartilhos, lavavam e passavam rendas e roupas de baixo. Lucíola, personagem de José de Alencar no romance com o mesmo nome da protagonista, mostra, numa cena, o papel das mucamas no cotidiano das mulheres abastadas. Ao sair para um passeio, "[...] a mucama lhe apresentava as luvas $[\ldots] " .4$

Debret nota como as mucamas eram também as grandes responsáveis pelo guarda-roupa elegante das senhoras e meninas ricas: "Uma família rica tem sempre negras lavadeiras e uma mucama encarregada especialmente de passar as peças finas, o que a ocupa pelo menos dois dias por semana, pois uma senhora só usa roupa passada de fresco e renova mesmo sua vestimenta para sair uma segunda vez de manhã. ${ }^{5}$ Aluísio Azevedo, escreveu em Casa de pensão: "Tinha [...] a mucama para lavar-lhe e engomar-lhe a roupa $[\ldots]]^{\prime} .6$

As mucamas, escravas de dentro de casa dedicadas À senhora da casa e às crianças, deveriam quase que necessariamente saber costurar, ao menos o básico, como fazer barras de vestidos, pregar botões, realizar pequenos remendos. Machado de Assis notava: “- Há de ser alguma patuscada, dizia ela, mudando a posição de um alfinete. Benedita vê se a barra está boa. - Está, sinhá, respondia a mucama de cócoras no chão [...]". ${ }^{7}$ Em Girândola de Amores, Januária, velha mucama, ajeitava o vestido de noiva de Clorinda, de quem havia sido mucama desde criança.

\footnotetext{
${ }^{4}$ José de Alencar. Lucíola. São Paulo: Edições Melhoramentos, s.d. p. 113.

${ }^{5}$ Jean-Baptiste Debret. Viagem pitoresca e histórica ao Brasil. T. I, vol. I e II, São Paulo: Martins Editora, 1940. p. 274.

${ }^{6}$ Aluísio Azevedo. Casa de pensão. São Paulo: Martins Editora, 1960. p. 246.

${ }^{7}$ Joaquim Maria Machado de Assis. Obra completa. Vol II, (Páginas recolhidas), s. ed., s.d. p. 271.
} 
Clorinda acabava de pôr seu véu de noiva e, de costas para o espelho, olhava por sobre o ombro a cauda do vestido. A velha Januária pregavalhe $[\ldots]$ o último alfinete dourado [...] Aos pés de Clorinda [...] uma mucama arranjava-lhe cuidadosamente a barra do vestido, compunha e ordenava os folhos e desfazia e ajeitava as pregas do cetim [...] Estava linda assim toda de branco, com o seu longo véu de filó, que lhe envolvia o busto gracioso, deixando todavia perceber o doce relevo da cabeça, engrinaldada de pálidas flores de laranjeira $\left[\ldots . .{ }^{8}{ }^{8}\right.$

Assim como as criadas de quarto e mucamas, as costureiras de família também podiam fazer parte da criadagem da família, que trabalhava próxima à dona da casa. Senhoras abastadas não compravam roupas na Europa sempre - as viagens se tornariam mais frequentes apenas no final do século XIX. Eram as modistas e as lojas de tecidos, como a Wallterstein, que copiavam modelos europeus que chegavam ao Brasil por meio de revistas ilustradas e gravuras. O Jornal da Moda, como veremos mais adiante neste capítulo, editado por dois períodos distintos no Rio de Janeiro, muitas vezes supriu essa necessidade de informação sobre as mudanças na moda, e o mesmo fizeram diversos outros veículos de informação para as mulheres.

As revistas, gravuras, ilustrações ou publicações de moda geralmente publicavam um texto descrito ao lado da imagem. Muitos ainda traziam moldes-padrão impressos em papel-seda em que uma modista ou costureira podia trabalhar como base, ou adaptar para o tamanho de sua cliente ou senhora. Mas esses eram serviços superespecializados, que nem toda casa podia pagar. Geralmente, as costureiras e modistas eram alugadas por dia para serviços mais simples como remendar e recosturar a roupa da família.

Esse hábito de uma costureira por dia, por semana ou por mês não era apenas brasileiro. Na Europa, assim como aqui, esse tipo de serviço doméstico sobreviveu por

\footnotetext{
${ }^{8}$ Aluísio Azevedo. Girândola de amores. São Paulo: Martins Editora, 1960. p. 1.
} 
muitas décadas, até meados do século XX. Natália Ginzgurg, escritora italiana e mãe do historiador Carlo Ginzburg, conta em seu livro de memórias Léxico familiar, sobre as diversas costureiras de sua mãe, que iam e vinham conforme passavam os anos e que acompanhavam a vida em família. "Essa Rina era uma espécie de costureira a domicilio, porém boa somente para revirar nossos casacos e remendar as calças. Não fazia roupas."9

O trabalho de modistas e costureiras que faziam roupas em casa diminuiu quando as máquinas de costura se tornaram mais comuns no Rio de Janeiro, em meados da década de 1870. Mas as costureiras de remendos continuaram a existir por muito tempo. Elas trabalhavam alguns dias por semana, revezando-se em diferentes casas. Se aprendessem também a costurar a máquina, sabiam que teriam trabalho garantido, seja em casa de famílias muito abastadas (e que podiam comprar uma máquina de costura própria), seja em ateliês. ${ }^{10}$

Boas mucamas e lavadeiras, que sabiam costurar, lavar e passar, valiam bastante nos mercados que vendiam escravos das cidades no século XIX. Diversos anúncios de jornal destacavam as qualidades de escravas costureiras, que podiam ser alugadas por dia. Gilberto Freyre destaca um anúncio de Recife: "Precisa-se comprar uma mulata moça que seja perfeita costureira de agulha e tesoura, paga-se bem agradando as suas qualidades: na rua do Trapiche, Recife, n. 40, se dirá quem a pretende". ${ }^{11}$

As moças também podiam ser vendidas para modistas, que as empregariam em seus ateliês: "Vende-se uma escrava muito moça, bonita figura que sabe cozinhar e engomar. É uma perfeita costureira própria para qualquer modista: na botica de Joaquim

\footnotetext{
${ }^{9}$ Natalia Ginzburg. Léxico familiar. Trad. port. São Paulo: Cosac\&Naify, 2009, p. 41.

${ }^{10}$ Sandra Lauderdale Graham. Proteção e obediência. Criadas e patrões no Rio de Janeiro. 18601910. Trad. port. São Paulo: Companhia das Letras, 1988, p. 51.

${ }^{11}$ Gilberto Freyre. O escravo nos anúncios de jornais brasileiros do século XIX. São Paulo: Companhia Editora Nacional, col. Brasiliana, 1979, p. 9.
} 
Ignacio Ribeiro Junior na praça da Boa Vista". ${ }^{12}$ Esse tipo de trabalho escravo especializado modificou as relações de trabalho de maneira profunda e duradoura ${ }^{13}$.

O pagamento por essas tarefas domésticas, com o passar do século XIX e o fim do tráfico (e mesmo após a abolição da escravatura), profissionalizou-se. Ou seja, esses serviços passaram a ser passíveis de recebimento de salário. Os chefes de família pouco a pouco se convenceram de que teriam de pagar as empregadas, costureiras, mucamas e lavadeiras. Supôs-se que esses serviços, feitos por mão de obra livre, custariam o equivalente ao de um aluguel de escravos.

Além das costureiras, as lavadeiras tomavam conta das roupas das famílias abastadas, muitas vezes acumulando funções de costura e limpeza. Era um trabalho pesado, que ocupava muitas trabalhadoras em muitos dias da semana. Debret notava que: "Uma família rica tem sempre negras lavadeiras e uma mucama encarregada especialmente de passar as peças finas, o que a ocupa pelo menos dois dias por semana, pois uma senhora só usa roupa passada de fresco e renova mesmo sua vestimenta para sair uma segunda vez de manhã". ${ }^{14}$

${ }^{12}$ Gilberto Freyre. O escravo nos anúncios de jornais brasileiros do século XIX. São Paulo: Companhia. Editora Nacional: col. Brasiliana, 1979, p. 9.

${ }^{13}$ Para uma discussão mais aprofundada sobre os escravos nas cidades, ver o livro de Flavio dos Santos Gomes et alii. Cidade negras. São Paulo: Alameda Casa Editorial, 2008.

${ }^{14}$ Jean-Baptiste Debret. Viagem Pitoresca e Histórica ao Brasil. T. I, vol. I e II, São Paulo: Martins Editora, 1940. p. 274. 


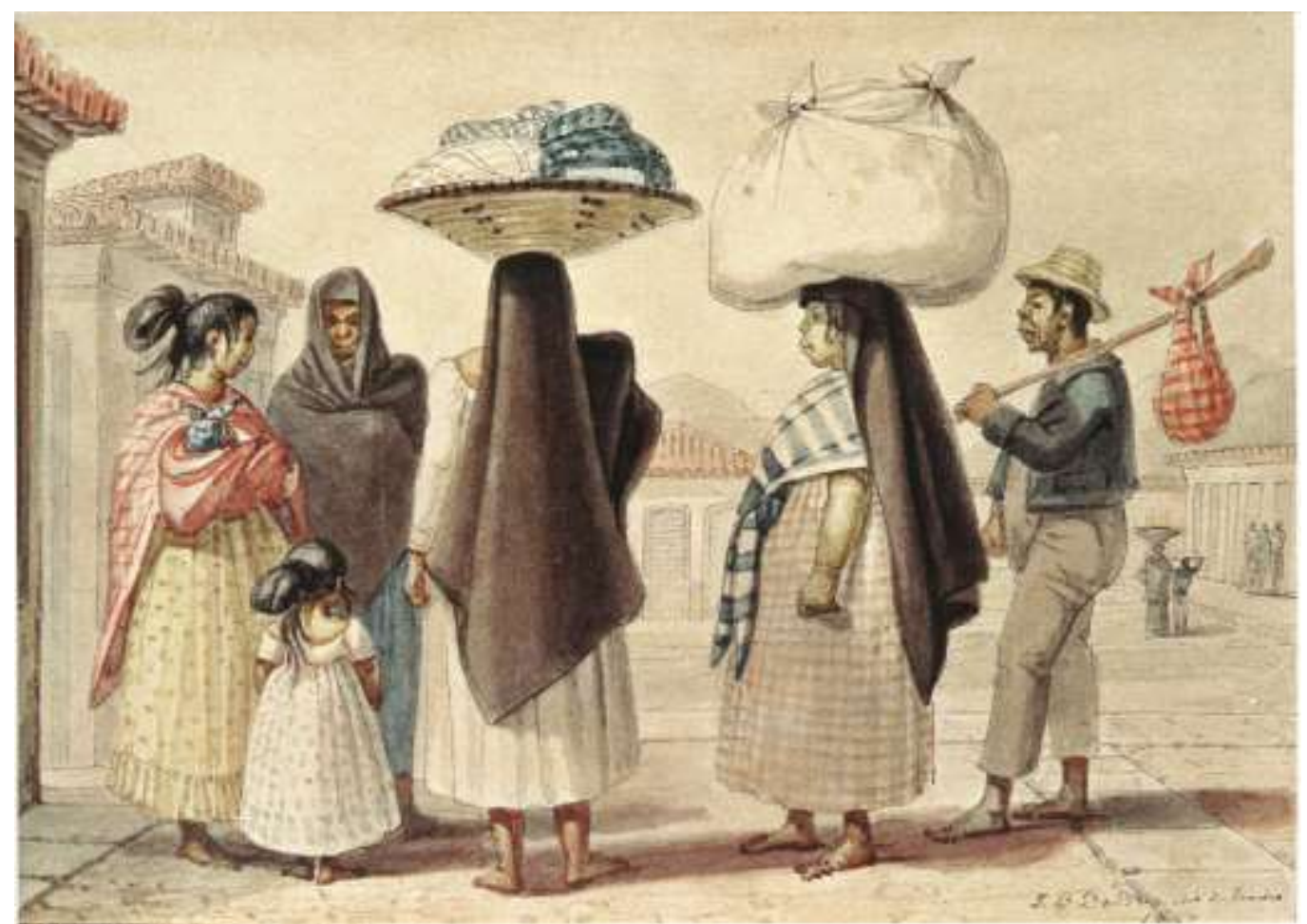

Debret: "Caboclas lavadeiras vivendo na cidade do Rio de Janeiro", cotidiano voltado para o cuidado com as roupas. ${ }^{15}$

As famílias abastadas não economizavam as roupas que usavam, tendo também toalhas brancas, guardanapos, lençóis e diversos tipos de panos em profusão. As roupas de baixo eram particularmente difíceis de serem lavadas, pois precisavam ser limpas e alvejadas com mais constância. Em muitas casas, existiam lugares especiais para se passar, dobrar e remendar as roupas. "Sentia-se ali um cheiro especial de roupa engomada e de roupa lavada. Justificando esse cheiro, viam-se acumuladas [...] pilhas de camisas dobradas, montões de peças de roupa branca e, dependuradas de uma corda, pelo cós, muitas anáguas, muitas saias, penteadores bordados e vestidos de linho com guarnições de renda". 16

As maneiras de lavar a roupa variavam muito e o sabão não era exatamente um produto abundante no Brasil. $\mathrm{O}$ que era feito aqui geralmente tinha cor escura e cheiro

\footnotetext{
15 Julio Bandeira e Pedro Correa do Lago. Debret e o Brasil. Obra completa. Rio de Janeiro: Capivara, 2008, p. 133.

${ }^{16}$ Aluísio Azevedo. O homem. São Paulo: Martins Editora, 1970. p. 113.
} 
ruim. Os sabões estrangeiros eram caros para a maioria da população. "Nesta região crescem, também, muitas árvores do sabão [...] cujos frutos são levados em quantidade para a cidade. A classe mais pobre do povo emprega-os em vez do sabão, visto que o sabão fino [...] está incluído entre os artigos caros da economia doméstica". ${ }^{17}$

Usavam-se sementes e folhas para se lavarem e alvejarem as roupas, como folhas de aloés e de uma árvore chamada "timbuba". Debret nota que:

[...] veem-se negras reunidas diariamente à beira do mesmo riacho límpido ocupadas em coarar a roupa ao lado das que a ensaboam de um modo infinitamente econômico, servindo-se de vegetais saponáceos como a folha de aloés e a folha da árvore chamada timbuba [...] bem como as de muitas outras. Assim, as lavadeiras deixam aos citadinos a despesa bastante onerosa do sabão estrangeiro, pois o que se fabrica no Brasil é de cor escura e impróprio para a roupa fina. Quanto às musselinas que não poderiam suportar a fricção de uma folha sem se esgarçarem, são lavadas estendendo-se sobre a grama, ao sol, e regando-se constantemente à medida em que secam [...]. Emprega-se também a bosta de cavalo e o suco de limão, este para fixar as cores de algodão estampado. ${ }^{18}$

Cada tipo de roupa tinha seu jeito de ser lavada: as roupas comuns e ordinárias, com sabão da terra; as roupas finas, com sabão estrangeiro (que deveria ser economizado pelas lavadeiras); as musselinas sendo lavadas sob a grama, numa espécie de rega constante e atenta; as roupas coloridas com cocô de cavalo e suco de limão. John Mawe, ao viajar por Minas Gerais, percebeu como as plantas nativas eram usadas para diferentes tipos de lavagem de roupas e que podiam também ser usadas para outros serviços domésticos. "Estes vegetais e plantas suculentas, reduzidas a cinzas, servem

\footnotetext{
${ }^{17}$ Johann Baptiste von Spix e Carl Friedrich Philippe Von Martius. Viagem pelo Brasil. Trad. port. Vol. I, Rio de Janeiro: Imprensa Nacional, 1938. p. 175.

${ }^{18}$ Jean-Baptiste Debret. Viagem pitoresca e histórica ao Brasil. T. I, vol. I e II, São Paulo: Martins Editora, 1940. p. 275.
} 
para fazer sabão. Quase todos os negros conhecem o processo de fabricação respectivo, que em quase todas as famílias é empregado para uso da casa. É um sabão muito forte, que limpa muito bem tudo que é de cor branca [...]". ${ }^{19}$

Já no começo do século XX, a jornalista Júlia Lopes de Almeida, em seu livro para noivas, ensinava as mocinhas a cuidarem da roupa da família, muitas das técnicas aprendidas com mães e avós: "Para se limpar roupa preta escove-a e limpe completamente, estenda sobre a mesa a parte desejada para cima, passe uma esponja molhada com café quente coado num pedaço de musselina, quando estiver meio enxuta, passe a ferro". ${ }^{20}$ Ou para vestidos de sarja azul - “deixam-se 24 horas em águas salgada, escovam-se bem as nódoas. Enxaguam-se em água salgada, penduram-se e passam-se úmidos"21

As lavadeiras podiam ser vistas pela cidade durante todo o dia e constituíam um grupo grande de escravos colocados para serem alugados. Maria Graham, quando chega ao Rio, escreveu:

Logo à entrada do Vale, uma pequena planície verde espraia-se para ambos os lados, através da qual corre o riacho sobre seu leito de pedras, oferecendo um lugar tentador para grupos de lavadeiras de todas as tonalidades, posto que o maior número seja de negras [...] Geralmente usam um lenço vermelho ou branco em volta da cabeça, uma manta dobrada e presa sobre um ombro e passando sobre o braço oposto, com uma grande saia. É a vestimenta favorita. Algumas enrolam uma manta comprida em volta delas, como indianos. Outras usam uma feia vestimenta europeia, com um babadouro bem deselegante amarrado adiante. ${ }^{22}$

\footnotetext{
${ }^{19}$ John Mawe. Viagens ao interior do Brasil. Trad. port. São Paulo, Belo Horizonte: EDUSP/ Itatiaia Editora, 1978. p. 181.

${ }^{20}$ Julia Lopes de Almeida. O livro das noivas. Rio de Janeiro: Castorino Mendes, 1929, p. 47.

${ }^{21}$ Julia Lopes de Almeida. O livro das noivas. Rio de Janeiro: Castorino Mendes, 1929, p. 47.

${ }^{22}$ Maria Graham. Diário de uma vagem ao Brasil e de uma estada nesse país durante parte dos anos de 1821, 1822, 1823. Trad. port. São Paulo: Companhia Editora Nacional, 1956. p. 177.
} 
Também o jornalista francês Charles Ribeyrolles notava a profusão de escravos de ganho na cidade, muitos dos quais ligados ao tratamento das roupas, tanto como mucamas, como lavadeiras: “A segunda divisão do povo negro, no Rio de Janeiro, constitui a classe numerosa dos criados de aluguel. Abri os jornais, lede os anúncios [...]. Aí encontrareis domésticos de mesa ou de quarto, trabalhadores, amas de crianças, lavadeiras, mucamas, cozinheiros, moços de cozinha, pajens". ${ }^{23}$

A historiadora francesa Michelle Perrot recupera o tempo das lavadeiras na França, quando as lavadeiras reuniam-se não apenas para lavar roupas, mas também para conversar, trocar receitas de remédios, informa-se sobre a vida na cidade e as agruras do cotidiano. "É que o lavadouro é para elas muito mais que um lugar funcional onde se lava a roupa: um centro de encontro onde se trocam as novidades do bairro, os bons endereços, receitas e remédios, informações de todos os tipos. Cadinhos do empirismo popular, os lavadouros são também uma sociedade aberta de assistência mútua: se uma mulher está no atoleiro, acolhem-na, fazem uma coleta para ela. $\{\ldots\}$ uma criança abandonada certamente aí encontra sua mãe."24

Com os passar dos anos, no século XIX, lavar ou tingir roupas tornou-se um negócio rentável, inclusive para empresas que podiam anunciar seus serviços no Almanaque Laemmert, como fez F.A. Salingre, em 1861. Sua oficina possuía máquinas de tingir e lustrar. Lustrar seria passar a ferro? Uma espécie de lavagem a frio dos vestidos mais finos? No seu anúncio, ele diz que esse processo é feito sem auxílio de alfinetes e pode ser usado em seda, lã, algodão, fitas, debruns, veludos, corpinhos ou

\footnotetext{
${ }^{23}$ Charles Ribeyrolles. Brasil pitoresco. Trad. port. Vol. I, São Paulo: Martins Editora, s.d., p. 168.

${ }^{24}$ Michelle Perrot. Os excluídos da história: operários, mulheres, prisioneiros. Trad. port. São Paulo: Paz e Terra, 1988, p. 203.
} 
xales. Ele também tingia chapéus e tirava manchas a seco de vestidos. Sua oficina ficava na rua do Cano, 29.

72

NOTABRLIDADES

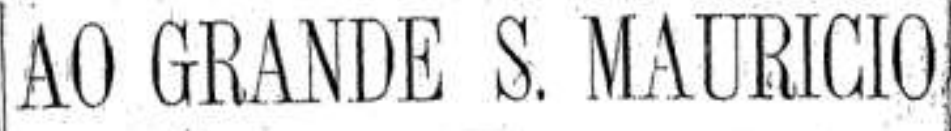

PROCESSOS

IPERFEICOADOS

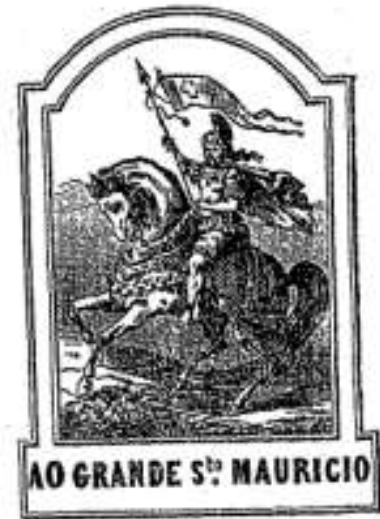

LIMPAR

B LUSTRAR

PARA

TINGIR

(2)

AO GRAHDE S'? HAURICIO

A VAPOR

E IMPRIMIR

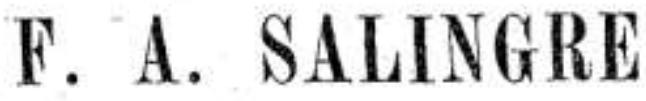

TINTUREIRO

HEA SETE DE BETE YIBHO จ9

ANTIGA DO CANO.

P. A. Salingkk, tem a houra de particinar ao respritarel publico, que năo tenda poupaclo esforços nem despezas, 0 sen estabeiccimiento está $\mathrm{h}$ je a par da qualquer deste zraeno na Europa, pois posstie as uachiaas dos processos os mais ajerfeccosdos, execuiados por bons ofliciaes que trabalhárẽo nas primeiras oflecinas de Paris e Lyon, e por isso poile zarantir aos seus freguezes toda a perfejçăo nos seus trabalhos.

\section{Tamben faze impressato en tecilos}

Psta nova arte satistaz ny caprirhos das Senhoras, e lem grande voga $\mathrm{em}$ Paris, pols sobre as corces lisas lazem impressies de lindos desenhos de qualquer corr, a vontade do freguez, prodazindo assim um elfelto vantajoso.

Tígem de qualquer côr toda a qualidade de fazenda.

Lustrão a vapor, dispensando o empreso de alfinetes, que mnitas vezes produzem un máo efleito.

Tirșo nódons de buda a sorte de fazenda, sem alterar as cores.

Limpjo a secco, sem molliar as sedas on as restimentas de senhoras, homens, etc.

Tírão o môfo per um hovo process?, sem alicrar as côres primitivas.

Restauraça geral de fazendas deterioradas dando-ftus a- mexma frescura nataral.

Tingem a Javio chapéos de pello e de paltha de todas as cûres itesejallas.

Almanaque Laemmert, $1861^{25}$

Em 1871, o anúncio continuava no Almanaque Laemmert, agora com mais destaque. Salingre fazia impressões em tecidos e continuava com o negócio de

${ }^{25}$ Almanaque Laemmert para 1861, seção "Notabilidades". 
tintureiro, "não tendo poupado esforços nem despesas" para igualar-se ao que de melhor havia na Europa. Continuava a tirar nódoas de fazendas, limpar a seco, tirar mofo e lavar chapéus. Era um estabelecimento com vida longa e com vasta clientela pelo Rio, e havia nesses anos prosperado, tendo se mudado para a rua Sete de Setembro, 29. ${ }^{26}$

Lavar roupas era um negócio no século XIX, não apenas no Brasil. Uma profissão que concentrava principalmente mulheres pobres, que trabalhavam em conjunto. As lavadeiras faziam parte da paisagem das cidades, causando brigas e confusões ao redor de bicas, chafarizes e rios. Zola escreveu A Taberna L'Assomoir, em 1876. O romance contava a história de Gervaise, uma lavadeira que ensaia um projeto de emancipação econômica, mas que, pressionada pelas circustâncias e pelo alcoolismo vê sua vida arruinar-se. No Rio de Janeiro, os lugares que reuniam tanta gente acabavam por se tornar locais de confusão, sendo muitas vezes alvo de batidas policiais. Brigas por amor, por tentativas de roubo ou mesmo por espaço ao redor das bicas e fontes de água acabavam inúmeras vezes numa profusão de palavrões.

No Rio de Janeiro de meados do século XIX, três locais principais concentravam as lavadeiras da cidade: o Chafariz das Lavadeiras, no campo de Santana, o chafariz no Largo da Carioca e o Mercado da cidade. ${ }^{27}$ “As casas pobres, só possuem um negro, mandam-no lavar roupa nos chafarizes da cidade, principalmente da Carioca ou do Campo de Sant'Ana, ambos cercados de vastos tanques especialmente destinados a esse fim. Por isso aí se encontram dia e noite lavadeiras, cujo bater de roupa se houve de longe". 28

\footnotetext{
${ }^{26}$ Almanaque Laemmert, p. 136.

${ }^{27}$ Sandra Lauderdale Graham. Proteção e obediência. Criadas e patrões no Rio de Janeiro. 18601910. Trad. port. São Paulo: Companhia das Letras, 1988, p. 51.

${ }^{28}$ Jean-Baptiste Debret. Viagem pitoresca e histórica ao Brasil. Trad. port. T.I, vol. I e II, São Paulo: Martins Editora, 1940. p. 274.
} 
Lavar roupas era um serviço pesado, que envolvia não apenas esfregar com sabão ou equivalente, mas torcer e bater com força nas roupas. "Aqui vêem-se tanques de pedra onde robustas lavadeiras batem roupa [...]"29, notou Daniel Kidder em 1838. Depois de batidas, as roupas tinham de descansar ao sol, repousadas na grama ou em arbustos. Nesse longo período de espera pelas roupas secas, as lavadeiras podiam cuidar das crianças que eventualmente as seguiam ao trabalho, ou namorar, ou mesmo apenas conversar com outras lavadeiras.

Costurar roupas, remendá-las, cuidar delas era um pequeno negócio no século XIX. Com o tempo, as lavadeiras e costureiras tiveram seus ofícios separados. Se por algum tempo ambas as profissões podiam andar juntas (mas isso não acontecia sempre) e as lavadeiras também faziam pequenas costuras e remendos, com a invenção da máquina de costura esse quadro vai mudar drasticamente. Ao longo do século, as costureiras vão ver seu ofício se especializar.

As máquinas de costura que se disseminaram ao longo do século XIX possibilitaram o desenvolvimento de uma velha profissão feminina: a de costureira. Em muitos casos, as mulheres podiam costurar para fora e permanecer em casa, complementando a renda familiar enquanto faziam trabalhos de costura. O trabalho feminino mudou de maneira radical com o advento das empresas capitalistas no século XIX e se tornou cada vez mais complexo.

As mulheres já haviam passado a fazer parte dos quadros de operários das fábricas na Europa, e a questão do trabalho feminino passou a ser extensivamente debatida no período. No começo do século XIX, Hegel vai falar de uma "vocação natural” dos dois sexos. "O homem tem sua vida real e substancial no Estado, na ciência ou em qualquer outra atividade do mesmo tipo. Digamos, de modo geral, na luta e no trabalho que o

${ }^{29}$ Daniel Parish Kidder. Reminiscências de viagens e permanência no Brasil, províncias do Norte. Trad. port. São Paulo: EDUSP/ Itatiaia Editora, 1972. p. 132. 
opõem ao mundo exterior e a si mesmo" ${ }^{30}$ A mulher, pelo contrário, seria feita para a piedade e o interior. "Se se colocarem as mulheres à frente do governo, o Estado se encontra em perigo. Pois elas não agem conforme as exigências da coletividade, mas segundo os caprichos de sua inclinação e seus pensamentos". ${ }^{31}$ Hegel podia achar que as mulheres não eram feitas para trabalharem em fábricas. Mas, no dia a dia, elas eram contratadas e recebiam muito menos que os homens por isso, o que ocasionava certa competição com os homens por empregos.

O trabalho com os tecidos e as costuras seria, por outro lado, uma "vocação natural" das mulheres, exposta claramente, por exemplo, na fala - recuperada pela historiadora francesa Michelle Perrot - de um delegado operário na Exposição Mundial de 1867. "À mulher, a família e os tecidos". 32

Ao longo das primeiras décadas do século XIX, até cerca de 1840, quando a industrialização tomava um fôlego crescente, o debate sobre o trabalho feminino nas fábricas era intenso. Alguns pensadores reformistas, como William Gaskell, diziam que o trabalho feminino nas fábricas roubava o peito das mulheres de seus filhos, pois as impediriam de amamentar. "Outros citavam a incompatibilidade entre as mulheres e a maquinaria, contrapondo o suave e o duro, natural e artificial, futuro e presente, reprodução da espécie e produção de bens inanimados". ${ }^{33}$ Falavam da imoralidade que

${ }^{30}$ Georg W. F. Hegel. Princípios da filosofia do Direito. Trad. port. São Paulo: Martins Fontes, 2009 , p. 155.

${ }^{31}$ Georg W. F. Hegel. Princípios da filosofia do Direito. Trad. port. São Paulo: Martins Fontes, 2009 , p. 155.

${ }^{32}$ Michelle Perrot. Os excluídos da história: operários, mulheres e prisioneiros. Trad. port. São Paulo: Paz e Terra, 2010, p. 178.

${ }^{33}$ Joan W. Scott. "A mulher trabalhadora". In: História das mulheres, o século XIX. Trad. port. Lisboa: Afrontamento, 1994, vol. IV, séc. XIX, p. 450. 
advinha de trabalhos pesados e clima na fábrica, dos palavrões masculinos, dos favores sexuais. $^{34}$

O trabalho fora de casa estaria na alçada masculina e as mulheres não deveriam "se meter"35 em coisas como greves ou reivindicações. ${ }^{36}$ Desta maneira, o desenvolvimento da fabricação das máquinas de costura ajudou as mulheres a encontrarem uma maneira de trabalhar ainda que dentro de casa. Era uma situação ideal para todos: as mulheres não teriam a reputação manchada ou a honra corrompida por andarem pelas ruas e fábricas, ganhariam um "extra" para ajudar na renda da casa e ainda não competiriam pelos postos de trabalhos masculinos dentro de fábricas. E, finalmente, esse trabalho não seria contabilizado como trabalho e, portanto, as mulheres sairiam da competição direta com os homens por postos de trabalhos nas fábricas. A venda de máquinas de costura foi cada vez maior ao longo do século XIX.

A máquina de costura aliava o antigo trato com as agulhas, que era prerrogativa das mulheres, com uma novidade tecnológica que podia ser manejada em casa, teoricamente, sem prejuízo dos afazeres domésticos ou do cuidado com os filhos. Foi exatamente a expansão da utilização das máquinas de costura que possibilitou um enorme aumento no número de roupas que eram vendidas. Mas a máquina de costura também possibilitou a transformação do ofício de costureira ou alfaiate em algo diferente. Nasceram os ateliês de costura, onde trabalhavam várias costureiras ou alfaiates ao mesmo tempo, sob a batuta de um mestre.

A maneira como as roupas passaram a ser fabricadas também se transformou e se especializou. Se até o começo do século XIX, as roupas que eram feitas fora de casa, em

\footnotetext{
${ }^{34} \mathrm{Na}$ França, foi revivido o "droit de cuissage" medieval, em que o dono do castelo teria o direito à primeira noite das noivas. No caso do século XIX, esse direito era reservado aos capatazes. Por causa disto, criaram-se as fábricas-convento, em que as mulheres teriam sua honra preservada.

${ }^{35}$ Michelle Perrot. As mulheres ou os silêncios da história. Trad. port. Bauru: Edusc, 2005, p. $233-$ 239.

${ }^{36}$ Idem, Ibidem.
} 
costureiras, eram confeccionadas de uma vez só, com o passar do tempo, começou a ocorrer uma subdivisão e uma crescente especialização do trabalho de se fazer roupas.

Alguns ateliês ou lojas grandes encomendavam a costureiras que trabalhavam em casa peças específicas: uma mulher podia se especializar em fazer camisas ou colarinhos, outra em pregar botões e uma terceira em fazer os punhos ou colocar rendas e ornamentos. Cada tipo de trabalho era propositalmente muito mal pago para que o preço da peça caísse cada vez mais. "Esse fenômeno está ligado ao desenvolvimento de uma indústria de vestuário e da roupa branca, grande forma de consumo do século XIX. Muito racionalizada, esta indústria associa fabricação em domicílio das peças, com uma intensa divisão do trabalho, e montagem em ateliês de centros urbanos.",37

As máquinas de costura no Brasil começam a ser vendidas para mulheres de elite, como a condessa de Barral, e depois se popularizaram e se tornaram mais baratas. ${ }^{38}$ Para uma operária na França, possuir uma máquina de costura própria seria a realização de um sonho, uma forma de possuir os meios para cuidar de sua vida, ser livre ou independente do sistema dos ateliês.

Para as mulheres que imigravam para o Brasil, possuir uma máquina de costura significava um novo tipo de status social - a de uma possível possuidora de um ateliê. Em escolas, conventos ou em casa, as meninas eram treinadas desde cedo para dominarem a máquina e se tornarem possíveis geradoras de uma renda familiar extra. As famílias remediadas davam às moças que casavam uma máquina, sabendo que seria muito usada no dia a dia da fabricação das roupas familiares, mas também poderia significar uma renda extra em tempos difíceis.

\footnotetext{
${ }^{37}$ Michelle Perrot. As mulheres ou os silêncios da história. Trad. port. Bauru: Edusc, 2005, p. $233-$ 234.

${ }^{38}$ Wanderley Pinho. Salões e damas do segundo império. São Paulo: Martins Editora, 1970, p. 226 e 227.
} 
Mas as máquinas de costura, assim como todo problema do trabalho feminino, causaram inúmeras controversas. Alguns médicos passaram a condenar o uso do aparelho, apresentando relatórios de que o movimento das pernas e pés para movimentar as máquinas causariam excitação sexual nas mulheres. A eles se uniriam alguns socialistas, preocupados em regulamentar o trabalho feminino e definir os salários masculinos. Assim, no Congresso Operário de Marselha, em 1879, em que se discutiam os rumos do movimento operário, também se levantou o problema das máquinas de costura que excitavam as mulheres: "Tal instrumento, com um movimento contínuo, excita o delírio histérico”, diziam os delegados presentes. ${ }^{39}$

Michelle Perrot vai associar a máquina de costura à histeria, problema feminino por excelência no século XIX. "Histérica, erótica, a máquina toca a mulher até sua intimidade mais secreta. O casal que elas formam torna-se suspeito. Aquelas pernas em perpétuo movimento não produziriam o gozo do orgasmo? Esta simbiose mulher e máquina mecaniza a mulher e sexualiza a máquina. A máquina torna-se mulher". ${ }^{40}$ Mas a mulher é sistematicamente excluída dos processos de criação e administração das máquinas de costura, processos sempre reservados aos homens, que são sempre chefes da família e da fábrica.

No Brasil, outro tipo de emprego, além do de costureira ou lavadeira, também esteve ligado ao cotidiano feminino durante todo o século XIX: o de vendedora ou dona de estabelecimentos em que se vendiam produtos ligados à moda e ao universo feminino. A algumas mulheres era permitido ser empresária, dona loja de importações. A outras, a abertura de ateliês de costura. Geralmente imigrantes ou viúvas, essas mulheres tiveram negócios e os administrariam com relativo sucesso, empregando

\footnotetext{
${ }^{39}$ Michelle Perrot cita o texto do congresso, Congrès ouvrier de Marselle, 1879, p. 171, em seu livro As mulheres ou os silêncios da história. Trad. port. Bauru: Edusc, 2005, p. 237.

${ }^{40}$ Michelle Perrot. As mulheres ou os silêncios da história. Trad. port. Bauru: Edusc, 2005, p. 238.
} 
outras mulheres como vendedoras ou costureiras. Muitas chegaram a ter escravas trabalhando em seus ateliês como costureiras, outras foram escravas forras que aprenderam um ofício num dos ateliês da cidade do Rio de Janeiro e passaram a vender seus serviços para fora, mais algumas eram imigrantes que abriam negócios.

Catharina Dazon foi uma dessas mulheres que abriram negócios ligados à moda na rua do Ouvidor. Em 1858, madame Dazon, como era conhecida, e seu filho possuíam uma loja que vendia "grande sortimento de sedas, cassas, chitas, bareges, camisinhas, saídas de baile, xales, rendas, chapéus de seda e palha, enfeites de cabeça, e tudo o que compõe o toalette de uma senhora". O estabelecimento ficava na rua do Ouvidor, no número 97. No anúncio publicado na seção de "notabilidades" do Almanaque Laemmert de 1858, aparece no canto esquerdo, em cima, as relações comerciais de Catharina com a Europa: "Casa d'Enghien, 46, Paris. Casa em Londres e Lyon". 41

Dazon havia emigrado para o Brasil com os pais e mais cinco irmãos no final dos anos 1810. Sua família era de Le Magne, na Suíça, região próxima a Lausanne. A família era antiga e, durante todo o século XVII, usou o sobrenome pelo qual Catharina viria a ser conhecida no Brasil, Dazon. ${ }^{42}$ Os pais, Louis e Françoise casaram-se em 1792. Tiveram seis filhos: Madaleine, François, Francillon, Anne, Catherine e Claude. ${ }^{43}$ Endividados, resolveram partir com a família num programa de imigração entre Suíça e Brasil. Os imigrantes marchariam até um porto na Holanda, de onde embarcariam. A viagem foi dura, mas, ao chegarem, tiveram de acampar em condições piores ainda. ${ }^{44}$

Assim, quando a viagem começou, a maioria dos membros da família já estava doente. Poucos dias depois do embarque, Anne morreu. Depois foi sua irmã Madaleine,

\footnotetext{
${ }^{41}$ Almanaque Laemmert 1858, p. 33.

${ }^{42}$ Algumas vezes podemos encontrar informações sobre a família com o sobrenome de La Magne.

${ }^{43}$ Ver site sobre imigração suíça <http://www.diesbach.com/sghcf $/ \mathrm{m} /$ magne.html $>$, consulta em $15 / 08 / 2012$.

${ }^{44}$ Ver site sobre imigração suíça <http://www.diesbach.com/sghcf $/ \mathrm{m} / \mathrm{magne} . h t m l>$, consulta em 15/08/2012.
} 
sua mãe, Françoise, e seu pai, Louis. Desembarcaram no Rio de Janeiro, apenas François, Catharine e Claude. Foram para a colônia de Nova Friburgo e depois para Cantagalo. Catharine, já Catharina, começou a plantar café e teve um filho, Louis Dazon, mas nunca se casou. ${ }^{45}$ Em 1849 , abriu sua primeira loja no Rio de Janeiro, já vendendo tecidos e roupas para senhoras e crianças.

Sua ligação com a Suíça pode ser vista no pé do anúncio do Almanaque Laemmert, na parte em que se lia que a loja vendia luvas Jouvin, um produto suíço por excelência. $\mathrm{O}$ estabelecimento foi bem sucedido e funcionou durante cerca de vinte anos na rua do Ouvidor. Em 1860, um cronista da Revista popular, "Carlos""46, não apenas indicou a loja de Madame Dazon para seu público leitor, como colocou a palavra de Catharina como símbolo de elegância e bom gosto: ${ }^{47}$

Agora que nos vamos ocupar da explicação dos tesouros que mais agradaram ao artista emissário, permiti que eu ceda a palavra a Mme. Catharina Dazon para vos fazer a Descrição da gravura de modas. (...) É ocioso lembrar-vos, que Mme. Catharina Dazon \& filho recebem por todos os paquetes a melhor escolha de artigos modernos e se incumbem de dar vida aos figurinos sujeitos ao seu hábil sistema de interpretar as criações artísticas. ${ }^{48}$

\footnotetext{
${ }^{45}$ Ver site sobre imigração suíça <http://www.diesbach.com/sghcf/m/magne.html〉, consulta em $15 / 08 / 2012$.

${ }^{46}$ O nome "Carlos" era um pseudônimo.

${ }^{47}$ Para uma explicação mais detalhada sobre as crônicas da Revista popular, ver artigo de Marcella dos Santos Abreu, "Paquetes, modas e salões: o desejo mimético nas crônicas da Revista popular (1859-1862)". In: Anais do Seta, vol. 2, 2008, p. 7-12.

${ }^{48}$ Carlos (1859-1861). "Crônica da quinzena", in: Revista popular: noticiosa, científica, industrial, histórica, literária, artística, biográfica, anedótica, musical, etc., Rio de Janeiro: B. L. Garnier, 1860, p. 255, 256.
} 


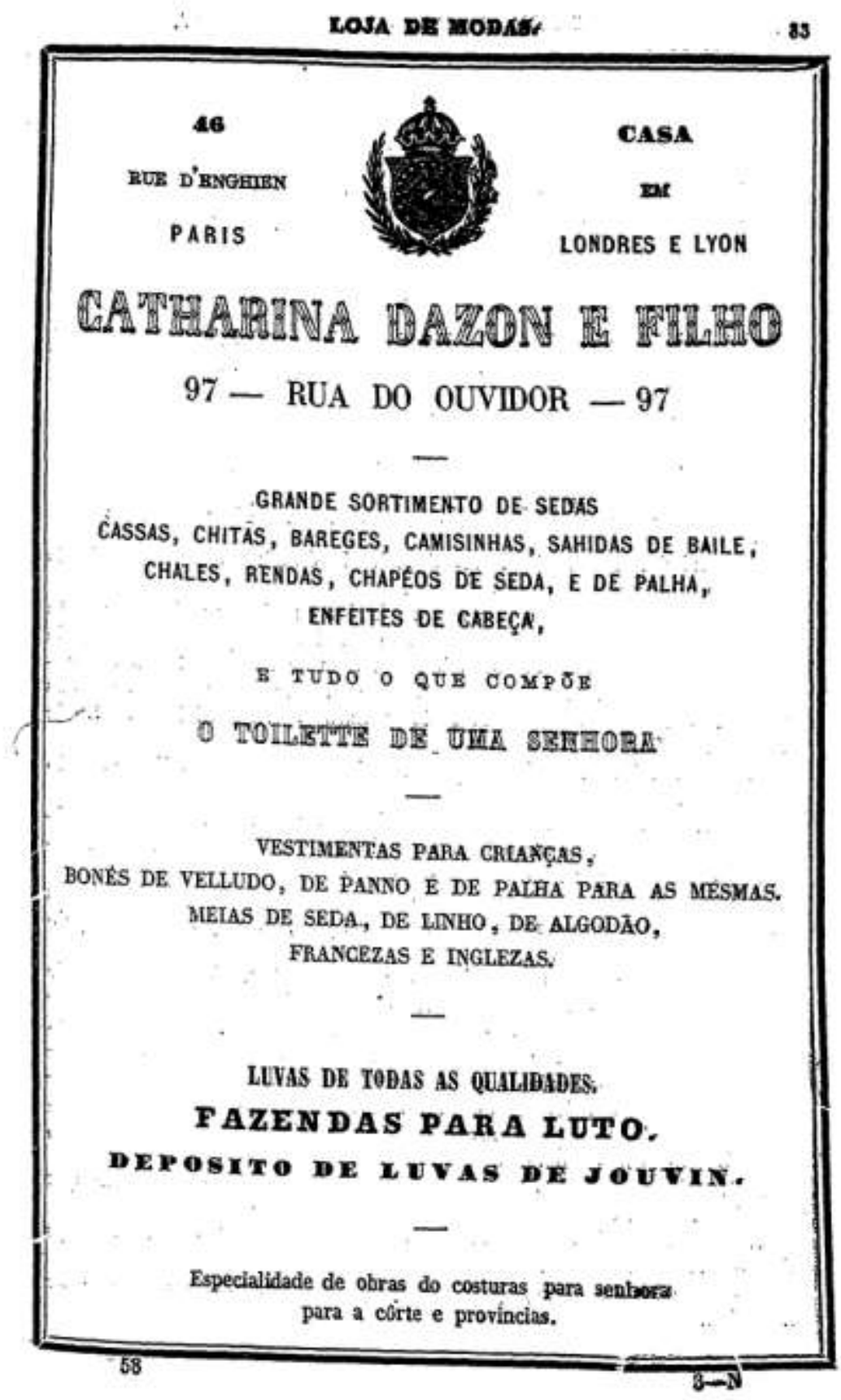

Como madame Dazon, outras mulheres também foram donas de lojas e armazéns no Rio de Janeiro imperial. Estabelecimentos como o de adame C. Creten \& $\mathrm{C}^{\text {ie }}$, À Ville de Bruxelas, localizado à rua do Ouvidor, 70, vendia camisas e ceroulas sob medida, assim como roupas de banho e roupões felpudos e também meias, lenços,

${ }^{49}$ Almanaque Laemmert 1858, p. 33. 
gravatas e colarinhos, panos de algodão e linhos, "oxfords e cambraias de cor", ${ }^{50}$ ou a loja de madame A. C. Favre, Ao Bastidor de Bordar, que comercializava lãs, sedas, frocos, miçangas, algodões, agulhas, crochês, talagarças, vidrilhos, desenhos para bordar e "tudo que é necessário para costuras". ${ }^{51}$

Algumas das donas de lojas do Rio de Janeiro eram modistas, como madame Celestine Mercier, parisiense, que se dizia premiada na exposição de 1873, e fazia roupas para batizados, casamentos e senhoras e ficava localizada na rua da Assembleia, 51.

${ }^{50}$ Veja abaixo o anúncio publicado no Almanaque Laemmert 1868, p. 54.

${ }^{51} \mathrm{O}$ anúncio de madame Favre está abaixo e foi publicado no Almanaque Laemmert 1858, p. 38. 


\section{GRANDE ATELIER DE COSTURA}

D2

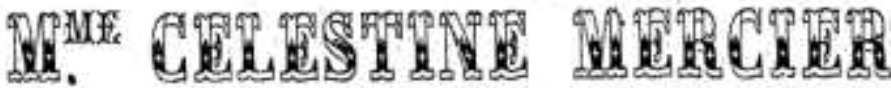

\section{MODISTA DE PARIS}

Premiada aa Exposiçáo Nacional đe 1873

Especialidade de enxovaes para casamentos, baptizados, e todos os objectos concernentes a toilette das senhoras.

- 51 RUA DA ASSEMBLÉA 51

RIG DE JANEIRQ.

\section{AO TOM PARISIENSE}

\section{MHODAS DR PAPRS}

\section{Rua Sete de Setembro 36}

GRANDE OFFICINA DE COSTUREIRA E MODISTA

- variado sortimento de chapéos para senhoras e meninas, sempre o que ha de mais moderno

Fuzendas para luto, bordados, enxovaes para baptizados, ete.

Enxovaes para casamento, fazendas brancrs, sedas o läs, etc.

Assim como um grande sortimento de fazendas de seda, 10 e algodá; bordado5, rendas, velludos, sains e camisas lisas e bordadas para senhoras e meninas; fitas, galoes, leques, chapéos de sol de teda, gravalas, etc., eic.

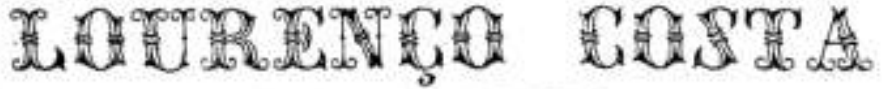
RHO DE DANEIRO. 


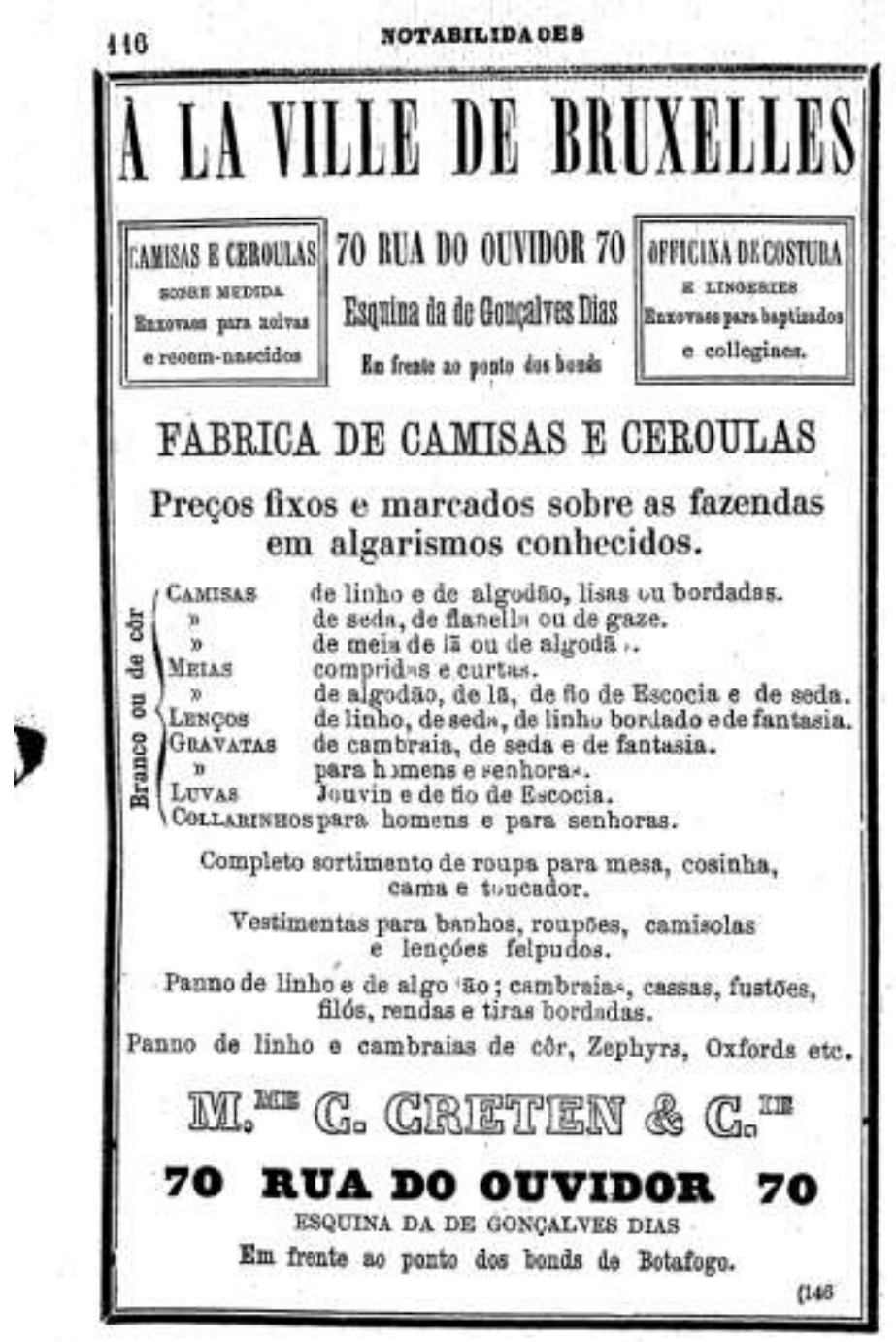

Madame Creten recebia grande sortimento de tecidos para sua loja ${ }^{53}$

As rendas, chapéus, xales, mantôs, vidrilhos de enfeitar, contas, missangas, punhos, golas eram itens, muitas vezes importados, que transformavam as roupas das mulheres e homens e podiam significar a diferença social entre "estar na moda" ou não. O escritor Aluísio Azevedo ao descrever um personagem dizia: "Fraque à inglesa! Colarinho da moda! Plastron! Meias de cor! Polainas! Sapatos de verniz! Flor à

\footnotetext{
${ }^{53}$ Almanaque Laemmert, 1876, p 143.
} 
gola!". ${ }^{54}$ E já dizia tudo. As casas que abasteciam o mercado carioca sabiam desse poder social e jogavam com estrangeirismos e objetos importados. Se a costureira ou o alfaiate fosse estrangeiro, melhor para os negócios. Muitas vezes, as mulheres imigrantes se aproveitavam desse fato para abrirem suas casas de comércio. Algumas comerciantes, inclusive, passaram a vender não apenas os vidrilhos, miçangas, luvas e sapatos, que caracterizavam o mercado de negócios para mulheres. Essas mulheres entraram no negócio de comercializar máquinas, as mais modernas do século XIX - desde beneficiadoras de café até máquinas de costura.

Madame Besse foi uma dessas negociantes e estabeleceu-se como fornecedora oficial da família real. O impacto da máquina de costura no Brasil do império de d.. Pedro II era tremendo e possibilitava o nascimento, ainda que a princípio bastante incipiente, da indústria de confecções. Veremos a seguir como a máquina de costura chegou ao Rio de Janeiro e teve uma história que acompanhou a da evolução da técnica e da indústria no século XIX.

54 Aluísio Azevedo. Filomena Borges. São Paulo: Martins Editora, 1960. p. 49. 


\section{LATAS, SEDAS E TODOS OS PERTEXCES PARA BORDAR.}

Loja de Lãas, Sedas frouxas, frocos e aviamentos de bordar.

\section{AO BASTIDOR DE BORDAR}

\section{9.. Rua do Ouvidor, 99.}

$M^{\text {me }}$ A. C. Favre tem a honra de participar a todos os seus freguezes e ao respeitavel Publico, tanto na cûrte, como nas provincias, que sua casa está sempre bem sortida em tudo o que ha de mais novo em lãas, sedas frouxas, torçaes, frocos, missangas, linhas, algodões, agulhas, crochetes, talagarça, papeis picados, vidrilhos, desenhos e mais todos os aviamentos que são precisos para bordar.

Tudo o que é necessario para costuras.

Tambem tem : fitas, rendas, blondas, gregas, franjas, galões, entremeios de cassa,-borlas, botões, barbatanas, luvas de todas as qualidades, e tudo o que se póde desejar de mais moderno e de bom gosto.

95. REA DO OUVIDOR, 95 .

\section{MONTEIRO \& COELHO}

\section{6 - Rua da Quitanda - 66}

completo sortimento de objectos de bordar, como sejão lãas, sedas, frocos, talagarças, torçal, desenhos, linhas, agulhas, caixas com pertences para costuras e crochet, fitas, franjas, galões, gregas, rendas, um completo sortimento de botões e todos os mais artigos pertencentes a modistas e costureiras.

55 Almanaque Laemmert 1858, p. 38. 


\section{A história das máquinas de costura no Rio de Janeiro: um anúncio brasileiro vende uma máquina de costura americana}

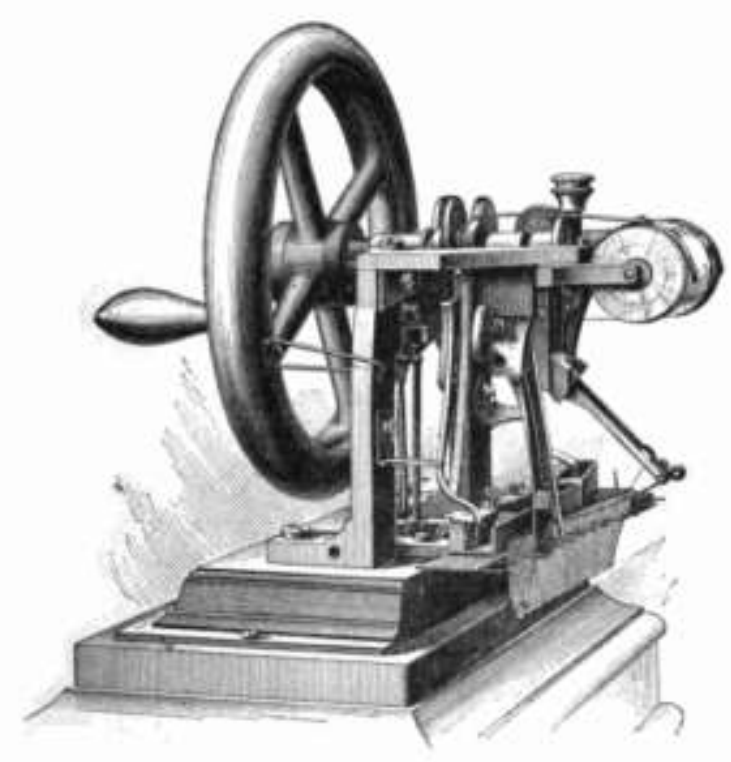

A máquina de costura Howe ${ }^{56}$

Um pequeno anúncio no Almanaque Laemmert de 1868 informava que a firma Vivaldi e Companhia, situada na rua da Ajuda, 8, vendia máquinas de costura Howe. Seu concorrente, Thomas Dutton Junior, da rua da Quitanda, 40, também vendia máquinas de costura, mas o anúncio não especifica a marca. Máquinas de costura eram uma novidade nesse período - e não apenas no Rio de Janeiro. Na realidade, já fazia alguns anos que a máquina de costura tornara-se uma realidade efetiva do mundo industrial e sua importância para confecção de roupas tornou-se fundamental. Recontar a história e evolução da máquina de costura no mundo, e suas sucessivas modificações industriais, nos ajuda a entender a importância desse pequeno anúncio de pé de página

\footnotetext{
${ }^{56}$ Ver caderno de imagens do livro de Christina Walkley e Vanda Foster. Crinolines ans crimpings irons. Victorian Clthes: how they were cleaned and cared for. Londres: Peter Owen, 1978.
} 
no Almanaque Laemmert em $1868^{57}$, e a compreender como se formou um ainda incipiente mercado de confecções de roupas no Rio de Janeiro.

Os cariocas, em meados do século XIX, viviam uma vontade de se modernizar, de andar no mesmo passo que as metrópoles europeias. Produtos importados, como sapatos, chapéus ou latas de doce, ou mesmo máquinas agrícolas, apareciam nos jornais como itens vendidos em diferentes casas importadoras. Modas estrangeiras, como a polca, os charutos, o baralho, os saraus, tornaram-se essenciais para mostrar o quanto o império brasileiro era afinado com os países europeus do mesmo período. Luis Felipe Alencastro vai explicar esse "surto" modernizante ao dizer que a partir dos anos 1850, com o fim do tráfico de escravos os fluxos de comércio externo brasileiro sofreriam uma rápida reorientação.

Considerando-se apenas os anos de 1840-50, constata-se que cerca de 335 mil africanos haviam sido ilegalmente importados no Império, representando um valor equivalente a $28 \%$ do total de importações legais efetuadas pelo país na mesma época. Os pagamentos desse contrabando negreiro corriam por fora. Em letras de câmbio emitidas pelos comissionários dos fazendeiros para serem sacadas, em favor dos traficantes, nas grandes casas importadoras de produtos brasileiros, em Lisboa, Porto, Nova York e Londres. ${ }^{58}$

Desta forma, quando o tráfico acaba, acontece um retorno das receitas que haviam sido obtidas com as vendas de produtos de exportação, em especial com venda de café, e que eram reservadas para financiar a compra de escravos. "O efeito na balança comercial e na balança de pagamentos do império é imediato. Comparando-se o

\footnotetext{
${ }^{57}$ Almanaque Laemmert, 1868. Consultado no dia 26 de agosto de 2011 no site da Biblioteca Nacional <http://www.bn.br $>$, consulta em 23/09/2013.

${ }^{58}$ Luís Felipe Alencastro. "Vida Privada e ordem privada no império". In: História da vida privada no Brasil II. São Paulo: Companhia das Letras, 1997, p. 37.
} 
quinquênio de 1845-50 ao de 1850-5 (o ano fiscal corria de junho a junho), contata-se que o valor das importações do Rio de Janeiro cresce uma vez e meia". ${ }^{59}$

Mas, ainda que o fim do tráfico tenha favorecido uma onda de produtos importados nas praças comerciais cariocas, esse sentimento de pertencimento a uma nova época que se modernizava também ajudava na sensação de que tudo estava para ser inventado, que as mercadorias ou notícias atravessavam o Atlântico num "pulo". Não à toa que no mesmo período em que abole o tráfico, inaugura-se uma linha regular de navios a vapor entre Liverpool, berço da revolução industrial inglesa, e o Rio de Janeiro. Aportavam por aqui, todo o dia 21 de cada mês, depois de uma viagem de 28 dias e com uma regularidade britânica, o Brazileira, o Luzitania, o Olinda e o Bahiana. $^{60}$

$\mathrm{Na}$ bagagem, tudo o que era estrangeiro tornava-se necessário e moderno. $\mathrm{Na}$ esteira das invenções que chegaram ao Brasil nesse período estava tanto a máquina de costura como os daguerreótipos, as máquinas fotográficas. Ambos permitiram não apenas o surgimento de novas profissões (fotógrafos, costureiras mecanizadas), mas a certeza de que o país entrava definitivamente na modernidade. A partir daí, a máquina de costura, que viria a ter um impacto considerável para a produção de roupas, entrou definitivamente para o cotidiano brasileiro. A máquina de costura, ao mesmo tempo em que engordava as estatísticas dos produtos importados no século XIX, dava início a um novo ramo da indústria - a princípio bem incipiente, é verdade - o de confecções.

\footnotetext{
${ }^{59}$ Luís Felipe Alencastro. "Vida Privada e ordem privada no império". In: História da vida privada no Brasil II. São Paulo: Companhia das Letras, 1997, p. 38.

${ }^{60}$ Luís Felipe Alencastro. "Vida Privada e ordem privada no império". In: História da vida privada no Brasil II. São Paulo: Companhia das Letras, 1997, p. 40.
} 


\section{A história da máquina de costura fora da aqui}

Agulhas de costura fizeram parte do mundo da confecção de roupas desde quase os tempos pré-históricos - algumas agulhas tendo sido achadas em sítios arqueológicos que datam de 20 mil anos atrás, com agulhas feitas de ossos para costurarem peles de animais abatidos. ${ }^{61}$ As primeiras agulhas de ferro datam do século XIV, e as primeiras agulhas com um olho para se passar o fio datam do século XV. Ambas não apenas melhoram as técnicas de costura, como possibilitaram a confecção de trabalhos mais delicados em menos tempo. Mas as agulhas dependiam de mãos habilidosas para que os tecidos fossem costurados e o trabalho podia não apenas levar muito tempo (dias ou meses em costuras e bordados mais sofisticados), como ocupar muitas costureiras. Dessa forma, as tentativas de se achar um método ou uma máquina que fizesse o trabalho manual foram crescentes ao longo dos séculos. ${ }^{62}$

Em 1755, foi depositada a primeira patente referente a uma máquina de costura. Era uma patente britânica, para uma máquina inventada por um alemão, Charles Wisenthal. Na descrição da patente está uma agulha especial, teoricamente feita para caber numa máquina de costura, mas o projeto para esta máquina de costura nunca foi encontrado, nem se sabe se a máquina realmente existiu. ${ }^{63}$ Conforme a revolução industrial ganhava corpo e novas máquinas modificavam as maneiras de se fazer os tecidos, a corrida por uma máquina de costura acirrou-se.

Em 1790, nova tentativa, desta vez por um inventor e marceneiro inglês, Thomas Saint. Ainda que não se saiba se essas primeiras tentativas resultaram numa máquina que realmente construída e usada, a patente de Saint mostra um buraco no tecido com uma agulha passando por ele - era a ideia básica da máquina de costura que

${ }^{61}$ Ver os três primeiros capítulos do livro de Carl Köhl, A history of costume. Nova York: Dover, 1963 , p. 53 a 161.

${ }^{62}$ Laurie Carlson. Queen of inventions. How the sewing machine changed the world. Brookfield: The Millbrook press, 2003, p. 3-15.

${ }^{63}$ Laurie Carlson. Idem, p. 3-15. 
conhecemos. Em 1804, existe uma patente francesa para Thomas Stone e James Henderson. No mesmo ano, outra patente, desta vez para certo Scott John Duncan. Ambas as invenções não funcionaram bem e rapidamente foram esquecidas. Anos depois, em 1814, um alfaiate austríaco, Josef Madersperger, construiu e patenteou sua invenção, mas ela também nunca funcionou direito. Os Estados Unidos entraram na corrida pela máquina de costura em 1818 com um protótipo inventado por John Adams Doge e John Knwles Scott. Mais um fracasso.

Todas essas recorrentes patentes e fracassos em se fazer uma máquina que realmente substituísse o trabalho manual da agulha demonstra a importância de um instrumento desse tipo para a evolução da técnica e do comércio de roupas e tecidos. Por isso, quando o alfaiate francês Barthelemy Thimonnier, em 1830, realmente conseguiu fazer uma máquina que funcionasse, a ira de costureiras e alfaiates desencadeou um motim, quase uma greve, de outros alfaiates e ateliês de costura contra a nova máquina e sua fábrica. Os alfaiates queimaram a fábrica, que supostamente faria uniformes para o exército francês, e quebraram a máquina que, desde o começo, tinha o aval do governo. ${ }^{64}$ Thomonnier voltou a ser apenas alfaiate e morreu na pobreza, apesar de ganhado vários prêmios em feiras e exposições. Baseada na patente original do alfaiate francês, hoje uma réplica de sua máquina de costura fica exposta no Museu de Ciência de Londres.

Apenas quatro anos depois, em 1834, um inventor americano, Walter Hunt ${ }^{65}$, também conseguiu fazer uma máquina de costura que funcionava e decidiu não patenteá-la por medo da repercussão negativa entre os alfaiates e costureiras. Hunt provavelmente ouviu falar tanto dos alfaiates franceses que queimaram a fábrica de

\footnotetext{
${ }^{64}$ Idem.

65 Walter Hunt também ficou famoso por inventar um rifle automático, um velocípede, um alfinete, um fogão a gás, um afiador de facas entre muitas outras máquinas.
} 
Thomonnier, como do movimento inglês dos ludistas, the luddists, que quebravam máquinas, queimavam fábricas, inventores e industriais. Mas, para entendermos esse medo e esse novo universo que tanto apavorava alfaiates e costureiras do mundo inteiro, é preciso fazer uma pausa - e nos debruçarmos sobre os graves acontecimentos que tiveram lugar na Inglaterra nas últimas décadas do século XVIII.

A revolução industrial e suas modificações no cotidiano, no tempo e na vida das pessoas, foi objeto de estudo de E. P. Thompson, que citou Costumes em comum.

Brave luddists we are, for breaking we come!

God save Ned Lud!

Machines to hell, we want our dignity

Breaking is good, join us and save Europe!

Break, break, break or die working!

Monster of industrialism, we want you broken!

Machines to the ground

Crash, crash! Bang! Bang! The sound of freedom these are!

Break one, break three, break all! All! $!^{66}$

O tempo do trabalho estava mudando no começo do século XIX; era agora regulado por relógios ou pelo tempo do trabalho nas máquinas. ${ }^{67}$ As máquinas de costura espalharam-se ao longo das décadas, transformando complemente o trabalho de se fazer roupas. Não à toa, os alfaiates se revoltaram: a antiga maneira de se costurar estava morrendo e era preciso se adaptar a um novo tempo e possuir novas habilidades, a habilidade de se adaptar às máquinas. Ainda que grande parte do trabalho de se confecionar um vestido fosse feito dentro de casas ou ateliês pequenos (ao contrário da

\footnotetext{
${ }^{66}$ E. P. Thompson. Costumes em comum. Trad. port. São Paulo: Companhia das Letras, 1998, p. 277.

${ }^{67}$ E. P. Thompson. Costumes em comum. Trad. port. São Paulo: Companhia das Letras, 1998, p. 267-304.
} 
produção fabril, que demandava grandes espaços para grandes máquinas), as máquinas de costura e as encomendas tinham um tempo diferente do tradicional trabalho de costura.

Thompson, ao analisar as mudanças no tempo do trabalho no século XVIII, afirmou: "Não existe desenvolvimento econômico que não seja ao mesmo tempo desenvolvimento ou mudança de uma cultura. E o desenvolvimento da consciência social, como o desenvolvimento da mente de um poeta, jamais pode ser, em última análise, planejado". ${ }^{68}$ Então, essas novas mudanças decorrentes da introdução da máquina de costura produziam uma nova cultura de trabalho, uma nova maneira de se relacionar com o trabalho e um novo tipo de trabalhador urbano.

Ainda que as novas máquinas de trabalho do século XIX causassem desconforto e revolta em alguns trabalhadores, as mudanças, invenções e melhoramentos das próprias máquinas não paravam. Em 1834, Walter Hunt inventou a primeira máquina de costura americana. Seu invento apenas costurava tecidos em linha reta, não fazia ziguezagues, nem voltas ou rendas. Pouco tempo depois, por causa da repercussão dos motins de alfaiates na Europa, Hunt desistiu de apimorar sua invenção e a patente nunca saiu. A primeira patente para uma máquina de costura americana foi a de Elias Howe, registrada em 1846, exatamente a marca que aparece no anúncio do Almanaque Laemmert de 1868. "A9 "A transição das roupas confecionadas em máquinas ocorreu num período anterior nos Estados Unidos, em comparação com a Europa., ${ }^{, 70}$

${ }^{68}$ E. P. Thompson. Costumes em comum. Trad. port. São Paulo: Companhia das Letras, 1998, p. 304.

${ }^{69}$ Diana Crane. A moda e seu papel social: classe, gênero e identidade das roupas. Trad. port. São Paulo: Senac, 2006, p. 153-160.

${ }^{70}$ Diana Crane. A moda e seu papel social: classe, gênero e identidade das roupas. Trad. port. São Paulo: Senac, 2006, p. 153. 


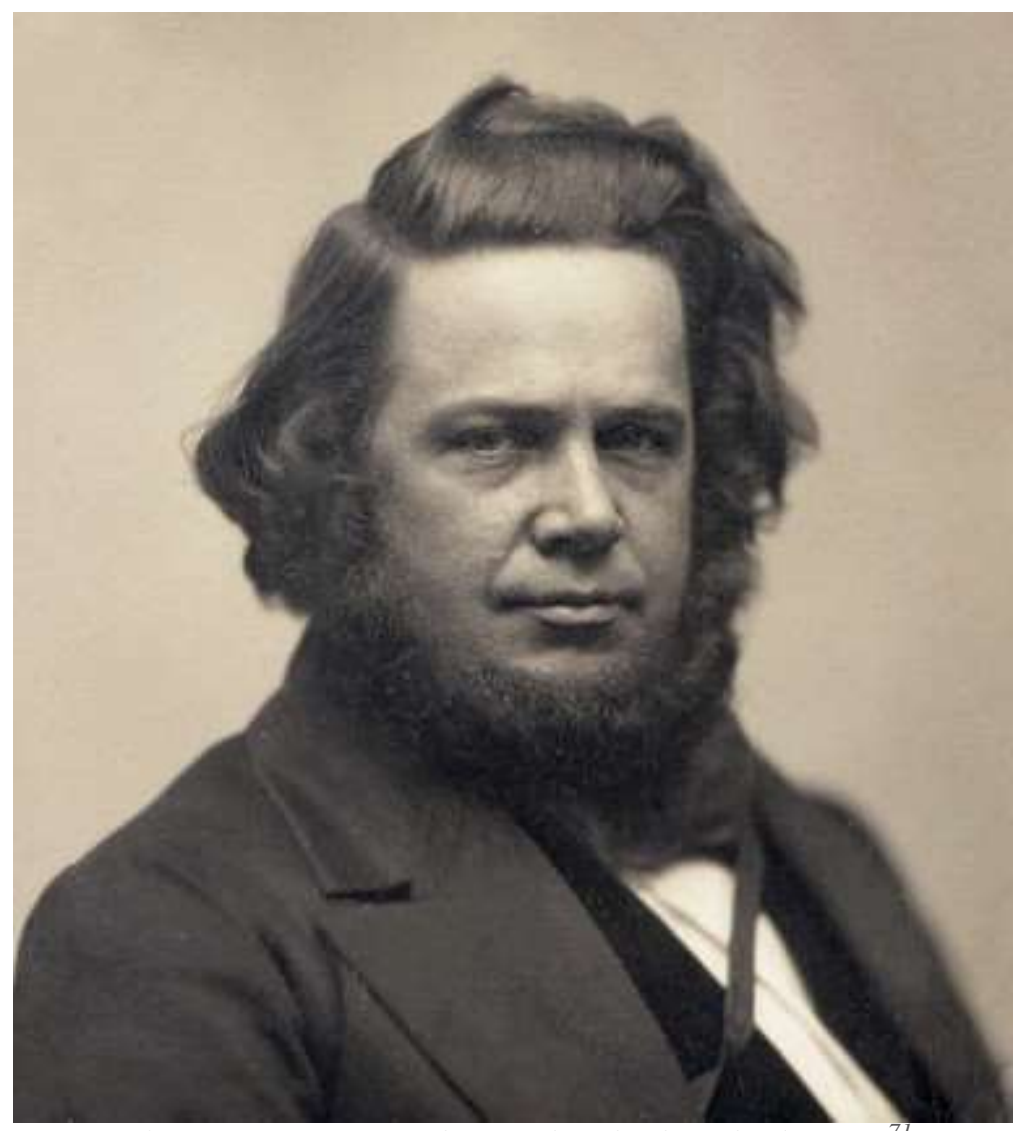

Elias Howe em foto de meados da década de 1850

Elias Howe nasceu em Massachusetts em 1819 e passou a infância e começo da adolescência trabalhando nas fábricas de tecidos ao redor de Lowell, cidade no norte dos Estados Unidos, considerada como o berço da revolução industrial americana. Em 1837, uma crise financeira causada pela especulação de bancos novaiorquinos deixou não apenas muitos trabalhadores sem emprego, mas causou uma recessão profunda, que durou cerca de cinco anos. Howe partiu para Cambridge, onde, até 1848, trabalhou no processo de cardagem ${ }^{72}$ da produção fabril local. Pouco depois, ele largou o trabalho na fábrica e começou como aprendiz numa loja de relógios e cronomêtros de precisão, cujo dono chamava-se Ari Davis. ${ }^{73}$

${ }^{71}$ Sarah Knowles Bolton. The story of Elias Howe and the sewing machine. Kindle edition, original de 1885 , s/pg.

${ }^{72}$ Processo em que duas escovas de lã, chamadas cardas, penteiam a lã para eliminar os nós.

${ }^{73}$ Laurie Carlson. Queen of inventions. How the sewing machine changed the world. Brookfield: The Millbrook press, 2003. 
Foi justamente enquanto trabalhava com os mecanismos delicados e minuciosos dos relógios que Elias Howe teve a ideia de aprimorar o sistema das máquinas de costura, criando um sistema de pesponto duplo. ${ }^{74}$

O pesponto acabou se tornando praticamente um sinônimo para costuras feitas na máquina e a invenção de Howe baseava-se em quatro detalhes técnicos principais: uma agulha com "olho" bem na ponta, um calcador por onde passava a agulha, um sistema de bolqueio e direcionamento do tecido e uma alimentação automática/manual do sistema inteiro. Esse tipo de costura entrelaçada, comum às primeiras máquinas de costura, não era muito diferente das costuras feitas à mão, em que dois pedaços de pano eram atados juntos pela costureira. Mas isso era um sistema muito complexo para uma máquina realizar - passar a agulha, juntar os panos, voltar com a agulha - e que só funcionava com poucos metros de linha.

Esse era também dos principais problemas dos inventores ao tentarem fazer funcionar uma máquina de costura no século XIX. Ao pensar numa agulha com um buraco embaixo, o olhal, Howe conseguiu com que a máquina passasse somente uma parte da agulha pelo tecido. Assim, a agulha seria presa à uma barra de agulhas, movimentada para cima e para baixo por um motor manual - com uma série complexa de engrenagens, que Howe deve ter aprendido a fazer funcionar quando era aprendiz de relojoeiro. Quando o ponto passava pelo tecido, ele puxava um pequeno laço da linha de um lado para outro, um mecanismo abaixo do tecido prenderia esse laço e entrelaçaria com outro pedaço da linha, juntando os tecidos.

A máquina, exibida pela primeira vez numa exposição industrial em Washington em 1846, custava o equivalente a US\$ 300. Para se ter uma ideia do quanto isso

\footnotetext{
${ }^{74}$ Pesponto duplo é o ponto da costura em que uma agulha torna sucessivamente a entrar um pouco atrás no lugar em que saiu o ponto anterior. Na verdade, é uma espécie de ponto reforçado e linear.
} 
representava para a época, um trabalhador médio, empregado num indústria de chapéus ganhava de US\$ 5 a 10 por semana nos Estados Unidos. Ninguém comprou a máquina na exposição, mas no dia 10 de setembro Howe recebeu a patente de número $5.346 .{ }^{75}$ As vendas continuaram fracas até Howe seguir para a Inglaterra, onde um grande empresário têxtil, William Thomas, havia comprado a patente de Howe. Em Londres, o inventor adaptou a máquina de costura (que ainda precisaria de muitos ajustes e melhorias para funcionar adequadamente) para costurar espartilhos e guarda-chuvas.

De volta à América, quase falido, Howe resolveu entrar na justiça para receber direitos por sua máquina. Depois de uma batalha bem sucedida de alguns anos em cortes americanas por causa da patente, contra outros fabricantes de máquinas de costura, entre eles Isaac Singer, o irmão de Elias, que se chamva Amasa, montou uma fábrica de máquinas de costura em Nova York. De lá, provavelmente, vinha a máquina de costura que chegou no Rio de Janeiro em 1868. O nome Howe era sinômino de máquinas de costura bem fabricadas e exportadas para o mundo todo. ${ }^{76}$

Howe participou da Guerra Americana de Secessão entre 1861 e 1865, refazendo sua fortuna ao vender uniformes para soldados. "Durante a guerra civil americana, de 1861 a 1865, a produção de roupas, em especial uniformes militares, feitas com máquinas de costura se expandiu nos Estados Unidos."77 Mas, logo depois de ser condecorado com a medalha de honra por Napoleão III, na Exposição Universal de Paris, em 1867, Elias morreu subitamente aos 48 anos. No mesmo ano, suas patentes caíram por terra e o império Howe começou lentamente a declinar, sendo substituído

\footnotetext{
75 Ver novamente o livro de Laurie Carlson, Queen of inventions: how the sewing machine changed the world (Brookfield: Millbrook press, 2003).

${ }^{76}$ Carl Köhl, A history of costume. Nova York: Dover, 1963.

${ }^{77}$ Diana Crane. A moda e seu papel social: classe, gênero e identidade das roupas. Trad. port. São Paulo: Senac, 2006, p. 154.
} 
rapidamente pelo de Isaac Singer, que possuía uma máquina melhor e técnicas mais modernas de propaganda e assistência técnica às máquinas.

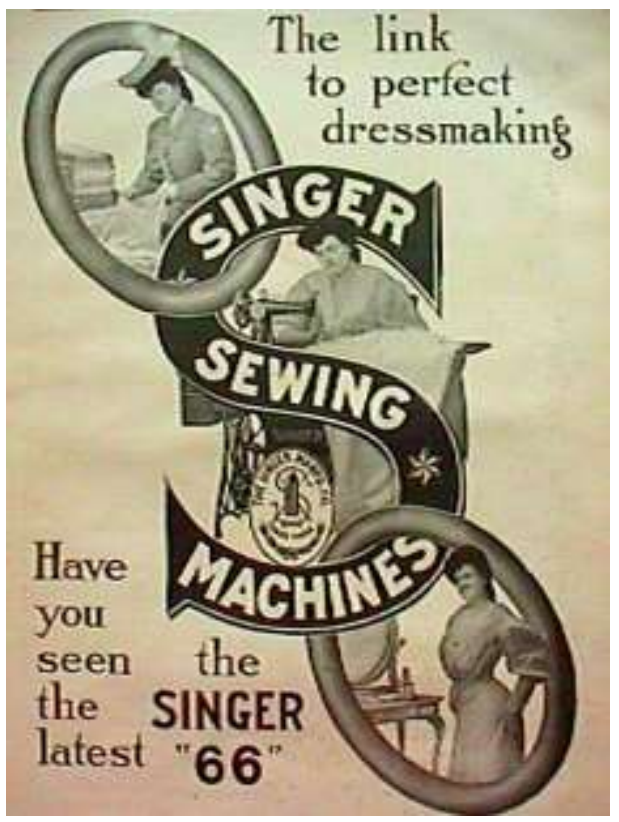

Um novo produto e uma nova maneira de vender: propagandas para mulheres ${ }^{78}$

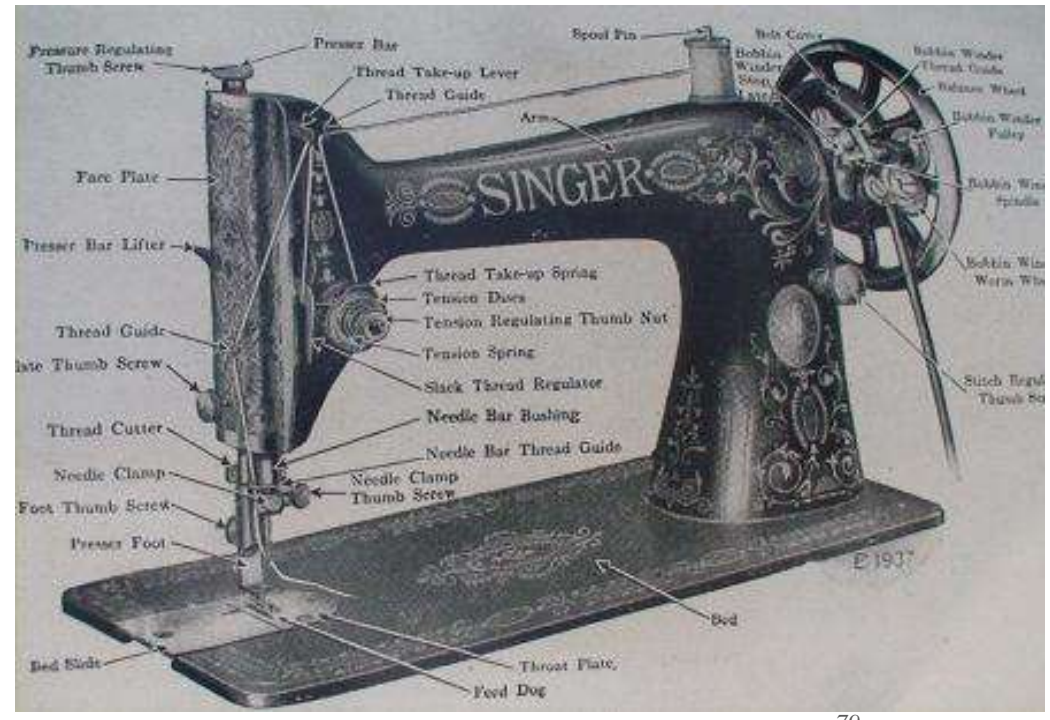

Uma Singer 1866: o ponto quase perfeito ${ }^{79}$

${ }^{78}$ Anúncio reproduzido por James Parton em seu livro Making of America. History of the sewing machine. Carlisle: Applewood books, 1972.

${ }^{79}$ James Parton em seu livro Making of America. History of the sewing machine. Carlisle: Applewood books, 1972 
Isaac Singer não foi apenas um adversário das máquinas de Elias Howe. Singer revolucionou o mercado ao tentar fazer as máquinas mais baratas e mais eficientes. $\mathrm{Na}$ verdade, Singer mudou a ideia de que as máquinas de costura deveriam estar em fábricas. Ele pensou e desenvolveu máquinas baseado numa ideia que vai se espalhar pelo século XIX - a de que as máquinas de costura eram aparelhos para serem usados em casa ou no máximo num pequeno ateliê. Desta forma, cada família poderia ter a sua máquina, fazer a sua costura. A ideia foi bem aceita inclusive pelas costureiras e alfaites, que as viram como uma maneira de aprimorar seu próprio trabalho, ganhando tanto em tempo como em dinheiro. Singer também montou um bem azeitado sistema de vendas, em que cada loja concordava em pagar 60 dólares por máquina e revendê-las por 125 dólares. $^{80}$

Nas propagandas da Singer, ficava claro que as máquinas de costura não representavam mais uma ameaça como antes, como foram os teares, na época de Thimmonier. As máquinas de costura podiam dar lucro e fazer do negócio de costurar roupas uma alternativa rentável. Singer também inovou ao vender sua máquina a prestação, com pequenas parcelas mensais. A empresa não parou de crescer e se expandir. "A aquisição dessas máquinas para uso doméstico foi facilitada pelo sistema de pagamento a prazo", afirmou Diane Crane. ${ }^{81}$

\footnotetext{
${ }^{80}$ Thomas J. Schlereth. Victorian America: transformations in everyday life. Nova York: Harper Collins, 1991, p. 153 e 154.

${ }^{81}$ Diana Crane. A moda e seu papel social: classe, gênero e identidade das roupas. Trad. port. São Paulo: Senac, 2006, p. 153-154.
} 


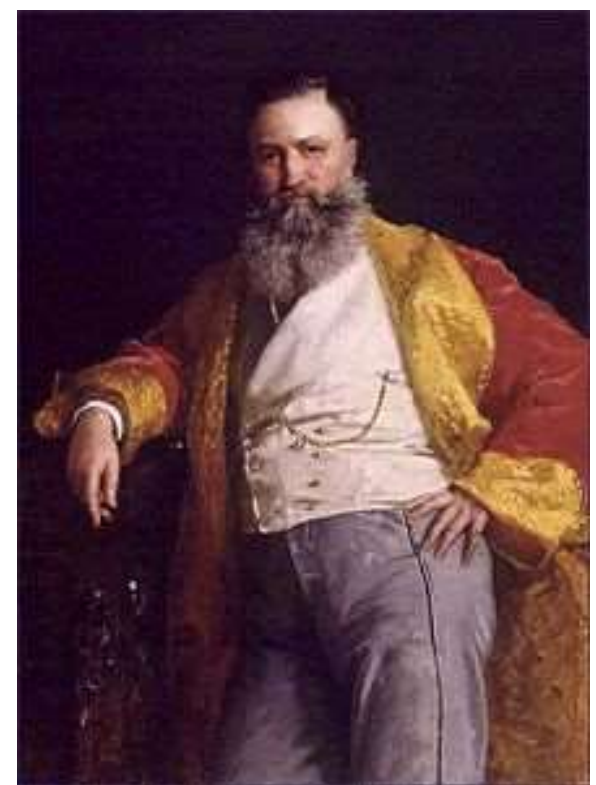

Retrato de Isaac Singer feito pelo pintor Edward Harrison May em $1869^{82}$

Isaac Singer, filho de imigrantes alemães nos Estados Unidos, foi ator em seus primeiros anos profissionais. Mas, antes disso, ainda no começo da adolescência, ele trabalhou com o irmão mais velho numa loja de máquinas. Foi com esse trabalho que ele aprendeu a lidar e consertar diferentes tipos de máquinas. Tendo inventado uma máquina de perfurar pedras e feito sucesso com seu invento, ele resolveu seguir com a carreira de ator profissional, apresentando-se em várias cidades (e tendo várias mulheres e filhos pelo caminho). Sua trupe não fez muito sucesso e ele resolveu voltar-se novamente para as invenções e máquinas. Com quase 40 anos de idade, na década de 1850, em Boston, ao tentar consertar outro invento, Singer deparou-se com uma máquina de costura quebrada. Para resolver o problema ele pensou numa solução que mudaria os rumos da moda para sempre. Ao invés dos pontos serem dados em círculo,

${ }^{82}$ Don Bissell, The first conglomerate: 145 years of the Singer sewing machine company. Edição do autor, 1999. 
eles costurariam melhor se fossem colocados em linha reta. A ideia foi colocada em

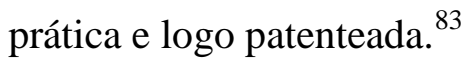

A guerra de patentes pelas máquinas de costura nos Estados Unidos não envolveu apenas as famílias Howe e Singer. Ao longo do século XIX, diferentes inventores tentaram aprimorar e otimizar os custos de novas máquinas. Na década de 1850, por exemplo, um fazendeiro da Vírginia chamado James Gibbs ao ver uma máquina Singer funcionando pensou num método de aperfeiçoar a maneira como a agulha fazia o "nó" da costura, o ponto propriamente dito. Gibbs conseguiu fazer uma máquina mais leve, com pontos mais firmes e muito mais barata, custando cerca de US\$ 50, enquanto as similares não saíam por menos de US\$ 100 na época. Não demorou muito para que ele e seu filho se juntassem à Charles Wilcox, um empresário e investidor em novas tecnologias. A cada mundaça ou aperfeiçoamento na máquina de costura, uma nova patente era requerida e recebia um número. Cada fabricante de máquinas de costura sabia das mudanças dos outros e aperfeiçoava suas próprias máquinas. A guerra nos tribunais parecia não ter fim, com vários empresários brigando pelo direito de fabricar sua própria invenção.

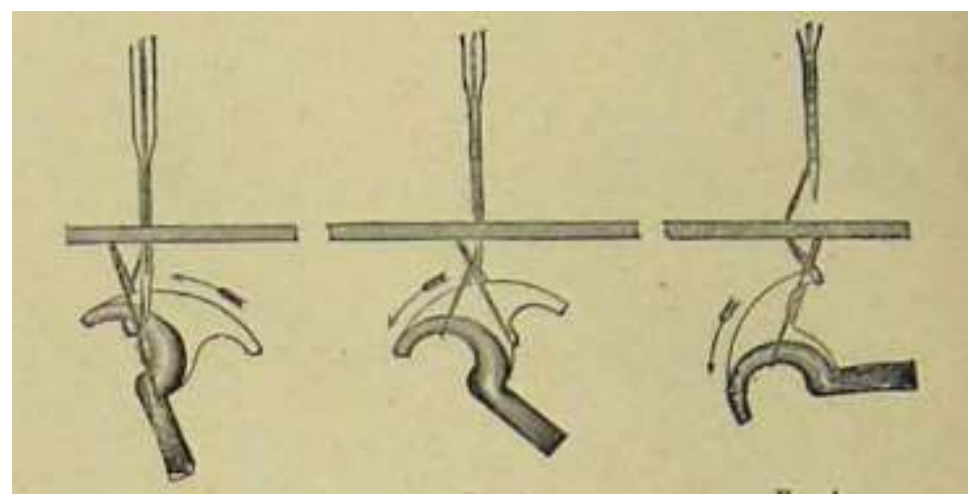

Um novo método de costura: um gancho "pega" a linha e faz uma espécie de nó ${ }^{84}$ ${ }^{83}$ Uma breve biografia da vida e realizações de Singer pode ser encontrada em Don Bissell, The
first conglomerate: 145 years of the Singer sewing machine company. Edição do autor, 1999. 


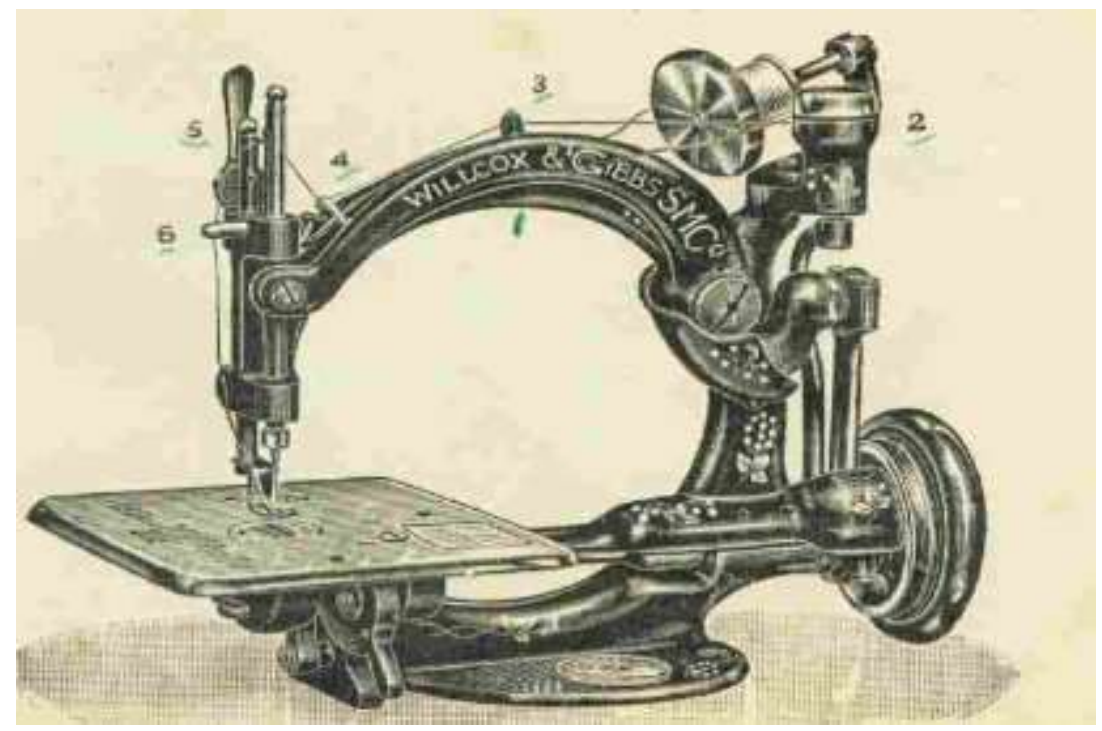

Uma máquina de costura Wilcox and Gibbs de 1890

Em 1875, foi feita uma enquete com famílias de trabalhadores qualificados e nãoqualificados de Massachusetts, nos Estados Unidos, que revelou que um terço delas possuía uma máquina de costura. ${ }^{85}$ Já para o final do século, a máquina havia se espalhado pelo país.

Na França, a máquina de costura foi comercializada por um sistema diferente, com intensa propaganda nas revistas femininas, com foco na dona de casa operária, que poderia adquirir uma máquina para ganhar dinheiro confecionando roupas para fora e não para si mesma. O sistema de financiamento da máquina não era como o dos Estados Unidos, em prestações, e a dona de casa era aconselhada a economizar para adquirir sua máquina.

Na França, a indústria de roupas prontas voltou-se inicialmente para as operárias; mulheres ricas que compravam esse tipo de vestimenta eram mal vistas. Os ateliês,

\footnotetext{
${ }^{84}$ A imagem reproduzidas nesta página estão no livro Christina Walkley e Vanda Foster. Crinoline and crimping irons. Victorian clothes: how they were cleaned and cared for. Londres: Peter Owen, 1978, pgs. 54 e 68.

${ }^{85}$ Ava Baron e Susan Kleo, "If I didn't have my sewing machine: women and sewing machine technology...”. In: Joan Jensen e Sue Davidson (orgs.). A needle, a bobbin a strike: women needleworkers in America. Filadélfia: Temple University Press, 1984, p. 30-35.
} 
então, espalhavam-se por Paris. ${ }^{86}$ No Brasil ocorreu algo semelhante. Mulheres de classe média e alta mandavam fazer suas roupas, ao invés de confeccioná-las em casa. Da mesma forma, as imigrantes, francesas ou de outras nacionalidades, abriam seus ateliês na rua do Ouvidor.

Um dos fatores para o sucesso da máquina de costura tanto na Europa como nos Estados Unidos, e depois no resto do mundo, foi a intensa comercialização de moldes. Sem a padronização de tamanhos teria sido impossível a popularização da máquina. "Na década de 1860, uma companhia americana começou a disitrbuir moldes de roupa em grande escala. Os moldes constituíam o complemento da máquina de costura, possibilitando às mulheres confecionar roupas da moda de alta qualidade na própria casa." 87

Logo depois da guerra civil americana houve uma grande expansão do comércio de roupas prontas femininas, decorrente das habilidades adquiridas durante a guerra na confecção de uniformes. As informações sobre as roupas podiam ser encontradas em catálogos de compras, que nessa época se espalhavam até mesmo pelas menores cidades americanas. $^{88}$ Diane Crane vai dizer que a produção dessas roupas vendidas por catálogo estimulou a confecção de vestidos mais simples, feitos para serem usados em casa, prenunciando uma moda, já bastante industrializada, do século XX. ${ }^{89}$

Nos Estados Unidos, a máquina de costura foi responsável por outro fenômeno importante para a venda de roupas prontas: a uniformização dos tamanhos. Cedo, os

\footnotetext{
${ }^{86}$ Judith G. Coffin, "Consumption, production and gender: the sewing machine in 19th France." In: Sonya Rose (org). Gender and class in modern Europe. Ítaca: Cornell University Press, 1996, 136.

${ }^{87}$ Diane Crane. A moda e seu papel social: classe, gênero e identidade das roupas. Trad. port. São Paulo: Senac, 2006, p. 154.

${ }^{88}$ Daniel E. Sutherland. The expansion of everyday life 1860-1876. Fayeteville: The University of Arkansas Press, 2000, p. 27-53.

${ }^{89}$ Diana Crane. A moda e seu papel social: classe, gênero e identidade das roupas. Trad. port. São Paulo: Senac, 2006, p. 154.
} 
produtores de máquinas de costura concordaram em fazer moldes de acordo com tamanhos padronizados, tanto para homens como para mulheres. Isso possibilitou que moldes fossem usados por mulheres em todo o país - impulsionando fábricas de roupas prontas. "A antropometria se desenvolveu junto da indústria de confecção" 90 primeiramente para homens e depois para mulhres. ${ }^{91}$

\section{A história da máquina de costura aqui}

Dessa maneira, os acontecimentos que tomavam lugar nos tribunais americanos não tardaram a repercutir no Brasil. Rapidamente, as máquinas de costura chegaram ao mercado brasileiro via porto do Rio de Janeiro. Em 1858, a Singer abriu a primeira loja no Brasil, na rua do Ouvidor, $117 . .^{92} \mathrm{~A}$ condessa de Barral, atenta às novidades estrangeira, ao que tudo indica, importou em 1854 uma das primeiras máquinas de costura para o Brasil. Usava-a em sua fazenda na Bahia e a emprestava para as amigas aprenderem a "costurar à máquina". Segundo Wanderley Pinho, a condessa de Barral “modificava costumes, lançava uma nova moda; e também introduzia a máquina de costura. Foi a primeira senhora baiana que possuiu um desses prodígios, tão cantados e decantados em crônicas entusiásticas, quando apareceram no Rio de Janeiro em 1854, por Otaviano e José de Alencar". ${ }^{93}$

Poucos anos depois, em 1859, o senhor Robert Dutton apareceu pela primeira vez no Almanaque Laemmert, anunciado sua loja de máquinas de costura logo após os anúncios de uma loja de mármore e de uma loja de meias. Seu depósito de máquinas de

\footnotetext{
${ }^{90}$ Thomas J. Schlereth. Victorian America: transformations in everyday life. Nova York: Harper Collins, 1991, p. 150 a 153.

${ }^{91}$ Thomas J. Schlereth. Victorian America: transformations in everyday life. Nova York: Harper Collins, 1991, p. 150 a 153.

${ }^{92}$ Ver a história da Singer no Brasil em 〈http://www.singer.com.br/institucional/historia.asp〉, consulta em 15/12/2012.

${ }^{93}$ Wanderley Pinho. Salões e damas do segundo império. São Paulo: Martins Editora, 1970, p. 226 e 227.
} 
costura ficava "situado na r. Da Quitanda, 40, sobrado". ${ }^{94}$ No ano seguinte, 1860 , outros lojistas vieram a se somar ao senhor Dutton, como a madame Besse, localizada na rua do Ouvidor, 92, $1^{\circ}$ andar, e J.M. Singer \& C., anunciando sua loja na rua do Ouvidor, 117. Outro negociante também anunciou o produto à venda na rua de S. Pedro, $166 .^{95}$

No ano de 1861, Madame Besse e Companhia mudou-se para a rua do Ouvidor, $35,1^{\mathbf{o}}$ andar. ${ }^{96}$ Nesse mesmo ano, sua oficina publicou o anúncio abaixo, ilustrando seus produtos à venda. Besse vendia máquinas de costura da marca Wheeler \& Wilson's. Nathaniel Wheeler e Allen B. Wilson abriram sua fábrica de fazer máquinas de costura em Water Town, Connecticut, em 1852. Rapidamente, os empresários entraram com a requisição de patentes tanto para um novo ponto feito pela máquina, como pelos pedais de acertar a costura. A guerra de patentes continuava - cada fabricante querendo que sua máquina fosse usada pelos consumidores - e cada máquina sendo mais e mais aperfeiçoada.

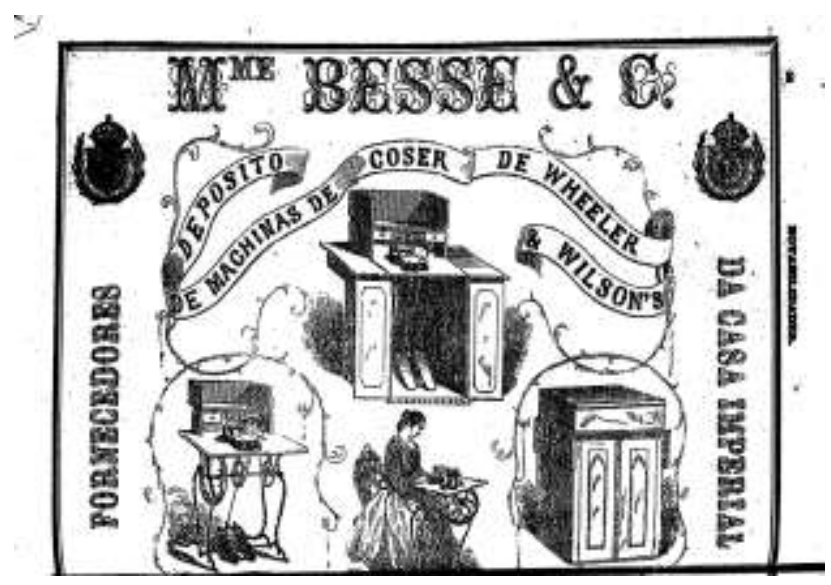

O anúncio da loja de madame Besse, que vendia máquina de costura Wheeler \& Wilson's ${ }^{97}$

\footnotetext{
${ }^{94}$ Almanaque Laemmert, 1859, pág. 632.

95 Almanaque Laemmert, 1860, pág. 645.

${ }^{96}$ Almanaque Laemmert, 1861, pág. 570.

${ }^{97}$ Almanaque Laemmert, 1861, "Notabilidades".
} 


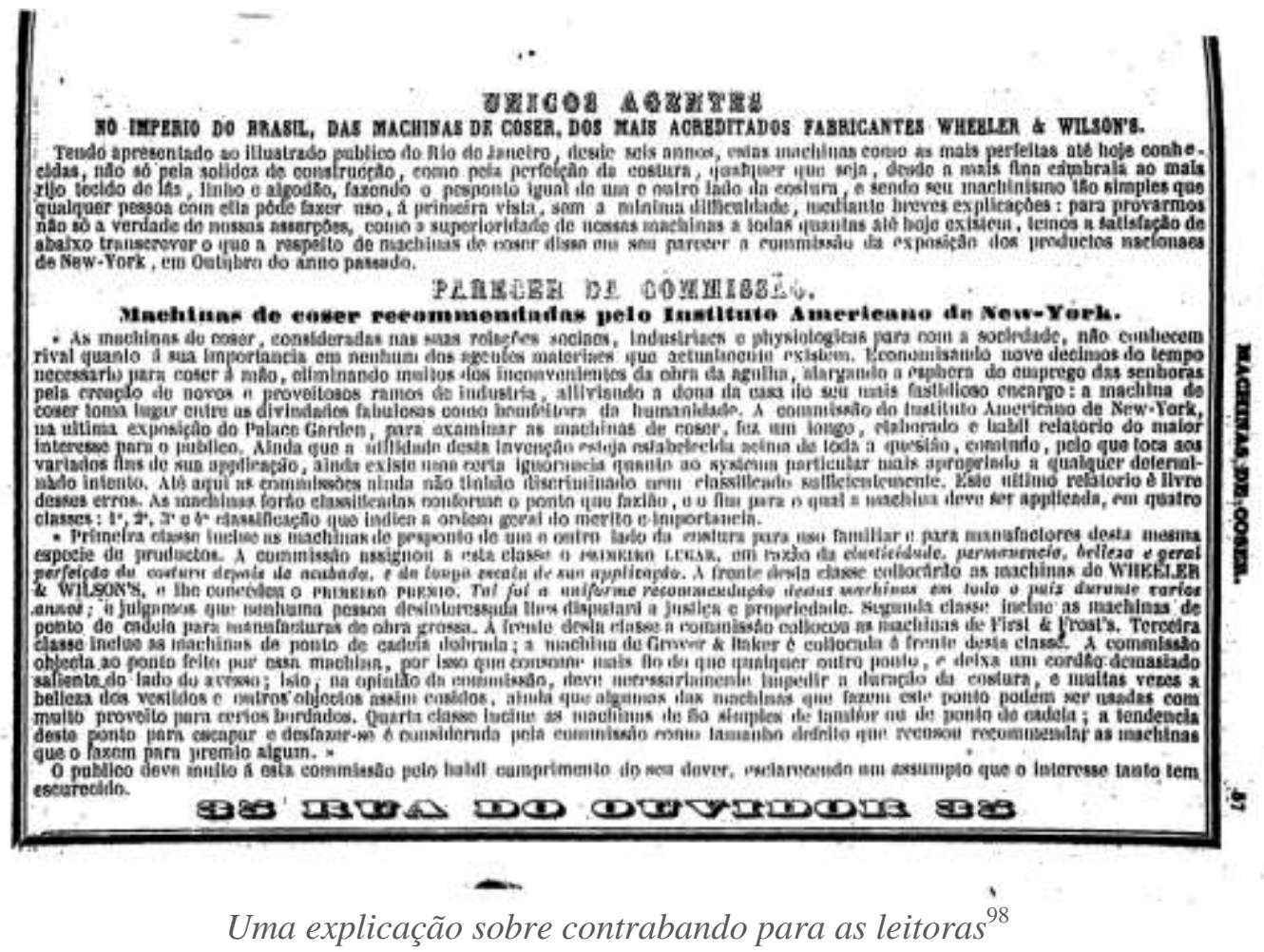

É interessante notar que, assim que máquinas começavam a ser comercializadas nos Estados Unidos, em questão de poucos anos já estavam disponíveis para os brasileiros. Todos os fabricantes participavam de feiras e exposições, recebendo medalhas e honras ao mérito. As feiras ou exposições serviam tanto para a validação da qualidade do produto que estava sendo oferecido, como uma forma de propaganda, sendo geralmente anunciados junto às máquinas.

Em 1868, os depósitos de máquinas de costura já haviam se multiplicado no Rio de Janeiro. George Ballard estava na rua da Quinta, 57; Henry Evans Milford, na rua do Ouvidor, 103; José Gomes de Oliveira havia se tornado o sucessor de madame Besse (não sabemos o motivo: teria ele comprado o estabelecimento?). Regis Conteville estava na rua de São José, 101; Thomas Dutton Junior continuava na rua da Quitanda, 40. Vivraldi \& C., estabelecido na rua da Ajuda, 8, vendia máquinas Howe.

${ }^{98}$ Almanaque Laemmert, 1861, "Notabilidades". 
Contudo, o mais interessante nesse ano de 1868 foi a junção de várias máquinas modernas, para diferentes finalidades, num mesmo espaço de vendas. José Gonçalves de Oliveira Sanches e Lidgerwood "G. Van Vlech" anunciavam e vendiam máquinas de costura e também máquinas agrícolas. As máquinas de costura eram, no período, claramente uma tecnologia de ponta prestes a se tornar indispensável no cotidiano das pessoas. Quem dominasse o mercado estaria não apenas vendendo mais itens dentre os vários produto novos do século XIX. Quem dominasse o mercado tinha a possibilidade de ganhar muito dinheiro.

Pouco depois, Lingerwood tornava-se representante da Singer no Brasil e anunciava que a grande produção americana possibilitava a venda de máquinas mais baratas para as famílias brasileiras. Os vinte anos de produção nos Estados Unidos garantiam um produto confiável a um bom preço. Alguns anos mais tarde, Lingerwood se tornaria representante de outros tipos de maquinário, como máquinas para o beneficiamento de café ou máquinas para a produção de tecidos. 


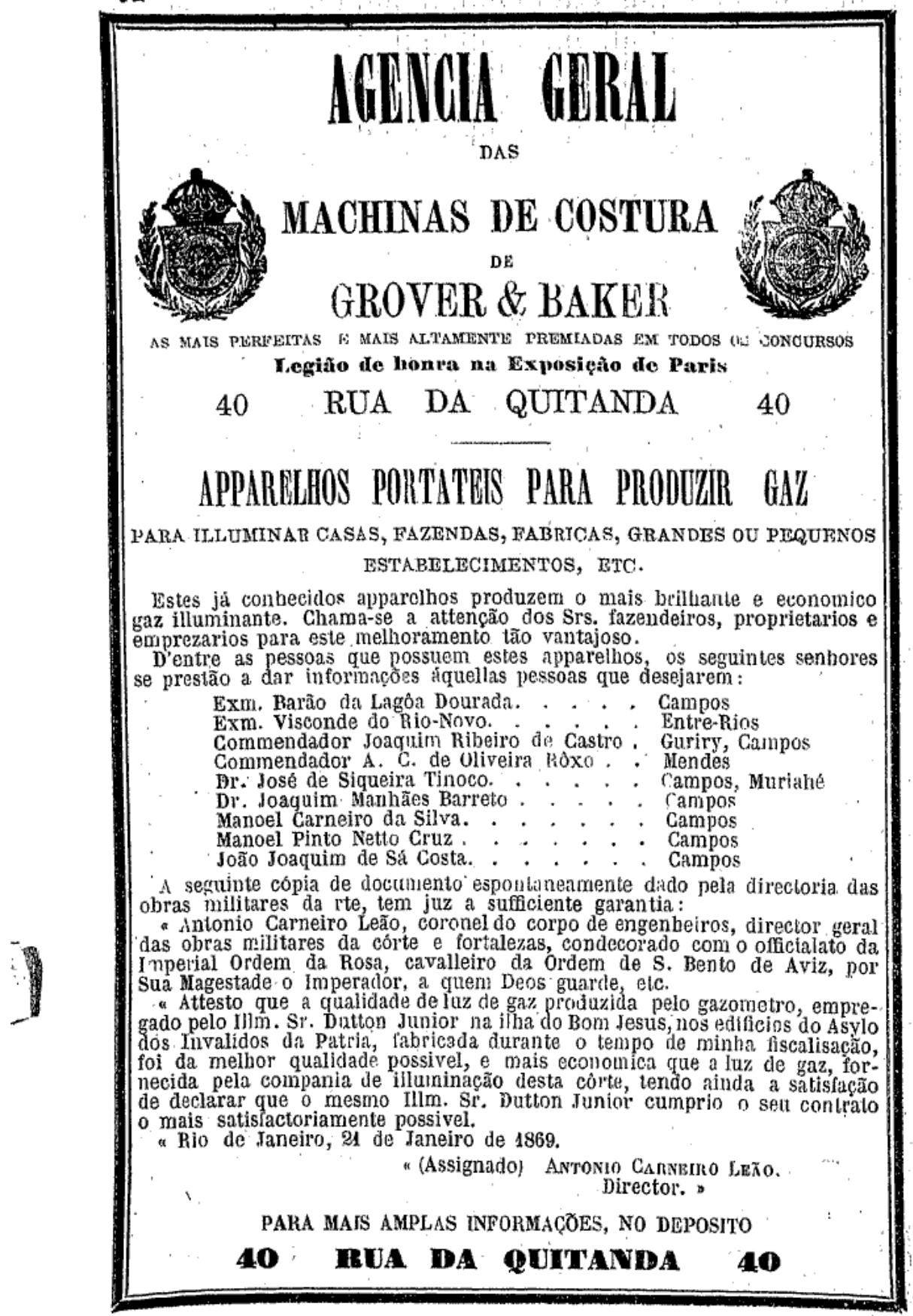

Máquinas de vários tipo: costuras e iluminação ${ }^{99}$

${ }^{99}$ Almanaque Laemmert, 1870, "Notabilidades". 


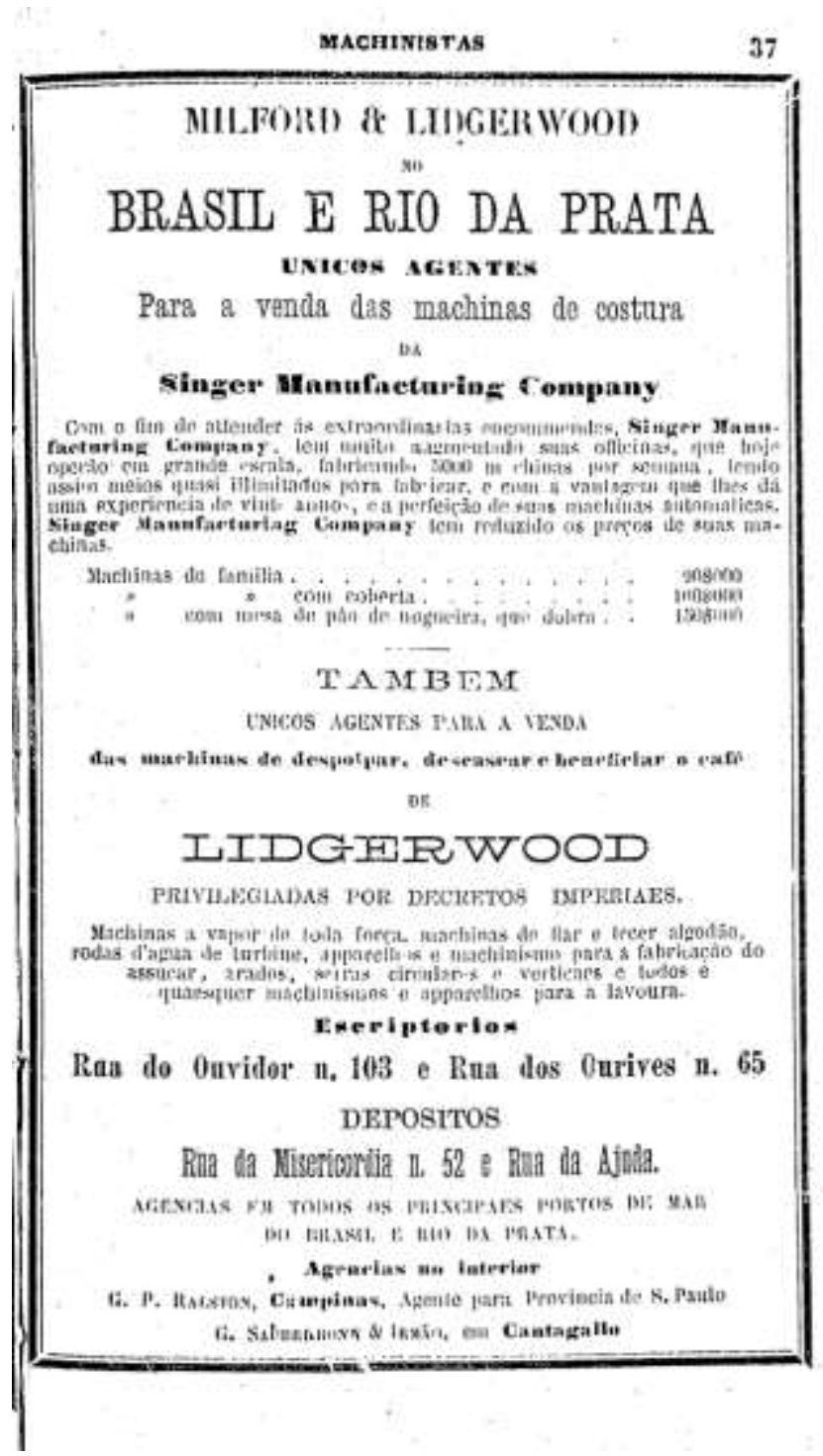

Máquinas Singer aumentam a produção e a venda ${ }^{100}$

O anúncio acima escondia um interessante conflito, surgido nos vinte anos de fabricação das máquinas de costura Singer nos Estados Unidos. Com cada fabricante de máquina clamando que sua invenção era a melhor e mais bem acabada e requerendo patentes atrás de patentes a cada nova pequena alteração ou melhoria nas máquinas, a guerra nos tribunais americanos era uma constante. ${ }^{101}$

\footnotetext{
${ }^{100}$ Almanaque Laemmert, 1871, "Notabilidades"

${ }^{101}$ Carlson, Laurie. The queen of inventions: how the sewing machine changed the world. The Millbrook press. Brookfield, 2003.
} 
Depois de alguns anos, com os adgovados de todos os lados ganhando muito dinheiro, os principais fabricantes de máquinas de costura nos Estados Unidos se uniram num cartel para controlar a fabricação das máquinas. Faziam parte desse grupo a Wheeler \& Wilson, a Singer, a Grover \& Baker e, claro, a empresa de Elias Howe, além de algumas outras empresas menores. $\mathrm{O}$ acordo entre todos era que cada máquina de costura feita pelas empresas participantes tinha de pagar US\$ 15 (o equivalente a duas semanas de salários de um empregado da fábrica) para o grupo. As empresas passaram a ser acusadas pela imprensa de monopólio, mas o cartel, que começou em 1856 continuou até 1877 . O grupo se autointitulava "A combinação entre os fabricantes de máquinas de costura". No final dos anos 1870, o congresso americano estabeleceu a lei que quebrava o monopólio do cartel e o preço da máquina de costura americana caiu bastante. Poucos anos depois, na década de 1880, a Singer cresceu tanto que acabou por controlar cerca de $75 \%$ do mercado. ${ }^{102}$

Conforme o mercado americano crescia e se especializava, as máquinas de costura tornavam-se um objeto comum no cotidiano em cidades como o Rio de Janeiro. As máquinas americanas, aliás, passaram a ter um papel muito importante para a economia brasileira e os importadores se multiplicavam. A máquina de costura ao mesmo tempo que outros tipo de máquinas também era importados, como descaroçadores de café e outros utensílios mecânicos para a lavoura. Tanto é que no Almanaque Laemmert de 1872 o lugar que era ocupado até então pelas máquinas agrícolas e de costura desdobra-se em duas entradas no índice: as máquinas para a agricultura e as máquinas de costura. ${ }^{103}$

\footnotetext{
${ }^{102}$ Uma das melhores histórias sobre o cartel de máquinas de costura e os primeiros fabricantes está no site <http://www.sewalot.com/sewing\%20machine\%20combination.htm>, consultado em $05 / 01 / 2012$.

${ }^{103}$ Ver o índice do Almanaque Laemmert em 1872.
} 
Por causa das diferentes falhas e dificuldades de costura do começo da comercialização das máquinas, nas décadas de 1850 e 1860, o mercado demorou para se estabelecer. Mas já para o final da década, quando o cartel foi dissolvido, comprar uma máquina de costura tornou-se um bom negócio tanto para uma família abastada como para um pequeno ateliê de costura. Dessa vez, ao contrário do que ocorrera com Thimmonier, costureiras e alfaiates viram a oportunidade de aumentar seus ganhos e não serem substituídos pelas máquinas.

Em 1873, já eram 23 os negociantes de máquinas de costura no Rio de Janeiro. Ao longo da década de 1870, que é quando a produção de máquinas de costura se estabiliza e cresce como negócio, diferentes importadores ofereceram seus produtos para os brasileiros. Ao longo desta mesma década esse número vai variar entre 20 e 25 casas importadoras, que abriram suas portas e passaram a vender máquinas também feitas fora dos Estados Unidos. Era o caso da Junken \& Ruh, anunciada pela casa Krutz \& Gluck, situada na rua dos Ourives, 102. A máquina era uma cópia alemã da Singer New Family, que foi produzida até a Primeira Guerra Mundial e que vendia muito bem no mercado inglês. ${ }^{104}$

Em 1877, um novo fenômeno começa a marcar o comércio de máquinas de costura no Brasil e nos dá a dimensão importância que elas adquiriram no cotidiano. O anúncio de d. Maria Almeida, publicado na página 59 da seção de "Notabilidades" do Almanaque Laemmert de 1877, avisa seus consumidores para as máquinas Singer falsificadas. O ateliê de d. Maria Almeida ficava na rua Uruguaiana, 145. Na mesma seção de anúncios do almanaque estão elencados outros 18 comerciantes que vendiam máquinas de costura. Quais seriam as falsas? Existiria um falsificador brasileiro ou as

${ }^{104}$ Ver o índice do Almanaque Laemmert em 1872. 
máquinas falsas eram importadas? Seriam mesmo as outras máquinas falsas e d. Maria apenas usava um recurso publicitário para vender seu produto? ${ }^{105}$

NOTABLLIDADES

ii!

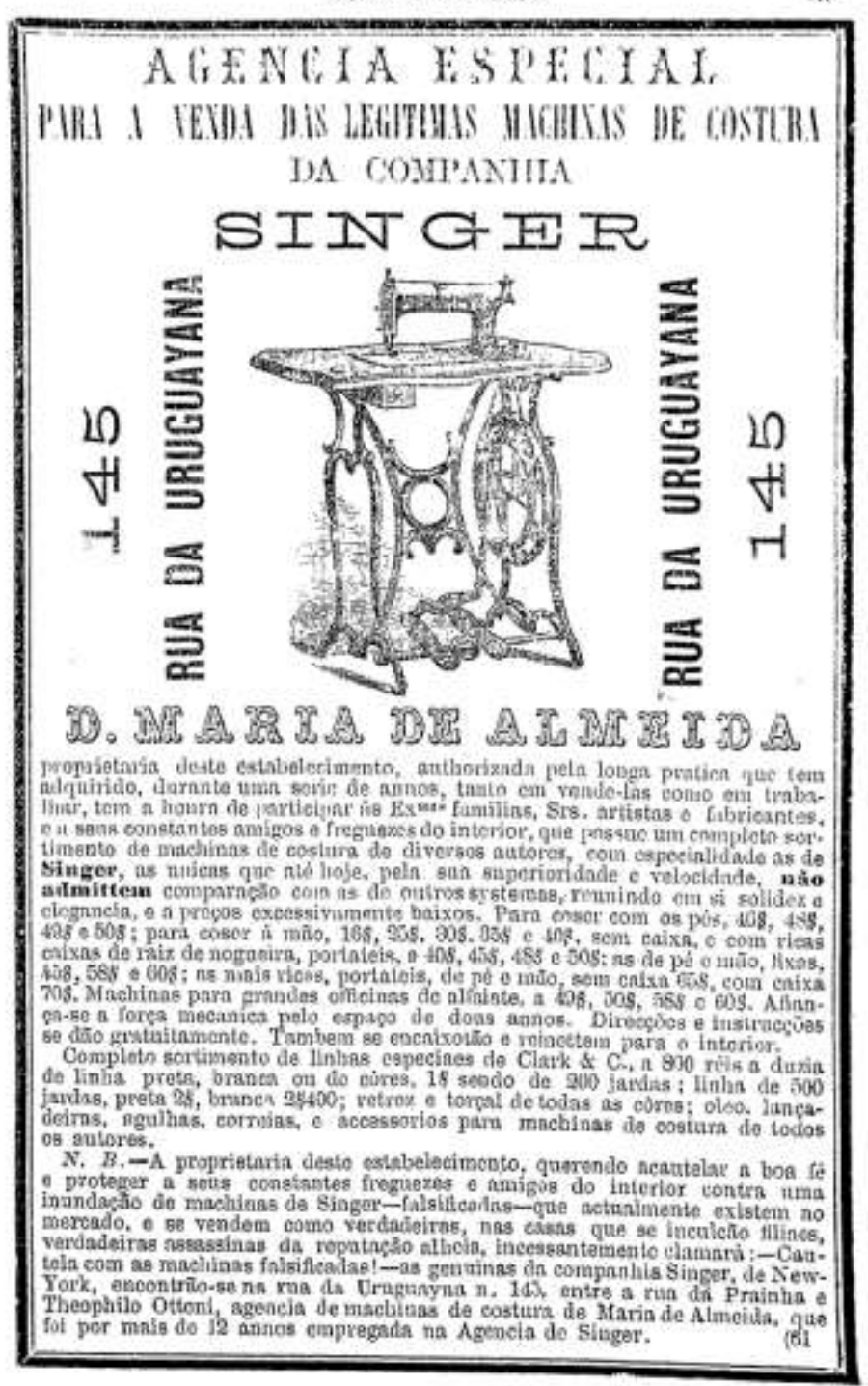

Anúncio no Almanaque Laemmert de máquinas de costura falsas ${ }^{106}$

\footnotetext{
${ }^{105}$ Ver a seção de "Notabilidades", página 59, do Almanaque Laemmert em 1877.

${ }^{106}$ Seção de 'Notabilidades”, página 59, do Almanaque Laemmert em 1877
} 
Abaixo reproduzo parte do anúncio de d. Maria de Almeida.

A proprietária desse estabelecimento, querendo acautelar a boa fé e proteger a seus constantes fregueses e amigos do interior contra uma inundação de máquinas de Singer - falsificadas - que atualmente existem no mercado e se vendem como verdadeiras, nas casas que se inculcão filiais, verdadeiras assassinas da reputação alheia, incessantemente clamará: Cautela com as máquinas falsificadas! - as genuínas da companhia Singer, de New York, encontram-se na rua Uurguaia, n. 145, entre a rua da Prainha e Theophilo Ottoni, agência de máquinas de costura de Maria de Almeida, que foi por mais de 12 anos empregada da Agência Singer. ${ }^{107}$

No anúncio de Maria de Almeida, percebemos também a importância das mulheres na venda de artigos relacionados à confecção de roupas. As mulheres possuíam não apenas ateliês de costura, mas também lojas de vendas de máquinas de costura. Em 1877, eram duas mulheres a terem lojas de máquinas. Na segunda metade do século XIX, portanto, ao longo do século XIX, as mulheres tornam-se, ao mesmo tempo, consumidoras e vendedoras de produtos. Com o aumento da escolaridade feminina, uma nova área do conhecimento nasceu voltada para vender produtos para mulheres. A publicidade passou a ser produzida e veiculada para mulheres, pensada para atrair sua atenção com temas caros ao universo feminino. No caso das máquinas de costura, a família, a economia doméstica, os filhos. Mas vendiam-se produtos para a beleza, para a saúde feminina, para o aparelhamento da casa.

${ }^{107}$ Ver a seção de 'Notabilidades”, página 59, do Almanaque Laemmert em 1877. 


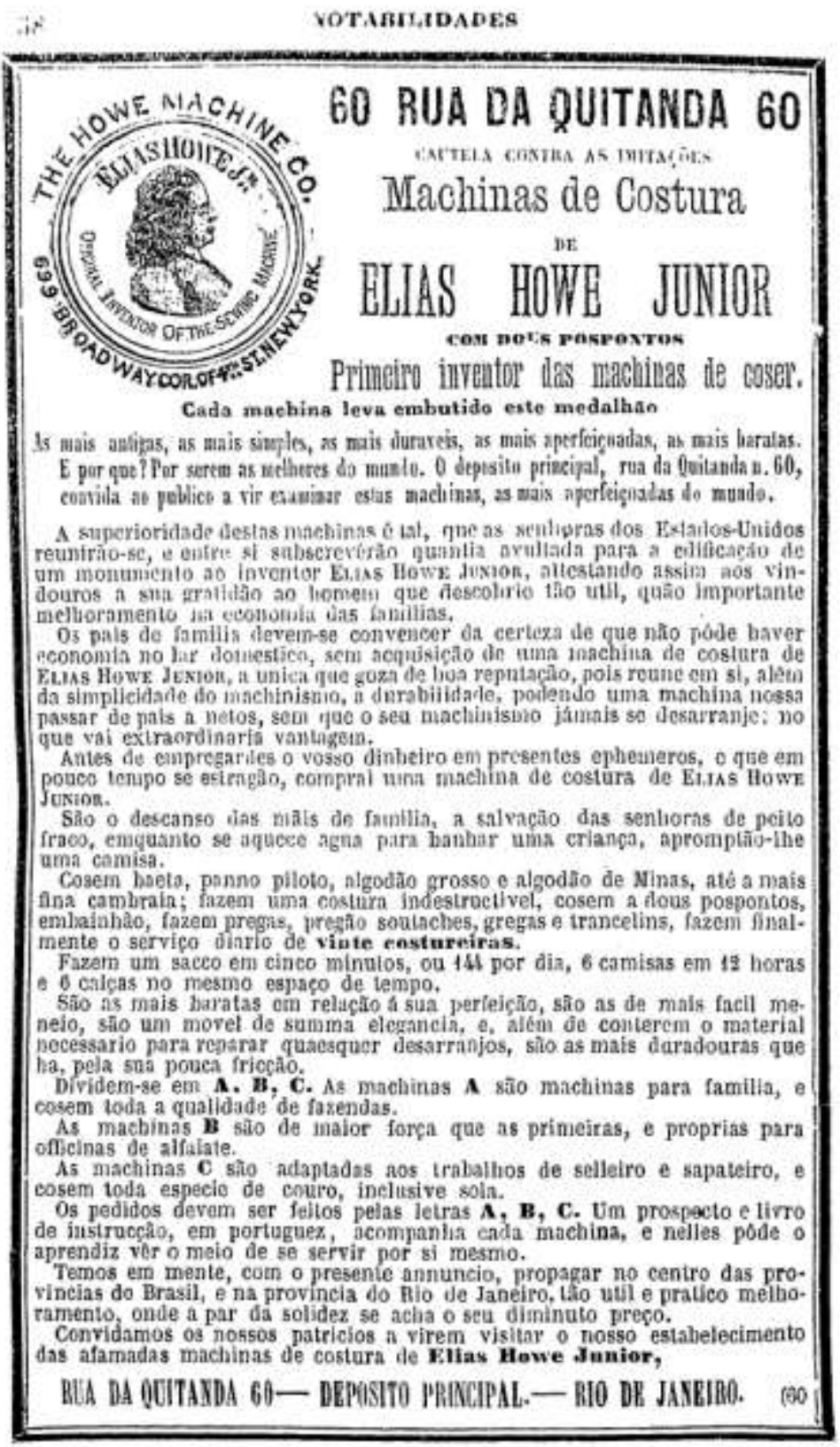

Anúncio de máquinas Howe para a família de $1877^{108}$

No anúncio, destacavam-se as qualidades da máquina Howe, “as mais antigas, as mais simples, as mais duráveis, as mais aperfeiçoadas, as mais baratas do mundo". ${ }^{109}$ Segundo a propaganda, os pais de família deveriam saber que não haveria maior

\footnotetext{
${ }^{108}$ Ver Almanaque Laemmert em 1877. Consulta em 9/2/2012.

${ }^{109}$ Ver Almanaque Laemmert em 1877.
} 
economia para o lar do que a aquisição de uma máquina de costura. As máquinas seriam “o descanso das mães de família, a salvação das senhoras de peito fraco, enquanto se aquece água para banhar uma criança, aprontam-lhe uma camisa". ${ }^{110}$

O anúncio, inclusive, informava os tempos de costura para cada peça do guardaroupa familiar e dos panos necessários ao bom andamento doméstico. "Fazem um saco em cinco minutos ou 144 por dia, 6 camisas em 12 horas e 6 calças no mesmo espaço de tempo”. As máquinas coseriam baeta, pano piloto, algodão grosso de Minas e a mais fina cambraia; fariam também dois pespontos, “embainhão, pregas, pregão soulaches, gregas e trancelins". ${ }^{111}$ No mesmo anúncio, percebemos que existiam três tipos de máquinas Howe: uma para uso doméstico, outra para oficinas de alfaiate e costureiras e um último tipo para sapateiros e seleiros.

A máquina de costura passou a fazer parte dos aparelhos mecânicos que ajudavam a dona de casa em suas tarefas cotidianas. O grande salto em vendas da Singer foi transformar a máquina de costura numa máquina de uso cotidiano para todas - das pequenas costureiras às donas de casa, passando por pequenas "fábricas" e ateliês sofisticados. No Brasil, os moldes para máquinas de roupas eram vendidos nas mesmas casas que comercializavam a máquina. Havia ainda, cursos sobre como manejar máquinas de costura, além de uma infinidade de agulhas, linhas e acessórios para melhor aproveitá-las.

Da visão de um cotidiano visto por viajantes à venda das máquinas do comércio carioca foram quase cinquenta anos. "Quase todas as senhoras fazem os seus próprios vestidos ou pelo menos cortam-nos e arranjam-nos para as escravas costurarem, pelos últimos figurinos de Paris. Sentam-se no meio de um círculo de negrinhas, pois sabe

\footnotetext{
${ }^{110}$ Idem.

${ }^{111}$ Idem ibidem.
} 
bem que, se o olhar do mestre engorda o cavalo da mesma forma olhar da patroa faz a agulha andar mais depressa." 112

O trabalho envolvia não apenas a confecção constante das roupas, mas remendos e modificações para adequar as roupas a uma nova moda ou modelo. Então, quando as mangas bufantes saíram de moda, costuravam-se novas mangas. Cinturas saíam ou voltavam para o lugar, flores enfeitavam mangas ou decotes e davam uma nova cor a velhos vestidos. E tudo isso feito tanto em casas que tinham mais dinheiro, como em residências remediadas. Aluísio Azevedo, já para o fim do século XIX, vai dar um exemplo interessante dessa prática ao descrever no romance Filomena Borges sobre os sofrimentos de uma jovem de classe média que precisava remendar seus vestidos num baile:

Quase nunca expunha o colo, e seus vestidos, sempre afogados, cosidos à garganta por um estreito colarinho de rendas, davam-lhe o ar passivo e contrafeito de uma pensionista das irmãs de caridade [...] Nas 'soirées' fazia impressão vê-la assentada horas esquecidas a um canto da sala; muito direita no seu espartilho [...] [...] Que de lágrimas não havia escondidas naqueles vestidos enfeitados pela quarta vez! Quanta amargura naqueles penteados, naquelas capas, naqueles leques, naqueles sapatinhos $[\ldots] \quad[\ldots]$ escovavam as roupas, acondicionavam as botinas, os leques e as joias falsas $[\ldots]^{113}$

Nesse processo do refazer constante das roupas, de adequá-las, passá-las para outros membros da família ou recosturá-las, os acessórios tinham extrema importância. Chapéus, luvas, leque, sapatos eram o que complementavam as roupas, dando-lhes um

\footnotetext{
${ }^{112}$ Daniel Parish Kidder e James Cooly Fletcher. O Brasil e os brasileiros. Trad. port. Vol. 1, São Paulo: Companhia Editora Nacional, 1941. p. 18.

${ }^{113}$ Aluísio Azevedo. Filomena Borges. São Paulo, Martins Editora, 1960. p. 15-6.
} 
caráter - ou não - de novidade. No próximo capítulo, veremos como os acessórios apareciam nas balanças de importação e espalhavam-se pelas ruas do Rio de Janeiro. 


\section{CAPÍTULO III. As mulheres no espelho: silhueta feminina e consumo no século XIX}

A razão substancial de nosso tenaz apego à saia é justamente essa: ela é dispendiosa e tolhe a cada instante aquela que a usa, incapacitando-a para qualquer esforço útil.

Thortein Veblen ${ }^{1}$

Não te resignes a ser em tua casa um objeto de luxo. A mulher não nasceu só para o adorno, nasceu para a luta, para o amor e para o triunfo do mundo inteiro.

Julia Lopes de Almeida ${ }^{2}$

\section{Anquinhas e crinolinas: a silhueta feminina no século XIX}

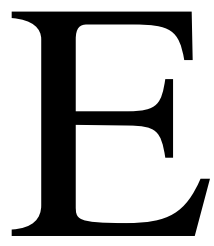
m meados do século XIX, as mulheres começaram a aparecer nas ruas do Rio do Janeiro. Ao contrário das primeiras décadas do século, moças e senhoras já saiam à rua e frequentavam confeitarias, bailes, saraus, teatros e a rua do Ouvidor. "Essa dona-de-casa ortodoxamente patriarcal, o padre Lopes Gama não se conformava [...] que estivesse sendo substituída nos sobrados e em algumas casas-grandes de engenho por um tipo de mulher menos servil e mais mundano;

\footnotetext{
${ }^{1}$ Thorstein Veblen, A teoria da classe ociosa. Trad. port. São Paulo: Abril Cultural, 1983, p. 8095 .

${ }^{2}$ Julia Lopes de Almeida. O livro das noivas. Rio de Janeiro: s/ed., 1896, p. 13.

${ }^{3}$ Gilberto Freyre. Sobrados e mucambos. Decadência do patriarcado rural e desenvolvimento urbano. Rio de Janeiro: José Olympio, 1951, p. 252-329.
} 
acordando tarde por ter ido ao teatro ou a algum baile; lendo romance; olhando a rua da janela ou da varanda; levando horas no piano, estudando lição de música; e ainda outras, na lição de francês ou na de dança". As roupas e a silhueta feminina acompanhavam as mudanças de hábitos e tentavam seguir a moda na Europa e, em especial, na França.

Paris, desde o século XVIII, fora a cidade inspiradora de tendências ligadas aos refinamentos dos hábitos da corte e ao vestuário da elite. ${ }^{4}$ Com o governo de Napoleão Bonaparte, uma parte da indústria de luxo foi estimulada por decretos e leis, como o que tentou impulsionar a região de Lyon, dando ênfase aos veludos, que podiam aparecer em acessórios, como laços, fitas ou mantôs. ${ }^{5}$ Em todo o mundo, o vestuário esboçaria uma tendência à internacionalização das formas, com certa tendência a uma pequena influência inglesa, mas dominada pelos costureiros franceses.

Aparentemente, o incentivo de Napoleão deu resultados e a França foi uma grande exportadora de veludos ao longo de todo o século XIX, como vemos abaixo na tabela de importações brasileiras de 1871/72.

\begin{tabular}{|l|r|r|}
\hline \multicolumn{3}{|l|}{ Tecido } \\
\hline Veludos & Quant. $(\mathrm{Kg})$ & Valor \\
\hline País & 205 & $6: 781 \$ 000$ \\
\hline Alemanha & 1 & $30 \$ 000$ \\
\hline Bélgica & 12 & $360 \$ 000$ \\
\hline Confed. Argentina & 1.683 & $42: 979 \$ 000$ \\
\hline França & 728 & $19: 111 \$ 000$ \\
\hline Grã-Bretanha & 4 & $312 \$ 000$ \\
\hline Portugal & 235 & $8: 392 \$ 000$ \\
\hline Países indeterminados & 2.868 & \\
\hline Total & & \\
\hline
\end{tabular}

\footnotetext{
${ }^{4}$ Norbert Elias. A sociedade de corte. Trad. port. Rio de Janeiro: Jorge Zahar editor, 2001.

5 François Boucher. História do vestuário no Ocidente, das origens aos nossos dias. Cosac\&Naify. Trad. port. São Paulo: 2010, p. 325. Foram consultados também os catálogos de Stella Blum, Victorian fashions \& costumes from Harper's Bazar 1867-1898, (Nova York, Dover: 1974) e Joanne Olian, Victorian and Edwardian fashions from 'La mode ilustrée', Nova York: Dover, 1998.
} 
No Brasil isso se traduz na adoção, pela nobreza e alta burguesia, de trajes em acordo com a moda europeia do período. Logo no começo do século XIX, Debret vai retratar essa influência cotidiana nos retratos que pinta das ruas do Rio de Janeiro entre 1816 e 1831. Em Vendedor de flores e fatias de coco, ele vai mostrar uma dama com seu vestido de cintura alta e mangas bufantes, com uma mantilha na cabeça (característica dos países ibéricos e sul-americanos). Na descrição do pintor, é ressaltado o hábito brasileiro de enfeitar o penteado com flores naturais, em especial, o cravo. ${ }^{6}$ Mas, mesmo claramente influenciado pelo corte francês, vemos que a mulher usa uma mantilha à espanhola, hábito que desapareceria em poucos anos, dando lugar aos chapéus e bonnets.

Com o fim do Império de Napoleão Bonaparte, as roupas se modificaram mais uma vez. As cinturas voltaram para o lugar e o estilo império desapareceu. A Inglaterra, impulsionada pela revolução industrial, passou a ter influência na moda, principalmente nas cores e padrões dos novos tecidos que saiam das fábricas. A França, porém, continuou sendo a grande referência mundial em cortes e estilos, criando e aperfeiçoando uma vigorosa indústria de confecções. ${ }^{7}$

Em 1837, na Inglaterra, a princesa Vitória tornou-se rainha da Grã-Bretenha e, ao longo do século, teria enorme influência sobre as atitudes das mulheres em relação ao que iriam vestir e como iriam se comportar. Casada com o príncipe Alberto, ela comprou em 1848 o castelo de Balmoral na Escócia. O gesto deu origem uma certa moda de tecidos xadrezes, que perdurou muito tempo. Os xadrezes também reforçavam

\footnotetext{
${ }^{6}$ Julio Bandeira e Pedro Correa do Lago. Debret e o Brasil: obra completa. Capivara: Rio de Janeiro, 2008, p. 138.

${ }^{7}$ Ver o livro de Daniel Roche. A cultura das aparências. Trad. port. São Paulo: Senac, 2007, em especial o capítulo "A economia dos guardas-roupas".
} 
a ideia de domesticidade tão cara à rainha. ${ }^{8}$ Essa domesticidade feminina ${ }^{9}$ foi traduzida pelo sucesso dos padrões florais em tons pastéis, usados no verão e na primavera, e dos estampados xadrezes em cores fortes, predominantes no outono e no inverno, símbolos dessa domesticidade burguesa. ${ }^{10}$

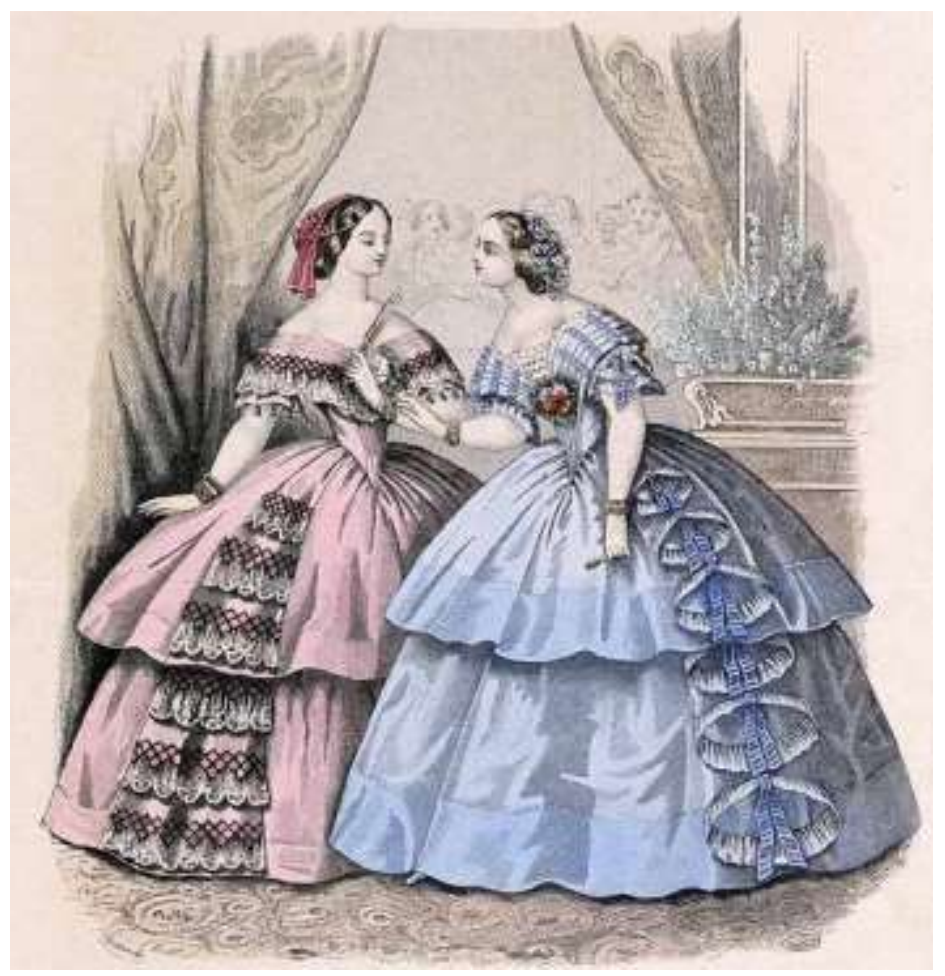

Azuis e rosas, com rendas eram preferidos pelas senhoras e senhoritas, como a Condessa de Baependi e Isabelinha Martins Pinheiros, que usaram essas cores num dos muitos saraus imperiais. ${ }^{11}$ A gravura faz parte da série que está no site do Museu Victoria and Albert. ${ }^{12}$

8 Ainda que muitas mulheres trabalhassem fora de casa, principalmente como operárias e costureiras, a imagem ideal de mulher passou ser a de mulher burguesa. Ver Thorstein Veblen, $A$ teoria da classe ociosa. São Paulo: Abril Cultural, 1983, p. 80-95.

${ }^{9}$ Thorstein Veblen, A teoria da classe ociosa. Trad. port. São Paulo: Abril Cultural, 1983, p. 8095 .

${ }^{10}$ François Boucher, História do vestuário no ocidente. Trad. port.São Paulo: Cosac \& Naify, 2010.

${ }^{11}$ Wanderley Pinho. Salóes e damas do segundo reinado. São Paulo: Martins Editora, 1970, p. 96.

12 Ver o site <http://www.vam.ac.uk/content/articles/i/introduction-to-19th-century-fashion/>. Consulta 4/1/2013. 
Foi dessa maneira que xadrezes, flores e saias amplas marcaram a silhueta feminina no século XIX. As roupas femininas passaram a traduzir uma crescente abundância de tecidos e a moda estabeleceu alguns de seus princípios básicos: a mudança constante de acessórios e itens do guarda-roupa para marcar o status social da mulher, o nascimento e estabelecimento de uma imprensa especializada em moda para mulheres, a criação e crescimento cada vez maior de uma indústria de confecções e de locais para venda dos novos produtos ligados ao vestuário. Nas palavras de Gilda e Mello e Souza, "a moda vai se tornar uma constante no século XIX."13

O ideal vitoriano de beleza passou a valorizar os atributos tipicamente femininos, como a fragilidade, a delicadeza e a dedicação ao marido. O grande sucesso dos poemas românticos, como os de Lorde Byron, valorizavam heroínas pálidas, com os cabelos presos em cachos, que desmaiavam por causa de corpetes muitos ajustados. ${ }^{14}$ Força e vigor seriam atributos desejáveis apenas em operárias e mulheres de negócio - as damas deveriam ficar longe da vida mundana, dedicando-se à criação dos filhos e aos cuidados da casa. As roupas e a moda seguiam esse ideal e tornavam a vida cotidiana bastante difícil.

Ao longo de todo o período, as cinturas ficaram marcadas pelo espartilho e as saias tornaram-se cada vez mais amplas, até meados da década de 1860. A ênfase do visual feminino era o contraste entre a cintura e saia. Assim, mesmo depois que as saias balão foram substituídas por anquinhas, a silhueta feminina continuou a ser marcada pelo contraste entre a cintura fina e saia $\operatorname{armada}^{15}$.

\footnotetext{
${ }^{13}$ Gilda de Mello e Souza. O espírito das roupas. São Paulo: Companhia da Letras, 1987, p. 145.

${ }^{14}$ Gilda de Mello e Souza. O espírito das roupas. São Paulo: Companhia das Letras, 1987, p. 70-75.

${ }^{15}$ Sobre a silhueta feminina no século XIX existem vários livros. Os mais usados neste estudo e que se destacaram em suas análises são os livros de François Boucher, História do vestuário no ocidente (Trad. port. São Paulo: Cosac \& Naify, 2010); N.J. Steveson, Cronologia da moda (Trad. port. Rio de Janeiro: Jorge Zahar, 2011); Stella Blum, Victorian fashions \& costumes from Harper's Bazar 1867-1898, (Nova York, Dover: 1974); Joanne Olian, Victorian and Edwardian
} 
Foi Paul Poiret, costureiro francês do final do século XIX e começo do XX quem, olhando para trás, num tom severo de crítica, afirmou que a imaginação das costureiras, entre 1820 e 1830, incidiu apenas em três pontos: fazer da saia um sino, da cabeça um monumento e do corpo um fuso. ${ }^{16}$ As saias amplas em formato de sino, com as cinturas bem marcadas, foram resultado do sucesso de duas peças do vestuário feminino: a crinolina e o espartilho. Gilberto Freyre vai acentuar essa dualidade ao falar a cintura da mulher brasileira na época das casas grandes, que se conservou artificial pelo uso exagerado do espartilho. ${ }^{17}$

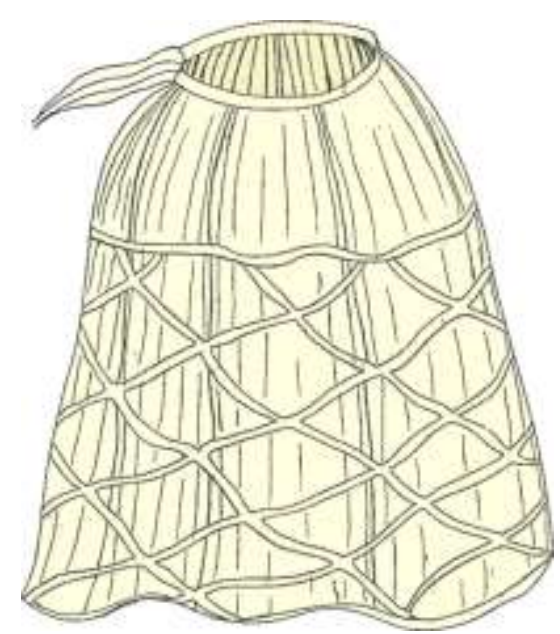

Um dos primeiros modelos em crina de cavalo, de 1846. Victoria and Albert museum ${ }^{18}$

A crinolina foi amplamente usada entre os anos de 1852 e 1870. Inicialmente foi feitas de crina de cavalo entrelaçadas (daí seu nome), criadas para substituir as muitas saias usadas sob os vestidos desde o fim da década de 1820 e começo da década de 1830. Mas, ao longo de todo o século XIX, a crinolina transformou-se de uma série de

fashions from 'La mode ilustrée` (Nova York: Dover, 1998); James Laver, Costume and fashion: a concise history (Londres: Thames\&Hudson, 2002) e Diana Crane, A moda e seu papel social (Trad. port. São Paulo: Senac, 2006).

${ }^{16}$ Paul Poiret, En habillant l'époque. Trad. port. Paris: Grasset, 1930.

${ }^{17}$ Gilberto Freyre. Casa Grande e senzala. Rio de Janeiro: José Olympio Editora, 1951, p. 261.

${ }^{18}$ Cf. <http://www.vam.ac.uk/content/articles/i/introduction-to-19th-century-fashion/>. Consulta 4/1/2013. 
saias e saiotes com babados usados debaixo dos vestidos, feitas também de linho e crina de cavalo, ao modelo de meados do século, a anquinha, com caudas e ênfase nas costas.

No início do período vitoriano, as saias eram presas ao corpete em pregas ou franzidos, mas à medida que se tornaram mais amplas, após 1841, desenvolveu-se um novo método, pregueando-se estritamente o tecido forrado e costurando pregas alternadas ao corpete. $\mathrm{O}$ sistema de ajuste exigia um corpete alongado, que se tornoucaracterística da época. ${ }^{19}$

Como muitas outras invenções, nos Estados Unidos, as crinolinas receberam patentes. A primeira saia, armada com aros, nos Estados Unidos foi patenteada em 1846, sob o número 4.584, por David Hough. Dez anos depois apareceu a crinolina armada com aros e presa com laços, numa forma mais próxima do conhecemos hoje. Também recebeu uma patente nos Estados Unidos, a de número 20.681. ${ }^{20}$

Em 1858, outro americano, W. S. Thompson, patenteou o modelo mais conhecido de crinolina, a em formato de gaiola. Outras patentes surgiram na França, na GrãBretanha, na Alemanha. Uma história, na realidade mais uma lenda associada ao nome da imperatriz Eugênia, diz que ela, ao visitar uma fábrica de espetos nos arredores de Paris chamada Peugeot forneceu o desenho de uma gaiola feita de arame destinada a libertar as mulheres da infinidade de saias e saiotes suados sobre o vestido, era a crinolina. A fábrica produziu o desenho e saiu da falência vendendo crinolina. Mais tarde, entrou no ramo de carruagens e depois de automóveis. ${ }^{21}$

O uso da crinolina tornou-se uma febre entre as mulheres, sendo a estrutura de aço muito mais leve que as saias e saiotes usados anteriormente. Os primeiros anos da

\footnotetext{
19 NJ Stevenson. Cronologia da moda. Trad. port. Rio de Janeiro: Zahar, 2011, p. 30-31 e Stella Blum, Victorian fashions \& costumes from Harper's Bazar 1867-1898, Nova York: Dover: 1974.

${ }^{20}$ Lucy Johnstone. "Corsets e crinolines in Vitorian fashion". Victoria and Albert Museum. $\langle$ http://www.vam.ac.uk/content/articles/c/corsets-and-crinolines-in-victorian-fashion/>. Consultado em 8/11/2012.

${ }^{21}$ Gilda de Mello e Souza. O espírito das roupas. São Paulo: Companhia das Letras, 1987, p. 99.
} 
década de 1860 viram o apogeu da crinolina, que atingiu seu tamanho máximo. Sob a ditadura da crinolina, calculava-se que para cada vestido fossem necessários de sete a dez metros de tecido. ${ }^{22}$ Fazer roupas novas ou costurar vestidos que estivessem na moda não era tão rápido quanto produzir tecidos em fábricas. As máquinas de costura apenas começavam a se popularizar e a indústria da confecção dava seus primeiros passos por isso, cada vestido demandava uma mão-de-obra hiper-especializada, que podia demorar meses numa só peça.

A maior parte do trabalho de costura de um vestido, por exemplo, era feita à mão. Assim, a moda dos vestidos armados com crinolina de alguma forma respondeu a um lapso de produção entre a indústria de confecção e a indústria têxtil. Ou seja, um vestido que usasse muito tecido respondia melhor à crescente produção inglesa de tecidos e à escassez de mão-de-obra. As mulheres teriam menos vestidos do no final do século XIX, mas eles feitos com muito mais pano. Com o passar dos anos, e a popularização da máquina de costura, esse lapso diminuiu e as saias e roupas também passaram a precisar de menos roupas. ${ }^{23}$

Walter Benjamin vai recuperar uma frase do filósofo alemão Friedrich Theodor Vischer (1808-1887) sobre a intensa relação entre o uso da crinolina e segundo império na França. “Considerávamos a crinolina o símbolo do segundo império na França, de sua mentira deslavada, de seu atrevimento leviano e ostentoso. Esse império riu... mas o mundo parisiense ainda teve seu tempo, antes de sua queda, de salientar na moda feminina outro aspecto de seu estado de espírito, e a república não se furtou de aceitá-lo e conservá-1o". 24

\footnotetext{
${ }^{22}$ N. J. Steveson, Cronologia da moda. Trad. port. Rio de Janeiro: Jorge Zahar, 2011, p. 54-55.

${ }^{23}$ N.J. Steveson, Cronologia da moda. Trad. port. Rio de Janeiro: Jorge Zahar, 2011, p.0 55.

${ }^{24}$ Friedrich Theodor Vischer. Mode e cynismus. In: Walter Benjamin. Passagens, p. 108. Trad. port. São Paulo/Belo Horizonte: Imprensa Oficial/Ed. UFMG, 2007.
} 
No Brasil, a crinolina também teve seu lugar entre as mulheres de elite. Exemplos tirados da literatura nos mostram como mulheres como Helena, de A carne, Lucíola, ou Aurélia, de Senhora "sabem" comportar-se e vestir-se em sociedade. No álbum de fotografias da princesa Isabel, vemos uma foto da princesa em meados da década de 1850 em que se percebe claramente o uso da crinolina e os vários babados da saia.

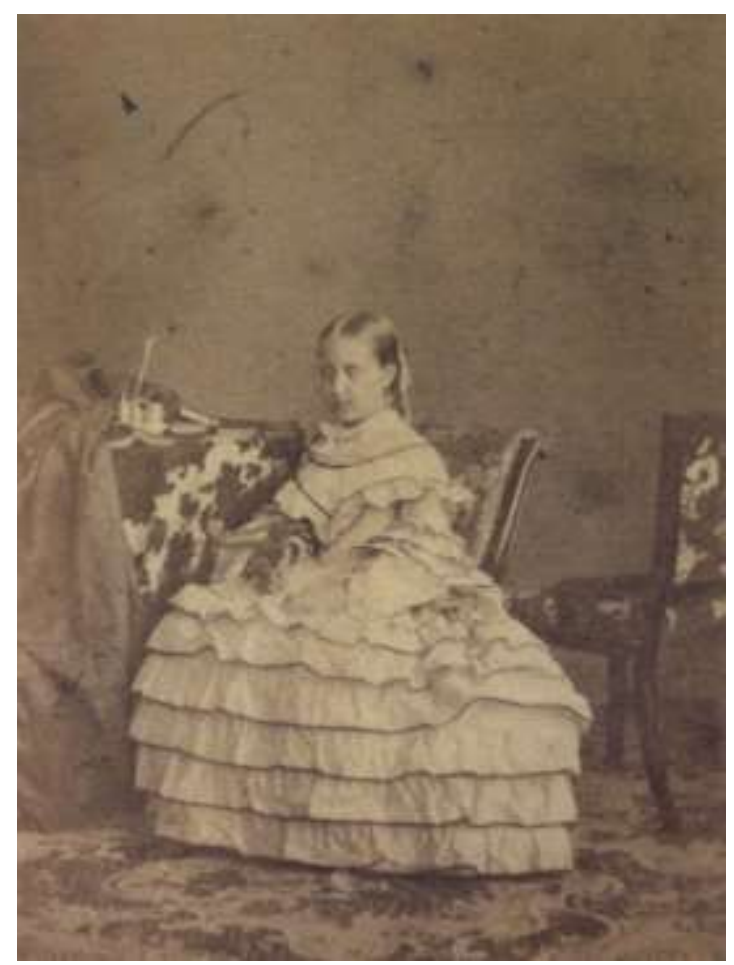

A princesa Isabel ainda criança em 1858, com sua crinolina e vários babados num vestido claro $^{25}$

Em outro foto, ela está alguns anos mais velha, no começo da adolescência. A saia, com a crinolina atinge seu máximo e o contraste com a cintura bem marcada é nítido, mesmo por debaixo do casaquinho de mangas abertas. A roupa estava na última moda, e condizia com a imagem de uma princesa plácida e reservada.

${ }^{25}$ Pedro e Bia Corrêa do Lago, Coleção Princesa Isabel: fotografia do século XIX. Rio de Janeiro: Capivara, 2008, p. 33. 


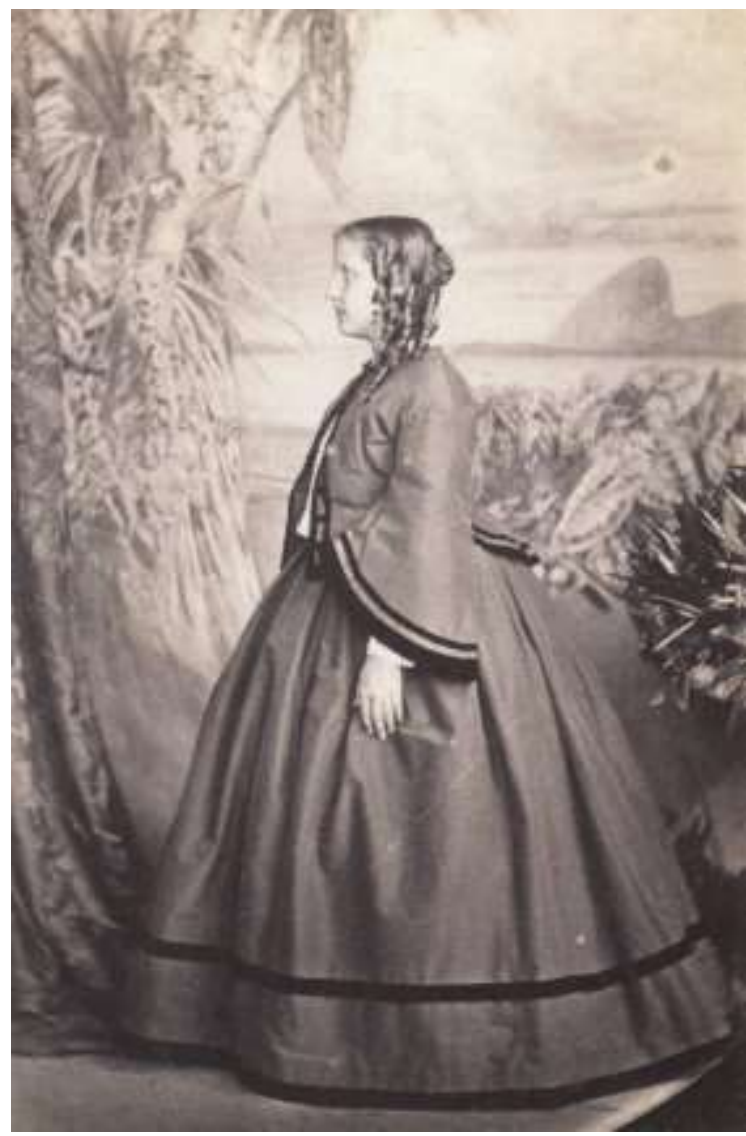

A princesa Isabel em 1861, quando as crinolinas já haviam atingido seu ápice ${ }^{26}$

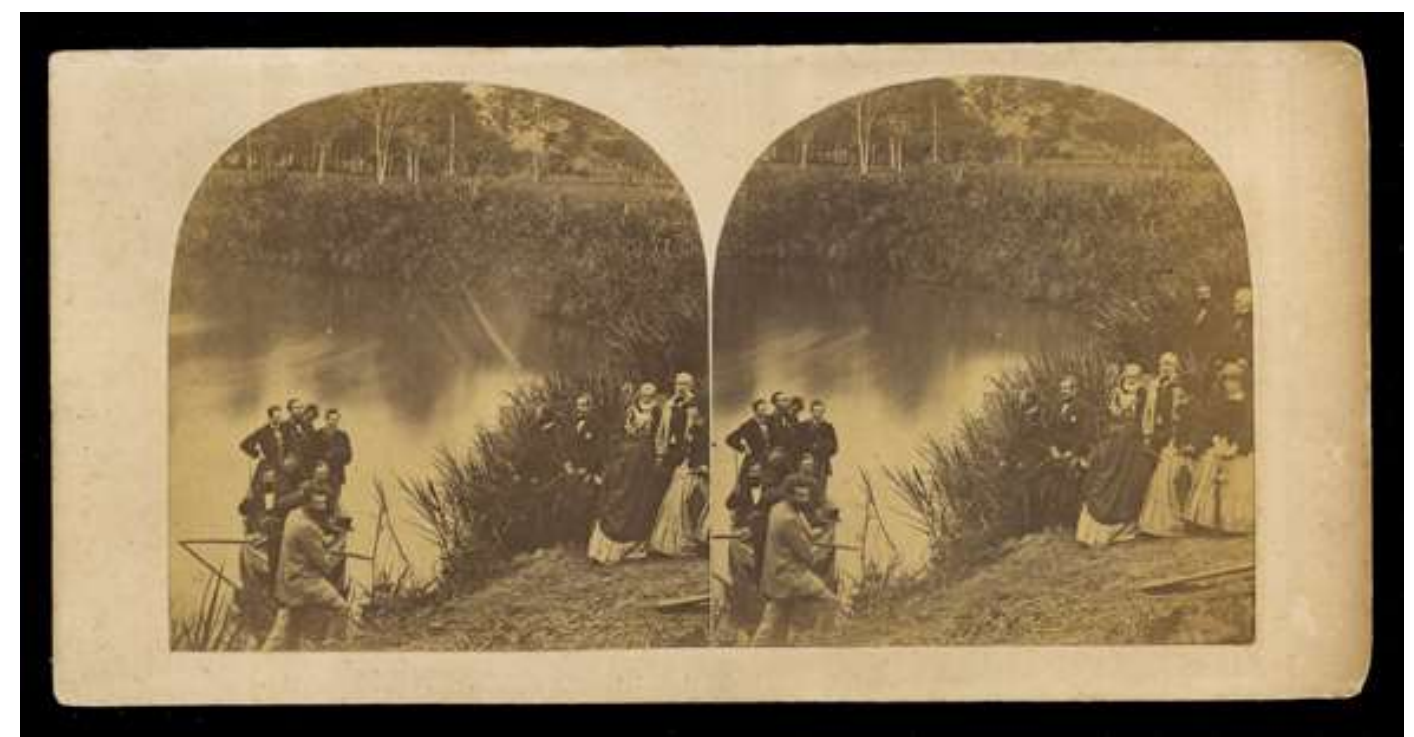

Na visita à quinta de Mariano Procópio em Juiz de Fora vêem-se as mulheres da família imperial com grande crinolinas em $1861^{27}$

${ }^{26}$ Pedro e Bia Corrêa do Lago, Coleção Princesa Isabel: fotografia do século XIX. Rio de Janeiro: Capivara, 2008, p. 39.

${ }^{27}$ Pedro e Bia Corrêa do Lago, Coleção Princesa Isabel: fotografia do século XIX. Rio de Janeiro: Capivara, 2008, p. 78. 
Assim, o espartilho e a crinolina se espalharam pelas lojas do comércio carioca. Em 1859, a casa de Catarina Dazon e filho, localizada na rua do Ouvidor, n. 97, que vimos no capítulo anterior, vendia máquina de costura e toda sorte de artigos para a "toilette de uma senhora": camisinhas, meias de seda, luvas e provavelmente crinolinas e espartilhos. $^{28}$

Em 1867, Rocha Costa e Miranda, donos de um armarinho de modas e perfumarias na rua das Violas, esquina com a rua da Candelária, informou ao público "a venda especial de camisas, camisinhas, corpinhos, calças, punhos, colarinhos, e meias para senhoras [...] saias-balão e de lã de babados, estofos e lavores diversos." Antonio Joaquim Magalhães, outro comerciante carioca, com estabelecimento na rua das Quitandas, no mesmo ano, também anunciou camisinhas e corpetes ${ }^{29}$ para senhoras entre seus produtos. ${ }^{30}$

\footnotetext{
28 Ver anúncio em notabilidades do ano de 1859, no Almanaque Laemmert. $\langle$ http://brazil.crl.edu/bsd/bsd/almanak/al1859/00001398.html. Consulta em 7/01/2013 >.

${ }^{29}$ Por todo o século XIX, no Brasil, os corpinhos e corpetes foram sinônimos de espartilhos.

${ }^{30} \mathrm{Cf}$. <http://brazil.crl.edu/bsd/bsd/almanak/al1867/00001290.html > consulta em 8/1/2013.
} 


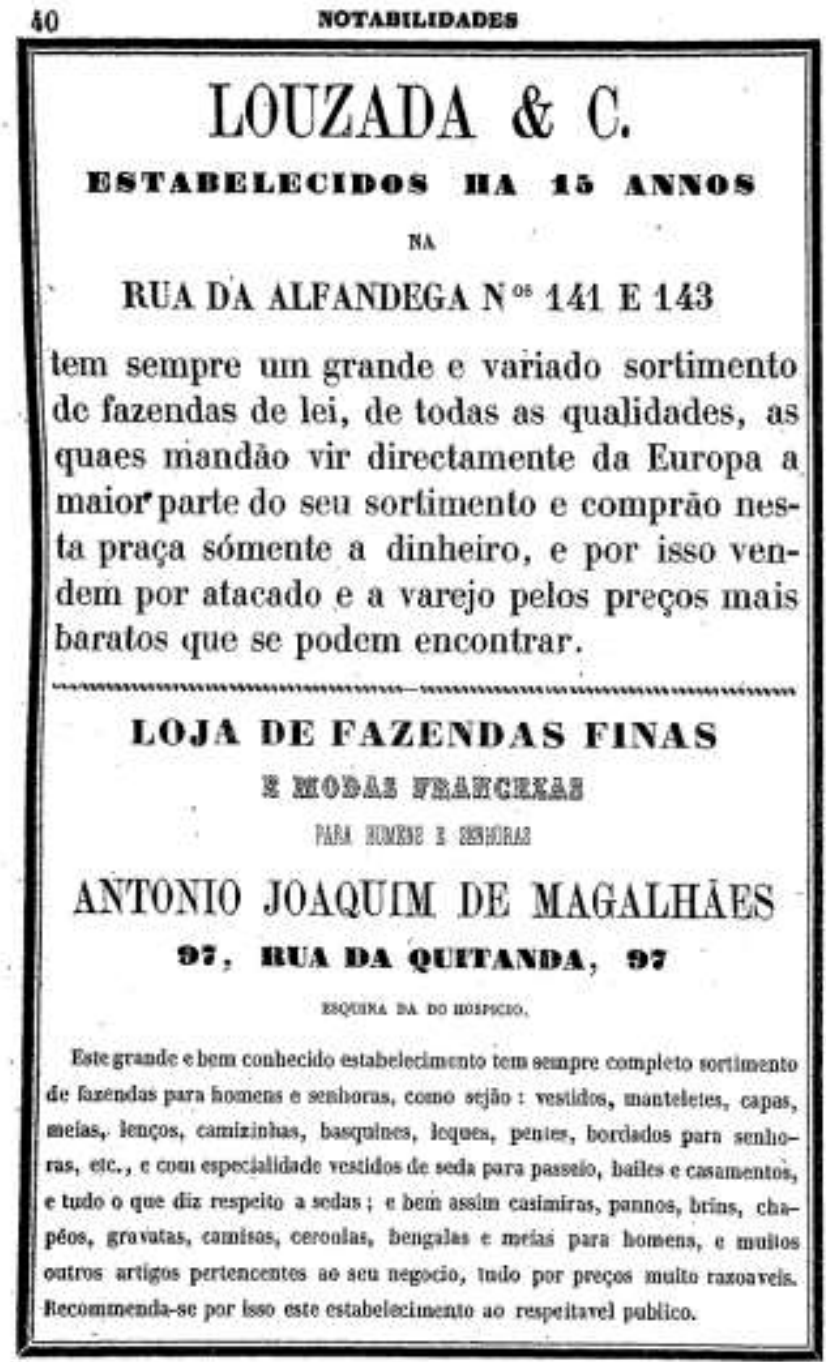

Anúncio com roupas íntimas no Almanaque Laemmert ${ }^{31}$

${ }^{31}$ Almanaque Laemmert de 1865, seção de "Notabilidades". 


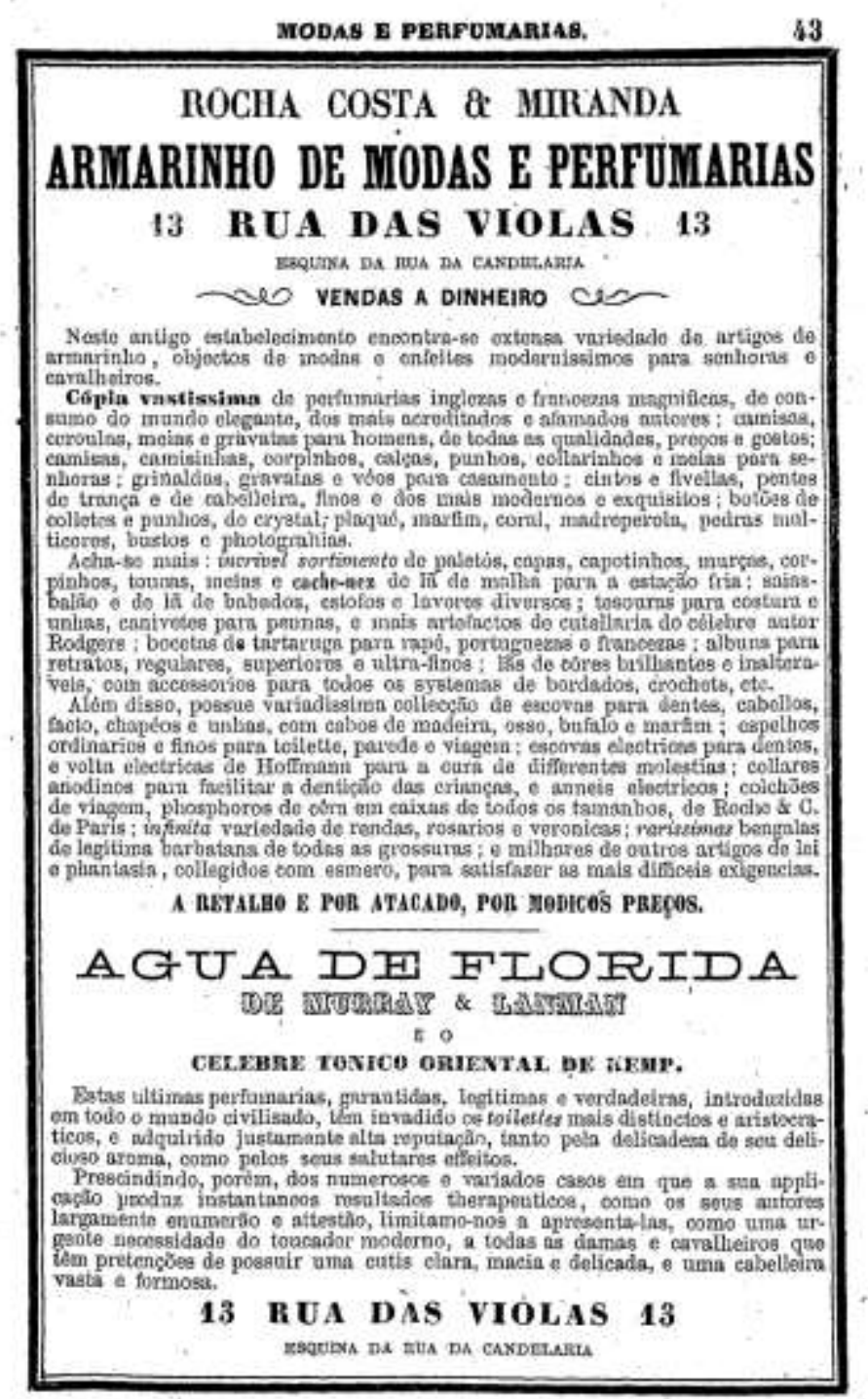

Saias-balão, camisinhas e corpinhos era vendidos na rua das Violas. ${ }^{32}$

O auge das crinolinas também coincidiu com a moda dos xales ou mantôs sobre os ombros, que ajudavam a espantar o frio na Europa. "A mulher passa a ser um triangulo equilátero, auxiliado pela voga dos xales e mantilhas que, tirados sobre o ombros e descendo pelas costas, escondem a cintura"33 Como vemos nas planilhas

${ }^{32}$ Cf. <http://brazil.crl.edu/bsd/bsd/almanak/al1867/00001290.html $>$. Consulta em 8/1/2013.

${ }^{33}$ Gilda de Mello e Souza. O espírito das roupas. São Paulo: Companhia das Letras, 1987, p. 63. 
abaixo $^{34}$, os xales podiam ser de diferentes materiais - de algodão, os mais baratos, a sedas, os mais caros. A Grã-Bretenha era a maior exportadora. Como os xales eram fáceis de fazer e podiam modificar inteiramente uma roupa sem a necessidade de se trocar o vestido, eles fizeram sucesso por todo o século XIX.

\begin{tabular}{|l|r|r|}
\hline Tecido \\
\hline Xales, mantas, e lenços de seda (excluídos os de renda) \\
\hline País & $\begin{array}{r}\text { Quant. } \\
(\mathrm{Kg})\end{array}$ & Valor \\
\hline Grã-Bretanha & & $39: 217 \$ 000$ \\
\hline França & & $12: 617 \$ 000$ \\
\hline Alemanha & & $5: 077 \$ 000$ \\
\hline China & & $3: 213 \$ 000$ \\
\hline Bélgica & & $3: 141 \$ 000$ \\
\hline Paraguai & & $600 \$ 000$ \\
\hline Estados Orientais & & $221 \$ 000$ \\
\hline Itália & & $15 \$ 000$ \\
\hline Portugal & & $3 \$ 000$ \\
\hline Total & & $60: 963 \$ 00$ \\
\hline
\end{tabular}

\begin{tabular}{|c|c|c|}
\hline \multicolumn{3}{|l|}{ Tecido } \\
\hline \multicolumn{3}{|c|}{ Xales, mantas, e lenços de linho } \\
\hline País & Quant. (kg) & Valor \\
\hline Grã-Bretanha & & $50: 924 \$ 000$ \\
\hline França & & $8: 701 \$ 000$ \\
\hline Bélgica & & $1: 301 \$ 000$ \\
\hline Itália & & $831 \$ 000$ \\
\hline Estados Orientais & & $698 \$ 000$ \\
\hline Portugal & & $359 \$ 000$ \\
\hline Alemanha & & $366 \$ 000$ \\
\hline Paraguai & & $23 \$ 000$ \\
\hline Total & & $63: 203 \$ 000$ \\
\hline
\end{tabular}

${ }^{34}$ Mapa geral das mercadorias importadas e despachadas para consumo anos de 1871-1872, $\mathrm{p}$. 17. Ver o arquivo no site http://memoria.nemesis.org.br/. Acesso em 20 de agosto de 2010. 


\begin{tabular}{|l|r|r|}
\hline \multicolumn{2}{|l|}{ Tecido Algodão } \\
\hline Xales, lenços, mantas, etc. \\
\hline País & Quant. (kg) & Valor \\
\hline Grã-Bretanha & & $542: 035 \$ 000$ \\
\hline Alemanha & & $170: 287 \$ 000$ \\
\hline França & & $66: 028 \$ 000$ \\
\hline Bélgica & & $15: 230 \$ 000$ \\
\hline $\begin{array}{l}\text { Países } \\
\text { indeterminados }\end{array}$ & & $4: 567 \$ 000$ \\
\hline Confed. Argentina & & $4: 037 \$ 000$ \\
\hline Estados Orientais & & $2: 723 \$ 000$ \\
\hline Portugal & & $1: 883 \$ 000$ \\
\hline Paraguai & & $65 \$ 000$ \\
\hline Total & & $806: 855 \$ 000$ \\
\hline
\end{tabular}

No inventário de José Roiz Veloso de Oliveira, de 1845, vemos xales de vários tipos, de filó, de chita, de cassa, casimira. A quantidade de roupas no inventário nos faz pensar que José Roiz talvez fosse um comerciante ou mascate, que visitava fazendas ou sítios para escoar sua mercadoria. A quantidade de mercadoria também nos mostra o sucesso dos xales entre as mulheres e sua duração ao longo do século. Estavam arrolados exatamente: 3 xales de filó bordados; véu de filó preto; 12 xales de casimira; 7 xales de casimira; 2 xales de lã e algodão; 9 xales atapetados; 4 xales de chita escarlate bordados de branco; 17 xales com franja bordada de lã; 2 xales escarlates grandes; 55 xales diversos; 93 xales diversos; véu de filó preto; meio xale de cassa antiga; 14 camisas; 26 jaquetas; 10 coletes; 2 meias; 13 calças; 8 pares de meias compridas; 8 pares de meias abertas; 2 dúzias de meias lisas; 1 dúzia de meias lisas; 4 dúzias de meias; 3 pares de meias de lã curtas; 9 pares de meias curtas. ${ }^{35}$

No final de década de 1850 e começo da década de 1860, as crinolinas começaram se tornar mais baratas e, portanto, acessíveis a mulheres de classe média e algumas operárias e criadas. Assim que a moda da crinolina se tornou mais acessível, revistas inglesas como a Punch tornaram essas mulheres alvo de piadas e críticas sociais - a

\footnotetext{
${ }^{35}$ Sem autor. Manuscritos do Arquivo do Estado de São Paulo. Caixa 95, Ordem 572.
} 
crinolina, portanto, saía de moda e era substituída pelas anquinhas na parte de trás do vestido $^{36}$. Desta forma, ao se tornar popular, a crinolina não servia mais como distintivo de classe social e foi substituída, já estabelecendo um padrão clássico de funcionamento da moda. ${ }^{37}$

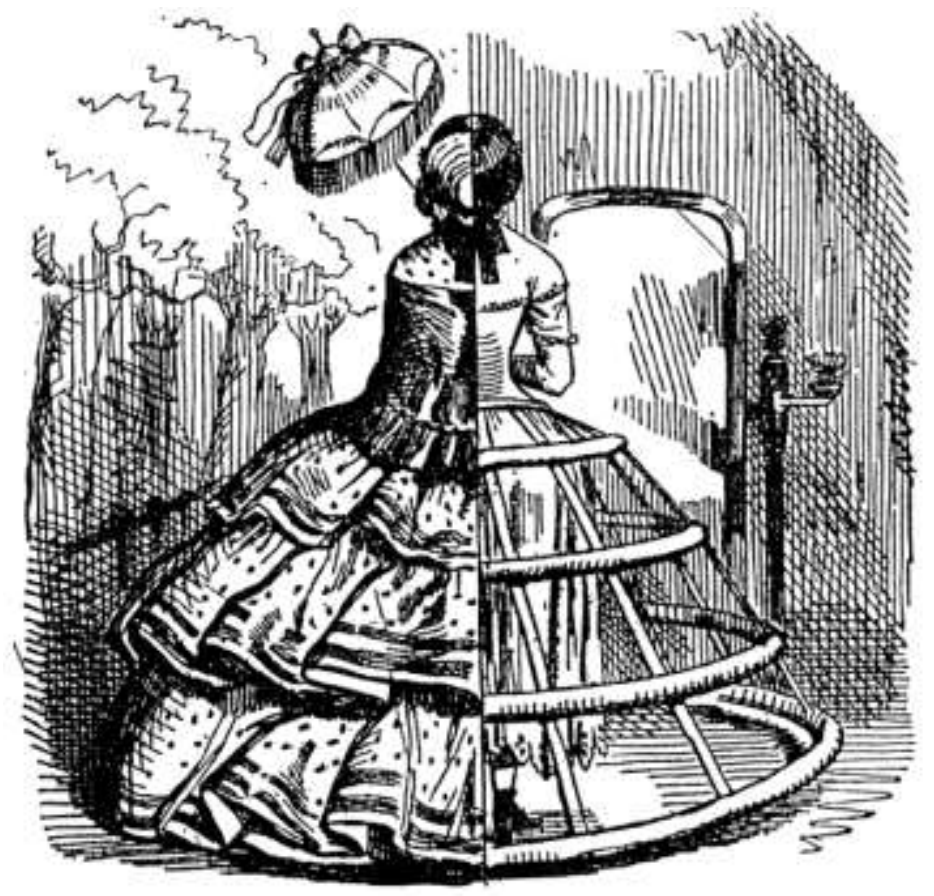

A crinolina proporcionou muitas sátiras picantes nos jornais, como vemos nesta gravura publicada do site do museu Victoria and Albert, que reproduz uma gravura irônica da revista Punch, de $1856^{38}$

Foi assim que, na década de 1860, a crinolina ao sair de moda, se modificou - e a silhueta feminina foi lentamente ficando plana na frente e criando uma espécie de "anquinha" na parte de trás do vestuário. A diminuição da peça fez com a roda do vestido diminuísse, tornando-se na década de 1870/80 um pouf, a ser colocado atrás do

\footnotetext{
${ }^{36}$ Elizabeth Wilson e Lou Taylor. Through the looking glass: a history of dress from 1860 to the present day. Londres: BBC books, 1988, p. 20-21.

${ }^{37}$ Ver o trabalho organizado por Arjun Appadurai (org.), The social life of things: commodities in cultural perspective. Nova York: Cambridge University Press, 1986, p. 3-64.

${ }^{38}$ Victoria and Albert Museum. http://www.vam.ac.uk/content/articles/c/corsets-and-crinolines-invictorian-fashion/. Consultado em 8/11/2012.
} 
vestido. "O interesse da figura total está nas costas, e os penteados repetem o ritmo em cascata de chutes, ondulations e cauda [...].",39

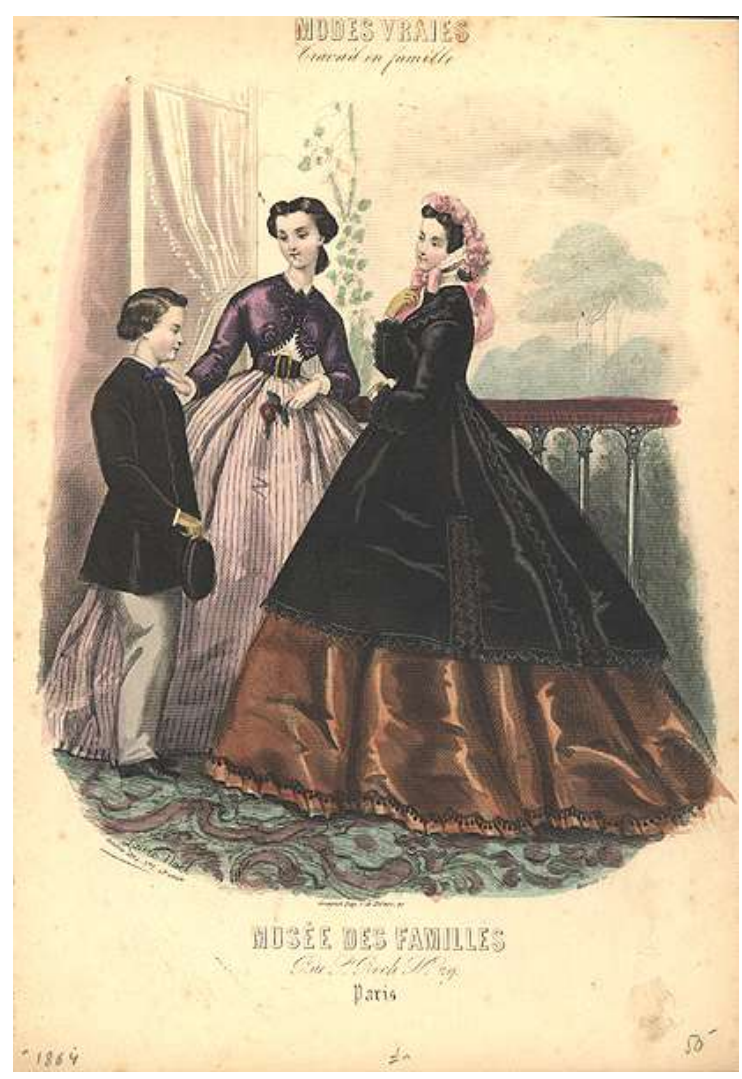

A crinolina estava se modificando, com maior ênfase na parte detrás da silhueta ${ }^{40}$

A ênfase na parte das costas da silhueta feminina fez com que o cabelo e os penteados tomassem súbita importância. Tranças, penteados, fivelas, coroas de ouro e diamantes transformavam os cabelos das mulheres em verdadeiras obras de arte, a serem apreciadas de costas, em bailes, nas missas e procissões, na rua do Ouvidor ou em jantares da corte. "O cabelo grande - tranças, cocós, cabelo solto, penteados elaboradíssimos, seguros ou completados por pentes, que na primeira metade do século

\footnotetext{
${ }^{39}$ Gilda de Mello e Souza. O espírito das roupas. São Paulo: Companhia das Letras, 1987, p. 63.

${ }^{40}$ Fashion Plate from Musee de Famille. http://content.lib.washington.edu. Consulta em 13/02/2013.
} 
XIX, com os nomes de 'tapa-missa' ou 'trepa-muleque', atingiram no Brasil formas bizarras e tamanhos incríveis [...]".

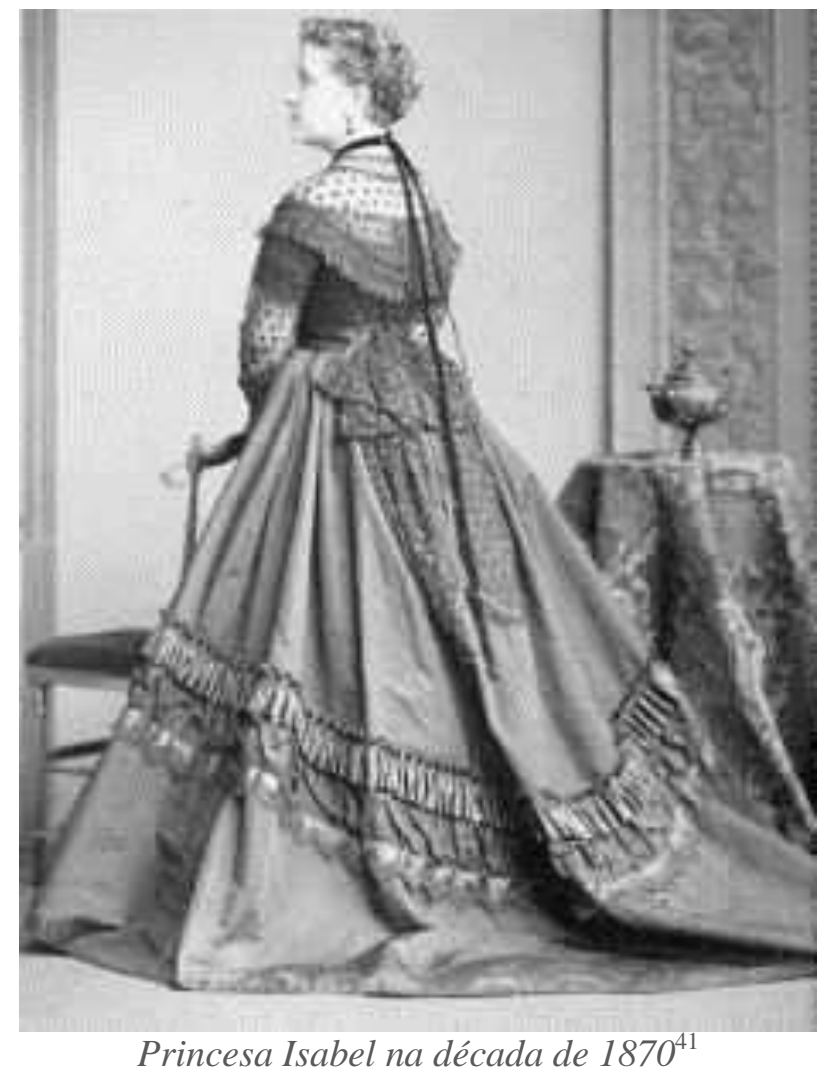

Os cachinhos feitos artificialmente, muitas vezes por cabeleireiros franceses, que caíam pelas orelhas das moças foram os preferidos de meados do século. Na foto de 1870, vemos a princesa Isabel, de costas, com seus cachos arrumados e prontos para a foto, de costas, seu vestido é enfeitado com laços de renda. O pescoço da princesa ainda jovem adornado com uma gargantilha (provavelmente de veludo) que lhe descia as costas e com uma cauda ampla. À falta de xampu, outros tratamentos eram dados às

${ }^{41}$ Pedro e Bia Corrêa do Lago, Coleção Princesa Isabel: fotografia do século XIX. Rio de Janeiro: Capivara, 2008, p. 91. 
cabeleiras das moças e senhoras. "O famoso cabelo ostentava-se [...] em cachos acastanhados e trescalantes de óleo de babosa."42

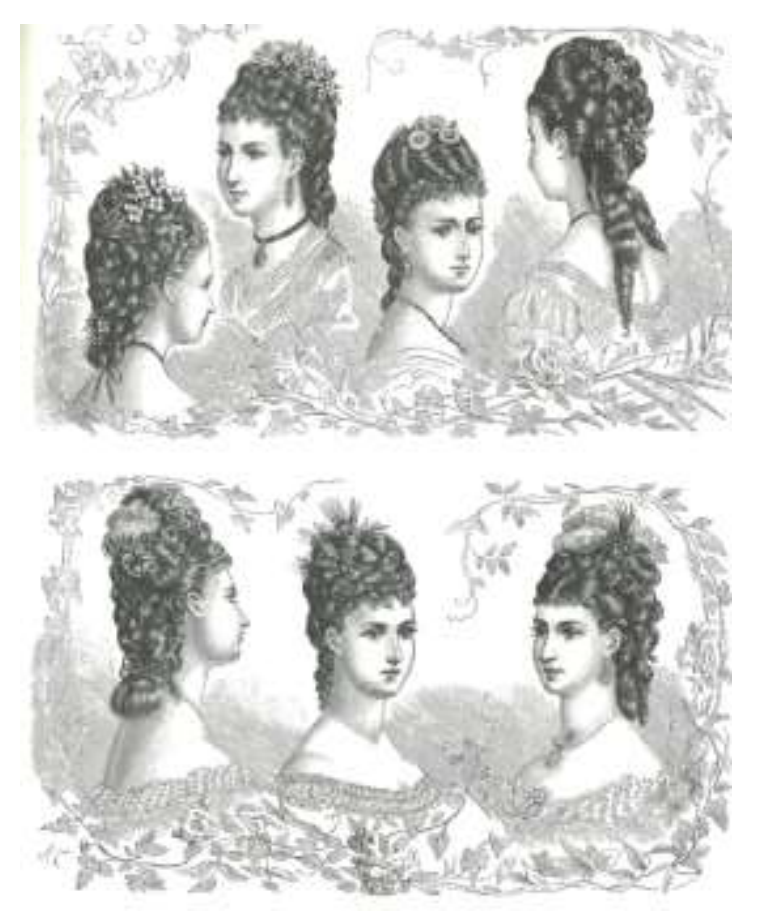

Estilos de cachos e penteados de $1876^{43}$

A ênfase na parte de trás da silhueta lentamente vai resultar num vestido ajustado, com mangas rentes ao corpo e uma anquinha, com babados e drapeados, que também podia se chamar de crinolinette. Até a década de 1870, a crinolinette jogava o busto para frente e os quadris para trás. ${ }^{44}$

Com o tempo, essa curvatura foi se acentuando e criando uma linha mais esbelta, que vemos na década de 1880. No quadro de Belmiro de Almeida, Arrufos, de 1887, a mulher chora por causa de uma briga com o homem sentado na cadeira a sua frente.

\footnotetext{
${ }^{42}$ Aluísio Azevedo. O mulato. São Paulo: Martins Editora/ Instituto Nacional do Livro/ MEC, 1975. p. 136.

${ }^{43}$ Stella Blum. Victorian fashion \& Costumes from Harper's Bazar, 1867-1898. 1000 illustrations. Nova York: Dover, 1974, p. 81.

${ }^{44}$ N. J. Steveson, Cronologia da moda. Trad. port. Rio de Janeiro: Jorge Zahar, 2011, p. 64-67. Ver também James Lever. Costume and fashion: a concise history. Londres: Thames \& Hudson, 2002, p. 196-217.
} 
Toda a ênfase da cena recai sobre o vestido amarelo pálido com drapeados e uma anquinha bastante pronunciada.

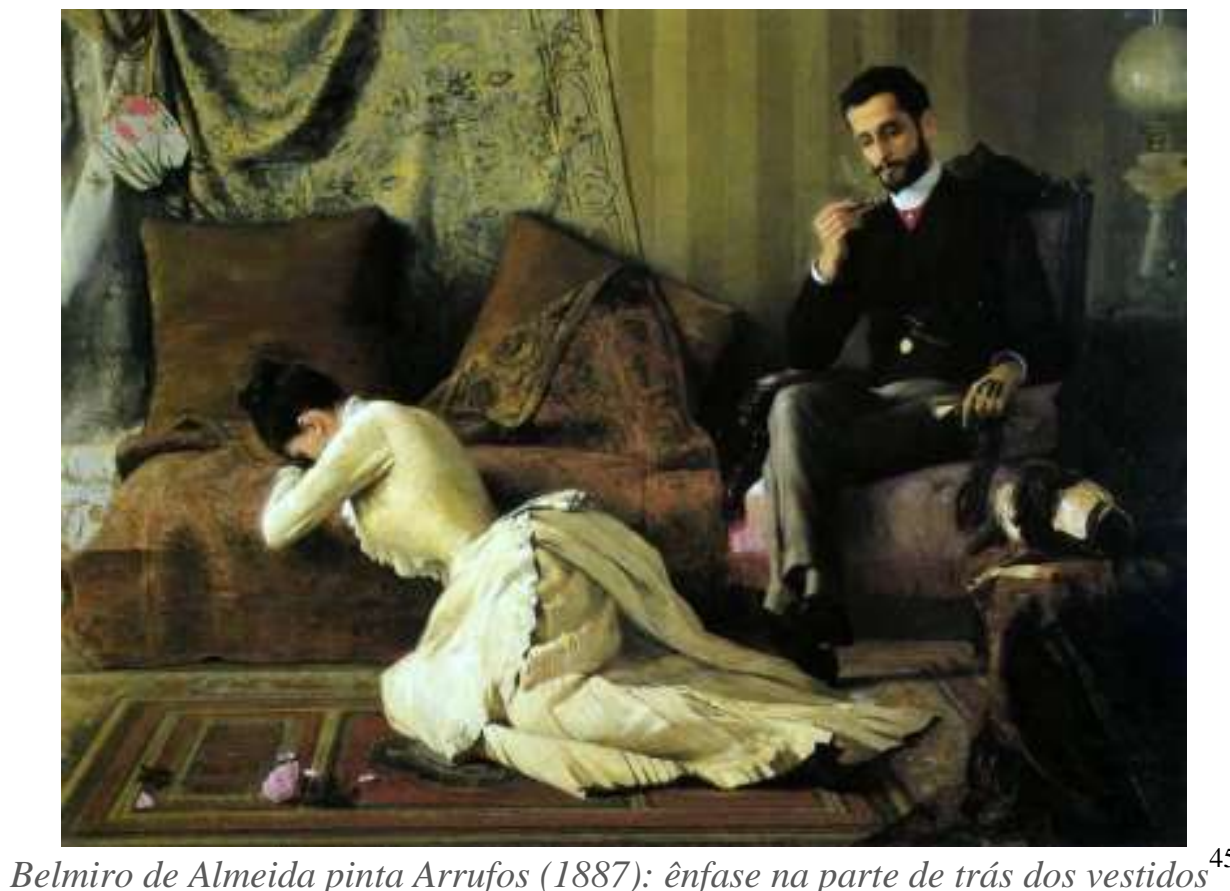

Wanderley Pinho, em Salôes e damas do segundo reinado, fez um resumo com bastante poesia as modas femininas que passaram pelo século XIX. Ele menciona que os salões do Casino (antigo salão de baile do império) viram de tudo ao longo do período.

Ali se exibiram desde os vestidos império de cintura alta, que faziam da mulher uma taça esguia e longa, expandida ao alto, como a querer despejar espumas de carne, dos decotes amplos e frouxos - à crinolina e a tournure e as anquinhas...[...] chegaram as complicadas modas que transformavam o corpo feminino num vitrina; umas mostrando o colo até o mais profundo de suas tentações, outras enchendo e salientando ou antes ocultando, os quadris, até os exageros de inverossimilhanças... [... $]^{46}$

\footnotetext{
45 Catálogo Arte do século XIX. In: Mostra do Redescobrimento, p. 178.Óleo sobre tela, $89,1 \times 116,1$. Museu Nacional de belas artes.

${ }^{46}$ Wanderley Pinho. Salões e damas do segundo reinado. São Paulo: Martins editora, 1970, p. 311.
} 
Nas descrições recuperadas pelo pesquisador, salta aos olhos a variedade de cores e modelos de vestidos, sempre descritos minuciosamente. Fica evidente também que, entre as mulheres de elite no Brasil, os códigos do vestuário tinham muita importância e significado. Uma dama da corte, aqui ou na Europa, nem sonharia em usar apenas uma roupa ao longo do dia. Os trajes variavam de acordo com o período e os afazeres: existia um roupão frouxo para a amanhã, um vestido para o chá e outro para a ceia. As trocas eram constantes e diárias e alguns guarda-roupas podiam valer fortunas. ${ }^{47}$

${ }^{47}$ Elizabeth Wilson e Lou Taylor. Through the looking glass: a history of dress from 1860 to the present day. Londres: BBC Books, 1989, p. 26. 


\section{Vestidos de todas as cores para todas as ocasiões}

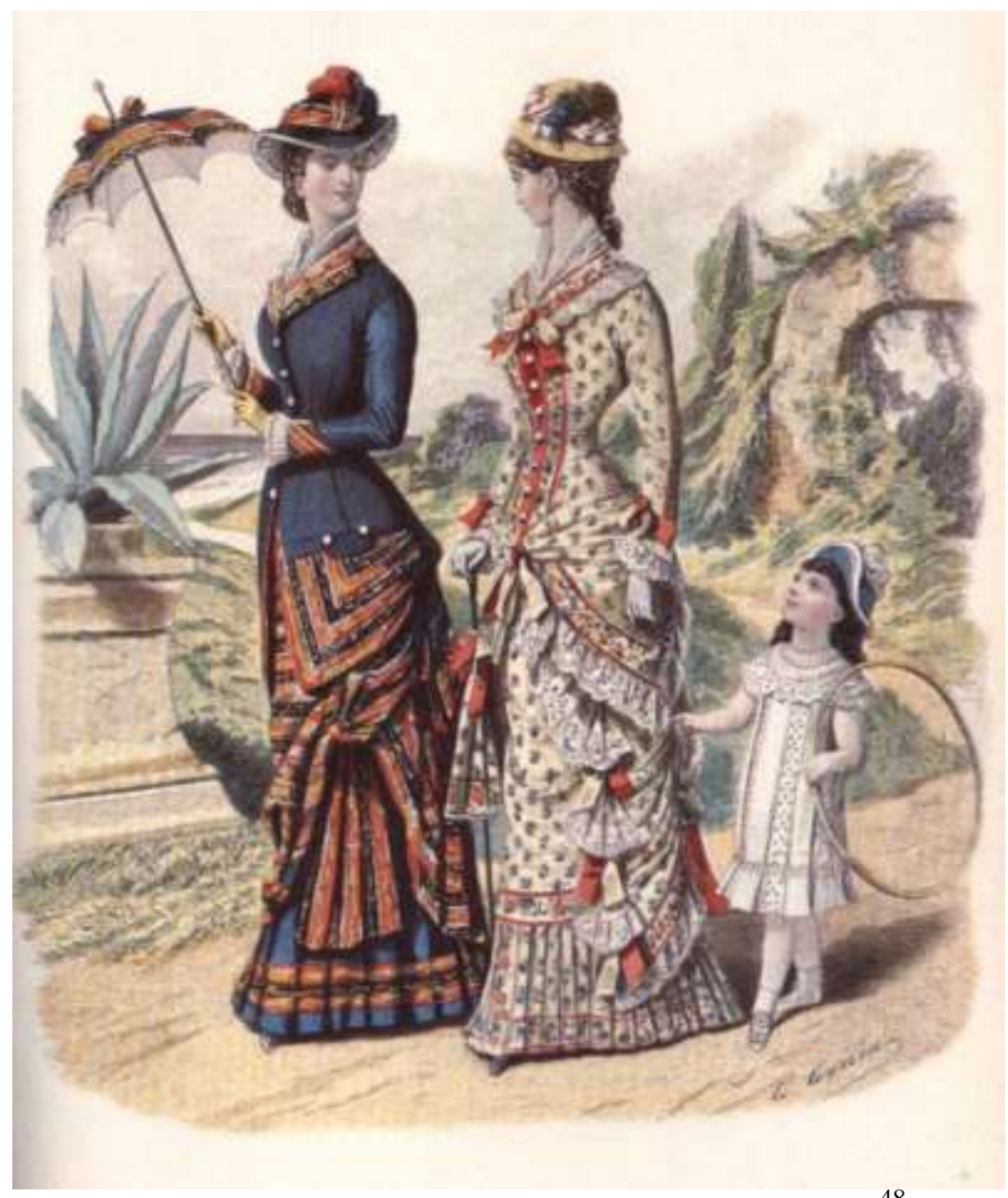

Nessa gravura, os vestidos justos da década de $1880^{48}$

O Livro das noivas, publicado no Rio no do final do século XIX, falava das múltiplas trocas de roupas que uma mulher de sociedade usava diariamente: “[...] nos múltiplos e engenhosos feitios das toilettes de baile ou caseiras, de visita ou de passeio, de jantar ou de soirée, nela não há fulgurantes tons, nem invenções artísticas [...]. ${ }^{, 49} \mathrm{E}$ Júlia Lopes de Almeida, a autora, ainda avisava: "Não se deve ter roupas demais nem de menos". 50

Mesmo assim, alguns periódicos de época, como a Marmorta Fluminense, recomendavam uma roupa para cada período do dia ou, pelo menos, uma para cada

48 Gravura de moda encontrada no site Victoria and Albert Museum: <http://www.vam.ac.uk/contentapi/search/?q=fashion\%20XIX\&limit=30>. Consulta 13/2/2012.

${ }^{49}$ Julia Lopes de Almeida. Livro das noivas. Rio de Janeiro: s/ editora, 1899, p. 23.

${ }^{50}$ Julia Lopes de Almeida. Livro das noivas. Rio de Janeiro: s/ editora, 1899, p. 25. 
ocasião: “de manhã. Uma senhora de gosto apurado deve usar roupão branco guarnecido de renda ou bordados ingleses. [...] nas reuniões de família, usam-se vestidos de tartalana ou escócia barege, cassas e garça de seda. Para traje de jantar, usase vestido com corpo guarnecido de rendas pregadas sobre uma tiara de tafetá."51

Em A pata da gazela, José de Alencar descreve uma moça rica e seu vestuário próprio para sair às ruas: "Por duas vezes avistara a fronte de Amélia coroada com um chapeuzinho de palha da Itália [...]. A moça tinha um roupão cor de café [...] as luvas eram da mesma cor de cinza das fitas do chapéu de palha [...] pousados na calçada dois pezinhos mimosos que palpitavam dentro das botinas de merino cor de cinza."52

Os processos de tingimento químico das roupas nasceram no século XIX, algumas décadas após a revolução industrial. Até então as roupas eram tingidas em sua maioria com elementos da natureza, como o pau-brasil. Mesmo assim, esses processos eram caros, demorados e o resultado do tingimento não era muito bom - as roupas desbotavam com as lavagens e a passagem do tempo. Ao longo do século, muitas cores passaram a ser produzidas sinteticamente a partir de descobertas da químicas. "A invenção do tingimento químico iluminou a aparência das damas vitoriana de maneira tão bem sucedida que podia se ver mulheres usando, por exemplo, um casaquinho magenta (também chamado de solferino) sobre um vestido rosa ou lilás, com um corpinho rosa e uma crinolina verde claro bordada com verde oliva."53

Mais uma vez, a escritora Júlia Lopes de Almeida, vai mencionará as múltiplas cores das roupas femininas: "A modista", escrevia ela, "deve ter imaginação, largas fantasias e ímpetos inventivos.” E continuava:

${ }^{51}$ A Marmorta fluminense está na Biblioteca Nacional e foi estudada por Maria do Carmo Teixeira Rainho, que publicou o livro A cidade e a moda (Brasília: Unb, 2002), p. 149.

${ }^{52}$ José de Alencar. A pata da gazela. São Paulo: Companhia Brasil Editora, 1951. p. 87.

${ }^{53}$ Elizabeth Wilson e Lou Taylor. Through the looking glass: a history of dress from 1860 to the presente day. Londres: BBC Books, 1989, p. 35. A tradução do trecho citado é minha. 
Criar novidades, executar todas as modas, ter a sua maneira, advinhar as cores convenientes às claras ou às trigueiras [...]. Uma jovem esbelta, pálida, loira pede-lhe uma toilette? Tela-á suave. Mística, leve, clara, cor da folha da ervilha, ou da do pessegueiro, ou branca, ou azul, ou creme; com umas rendas finas como flocos de espuma [...] É uma senhora morena, alta majestosa, quem lhe encomenda um vestido para o próximo baile? Falo-á de veludo vermelho, ou de cetim brilhante, enfeitalo-á com cores novas esquisitas, com bouquets de plumas d'aves selvagens, ou de grande flores fantásticas ... ${ }^{54}$

As cores, assim como as flores, também passaram a possuir um complexo código simbólico, já que a maioria da população (ainda mais no Brasil) não sabia ler nem escrever. ${ }^{55}$ As cores queriam dizer muitas coisas: desde o preto do luto ao branco da pureza, ao rosa das boas intenções, o lilás da seriedade, o azul da alma limpa. Esses significados estavam em constante transformação. Por isso "o significado de uma cor é, em grande parte, a história da cor. É um significado adquirido pelo movimento através do tempo." 56

A gama de cores que vai permear o guarda-roupa feminino no século XIX tinha a predominância do branco e do preto. Essa era uma ideia que, de certa maneira, retomava conceitos da reforma protestante. Para os protestantes, o preto era sinal de piedade, de uma vida regrada voltada a Deus. Às mulheres e crianças estava destinado o branco. ${ }^{57}$

O branco proporcionava às mulheres um visual que ressaltava a castidade e a pureza de sentimentos. A rainha Vitória escolheu o branco para se casar em fevereiro de 1840, cujo significado até então simbolizava riqueza e prosperidade. Com seu vestido

\footnotetext{
${ }^{54}$ Julia Lopes de Almeida. Livro das noivas. Rio de Janeiro: s/ editora, 1899, p. 24.

${ }^{55}$ Sobre as cores, ver os dois livros do historiador da arte inglês John Gage. Colour and culture: practice and meaning from Antiquity to Abstraction. Londres: Thames and Hudson, 1996; e La couleur dans l'art. Londres: Thames and Hudson, 2003. .

${ }^{56}$ John Harvey. Homens de preto. Trad. port. São Paulo: Editora da Unesp, 2003., p. 17.

${ }^{57}$ John Harvey. Homens de preto. Trad. port. São Paulo: Unesp, 2004.
} 
de casamento branco, a jovem monarca ressaltou a pureza de seus sentimentos e de sua sexualidade. Outras rainhas, anteriormente, haviam usado o azul para simbolizar a pureza de intenções ao se casarem, mas Vitória preferiu o branco e fez do gesto uma tradição - logo depois, a imperatriz Eugênia seguiu seu exemplo também se casando de banco em 1853.

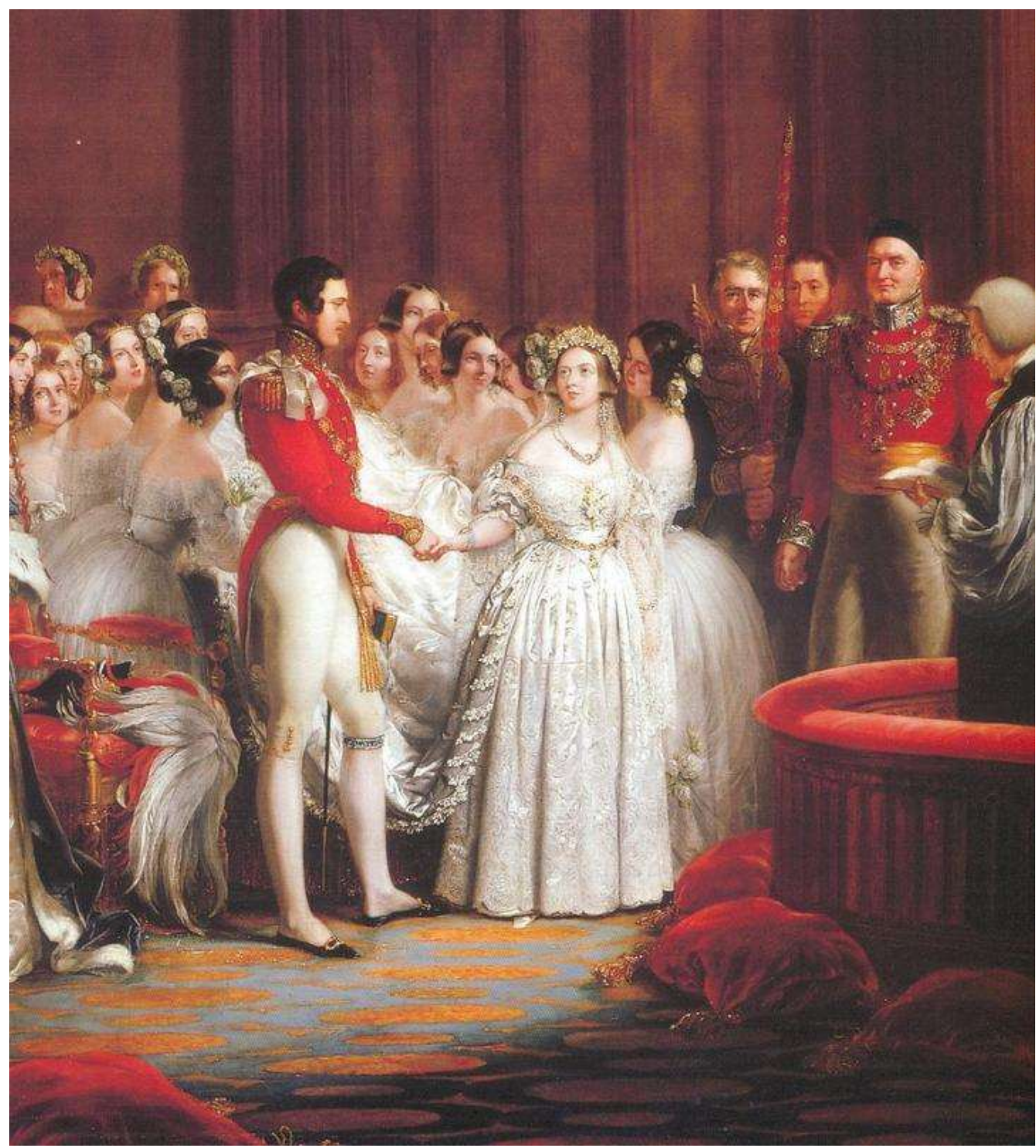

O quadro de George Hayter mostra o casamento da rainha Vitória em 1840 e destaca o branco do vestido da rainha ${ }^{58}$

${ }^{58} \mathrm{O}$ vestido branco é o centro do quadro de sir George Hayter, Queen's Vitoria and Albert Marriage. Óleo sobre tela $(195.8 \times 273.5 \mathrm{~cm})$. O quadro pode ser visto na Royal collection: http://www.royalcollection.org.uk/egallery/object.asp?object=407165. Consulta em 26/2/2013. 


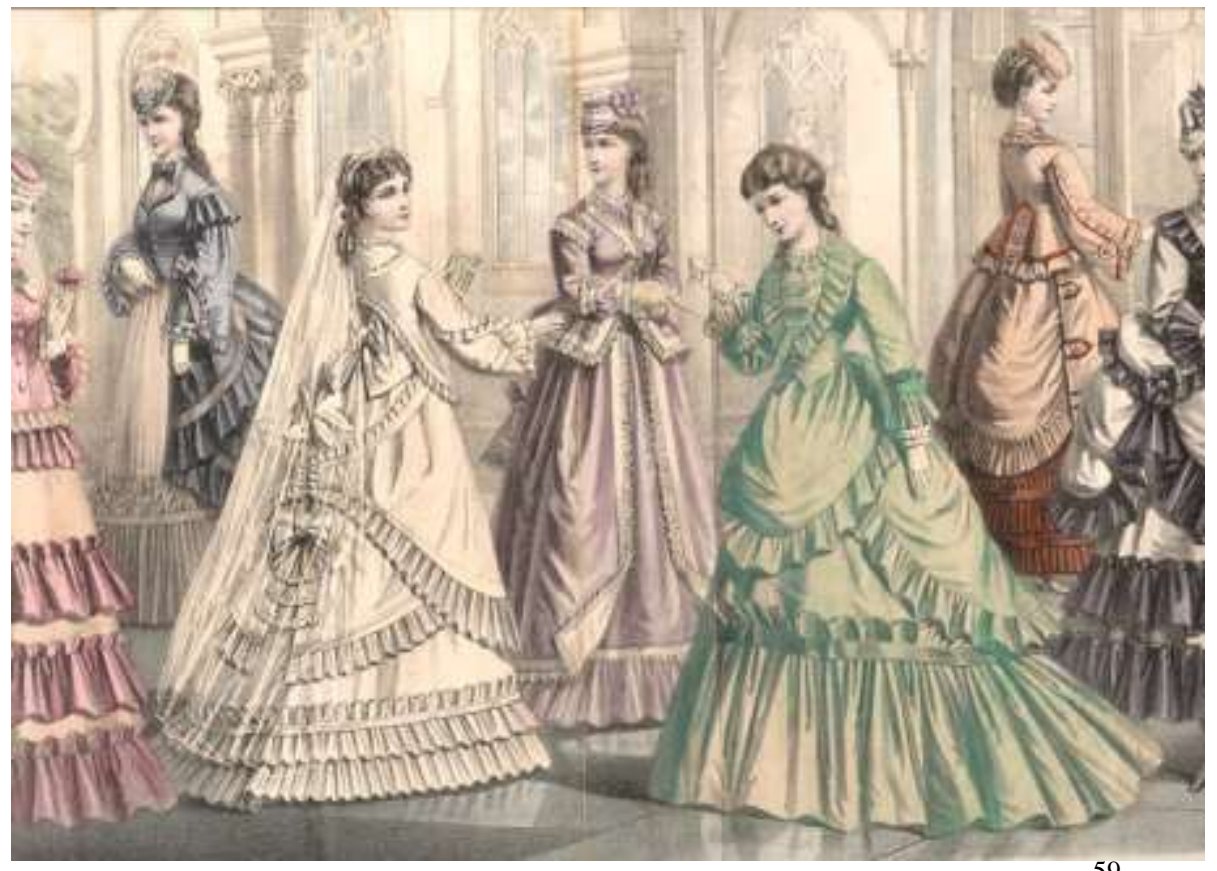

Vestidos de setembro de 1870, incluindo um de noiva, em branco 59

No Rio de Janeiro do século XIX, o branco era usado principalmente por jovens da elite. José de Alencar ao descrever uma personagem, uma moça, dizia de seus “[...] contornos harmoniosos que se destacavam entre as ondas de cambraia de seu roupão branco."60. Ele também trata da penitência de uma viúva que ousava pela primeira vez usar branco, anos depois da morte do marido: "Pela primeira vez depois de cinco anos Carolina trajava de branco; mas as fitas dos laços, as pulseiras, o colar, eram pretos ainda."

O branco condizia com o clima tropical do Rio de Janeiro, ajudando a amenizar o calor das roupas pesadas. Muitas vezes era usado em casa, em um roupão solto. A cor se usada para passeios também estabelecia uma distinção social clara, já que apenas as moças ricas ou nobres podiam manter roupas claras sempre impecáveis, sem nódoas ou sujeira.

59 Frank Leslie's Ladies Magazine Catalogue, setember 1870, encontrado no site <http://fairhavenprintshop.com/women.htm>. Consulta em 19/02/13.

${ }^{60}$ José de Alencar. Cinco minutos. São Paulo: Edições Melhoramentos, s.d., p. 34.

${ }^{61}$ José de Alencar. A viuvinha. São Paulo: Edições Melhoramentos, s.d., p. 151. 
O branco também ressaltava a juventude e a pureza - certamente serviu de metáfora muitas vezes para os escritores, como José de Alencar ou Aluísio Azevedo. Como em Sonhos d'Ouro, de Alencar: "Tinha um vestido branco de extrema simplicidade, fitas no cinto e no cabelo, botinas de duraque [...] e uma gargantilha de veludo da mesma cor, com um medalhão de jaspe. Era de jaspe também a pulseira [...]".62 Ou por Aluísio Azevedo, em Filomena Borges, ao se referir a uma noiva de classe média com vestido de chamalote branco. ${ }^{63}$

Domitília de Castro, a marquesa de Santos e amante de d. Pedro I, teve seu retrato pintado com um vestido branco cheio de simbolismo. Na mesma época em que ganhou o título de marquesa a faixa rosa pálido e branca é amarrada na cintura com um brasão em ouro. $\mathrm{O}$ decote é debruado em renda branca, assim como as mangas abrem-se em um tecido fino e transparente (gaze? musselina?). As joias - as pulseiras de pérolas em ambos os punhos, o colar de quatro voltas de pérolas e diamantes, o brinco pendente, as diademas e presilhas de brilhantes no cabelo, os anéis em todos os dedos - demonstram, ao mesmo tempo, poder e riqueza, mas também certa insegurança. Seria como se a marquesa quisesse provar para a posteridade por meio do uso excessivo de joias que era uma mulher poderosa e importante na corte. ${ }^{64}$

\footnotetext{
${ }^{62}$ José de Alencar. Sonhos d'ouro. t. I, Rio de Janeiro: Livraria Garnier,1872, p. 189.

${ }^{63}$ Aluísio Azevedo. Filomena Borges. São Paulo: Martins Editora, 1960, p. 23.

${ }^{64}$ Sobre a relação tempestuosa de d. Pedro I e a marquesa de Santos ver o livro D. Pedro, imperador do Brasil e rei de Portugal. São Paulo: Alameda Casa Editorial, 2013.
} 


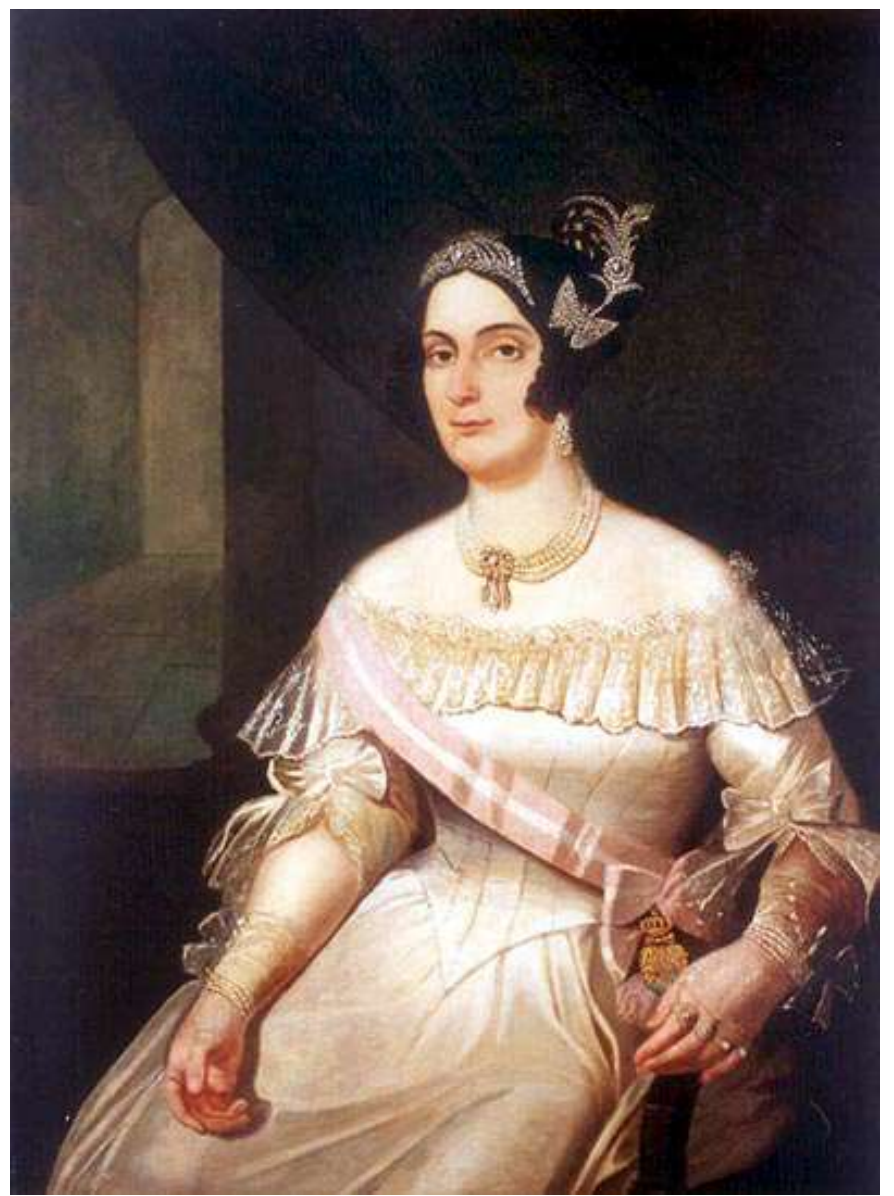

Domitília de Castro, marquesa de Santos, retratada por Francisco Pedro do Amaral ${ }^{65}$

Já a baronesa do Piraí, Cecília Pimenta de Almeida Frazão de Souza Breves, escolheu, ao posar para Claudio José Barandier, um vestido branco sem decote, complementado por uma capa preta amarrada por uma touca com laços em verde e rosa. A imagem data provavelmente de década 1850 e 1860, com a baronesa já em avançada idade (ela viria a falecer em 1866, com 84 anos de idade). Admirado na corte, e famoso por seus retratos, nesse quadro as roupas escolhidas por Cecília Breves mostram seu status e sua posição na corte.

${ }^{65}$ O quadro "Domitília de Castro, marquesa de Santos", foi pintado por Francisco Pedro do Amaral em cerca de 1826, quando a marquesa tinha 29 anos. Encontra-se no Museu Histórico Nacional, no Rio de Janeiro. É um óleo de 140x87 cm. 


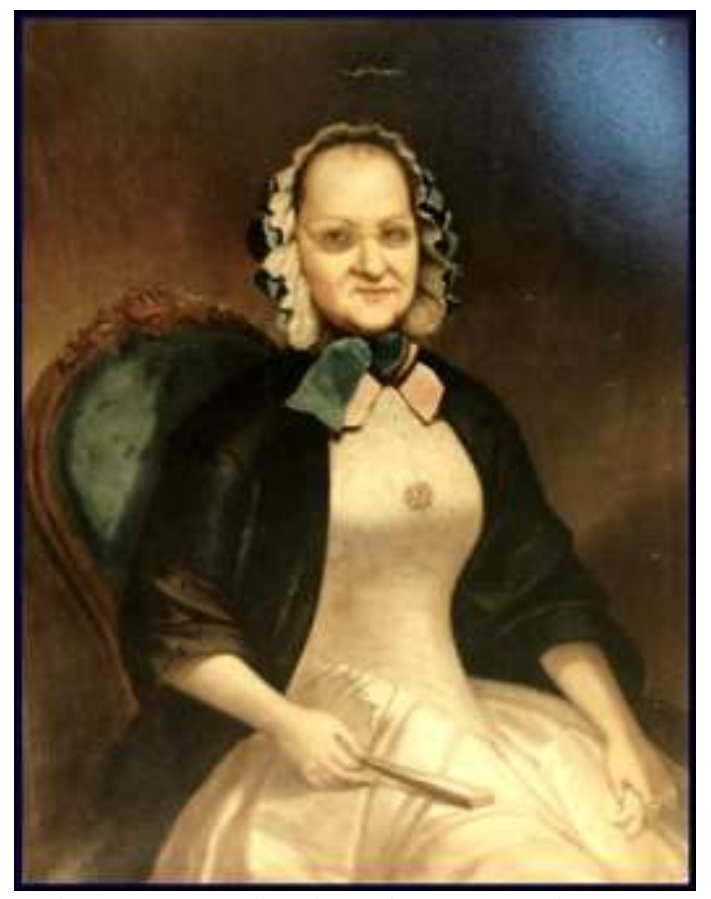

A baronesa de Piraí, Cecília Pimenta de Almeida Frazão de Souza, retratada por Claude J. Barandier em meados do século XIX ${ }^{66}$

O branco podia vestir senhoras mais idosas, como a baronesa de Piraí, como mocinhas - o que era mais comum. Em Casa de pensão, Azevedo vai descrever uma personagem feminina, ao mesmo tempo inocente e sensual, num vestido de fustão branco apertado: "Vestia fustão branco, sarapintado de pequenas flores cor-de-rosa. [...]. O vestido curto, muito cosido ao corpo, eluvava-lhe as formas [...]. Espartilhada, como estava [...]. Sentia-se-lhe dentro das mangas do vestido a trêmula carnadura dos braços; e os pulsos apareciam nus $[\ldots]^{\prime,}{ }^{67}$

O branco era uma cor destinada às mulheres - e aos acessórios masculinos. É do romancista alemão Johann Wolfgang Goethe uma Doutrina das cores em 1810. Ele vai dizer que "o caráter da cor tem a ver com o caráter da pessoa. Homens cultivados têm aversão às cores. Isso se deve em parte à fraqueza do órgão de visão, em parte ao gosto

${ }^{66}$ O pintor Claude J. Barandier, autor de A condessa de Piraí, Cecília Pimenta de Almeida Frazão de Souza $(22,5 \times 17,2 \mathrm{~cm})$, era o preferido da corte e muitos retratos das famílias nobres brasileiras. Este óleo pertence à coleção do Instituto Histórico e Geográfico Brasileiro, IHGB, Rio de Janeiro, s/d.

${ }^{67}$ Aluísio Azevedo. Casa de pensão. São Paulo: Martins Editora, 1960. p. 87. 
inseguro, que prefere se refugiar na completa negação. As mulheres agora se vestem frequentemente de branco." ${ }^{, 68} \mathrm{E}$ isso era particularmente verdade na época em vivia Goethe, influencia dos ares libertários após a Revolução Francesa, quando as mulheres usavam o estilo o diáfano império, com musselinas brancas apertadas embaixo do busto.

Julia Lopes de Almeida associava o branco à limpeza doméstica. Citando as várias cores das toilettes femininas dizia em seu Livro das noivas: "Para fazer costura branca é preciso ter um gênio especial, sereno e paciente [...]. A roupa branca deve ser ampla, talhada com gosto, bordada com carinho; há pontos adequados a cada peça, modelos graciosos, variados, desde os mais singelos até os mais complicados e trabalhosos". 69

Assim, a predominância do branco nas roupas femininas era ultrapassada apenas pela cor preta, que se tornou símbolo da vestimenta do século XIX. A ascensão da burguesia e o aparente desapego das coisas materiais, incentivado pelo romantismo, tornava o preto a cor ideal para passar uma imagem de comedimento e seriedade. ${ }^{70}$ Além do mais, o preto não precisava de muitas lavagens. Também não aparentava sujeira e seu tingimento era relativamente fácil. O preto havia se tornado a cor da Revolução Industrial. $^{71}$

A cor, ou a ausência de cor, como preferiam alguns dos filósofos da época, também era natural numa sociedade em que o luto frequente. Pais, irmãos, filhos, cunhados, tias ou sobrinhos eram velados e enterrados com regularidade quase cotidiana. Numa sociedade em que os homens eram responsáveis pela posição social da mulher, elas podiam passar anos de preto por causa do marido. "Em meados daquele

\footnotetext{
${ }^{68}$ Johann Wolfgang Goethe. Doutrina das cores. Trad. port. São Paulo: Nova Alexandria,1993. p. 34.

${ }^{69}$ Julia Lopes de Almeida. Livro das noivas. Rio de Janeiro: s/editora, 1896, p. 25.

${ }^{70}$ Juliana Schmitt. Mortes vitorianas: corpos, luto e vestuários. São Paulo: Alameda Casa Editorial, p. 114-115.

${ }^{71}$ John Harvey. Homens de preto. Trad. port. São Paulo: Unesp, 2004.
} 
século, o negro das roupas tornou-se o uniforme tanto das elites, aristocratas ou profissionais liberais, e o operariado. A moda do luto foi, então, uma moda para todos.",72

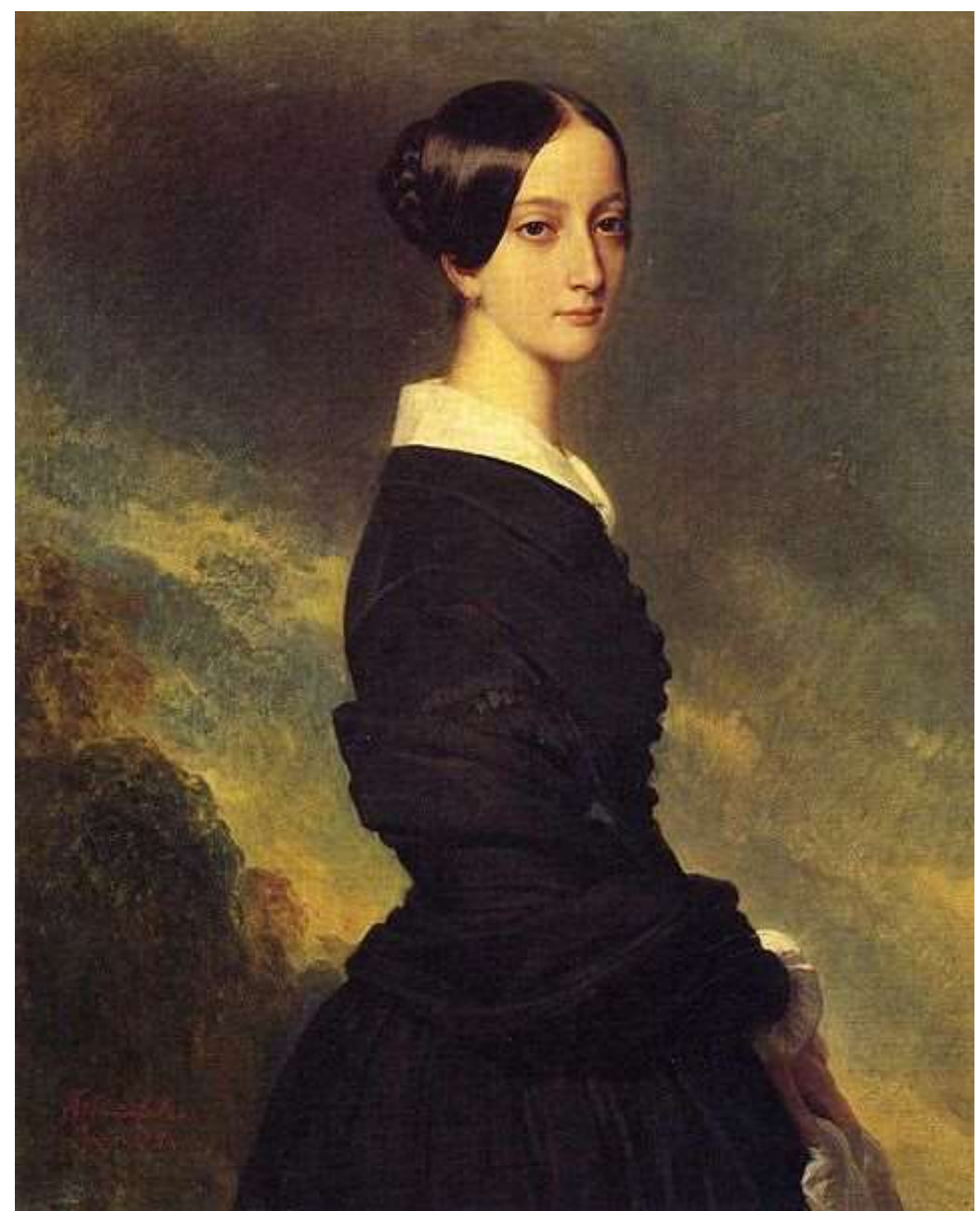

D. Francisca de Bragança, princesa de Joinville, em 1844, retratada por Franz Xaver Winterhalter ${ }^{73}$

D. Francisca de Bragança nasceu em 1824 e foi a quarta filha do imperador d. Pedro I com d. Maria Leopoldina. Cresceu no Rio de Janeiro, ao lado do imperador d. Pedro II e das irmãs d. Januária e d. Paula Mariana. Casou-se em $1^{\circ}$ de maio de 1843

\footnotetext{
${ }^{72}$ Juliana Schmitt. Mortes vitorianas: corpos, luto e vestuário. São Paulo: Alameda Casa Editorial, 2010, p. 79.

${ }^{73}$ D. Francisca de Bragança em retrato de Franz Xaver Winterhalter em 1844. Óleo sobre tela, sem tamanho. Museu Imperial <http://www.museuimperial.gov.br>. Consulta em 25/3/2013.
} 
com Francisco Fernando de Orléans, almirante e terceiro filho do Rei de França Luís Felipe I de Orléans e de Maria Amélia de Bourbon-Sicília, princesa de Nápoles. ${ }^{74}$ Nesse retrato de Franz Xaver Winterhalter, a princesa de Joinville tinha 20 anos e acabava se casar e se mudar para França. Nas roupas escolhidas, o preto, em contraste com o branco da gola e das mangas, mostra sobriedade para uma recém-casada.

"Por toda parte o preto predominava. Os caixeiros das lojas, manejando as vassouras, já vestiam, às sete da manhã, elegantes redingotes de casemira. O branco, nesse país, onde o preto deveria ser castigo para os galés, era desconhecido"75, escreveu François Biard em suas observações sobre o país por volta de 1858. Ainda que isso não fosse totalmente verdade, e as roupas pudessem ser de muitas cores, o preto era uma constante para homens e mulheres. "Na capital, a indumentária das mulheres varia de acordo com a moda. Entretanto, elas não gostam de mudar nem de tecido nem de cor, sendo os vestidos quase sempre de tafetá preto" ${ }^{, 76}$, observou o pintor Rugendas.

No retrato da imperatriz feito pelo pintor brasileiro acadêmico, aluno de Debret, José Correa de Lima (1814-1857), vemos a jovem noiva com um vestido azul muito escuro, quase preto, enfeitado com pequenos babados brancos ao redor do colo, um colar e um retrato do imperador, além de uma faixa azul clara. Os cabelos em cachos, presos por uma coroa de pedras preciosas. $\mathrm{O}$ retrato não era fiel à realidade e quando a jovem rainha chegou, d. Pedro II ficou bastante decepcionado. Anos depois, já uma senhora de quase 30 anos, a imperatriz deixou-se retratar, numa foto colorizada, com um simples vestido preto, sem joias ou adornos, com os cabelos preto presos atrás da cabeça.

\footnotetext{
${ }^{74}$ Dom Pedro, imperador do Brasil e rei de Portugal. São Paulo: Alameda Casa Editorial, 2013, p. 16-84.

${ }^{75}$ François Biard. Dois anos no Brasil. Trad. port. Rio de Janeiro: Imprensa Nacional, 1945. p. 31.

${ }^{76}$ João Maurício Rugendas. Viagem Pitoresca Através do Brasil. Trad. port. São Paulo: EDUSP/ Biblioteca Histórica Brasileira/ Martins Editora, 1972, p. 81.
} 


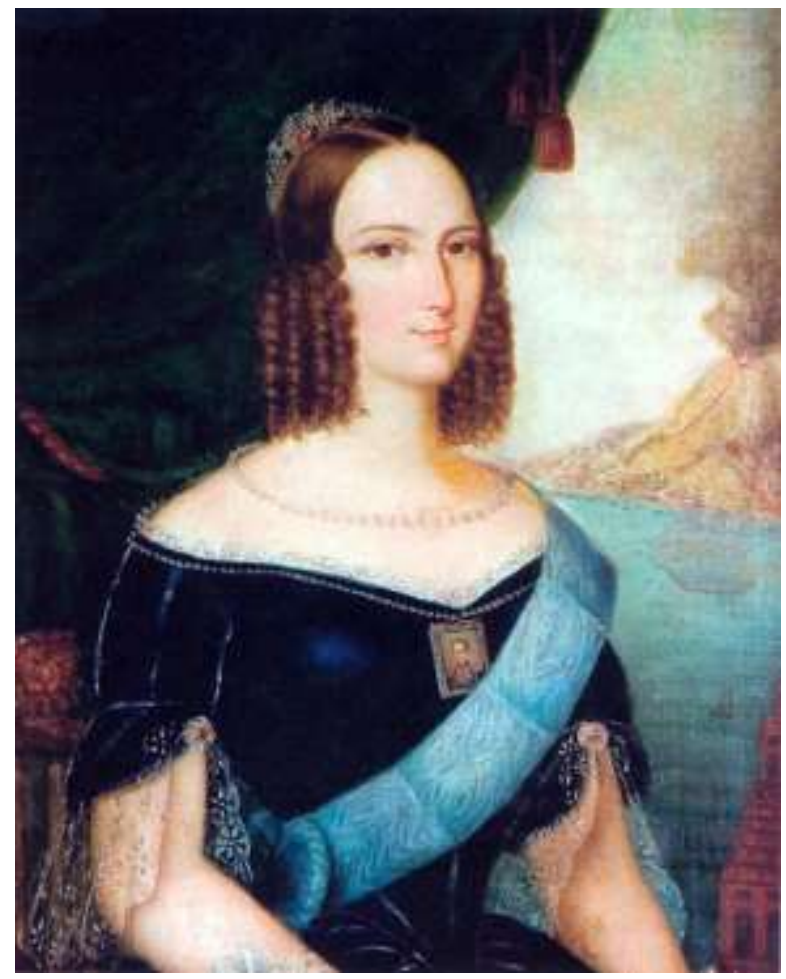

A imperatriz Teresa Cristina aos 21 anos em retrato infiel feito por Jose Correa de Lima ${ }^{77}$

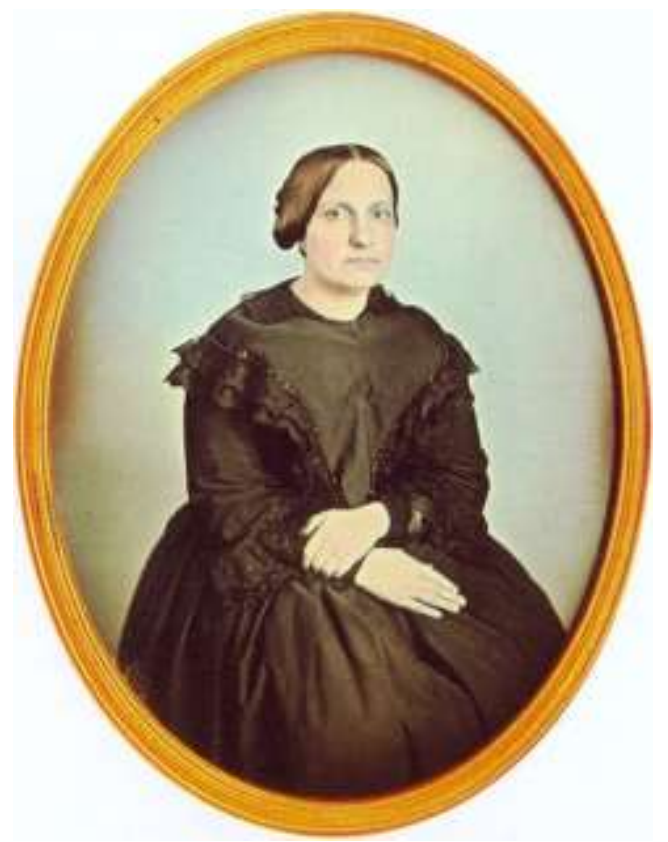

A imperatriz Teresa Cristina com 29 anos, em foto ${ }^{78}$ de Abram Louis Buvelot, na década de 1850

${ }^{77}$ Reprodução da Revista de História da Biblioteca Nacional. N. 17, ano, fevereiro de 2007. Óleo sobre tela, $65 \times 70 \mathrm{~cm}$, c. 1843 . O quadro encontra-se atualmente no Museu Imperial de Petrópolis. ${ }^{78}$ Bia Corrêa do Lago. Os fotógrafos do Império: a fotografia brasileira no Século XIX. Rio de Janeiro: Capivara, 2005. 
O preto das roupas passava simbolizar a riqueza e a vida burguesa - até para os escravos, isto fica evidente neste trecho de Robert Avé-Lallemant, em que o viajante descreve uma família abastada do sul do país:

\begin{abstract}
Assim como uma família, viajando de carro no Rio Grande, gosta de ver diante de si muitos cavalos ou bois, para exibir certa riqueza, assim também uma tropa de escravos, sobretudo de escravas e até muitas vezes com vestidos de cetim preto e corrente de ouro em volta do pescoço, nas regiões onde predomina o trabalho escravo, serve como reclama de abundância. ${ }^{79}$
\end{abstract}

José de Alencar tem inúmeras personagens femininas trajadas de preto em sinal de luto ou de uma vida regrada, burguesa. "Trajava um vestido de cetim preto, simples e elegante [...]"80 , vai escrever em A viuvinha; ou em Lucíola quando, diz que "Ambas [se] trajavam de preto, com véus espessos [...]. De volta da missa, tomaram de novo as suas alvas roupas de cassa [...]" ${ }^{\prime 81}$. Machado de Assis, em D. Casmurro, escreveu que a senhora, viúva, [...] "vivia metida em um eterno vestido escuro [...] com um xale preto, dobrado em triângulo e abrochado ao peito por um camafeu. Os cabelos, em bandós, eram apanhados sobre a nuca por um velho pente de tartaruga [...].",82

\footnotetext{
${ }^{79}$ Robert Avé-Lallemant. Viagem pelo norte do Brasil no ano de 1859. Trad. port. Vol. I, Rio de Janeiro: Ministério da Educação e Cultura/ Instituto Nacional do Livro, 1961, p. 194.

${ }^{80}$ José de Alencar. A viuvinha. São Paulo: Edições Melhoramentos, s.d., p. 117.

${ }^{81}$ José de Alencar. Lucíola. São Paulo: Edições Melhoramentos, s.d., p. 191.

${ }^{82}$ Joaquim Maria Machado de Assis. Dom Casmurro. São Paulo: Editora Ática, 1974. p. 15.
} 


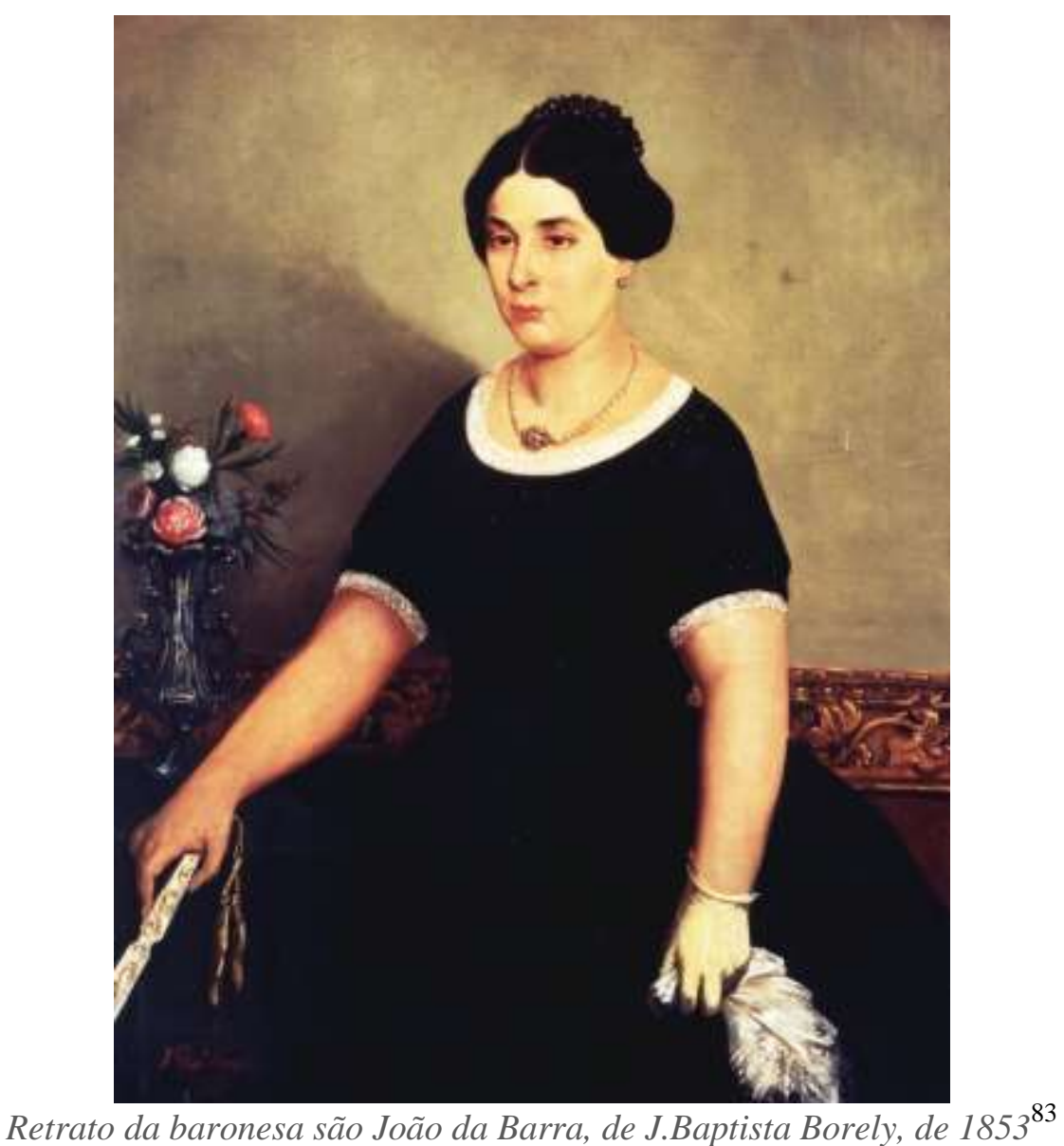

O preto também era cor de se ir à missa, atividade feminina por excelência. Então, uma variedade de relatos de viajantes, como neste caso Debret, contam que:

A vestimenta da senhora apresenta um exemplo do traje usado nas cerimônias da igreja; [...].. Uma senhora de boa sociedade ajusta aos cabelos um lindo véu bordado, preto ou branco [...]. A saia de filó preto bordado, usada por cima de um forro branco ou de qualquer outra cor clara, constitui o traje rico mais decente; um calçado elegante completa a indumentária da devota rebuscada nos seus enfeites. ${ }^{84}$

${ }^{83}$ Retrato da baronesa são João da Barra, de J. Baptista Borely, de 1853. Óleo sobre tela (115,5 x 89,6 cm). Coleção"Museus do Estado do Rio de Janeiro".

${ }^{84}$ Jean-Baptiste Debret. Viagem pitoresca e histórica ao Brasil. Trad. port. T. II, vol. III, São Paulo: Martins Editora, 1940, p. 159-161. 


\section{Outro documento informa:}

Aos domingos as mulheres, tanto as brancas como as de cor, vestemse todas de preto, na maior parte de seda, com meias de seda branca, sapatos correspondentes e sobre a cabeça um véu preto de fino crepe que cobre a metade do corpo e realça a palidez do rosto [...]. Posto que saiam pouco e só raramente façam vida social [...] as damas de qualidade e as mulheres em geral possuem amplos guarda-roupas de linho e sedas de toda classe, guarnecidos de outros enfeites. Quem dispuser de véus petinet, musselinas bordadas ou vestidos de seda pura fará fortuna, porque estes artigos, não obstante as modistas francesas e os armarinhos de luxo, são escassos e alcançam preços enormes. Nenhuma senhora [...] sai à rua sem que lhe siga atrás um negro ou negra bem vestido em traje de seda [...]. ${ }^{85}$

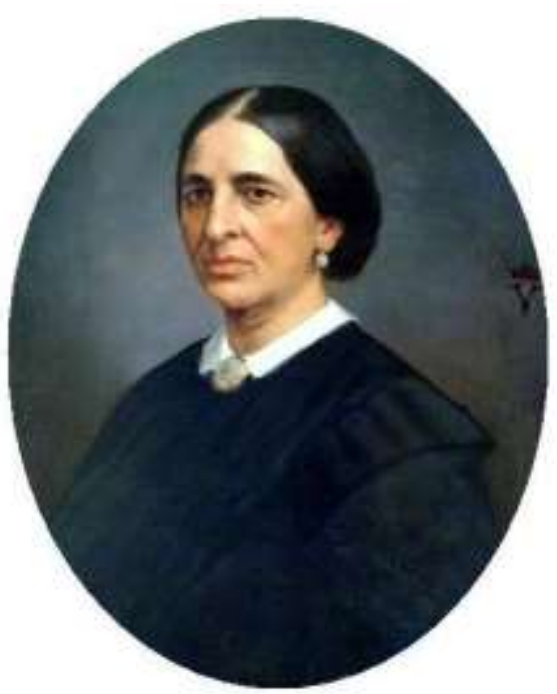

Retrato da marquesa de Valença, Ilídia Mafalda de Souza Queiróz: o contraste entre preto e branco simbolizava a austeridade burguesa ${ }^{86}$

${ }^{85}$ Theodor von Leithold e Ludwig von Rango. O Rio de Janeiro visto por dois prussianos em 1819. Trad. port. São Paulo: Companha Editora Nacional, 1966, p. 30-2.

${ }^{86}$ O quadro "Marquesa de Valença, Ilídia Mafalda de Souza Queiróz", autor anônimo e sem datação, está no Museu de História e Artes do Estado do Rio de Janeiro. É um óleo sobre tela de 73 $\times 59 \mathrm{~cm}$. Ver o site <http://www.museusdoestado.r.gov.br/sisgam/arquivos/MHAERJ/fotos/002875.jpg $>$. Consultado em 25/2/2012. 
As roupas e acessórios muitas vezes eram coloridos, com vermelhos, rosas, azuis, amarelos, roxos ou verdes se destacando em trajes de moças e senhoras. A fotografia da época pode enganar os olhos e o pesquisador, já que as técnicas de revelação eram rudimentares. Tudo o que parece ser branco pode ser rosa claro (como veremos na foto de época colorida da condessa de Pinhal) ou amarelinho, e aparecer como branco na foto. E também ao contrário, o roxo bem escuro pode aparecer como sendo preto.

$\mathrm{Na}$ tela de François Claudius Compte-Calix, reproduzida abaixo, a marquesa do Itamarati, Maria Romana Bernardes da Rocha, aparece retratada não apenas com várias cores, um vestido em branco quase gelo, com uma aplicação de renda preta e flores vermelhas enfeitando o busto, mas paramentada com o último rigor da moda e uma enorme crinolina por baixo do vestido. O quadro não é datado, mas a enorme crinolina redonda nos dá a ideia que deve ter sido provavelmente pintado na primeira década de 1850, quando, junto com o marido, o conde de Itamarati, em 1859, construiu o palacete no centro do Rio. 


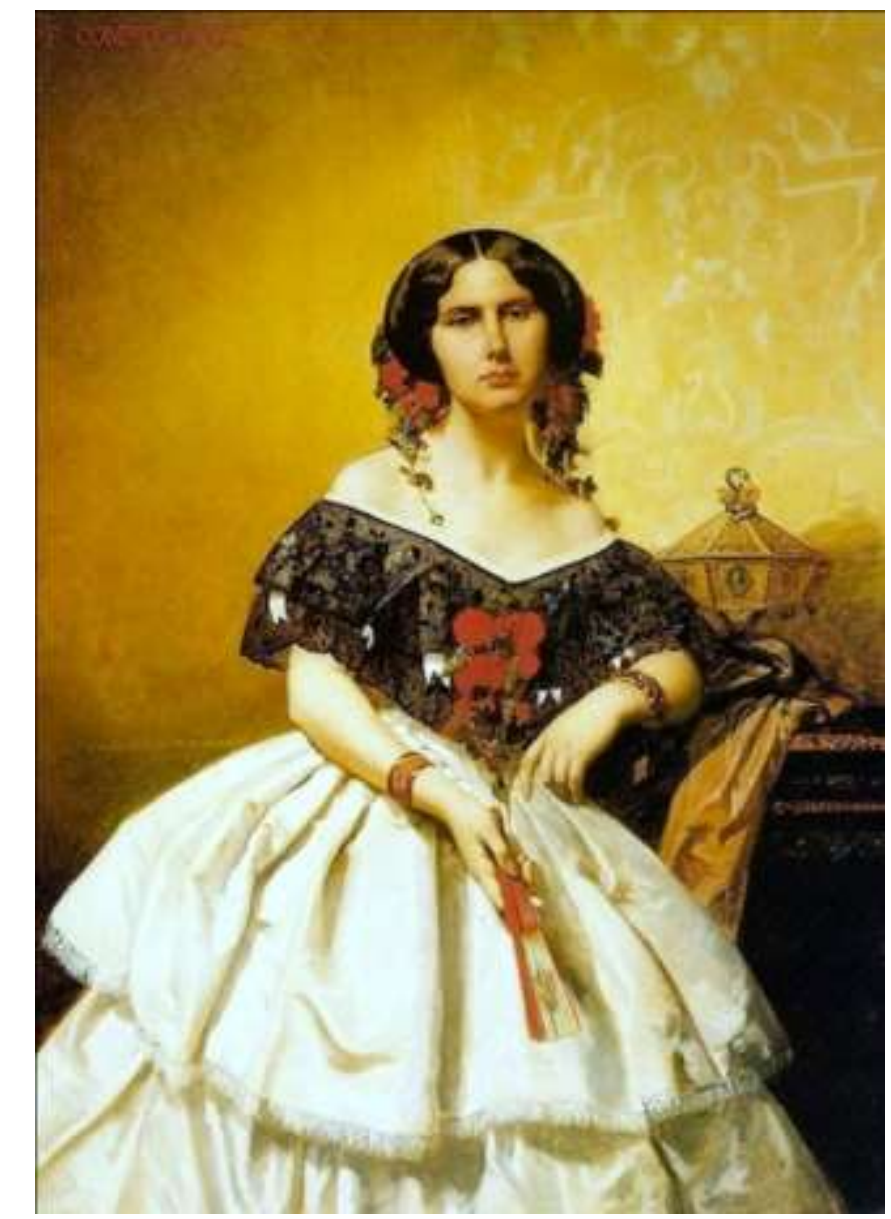

Maria Romana Bernardes da Rocha, marquesa do Itamarati, retratada por François Claudius Compte-Calix ${ }^{87}$

As cores foram uma constante em pinturas de família. Além da família real brasileira, membros da corte brasileira gostavam de ser ver retratados por pintores muitas vezes estrangeiros, como o austríaco Ferdinand Krumholz, que, no Brasil entre 1848 e 1853, fez diversos quadros do imperador e sua família e outros nobres da corte. Esses quadros permitem observar toda a diversidade cromática das vestes no segundo império. Mas existe outra fonte importante para percebermos as cores das roupas de época, as crônicas sociais dos jornais. A cada baile, saiam nos jornais cariocas, como no Diário do Rio de Janeiro de setembro de 1869, descrições detalhadas das vestimentas

87 "Marquesa do Itamarati”, retratada por François Claudius Compte-Calix. O óleo encontra-se no Palácio do Itamarati, Museu Histórico e Diplomático - Rio de Janeiro. Dimensões $144 \times 105 \mathrm{~cm}$. s/d. Catálogo Itamaraty Safra 1993. 
das senhoras e mocinhas que estiveram presentes ${ }^{88}$. Assim, vemos que cores faziam parte das roupas usadas pela corte e pela nobreza, além de possuíram um intrincado simbolismo para a época.

Até meados do século XIX as técnicas de tingimento ainda eram fundamentalmente naturais, com plantas, flores, raízes ou animais que funcionavam como agentes tingidores. ${ }^{89}$ Nem sempre o tingimento dava certo e as cores costumavam desbotar facilmente ao serem lavadas. A corrida para produtos que pudessem resultar em cores duráveis e vibrantes remontava à Idade Média. O pau-brasil, por exemplo, foi largamente usado nos primeiros séculos da colonização portuguesa. ${ }^{90} \mathrm{O}$ resultado dos tecidos tingidos por ele era claramente superior - um vermelho vivo que não desbotava. Vermelhos resultantes do tingimento com pau-brasil valiam mais. Por isso, quando a revolução industrial começou, a procura por agentes sintéticos ou naturais que pudessem ser usados com segurança em larga escala também teve início.

O vermelho, em particular, era uma das cores mais difíceis de serem conseguidas. Em 1826, um químico francês, Pierre-Jean Robiquet descobriu a alizarina, o pigmento era da família de rubáceas. Algumas décadas mais tarde, em 1868, dois químicos alemães, Carl Graebe e Carl Libermann, descobriram como fazer a cor vermelha sinteticamente, a partir da alzarina. Em pouco tempo, a indústria incorporou a nova e mais barata maneira de se tingir tecidos e, no final do século, o vermelho já havia se popularizado. $^{91}$

\footnotetext{
${ }^{88}$ Wanderley Pinho. Salões e damas do segundo reinado. Rio de Janeiro: Martins Editora, 1970, p. 305.

${ }^{89}$ Ver John Gage. Colour and culture: practice and meaning from Antiquity to Abstraction. Londres: Thames and Hudson, 1996; e Jane Tozer e Sarah Levitt. Fabric of society. Manchester: Laura Ashley publishing, 1983, "Fine Linen" e "shopping for clothes".

${ }^{90}$ Gilberto Freyre. Casa Grande e senzala. São Paulo: Global, 2005.

${ }^{91}$ Jane Tozer e Sarah Levitt. Fabric of society. Manchester: Laura Ashley publishing, 1983, p. 3740 .
} 
A esta altura o significado da cor vermelha havia se modificado - da cor do martírio de Cristo, usada por reis e nobres desde a antiguidade, para a cor do socialismo, por causa da Revolução Francesa ${ }^{92}$. Raramente se verá uma mulher de sociedade vestida com um traje vermelho - o que a associaria às moças de vida fácil. A cor aparecia mais em detalhes, em lenços ou mantilhas, muitas vezes usada por escravas, malandros ou gente da fazenda, que não entenderia de moda. "As negras têm geralmente um talhe flexível e elegante [...]. É raro encontrar uma negra, mesmo de 17 a 18 anos, cujo colo tenha conservado as formas que tanto buscamos [...]. Contudo, não lhes falece certa arte para dissimular a sua flacidez com um pedaço de pano azul ou vermelho". 93

Contudo, um vermelho rico e encorpado, se usado com os acessórios certos e por damas da sociedade carioca acrescentava bom gosto e beleza às moças. A condessa de Iguaçu, Maria Isabel de Alcântara Brasileira, deixou-se retratar com essa cor. Talvez o pintor, o austríaco Ferdinand Krumholz, com a escolha do vermelho, fizesse uma alusão à mãe de Maria Isabel, Domitília de Castro Canto e Mello, célebre amante de d. Pedro I. Maria Isabel foi a quarta filha bastarda desse relacionamento, criada pela mãe. Mas a explicação pode ser mais simples - a condessa poderia gostar de seu rico vestido vermelho. Vermelho também tinha sido a cor preferida de reis e nobres na Idade Média.

\footnotetext{
${ }^{92}$ Os revolucionários franceses eternizaram o gorro vermelho dos jacobinos, usado no período do terror.

${ }^{93}$ Louis François de Tollenare. Notas dominicais tomadas durante uma viagem em Portugal e no Brasil em 1816, 1817 e 1818. Trad. port. Salvador: Livraria Progresso Editora, 1956, p. 80-1.
} 


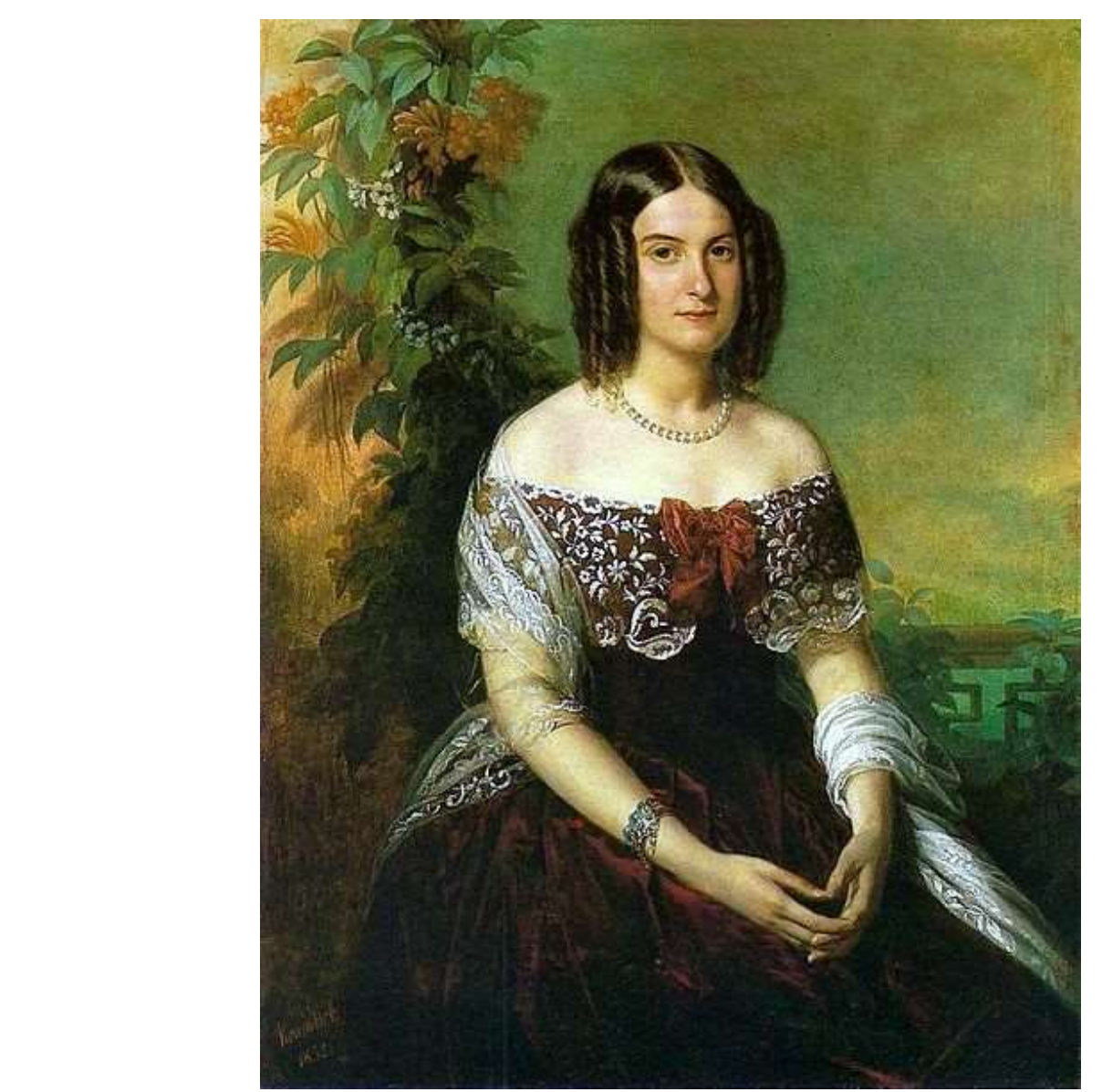

A condessa do Iguaçu retratada por Ferdinand Krumholz em 1852 com um vestido vermelho escuro e laço de veludo no decote recoberto com renda branca ${ }^{94}$

Ao contrário do vermelho, como uma variante mais suave, estava o rosa - esse sim usado por senhoras e senhoritas de sociedade preocupadas com a moda. "A festa de Fernando realizou-se na véspera da sua partida. Magdá [...] pôs um vestido de cassa corde-rosa, todo enfeitado de margaridas, deixando ver em transferência a ebúrnea riqueza do colo e dos braços." ${ }^{95}$, escreveu Aluísio Azevedo. Na foto pintada a condessa do Pinhal aparece séria com um vestido cor-de-rosa, com mangas bufantes, renda branca e um broche e um colar.

\footnotetext{
${ }^{94}$ Ferdinand Krumholz. Retrato da Condessa de Iguaçu, 1852. Museu Nacional de Belas Artes (inventário). Óleo sobre tela $(116 \times 90 \mathrm{~cm})$.

${ }^{95}$ Aluísio Azevedo. O homem. São Paulo: Martins Editora, 1970, p. 50.
} 


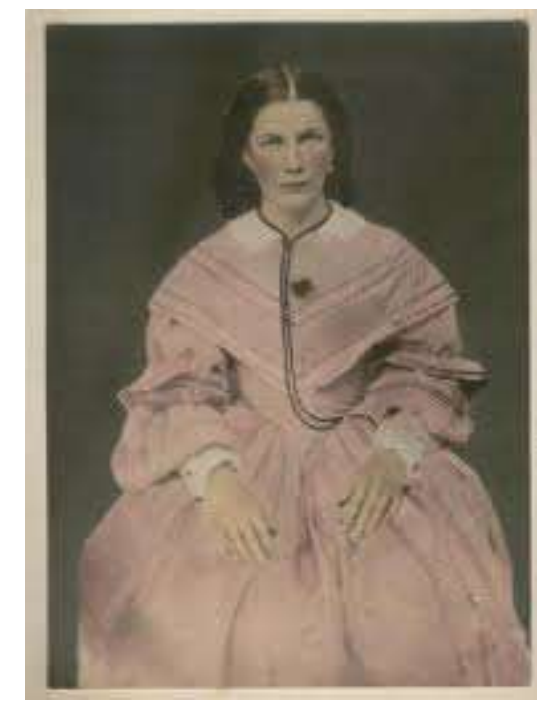

A condessa do Pinhal, Ana Carolina de Mello Oliveira, de rosa, em foto anônima pintada da época de seu casamento em $1863^{96}$

O tingimento industrial de tecidos teria começado com a descoberta pelo estudante de química alemão William Perkin, de uma substância posteriormente chamada de mauveine, derivada do alcatrão de hulha e produtora dos pigmentos sintéticos de tinta para tecidos. ${ }^{97}$ A cor resultante desse processo era uma espécie de roxo bastante vivo. Perkin patenteou sua invenção em 1870, um dia depois dos químicos Carl Liebermann e Carl Graebe terem também pateteado a síntese química da alzarina, que dava o vermelho sintético. Assim, as descobertas químicas alemãs continuaram pelas próximas décadas e transformaram a Alemanha numa potência industrial. Novas e brilhantes cores foram sendo usadas pela indústria que nascia, como o amarelo, o magenta, o azul - eram também muito mais baratas. ${ }^{98}$

O amarelo foi uma das cores sintéticas produzidas. O amarelo era resultante de um composto derivado da anilina e foi primeiramente comercializado em 1864, um ano

${ }^{96}$ A condessa do Pinhal em foto anônima pintada da época de seu casamento, em 1863. A foto encontra-se no site <www.arrudabotelho.com.br $>$. Consulta 26/02/2013.

${ }^{97}$ A hulha é uma espécie de carvão mineral que contém betume, foi muito estudada no século XIX e utilizada na indústria.

${ }^{98}$ Jane Tozer e Sarah Levitt. Fabric of society. Manchester: Laura Ashley publishing, 1983, p. 40. 
após o preto sintético estar disponível no mercado. Sempre foi associado à riqueza e ao luxo, por uma evidente associação com o ouro. Até a descoberta do amarelo sintético, usavam-se elementos naturais para se tingir os tecidos, como xixi de vaca, os ocres da terra e arsênico.

No mesmo período, o amarelo também apareceu em vestidos na corte brasileira, como intrincado modelo dourado vestido pela marquesa do Paraná, Maria Henriqueta Netto Carneiro Leme, ao posar para Emílio Bausch. A marquesa, dama de companhia da imperatriz e pertencente a uma das mais influentes famílias da corte, mostrava todo o poder do marido, Honório Hermeto Carneiro Leão, que havia sido ministro da Justiça e dos Negócios Estrangeiros. Maria Henriqueta aos 47 anos veste um modelo dourado, adequado para festas, com um decote profundo, adornado por rendas pretas e um camafeu com a imagem do marido. Brincos, um longo colar de pérolas e pulseiras completam as joias escolhidas para o quadro. O cabelo é preso atrás da cabeça, num coque que termina em plumas de avestruz. Com esta imagem, ela torna-se a imagem perfeita de uma dama de companhia da imperatriz, com poder e grande influência na corte. 


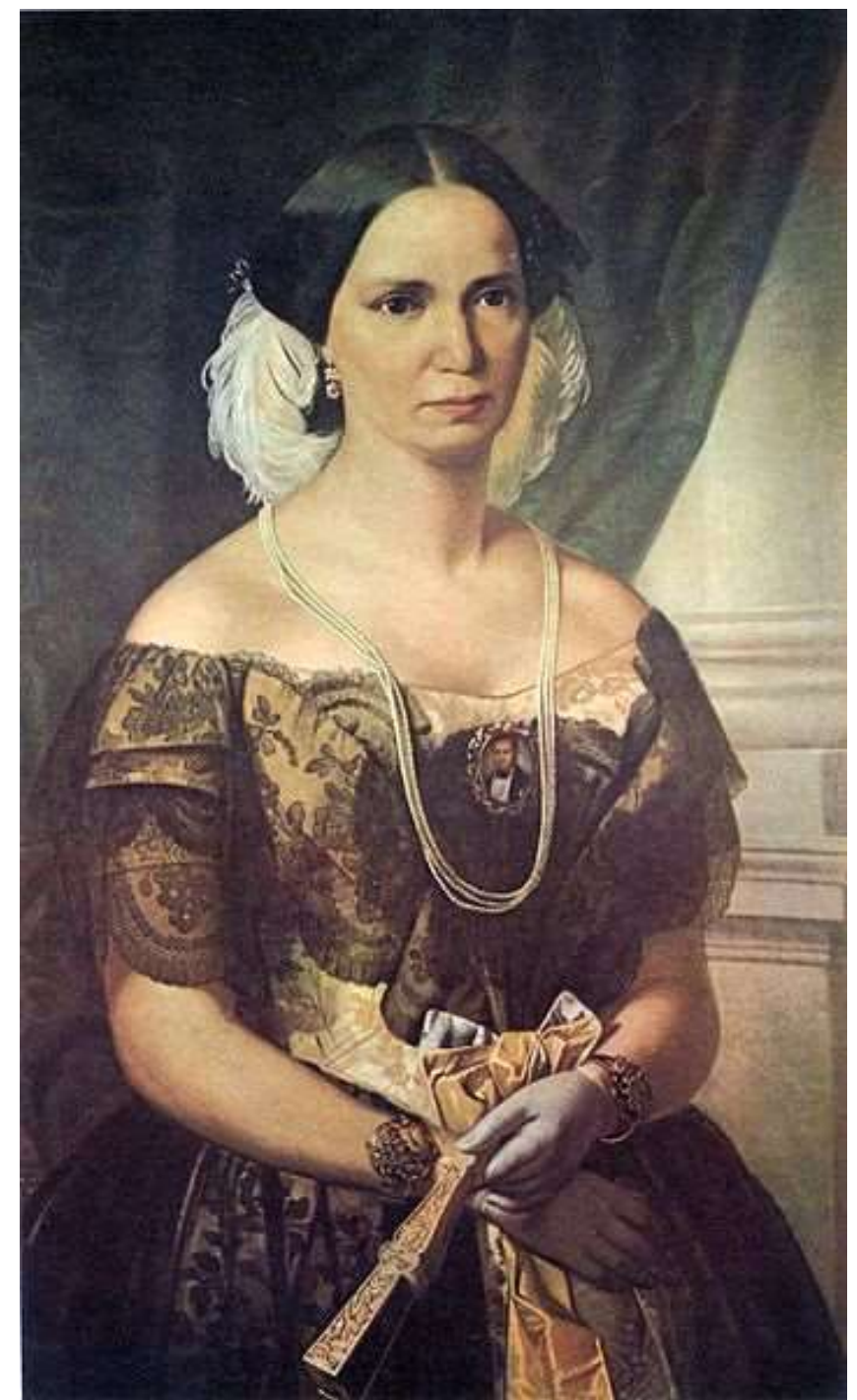

A marquesa do Paraná, Maria Henriqueta Netto Carneiro Leme, retratada por Emil Bauch em 185699: vestido amarelo-dourado com laços e renda preta mostra a importância política do marido

No verbete azul do Dicionário de Rapahel Bluteau, a cor aparece como uma palavra derivada do árabe, “zul”, e usada por pintores em seus quadros. Estava também ligada a alguns uniformes de casas reais, à ideia de misericórdia e ao pigmento derivado do lápis-lázuli. ${ }^{100} \mathrm{O}$ azul começou a ser usado no Antigo Egito a partir do pigmento da pedra lápis-laluzi triturada. Era a cor do céu e do deus Amon. Na Índia o azul era obtido

${ }^{99}$ Maria Henriqueta, Marquesa de Paraná (1809-1887), 1856. Esposa de Honório Hermeto Carneiro Leão, Marquês de Paraná. Tela de Emílio Bauch. In: Grandes personagens da nossa história. v.2. São Paulo: Abril, 1972.

${ }^{100}$ Dicionário de Raphael Bluteau encontra-se on line no site do Instituto de Estudos Brasileiros <http://www.ieb.usp.br/catalogo_eletronico/>, o verbete "azul" foi consultado em 7/3/2012. 
a partir do pigmento de uma planta, o índigo. Em Roma, o índigo importado dos indianos para ser usado nas cores das roupas dos trabalhadores. Na época, era também a cor associada aos períodos de luto e aos bárbaros, como os celtas, que tingiam suas roupas com o woad, Isatis tinctoria, uma árvore comum na Europa. ${ }^{101}$ No final do período medieval, tornou-se relativamente comum o uso de roupas tingidas com o "pastel woad", que mais tarde ficou conhecido apenas como "pastel" na região de Toulouse. $^{102}$

Uma pequena guerra comercial entre os dois azuis começou na renascença. Tanto o índigo indiano quanto o woad pastel tinham o mesmo princípio ativo, que resultava num tingimento azul. Com a conquista inglesa da índia, no final do século XVIII, o mercado para o índigo indiano se estabeleceu e levou à ruína cidades como Toulouse, que dependiam do tingimento de tecidos com o woad. O produto indiano dava um azul mais profundo. ${ }^{103}$ A Inglaterra, depois da dominação da Índia, passou a exportar o índigo por um preço muito mais barato que o woad - e o resultado foi uma espécie de explosão de tecidos azuis tingidos com o índigo indiano.

Foi basicamente esse índigo indiano que tingiu as roupas de azul no século XIX. Não fazia muito tempo que, desde meados do XVIII, a grande disponibilidade de índigo no mercado colaborou para que o azul passasse a ser usado nos uniformes militares e de policiais. O azul também foi a cor dos uniformes dos homens que libertaram os Estados

\footnotetext{
${ }^{101}$ Ver o livro o livro clássico de Roger Fry, Visão e forma (Trad. port. São Paulo: Cosac \& Naify, 2002) sobre arte e também o trabalho de John Gage. Colour and culture: practice and meaning from Antiquity to Abstraction. Londres: Thames and Hudson, 1996. E também, o livro de Francis Frascina, Nigel Blake, Briony Fer, Tamar Garb e Charles Harrison, Modernidade e modernismo: a pintura francesa no século XIX (Trad. port. São Paulo: Cosac \& Naify, 1998). Não é fácil encontrar trabalhos sobre cores e pigmentos no século XIX e eu tive muitas vezes de recorrer a algumas histórias da arte e da pintura. O controverso livro de Michel Pastoureau, Bleu. Histoire d'une couleur. (Paris : Le Seuil, 2000) é uma exceção.

${ }^{102}$ Michel Pastoureau, Bleu. Histoire d'une couleur. Paris : Le Seuil, 2000, p. 48-53.

${ }^{103}$ Michel Pastoureau, Bleu. Histoire d'une couleur. Paris : Le Seuil, 2000, p. 83.
} 
Unidos $^{104}$, a cor dos guardas que protegiam Luis XVI, os regimentos de Napoleão ${ }^{105}$, cor escolhida para ser a da polícia de Londres. Em 1868, um químico alemão, Johann Friederich von Bayer, descobriu um índigo sintético, que foi colocado no mercado em 1897 e popularização da cor. ${ }^{106}$

No Brasil, ao longo do século XIX, o azul vindo do índigo indiano em tecidos ingleses foi muito usado em vestidos. Como aconteceu no traje da princesa Isabel no baile de 16 de maio de 1872, quando ela vestiu um traje de "cetim azul com finíssima renda branca na saia e no corpinho, ornados de graciosos grupos de botões de rosas; flores iguais, porém unidas, prendiam o penteado em cachos, adereço de brilhantes". ${ }^{107}$

August Muller, pintor alemão discípulo de Debret, pintou o retrato da baronesa de Vassouras, Ana Alexandrina Teixeira Leite, entre a década de 1850 e 1860. Em 1851, Ana havia acabado de se casar com um primo, Francisco José Teixeira Leite. Ela era trinta anos mais nova do que o noivo e era o segundo casamento do barão. No retrato, ela exibe a aliança e um vestido azul, com rendas pretas sobrepostas e grandes mangas brancas. Todos os símbolos do casamento de uma mulher de sociedade da época estão presentes: o azul representando a pureza de sentimentos (mais condizente que o branco para uma segunda núpcia), os anéis, o broche de ouro fechando colarinho, o véu rendado preto adornando o penteado, os metros e metros de um rico tecido azul profundo, a cidadezinha ao fundo.

\footnotetext{
104 John Mollo. Uniforms of the American Revolution in color. Nova York: Stirling Publications, 1991 , p. 177.

${ }^{105}$ Napoleão, por causa do bloqueio continental, tingia os uniformes de woad. Ver a ótima resenha de Annie Geffroy sobre o livro já citado de de Michel Pastoureau, Bleu. Histoire d'une couleur (Paris: Le Seuil, 2000, 216 p.) na revista Mots, le languages politiques, n. 70, 2002.

${ }^{106}$ Michel Pastoureau, Bleu. Histoire d'une couleur. Paris : Le Seuil, 2000, p. 111.

${ }^{107}$ Wanderley Pinho. Salóes e damas do segundo reinado. Rio de Janeiro: Martins Editora, 1970, p. 305.
} 


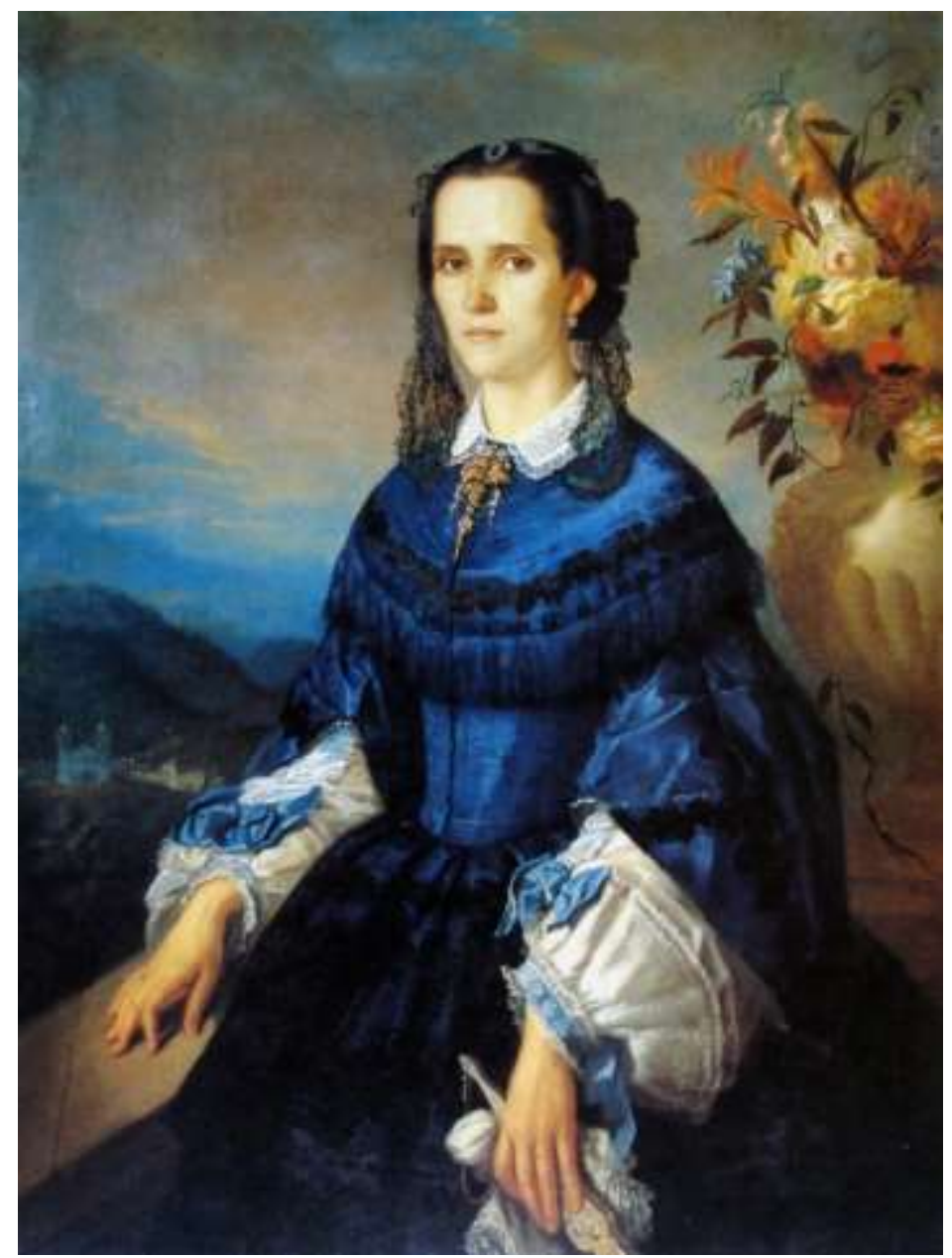

A Baronesa de Vassouras, Ana Alexandrina Teixeira Leite, retratada logo após o casamento em um vestido azul por August Muller em meados do século XIX ${ }^{108}$

Irmão do azul na palhete de cores, o verde por muito tempo foi usado a partir de pigmentos de árvores ou plantas. O Bluteau associa o verde a uma variedade de plantas e hortaliças. "A cor que a natureza dá às ervas e árvores"109, diz o começo do verbete sobre a cor e a seguir elenca uma série de plantas e variedades de verde, como o aspargo e a arruda.

Até meados do século XVIII, os processos de tingimento de tecidos com o verde não eram muito duradouros - e a cor costumava desbotar ao ser lavada e usada frequentemente. Usava-se malaquita, cobalto ou cobre para se conseguir tons verdes,

108 August Müller, "Baronesa de Vasssouras", 150x94 cm. In: Arte do século XIX. Catálogo Mostra do Redescobrimento, 2000, p. 82.

${ }^{109}$ Ver o site do IEB, o verbete "verde": $<$ http://www.ieb.usp.br/catalogo_eletronico/>. Consulta em 14/3/2012. 
mas até a descoberta de um pigmento verde sintético, era difícil se obter um verde “estável” e "durável”. Esse primeiro pigmento sintético era feito com arsênico. ${ }^{110}$ Alguns tons de verde sintético, como "verdegris" ou o "verde de Paris" eram tóxicos, pois continham altas dosagens de arsênico e cobalto. ${ }^{111}$

O verde era especialmente importante para a família real brasileira - era cor da bandeira imperial brasileira, a cor da casa de Bragança, de d. Pedro I (o amarelo seria o da casa de Habsburgo, de d. Leopoldina). Por isso, em diversas ocasiões oficiais durante o Segundo Império, os membros da família imperial, em especial a imperatriz Tereza Cristina e as princesas Isabel e Leopoldina, usaram verde em suas roupas. No baile de maio de 1872, "trazia a imperatriz um vestido de seda verde com guarnições de renda branca larga formando apanhados presos com ramos de flores escuras e veludo; flores iguais ornavam em trepadeira o penteado; adereço de pérolas e brilhantes."

O verde também esteve presente em descrições de personagens, no cotidiano das mulheres de elite do Rio de Janeiro. Aurélia usava verde pela manhã: “A moça trazia nessa ocasião um roupão de cetim verde cerrado à cintura por um cordão de fios de ouro [...]. A moça reclinara a fronte sobre a mão direita, cujo braço nu, apoiado na mesa, surgia de entre os fofos da cambraia que frocavam a manga do roupão." ${ }^{\text {113 }}$ Para usa verde à tarde, numa espécie de túnica: “Trazia Aurélia uma túnica de cetim verde, colhida a cintura por um cordão de torçal de ouro, cujas borlas tremiam com seu passo modulado. $^{114}$

\footnotetext{
${ }^{110}$ François Delamare. Colour: the history of dyes and pigments. Nova York: Discoveries, 2002.

${ }^{111}$ François Delamare. Colour: the history of dyes and pigments. Nova York: Discoveries, 2002.

${ }^{112}$ Wanderley Pinho. Salões e damas do segundo reinado. Rio de Janeiro: Martins Editora, 1970, p. 305.

113 José de Alencar. Senhora. São Paulo: Ática, 1971. p. 223.

${ }^{114}$ José de Alencar. Senhora. São Paulo: Ática, 1971. p. 72.
} 


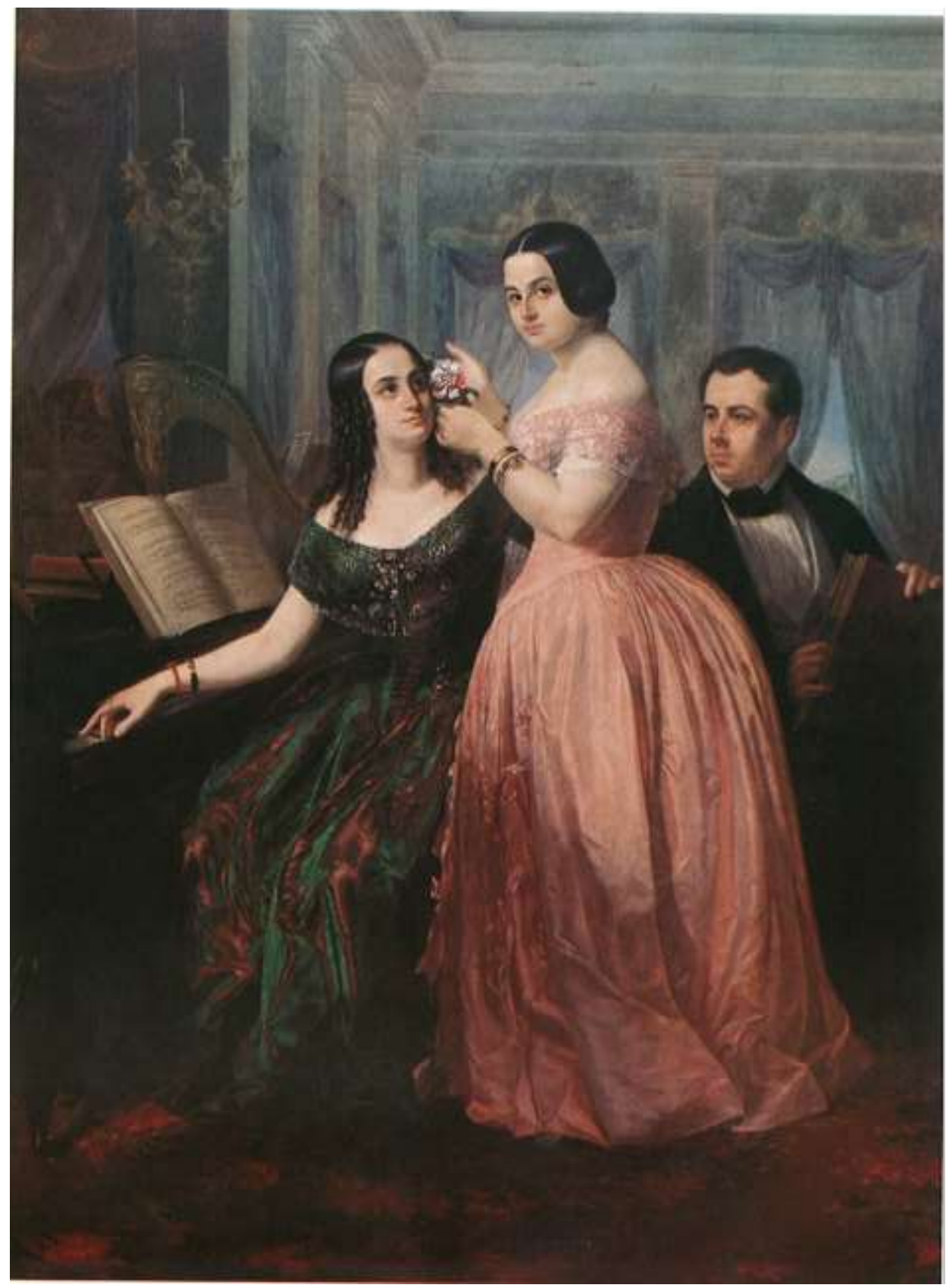

Francisco Manuel e suas filhas, num retrato de José Correa de Lima de 1850: o piano e as roupas eram símbolos de distinção para a elite imperial ${ }^{115}$

As meninas do quadro acima estão vestidas com suas melhores roupas, uma ao piando de vestido furta-cor verde, com rendas no decote e pulseiras delicadas. Outra, de rosa, com um decote enfeitado por uma renda branca e lacinhos na frente do vestido. As crinolinas de ambas estão evidentes na pintura de José Correa de Lima, discípulo de

\footnotetext{
${ }^{115}$ Luiz Felipe Alencastro (org.) História da vida privada no Brasil II. São Paulo: Companhia das
} Letras, 1997, caderno de imagem. 
Debret que atuava na corte em meados do oitocentos. O pai zela por ambas, com um grande livro na mão. Tudo na pintura representava a elite imperial: o piano, as moças, o grande livro, cortinas, candelabros e harpas na casa fazem um cenário de fundo que ressalta a riqueza e distinção das personagens da cena.

No broche reproduzido abaixo, que faz parte da coleção Sérgio Eduardo Lemgruber do Museu Imperial, em Petrópolis, vemos d. Mariana Velho Ribeiro de Avellar, viscondessa de Ubá, em um vestido verde adornado por um corpete rendado de branco e pedras no busto. A família Avellar foi importante proprietária de terras, cultivadas com café na região de Paty de Alferes, no Rio de Janeiro. Sua fazenda chamava-se Pau Grande e Mariana era filha de José Maria Velho da Silva e Leonarda

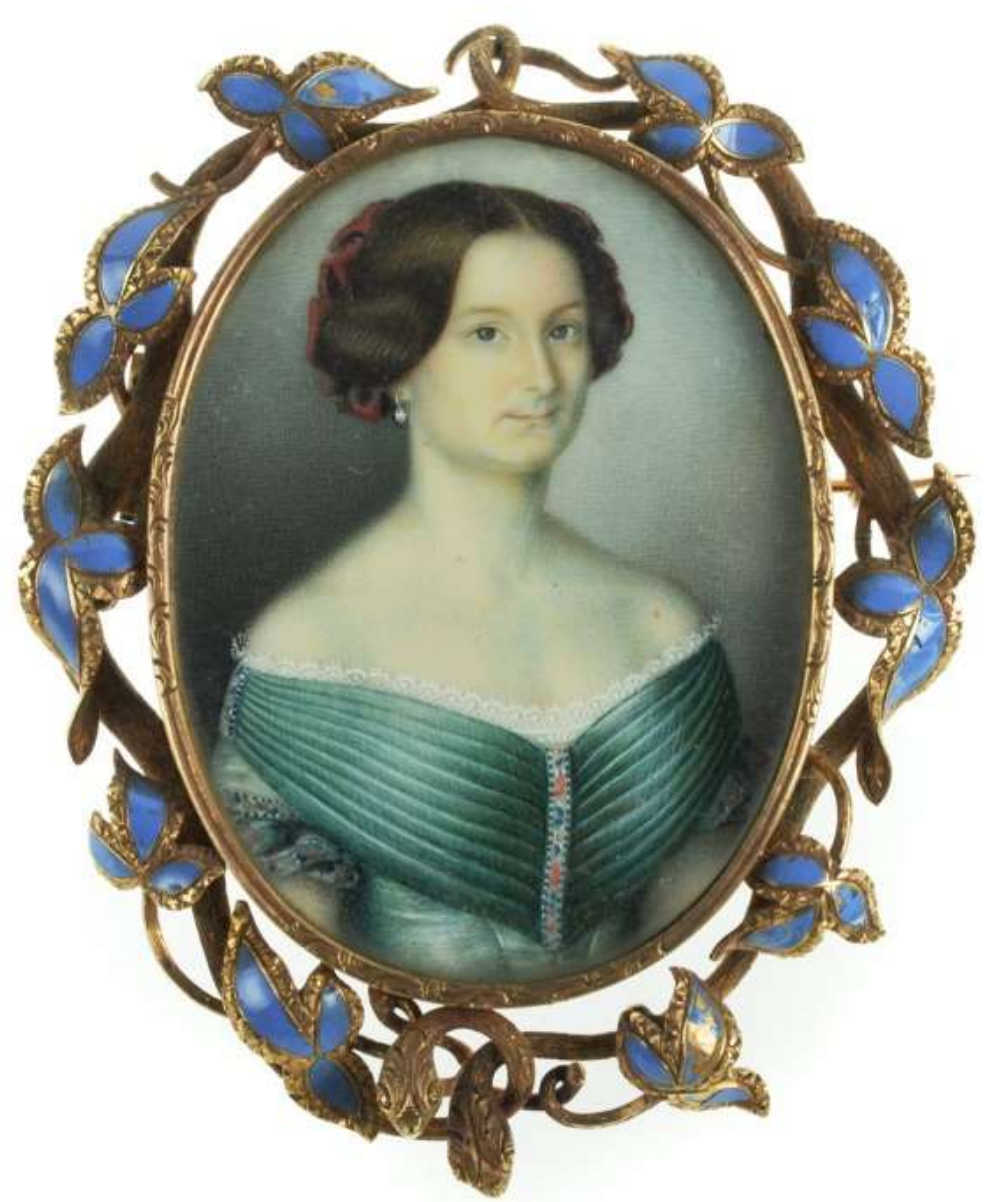

Maria Velho da Mota, dama de honra imperatriz Tereza Cristina. Com muita influência na corte, a família Avellar foi uma das mais ricas do império. ${ }^{116}$

Adereço feminino de meados do século XIX em que aparece o retrato de $d$. Mariana Velho Ribeiro de Avellar, viscondessa de Ubá, em um vestido verde 117

${ }^{110}$ Ver os livros do genealogista Roberto Meneses de Morais. Os Ribeiro de Avellar na Fazenda Pau Grande (Paty do Alferes). Rio de Janeiro: Colégio brasileiro de genealogia, 1994; e o texto de Luiz Felipe de Alencastro, "Vida privada e orfdem privada no império". In: Luiz Felipe Alencastro (org.) História da vida privada no Brasil II. São Paulo: Companhia das Letras, 1997, p. 12-93.

${ }^{117}$ Este adereço feminino faz parte da coleção Sérgio Eduardo Lemgruber e está disponível no site do museu imperial: http://187.16.250.90:10358/handle/acervo/84. Consulta em 4/3/13. 
O verde também foi o tom do movimento romântico. A cor representava uma volta à natureza em um momento em que a revolução industrial enchia o ar das cidades de fumaça cinza. Os românticos, ao se voltarem para símbolos e cores medievais, também recuperaram o significado medieval do verde, então associado às feiticeiras, bruxas e dragões, e se tornaram grandes propagadores da cor em quadros, descrições literárias e nas roupas do cotidiano. ${ }^{118}$

\section{Calças para mulheres: gênero e sociedade no século XIX}

A silhueta feminina no século XIX ficou marcada pela crescente distinção entre os gêneros. As enormes crinolinas ou anquinhas contrastavam com os homens vestidos de calças, fraques ou ternos, com seus chapéus e cartolas. Mas, conforme se generalizava o uso da crinolina e posteriormente da anquinha, associados aos espartilhos, alguns reformadores tentaram mudar a aparência geral das mulheres. Eram, em geral artistas ou médicos, que denunciavam as deformações anatômicas causadas pelo espartilho, pela crinolina e pelas anquinhas.

As primeiras ideias de mudança de vestuário vieram da Revolução Francesa - e da participação política das mulheres ${ }^{119}$ No começo das décadas de 1830 e 1840 , conforme as crinolinas cresciam e o uso do espartilho se generalizava, médicos, artistas reformadores e feministas reclamavam dos males da saúde da moda e propunham uma maneira diferente para que as mulheres se vestissem. ${ }^{120}$ A feminista americana Amélia Jenks Bloomer propôs seriamente que as mulheres usassem calças.

\footnotetext{
${ }^{118}$ Timothy Hilton. The Pre-Raphaelites. Londres: Thames \& Hudson, 1995, p. 161 a 175.

${ }^{119}$ Tania Morin. Práticas e representações das mulheres na revolução francesa-1789-1795. São Paulo, Alameda Casa Editorial, 2013, no prelo.

${ }^{120}$ Elizabeth Wilson e Lou Taylor. Through the looking glass: a history of dress from 1860 to the present day. Londres: BBC Books, 1989, p. 28.
} 


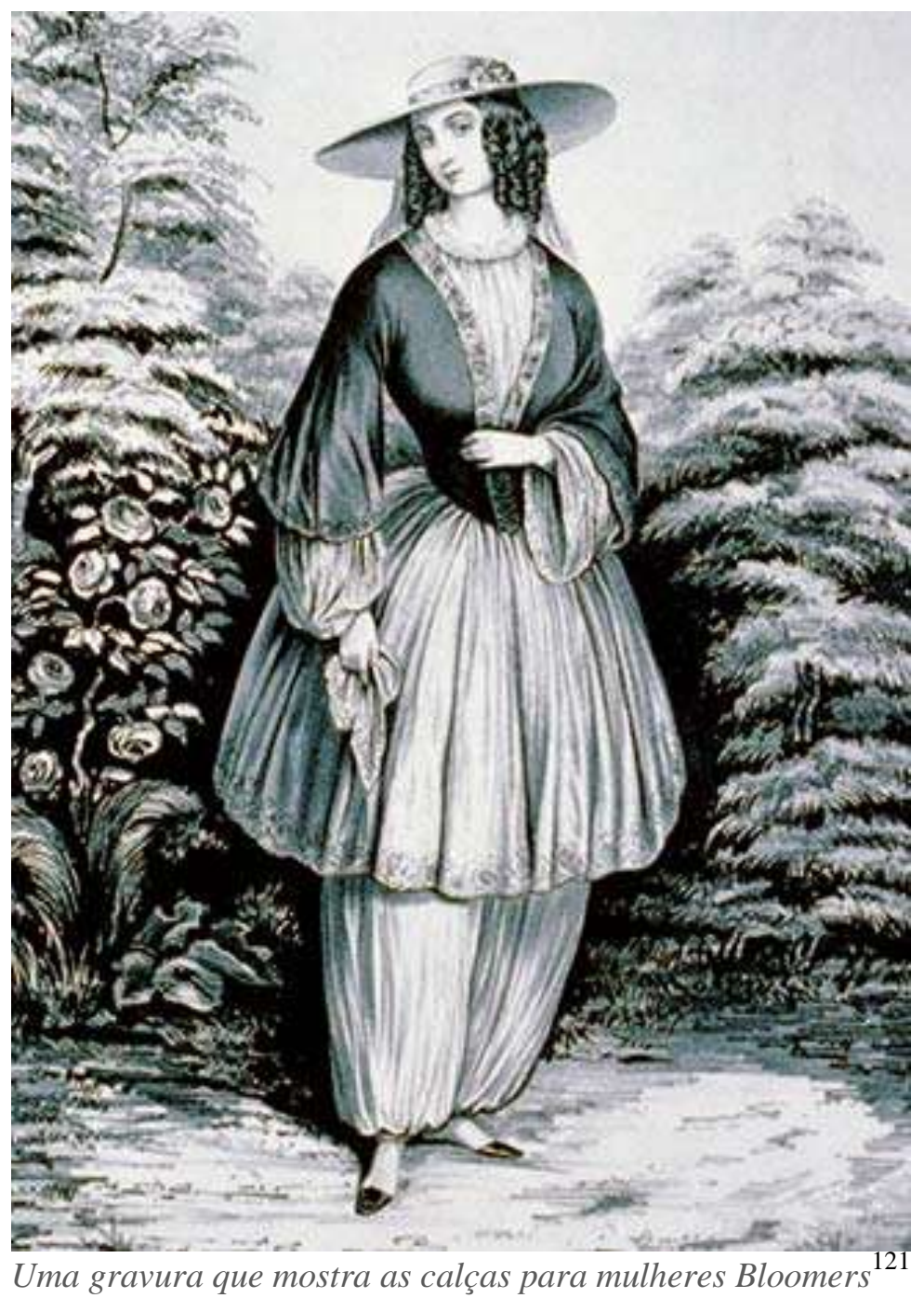

A ideia do uso de calças por mulheres circulava nas comunidades socialistas e feministas da América do Norte, ainda que parecesse ridícula para a população em geral. Foi uma advogada, Elizabeth Smith Miller, Libby Miller, quem realmente vestiu calças à turca com um vestido de babados por cima e saiu às ruas. Amélia Bloomer noticiou o fato em seu jornal feminista, The Lily, e as calças se tornaram sinônimo de

${ }^{121}$ Library of Congress, Washington, D.C. (digital. id. cph 3b49861). No site da Enciclopédia britânica: 〈http://www.britannica.com/EBchecked/media/112190/A-Currier-Ives-rendition-of-thebloomer-costume-influenced-by $>$. Consulta 8/2/2011. 
seu sobrenome, Bloomer. ${ }^{122}$ Amélia também usava as calças e era constantemente ridicularizada pela população.

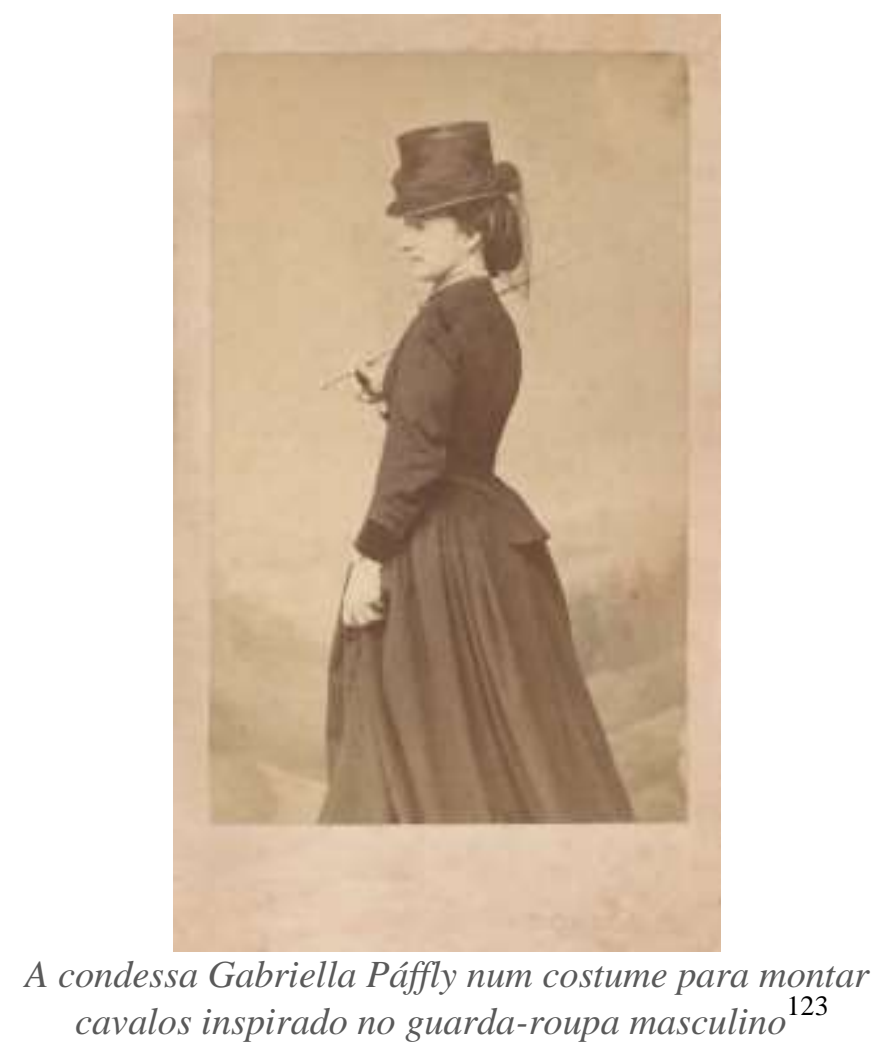

$\mathrm{Na}$ vida prática, no Brasil, era possível para as mulheres usarem calças, sob vestidos. Algumas eram viúvas, tinham filhos ainda pequenos e possuíam fazendas. Precisavam andar pelas matas e campos para administrar suas terras. Em Minas Gerais, no começo do oitocentos, um viajante deparou-se com uma dessas mulheres e escreveu: "Elas montam como os homens, o que as obriga a usarem calças, sobre as quais vestem uma larga saia de montar." ${ }^{24}$ Mais para o final do século XIX, uma série de nova

\footnotetext{
${ }^{122}$ Elizabeth Wilson e Lou Taylor. Through the looking glass: a history of dress from 1860 to the present day. Londres: BBC Books, 1989, p. 28.

${ }^{123}$ A foto foi feita pelo fotógrafo húngaro Borsos József, em 1870, e foi tirada de um site dedicado inteiramente à moda (www.grand ladies.com). Esta imagem especificamente está no endereço: $\langle$ http://www.gogmsite.net/early_victorian___1837___18/countess-gabriele-palffy-am.html $>$. Consulta em 12/3/2013.

${ }^{124}$ G. Wilhelm Freireyss. Viagem ao Interior do Brasil nos Anos de 1814-1815. Trad. port. vol. XI, São Paulo, Revista do Instituto Histórico e Geográfico de São Paulo, 1906. p. 166.
} 
atividades ligadas ao lazer mudam o guarda-roupa feminino. Tenis, iatismo, ciclismo, caça a borboletas deixaram as roupas mais leves, cheias de detalhes masculinos, como gravatas, botas e suspensórios. Como vemos na gravura de moda abaixo, os chapéus diminuem e a roupa, em geral, fica mais prática.

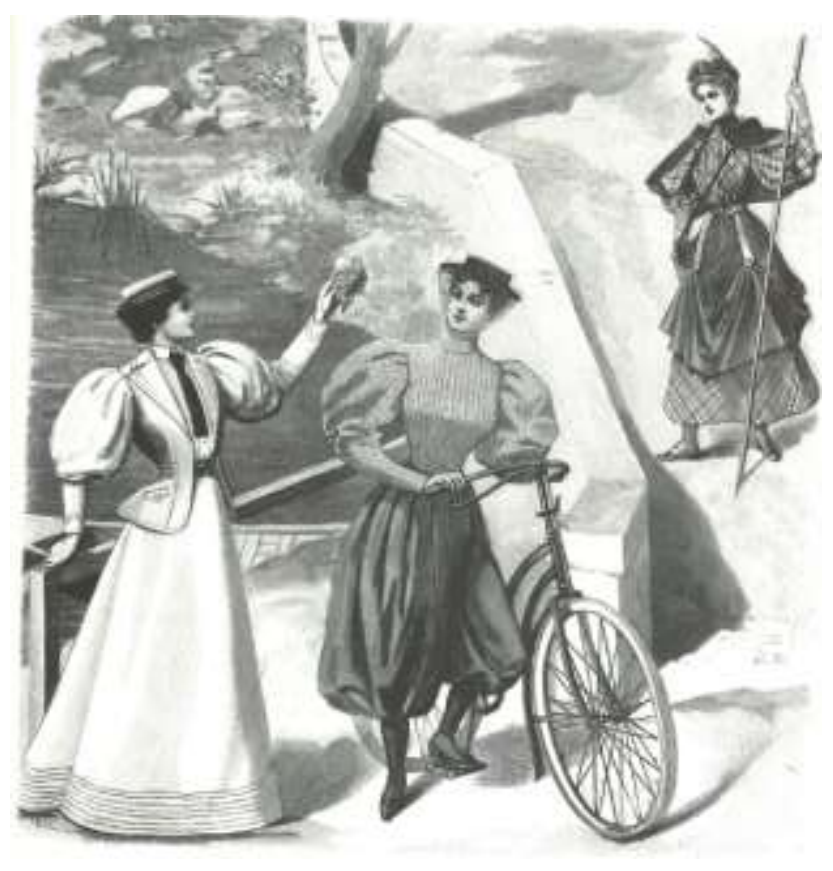

No final do século, esportes inspiram o guarda-roupa feminino ${ }^{125}$

Ainda que o uso de calças por mulheres fosse muito mal visto pela população em geral, alguns elementos do guarda-roupa masculino foram incorporados pelas mulheres, como foi o caso dos paletós, das gravatas, e muitas das roupas para montar e fazer esportes. "Havia, de fato, dois estilos de roupas para mulheres na segunda metade do século XIX. Fotografias atestam a existência de um outro estilo, que coexistia com a moda dominante, o qual chamarei de 'alternativo'. Ele incorporava itens do vestuário masculino, tais como gravatas, chapéus, paletós, coletes e camisas, ora usados

${ }^{125}$ Joanne Olian. Victorian and Edwardian fashions from 'la Mode Illustrée”. Nova York: Dover, 1998, p. 123 
isoladamente, ora combinados entre si, mas sempre em conjunto com peças femininas da moda". ${ }^{126}$ Essas peças femininas eram saias.

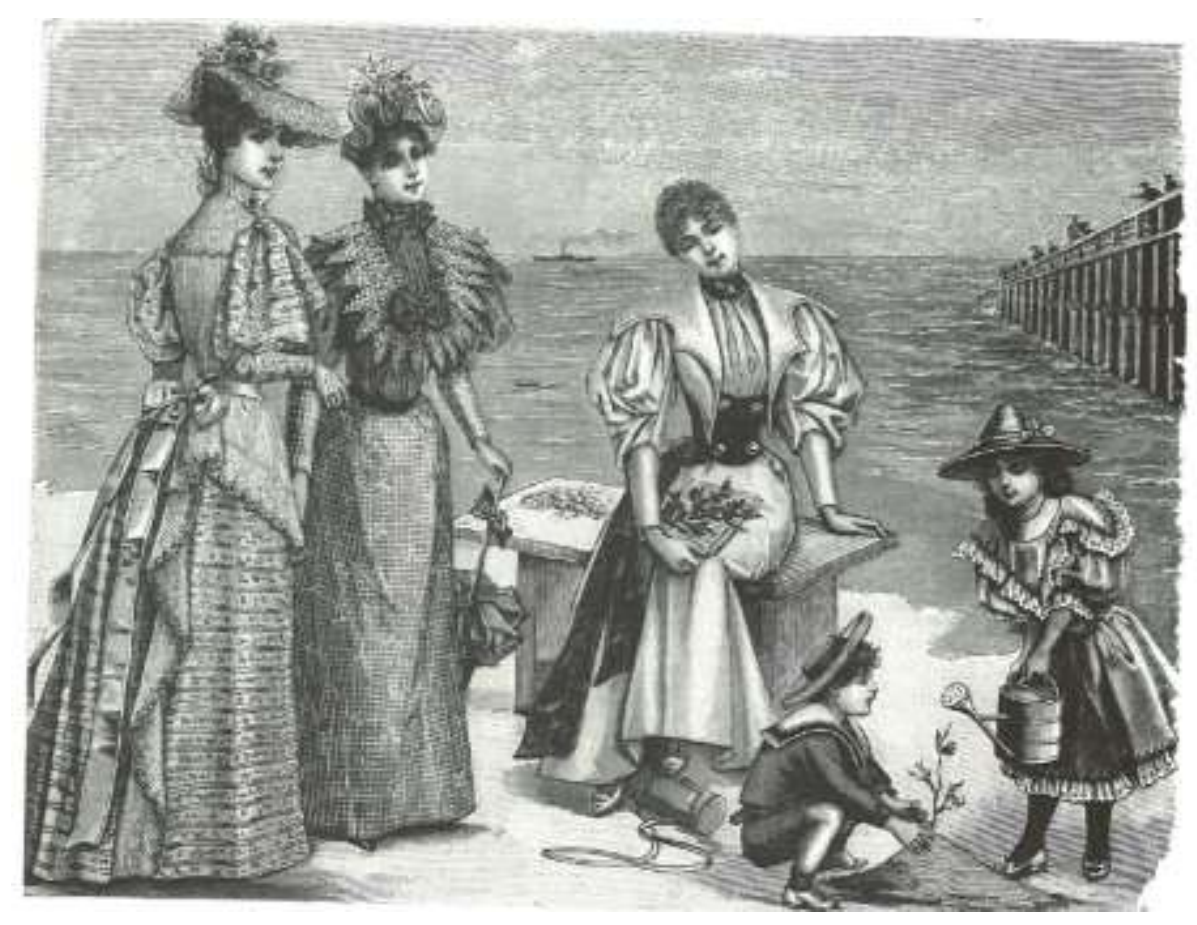

Novas roupas para novas atividades: ir paria era uma delas ${ }^{127}$

Alguns românticos, em especial os ingleses de um movimento literário e pictórico chamado de pré-rafaelistas, chegaram a pregar outro tipo de reforma radical nas vestimentas das mulheres, liberando-as dos espartilhos, das crinolinas, saiotes e anquinhas. Os verdes, marrons, azuis e cinzas estavam entre as cores mais usadas tanto nestas novas vestes como nos quadros que pintavam $^{128}$. Dante Gabriel Rossetti, Edward Burne Jones e William Morris, socialistas utópicos que fizeram parte desse movimento, apresentaram, na década de 1860, como uma reação à crinolina, o que consideravam o

\footnotetext{
${ }^{126}$ Diana Crane. A moda e seu papel social: classe, gênero e identidade das roupas. Trad. port. São Paulo: Senac: 2006, p. 201

${ }^{127}$ Joanne Olian. Victorian and Edwardian fashions from 'la Mode Illustrée”. Nova York: Dover, 1998 , p. 119

${ }^{128}$ Elizabeth Wilson e Lou Taylor. Through the looking glass: a history of dress from 1860 to the presente day. Londres: BBC Books, 1989, p. 31.
} 
vestido ideal para as mulheres, com mangas e cinturas soltas, sem rendas, laços ou qualquer ornamento.
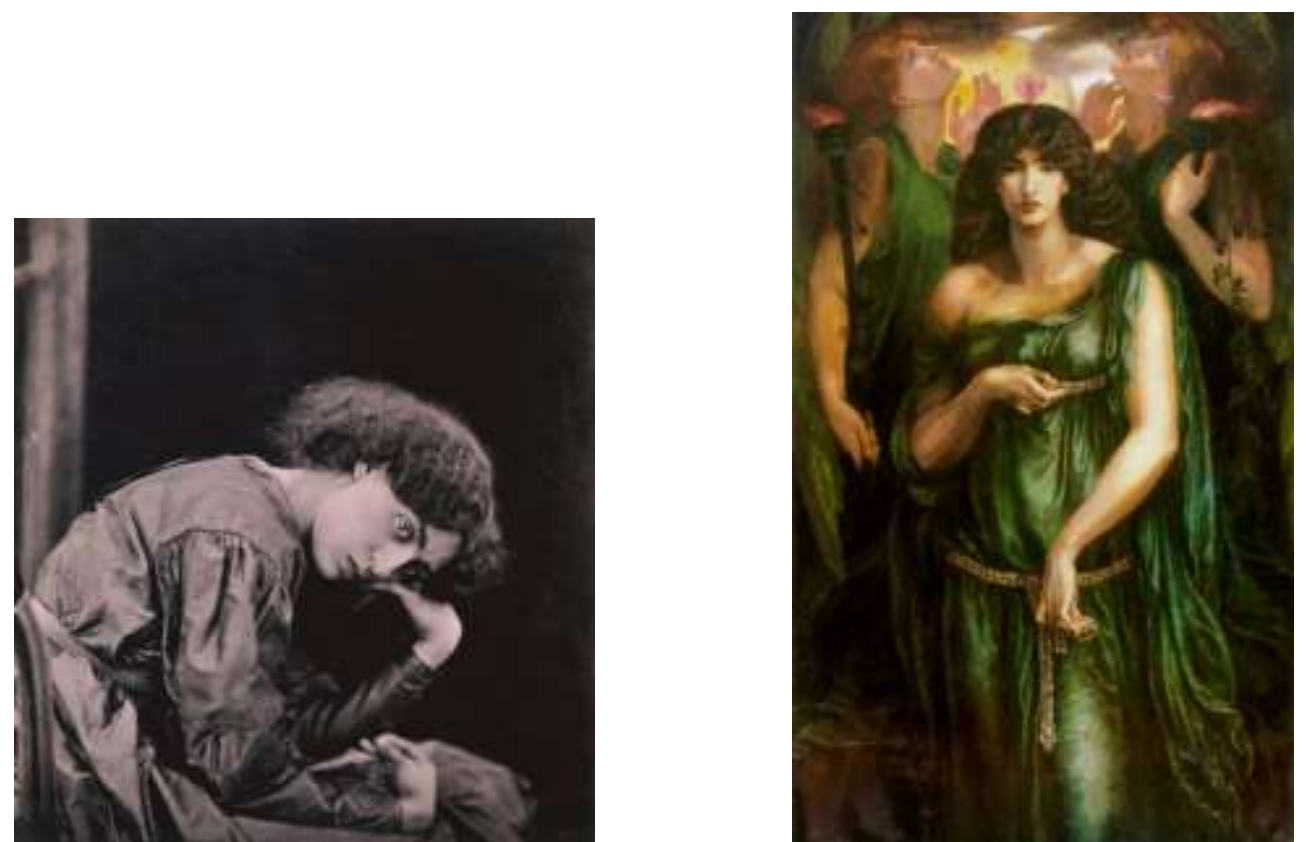

Jane Morris, mulher de William Morris, posa para Dante Gabriel Rossetti em 1867 com as novas roupas propostas pelo pré-rafaelistas. ${ }^{129}$ Ao seu lado o quadro, também de Rossetti, Astarte Syriaca ${ }^{130}$ : novas vestimentas para uma nova mulher inspirada na Idade Média

Mesmo em mulheres que não faziam parte da elite essa grande variedade cores resultantes dos processos químicos de tingimento de tecidos apareciam no dia-a-dia. As prostitutas cariocas, por exemplo, vestiam-se com roupas bastante coloridas, marcando claramente a distinção entre elas e as mulheres de elite que se viam cada vez mais pelas ruas do Rio. Mais uma vez, é Debret quem vai dar uma descrição mais detalhadas do cotidiano carioca:

[...] a prostituta [...] não teme mostrar-se. [...]. Veste em geral uma blusa de seda de cor viva, sobrecarregada de cordõezinhos e pingentes de seda ou de fitas de cores berrantes; juntados de maneira estranha

\footnotetext{
129 Timothy Hilton. The Pre-Raphaelites. Londres: Thames \& Hudson, 1995, p. 164.

${ }^{130}$ Elizabeth Wilson e Lou Taylor. Through the looking glass: a history of dress from 1860 to the presente day. Londres: BBC Books, 1989, p. 30-33
} 
esses enfeites são sempre chocantes pela falta de harmonia com o fundo em que assentam. Uma guarnição mais ou menos semelhante sobrecarrega o babado de uma saia branca de magnífica musselina das Ilhas; meias de seda branca e sapatos de tela de seda azul-céu, rosa, amarelo-claro ou verde completam a indumentária. Quando rica, ela usa a saia de renda preta bordada, destacando-se por transparência a saia de baixo, de seda branca, rosa ou amarela, às vezes mesmo preta, com fitas de cor passadas nas guarnições."

O casamento da nobre espanhola Eugenia de Montijo com Carlos Luís Napoleão Bonaparte, Napoleão III, em 19 de janeiro de 1853, consolidou a ascensão da burguesia e o poder do II Império na França. Se Napoleão III promoveu uma reforma urbana em Paris sem precedentes, levada a cabo pelo Barão Haussmann, Eugênia fez o mesmo com que as mulheres vestiam. Ela foi a última imperatriz a lançar moda e promover de maneira sistemática a indústria do vestuário na França. Gilda de Mello e Souza a chama de "a primeira grande vedette a serviço de uma indústria que se organiza". ${ }^{132}$ Paris tornava-se a cidade-luz, com bulevares, avenidas e passeios, à custa de demolição de muitas casas e ruas da cidade antiga. Da mesma maneira, as mulheres, sob a batuta da imperatriz, transformavam-se em uma espécie de sino ambulante, com saias rodadas que as deixavam quase sem movimento.

Eugênia viveu numa época complexa, em que a ascensão da burguesia passava a ditar uma série de comportamentos. Assim, através de roupas e adereços, a moda tornava a burguesia, nobre, e a nobreza, burguesa. Da mesma maneira que aconteceu com o restaurante no início do século $\mathrm{XIX}^{133}$, a moda passou a significar que o acesso a

\footnotetext{
${ }^{131}$ Jean-Baptiste Debret. Viagem Pitoresca e Histórica ao Brasil (1816-1839). Trad. port. T. II, vol. III, São Paulo: Martins Editora, 1940. p. 40.

${ }^{132}$ Gilda de Mello e Souza. O espírito e as roupas: a moda no século XIX. São Paulo: Companhia das Letras, 1987, p. 133.

${ }^{133}$ Ver minha dissertação de mestrado, "Sabores urbanos", em especial o capítulo, "Cafés, hotéis e restaurantes", p. 105 a 123. FFLCH, 2007.
} 
determinados lugares e determinadas situações sociais - uma festa, uma confeitaria, uma reunião elegante - seria permitido a famílias que não pertencessem à nobreza. Vestir-se adequadamente dava pouco a pouco lugar para as condições de nascimento.

A essa nova classe social, que se consolidava no século XIX, usava a moda - e a constante troca de detalhes, adereços, manias e gestos - para afirmar-se como classe dominante. O escritor francês Marcelo Proust, em seu romance Em busca do tempo perdido, livro em que narra a ascensão social da burguesia, mostrava como esses pequenos gestos eram importantes. A certa altura, o narrador vai falar de algumas manias de Madame Swann:

Madame Swann deixava raramente de adotar os usos que passavam por elegantes numa estação e que, não conseguindo se manter, eram logo abandonados (muitos anos antes ela tivera seu "handsome cab" e mandara imprimir num convite para almoçar que era "to meet" um personagem mais ou menos importante). Frequentemente, esses usos nada tinham de misteriosos e não exigiam iniciação. Foi assim que, pequena inovação daqueles anos e importada da Inglaterra, Odette mandara fazer para seu marido, cartões onde o nome Charles Swann vinha precedido de "Mr.",134

Desta forma, saber comportar-se, vestir-se e mostrar-se em sociedade refletiu a ascensão da burguesia ao longo do século XIX. No Brasil, com um império que não possuía tradição e uma corte que se transformava recebendo continuamente novos membros, esse tipo de atitude funcionava como uma espécie de validação ou de "pertencimento" à classe dominante. José de Alencar em seus romances nos mostra como isso funcionava no cotidiano. Em A pata da gazela, Horácio, o protagonista, “o

\footnotetext{
${ }^{134}$ Marcel Proust. Em busca do tempo perdido. Trad. port. Livro: A sombra das raparigas em flor. São Paulo: Globo, 2004, p. 157.
} 
leão e o príncipe" da moda carioca, sabia onde estava pisando e o que significava cada gesto.

Os sucessivos encontros da rua Ouvidor; a conversa no Bernardo; a visita indispensável ao alfaiate; as anedotas de Alcazar na noite antecedente; as crônicas anacreôntica do Rio de Janeiro, chistosamente comentada; algumas rajadas de maledicência, que é a pimenta social; todas essas ocupações importantes, que absorvem a vida do leão, distraíram Horácio a ponto de se esquecer ele do objeto guardado no bolso do paletó. ${ }^{135}$

Gilda de Mello e Souza, no capítulo "A luta das classes" em $O$ espírito das roupas, lembra, por exemplo, de Quincas Borba, de Machado de Assis. "Um livro como Quicas Borba, de Machado de Assis, dá-nos uma visão preciosa de uma sociedade desse tipo, onde à riqueza cabe a supremacia, a felicidade nos negócios fazendo o indivíduo alcançar um alto posto na escala social, da mesma forma que uma herança dilapidada o arremessa ao ponto inicial donde partira para uma trajetória brilhante e fugaz". ${ }^{136}$

Parecer pertencer à elite no Brasil, onde a escravidão permeava os ideais de trabalho e ociosidade, era ainda mais importante. Por isso, a distinção social pelas roupas ao longo do século XIX passou se tornar cada vez mais importante. Ao mesmo tempo, esse foi um período em que as mulheres começaram a sair de casa e passear pela cidade: fazendo compras, indo aos mercados, tomando sorvetes, frequentando confeitarias ao invés das apenas habituais visitas e idas à igreja e procissões. ${ }^{137}$

\footnotetext{
${ }^{135}$ José de Alencar. A pata da gazela. São Paulo: Saraiva, 1958, p. 11.

${ }^{136}$ Gilda de Mello e Souza. O espírito e as roupas: a moda no século XIX. São Paulo: Companhia das Letras, 1987, p. 115.

${ }^{137}$ Ainda que a discussão sobre gênero e a moda não sejam o foco da obra de Gilberto Freyre, a mudança de costumes no século XIX é uma das maiores contribuições do sociólogo pernambucano. Ver o capítulo "O engenho e a praça; a casa e a rua". Gilberto Freyre. Sobrados e mucambos. Rio de Janeiro: José Olympio, 1951. Ver também a análise de Heloísa Barbuy sobre o
} 


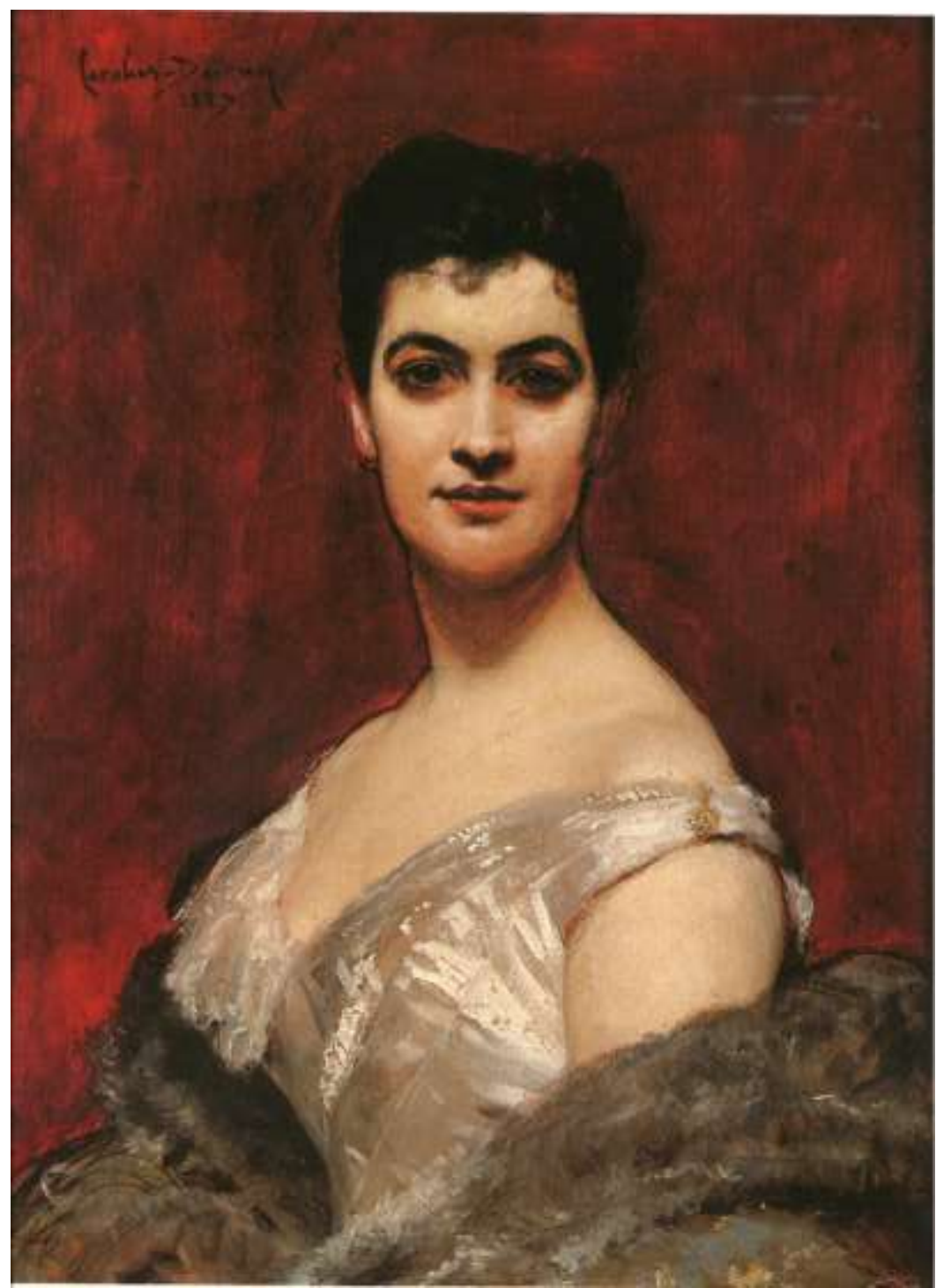

Eufrásia Teixeira Leite era amiga de Joaquim Nabuco, herdeira da Casa de Hera, em Vassouras: símbolo de uma nova mulher, que preferiu viver de rendas em Paris ${ }^{138}$

Ao longo do século, a mulher passou a ser antítese social do homem, segundo

Gilda de Mello e Souza. O contraste não poderia ser mais evidente - enquanto as moças

Gilberto Freyre no livro A cidade-exposição. Comércio e cosmopolitismo em São Paulo 18601914. São Paulo: Edusp, 2006, p. 37.

${ }^{138}$ Luiz Felipe Alencastro (org.) História da vida privada no Brasil II. São Paulo: Companhia das Letras, 1997, acerno de imagens. O pintor desse quadro não é identificado e a tela encontra-se no Museu da Casa de Hera, em Vassouras. Para história romanceada da vida de Eufrásia, ver Claudia Lage. Mundos de Eufrásia. A história do amor enter a incrível Eufrásia Teixeira Leite e o notável Joaquim Nabuco. Rio de Janeiro: Record, 2009. 
e senhoras de elite tinham seus trajes cada vez mais rebuscados e restritivos, os homens caminharam na direção oposta, com uma simplicidade de vestir evidente. Aos homens de sociedade ficava reservado, o trabalho nas indústrias, as invenções geniais da ciência, as criações artísticas, a vida fora de casa, a sobriedade ao vestir. Às mulheres, a casa e os filhos, os cuidados com o vestir, a tutela do pai ou marido, as compras do lar.

Mas, aos poucos, esse quadro começou a mudar, e as mulheres começaram a sair de casa, seja para comprar os novos produtos oferecidos nas lojas, seja para trabalhar como vendedoras ou costureiras. Ao ficar investida do abastecimento do lar, a mulher passou a poder sair à rua para adquirir os bens que seriam usufruídos pela família. Ao mesmo tempo, uma série de profissões femininas ligadas a esse novo afazer feminino foram sendo criadas. Vendedoras, operárias da indústria de renda ou de vestimenta, costureiras em ateliês de moda, jornalistas e escritoras. A mulher pode ter saído de casa no século XIX, mas acabou transformando a história de suas relações de trabalho e de produção. $^{139}$

\section{A mulher como consumidora}

Para além das transformações na silhueta feminina no século XIX, a mulher passou por uma transformação no seu papel social ainda mais radical. Se até a industrialização, esperava-se que as mulheres de elite ficassem em casa, dedicadas à educação dos filhos, com as mudanças da economia ao longo do século, isso se modificou. ${ }^{140}$ Às mulheres foi exigido um novo tipo de conhecimento - de saber comprar as mercadorias constantemente renovadas e colocadas à venda.

\footnotetext{
${ }^{139}$ Micelle Perrot. As mulheres ou os silêncios da história. Trad. port. Bauru: Edusc, 2005, p. 263278.

${ }^{140}$ Michelle Perrot. As mulheres ou os silêncios da história. Trad. port. Bauru: Edusc, 2005. Essa discussão permeia todo o trabalho de Perrot, mas se sobressai nos capítulos: "Da ama-de-leite à funcionário do escritório ... trabalhos de mulheres na França do século 19", "O que é um trabalho de mulher?" e "O gênero na cidade". A discussão sobre o papel da mulher também pode ser
} 
O conhecimento sobre o que a família deveria consumir se tornou a principal atividade das mulheres de elite. Além de diferentes empregados empenhados nas tarefas domésticas, o número de máquinas que ajudavam a fazer este trabalho cotidiano também aumentou no século XIX, liberando a dona de casa para se dedicar a outras ocupações além das de casa - incluindo a leitura de romances e jornais, as idas aos bailes, teatros e, claro, às compras.

Gilda de Mello e Souza diz que, para as mulheres, esse tempo livre aumentou o interesse pela moda. "O desenvolvimento da indústria havia libertado o sexo feminino de uma série de atividades produtivas que até então se realizavam no âmbito doméstico. O centro urbano fornecia com mais facilidade e mais barato o pão, a fazenda, a renda, o vestido feito, o chapéu, e as crescentes especializações das funções criava uma série de novos empregos, tanto nas fábricas como nos lares [...]. ${ }^{141}$

Na moda, a mulher "revolucionária" sem espartilho, com vestidos de musselines e gazes $^{142}$, “fruto" das atitudes libertadoras revolução francesa e do reinado de Napoleão, foi substituída por um ideal de dona-de-casa preocupada com marido, os filhos e as “coisas do lar". A essa nova mulher que surgiu no século XIX foi confiado um novo papel, o de consumidora, de compradora dos produtos que abasteceriam o lar. Isto representava um novo papel para as mulheres, que estava sendo construído no mesmo momento em que o capitalismo industrial se fortalecia.

encontrada em Thorstein Veblen. Trad. port. A teoria da classe ociosa. São Paulo: Abril Cultural, 1983.

${ }^{141}$ Gilda de Mello e Souza. O espírito das roupas: a moda no século dezenove. Companhia das Letras1987, p. 89-92

${ }^{142}$ Tania Morin. Virtuosas e perigosas. As mulheres na Revolução Francesa. São Paulo: Alameda Casa Editorial, 2013, no prelo. 


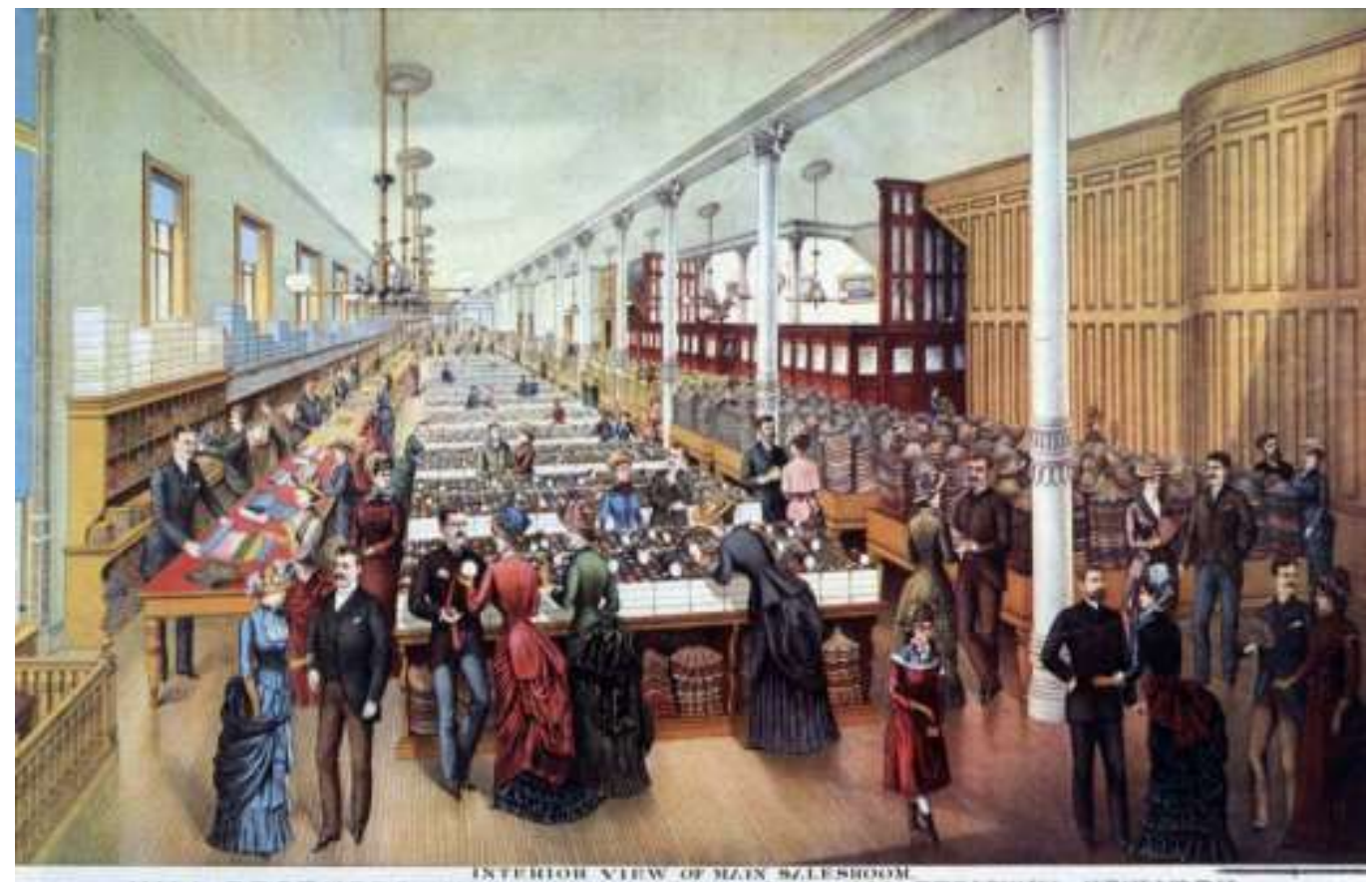

HILL BROTHERS. MILLINERY GOODS. 564 a 566 BROADWAY. NEW YORK.

Interior da loja Hill Brothers Millinery Goods, em Nova York em $1885^{143}$

Nos Estados Unidos, o consumo de mercadorias logo fez parte do cotidiano de diferentes extratos sociais. As máquinas de costuras e os tamanhos padronizados logo deram origem a lojas de roupas prontas e a catálogos de roupas que podiam ser encomendados pelo correio e entregues até mesmo nos lugares mais difíceis. $\mathrm{Na}$ gravura acima, vemos uma loja em Nova York, que pode ter sido bastante semelhante ao Paraíso das damas, de Zola, e as lojas de departamento em geral. As principais mercadorias vendidas eram panos, mas alguns itens do guarda-roupa femininos, como meias, luvas, echarpes e xales, já eram oferecidos à consumidoras. ${ }^{144}$

Thorstein Veblen, teórico conservador americano que pensou sobre classe, consumo e moda durante a Belle Époque, ao procurar entender o que acontecia com sua

\footnotetext{
${ }^{143}$ Cartaz de propaganda da loja Hill Brothers millenery goods, em Nova York, em 1885. Este cartaz faz parte da seção educativa da University of California - History Project, e pode ser encontrada no site da instituição: http://historyproject.ucdavis.edu/ consulta em 19/07/2012

${ }^{144}$ Thomas J. Schlereth. Victorian America: transformations in everyday life. Nova York: Harper Collins, 1991, p. 151 a 155.
} 
própria sociedade, tenta explicar os motivos pelos quais o vestuário feminino adquiriu tamanhas proporções e importâncias significativas ao longo do século XIX:

[...] no decurso do desenvolvimento econômico, tornou-se ofício da mulher consumir para o chefe da casa, sendo o seu vestuário planejado com esse fim em vista. Aconteceu, porém, que o trabalho ostensivamente produtivo é demasiado desairoso para as mulheres que se prezam e daí tomar-se especial cuidado na criação de vestidos femininos, a fim de dar ao observador a impressão (frequentemente fictícia) de que a mulher que o usa não pode habitualmente se entregar a qualquer trabalho útil. ${ }^{145}$

Veblen vai falar que, conforme o capitalismo industrial se tornava mais forte, os volumes das saias das mulheres aumentavam. A vida de uma mulher, portanto deveria ser cuidar da casa e do marido e sua silhueta refletiria esse ideal ao longo do século. “[...] o salto alto, a saia, o chapéu pouco pratico, o espartilho, o geral menosprezo por os usa são outros tantos artigos a provar que, plano da vida civilizada, a mulher continua, em teoria, economicamente dependente do homem." ${ }^{\text {"146 }}$ Mas a essa mulher que é serva do marido estava reservado um papel fundamental na sociedade capitalista: "a rude verdade no tocante a todo esse ócio e atavios por parte das mulheres tem por base o fato de serem elas servas às quais $[. .$.$] foi delegado o ofício de fazer realçar no seu amo a$ aptidão para despender", ou seja, para consumir. ${ }^{147}$

Quanto mais arrumada e na moda ao mostrar-se em sociedade a mulher se apresentava, melhor seria o status de marido. Desta maneira, a Imperatriz Eugênia, com sua constante troca de roupas e obsessão por costureiros e vestidos, reafirmava

\footnotetext{
${ }^{145}$ A única tradução que temos de Veblen no Brasil é esta e não é boa. O tradutor confunde colete com espartilho ou corpete, entre outros erros. Thorstein Veblen, A teoria da classe ociosa. Trad. port. São Paulo: Abril Cultural, 1983, p. 82.

${ }^{146}$ Thorstein Veblen, A teoria da classe ociosa. Trad. port. São Paulo: Abril Cultural, 1983, p. 83.

${ }^{147}$ Thorstein Veblen, A teoria da classe ociosa. Trad. port. São Paulo: Abril Cultural, 1983, p. 83.
} 
continuamente a importância e poderio da França do império de Napoleão III. Desta forma, pensadores contemporâneos como Mary Douglas, Arjun Appadurai ou Jean Baudrillard vão colocar o consumo na esfera das trocas sociais. ${ }^{148}$ "Eu acho que o consumo é eminentemente social, relacional e ativo ao invés de ser um ato privado, atomizado ou passivo". ${ }^{149}$ Ao consumirem produtos as mulheres estariam se relacionando tanto com outras mulheres como com o resto da sociedade.

No Brasil, José de Alencar vai sutilmente explicitar essa premissa em Senhora, de 1875. Divido em quatro partes, "o preço", "quitação", "posse" e "resgate”, o romance inverteu a lógica "normal" da sociedade da época. ${ }^{150}$ Aurélia, filha de uma costureira, comprou seu marido e "usou-o" em eventos sociais. O livro é chocante para os padrões morais do período, mas o final redime tanto a sociedade como Aurélia, que se tornou a dócil esposa de seu marido, Fernando Seixas, depois de lhe restituir o dote de 100 contos de réis. ${ }^{151}$ Fernando é "consumido" pela mulher, como uma mercadoria, numa clara inversão de papeis.

Esperava-se que a esposa de um marido de classe média e alta comprasse e gastasse o dinheiro da família de maneira que seu status ficasse evidente. Thorstein Veblen mostrou o quanto era importante para a sociedade do século XIX que as mulheres de classe média e alta ficassem em casa e se tornassem consumidoras dos novos bens e equipamentos colocados no mercado. Uma série de novos acessórios, roupas, penteados, chapéus, sapatos e a maneira de se usar as roupas provavam esse

\footnotetext{
${ }^{148}$ Ver Mary Douglas, $O$ mundo dos bens: por uma antropologia do consumo. Trad. port. Rio de Janeiro: editora da UFRJ, 2004; Jean Baudrillard, A sociedade de consumo. Trad. port. Lisboa: edições 70 e Arjun Appadurai, The social life of things: commodities in cultural perspective, Nova York: Cambridge University Press, 1986.

${ }^{149}$ Arjun Appadurai, The social life of things: commodities in cultural perspective, Nova York: Cambridge University Press, 1986, p. 31.

${ }^{150}$ José de Alencar. Senhora. São Paulo: Ática, 1986.

${ }^{151}$ As discussões com Haroldo Ceravolo Sereza sobre os romances do século XIX e a sociedade brasileira muito enriqueceram este trabalho. Haroldo Ceravolo Sereza O Brasil na Internacional naturalista: adequação estética, do método e da temática naturalistas no romance brasileiro do século 19. Tese de doutorado/FFLCH/USP, 2012.
} 
fato. As mulheres deveriam conhecer as modas e tentar "de qualquer maneira" vestir-se adequadamente. $\mathrm{O}$ espartilho, que na tradução brasileira virou colete, ou corpinho, era a maior prova disso: tolhia os movimentos, ao mesmo tempo em realçava os atributos desejados numa mulher - cintura fina e colo destacados.

$\mathrm{O}$ vestuário feminino vai ainda mais longe que o masculino no sentido de demonstrar que quem o usa abstém-se de trabalhar em obra produtiva. Não é necessário argumentar para dar força à generalização de que as modas mais elegantes em chapéus femininos até chegam, mais a cartola masculina, a impossibilitar o trabalho. $\mathrm{O}$ calçado feminino se acrescenta do assim chamado salto alto francês para provar o ócio obrigatório a que obriga o seu polimento; porque o salto alto - é óbvio - torna extremamente difícil até mesmo o mais simples e o mais indispensável trabalho manual. O mesmo é verdade no tocante à saia e demais roupas que caracterizam o traje feminino. A razão substancial de nosso tenaz apego à saia é justamente essa: ela é dispendiosa e tolhe a cada instante aquela que a usa, incapacitando-a para qualquer trabalho útil. O mesmo também é verdadeiro no tange ao costume feminino de trazer os cabelos excessivamente compridos. 152

No Brasil, em Lucíola, de José Alencar, a protagonista começa o romance como uma prostituta de luxo, voraz consumidora das modas da rua do Ouvidor. Por amor a Paulo, ela tenta se redimir, se volta a Deus, abdica do consumo e termina casta, numa casa afastada da cidade. A mulher, portanto, teria como destino o trabalho em casa, preferencialmente voltado para Deus e para a família. ${ }^{153}$

Criou-se a noção de que o "o lugar das mulheres era em casa", o que ajudava a promover uma espécie de ambivalência entre as famílias de trabalhadores em relação ao que seria decente ou não para uma mulher fazer. Certamente isso serviu de justificativa ideológica para a entrada ou a saída da mulher do mercado de trabalho, já que o trabalho

\footnotetext{
${ }^{152}$ Thorstein Veblen, A teoria da classe ociosa. Trad. port. São Paulo: Abril Cultural, 1983, p. 83.

${ }^{153}$ José de Alencar. Lucíola. São Paulo Paulo: Saraiva, s/d.
} 
feminino (e o infantil) funcionou por muito tempo como uma "reserva de braços". ${ }^{154} \mathrm{E}$, mesmo assim, o lugar ideal da mulher não era fábrica ou no mundo no trabalho, era em casa e, aos poucos, passou ser na rua, comprando os itens que a família iria consumir.

Em outro romance do século XIX, A carne, de Júlio Ribeiro, Manuel, o protagonista, pede para que Helena espartilhe-se somente para ele antes do encontro amoroso. Na fazenda, ao andar de cavalo, vasculhar as plantações, dar ordens aos escravos, Helena não usava o acessório, reservado para sua vida na cidade, para os bailes e teatros da corte. Nestas cenas percebemos muito claramente os diferentes usos do espartilho. No trabalho, tornava-se impossível usá-lo; ao ser vista em sociedade, na cidade, era elemento fundamental para provar a que classe pertencia. ${ }^{155}$

Para Gilda de Mello e Souza, as vestimentas possuíam uma linguagem simbólica, que se traduzia na diferenciação de classes. Ela escreve que:

Isto porque a vestimenta é uma linguagem simbólica, um estratagema de que o homem sempre se serviu para tornar inteligíveis uma série de ideias como o estado emocional, as ocasiões sociais, a ocupação ou o nível do portador. Cada classe, por exemplo, possuía certo número de sinais que a caracterizavam: uma amplidão determinada da saia das mulheres ou do gibão dos homens, um dado comprimento da saia das mulheres ou da largura dos sapatos, uma extensão diversa da cauda, dos véus ou das mangas. Tais recursos, que à medida que se elevava na escala social se tornavam mais exagerados, teriam como objetivo é o ponto de vista de Veblen - demonstrar através do desconforto, a todos os observadores, que seu portador não estava empenhado em nenhuma espécie de trabalho produtivo e pertencia, por conseguinte, à classe ociosa. ${ }^{156}$

\footnotetext{
154 Stuart Ewen. "Mamães, papai e as crianças: rumo a uma arquitetura moderna da vida cotidiana". In: Bravo mundo novo: novas configurações da comunicação e do consumo (org. CEPM). Trad. port. São Paulo: Alameda Casa Editorial, 2009, p. 241-315.

${ }^{155}$ Júlio Ribeiro. A carne. São Paulo: Martin Claret, 1999.

${ }^{156}$ Gilda de Mello e Souza. O espírito das roupas. São Paulo: Companhia das Letras, 1987, p. 125.
} 
O desenvolvimento da máquina de costura - e sua ampla comercialização a partir da década de 1850 - abriu novas perspectivas para a indústria de confecções. As roupas "de baixo", ou "roupas brancas", como eram chamados espartilhos, saiotes e crinolinas também fizeram parte desse crescente aumento na confecção de roupas. "Ainda que muitos espartilhos de 1850 fossem ainda costurados à mão, a velocidade da máquina de costura significou que os produtores podiam $\mathrm{f}$ muito mais e numa variedade maior de designs do que antes." 157

As roupas "de baixo", ou roupas brancas, eram um dos maiores focos desse novo consumo da nascente indústria de confecções. Michelle Perrot vai ressaltar o caráter real e simbólico das roupas brancas, ${ }^{158}$ Daniel Roche vai marcar a importância do estabelecimento de um reino do decoro, em que as roupas íntimas vão ganhar cada vez mais importância conforme o século XIX chega ao seu fim. ${ }^{159}$ Gilda de Mello e Souza vai retomar a linguagem simbólica das roupas para a distinção social - e as roupas íntimas marcariam como poucos itens do vestuário essas distinções, tendo no espartilho e na crinolina os exemplos máximos das distinções de classe. ${ }^{160}$

\footnotetext{
${ }^{157}$ Lucy Johnstone. "Corsets e crinolines in Victorian fashion". Victoria and Albert Museum. $<$ http://www.vam.ac.uk/content/articles/c/corsets-and-crinolines-in-victorian-fashion/>. Consultado em 8/11/2012.

${ }^{158}$ Michelle Perrot. As mulheres ou os silêncios da história. Trad. port. Bauru: Edusc, 2005, p. 233-240.

${ }^{159}$ Daniel Roche. A cultura das aparências. Uma história da indumentária. Trad. port. São Paulo: Sena, 2007, p. 103-116.

${ }^{160}$ Gilda de Mello e Souza. O espírito das roupas. São Paulo: Companhia das Letras, 1987, p. $125-130$.
} 


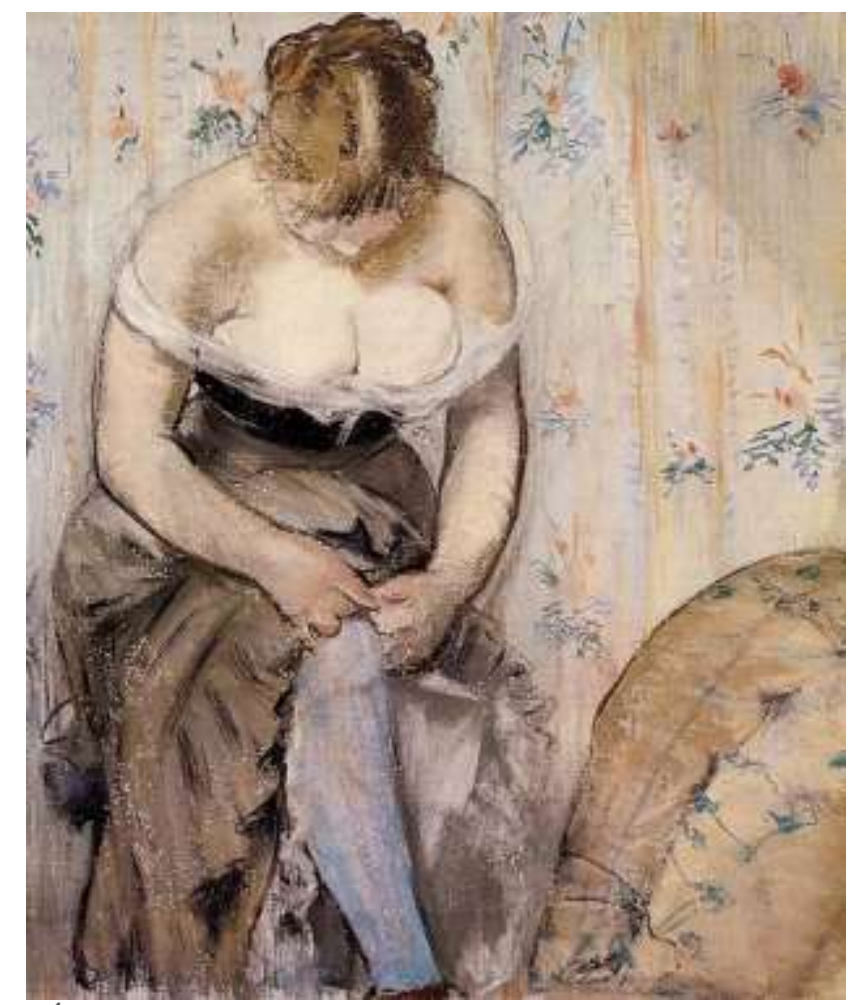

Édouard Manet, Femme à la jarretière, 1878-1879: cena cotidiana na vida de uma mulher ${ }^{161}$

No quadro de Manet (1832-1883), pintado na década de 1870, vemos uma mulher ainda não inteiramente vestida, ajeitando sua meia azul, ainda com a camisa de baixo e o espartilho. É uma cena íntima, que mostra os cuidados com o corpo e com a higiene pessoal, atitudes que se acentuam no período. Assim, vemos como o consumo de roupas brancas, que estava ligado aos cuidados e higiene pessoal, tão importante para a sociedade do século XIX, impulsionou o consumo de roupas em geral. Conforme as décadas se sucediam, o consumo de roupas e o comércio de maneira geral aumentavam. Saber consumir, o que comprar para a família, tornou-se um atributo feminino por excelência - elogiado em manuais de etiqueta, como $A$ arte de viver em sociedade, de Maria Amalia Vaz de Carvalho, ${ }^{162}$ ou o Livro das noivas, de Julia Lopes de Almeida. ${ }^{163}$

161 Èdouard Manet, Femme à la Jarretière, 1878-1879. Pastel, 55x 46 cm, atualmente está no Ordrupgaard, no norte de Copenhagen, Dinamarca.

${ }^{162}$ Maria Amalia Vaz de Carvalho. A arte de viver em sociedade. Lisboa: Parceria Antonio Maria Pereira, 1909.

${ }^{163}$ Julia Lopes de Almeida. Livro das noivas. Rio de Janeiro: Francisco Alves \& Cia. $3^{\text {a }}$ edição, 1914. 
A propaganda dava seus primeiros passos e no Almanaque Laemmert, vemos muitos exemplos de anúncios dirigidos para mulheres.

Em torno do consumo feminino começaram a girar potentes mecanismos de produção fabril - num primeiro momento, de tecidos que se transformavam depois em roupas, e mais tarde, conforme avançava o século, de roupas prontas. Émile Zola, em $O$ paraíso das damas, vai deixar claro esse mecanismo ao fazer um personagem dizer que: "Mais importante que os fatos até agora mencionados, no pico da mecânica mercantil vinha da exploração da mulher. Tudo convergia para isso: o capital incessantemente renovado, o sistema de acúmulo de mercadorias, os preços baixos que atraem, a marcação em cifras conhecidas que tranquiliza." ${ }^{164}$ Em torno da mulher se organizou uma indústria de confecções de roupas e acessórios que, segundo a moda da época, deveriam ser periodicamente renovadas.

No quadro de Edgar Degas (1834-1917), “A chapelaria”, reproduzido abaixo vemos uma mulher admirando chapéus numa loja. Vestida com um rico vestido de seda verde e luvas altas, ela parece segurar na boca o alfinete que prenderá o chapéu escolhido. A loja é quase despida de elementos representativos, fora a mesa e os mostradores de chapéus, vemos cortinas e uma parede azul. As lojas no século XIX se transformaram em lugares preparados para receberam mulheres, para que elas se sentissem confortáveis, seguras e gastassem dinheiro em diferentes mercadorias. Degas propositalmente deixou ambíguo o papel da mulher no quadro - será uma vendedora, uma fazedora de chapéus ou uma compradora? Ainda assim, todos os papeis eram novos para as mulheres na época.

${ }^{164}$ Émile Zola. O paraíso das damas. Trad. port. São Paulo: Estação Liberdade, 2007, p. 112. 


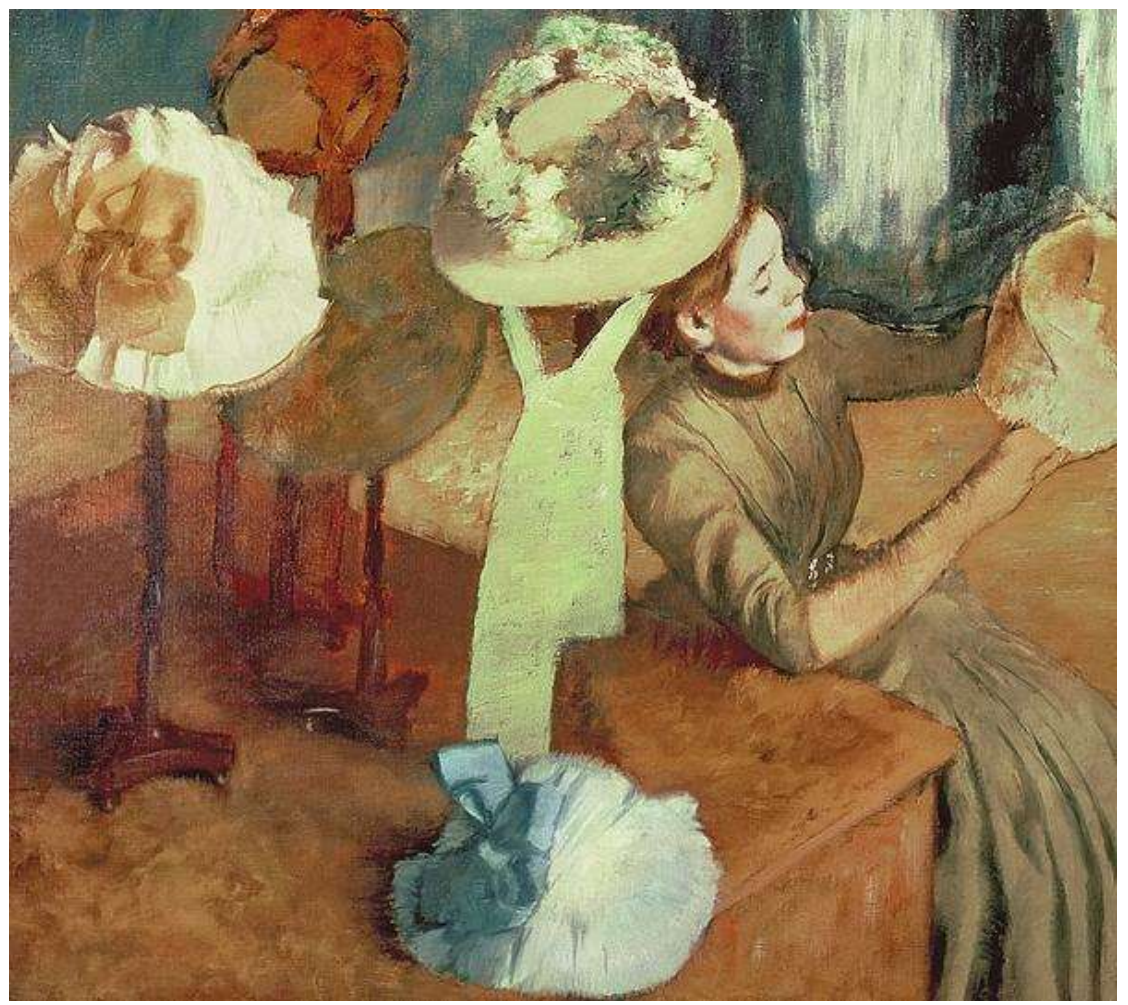

O quadro, A chapelaria, de Edgar Degas confunde propositalmente a consumidora com uma fazedora de chapéus, ambas atividades comuns às mulheres no século XIX ${ }^{165}$

Ao mesmo tempo, em torno do consumo feminino foram criados poderosos mecanismos de propaganda. Com uma maior taxa de alfabetização entre as mulheres no século XIX, as revistas e jornais femininos criaram anúncios do que seria necessário e adequado para uma família. No Brasil, o Mãe de Família ou Jornal das Senhoras ajudavam as mulheres a se decidirem sobre o que deveriam comprar. Anúncios de leite condensado para bebês (uma tentativa de substituir as amas de leite, um assunto polêmico no século XIX), de tecidos recém-chegados de Paris ou das botinas da Viana e \& Cia. se misturavam aos conselhos em reportagens sobre a melhor costureira do Rio, madame Barat, do melhor teatro ou ópera em cartaz na cidade. ${ }^{166}$

As roupas deveriam ser constantemente renovadas de acordo com a moda. Os anúncios de jornais e as colunistas dos jornais e revistas não cansavam de repetir a

\footnotetext{
${ }^{165}$ O quadro de Edar Degas, A chapelaria (1879-1886), está no Instituto de Arte de Chicago. Óleo sobre tela, $100 \times 110,7 \mathrm{~cm}$.

${ }^{166}$ Jornal das Senhoras, ano I, n. I, p. 5-7.
} 
máxima para as senhoras e senhoritas modernas: comprar, consumir renovar eram as palavras mais usadas. "A moda tem seu princípio fundamental de que deve partir. No tempo em que a aristocracia tinha uma vida à parte, o princípio da moda - era a riqueza. Hoje que os costumes mudaram e que a moda se fez mais popular e democrática - o seu princípio é a elegância e a riqueza.", escreve a colunista do Jornal das Senhoras, Cristina em 15 de maio de $1853 .{ }^{167}$ Os novos tempos haviam desbancado a ditadura na moda os gostos aristocráticos e, nesses novos tempos, dado lugar a um elemento impalpável, a elegância. A riqueza. E talvez a autora não tenha se dado conta, não mais aristocrática, mas agora burguesa.

Quando os anúncios para mulheres começam a aparecer nos primeiros números do Almanaque Laemmert, em 1844 não existe propaganda propriamente dita dos estabelecimentos comerciais, apenas uma lista separando comerciantes por ramos de produtos. Logo depois da lista de personalidades do governo, prefeitos, veadores, militares, banqueiros, começam os estabelecimentos ligados à indústria, por ordem alfabética, dos abridores de metais, águas minerais e armarinhos e brinquedos para crianças, na página 240, às tipografias e vidraceiros, na página 257 da edição. ${ }^{168}$ Assim, em 1844 são apenas 17 páginas de listas de estabelecimentos comerciais e industriais no Rio de Janeiro.

Em 1851, as páginas dedicadas ao comércio e indústria vão da de número 350 à 418, totalizando 68 páginas, mas ainda sem propagandas, apenas listas de nomes e endereços de profissionais. Somente em 1856, o Almanaque criou um guia de ruas e de estabelecimentos comerciais. E, somente em 1857, apareceram claramente anúncios pagos.

\footnotetext{
167 Jornal das Senhoras, 15 de maio de 1853, p. 20.

${ }^{168}$ Ver Almanaque Laemmert de 1844.
} 


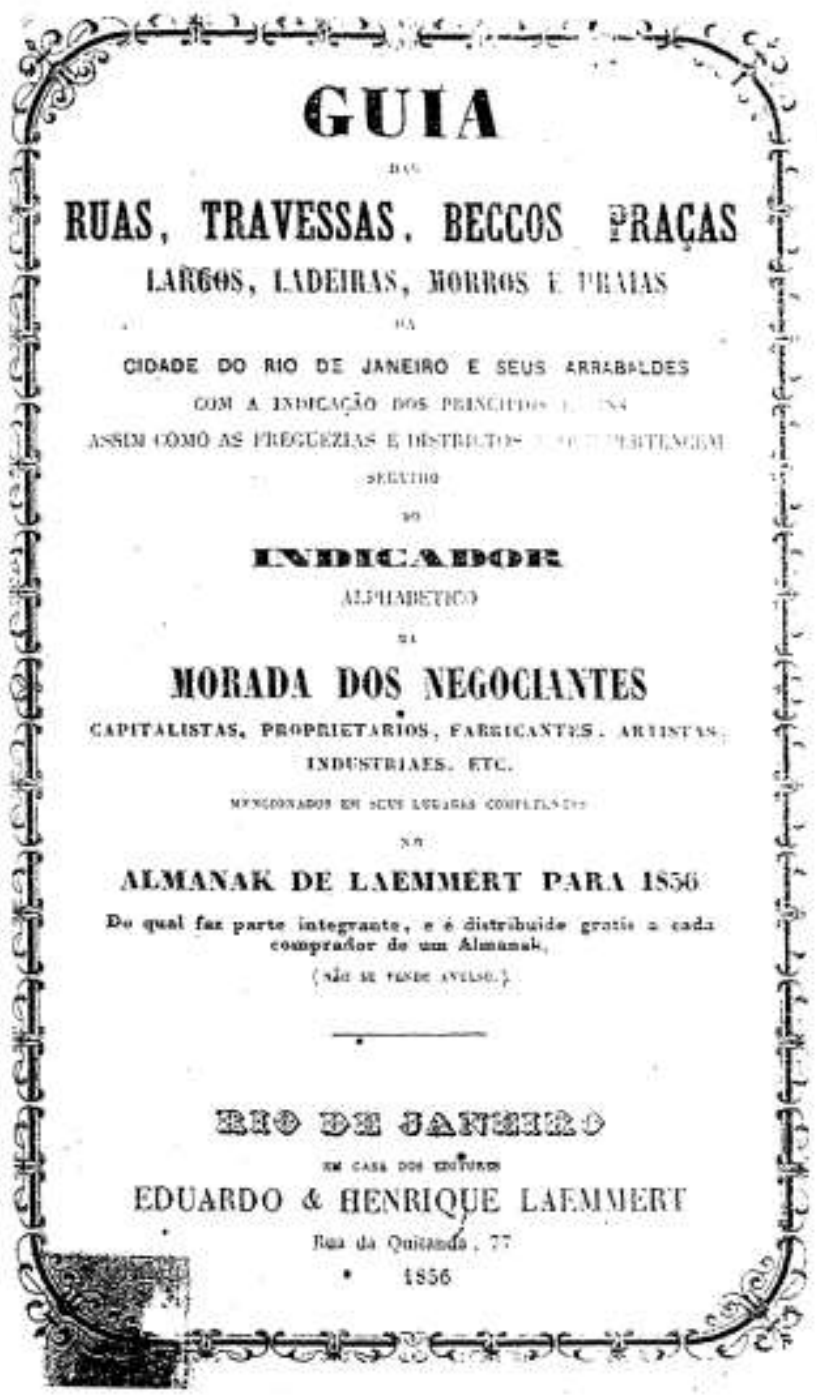

Almanaque Laemmert de 1856: ainda sem publicidade ${ }^{169}$

No ano seguinte, é que os irmãos Eduardo e Henrique Laemmert percebem o potencial comercial do Almanaque e começam a sessão "Notabilidade", com anúncios e propagandas. A primeira propaganda do Almanaque é de um consultório médico, do dr. Manoel Pereira da Cunha Novaes. A seção médica será fixa até o fim do século, provavelmente fazendo muito sucesso. Assim, aparecem propagandas do chocolate Vichy para indigestão, do professor de piano Achille Arnaud, da óptica de José Maria dos Reis.

${ }^{169}$ Almanaque Laemmert de 1856, p. 241. 
Nas primeiras propagandas para mulher, estão a dos armarinhos, que listam tudo o que se podia encontrar na loja, como o estabelecimento de Monteiro \& Coelho, na rua da Quitanda n. 66, que possuía: objetos para bordar, lãs, sedas, frocos, talagarças, torçal, desenhos, linhas, caixas, galões, botões e todos os artigos pertencentes a modistas e costureiras. $^{170}$

O Almanaque Laemmert refletia o que acontecia no próprio comércio, com a crescente especialização e diversificação e lojas e produtos. Ao longo do século XIX, o Rio de Janeiro "europeizava-se", o que certamente incluía a adoção de costumes diferentes e o nascimento de uma sociabilidade baseada em festas e salões, em "visitas" e idas a estâncias climáticas, como Petrópolis.

Se no começo do século XIX, as roupas podiam ser herdadas, muitas arroladas em testamentos até meados do século XIX como itens de significativo valor, em pouco mais de 50 anos, as roupas se popularizaram. A silhueta feminina refletiu essa abundância de tecidos, com a utilização de vestidos com crinolinas e anquinhas. Ao mesmo tempo, o conhecimento sobre o que uma família deveria consumir acabou por se tornar a principal atividade das mulheres abastadas no século XIX. Aos homens, cabiam os negócios e vida mundana.

${ }^{170}$ Almanaque Laemmert de 1857, p. 37 da seção de notabilidades. 


\section{CAPÍTULO IV. \\ Os homens no espelho: novas roupas para dândis, barões e militares}

O segundo reinado não se compreenderia sem os barões, coronéis, comendadores e conselheiros. A imensa rede de títulos, comendas e patentes doura a sociedade, revelando, debaixo dos embelecos, rigoroso mecanismo de coesão de forças. Raimundo Faoro ${ }^{1}$

\section{Por todo o século, dândis em preto}

$\int \begin{aligned} & \text { orácio de Almeida, nosso príncipe da moda, protagonista do romance } A \\ & \text { pata da gazela, de José de Alencar, era assíduo frequentador da rua do } \\ & \text { Ouvidor, aonde encontrava as últimas novidades para se vestir com }\end{aligned}$ elegância, no último rigor da moda. Horácio era, afinal, "uma das tantas inteligências desperdiçadas no incessante bulício da moda". ${ }^{2}$

Sua vida consistia em saber se vestir e se comportar em sociedade. Não trabalhava. Não se dedicava à ciência, nem à literatura, nem à sociedade. "A política [...] quando não dá em especulação passa a mistificação. A ciência, se escapa de mania, torna-se uma gleba em que sábio trabalha para o néscio. Literatura e arte são plágios; quem pode fazer poesia e romance ao vivo não se dá ao trabalho de reproduzi-los; nem contempla estátuas, quem lhes admira os modelos animados e palpitantes." A moda era

\footnotetext{
${ }^{1}$ Raimundo Faoro. Machado de Assis: a pirâmide e o trapézio. São Paulo: Globo, 2010, p. 40.

2 José de Alencar. A pata da gazela. São Paulo: coleção Saraiva, s/d, p. 19.
} 
seu refúgio e sua maneira de se expressar. Mas isto era uma novidade para os homens no século XIX.

Horácio era um dândi. Os dândis começaram a aparecer como um grupo social específico no começo do século XIX. Era tanto um grupo social como uma filosofia de vida, que incluía maneiras muito específicas de se vestir e de se comportar em sociedade. "Hoje em dia, a palavra dândi pode evocar a ideia de um almofadinha pitoresco, mas essa imagem é equivocada. No século XVIII, a roupa dos grã-finos e, em seguida, dos macaronis, era realmente elaborada e policromática, mas o que os dândis introduziram foi uma elegância sóbria e comedida".3

Os dândis surgiram num período de transição, entre o fim do século XVIII e as primeiras décadas do século XIX, com o estabelecimento e a ascensão da burguesia industrial. Os homens que aderiram a esta filosofia de vida representavam uma era -ainda que ela durasse todo o século XIX, até os primórdios da Primeira Guerra Mundial. As antigas definições de classe, que podiam ser vistas nas roupas, haviam perdido lugar para a democracia. Por um período de pouco mais de vinte anos, as mulheres passaram a usar túnicas transparentes, claramente inspiradas pelas vestes gregas. Para os homens estava reservada a sobriedade.

O poeta Charles Baudelaire escreveu uma definição mais precisa do que era ser dândi: “O dandismo surge, sobretudo, nas épocas transitórias em que a democracia não é ainda toda-poderosa, em que a aristocracia está enfraquecida e desvalorizada apenas parcialmente". Desta forma, alguns homens "deslocados de sua classe, descontentes, destituídos de uma ocupação, mas todos ricos de uma força inata, são capazes de conceber o projeto de fundar uma nova espécie de aristocrata, tanto mais difícil de

\footnotetext{
${ }^{3}$ John Harvey. Homens de preto. Trad. port. São Paulo: Editora Unesp, 2001, p. 37.

${ }^{4}$ Tomaz Tadeu (org). Baudelaire, Balzac e D’Aurevilly (escritos). Manual do dândi: a vida com estilo. Trad. port. Belo Horizonte: Autêntica, 2009, p. 17.
} 
abater quanto estará baseada nas mais preciosas, nas mais indestrutíveis faculdades, e nos dons celestes que nem o trabalho nem o dinheiro podem conferir". 5 E Baudelaire terminou, afirmando categoricamente que o dandismo "é o último rasgo de heroísmo nas decadências". 6

O dandismo nasceu logo após o fim da Revolução Francesa, época em que os valores intrínsecos à nobreza já haviam caído, ou estavam caindo, por terra. Ser duque, conde ou barão já não valia mais como indicador social ou mesmo de classe. Era preciso ser mais - e dominar uma série de regras e etiquetas para ser considerado um dândi, um legítimo representante da sociedade "mais elevada". 7

A dominação econômica inglesa traduzia-se pela predominância de modos ingleses nos tratos sociais, com apertos de mão e um certo distanciamento físico. Os dândis foram, sobretudo, ingleses. A palavra, inclusive, é de origem inglesa, dandy. Um manual de etiqueta português da Belle Époque dá essa noção claramente: “O dandismo, de resto, aclamado na França antes de ter nome, é, segundo B. d’Aurevilly, não a forma universal da vaidade humana, mas uma forma de vaidade muito particular: a vaidade inglesa. É a força da originalidade inglesa, imprimindo-se na vaidade humana que produz o dandismo". ${ }^{8}$

Um dos primeiros dândis foi um inglês chamado Georges "Beau" de Brummell (1778-1840). Filho de ambiciosos funcionários da coroa da Inglaterra e estudante de colégios de elite, como Eton e Oxford, Brummell criou uma nova moda para os homens. Para ele as calças curtas e coloridas, usadas com meias até o joelho, eram abomináveis. Os homens deveriam usar calças pretas longas e sóbrias, com casacas igualmente pretas,

\footnotetext{
${ }^{5}$ Idem.

${ }^{6}$ Idem ibidem.

${ }^{7}$ Tomaz Tadeu (org). Baudelaire, Balzac e D’Aurevilly (escritos). Manual do dândi: a vida com estilo. Trad. port. Belo Horizonte: Autêntica, 2009, p. 47.

${ }^{8}$ Maria Amália Vaz de Carvalho. A arte de viver na sociedade. Lisboa: Parceria Antonio Maria Pereira, 1909, $4^{\text {a }}$ edição, p. 16-18.
} 
camisas brancas e gravatas que podiam ser pretas ou brancas. Lentamente, as cores que predominavam no guarda-roupa masculino antes da Revolução Francesa foram desaparecendo, dando lugar a vestimentas pretas e sóbrias.

Brummell acabou perdendo sua pouca fortuna nos jogos. Emigrou para Grécia, depois para Itália, aonde vivia com poucos recursos, mas ainda possuía amigos, vestiase e portava-se como antes. "É necessário notar que os maiores dandys eram, ou foram ao declinar da vida, grandes estadistas, grandes poetas e grandes políticos. Brummell é um dos poucos, é talvez o único que não foi nada."9

A roupa ideal para os homens do novo século XIX deveria ser calças e casacas pretas. Um visual, claramente inspirado pelos dândis, que adotaram o estilo de Brummell. Segundo o Novo manual do bom-tom, o homem de bom senso não deveria fazer notar-se pela excentricidade e deveria vestir "Casaca e calça de pano fino preto, colete e lenço no pescoço branco formam o resto do vestuário do bom-tom [...] Caixa de ouro para rapé, relógio, luneta, tendo-se a vista curta, também de ouro, são os únicos objetos admissíveis para uma pessoa de juízo". ${ }^{10}$

Mas os dândis também foram protagonistas de uma drástica mudança de costumes. Eram, muitas vezes, artistas, como Baudelaire, que dizia que "o dandismo é um sol poente; como o astro que declina, é soberbo, sem calor e pleno de melancolia, Mas, desgraçadamente, a maré montante da democracia - que invade tudo e tudo nivela - afunda diariamente esse último do orgulho humano [...]". ${ }^{11}$ Ou como Balzac, que se

\footnotetext{
${ }^{9}$ Maria Amália Vaz de Carvalho. A arte de viver na sociedade. Lisboa: Parceria Antonio Maria Pereira, 1909, $4^{\text {a }}$ edição, p. 19.

${ }^{10}$ Ver o Jornal das Senhoras, ano II, n. 25, 19 de junho de 1853.

${ }^{11}$ Tomaz Tadeu (org). Baudelaire, Balzac e D’Aurevilly (escritos). Manual do dândi: a vida com estilo. Trad. port. Belo Horizonte: Autêntica, 2009, p. 17
} 
juntou a outros escritores para escrever um Tratado da vida elegante para homens, que incluía saber se vestir e portar-se adequadamente em sociedade. ${ }^{12}$

Lord Byron e os artistas românticos também foram grandes inspiradores para os dândis - e muitos foram eles mesmos dândis e propagadores de uma filosofia de vida para novos tempos da democracia e vitória do dinheiro. Assim, os dândis e românticos podiam correr o mundo para lutar por países e ideais, como fez Byron na Grécia, mas a vida de um verdadeiro dândi pressupunha apenas ócio e fortuna.

“A vida elegante é [..] a arte de animar o repouso. O homem habituado ao trabalho não pode compreender a vida elegante.", escreveu Balzac no seu Tratado sobre a elegância. Ele finalizou o texto com a seguinte afirmação: "Para ser fashionable é preciso desfrutar do repouso sem ter passado pelo trabalho, ou seja, acertar uma quadra na loto, ser filho de milionário príncipe, ter uma sinecura ou acumular vantagens."13 $\mathrm{E}$ mais ainda, no manual de boas maneiras da belle époque, estava escrito que "nunca se poderá ensinar a arte de ser um perfeito dandy. Nasce-se com esse dom ou nasce-se em ele". ${ }^{14}$ Retrato de Dom Augusto, Duque de Leuchtenberg por Karl Joseph Stieler na década de 183015: camisa branca, casaca preta e uma pele caracterizam o novo homem elegante do século XIX

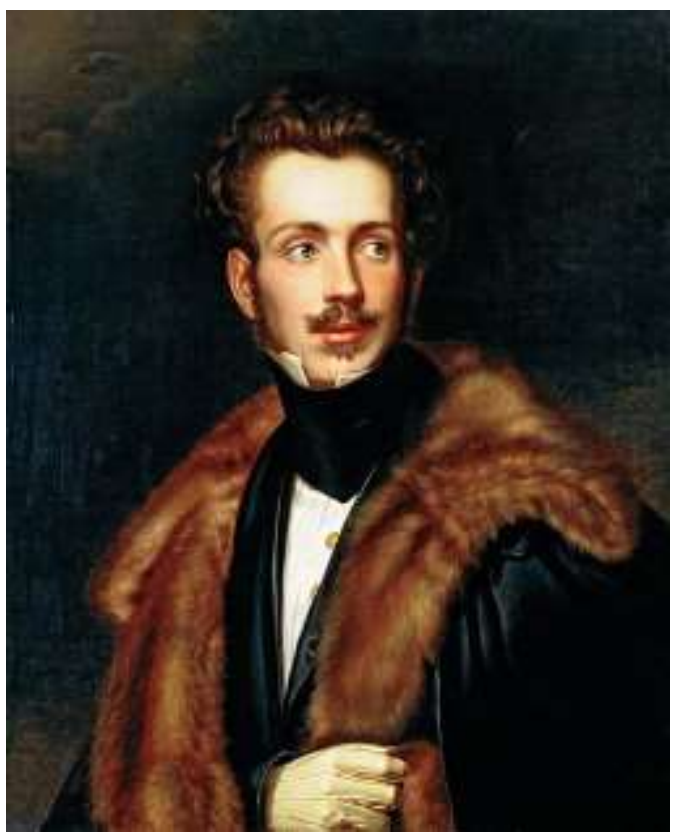

\footnotetext{
${ }^{12}$ Tomaz Tadeu (org). Baudelaire, Balzac e D’Aurevilly (escritos). Manual do dândi: a vida com estilo. Trad. port. Belo Horizonte: Autêntica, 2009, p. 47. 20-74.

${ }^{13}$ Tomaz Tadeu (org). Baudelaire, Balzac e D’Aurevilly (escritos). Manual do dândi: a vida com estilo. Trad. port. Belo Horizonte: Autêntica, 2009, p.31.

${ }^{14}$ Maria Amália Vaz de Carvalho. A arte de viver na sociedade. Lisboa: Parceria Antonio Maria Pereira, 1909, $4^{\text {a }}$ edição, p. 19.

${ }^{15}$ Retrato de Dom Augusto, Duque de Leuchtenberg por Karl Joseph Stieler. Óleo sobre tela, 72.2 $\times 58 \mathrm{~cm}$. O quadro, de 1835, está no inventário da Pinacoteca do Estado de S. Paulo $\langle$ http://pt.wikipedia.org/wiki/Pinacoteca_do_Estado_de_S\%C3\%A3o_Paulo\#A_cole.C3.A7.C3.A 30>. consulta 20/3/2013.
} 
Foram vários os dândis na sociedade brasileria do século XIX. Entre os estrangeiros que passaram por aqui estava d. Augusto de Beauharnais (1810-1835), duque de Leuchtenberg, irmão mais velho de d. Amélia de Leuchtenberg (1812-1873), segunda mulher de d. Pedro I. Ele foi o marido de d. Maria II de Bragança (1822-1801), rainha de Portugal, irmã de d. Pedro II (1825-1891). D. Augusto esteve no Brasil junto com a irmã, quando esta veio se casar com d. Pedro I, em 1829. Ele morou no palácio de São Cristóvão de 1829 até 1831, quando d. Pedro I abdicou e, durante esse período, foi condecorado com o título de duque de Santa Cruz. ${ }^{16}$ D. Augusto viveu pouco e morreu em Portugal, consequencia de um ataque do coração.

No quadro, reproduzido acima, vemos o retrato de d. Augusto vestindo-se elegantemente segundo a última moda europeia: casaca preta, camisa branca com botões dourados, luvas de pelica creme, gravata preta e uma pele de animal. Os cabelos castanhos cacheados e levemente ondulados, o bigode e barba leves estavam de acordo

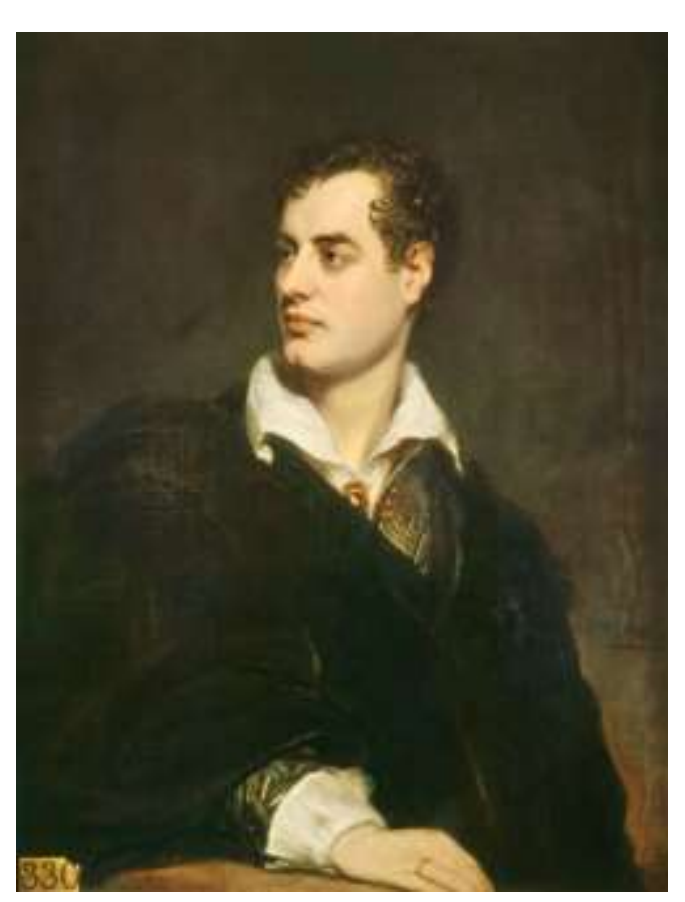
com os ideiais romanticos da época e ele acabou se parecendo muito com o romântico Lord Byron (1788-1824), que podemos ver no retrato reproduzido abaixo.

Lord Byron: inspiração romântica para roupas masculinas ${ }^{17}$

\footnotetext{
${ }^{16}$ Eugênio dos Santos. Dom Pedro, imperador do Brasil e rei de Portugal. São Paulo: Alameda Casa Editorial, 2013, p. 83-102.

${ }^{17}$ Quadro "Lord Byron", de Thomas Philipps, pintado em 1824. Óleo sobre tela, UK Government Art Collection. Consulta em 25/3/2013.
} 
Até as primeiras décadas do século, os homens tinham um guarda-roupa colorido, com peças contrastantes, que indicavam riqueza, afinal os processos de tingimento de tecidos ainda era caros e apenas a elite podia usá-los à vontade. Podemos ver claramente essa mudança de comportamento ao pegarmos alguns inventários do final do século XVIII, como o de Domingo de Abreu Vieira, em que aparecem "uma casaca de pano berne escarlate com sua abotoadura de casquinha lavrada, branca; fraque com sua véstia de droguete encarnado, usado com botões de casquinha pequenos." 18 No longo inventário do inconfidente Claudio Manuel da Costa, reproduzido abaixo, as cores estão por toda lado, da casaca de cereja à véstia de cetim cor-de-rosa.

Casaca de veludo cor de cereja. Véstia branca de matizes. Véstia de cetim com seu calção carmezim de dados. Calção de cambraia verde. Casaca de belbute amarelo. Casaca de ganga com sua véstia e calção do mesmo, bordada de preto, e calções de pano verde. Chapéu coberto de cetim preto. Casaca véstia de sarja preto de seda e um calção de belbute preto. Casaca de droguete castor. Véstia de cetim cor-de-rosa de ramas de ouro e matizes. Casaca e véstia de chita abrilhantada. Vestido de seda preto, inteiro. Capa de seda. Véstia de seda, bordadura larga. 3 camisas de bretanha, uma delas com babados de renda. 3 pares de meias de seda branca. Penteador de bretanha com sua renda. 8 camisas de bretanha com seus babados. 2 ceroulas de pano de linho. Ceroula recortada por baixo. 5 pares de meia de linho. Véstia de chita. Véstia de chita verde. Chambre de chita. Sobretudo de barregana alvadia. 2 pares de botas. 2 casacas de pajens com suas véstias e dois calções de pano escuro forrados de amarelo as casacas e as véstias e calções amarelos. Chapéu pequenino usado com seu galão de ouro. Camisa de pano de linho. Calcão de seda preto. Casaca e véstia de pano verde caseada de prata jaezada. Calça e véstia de selescia encarnada. Calção de chita amarelo. Casacão de baetão acamurçado pintado. Chapéu fino. 2 camisas de bretanha com seus

${ }^{18}$ Autos da Devassa da Inconfidência Mineira (1789-1791). vol. V, Rio de Janeiro: Ministério da Educação/ Biblioteca Nacional, 1936. p. 224. 
babados. 2 pares de ceroulas de pano de linho. 2 pares de meias de linho. Par de meias pretas de laia. 2 pares de meias de seda pretas. Par de sapatos pretos, com suas fivelas de luto. Capote de baetão de riscas pintado. $^{19}$

No retrato, feito pelo pintor português Simlício Rodrigues de Sá em 1825, o marquês de Inhambupe, Antonio Luiz Pereira da Cunha (1760-1837), usava ainda calças curtas, com meias brancas e uma jaqueta preta de estilo militar, bastante bordada em prata, destacando as comendas que havia ganhado. $\mathrm{O}$ marquês formou-se em direito em Coimbra e foi senador por Pernambuco ente 1826 e 1837. Entre as comendas que exibia, estava a Imperial Ordem do Cruzeiro, com as cinco pontas representando o cruzeiro do sul, concebida por d. Pedro I após a independência, e concedida àqueles que ajudaram a formar o primeiro império.

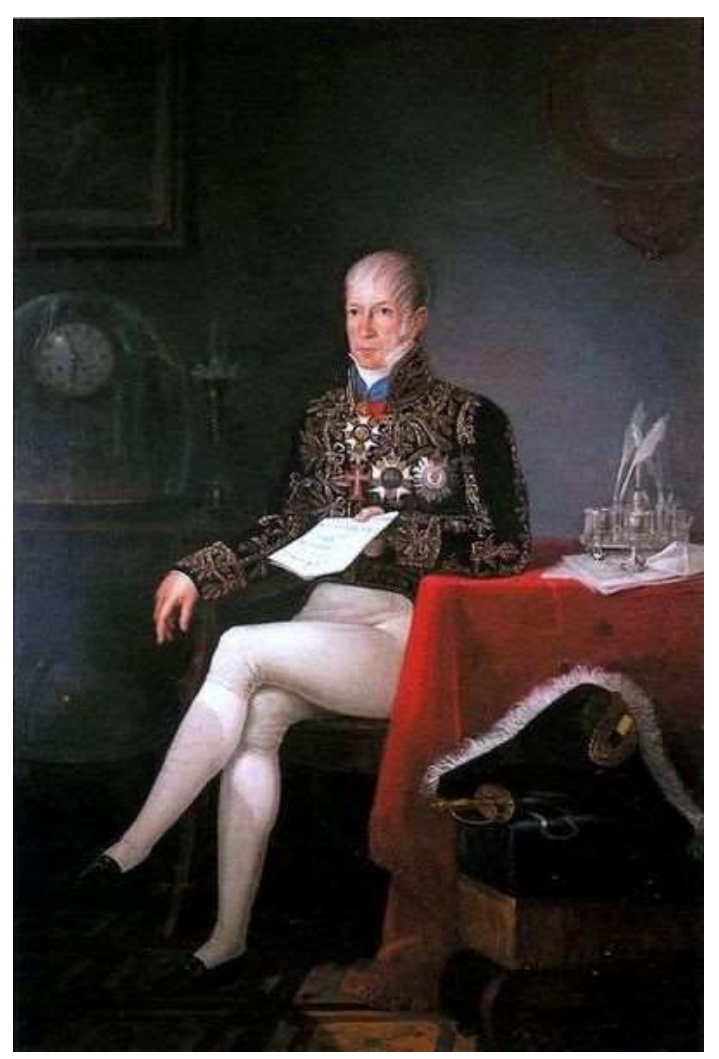

O marquês de Inhambupe, Antonio Luiz Pereira da Cunha, em 1825, retratado por Simlício Rodrigues de $S a^{20}$

${ }^{19}$ Autos da Devassa da Inconfidência Mineira (1789-1791). vol. V, Rio de Janeiro: Ministério da Educação/ Biblioteca Nacional, 1936, p. 265-7, 269, $273-4$.

${ }^{20} \mathrm{O}$ quadro se encontra no Museu Nacional de Belas Artes e é um óleo sobre tela de 1,98x1,31 m. 
Já no quadro do visconde e da viscondessa da Cachoeira, Juiz José de Carvalho e Ana Vidal, reproduzido abaixo, vemos o visconde de pé e sua mulher sentada ao seu lado, numa pose clássica. Luiz José de Carvalho foi escolhido senador em 1826, sem ter exercido o cargo, que era vitalício, pois faleceu logo em seguida. Era também formado em Direito pela Universidade de Coimbra, e escreveu os estatutos que organizaram os cursos jurídicos do Brasil, logo que foram criados. O quadro é, provavelmente, da época em que foi escolhido senador.

$\mathrm{O}$ visconde de Cachoeira vestia um uniforme militar completo, com jaleco militar verde e dourado, calças brancas também ainda curtas, presas logo abaixo do joelho, complementadas por meias brancas e sapatos de fivela pretos. Sua esposa, Ana Vidal, estava vestida com um modelo branco estilo império, cinto dourado logo abaixo do busto, uma coroa de plumas, colar, pulseira, anéis, um leque e sapatos brancos - no braço esquerdo, segura um manto verde bordado. Ambos fazem uma referência clara à independência do país. Além disso, aqui as cores nas roupas masculinas estavam evidentes.

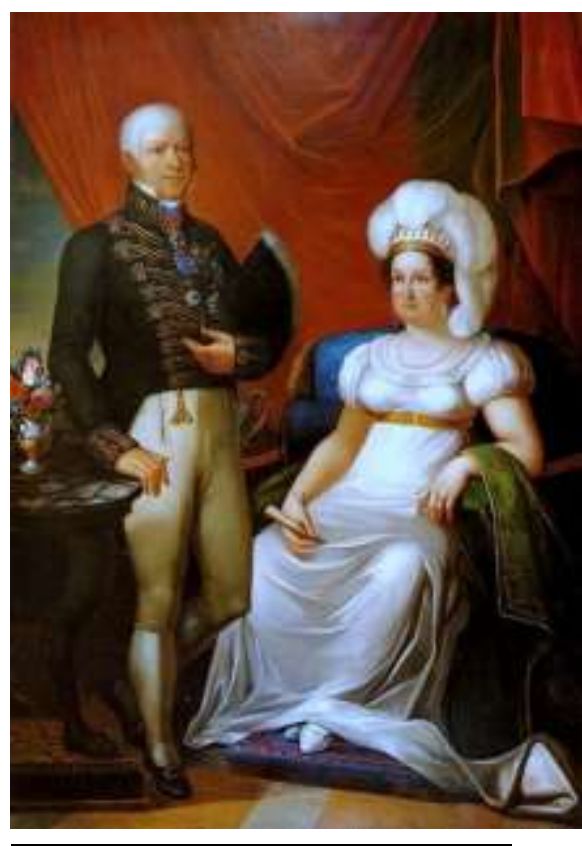

Luiz José de Carvalho e D. Ana Vidal Carneiro da Costa, Visconde e Viscondessa da Cachoeira ${ }^{21}$

${ }^{21}$ Óleo sobre tela de pintor desconhecido, século XIX (provavelmente das primeiras décadas do século XIX; 2,22x1,54 m, Acervo artístico do Ministério das Relações Exteriores (palácio do Itamarati, Brasília) 
Assim, foi apenas no começo da década de 1840 que usar cores nas roupas masculinas passou a ser visto como sinônimo de deselegância e mau gosto. "Desde a monarquia de julho," escreveu Walter Benjamin, "o preto e cinza começaram a predominar nos trajes masculinos. Essa novidade foi tratada por Baudelaire em Salão de 1845." 22 As cores sumiram das roupas dos homens e todos pareciam envergar o mesmo fraque preto e camisa branca. "Antes de tudo, o verdadeiro pintor será aquele que souber extrair da vida presente o seu lado épico e nos ensinar a compreender em linhas e cores como somos grandes e poéticos em nossas gravatas e botas envernizadas"23.

No Jornal das Senhoras ${ }^{24}$, editado no Rio a partir de 1852, a jornalista descrevia seu desgosto por ver homens trajando cores, o que considerava o cúmulo do mau gosto. “[...] o que nos causava impressão era ver que em um baile da ordem da Vestal, frequentado por pessoas respeitáveis, se haviam apresentado alguns interessantes cavalheiros trajando calças de cor, outros trazendo na mão chapéu branco, etc, como se estivessem em alguma festa de campo $[\ldots] . .^{25}$

Ao longo do oitocentos, o preto se tornou a cor dos homens elegantes por excelência. Era ao mesmo tempo a cor do luto - uma obsessão dos vitorianos -- e a cor com qual se vestiam os homens de elite. Walter Benjamin vai falar da democracia dos homens vestidos de preto, indiferenciados na multidão do século XIX. "A roupa preta não tem apenas sua beleza política, expressão da igualdade universal, mas também sua beleza poética, sem dúvida expressão da alma pública representada numa imensa

\footnotetext{
${ }^{22}$ Walter Benjamin. Charles Baudelaire: um lírico no auge do capitalismo. Trad. port. São Paulo: Brasiliense, 2000, p. 76.

${ }^{23}$ Walter Benjamin. Charles Baudelaire: um lírico no auge do capitalismo. Trad. port. São Paulo: Brasiliense, 2000, p. 76.

${ }^{24}$ O Jornal das Senhoras começou a ser editado no Rio de Janeiro em $1^{\circ}$ de janeiro de 1852 pela argentina e feminista Joana Paula Manso de Noronha (1819-1875). Muitas mulheres colaboravam com o jornal, mas como anônimas. Depois de seis meses, ele passou a ser dirigido por Violante de Bivar e Velasco (1816-1874).O jornal vai durar até 1855. Os números atualmente estão online no site da Biblioteca Nacional <http://objdigital.bn.br/acervo digital/div periodicos/per700096/>. Consulta em 8/04/2013.

${ }^{25}$ Jornal das Senhoras, ano II, n. 42, 22 de outubro de 1854.
} 
procissão de gatos pingados [...]". ${ }^{26}$ Isso certamente poderia ser verdade nas primeiras décadas do século, com os artistas como Baudelaire e Balzac a fazerem elogios ao dandismo. Contudo, a indiferenciação entre os cidadãos passou a cada vez mais significar uma indiferenciaçao entre quem possuía dinheiro ou quem possuía um título de nobreza e não entre outros membros da sociedade, como os trabalhadores e seus patrões, os comerciantes e os pequenos funcionários do governo, que não usavam tanto o preto.

Saber usar o preto, bem como casacas e as calças condizentes certamente eram passaporte para um mundo de privilégios. Benjamin percebe essa mudança ao longo do século quando vai citar um político da Alemanha. Quinze anos mais tarde, o democrata Vischer, da Alemanha do Sul, ao fazer uma crítica da moda masculina, chega a conclusões semelhantes às de Baudelaire. Só muda o acento: o que em Baudelaire aparece como tonalidade de perspectiva crepuscular do moderno, em Vischer surge como brilhante argumento para a luta política. "Declarar a cor - escreve Vischer com vista ao reacionarismo dominante desde 1850 - passa por ridículo ${ }^{27}$, ser rígido passa por infantil; como então o vestuário não se tornaria sem cor, largo e apertado ao mesmo tempo?"28

Ao mesmo tempo em que o uso da cor preta, a casaca preta também se transformou em símbolo máximo da sofisticação masculina e sua utilização perpassou quase todo o século XIX. Em 1838, o viajante Daniel Kidder, observou que o uso da casaca já era obrigatório para se frequentar determinados lugares públicos. "Presume-se que todo o indivíduo de respeito se vista bem, e com propriedade. Daí o fato de se não

\footnotetext{
${ }^{26}$ Walter Benjamin. Charles Baudelaire: um lírico no auge do capitalismo. Trad. port. São Paulo: Brasiliense, 2000, p. 76.

${ }^{27}$ Ele quer dizer declarar a cor do partido a que se pertence.

${ }^{28}$ Walter Benjamin. Charles Baudelaire: um lírico no auge do capitalismo. Trad. port. São Paulo: Brasiliense, 2000, p. 76 e 77.
} 
poder entrar em repartições públicas, no Museu ou na Biblioteca Nacional sem ser de casaca" $^{29}$

No mesmo período, Karl Marx lutava para escrever $O$ Capital na Biblioteca Nacional de Londres - onde também só se podia frequentar de casaca. Por causa dos constantes problemas financeiros, a casaca de Marx entrava e saía constantemente da loja de penhora, atrapalhando seu ritmo de escrita. ${ }^{30}$ A casaca era tão importante para vida social que Baudelaire escreveu: "Não é este o inevitável uniforme de nossa época sofredora, carregando nos ombros, negros e estreitos, o símbolo de um luto perpétuo?"31

No Brasil, os dândis eram muitas vezes vistos como homens fúteis e vazios, que apenas se preocupavam com a aparência. No Jornal das Senhoras de 6 de fevereiro de 1853, foi publicado um artigo em que a cronista dizia que os dândis tinham como interesse supremo "contar histórias do seu alfaiate, das luvas que comprou na Casa Wallerstein, da casaca que desta vez lhe converteu em um chefe de obra, das calças, do colete, das unhas, da correntinha do seu relógio, enfim, de tudo quer diz respeito a futilidades." ${ }^{, 32}$ Podemos ver certa crítica a essa atitude na descrição que fizemos de Horácio, personagem de A pata da gazela.

Foram os dândis que, apesar das críticas, deram o tom para roupa masculina no século XIX. "A roupa masculina perdera, no século XIX, sua função ornamental, deixando de ser uma arma de sedução erótica”, afirma Gilda de Mello e Souza. ${ }^{33}$ O que mais iria importar numa veste masculina não seriam mais as cores ou os brocados e

${ }^{29}$ Daniel Parish Kidder. Reminiscências de Viagens e Permanência no Brasil, Rio de Janeiro e Províncias de São Paulo (1837-1838). Trad. port. São Paulo: EDUSP/ Itatiaia Editora, 1972, p. 128-9.

${ }^{30}$ Peter Stallybrass. O casaco de Marx: roupas, memória e dor. Trad. port. Belo Horizonte: Autêntica, 2008.

${ }^{31}$ O texto "Le salon de 1846" está no livro de Charles Baudelaire. Selected writings on art and literature. Londres: Penguin: 1992, p. 46.

${ }^{32}$ Jornal das Senhoras, ano II, n. 6, 6 de fevereiro de 1853.

${ }^{33}$ Gilda de Mello e Souza. O espírito das roupas. A moda no século dezenove. São Paulo: Companhia das Letras, 1987, p. 75. 
bordados - o que importaria, e distinguiria os homens de sociedade, seriam os tecidos e o caimento das vestes. "Este [...] apresentava a melhor aparência desse mundo - fraque, chapéu alto, lunetas e bigode", dizia a descrição de uma personagem de Aluísio Azevedo. ${ }^{34}$ Balzac reforça essa ideia ao dizer que "não existe unidade possível sem o esmero, sem a harmonia, sem a simplicidade relativa". ${ }^{35}$

Em Senhora, José Veríssimo descreve o suprassumo do homem elegante para a época. Para tanto, ele precisava fazer roupas no Raunier, ter chapéus claque como em Paris, luvas Jouvin impecáveis e botinhas do sapateiro Campas. Um código social, que talvez só fosse bem decifrado, por quem frequentava os altos círculos cariocas.

\begin{abstract}
Assim no recosto de uma das velhas cadeiras de jacarandá via-se nesse momento uma casaca preta, que pela fazenda superior, mas, sobretudo, pelo corte elegante e esmero do trabalho, conhecia-se ter o chique da casa Raunier, que já era naquele tempo o alfaiate da moda. Ao lado da casaca estava o resto de um traje de baile [...] finíssimo chapéu claque do melhor fabricante de Paris; luvas de Jouvin cor de palha; e um par de botinas como o Campas só fazia para os seus fregueses prediletos. ${ }^{36}$
\end{abstract}

Os homens, apesar da aparente simplicidade da roupa, possuíam códigos de vestimenta bastante rígidos no século XIX e, nesse sentido, aproximavam-se de suas mulheres de crinolina. Uma casaca mal cortada, um fraque puído, um sapato gasto, podia acabar com a reputação de um homem de sociedade. Foi o aconteceu no romance de Aluísio Azevedo, A condessa de Vésper. "Fazia má impressão vê-lo com a sobrecasaca puída do uso e das teimosas escoriações, com os seus sapatos remontados,

\footnotetext{
${ }^{34}$ Aluísio Azevedo. A Condessa de Vésper. São Paulo: Martins Editora/ Instituto Nacional do Livro (MEC), 1973. p. 90.

${ }^{35}$ Tomaz Tadeu (org). Baudelaire, Balzac e D’Aurevilly (escritos). Manual do dândi: a vida com estilo. Trad. port. Belo Horizonte: Autêntica, 2009, p. 69.

${ }^{36}$ José de Alencar. Senhora. São Paulo: Editora Ática, 1971, p. 29-30.
} 
o seu espinhoso colarinho a arrancar-lhe as cordoveias do magro pescoço com as caprichosas franjas dos fiapos do linho [...] o velho chapéu de copa alta [...] as botas encalavradas $[\ldots] " .37$

A falta de gosto, a colocação de cor equivocada, o modo de portar um chapéu, uma bengala ou uma luva - tudo isso podia ser motivo de desgraça ou inadequação social. No Jornal das Senhoras, a falta de gosto era sempre motivo para uma crônica apaixonada:

Não há coisa que acarrete mais desprezo do que o ridículo nas modas, e essa é a razão do menoscabo que se tributa a muitos elegantes. [...] Levava nosso herói um chapéu que apenas teria um palmo de altura, e que ele intitulava à Quaker; uma sobrecasaca cor de cinza tão curta que não tinha de aba nem dois palmos, um lenço de seda amarela ao pescoço e um vermelho dependurado na algibeira; suas calças roxas deixavam entrever unicamente o bico do pé. ${ }^{38}$

Machado de Assis, em Memórias póstumas de Brás Cubas, que se passa em meados do século, descreveu uma cena em que a roupa puída era o tema central da descrição de um homem no fim de seus dias:

As roupas, salvo o feitio, pareciam ter escapado ao cativeiro da Babilônia [...]. Imaginem agora uma sobrecasaca, mais larga do que pediam as carnes [...] a cor preta ia cedendo o passo a um amarelo sem brilho; o pelo desaparecia aos poucos; dos oito primitivos botões restavam três. As calças, de brim pardo, tinham duas fortes joelheiras, as bainhas eram roídas pelo tacão de um botim sem misericórdia nem graxa. Ao pescoço flutuavam as pontas de uma gravata de duas cores

\footnotetext{
${ }^{37}$ Aluísio Azevedo. A Condessa Vésper São Paulo: Martins Editora/ Instituto Nacional do Livro (MEC), 1973. p. 83, 92, 97.

${ }^{38}$ Jornal das Senhoras, ano III, n. 42, 22 de outubro de 1854.
} 
[...] apertando um colarinho de oito dias [...] trazia também um colete de seda escura, roto a espaços, e desabotoado. ${ }^{39}$

E, ainda que regras suntuárias tivessem sido abolidas com a Revolução Francesa, no Rio, em meados do século XIX, nem todo mundo podia vestir-se como um homem de sociedade, de fraque e bengalas e cartola. Os caixeiros eram parte central do comércio carioca. Não eram ricos, porém tinham acesso às mercadorias que denotavam bom gosto e uma classe social acima da sua. Sabiam vender e, portanto, sabiam como consumir, ou seja, como vestir-se adequadamente.

Nem todos os caixeiros podiam vestir-se de fraque, alguns o faziam e andavam pelas ruas do Rio como dândis, demonstrando o poder de se usar uma roupa bem cortada em sociedade:

Nesse tempo [...] os empregados do comércio não gozavam em geral de certas regalias, que só mais tarde lhes foram conferidas pelos patrões. O bigode, a gravata, o fraque, por exemplo, eram fruto proibido para os caixeiros. [...] Mas o comendador Ferreira não se deixava levar por tão mesquinho preconceitos e dava aos seus empregados plena liberdade de deixar crescer o bigode, vestir um fraque $[\ldots][\ldots]$ o pretensioso caixeiro ataviava-se com roupas de casimira francesa [...] E o fato é que ficava um rapagão, quando enverdava o fraque de pano fino, vestia um par de calças novas armava o seu chapéu alto e ganhava a rua, rangendo as botinas [...] compareceu ao casamento do patrão $[\ldots]$ de $[\ldots]$ casaca. ${ }^{40}$

Os homens bem vestidos também eram descritos com acuidade pelos romancistas, passando a ideia da importância da roupa para se descobrir qual o lugar na sociedade

\footnotetext{
39 Joaquim Maria Machado de Assis. Memórias Póstumas de Brás Cubas. São Paulo: Editora Ática, s.d. p. 82-3.

${ }^{40}$ Aluísio Azevedo. Girândola de Amores. São Paulo: Martins Editora, 1960. p. 162-3.
} 
pertenceria a pessoa. Mais uma vez, é Aluísio Azevedo quem vai descrever um homem perfeitamente elegante, em $O$ homem, ainda que com certa ironia aos novos modos burgueses do personagem:

[...] vestia calça e paletó de pano preto, novo em folha; nada de colete; tinha grandes sapatos de bezerro, engraxados, chapéu de lebre e gravata branca de cetim com alfinete de ouro atravessando o laço. $\mathrm{O}$ casaco fechava-se-lhe sobre o estômago, deixando ver um peito da camisa, que era a última expressão da arte de reduzir o pano à madeira por meio do polvilho e do ferro de engomar; de tão duro e violento, rompia por entre as golas da roupa e abaulava-se arrogante uma só curva de alto a baixo; três botõezinhos de osso tingido de vermelho desfrutavam a suprema honra de guarnecer esta preciosidade. Levava dobrado ao pescoço, para resguardar o colarinho do suor, um lenço usado pela primeira vez $[\ldots]^{41}$

Numa pensão carioca da época, era comum estudantes que dividiam o mesmo quarto pendurarem as roupas que usavam em bailes pelas cadeiras e camas. Mostravam ao mesmo tempo bom gosto e certo ar de conhecer as regras do bem vestir da corte, certa indolência. "Nas cabeceiras das três camas e ao comprido das paredes, sobre jornais velhos e desbotados, dependuravam-se calças e fraques de casimira [... $]^{42}$

Muitos tipos diferentes podiam frequentar as ruas da época. No Maranhão, viamse os comerciantes, uma espécie de classe média, com seus paletós e calças de brim brancas, os cônegos, de preto, com meias escarlates e os aristocratas, a elite da cidade, vestidos à moda do século, ou seja, como dândis.

[...] aqueles três surgiram na rua, formando cada qual mais vivo contraste com os outros: Manuel no seu tipo pesado e chato de

${ }^{41}$ Aluísio Azevedo. O homem. São Paulo: Martins Editora, 1970, p. 191.

${ }^{42}$ Aluísio Azevedo. Casa de Pensão (1884). São Paulo: Martins Editora, 1960. p. 58. 
negociante, calças de brim e paletó de alpaca; o cônego imponente na sua batina lustrosa, aristocrata, mostrando as meias de seda escarlate e pé mimoso, apertadinho no sapato de polimento; Raimundo, todo europeu, elegante com uma roupa de casimira leve adequada ao clima do Maranhão, escandalizando o bairro comercial com o seu chapéude-sol coberto de linho claro e forrado de verde pela parte de dentro $[\ldots .$.$] roupa clara e um chapéu de palha [\ldots]^{43}$

Já o carioca de classe média que ficava noivo mostrava respeito à amada ao vestirse adequadamente para o casório: “[...] passar uma noite inteira enfronhado em calças pretas, camisa bordada e gravata branca [...] de casaca, luvas de pelica, à espera da noiva [...]". ${ }^{44}$ Para o Jornal das Senhoras essa era a máxima prova do amor. “[...] o estúpido cobre-se de joias, o tolo adorna-se, mas o homem elegante veste-se bem. A elegância nos homens deve ser na razão inversa do seu amor: no trajar - simples e moderado; no amor, excessivos e verdadeiros" ${ }^{\text {45 }}$.

\section{Os barões, a política e as casacas}

A casaca, as calças e o preto. Esses foram os três elementos que definia a base da silhueta masculina elegante no século XIX. D. Pedro II passou os anos de seu governo com casacas e calças pretas - eram sua vestimenta preferida e também a maneira com a qual gostava de ser retratado. "A adoção de casacas, sobrecasacas, cartolas e outros acessórios do guarda-roupa do cidadão comum era a principal forma pela qual d. Pedro buscava promover, tanto no Brasil quanto no exterior, a imagem de 'imperadorcidadão", 46

${ }^{43}$ Aluísio Azevedo. O Mulato. São Paulo: Martins Editora/ Instituto Nacional do Livro/ MEC, 1975. p. 111.

${ }^{44}$ Aluísio Azevedo. Filomena Borges (1884). São Paulo: Martins Editora, 1960. p. 26, 172-3

${ }^{45}$ Jornal das Senhoras. Ano II, 2 de outubro de 1953.

${ }^{46}$ Marcelo de Araújo. D. Pedro II e moda masculina na época vitoriana. São Paulo: Estação das Letras e cores, 2012, p. 24. 
Mais do que uma imagem burguesa, ao vestir-se com calças e casacas pretas - e também com camisa branca, gravata, relógio de ouro e comendas - d. Pedro era o retrato do poder aristocrático. No quadro feito por Delfim Câmara em 1875, ele era a face pública do império. Muitas de suas roupas, e provavelmente o que vestia para posar para o pintor, vinha do alfaiate inglês Henry Poole, pois d. Pedro II havia visitado seu estabelecimento em 1871 , por ocasião de sua primeira visita à Inglaterra. ${ }^{47}$

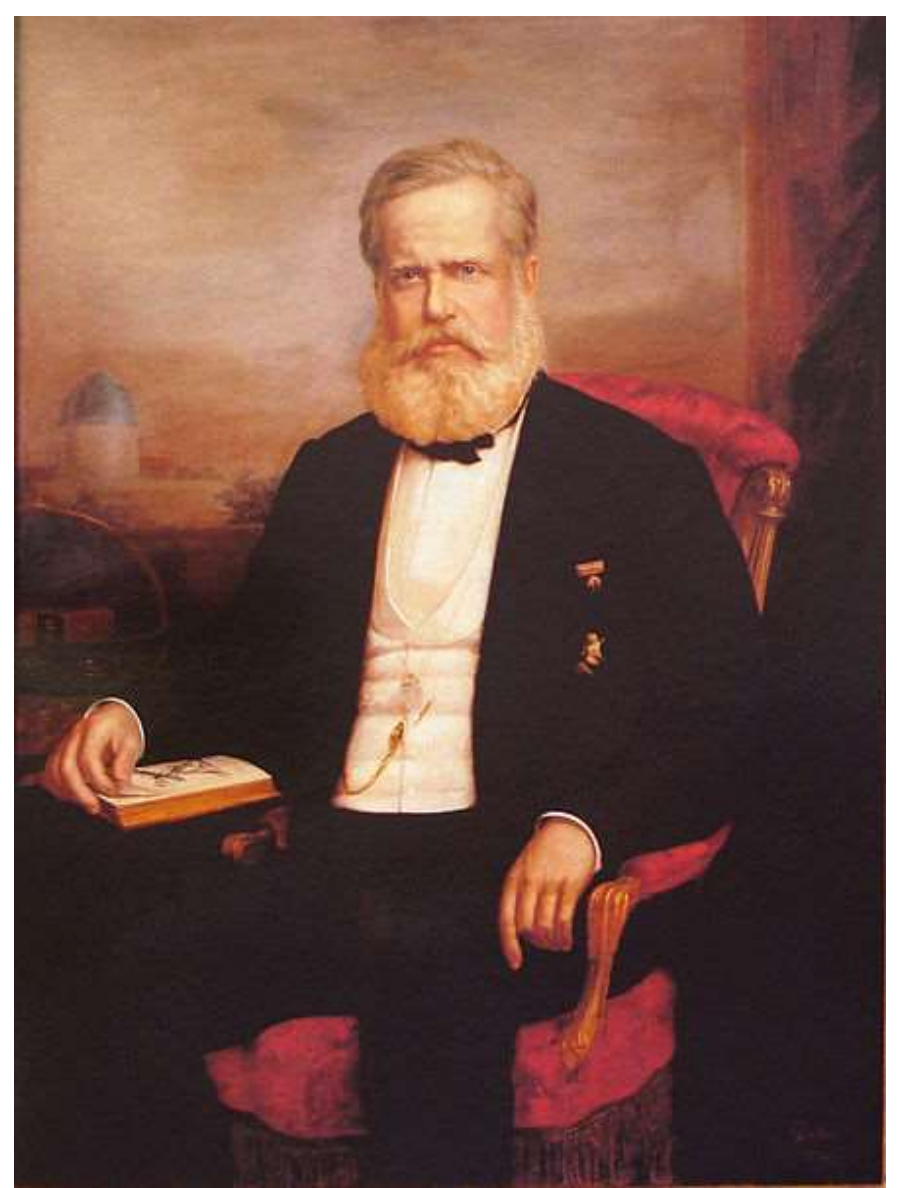

D. Pedro II, com 49 anos, em retrato de Delfim da Câmara de 1875: roupas de um imperador brasileiro pertencente à nobreza europeia ${ }^{48}$

Aberta em 1806, a firma de Henry Poole ganhou fama ao fazer os uniformes militares usados na batalha de Waterloo. Com o tempo, ganhou clientes aristocráticos de todo a Europa. Napoleão III usava as roupas de Poole, bem como Alberto de Saxe-

\footnotetext{
${ }^{47}$ Marcelo de Araújo. D. Pedro II e moda masculina na época vitoriana. São Paulo: Estação das Letras e cores, 2012, p. 25

${ }^{48}$ Retrato de d. Pedro II, feito por Delfim da Câmara em 1875. Óleo sobre tela, 127x95 cm, <http://www.museuhistoriconacional.com.br/>. Consulta 23/3/2013.
} 
Coburg e Gota, e Eduardo VII, respectivamente, marido e filho da rainha Vitoria. A casaca, as calças pretas, o fraque - uma moda que começou com os dândis - acabaram por se tornar a roupa da elite no século XIX. Na visita que fez a Poole, d. Pedro comprou 1 par de calças pretas, 2 casacas, 3 coletes de casimira, 4 pares de casacos de angola, 5 sobrecasacas de angola, 6 coletes de seda com gola, 8 coletes de seda sem gola e 9 calças de angola. ${ }^{49}$

No retrato acima, d. Pedro veste-se como um imperador de seu tempo, um representante à altura da casa de Bragança. Os símbolos de poder imperial estavam todos presentes no quadro: as roupas de acordo com a ocasião solene, as comendas, o livro, os acessórios elegante (o óculos repousado no livro e o relógio que pode ser percebido pela correntinha de ouro que sai do colete). Assim, num período de transição como aquele, em que os símbolos de uma sociedade de corte estavam se apagando e novos símbolos de poder estavam surgindo, a casaca e as calças pretas funcionavam como um atestado de classe.

No retrato reproduzido abaixo, vemos o príncipe Albert de Saxe-Coburg e Gotha (1819-1861), marido da rainha Vitória, vestido como um aristocrata do século XIX, numa roupa no meio do caminho entre um uniforme militar e a tradicional casaca e calças pretas. Da mesma maneira que d. Pedro II, Albert se colocava como um representante da aristocracia europeia. O preto das roupas se destacava e as cores ficavam por conta das comendas e ordens reais. Todos os símbolos do poder estão presentes no quadro: a pose, a espada, os tecidos vermelhos, os móveis dourados, os livros e papéis de Estado.

\footnotetext{
${ }^{49}$ Marcelo de Araújo. Dom Pedro II e a moda masculina na época vitoriana. São Paulo: Estação da Cores e Letras, 2012, p. 143.
} 


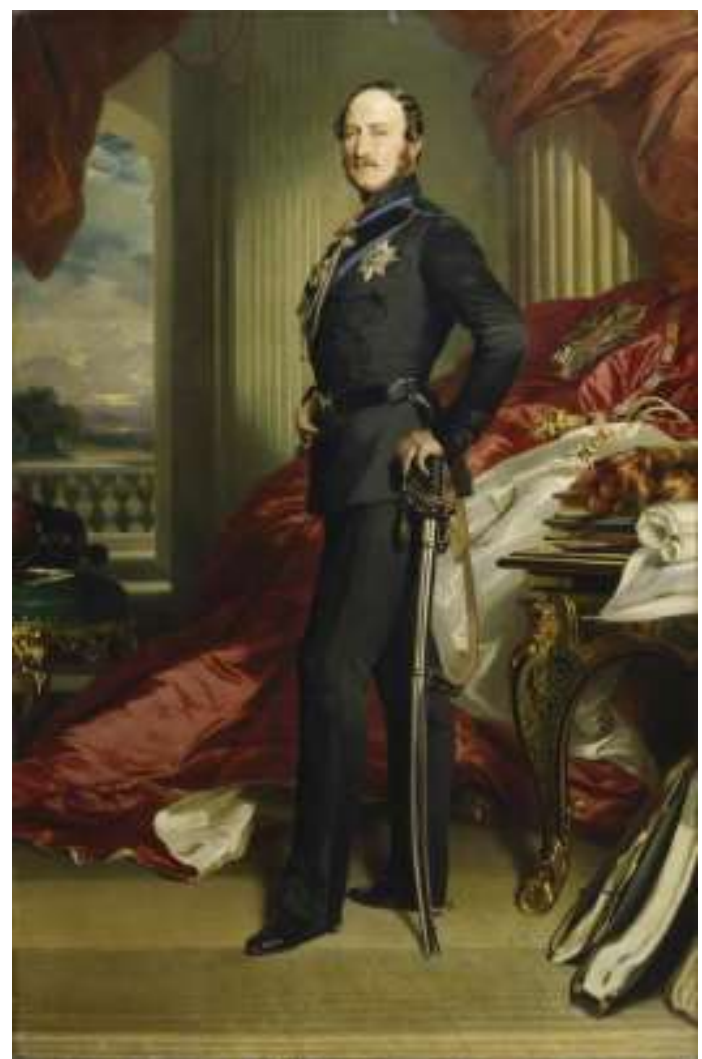

O príncipe Albert de Saxe-Coburg e Gotha marido da rainha Vitória, em quadro de Franz Xavier Winterhalter de $1867^{50}$

Outros reis vitorianos vestiam-se de forma semelhante - assim como marqueses, duques, barões e membros da aristocracia europeia. Mas uma nova classe social, a burguesia, também passou a se vestir desta forma. Ao longo do século XIX, ambas as classes, capitalistas e nobres, vão se misturar de tal forma que não se podia dizer, por um retrato ou pintura, quem era quem ou quem possuía o quê. O que era certo é que eles se diferenciavam brutalmente de outros homens - os comerciantes e os trabalhadores que usavam outro tipo de vestimenta. Aristocratas e capitalistas passaram a formar um grupo cada vez mais homogêneo e, de certa forma, internacional.

${ }^{50} \mathrm{O}$ quadro do princípe Alberto de Saxe-Coburg e Gotha foi pintado por Franz Xaver Winterhalter, que também fez retratos da nobreza e família real brasileira e de outras famílias nobre europeias. É um óleo sobre tela de $241.3 \times 156.8 \mathrm{~cm}$, dado ao príncipe pela rainha Vitória em 1867. Está atualmente na National Portrait Gallery, em Londres <http://archivecatalogue.npg.org.uk/Public/>. Consulta em 19/9/2013. 


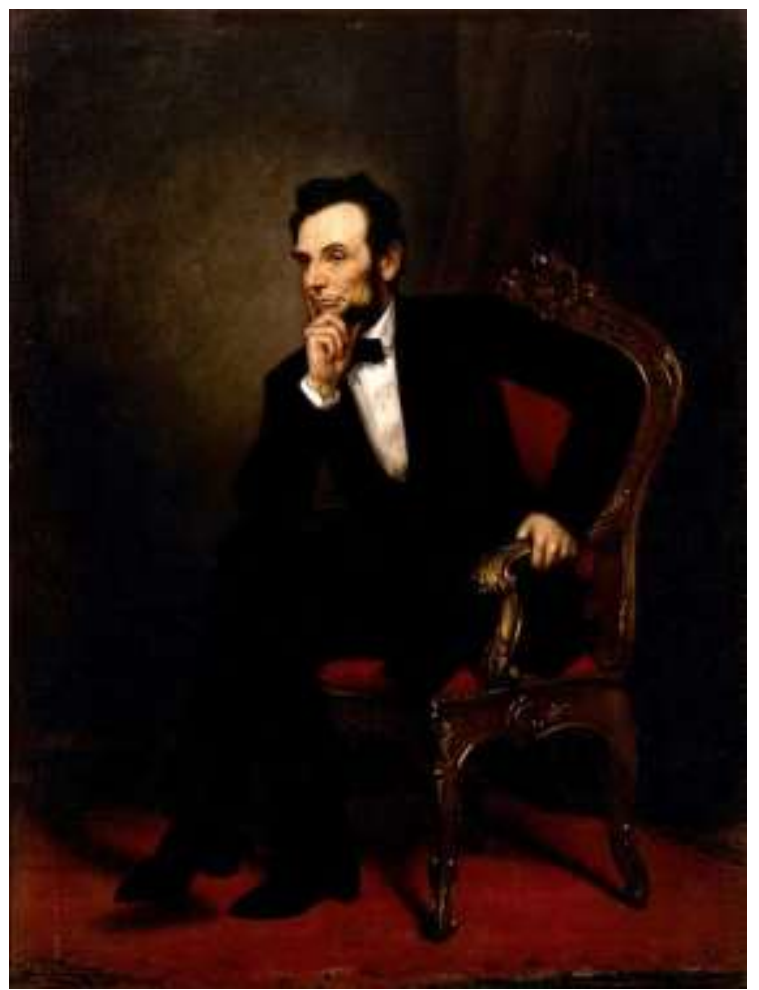

\footnotetext{
Abraham Lincoln posou em 1869 com casaca preta e camisa branca para George Peter Alexander Healy ${ }^{51}$
}

Em vários países, monarquias ou repúblicas, da Europa ou do Novo Mundo, vemos os membros da elite vestirem-se como dândis. Abraham Lincoln, presidente dos Estados Unidos, se vestia com calças pretas, camisa branca, gravata e calças pretas para o retrato oficial. O príncipe Albert de Saxe-Coburg-Gota, quarto filho da rainha Vitória, também está vestido de acordo com os padrões aristocráticos do século XIX, bem o como Napoleão III, de calças cinzas e casaca preta.

${ }^{51}$ O quadro “Abraham Lincoln” é um óleo sobre tela de George Peter Alexander Healy, de 1869, e está na sala de jantar da Casa Branca, nos Estados Unidos. Pertence ao Museu da Casa Branca $<$ http://www.whitehousehistory.org/whha_about/whitehouse_collection/whitehouse_collection-

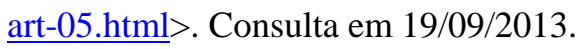




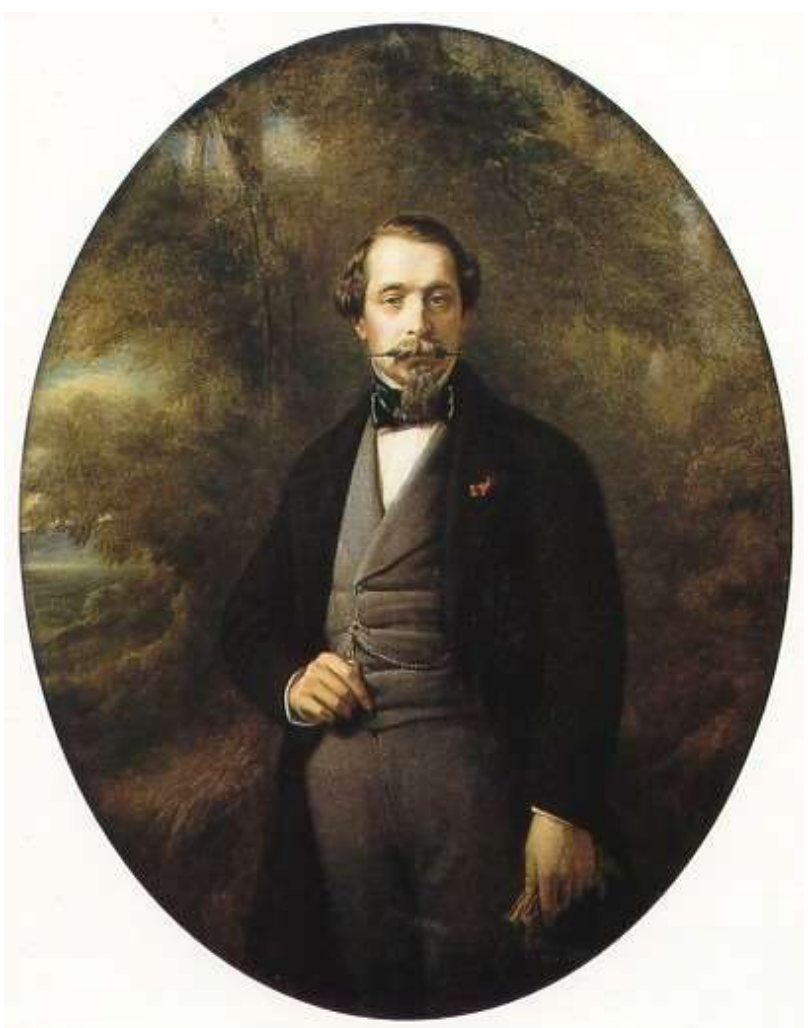

Carlos Luís Napoleão Bonaparte, Napoleão III usava casaca preta, coleta e calças cinza e uma gravata preta no quadro de Winterhalter ${ }^{52}$

Membros da pequena nobreza, ou ricos capitalistas, banqueiros e financiadores do Estado também usavam o mesmo tipo de vestimenta, tanto no dia a dia como em retratos oficiais. Franz Xavier Winterhalter (1805-1873) foi um dos pintores preferidos pela realeza europeia que também retratou membros da nobreza brasileira, como a princesa de Joinville, Francisca de Bragança, quarta filha de d. Pedro I. Quando se recupera os retratos que pintou, muitos reproduzidos aqui, vemos imagens tanto de homens como de mulheres, uma espécie de desfile da elite europeia. Ambos, estavam vestidos de acordo com sua posição social. No século XIX, a casaca, as calças e o preto haviam se tornado a roupa de elite para os homens, da mesma maneira que o século XVIII, as calças curtas e perucas brancas haviam diferenciado os nobres do resto da população. No quadro abaixo, Arthur Wellesley, duque de Wellington, conversa com sir

${ }^{52}$ Napoleão III em quadro de Franz Xaver Winterhalter, de 1857, auge do poder do império. È um óleo sobre tela, originalmente redondo, sem tamanho, e pertencente à coleção do Musée National du Château de Compiègne. 
Robert Peel e o que se destaca no quadro são as calças pretas ajustadas e as casacas, quase um uniforme obrigatório para os membros masculinos da elite do século XIX.

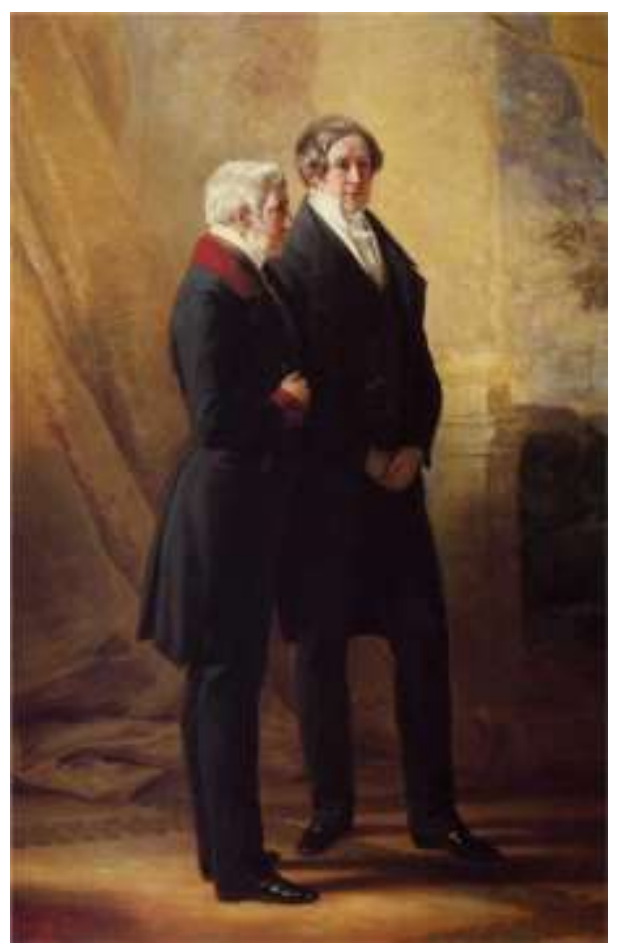

Arthur Wellesley, Duke of Wellington, com sir Robert Peel em retrato de Franz Xaver Winterhalter de $1844^{53}$

No Tratado da vida elegante, Balzac vai dizer que "o talento, o dinheiro e o poder conferindo os mesmos direitos, o homem aparentemente frágil e despojado que cumprimentais contrafeito com um ligeiro aceno de cabeça, logo estará no ápice do Estado, e aquele que saudais obsequiosamente voltará amanhã ao nada da fortuna sem poder" ${ }^{2}$. "Uma certa maneira de vestir-se anuncia uma certa esfera de nobreza e de bom gosto. Cada fortuna", completa o escritor francês, "tem sua base e seu cume". ${ }^{55}$ A maneira de se vestir, desta forma, traduzia a posição social momentânea de quem vestia

\footnotetext{
${ }^{53}$ Arthur Wellesley e sir Robert Peel. Óleo sobre tela de Franz Xaver Winterhalter, de 1844, com 97,8 x 149,5 cm, está Royal Collection, no castelo de Windsor Castle, na Inglaterra.

${ }^{54}$ Honoré de Balzac. "Tratado da vida elegante". In: Tomaz Tadeu (org). Baudelaire, Balzac e D’Aurevilly (escritos). Manual do dândi: a vida com estilo. Trad. port. Belo Horizonte: Autêntica, 2009, p. 69.

${ }^{55}$ Honoré de Balzac. "Tratado da vida elegante". In: Tomaz Tadeu (org). Baudelaire, Balzac e D'Aurevilly (escritos). Manual do dândi: a vida com estilo. Trad. port. Belo Horizonte: Autêntica, 2009, p. 69.
} 
determinada roupa. As oscilações de status da burguesias e sobrepunham à suposta lógica estável da aristocracia.

No Brasil, com uma nobreza sem tradição, riqueza e aristocracia se misturavam ainda mais. Vender títulos era um negócio do Estado - e fazia-se nobre quem podia ser rico. Uma lista de prováveis candidatos a um posto de nobreza era elaborada pelo Conselho de ministro do Império, com a ajuda dos presidentes de província e deputados influentes nos dois partidos da corte, o liberal e o conservador. ${ }^{56}$

O imperador podia escolher os candidatos a nobre algumas vezes por ano, geralmente no dia 2 de dezembro, seu aniversário, ou nos dias 14 de março, aniversário da imperatriz, ou 24 do mesmo mês, aniversário do juramento da Constituição de 1824. D. Pedro II, então, enviava por meio dos ministros, a "graça" ao escolhido que teria de pagar pelo título. Para um barão, a categoria mais baixa no império, eram $750 \$ 000$. Para um visconde 1:025\$000, para um conde 1:750\$000, para um marquês 2:020\$000 e para um duque, 2:450\$000. Mas os duques, no império, se limitaram a membros da família real, como a condessa de Iguaçu, filha bastarda de d. Pedro I, ou ao duque de Caxias, pelo que fez na Guerra do Paraguai. Todos os títulos tinham de pagar os papéis para a petição, $366 \$ 000$, e o registro do brasão, $170 \$ 000 .{ }^{57}$ Desta forma, o império encheu-se barões, que ajudavam a legitimar o poder de d. Pedro II, ao mesmo tempo em que se tornavam nobres e financiavam os gastos do Estado.

“A baronia sofria um exame prévio, que definia a habilitação para o ingresso no estamento, com a inspecção acaso escrupulosa ao tempo de d. Pedro II, em que não se desprezavam os padrões de moralidade convencional", escreveu Raimundo Faoro em

\footnotetext{
${ }^{56}$ Raimundo Faoro. Machado de Assis, a pirâmide e o trapézio. São Paulo: Globo, 2001, p. 43-45.

${ }^{57}$ Os dados se referem a abril 1860. Ver Stanley Stein. Grandeza de decadência do café. Trad. port. São Paulo: Brasiliense, 1961, p. 295 e 296.
} 
Machado de Assis, a pirâmide e o trapézio. ${ }^{58}$ Esse exame incluía não apenas o nível de riqueza da família, mas a maneira como se comportava o candidato, quais suas relações sociais e como se enquadrava no espectro político do império. ”Dom Pedro estabeleceu certas normas para a concessão de títulos. Aos estadistas do reino anterior, envelhecidos no serviço público, fez marqueses; viscondes, aos presidentes do Supremo Tribunal de Justiça; aos mais distintos comandantes da Guarda Nacional, barões. Só foram duques, os príncipes de sangue: abriu honrosa exceção para o marquês de Caxias, ao regressar, vitorioso, do Paraguai". 59

Se o diletantismo elegante dos dândis como Horácio podia chocar jornalistas com uma crescente moral burguesa, como a cronista do Jornal das Senhoras, a riqueza perfeita, no segundo reinado, seria a originária de herança ou de ganho na loteria. Ter trabalhado com profissões que exigiam esforço e suor para enriquecer era mal vista. A nobreza demandava uma maneira de viver decorrente de rendimentos altos. Afinal, os candidatos a barões deviam usufruir de uma renda adequada ao seu pretendido novo status social.

Porque os títulos não importavam vantagens materiais, porém exigiam adequado tratamento: só poderiam usá-los, portanto, nas classes sociais, os potentados: poucos comerciantes (Mauá, Meriti, Itamarati, Bonfim..); na sua maioria, os fazendeiros; e políticos, militares, professores, mesmo homens de letras (Araguaia, Taunay, Porto Seguro, Paranapiacaba, Ramiz, Macaúbas, Santo Angelo...) - os expoentes, os notáveis. ${ }^{60}$

Viver e portar-se adequadamente em sociedade era essencial à aristocracia do segundo reinado. Assim, os títulos de nobreza brasileiros, com seus estranhos nomes

\footnotetext{
${ }^{58}$ Raimundo Faoro. Machado de Assis, a pirâmide e o trapézio. São Paulo: Globo, 2001, p. 44.

${ }^{59}$ Raimundo Faoro. Machado de Assis, a pirâmide e o trapézio. São Paulo: Globo, 2001, p. 44.

${ }^{60}$ Raimundo Faoro. Machado de Assis, a pirâmide e o trapézio. São Paulo: Globo, 2001, p. 44.
} 
indígenas referentes a acidentes geográficos - como os barões de Aguapeí, de Buruju, de Carapebus, de Guararapes, o Itapororoca, de Itapiruma ou de Jeremoabo, para ficarmos em apenas alguns exemplos -, vestiam-se com o rigor da moda europeia, de casaca e calças pretas, colete e gravata (que podia ser preta ou branca) e impecável camisa branca.

$\mathrm{Na}$ imagem pintada por Jean Baptiste Borely (c. 1815- c.1880), pintor francês radicado no Brasil, vemos o barão de são João da Barra, José Alves Rangel (17791855), vestido como um membro da aristocracia: calças pretas, casaca preta, coleta e camisa branca e gravata preta. Na lapela, suas comendas bastante visíveis e o tradicional relógio de bolso. O quadro foi, provavelmente, encomendado depois que ele ganhou o título de "barão" pelo decreto de 25 de março de 1849.

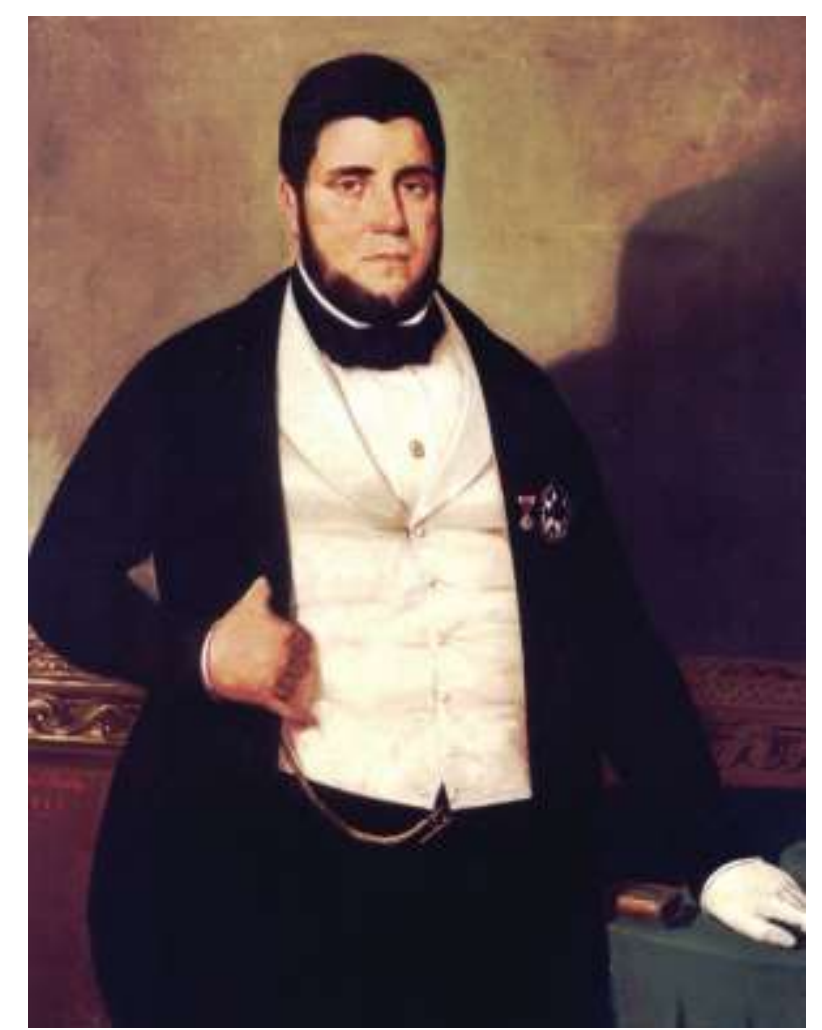

Retrato do barão são João da Barra, José Alves Rangel, em 1853, feito por Jean Baptista Borely ${ }^{61}$

${ }^{61}$ Retrato do Barão são João da Barra em 1853, feito por J. Baptista Borely. Óleo sobre tela. (114,7 X 86,0 cm). Coleção "Museus do Estado do Rio de Janeiro". 
No império, os títulos eram individuais e não transferíveis, então era preciso recomprovar a legitimidade e a "honra" da família se os descendentes do titulado quisessem também usufir do privilégio. Formavam-se, dessa forma, uma espécie de “clã" familiar de nobres. Foi o que aconteceu com José Alves Rangel, cujo filho Francisco José Alves Rangel (?- 1892) também recebeu o título de barão, em 24 de março de 1881 , e de visconde em $1882 .^{62}$

A ideia de clã de nobres também esteve presente na família do conde de Imaratai, Francisco José da Rocha Leão (1806-1883), cujo pai, homônimo, rico comerciante luso-português, também havia sido barão. No quadro abaixo, Francisco José da Rocha Leão, o filho, pousa a mão em uma cadeira, enquanto segura uma luva branca com a outra. Em suas roupas, a representação típica de um homem muito rico no século XIX, nas mesmas casaca e calças pretas, com camisa branca e gravata preta. Afinal, o conde de Itamarati foi um grande capitalista e proprietário rural do império, além de ter sido um coronel-comandante da Guarda Nacional da Corte, um membro ativo da Junta Administrativa da Caixa de Amortização, da Caixa Econômica e um sócio fundador do Imperial Instituto de Agricultra. "Não bastava ser rico, fazendeiro ou comerciante, para obter a baronia, nem essa era consequência daquele estado [...] do fazendeiro, fazia um fazendeiro do império, do comerciante, um comerciante do império.” Francisco José da Rocha Leão era um dos grandes do império, que trabalhou com afinco para o imperador.

O quadro foi pintado por François Claudius Compte-Calix (1813-1880), pintor francês, discípulo de Claude Bonnefond, que se tornou um dos favoritos da nobreza francesa do período da "mornarquia de julho", sob a regência de turbulenta de Luis Felipe I. Compte-Calix, que nasceu e estou em Lyon, usava temas do século XVIII para

\footnotetext{
${ }^{62}$ Raimundo Faoro. Machado de Assis, a pirâmide e o trapézio. São Paulo: Globo, 2001, p. 45.
} 
montar suas composições no ateliê que mantinha em Paris. O conde deve ter encomendado o quadro na década de 1850, quando ganhou título de segundo barão, em 25 de março de 1854 , e inaugurou seu belo palacete, em $1859 .{ }^{63}$

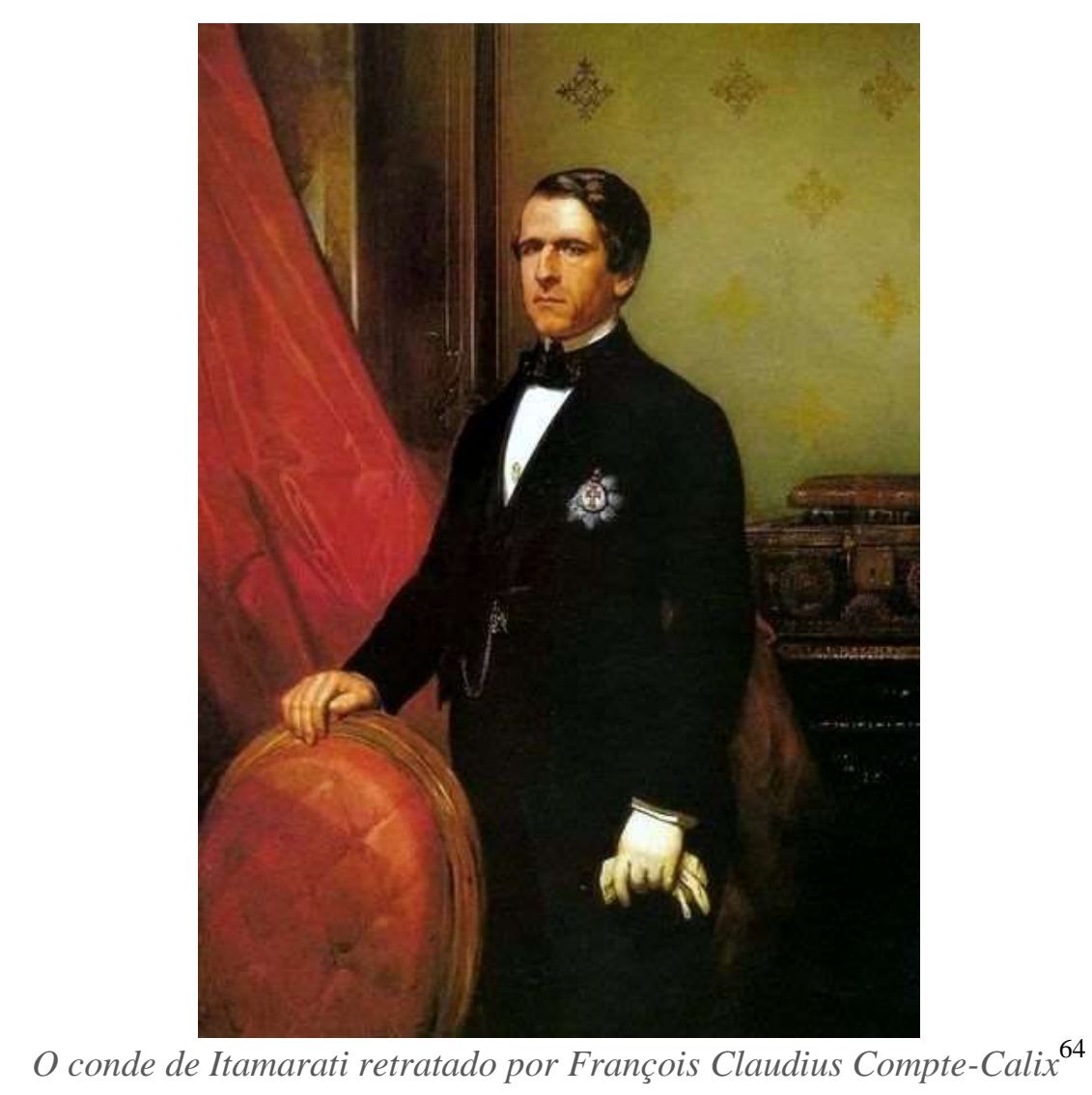

Algumas vezes empresários alcançavam uma posição de destaque na sociedade e eram premiados com títulos e comendas. Era o caso do Irineu Evangelista de Souza (1813-1889). Mauá foi o responsável pela implantação da primeira fundição de ferro e estaleiro no país, pela construção da primeira ferrovia brasileira (quando ganhou o título de barão), pela estrada de ferro Mauá, no Rio de Janeiro, pelo início da exploração com

${ }^{63}$ A casa, em estilo neoclássico, ficava na rua Marechal Floriano e era conhecida como "Palácio Itamarati”. Foi construída por José Maria Jacinto Rebelo, discípulo de Grandjean de Montigny (1776-1850), arquiteto francês radicado no Brasil desde os tempos de d. João VI. Nos primeiros anos da república, quando o Rio ainda era capital, o palácio do conde de Itamarati serviu de sede da presidência e depois como sede para o Ministério das Relações Exteriores.

${ }^{64}$ Óleo sobre tela, de François Claudius Compte-Calix, que se encontra no Museu Histórico e Diplomático (Palácio do Itamaraty). $144 \times 105 \mathrm{~cm}$. 
barcos a vapor tanto do rio Amazonas como o do Guaíba, no Rio Grande do Sul, pela instalação da iluminação pública a gás no Rio, pela a criação do primeiro banco privado do Brasil e pela a instalação do cabo submarino telegráfico entre a América do Sul e a Europa.

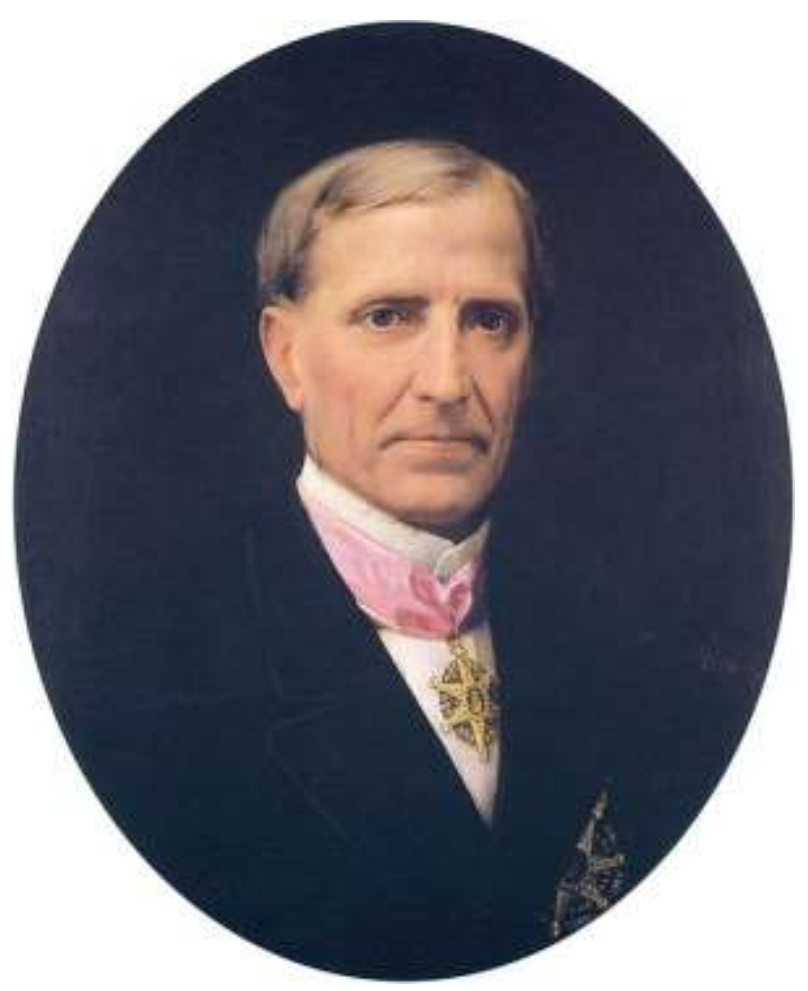

Irineu Evangelista de Souza, o barão e depois visconde de Mauá, c. $1872^{65}$

O visconde de Mauá foi o capitalista brasileiro que teve a maior atuação nas décadas de 1850, 1860 e 1870. Seu banco Banco Mauá, MacGregor \& Cia faliu em 1878, pouco depois dele se tornar visconde em junho de 1874. Ele foi pintado pelo pintor francês Édouard Viénot ${ }^{66}$, que fora nomeado o "retratista e fornecedor da Casa Imperial", através do alvará de 20 de agosto de 1869. No quadro, vemos o barão, Irineu

${ }^{65}$ O quadro de Édouard Viénot de cerca de 1872, sem tamanho. Reproduzido do livro de Antonio Candido. Um Funcionário da Monarquia: ensaio sobre o segundo escalão. Rio de Janeiro: Ouro Sobre Azul, 2002, p. 114.

${ }^{66}$ Viénot mantinha um ateliê em Paris. 
Evangelista de Souza, usar a comenda da Imperial Ordem da Rosa ${ }^{67}$ no lugar da gravata e um fraque preto com camisa branca. Provava, com a roupa cuidadosamente escolhida, que fazia parte dos grandes do império. ${ }^{68} \mathrm{E}$ mostrava que, com o título de barão, em 1854, e depois o de visconde, em 1874, entrava definitivamente para a política. E, para os homens do império, a verdade estava na vida polítca. ${ }^{69}$

“A ação de Mauá junto ao Banco do Brasil estava intimamente ligada à política econômica de Souza Franco. Analisando as mudanças dos Estatutos [do banco do Brasil], propostas por Mauá e seu grupo, ficou clara a necessidade de controlar o Banco do Brasil, visando auxiliar a política econômica do ministro da fazenda, que beneficiaria o próprio Mauá” ${ }^{70}$ Outros, como Mauá, fizeram parte da conturbada vida política do império, misturando negócios pessoais e de Estado. Jerônimo José de Mesquita (18261886), conde de Mesquita, mandou fazer este retrato por ocasião do recebimento de seu título de conde, 1885. Ele foi vereador do Rio de Janeiro e também diretor do Banco do Brasil. Foi também comendador da Imperial Odem da Rosa, da Imperial Ordem de Cristo e da Real Ordem de Nossa Senhora da Conceição de Vila Viçosa. No retrato baixo, aparece com a Imperial Ordem de Cristo. ${ }^{71}$

${ }^{67}$ A Imperial Ordem da Rosa foi criada por d. Pedro I em homenagem a um vestido da imperatriz Amélia quando esta chegou ao Brasil. Era uam das maiores honrarias oferecidas pelo império.

${ }^{68}$ Sobre Mauá ver o excelente estudo de Carlos Gabriel Guimarães, A presença inglesa nas finanças e no comércio no Brasil imperial: os casos da Sociedade bancária Mauá, MacGregor \& Cia(1854-1866) e da firma inglesa Samuel Phillips \& Cia (1808-1840). São Paulo: Alameda Casa Editorial, 2012.

${ }^{69}$ Raimundo Faoro. Machado de Assis, a pirâmide e o trapézio. São Paulo: Globo, 2001, p. 129.

${ }^{70}$ Carlos Gabriel Guimarães, A presença inglesa nas finanças e no comércio no Brasil imperial: os casos da Sociedade bancária Mauá, MacGregor \& Cia(1854-1866) e da firma inglesa Samuel Phillips \& Cia (1808-1840). São Paulo: Alameda Casa Editorial, 2012, 188.

${ }^{71}$ Carlos Gabriel Guimarães, A presença inglesa nas finanças e no comércio no Brasil imperial: os casos da Sociedade bancária Mauá, MacGregor \& Cia(1854-1866) e da firma inglesa Samuel Phillips \& Cia (1808-1840). São Paulo: Alameda Casa Editorial, 2012, 188, p. 145. 


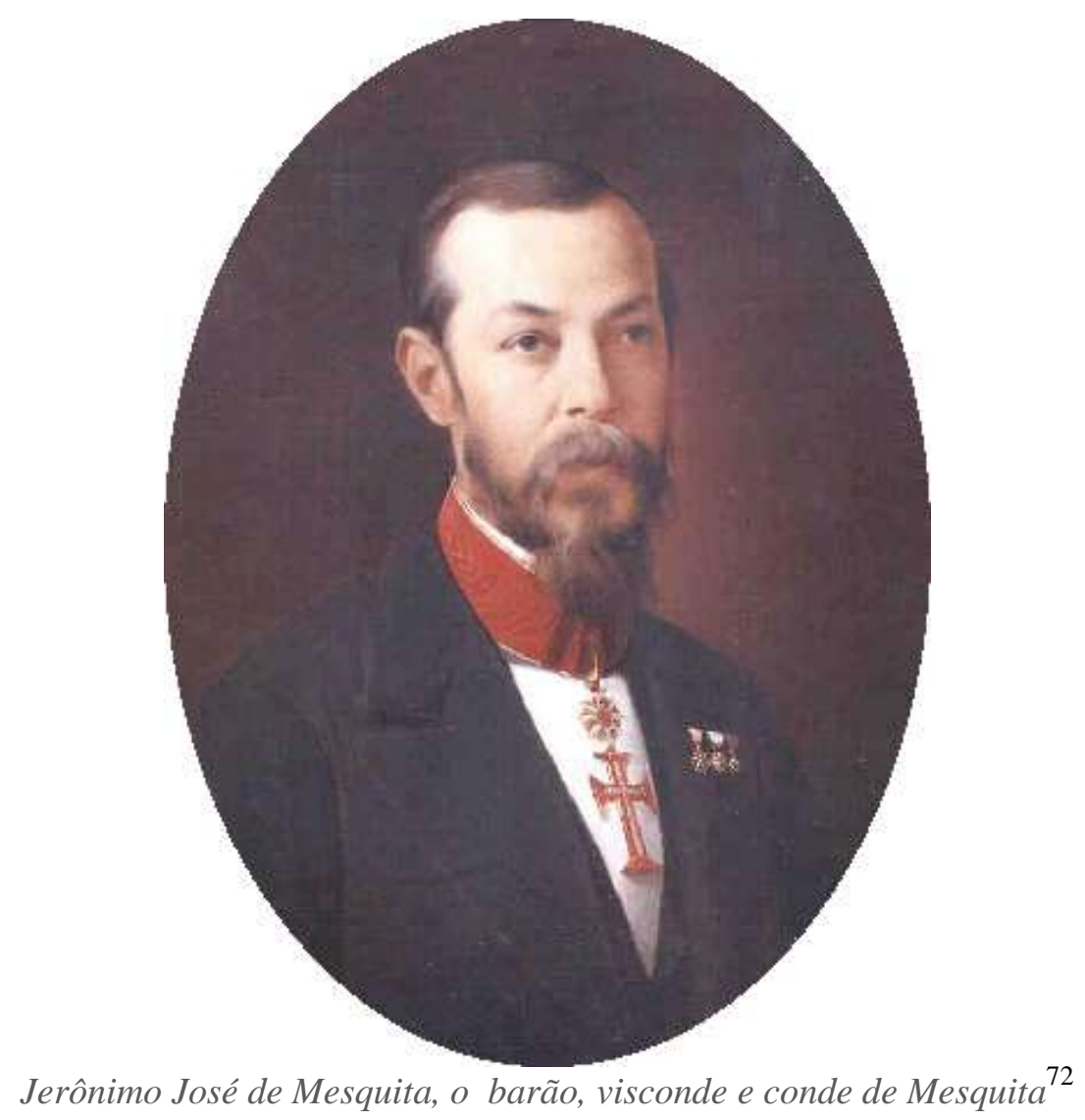

A política era inevitável para quem queria brilhar nos salões do império - ela servia tanto para garantir a fortuna da família, como para multiplicá-la e deixar os herdeiros em boa posição. Política e nobreza se entrelaçavam, e brilhavam nos salões e bailes do império. Fazer-se retratar por pintores da moda, como Viénot, Winterhalter ou Emílio Bausch, era fundamentel para provar-se pertencedor a um círculo social rico e aristocrático. Vestir-se e postar-se de acordo com a ocasião também.

Os barões do império tinham fazendas de café no vale do Paraíba. Vassouras, Bananal, Piraí foram cidades importantes, que nasceram à sombra ou deram origiem a títulos nobiliárquicos. Mas, ainda que as fazendas de café fossem a base da economia cafeeira do segundo império, era para corte no Rio de Janeiro, que convergia toda vida econômica do império.

72 Óleo sobre tela, pintado por Décio Vilares, em 1888, sem tamanho disponível, coleção particular

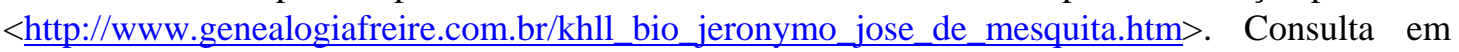
$19 / 9 / 2013$. 
À semelhança de Paris e Londres, o Rio era a cidade mais importante - o lugar das festas, dos saraus, das nomeações de títulos, do dinheiro acumulado por agentes resultante da venda do café no exterior. Era o lugar onde títulos eram ganhos com a bajulação ao imperador, fortunas eram feitas com planos de urnabização e reformas, o lugar do comércio elegante - era, enfim, o objeto de desejo dos que queriam subir na vida, o lugar dos vícios, do lucro e das fortunas fáceis.

\section{Os militares valsam entre os palácios da cidade e as fazendas do Vale do Paraíba}

Calças brancas eram muito populares no Brasil no século XIX. Mostravam asseio e riqueza, já que tinham de ser mantidas sempre bem limpas e aliviavam o calor. "O Freitas [...] no seu grande colarinho em pé. Não relaxava as calças brancas, e gabava-se do segredo de conservá-las limpas e engomadas $^{73}$ durante uma semana: trazia sempre, apesar do calor da província, o colarinho duro e o peito da camisa irrepreensível; gravata preta $[\ldots]$ invariavelmente $[\ldots]$ Usava sapatos rasos, de polimento $[\ldots]^{\prime, 74}$

Machado de Assis, em Dom Casmurro, também vai descrever o uso de calças brancas. "Levantou-se para ir buscar o gamão [...] e vi-o passar com as suas calças brancas engomadas, presilhas, rodaque e gravata de mola [...]. Trazia as calças curtas para que lhe ficassem bem esticadas. A gravata de cetim preto, com um aro de aço por dentro, imobilizava-lhe o pescoço; era então moda. O rodaque de chita, veste caseira e leve, parecia nele uma casaca de cerimônia. ${ }^{75}$

Em A condessa de Vésper, de Aluísio Azevedo, um personagem veste calças brancas e exibe sua riqueza pela sala: “[...] ela, porém, não o podia ver nas suas

\footnotetext{
${ }^{73}$ Grifo meu.

${ }^{74}$ Aluísio Azevedo. O Mulato. São Paulo: Martins Editora/ Instituto Nacional do Livro/ MEC, 1975. p. 85.

${ }^{75}$ Joaquim Maria Machado de Assis. Dom Casmurro. São Paulo: Editora Ática, 1974. p. 11.
} 
invariáveis calças brancas, casaco sem coletes, a camisa carregada de brilhantes, o farol ao dedo e o charutão ao canto da boca $[. ..]{ }^{76}{ }^{76}$ No Jornal das Senhoras a cronista acha perfeitamente aceitável o uso de paletó claro e chapéu branco por um moço elegante: “O paletó claro e o chapéu branco revela, em todo, o seu bem talhado e agradável vestuário, a elegância a o bom gosto do moço sem afetações". 77

Mas os barões, os conselheiros e comendadores, com suas calças brancas cuidadosamente engomadas ou seus conjuntos de calças e casacas pretas, não fecham o círculo da aristocracia do segundo reinado. "Há a base o cimento de toda a ordem administrativa, política e social, que a Guarda Nacional corporifica e simboliza". ${ }^{79} \mathrm{O}$ segundo império parece, de certa maneira, obcecado por feitos militares - e a guerra do Paraguai corporifica esse sentimento. Dos 123.000 soldados que foram para a guerra, 59.669 seriam provenientes da Guarda Nacional. ${ }^{80}$ Também foi importante para fomentar esse "sentimento" militar a grande quantidade de motins e revoltas que estouraram ou longo do império, todos combatidos pela Guarda Nacional. ${ }^{81}$

Esse sentimento militar, que era mais forte na capital do império, o Rio de Janeiro, traduzia-se em romances - como o de Manuel Antonio de Almeida, Memórias de um soldado de milícias, ou em contos, como, entre muitos de Machado de Assis, "O espelho", sobre o alferes João - ou nas roupas dos homens. Vestir-se de militar, ou com roupas militares, era comum entre a nobreza e a elite. Deixavam-se retratar em grandes quadros a óleo, com medalhas e comendas que demonstravam poder.

\footnotetext{
${ }^{76}$ Aluísio Azevedo. A Condessa Vésper. São Paulo: Martins Editora/ Instituto Nacional do Livro (MEC), 1973. p. 334.

77 Jornal das Senhoras, 2 de outubro de 1853.

${ }^{78}$ Raimundo Faoro. Machado de Assis, a pirâmide e o trapézio. São Paulo: Globo, 2001, p. 48.

${ }^{79}$ Idem Ibidem.

${ }^{80}$ Francisco Doratitioto. Maldita guerra: nova história da guerra do Paraguai. São Paulo: Companhia das Letras, 2002, p. 456-471.

81 Monica Duarte Dantas (org.). Revoltas, motins e revoluções. São Paulo: Alameda Casa Editorial, 2011.
} 
Foi o que fez Hermeto Carneiro Leão (1801- 1856) no quadro de Emílio Bausch reproduzido a seguir. Eleito em 1830 para representar Minas Gerais na Assembleia Geral Legislativa, onde ficou até 1841, Hermeto foi um dos fundadores do "partido da maioria" ou "partido majoritário", durante a regência, em 1837, e que mais tarde se transformaria no partido conservador. Foi eleito presidente da província do Rio de Janeiro, senador, e presidente do conselho de ministro pela primeira em 1843. Desentendeu-se com o imperador e foi enviado a Pernambuco para investigar a Revolução Praieira. Voltou ao Rio e foi, em 1853, mais uma vez nomeado presidente do conselho de ministros com o "Gabinete da Conciliação". Havia, afinal, se tornado o político mais poderoso do país. Hermeto morreu logo depois, em setembro de 1856, de uma febre súbita, no auge da carreira. ${ }^{82}$

No quadro de 1856, o ano de sua morte, vemos o político orgulhoso de seus feitos políticos em Pernambuco. Altivo, usava uma casaca militar azul escura, bordada em dourado, com golas altas, comendas no peito, uma faixa vermelha, luvas, chapéu e calças brancas. Sua mão esquerda brinca com um botão dourado, enquanto a direita segura firme um chapéu com as insígnias do império.

${ }^{82}$ Monica Duarte Dantas (org.). Revoltas, motins e revoluções. São Paulo: Alameda Casa Editorial, 2011, p. 355-391. E veja também o livro de Fernando da Cruz Gouvea. Marques de Paraná, o traço todo do concialiador. Recife: Editora Universitária da UFPE, 2009. 


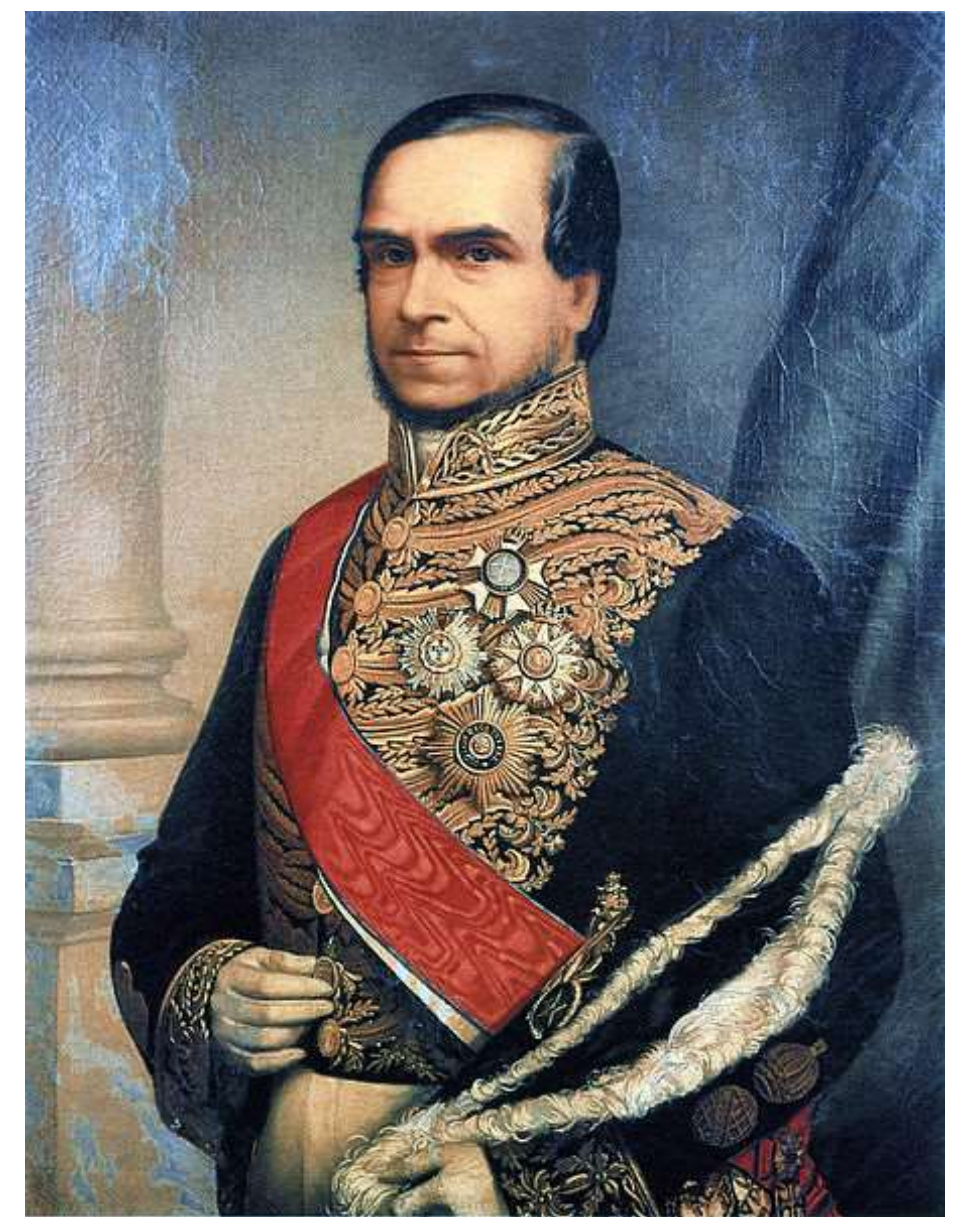

Honório Hermeto Carneiro Leão, marquês do Paraná, em 1856, retratado por Emílio Bauch ${ }^{83}$

Os uniformes militares eram também usados em ocasiões sociais, como bailes, jantares e reuniões. Eram coloridos, com casacas que podiam ser verdes, azuis, vermelhas, bordôs, cinzas ou pretas - todas enfeitadas com galões e comendas douradas, geralmente bordadas a ouro. As comendas, que aparecem nos quadros, podiam ser encontradas em joalherias como a de Carlos Valais, joalheiro de d. Pedro II, que tinha loja na rua do Ouvidor, n. 81.

${ }^{83}$ Honório Hermeto Carneiro Leão, marquês of Paraná, c.1855, retratado por Emílio Bauch. É um óleo sobre tela, $0.95 \mathrm{~m}$ x $0.75 \mathrm{~m}$. O quadro está no Instituto Histórico e Geográfico. Essa foi uma reprodução do livro de Antonio Candido. Um funcionário da monarquia: ensaio sobre segundo escalão. Rio de Janeiro: Ouro sobre azul, 2002, p. 56. 


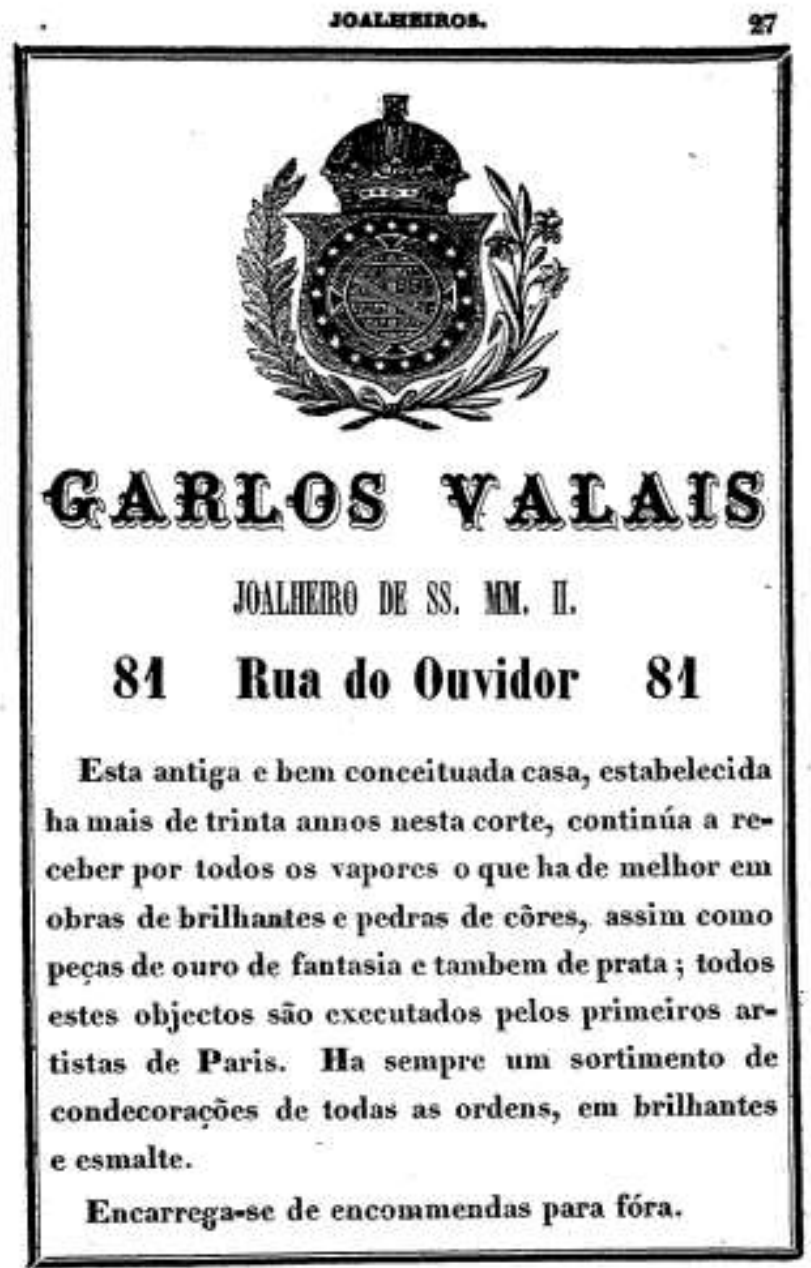

Anúncio da joalheria de Carlos Valais publicado no Almanaque Laemmert de $1862^{84}$

Já as casacas militares e seus galões podiam ser encomendados ou comprados em casas como a de Firmino de Azevedo Alvez, na rua do Cano, n. 41, que se encarregava “de aprontar uniformes para aramada, exercito e guarda nacional com a maior prontidão e nitidez." "Nesta casa", dizia o anúncio, “aprontavam-se também mantos de cavalheiros de todas as ordens". Encontravam-se também toda sorte de galões dourados e prateados, canotilhas e lantejoulas de ouro para bordar. ${ }^{85}$

\footnotetext{
${ }^{84}$ Almanaque Laemmert de 1862, p. 27.

${ }^{85}$ Almanaque Laemmert de 1862, p. 65.
} 


\section{h1-RUA DO CANO-41 \\ ㅍ1KIITO D’EZ카표DO AIV포

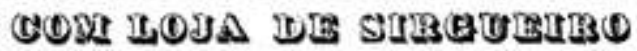 \\ bincarnega-se: de apromptar uniformes para a armacta, exercito e guarda} narional, coun a maior prosuptidẫo e uitilez. Nesta casis su: apromptâo tambem manlos de cavallicifo de todas as ordens.

Encontror-se-ha sempre sortimento de gatöes de ouro e prata finos e entrelinos, canotllihos, lentejoulias e fins de ouro para bordar, bem como sedas de córes en carreteis, lins, cintos de matha de seda e cidarco, citapíos do pagens e ate marialneirox, ditus de pallsa do Chile, lonira, lebre, wleados de côres e pretos para mesas, etc.

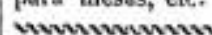

\section{BRAZ JOSE PAIA}

morador deboixo do passadien a teharia do Pax'o da cidade, encarrega-se de toda e qualquer funceão para a cidade $e$ firs della, fornecendo o servieo necossario, e incumbinulo-se da direccāis e cxecuctio de qualquer irabalho que se oflereça pertencente s cópa, crinina e gelados; para saraos, bailes, jantares, bufets, etc., etc. Assezura is pessoas que o quixcrem hourar ean a sua confisnca um perfeito desempenho, e a maior moderaçie possivel nos prescos.

Incumbe-se igualmente de apromptar em sua easa de morada qualquer encommenda arulsa por mais pequena que seja, e de remettè-la i casa das pessoas que : fixrem, $\mathrm{cm}$ qualquer los pontos desta cidade e sens sulurbios.

Escusado é dizer-se que o $\mathrm{Sr}$. Braz José Maia é um dos mais habeis cozinheiros e copeiros que temos nesta capital, por ser ha mais de vinte annos bem conbecido do respeitavel publico : reunindo ainda mais a vantagem le ser nm excellente mestre sorveteiro. N. daR.

witน

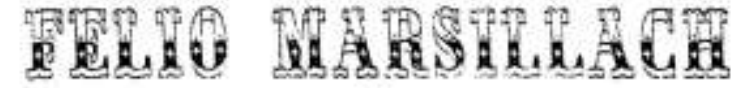
$\cos 3$ ESTALEIRO DE CONSTRLCÇ̃̃O NAVAL 102-RUA DA SAUDE-102

Estabelecimento completo de tedo quanto é necessario as fabrico o reqaro de vavios.

Neste grande estabelecimento ha um variado e completo sortimento de madeiras de todas as qualiblades, principalmente mastros de paroba e pinho, de todas as grossuras c comprimentos: igualmente ver guntas de pinho de todas as qualidades, prunchöes $\mathrm{c}$ taboas de pinho da Suecia e Riga de toda a grossura e comprimento, etc, ett.

Ha sempre neste estabelerimento earpinteiros e calafates promptos us ordens dos freguexes a maís pessoas que sc dirijão a elle.

62 $\mathrm{N}-5$

Anúncio do Almanaque Laemmert: tudo para uniformes militares ${ }^{86}$

${ }^{86}$ Almanaque Laemmert de 1862, p. 65 


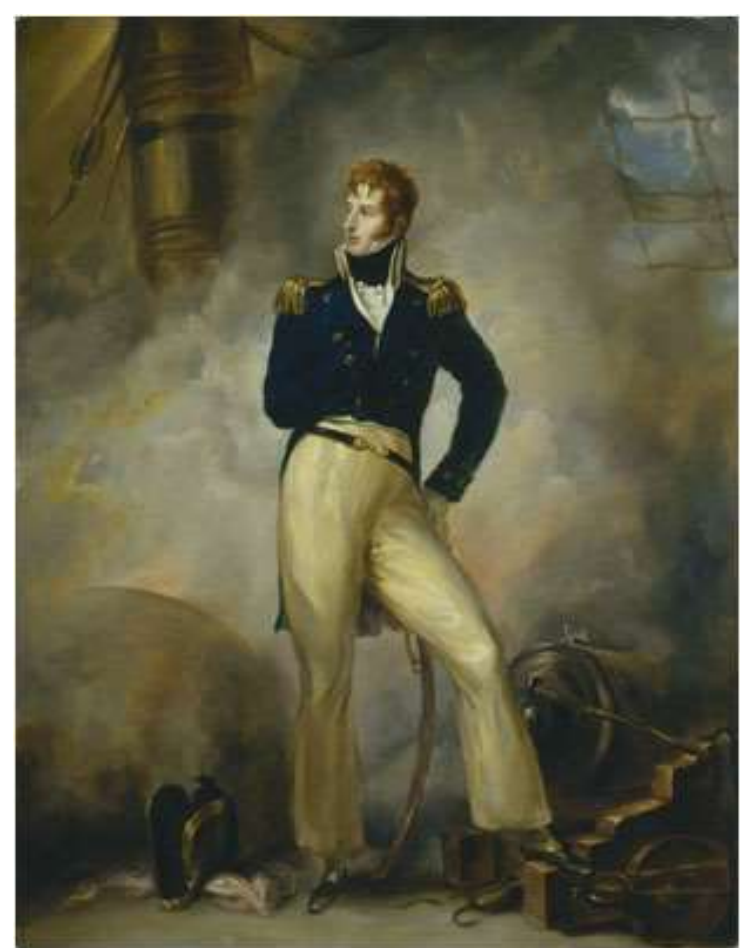

Retrato de Thomas Cochrane em 1807: uso de roupas de marinheiro se tornou comum ao longo do século XIX ${ }^{87}$

Podemos ver uniformes militares sendo usados desde o começo do século XIX e por toda a Europa. Thomas Cochrane (1775-1860) foi um oficial escocês, o décimo conde de Dundonald, que ajudou a formar a marinha brasilera depois da independência. Depois de combater as tropas de Napoleão com sucesso, Cochrane se afastou da marinha britânica e engajou-se uma série batalhas em países latino-americanos que buscavam a independência, como o Chile e o Brasil. Era uma espécie de corsário, contratado pelos governos para cuidar de navios e das guerras de independência. Pela sua atuação durante os eventos que ocorrem após 1822, d. Pedro I transformou-o no primeiro marquês do Maranhão.

No retrato reproduzido acima, vemos Thomas Cochrane vestido como um marinheiro, com calças brancas, jaqueta azul, gravata azul, espada e camisa branca. "A

\footnotetext{
${ }^{87}$ Óleo sobre tela de Peter Edward Stroehing. Dimensões: 0, 91m x 0,71m. O quadro está guadado no arquivo nacional inglês, que foi consultado em 10/4/2013, no site <http://webarchive.nationalarchives.gov.uk/+/http://www.gac.culture.gov.uk/search/Object.asp?ob ject_key=12178>. Consulta em 19/9/2013.
} 
moda do preto só começará em 1840 mais ou menos, devido a Bulwer Lytton e aos escritores românticos. Ela vai alastrar-se mesmo pela gravata, e o homem se cobrirá de luto até o advento do esporte, que de novo introduz as cores claras", escreveu Gilda de Mello e Souza. Contudo, isso nem sempre era verdade.

Usados em todas as ocasiões, tanto no dia a dia como em eventos sociais, e das mais diversas maneiras, tanto em fardas mais simples e como elegantes trajes de general, os uniformes militares eram coloridos. No século XIX, os uniformes militares apenas começavam a se diferenciar das roupas civis do cotidiano. Eram, em geral, a mesma roupa do dia a dia, acrescida de botões e outras insígnias indicativas de prestígio. "Mas é importante notar que as fardas de d. Pedro II eram basicamente casacas ás quais se acrescentavam ornamentos diversos, como por exemplo, dragonas, bordaduras, galões, talim, botões especiais, etc." ${ }^{88} \mathrm{O}$ mesmo acontecia com os outros homens.

As vestes militares possuíam várias cores, combinadas com calças brancas e sobrecasacas coloridas dependendo da patente do militar, bordadas e acrescida de símbolos os mais diversos. Durante a Guerra do Paraguai, entre 1864 e 1870, vestir-se com uniformes militares estava na ordem do dia. Na litogravura reproduzida abaixo vemos um soldado e um oficial com seus uniformes de guerra. O soldado vestia um jaleco de trabalhador azul, com uma espécie de boné com abas grandes, e cintos para prender os apetrechos e uma mochila. Já o oficial vestia uma espécie de sobrecasaca azul, com uma dobra vermelha (o forro?), galões nos ombros, calças brancas, cinto preto e botas.

\footnotetext{
${ }^{88}$ Marcelo de Araújo. Dom Pedro II e a moda moderna na época moderna. São Paulo: Estação das Letras, 2012, p. 25.
} 


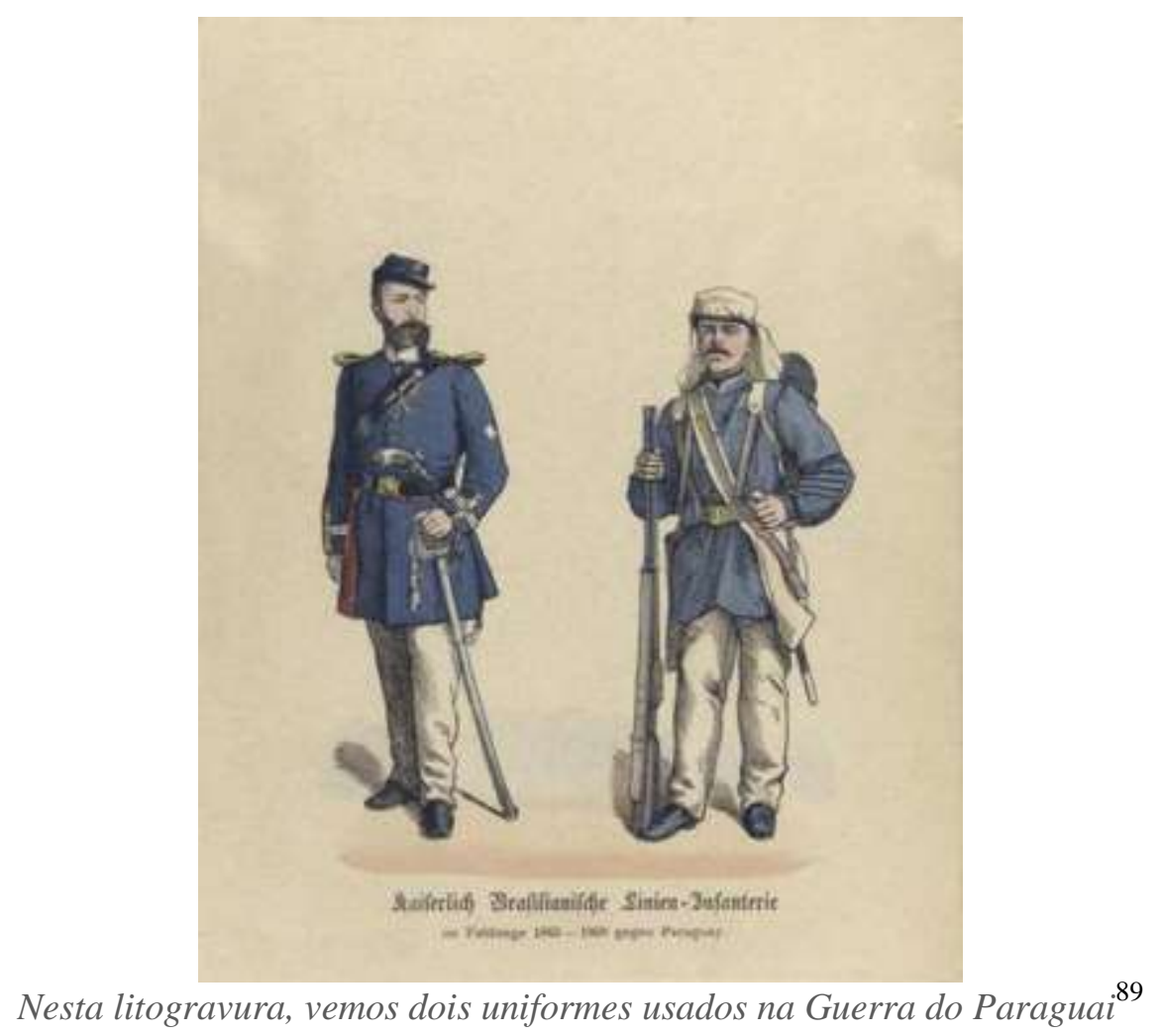

Evidentemente esses uniformes eram os uniformes ideais, e o cotidiano da guerra fazia com que os homens e suas roupas se apresentassem de maneira diferente: eram sujos, mal cortados, nem todos tinham roupas adequadas etc. Mas as cores apareciam claramente. $\mathrm{O}$ azul, o vermelho e branco estavam presente nessas roupas.

${ }^{89}$ A litogravura está no Vinkhuijzen book of military uniform, de Hendrik Jacobus Vinkhuijzen, publicado pela primeira vez na Alemnaha e data de 1867. O livro digitalizado pela Biblioteca de Nova York e a coleção inteira de imagens de uniformes militares está disponível no endereço $<$ http://digitalgallery.nypl.org/nypldigital/dgkeysearchresult.cfm?keyword=Hendrik+Jacobus+Vin khuijzen+Brazil>. Consulta 10/4/2013. 


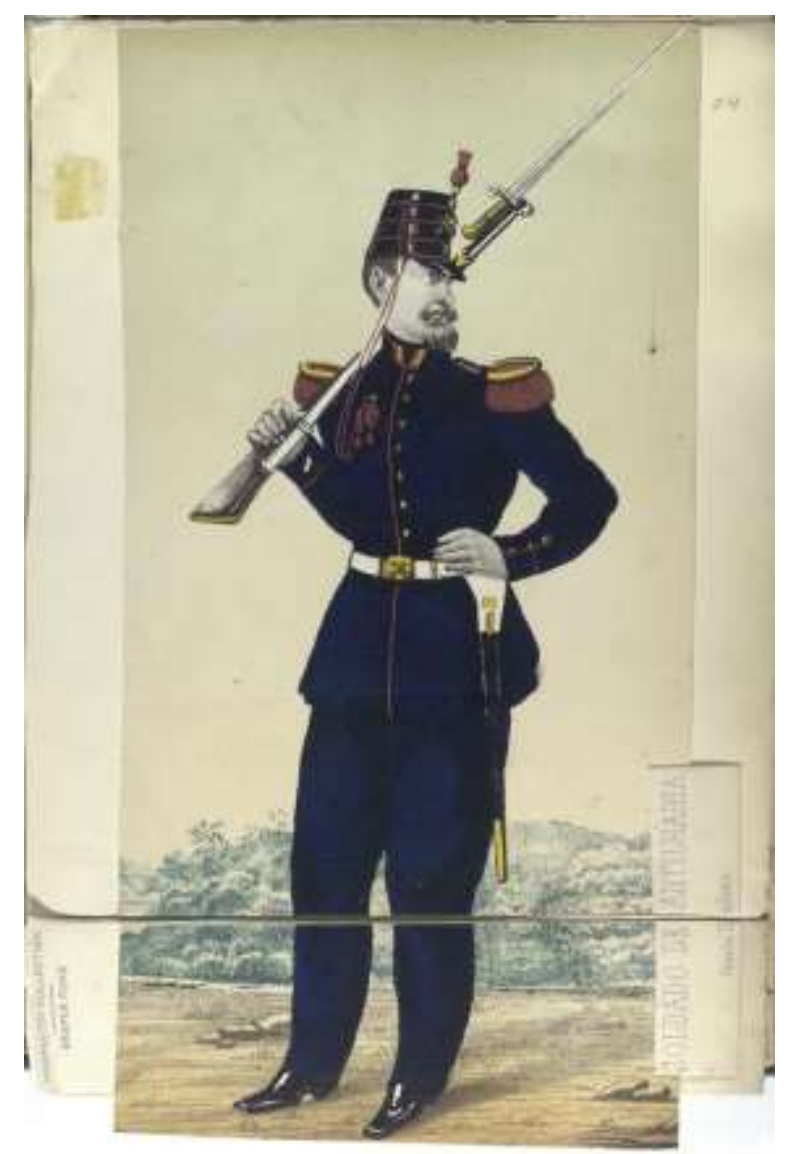

Soldado de artilharia em grande uniforme na Guerra do Paraguai ${ }^{90}$

A nobreza, afinal, gostava de lembrar seu passado ligado aos feitos militares, e deixar-se retratar com uniformes militares passava a ideia de poder e dominação, tão caros à famílias reais europeias em busca de legitimidade política ao longo de todo o século XIX. ${ }^{91}$ O príncipe Albert, da Inglaterra, marido da rainha Vitória, em diversas ocasiões vestia-se com uniformes militares. No quadro abaixo vemos um uniforme azul escuro, com botões e comendas douradas e saindo do pescoço enrolado numa gravata preta, uma gravata, uma medalha vermelha. $\mathrm{Na}$ altura do peito direito, outra condecoração, em prata e dourado. Uma camisa branca aparece sutilmente nas mangas

${ }^{90}$ Litogravura de Hendrik Jacobus Vinkhuijzen, no livro no Vinkhuijzen book of military uniform Site da Biblioteca Pública de Nova York. Consulta 13/4/20013.

$<$ http://digitalgallery.nypl.org/nypldigital/dgkeysearchdetail.cfm?trg=1\&strucID=120816\&imageI $\mathrm{D}=83985 \&$ total $=31 \&$ num $=0$ \&word $=$ Hendrik $\% 20 \mathrm{Jacobus} \% 20$ Vinkhuijzen $\% 20 \mathrm{Brazil} \& \mathrm{~s}=1 \&$ notw ord $=\& \mathrm{~d}=\& \mathrm{c}=\& \mathrm{f}=\& \mathrm{k}=1 \& \mathrm{lWord}=\& \mathrm{lField}=\& \mathrm{sS}$ cope $=\& \mathrm{sLevel}=\& \mathrm{sLabel}=\&$ sort $=\& i m g \mathrm{~s}=20 \& p o s=1$ $0 \& \mathrm{e}=\mathrm{W}>$. Consulta em 19/9/2013.

${ }^{91}$ Eric Hobsbawn. A era do capital, 1848-1875. São Paulo: Paz e Terra, 1986, p. 221-239. 
da casaca. Toda a atitude do príncipe no retrato revelava altivez, segurança e um rígido porte militar, já sua mão direita segura a espada com bastante evidência. É desse período os atendados contra a vida da rainha, o de 1840 e o de 1842 , em que ambos andavam de charrete quando foram quase atingidos pelas balas. Ao controlar a situação, Albert se tornou cada vez mais popular entre os súditos e o quadro mostra a segurança e o seu crescente poder na corte. ${ }^{92}$

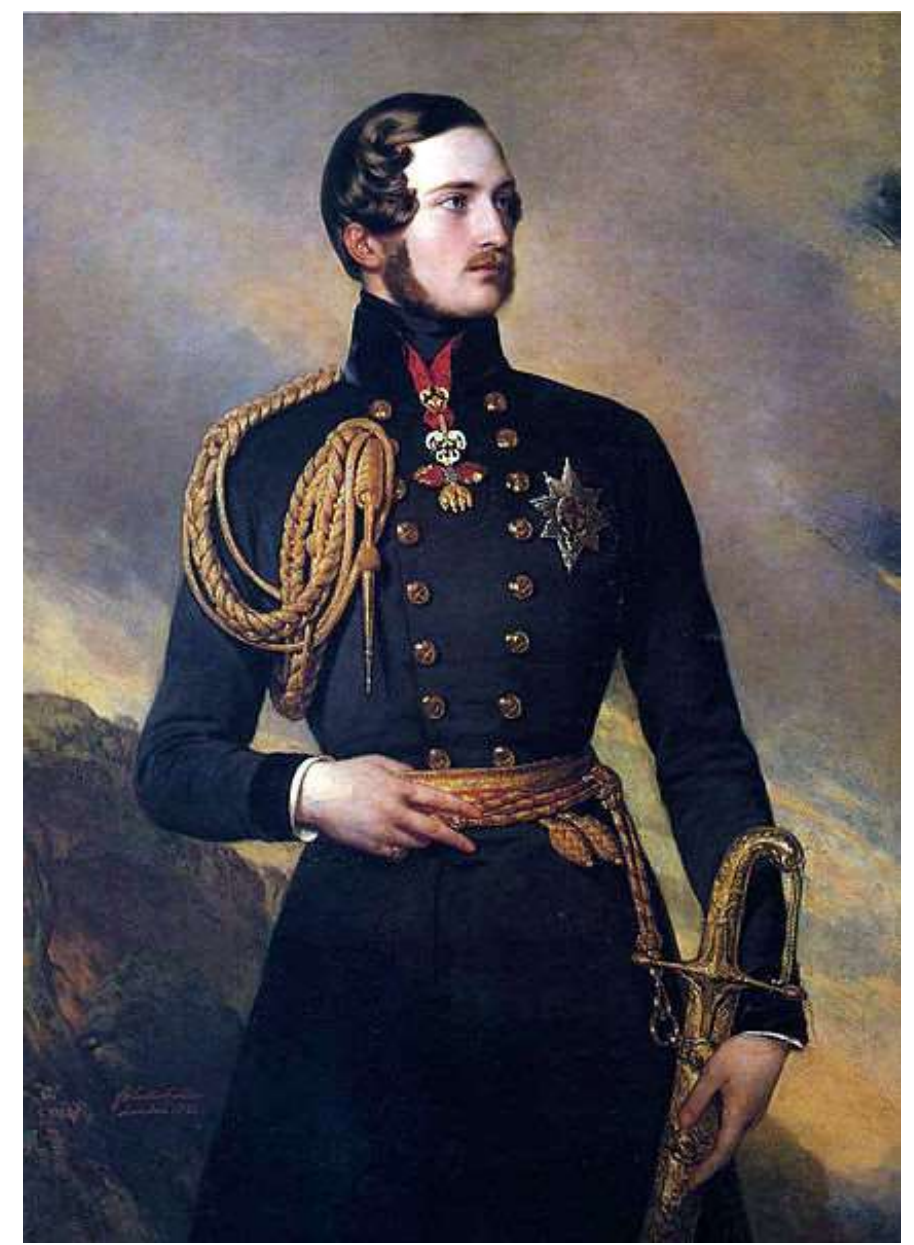

Princípe Alberto de Saxe-Coburg Gota em retrato de Franz Winterhalter em $1842^{93}$

${ }^{92}$ Christopher Hilbert. Queen Victoria: a personal history. Nova York, Peguin, 1997.

93 O retrato é um óleo sobre tela de 132.7 x $97.2 \mathrm{~cm}$ e está Royal Collection $<\mathrm{http} / / / \mathrm{www}$.royalcollection.org.uk/eGallery/object.asp?maker=12557\&object=401412\&row $=1 \&$ detail=about $>$. Consulta em 19/9/2013. 
D. Pedro deixou retratar-se diversas vezes ao longo da vida época em uniformes militares. Quando tinha 12 anos, já estava com casaca preta, galões dourados, faixa azul, calças brancas, luva e espada na mão direta. Uma comenda substituía a gravata e ele ainda portava uma joia com pedras azuis e fita vermelha, o Tosão de Ouro, e no peito, a comenda da Grã-Cruz do Cruzeiro. Todo o conjunto mostrava um menino claramente mais velho, calmo e compenetrado, pronto para assumir o poder. O conjunto final fica bastante colorido e realça as qualidades tanto militares como aristocráticas do futuro imperador. $^{94}$

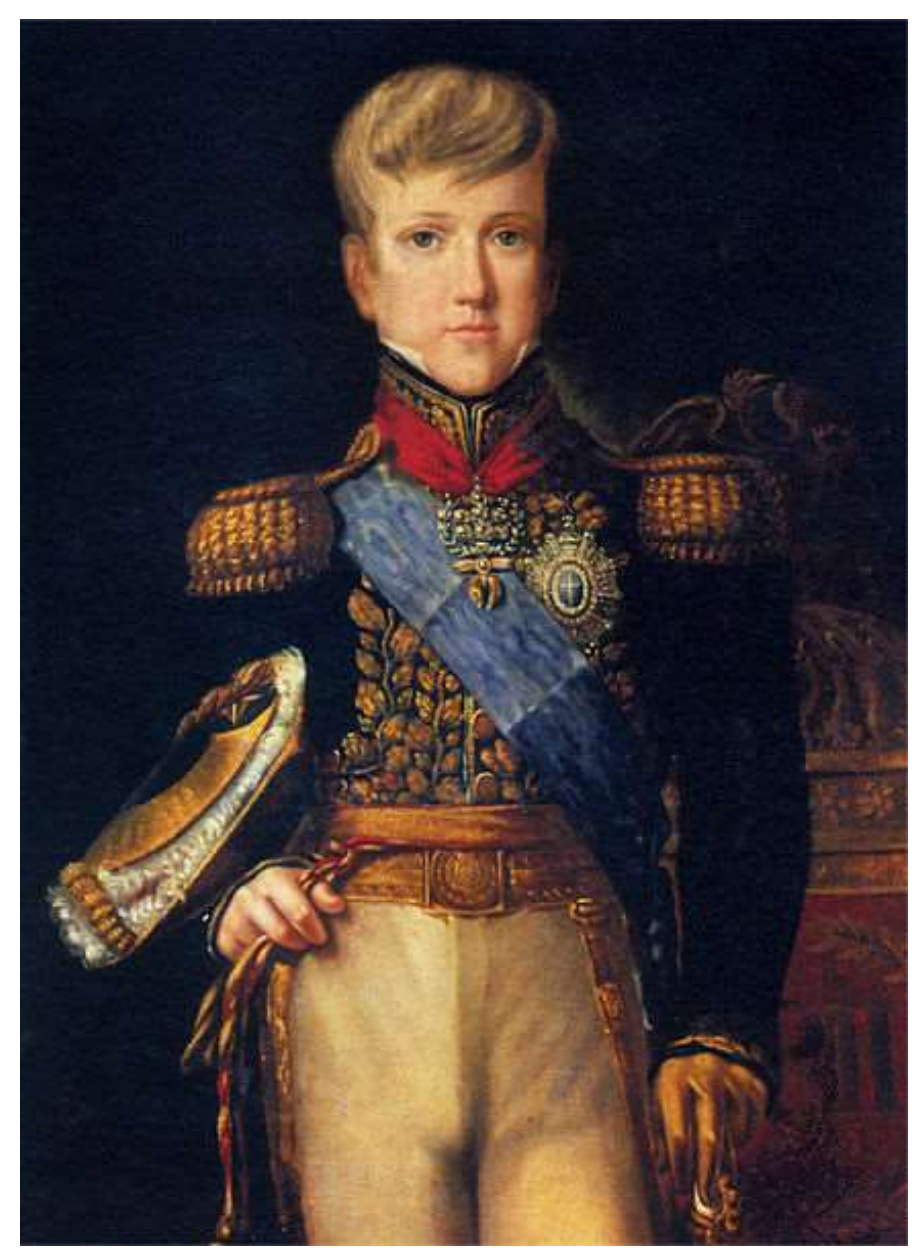

D. Pedro II veste uniforme militar aos 12 anos, em 1837, retratado por Félix Émile Taunay ${ }^{95}$

94 Lilia Moritz Scwarcz. As barbas do imperador: d. Pedro II, um monarca nos trópicos (São Paulo: Companhia das Letras, 1998, p.118-120.

95 O quadro, um óleo sobre tela, é de Félix Émile Taunay, com $90 \times 66 \mathrm{~cm}$. Está no Museu Imperial em Petrópolis. Esta reprodução foi tirada do livro de Lilia Moritz Scwarcz. As barbas do 


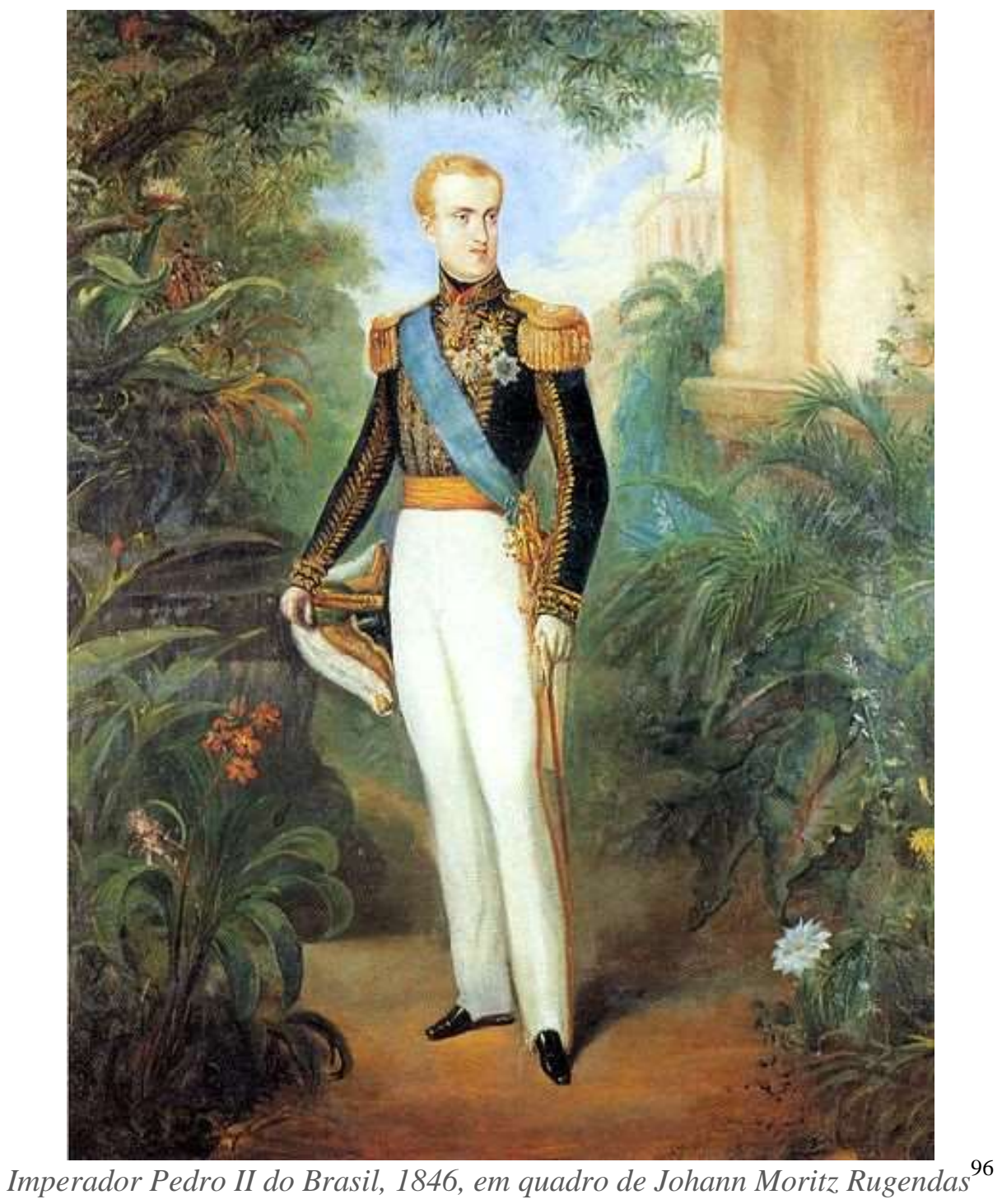

Alto e plenamente desenvolvido, d. Pedro II aparece no quadro de Rugendas quase que com as mesmas roupas usadas aos 12 anos. Já tinha 20 anos e estava casado, provavelmente com um filho, o princípe Afonso (1845-1847), já nascido e outro a caminho, com a princesa Isabel (1846-1921). Na época, ele viria a enfrentar uma das

imperador: d. Pedro II, um monarca nos trópicos (São Paulo: Companhia das Letras, 1998, caderno de imagens).

${ }^{96}$ Este quadro de Rugendas é um óleo sobre tela, retirado do livro de Pablo Diener, Maria de Fátima da Costa. Rugendas e o Brasil. São Paulo: Capivara, 2002. 
muitas crises de seu longo império, o problema do tráfico negreiro e a revolução praieira, de $1848 .^{97}$

Mais velho, e às vésperas da Guerra do Paraguai, no quadro reproduzido abaixo, d. Pedro estava com 39 anos. No quadro de Vitor Meireles, vemos as representações usuais com as quais o imperador gostava de se ver retratado: o globo e os livros, os quadros e os bustos de mármore. No uniforme de gala, a casa preta está ricamente bordada com fios de ouro, até as calças brancas apresentam um bordado dourado, um cinto destaca-se na cintura, as comendas estão todas no peito e as faixas com os símbolos do poder imperial ficam em primeiro plano.

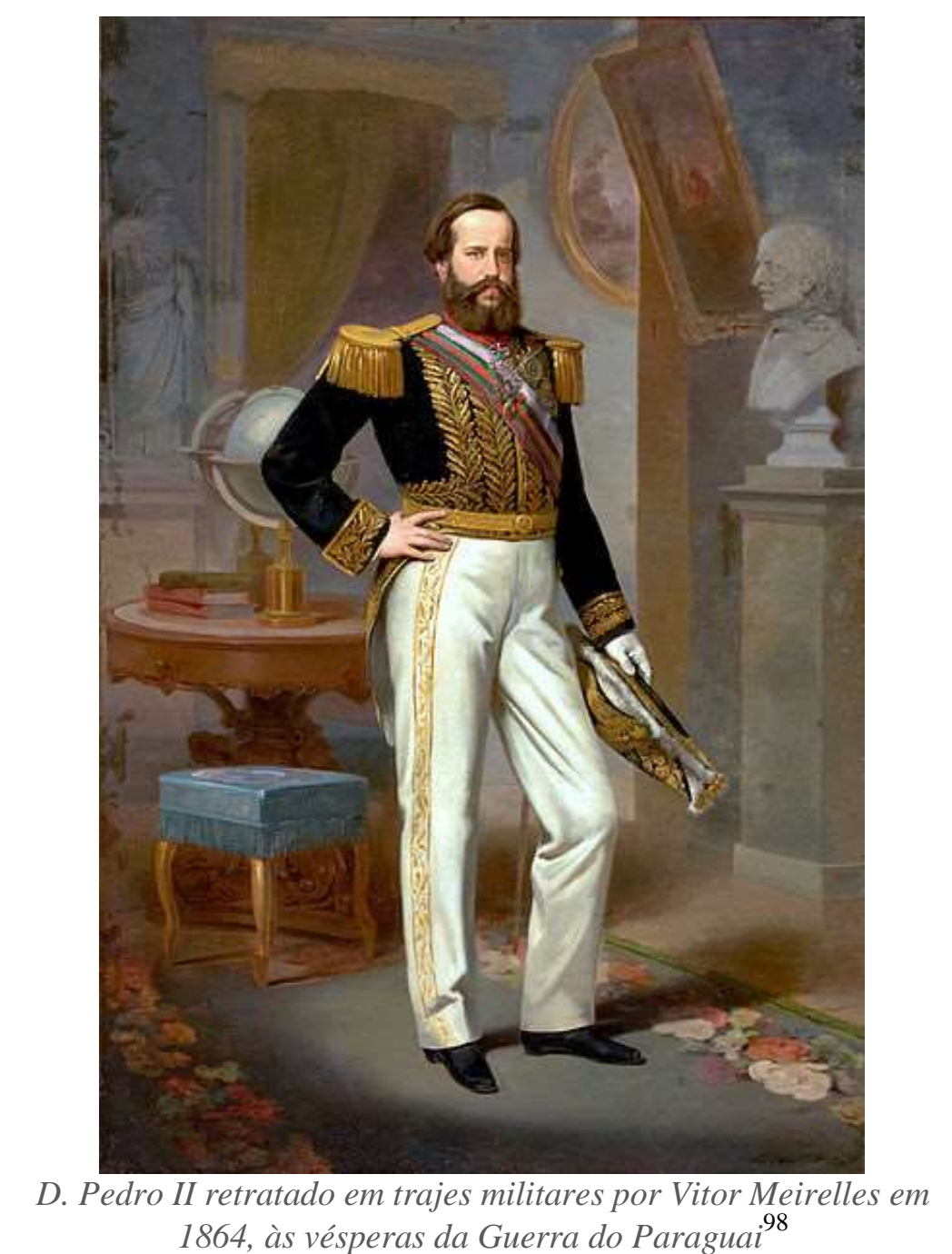

${ }^{97}$ Sobre as revoltas no Império, ver o livro de Monica Duarte Dantas (org.). Revoltas, motins $e$ revoluções. São Paulo: Alameda Casa Editorial, 2011. 
Olhando fixamente para o espectador, d. Pedro parecia um homem com uma missão. Mas ele pagou um preço caro pela guerra. Dívidas que se acumulavam desde a Independência, cresceram com a conflagração da guerra. Tímido por natureza, depois do Paraguai, d. Pedro não quis mais nem saber de bailes - e os jantares no paço de São Cristóvão passaram a se limitar à canja usual.

"Mais é ainda um palaciano, um amigo do imperador e sua família, o visconde de Taunay, quem testemunha: São Cristóvão foi sempre um paço triste e severo: e a morado não da alegria, mas do dever sereno e vigilante". 99 Depois da guerra, podemos ver d. Pedro na fotografia a seguir de Joaquim Insley Pacheco. O Brasil saíra vitorioso do Paraguai, mas a um preço alto. ${ }^{100} \mathrm{Na}$ foto os símbolos do poder desapareceram, à exceção de um vaso com flores do campo. O chão do estúdio parecia estar sujo ou desgastado, com o tapete manchado. Mesmo num retrato "oficial", o imperador mostrava-se gordo, com a casaca de almirante aberta, as pernas cruzadas num atitude extremamente informal, com um olhar vago...

${ }^{98}$ Óleo sobre tela de Vitor Meirelles, com $252 \times 165 \mathrm{~cm}$, que está no Museu de Arte de São Paulo (Masp), <http://www.masp.art.br/>, consulta em 23/09/2013.

${ }^{99}$ Wanderley Pinho. Salões e damas do segundo império. São Paulo: Martins Editora, 1970, p. 143.

${ }^{100}$ Francisco Doratitioto. Maldita guerra: nova história da guerra do Paraguai. São Paulo: Companhia das Letras, 2002, p. 456-471 


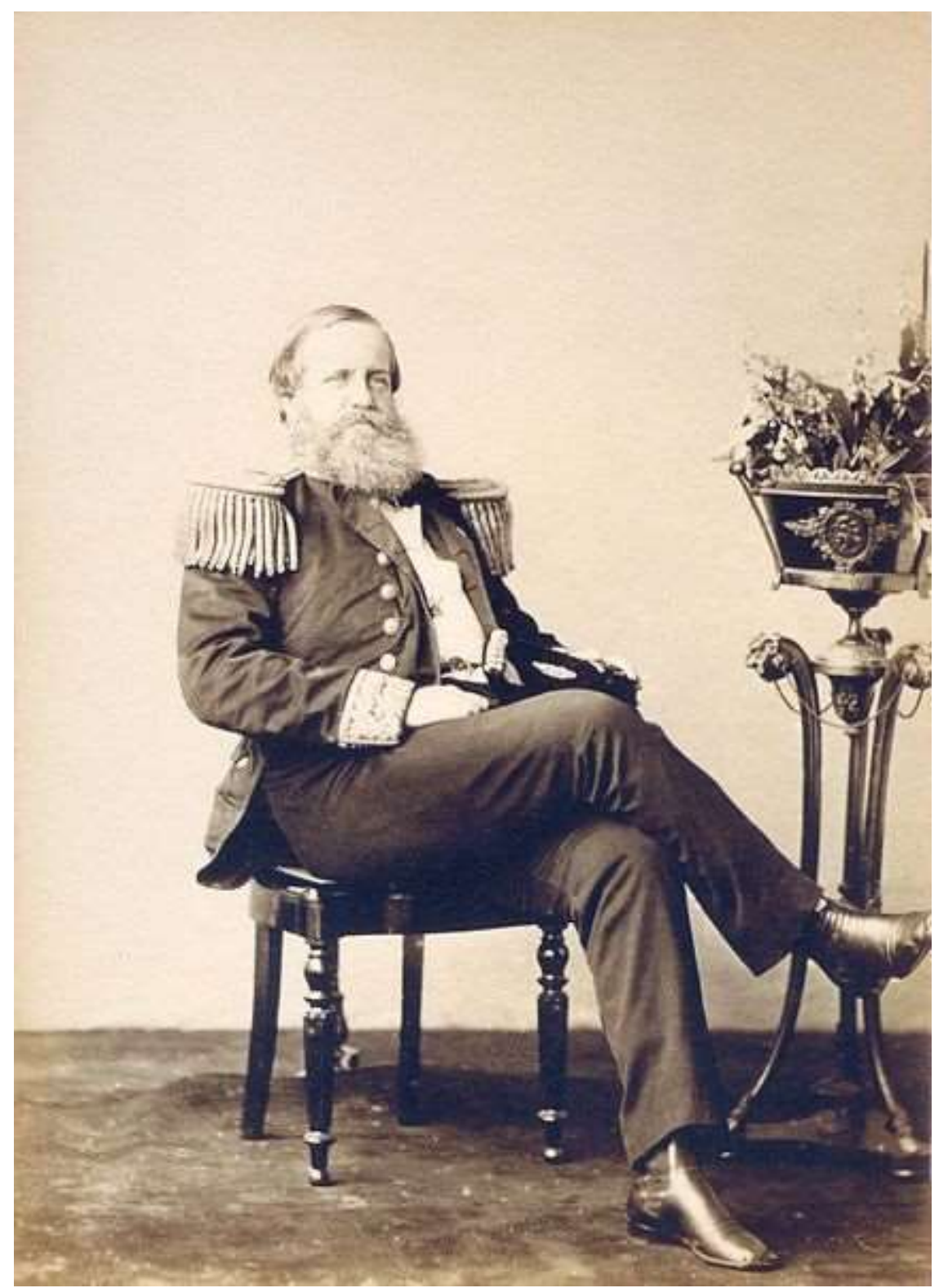

"Imperador Dom Pedro II do Brasil com uniforme de Almirante", 1870, com 44 anos de idade, em foto de Joaquim Insley Pacheco (1830-1912) ${ }^{101}$

Mas a guerra trouxera outros heróis ao cenário nacional. O conde d’Eu, Luís Filipe Maria Fernando Gastão de Orléans (1842-1922), que havia se casado com a princesa Isabel em 1864, teve participação ativa no conflito, ainda que apenas no final tanto que Pedro Américo retratou num quadro de batalha, a de Campo Grande. Originalmente designado para se casar com a princesa Leopoldina, quando chegou ao Brasil com o primo Luís Augusto de Saxe-Coburgo-Gota, encantou a princesa Isabel. O

${ }^{101}$ A foto de Joaquim Insley Pacheco está no livro De volta a luz: fotografias nunca vistas do imperador. São Paulo: Banco Santos/ Rio de Janeiro: Fundação Biblioteca Nacional, 2003. 
imperador deixou que as irmãs trocassem de par e ele se tornou marido de Isabel. Surdo com a passar dos anos, Gastão sempre foi uma figura antipática aos olhos da população em geral, e, em especial, dos republicanos. ${ }^{102}$

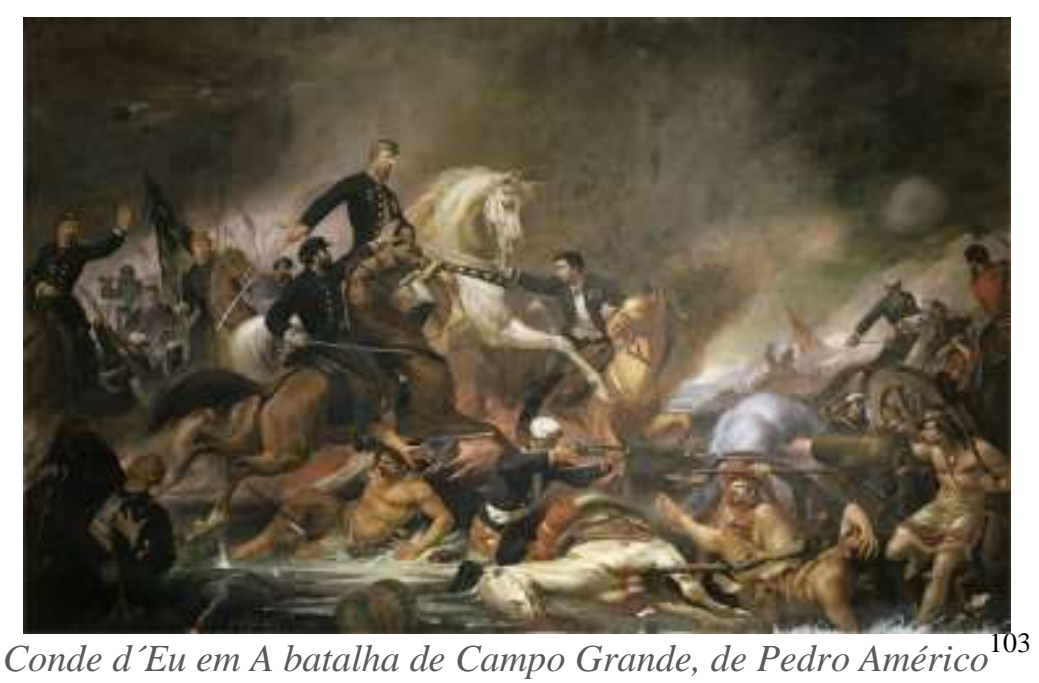

O duque de Caxias, Luís Alves de Lima e Silva, foi outro personagem que se destacou e ganhou a mais alta honraria do império, o título de duque, depois de vitórias na guerra. Ele foi também o responsável pelo fim do império, com a proclamação da República em 15 de novembro de 1889.

\footnotetext{
${ }^{102}$ Wanderley Pinho. Salões e damas do segundo império. São Paulo: Martins Editora, 1970, p. 147.

${ }^{103}$ Este quadro de Pedro Américo é um óleo sobre tela de $332 \times 530 \mathrm{~cm}$, que se encontra no Museu Imperial.
} 


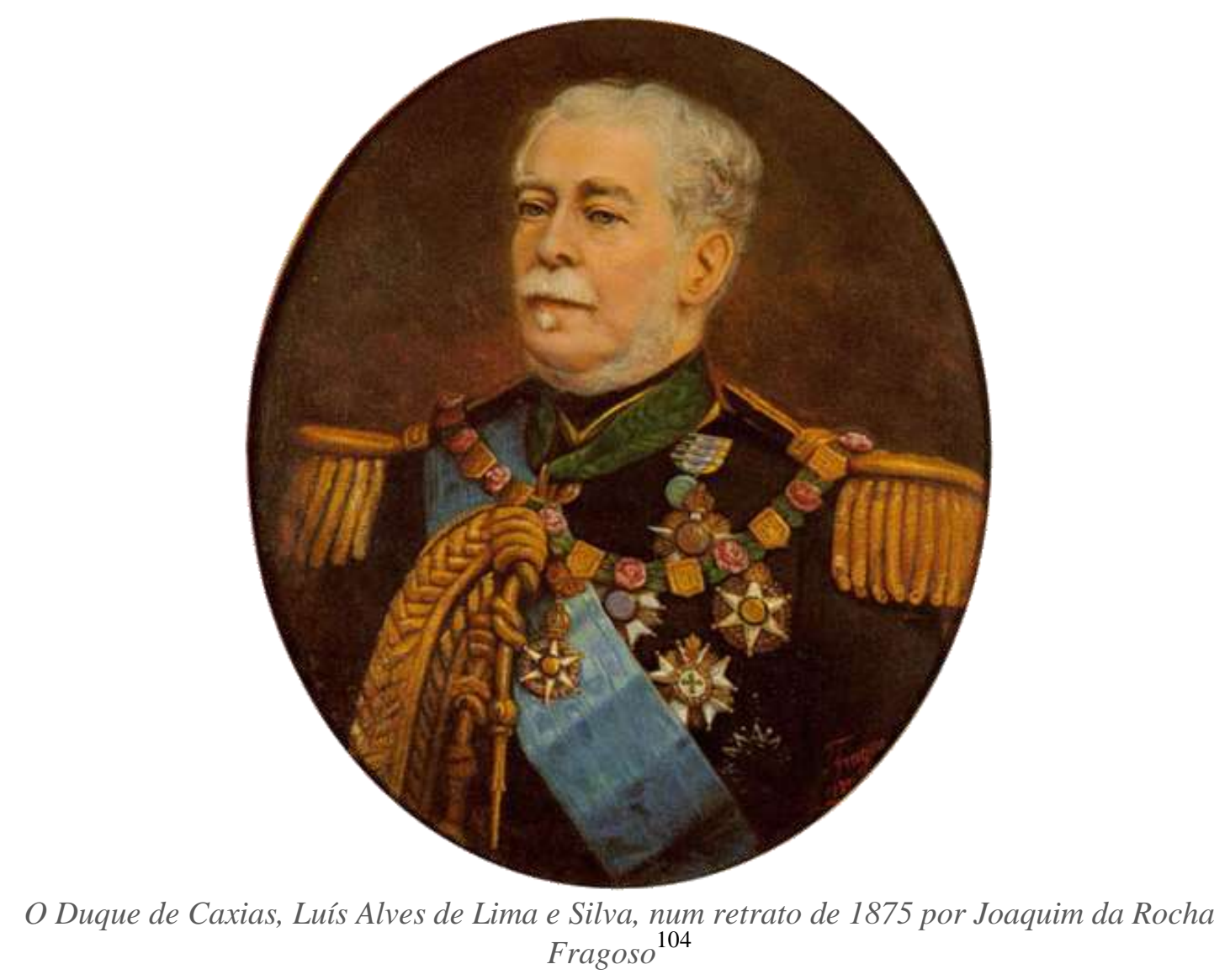

Ainda que houvesse a predominância do preto, ela não era a única cor usada no dia a dia. Diversas lojas da rua do Ouvidor vendiam não apenas a casaca e a calças pretas, mas também várias outras cores, para homens e meninos. A casa Fróes \& C., em 1876, vendia fatos de casimira de cores para viagem, calças de casimira preta e de cores, paletós, fraques de casimira de cores, paletós, sacos de pano, casimira e flanela azul, calças de brim branco, bem como camisas, ceroulas, meias, lenços, colarinhos, punhos, gravatas, camisas de flanela branca, de cor...

\footnotetext{
${ }^{104}$ Retrato do Duque de Caxias, Luís Alves de Lima e Silva, feito por Joaquim da Rocha Fragoso em 1875. Óleo sobre tela, 80 x $65 \mathrm{~cm}$, Museu Imperial. <http://ww.museuimperial.gov.br.> Consulta 13/3/2013.
} 


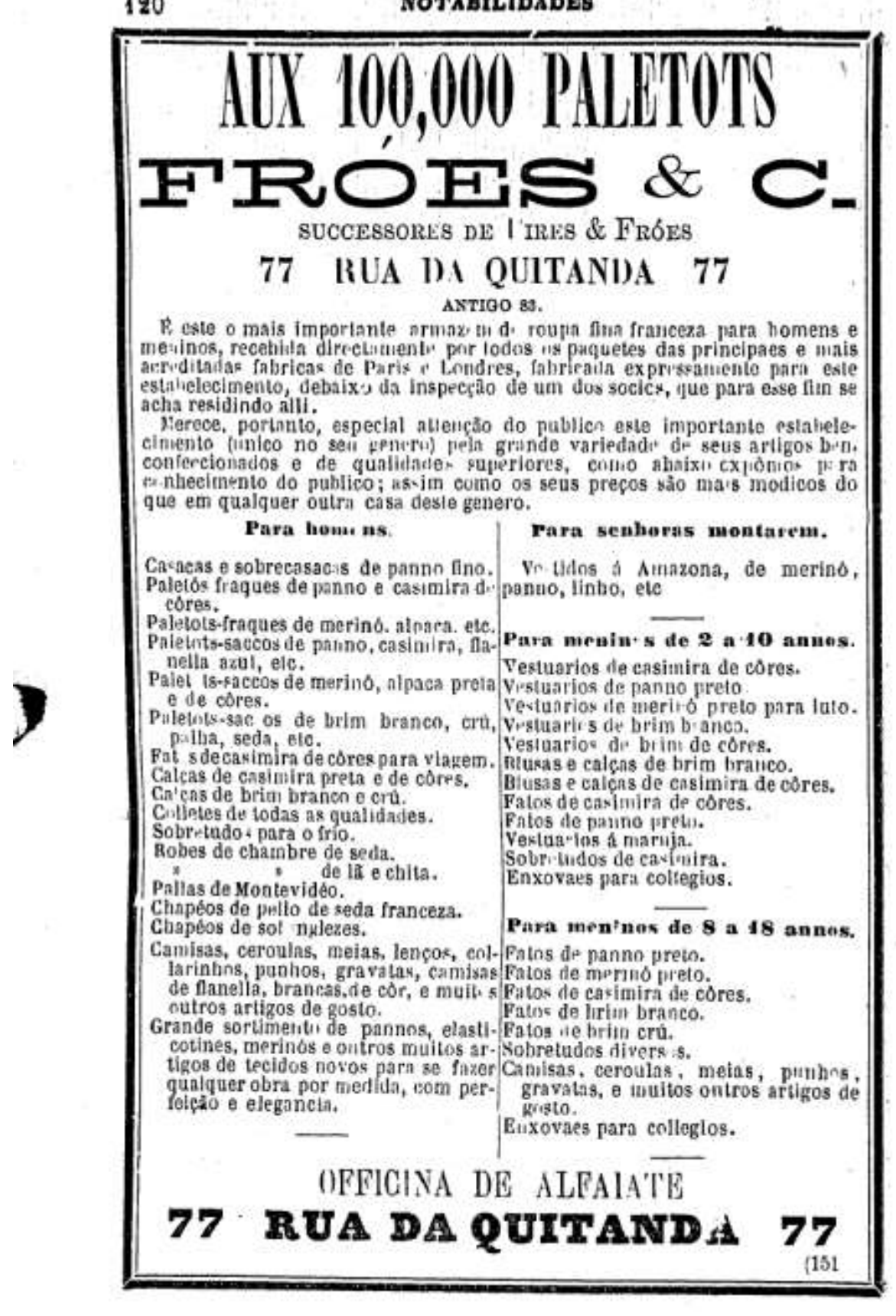

Anúncio com roupas coloridas para homens à venda em $1876^{105}$

Ainda que o comércio mais popular de roupas para homens usasse vários tipos de chapéus, cores e ou formatos, podemos perceber que roupa masculina para a elite no

105 Almanaque Laemmert 1876, p. 120. 
século XIX se simplificou progressivamente e tendeu a cristalizar-se num uniforme. ${ }^{106}$ Do riding coat, ou redingote em francês, ao terno e ao chapéu coco, a roupa masculina solidificou-se numa silhueta bastante específica entre os membros da alta burguesia e da aristocracia europeia do século XIX.

106 Gilda de Mello e Souza. O espírito das roupas: a moda no século dezenove. São Paulo: Companhia das Letras, 1987, p. 64. 


\section{CAPÍTULO V. Viver e mostrar-se em sociedade: o comércio, os acessórios de moda e as festas na corte}

Só no consumo o produto conhece a sua realização última. (...). Sem produção não há consumo; mas sem consumo também não haveria produção porque, neste caso, a produção não teria qualquer objetivo.

$\operatorname{Karl} \operatorname{Marx}^{1}$

Era a mulher que os magazines disputavam, a mulher que capturavam na armadilha dos preços, depois de tê-las atordoado diante das vitrines.

Émile Zola ${ }^{2}$

\section{Os encantos do consumo numa nova cidade}

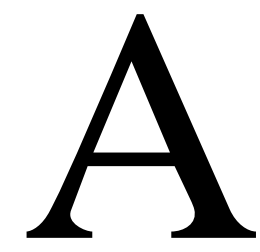
o longo do século XIX, o comércio carioca aumentou na mesma proporção em que chegavam os navios estrangeiros, carregados tanto mercadorias como estrangeiros. Entre 1847 e 1848 chegaram 785 embarcações - entre 1848 e 1849 foram 849 embarcações estrangeiras. ${ }^{3}$ Em 1850, foi inaugurada uma linha regular de navios a vapor entre o Rio de Janeiro e Liverpool na

\footnotetext{
${ }^{1}$ Karl Marx. Contribuição para a economia política. Trad. port. Lisboa: Editorial Estampa: 1973, p. 219.

${ }^{2}$ Émile Zola. O paraíso das damas. Trad. port. São Paulo: Estação Liberdade, 2007, p. 112.

${ }^{3}$ Almanaque Laemmert de 1850, p.07 da seção de suplementos
} 
Inglaterra. "O tempo imperial entra em sincronia com o tempo da modernidade europeia. Compras e vendas de mercadoria, cartas e encomendas, taxas de câmbio, juros comerciais, viagens de parentes e amigos possuíam, doravante, um parâmetro temporal fixo. Chovesse ou fizesse sol, com vento ou sem vento, a Linha de Paquetes a Vapor de Liverpool mantinha o ritmo de seus vapores Brazileira, Luzitana e Bahiana com uma pontualidade naturalmente britânica [...].",

Os estrangeiros presentes na cidade do Rio de Janeiro também passaram a chegar em maior número. Em 1851, eram 112.373 entre a população livre e escrava, desse total, 77.217 eram homens e 35.156 eram mulheres. Entre a população livre, 21.323 eram portugueses (homens) e 5.426 eram portuguesas (mulheres). Assim, eram 8.912 homens de outras nações e 2.263 mulheres também de outras nações. Entre os africanos libertos, 3.853 eram homens e 4.596 eram mulheres. ${ }^{5}$

Para além do fim do tráfico, uma parte significativa dos estrangeiros que chegavam à corte na década de 1850 vinha por causa de um "efeito indireto da corrida do ouro na Califórnia" ${ }^{6}$, nos Estados Unidos. Para se ir de Nova York a Califórnia, como não existia o canal do Panamá, nem estradas suficientemente boas, era preciso embarcar num navio e dar a volta completa na América do Sul. "Nessa rota, uma escala na Bahia ou no Rio ocorria com frequência.". 7 Assim muitos desembarcavam no Brasil e a rota contribuiu para que a corte se tornasse uma escala definitiva nos navios americanos.

Foram justamente esses estrangeiros que chegaram ao país no século XIX os que possuíam as maiores condições de ascensão social. "A sociedade capitalista que começa

\footnotetext{
${ }^{4}$ Luiz Felipe Alencastro. História da vida privada no Brasil II. Companhia das Letras, 1997, v. II, p. 39.

5 Almanaque Laemmert de 1851, p.240 da seção de suplementos.

${ }^{6}$ Luiz Felipe Alencastro. História da vida privada no Brasil II. Companhia das Letras, 1997, v. II, p. 40 e 41.

${ }^{7}$ Luiz Felipe Alencastro. História da vida privada no Brasil II. Companhia das Letras, 1997, v. II, p. 41.
} 
a se estruturar não somente define suas classes, mas também os mecanismos de ascensão social. As maiores possibilidades estavam ao alcance dos comerciantes estrangeiros, que enriqueciam pelo comércio, mas também passavam a se dedicar a outros negócios, como indústria, finanças e, curiosamente, compravam terras, seja como forma de especulação, exponenciada pela lei de 1850 e pela chegada das ferrovias, ou para a produção do café". ${ }^{8}$ Esses podiam ascender socialmente, mas ainda estavam longe de ganhar títulos de nobreza, referência definitiva de classe e poderio econômico. Donos de lojas importantes, e ricos, como Wallerstein, seriam "meramente filhos do dinheiro e não têm outros dogmas, nem aspiram a um credo diverso, mais alto". 9

Wallerstein possuía uma das mais importantes lojas/ateliês de costura do Rio em meados do século XIX. Em 1857, a casa já anunciava seu negócio. Preferida da corte, o armazém e "loja de modas e fazendas francesas" situado na rua do Ouvidor n. 70, anunciava que:

Com casa em Paris e em Londres, recebem fazendas por os vapores de Southmpton, e do Havre, encarregam-se de qualquer encomenda, tanto para França, como para a Inglaterra, Alemanha, Bélgica e Itália: encontra-se, sempre nos armazéns grande sortimento de fazendas francesas, inglesas e da Índia; toda a qualidade de artigos próprios para toilette de uma senhora, sedas, lãs, cassas, meias, rendas, modas, enfim, tudo o que aparece de novidade; algumas vezes ainda antes de conhecidas e vistas em Paris, são imediatamente remetidas pelos vapores; artigos de todas as qualidade para homens e meninos, chapéus e bonés, pano de casimira, brins, fazendas para coletes, grande sortimento de camisas, roupa feita, luvas, meias etc; morins e

\footnotetext{
${ }^{8}$ Milena Fernandes de Oliveira. O mercado do prestígio: consumo, capitalismo e modernidade na São Paulo da Belle Époque (1890-1914). São Paulo: Alameda Casa Editorial, no prelo, p. 172.

${ }^{9}$ Raimundo Faoro. Machado de Assis: a pirâmide e o trapézio. São Paulo: Globo, 2001, p. 30.
} 
linhos, lenços de linha, cambraia e seda da Índia, leques, óculos para teatro, lenços, casinhas bordadas, etc. ${ }^{10}$

A propaganda em veículos de comunicação, como jornais, almanaques e revistas, marcaria a passagem da sociedade mercantil para o capitalismo periférico. "No capitalismo periférico em formação, a publicidade nascente em tal contexto marca a passagem de uma sociedade mercantil regulada pela compra e venda de escravos para uma sociedade em que a mão-de-obra é livre e, enquanto tal, também livre é o seu acesso aos padrões de consumo divulgados especialmente pela imprensa."11

Desta forma, as lojas erguidas e geridas por estrangeiros multiplicavam-se pelo Rio de Janeiro. Por uma análise do Almanaque, vemos que as lojas francesas na corte multiplicam-se com o passar dos anos, indo de 22 em 1850 a 110 em $1880 .{ }^{12}$ Luís Felipe Alencastro vai dizer que a "chegada de profissionais europeus engendram no Rio de Janeiro um mercado de hábitos de consumo relativamente europeizados". ${ }^{13}$ Chega de tudo ao Rio, de joias a cavalos de raça e pianos.

\begin{tabular}{|r|r|}
\hline Ano & $\begin{array}{r}\text { Lojas de moda e fazendas } \\
\text { francesas }\end{array}$ \\
\hline 1850 & 22 \\
\hline 1860 & 49 \\
\hline 1870 & 51 \\
\hline 1880 & 110 \\
\hline
\end{tabular}

${ }^{10}$ Almanaque Laemmert de 1857, p. 42 da seção de notabilidades.

${ }^{11}$ Milena Fernandes de Oliveira. O mercado do prestígio: consumo, capitalismo e modernidade na São Paulo da Belle Époque (1890-1914). São Paulo: Alameda Casa Editorial, no prelo, p. 168.

12 Quem me chamou a atenção para isto foi Maria do Carmo Teixeira Rainho, em seu livro $A$ cidade e a moda. Brasília: editora da UnB, 2002, p. 53.

${ }^{13}$ Luiz Felipe Alencastro. História da vida privada no Brasil II. Companhia das Letras, 1997, VOL. II, p. 36 e 37. 
O Rio de Janeiro em que Wallerstein abriu seus negócios modificou-se profundamente no século XIX. Influenciados pela França de Napoleão III, várias cidades do mundo fizeram planos de urbanização mais ou menos radicais. Na Paris de Napoleão III, o barão de Haussmann demoliu a cidade medieval para construção de ruas, bulevares e edifícios. Entre 1860 e 1870, a cidade foi colocada abaixo para a construção de novas avenidas, novos edifícios, novas praças. "Vários planos urbanísticos, para dar conformação às principais cidades da Europa e das Américas, tiveram lugar no século XIX. [...] O século XIX - o longo século XIX - foi, assim, a era de ouro das reurbanizações planejadas". ${ }^{14}$

Uma série de outras modificações urbanas foi feita, como a instalação de esgotos e de uma iluminação a gás mais eficiente à noite. "Sob Napoleão III cresce mais rapidamente o número de lampiões a gás. Isso elevou o grau de segurança da cidade; fez a multidão em plena rua sentir-se, também à noite, como em sua própria casa; removeu do cenário grande o céu estrelado e o fez de modo mais radical que seus prédios altos". 15

O nascente capitalismo industrial trouxe uma nova maneira de viver na cidade, que teve de ser modificada, adaptada às novas condições de vida. Não à toa, Londres foi uma das primeiras cidades a ter modificações acentuadas na paisagem urbana, com uma rede de esgotos e iluminação a gás. Ainda assim, as moradias para os operários eram péssimas, a fumaça das fábricas sufocava as pessoas, que morriam de fome, de doenças,

\footnotetext{
${ }^{14}$ Heloisa Barbuy. A cidade-exposição: cidade e cosmopolitismo em São Paulo, 1860-1890. São Paulo, Edusp, 2007, p. 70.

${ }^{15}$ Walter Benjamin. Paris no segundo império. In: Obras Escolhidas III. Charles Baudelaire, um lírico no auge do capitalismo. Trad. port. São Paulo: Brasiliense, 2000, p. 47.
} 
da falta de saneamento. ${ }^{16} \mathrm{Na}$ viva descrição de Engels, as ruas populares misturam hábitos antigos, com uma nova forma insalubre de viver.

$\mathrm{Na}$ Inglaterra, esses bairros de má-fama se estruturam mais ou menos da mesma forma que em todas as cidades: as piores casas na parte mais feia da cidade; quase sempre uma longa fila de tijolos, de um ou dois andares, eventualmente com porões habitados e em geral dispostas de maneira irregular [...]. Habitualmente as ruas não são planas nem calçadas, são sujas, tomadas por detritos vegetais e animais, sem esgotos ou canais de escoamento, cheias de charcos estagnados e fétidos. A ventilação na área é precárias, dada a estrutura irregular do bairro e, como nesses espaços restritos vivem muitas pessoas, é fácil imaginar a qualidade do ar que se respira nessas zonas operárias - onde, ademais, quando faz bom tempo, as ruas servem aos varais que, estendidos de uma casa a outra, são usados para secar a roupa. ${ }^{17}$

Londres, ao longo de todo o século XIX, foi um lugar ambíguo, que misturava as tecnologias mais avançadas para o aparelhamento urbano, com as piores condições de vida. Era, nos dizeres Charles Dickens, "o melhor e o pior dos tempos". ${ }^{18}$ Londres era, ao mesmo tempo, a melhor e a pior cidade para se viver. O livro de Dickens também vai falar de Paris, comparando as condições de vida, ou melhor, de sobrevivência, nas duas cidades mais emblemáticas do século XIX. "As condições de vida na cidade grande e moderna criaram condições e necessidades específicas de sensibilidade e comportamento". 19

\footnotetext{
${ }^{16}$ Ver, entre outros, O livro de Friederich Engels, A situação da classe trabalhadora na Inglaterra (São Paulo: Boitempo, 2007); o de Jack London, O povo do abismo: fome e miséria no coração do império britânico. (São Paulo: Editora Fundação Perseu Abramo, 2004); e o de John Tomson; Victorian London Street Life in historic phtotographs (Nova York: Dover Publications, 1877, $2^{\text {a }}$ edição).

${ }^{17}$ Friederich Engels, A situação da classe trabalhadora na Inglaterra. Trad. port. São Paulo: Boitempo, 2007, p. 70.

${ }^{18}$ Charles Dickens. Um conto de duas cidades. Trad. port. São Paulo: Estação Liberdade, 2008.

${ }^{19}$ Leopoldo Waizbort. As aventuras de Georg Simmel. São Paulo: editora 34, 2006, p. 322.
} 
Ao mesmo tempo que Londres, Paris ou Berlim se modificaram para abrigar fábricas e operários, também foram feitas transformações no sentido de abrir lugar para as novas mercadorias que continuamente chegavam ao mercado. Paris, Londres, Berlim e muitas outras cidades do mundo foram modificadas para dar cada vez mais vazão ao fluxo do crescente comércio.

Assim, Paris, sob a batuta de Hussmann, tornou-se um lugar voltado para o consumo, cidade pensada para facilitar o transito de mercadorias e de pedestres. Denise, protagonista de $O$ paraíso das damas, de Zola, encanta-se e assusta-se com a cidade grande. "Ela dava as mãos a Pepe, e a Jean a seguia, todos os três esgotados pela viagem, intimidados e perdidos no meio da vasta Paris, os olhares atônitos diante dos altos edifícios, perguntando a cada esquina onde ficava a rue de la Michodière, onde residia o tio Baudu." 20

A segunda exposição universal de Paris, inaugurada por Napoleão III em $1^{\circ}$ de abril de 1867, durou até 3 novembro do mesmo ano. Na época, existiu uma polêmica sobre qual teria sido a primeira exposição universal - os ingleses diziam que foi a de 1851, a "Great exhibition of the works of industry of all nations", que construiu o Palácio de Cristal, mas os franceses citavam a uma feira de produtos realizada em 1798. ${ }^{21}$ As exposições universais foram "projeto de uma burguesia cujo dogmatismo, cuja crença numa verdade universal, num sistema hegemônico, vigem por todo o século XIX e só perdem a força já no início do século XX". ${ }^{22}$ Modelos burgueses, as exposições traduziriam em produtos um modo de vida e um futuro calcado no poder das máquinas, no trunfo da produção industrial.

\footnotetext{
${ }^{20}$ Èmile Zola. O paraíso das damas. Trad. port. São Paulo: Estação Liberdade, 2007, p. 31.

${ }^{21}$ Heloisa Barbuy. A exposição universal de 1889 em Paris. São Paulo: História social/ edições Loyola, 1999, p. 38.

${ }^{22}$ Heloisa Barbuy. A exposição universal de 1889 em Paris. São Paulo: História social/ edições Loyola, 1999, p. 39.
} 
O Brasil participou de muitas exposições universais no século XIX - da feira no Champs de Mars, em Paris, França, em 1867; de Viena, Áustria, em 1873; de Filadélfia, Estados Unidos, em $1876^{23}$; da feira de 1889, de novo em Paris, quando o país apresenta um rico catálogo ilustrado. ${ }^{24}$ Durante o império, o Rio abrigou exposições nacionais em 1861, 1866, 1873, 1875, 1881 e 1888/1889, que, apesar de menores, foram bastante visitadas. A de 1875, por exemplo, recebeu 67 mil pessoas em 45 dias de exposição.

As exposições que tomaram lugar no Rio de Janeiro tentavam mostrar a capital do país de maneira diferente. Na corte, as tentativas de transformações urbanas começaram cedo, já em meados da década de 1840, impulsionadas pela coroação precoce de d. Pedro II. As cidades brasileiras por muito tempo apresentaram feições coloniais, acanhadas, pobres e sujas. ${ }^{25}$ E o Rio de Janeiro não foi exceção. Já no começo do século XIX, era a cidade, capital do novo império, a mais visitada do Brasil por viajantes e estrangeiros, que relataram seus problemas urbanos e sua falta de salubridade. "A precariedade das condições de vida de seus habitantes fazia com que elas fossem vistas como lugar de gente pobre, como antro de promiscuidade e doenças. O acanhamento das casas, a estreiteza e sinuosidade das ruas e a mistura de funções e atividades eram referência recorrentes nos relatos dos viajantes e documentação oficial.",26

"Pode-se fixar o ano de 1840 o início do espraiamento dos habitantes, com o abandono das ruas apertadas do centro da cidade. Tornaria possível às classes pobres

\footnotetext{
${ }^{23}$ Quando Graham Bell apresentou o telefone à d. Pedro II.

${ }^{24}$ Sobre as exposições universais ver o ótimo quadro preparado por Paulo Roberto de Almeida. Formação da diplomacia econômica no Brasil. São Paulo: Senac, 2001, p. 245 a 247; e também Francisco Foot Hardman. Trem fantasma: a modernidade na selva. São Paulo: Companhia das Letras, 1988 e Sandra Pesavento. Exposições universais: espetáculos da modernidade no século XIX. São Paulo: Hucitec, 1997.

${ }^{25}$ Ana Lúcia Duarte Lanna. Uma cidade na transição, Santos, 1870-1913. São Paulo: Hucitec, 1996, p. 37.

${ }^{26}$ Ana Lúcia Duarte Lanna. Uma cidade na transição, Santos, 1870-1913. São Paulo: Hucitec, 1996, p. 37.
} 
ganhar o centro, sem o auxílio de condução própria, reduzida ao burro ou ao cavalo.»27 Outras novidade urbanas surgiam com o passar dos anos, dando ao Rio um ar mais cosmopolita. Em 1868 começam os bondes regulares - que serão substituídos por elétricos depois do fim do império, em 1892. "O homem do segundo reinado", escreve Raimundo Faoro, "não está satisfeito nem conformado com o passo que o progresso lhe proporcionou. Ele quer tudo depressa, sabe que a própria eletricidade cederá lugar a uma força nova." 28

Gilberto Freyre vai dizer que no século XIX o patriarcalismo no Brasil se urbanizou. ${ }^{29}$ Que, pelas mãos de Mauá e de empresários ingleses, os serviços urbanos no Rio de Janeiro se aperfeiçoaram e, com eles - iluminação, calçamento e por fim, saneamento -, mudaram também um modo de vida nas cidades. "A vida ficara mais livre da rotina doméstica. A rua - outrora só de negros, mascates, moleques - se aristocratizaria." 30

As transformações decorrentes do dinamismo das exportações de café crescimento da população, ampliação da rede de serviços, estradas, chegada de imigrantes - criaram condições para a adoção de novos costumes cosmopolitas e, gradativamente, ajudaram a impulsionar o surgimento de negócios e empresas localizados na cidade e, em especial, no Rio de Janeiro. ${ }^{31}$

\footnotetext{
${ }^{27}$ Raimundo Faoro. Machado de Assis: a pirâmide e o trapézio. São Paulo: editora Globo. 2001, p. 64.

${ }^{28}$ Raimundo Faoro. Machado de Assis: a pirâmide e o trapézio. São Paulo: editora Globo. 2001, p. 64.

${ }^{29}$ Gilberto Freyre. Sobrados e mucambos. Rio de Janeiro: José Olympio, 1951 (2a edição), p. 144.

${ }^{30}$ Gilberto Freyre. Sobrados e mucambos. Rio de Janeiro: José Olympio, 1951 (2a edição), p. 144 e 145.

${ }^{31}$ Florestan Fernandes. A revolução burguesa no Brasil. Rio de Janeiro: Jorge Zahar, 1974 , p. 27
} 


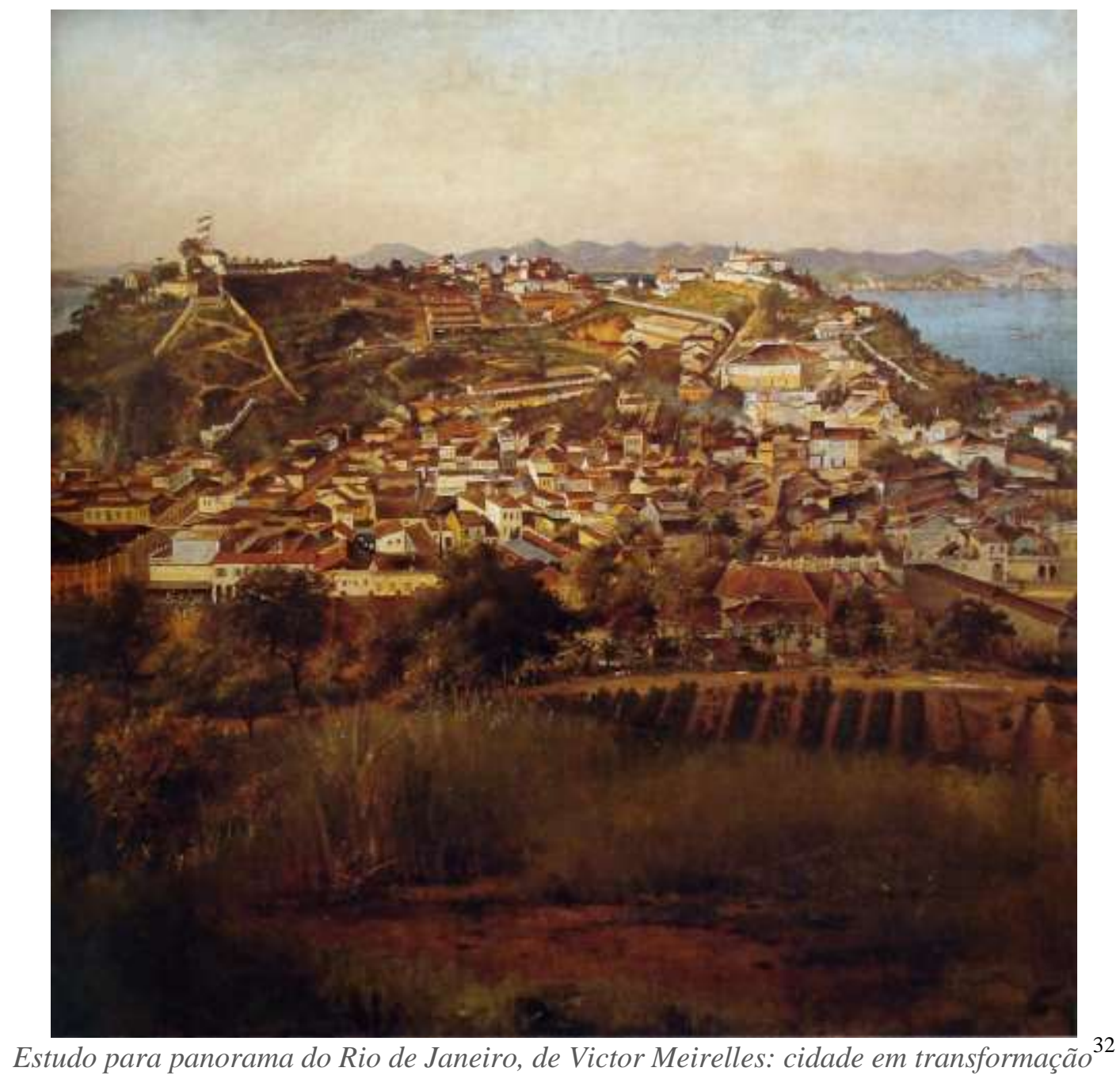

No estudo que o pintor Victor Meirelles (1832-1903) fez da cidade na década de 1880, vemos em primeiro plano pequenas chácaras com plantações e, ao fundo, a cidade que crescia e se espalhava pelos morros. Dos bairros de subúrbio - com as casinhas e pequenas igrejas - à cidade em volta da baia da Guanabara. Ao longo de todo o século XIX, a cidade do Rio vai crescer e se espalhar pelos morros ao redor da orla. A urbanização traria novos hábitos, como o de fazer compras na cidade.

Assim, Gilberto Freyre vai mostrar como muito dos objetos do cotidiano que eram feitos dentro das casas - o sabão, os queijos, alguns móveis, os vestidos, os sapatos -

32 "Estudo para panorama do Rio de Janeiro", de Victor Meirelles foi produzido na década de 1885. Esta imagem foi reproduzaida do catálogo Arte brasileira do século XIX, da Mostra do redescobrimento. São Paulo: 2000. 
passaram a ser feitos por lojas especializadas, comandadas, principalmente, por estrangeiros. "As senhoras mais chiques penteando-se não mais à portuguesa, ou quase à oriental, mas à francesa, vestindo-se também à francesa, indo ao teatro ouvir óperas cantadas por italianas, a quem os estudantes ofereciam bouquets, faziam discursos, dedicavam sonetos." 33

As mudanças nos hábitos cotidianos abriram caminho para a mudança na vida econômica. ${ }^{34}$ E o contrário também foi verdadeiro: as mudanças de ordem econômica trouxeram transformações de mentalidade importantes. A independência do país, afirmou o sociólogo Florestan Fernandes, ao romper com o estatuto colonial, criou condições de expansão da burguesia e, em particular, da valorização social do "alto comércio”. Uma parte considerável das potencialidades capitalistas da grande lavoura "foram canalizadas para o crescimento econômico interno, permitindo o esforço concentrado da fundação de um Estado nacional, a intensificação concomitante do desenvolvimento urbano e a expansão de novas formas de atividades econômicas, que os dois processos exigiam" 35 .

Desta forma, quando a cidade mudou para receber um novo tipo de aparelhamento urbano - as calçadas, a iluminação, a rede de esgotos, as vias mais largas - ela estva mudando para dar lugar também para um novo tipo de fruição urbana, ligada ao consumo tanto das mercadorias que chegavam pelo porto, como da cidade com praças, sorveterias, confeitarias, hotéis e restaurantes. As ruas transformam-se para receber vitrines e pédios comerciais, como os da rua do Ouvidor. O fluxo de mercadorias

\footnotetext{
${ }^{33}$ Gilberto Freyre. Sobrados e mucambos. Rio de Janeiro: José Olympio, 1951 (2a edição), p.145.

34 "O consequente desenvolvimento de certas indústrias não teria sido tão imediato se as populações urbanas não se tivessem acostumados tão rapidamente ao uso de produtos relativamente estranhos às tradições da antiga sociedade", afirmou Richard Graham. (Grã Bretanha e o início da modernização no Brasil. Trad. port. São Paulo: Brasiliense, 1973, p. 129).

${ }^{35}$ Florestan Fernandes. A revolução burguesa no Brasil. Rio de Janeiro: Jorge Zahar, 1974, p. 27.
} 
passou a acontecer com mais rapidez e precisava ser escoado. Carruagens se modificaram e ruas foram alargadas.

Locomotivas, iluminação a gás, telégrafo, rede de abastecimento de água, encanamento do rio Maracanã, ateliês de costura, sapateiros, fotógrafos ${ }^{36}$. Foram muitos os novos equipamentos urbanos que mudaram o Rio de Janeiro no século XIX. A modernidade e a civilização vinham não apenas com esses novos aparelhos urbanos, mas com a capacidade, o tempo, o dinheiro e a maneira "certa" de usufrui-los. Mesmo assim, a cidade mudava lentamente e as transformações urbanas se juntavam ao que restava da cidade colonial.

A arquitetura da cidade, com ruas apertadas e cortiços apinhados de gente, não favorecia um comércio de rua, ou a atividade lúdica de um novo tipo urbano, o flâneur, cujo fim maior era usufruir um novo tipo de cidade. O Rio era uma cidade que tentava acompanhar as transformações urbanas do século XIX, que pedia passagem para os bondes, carruagens ou charretes, que pedia também novas calçadas, novas lojas e vitrines para os novos consumidores e uma nova maneira de se usar a cidade.

Bondes, carruagens, cadeirinhas tornavam as ruas cheias de gente, máquinas e cavalos, numa mistura de edificações antigas e novas, de calçamentos novos e outros semidestruídos. As ruas demoraram alguns anos para se encherem de pedestres e veículos, as calçadas ainda não estavam bem estabelecidas para um flâneur. Novos e velhos veículos conviviam e se chocavam, e davam a ideia de um novo tempo, de uma nova maneira de ver o mundo.

\footnotetext{
${ }^{36}$ As transformações urbanas cariocas foram realizadas mais ou menos no mesmo período, em meados do século XIX A locomotiva baronesa começou a circular no Rio de Janeiro em 30 de abril de 1854, num percurso de 14 quilômetros entre a Baía de Guanabara e a Serra da Raiz, em Petrópolis. A iluminação a gás ficou a cabo da Companhia de Iluminação a Gás, criada em 25 de março de 1854. Três anos depois, o gás já chegava a 3.027 lampiões públicos, 3.200 residências e três teatros. A rede de abastecimento de água começou a ser feita pelo engenheiro Antonio Gabrielli em 1876. O encanamento do Rio Maracanã foi feito em 1850.
} 
Machado de Assis escreveu um conto, "Anedota do Cabriolé”, sobre as carruagens que circulavam no Rio de Janeiro em meados do século XIX. "A geração de hoje não viu a entrada e a saída do cabriolet no Rio de Janeiro. Também não saberá do tempo em que o cab e o tilbury vieram para o rol dos nossos veículos de praça ou particulares. $\mathrm{O} c a b$ durou pouco. O tilbury, anterior aos dois, promete ir à destruição da cidade. $^{37,}$

As carruagens, carros ou landaus que andavam pelas ruas do Rio davam a medida do progresso - ou retrocesso econômico do país. Dias após o encilhamento, a febre especulativa comandada pelo Visconde de Ouro de Preto pouco antes da proclamação da república, Machado de Assis vai escrever que o resultado dessa política econômica foram as ruas do Rio terem sido tomadas por carruagens. "Nada", escreveu Raimundo Faoro, "atesta melhor a transformação que se operava na vida urbana. As carruagens, puxadas por parelhas de cavalos raros, quebravam a pasmaceira do Segundo Reinado e começo da República, publicando 'o deslumbramento e agitação, epopeia do ouro da cidade e do mundo." 38

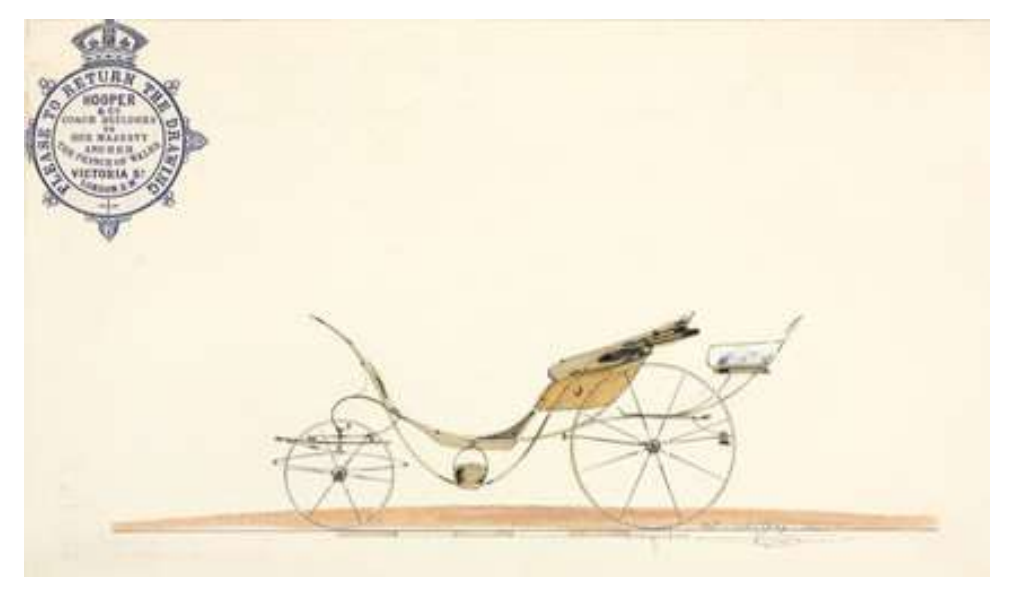

\section{Um cabriolet com quatro rodas. Em inglês era chamado de Phaeton, em homenagem a Phaeton, filho de Hélio, que dirigia um carro semelhante em direção ao sol ${ }^{39}$}

\footnotetext{
${ }^{37}$ Joaquim Maria Machado de Assis. "Anedota do cabriolet".

${ }^{38}$ Raimundo Faoro. Machado de Assis: a pirâmide e o trapézio. São Paulo: Globo , 2001, p. 63.

${ }^{39}$ Este carro especificamente foi usado pela rainha Vitória e o príncipe Alberto pela firma Hopper \& Cia. A gravura está localizada no site inglês, Science and Society Picture Library, $<$ http://www.ssplprints.com/>. Consulta em 12/06/2013.
} 


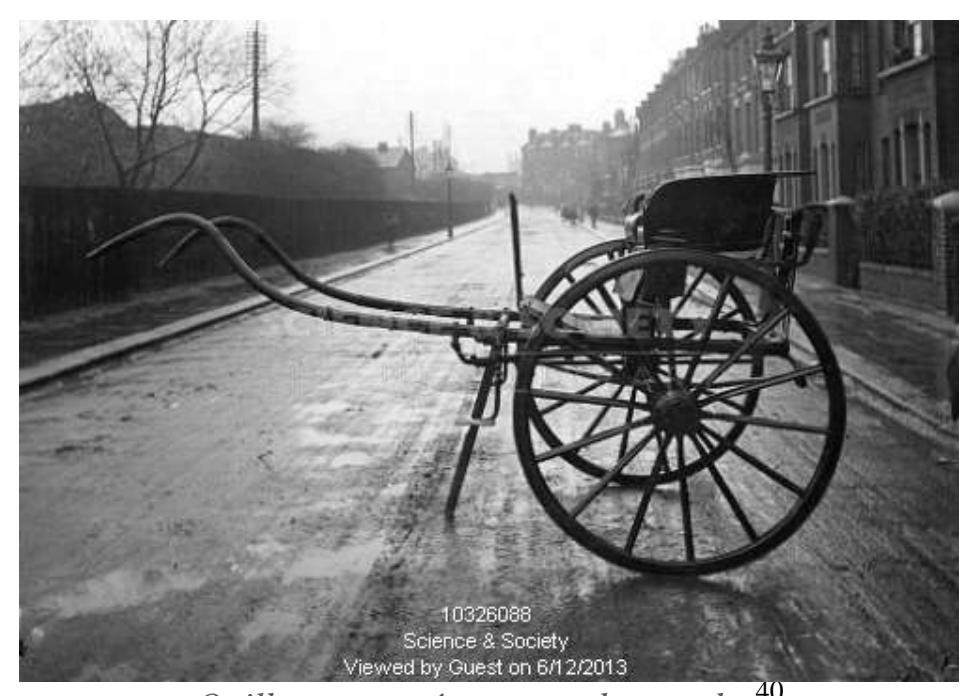

O tilbury possuía apenas duas rodas ${ }^{40}$

Apinhada de gente, com um porto grande, escravos por toda parte, infecções e doenças se espalhando por ruas mal cuidadas ou sem cuidados nenhum, sem calçamento e sem coleta de esgotos, os cariocas demoraram a ter o centro refeito aos moldes de grandes cidades europeias. A grande reforma urbana do Rio de Janeiro, inspirada em nas transformações da Paris de Georges Haussmann, só aconteceu sob a administração de Francisco Pereira Passos (1836-1913), entre 1902 e 1906.

Assim, no Rio de Janeiro, principalmente, com o dinheiro circulando por causa da venda de café, esse processo cosmopolitização refletiu-se tanto nas necessidades de remodelação urbana como no estabelecimento de hábitos, costumes e produtos importados, "burgueses", vindos da Europa. As roupas refletiam esse novo cosmopolitismo, bem como os lugares aonde se podia comprar os produtos ligados a essa nova maneira de ser. Esses novos estabelecimentos, muitas vezes abertos por imigrantes especializados (alfaiates, sapateiros, costureiras, joalheiros, marceneiros), davam origem a diferentes tipos urbanos que, junto com negociantes, agiotas, exportadores, funcionários do governo, ajudavam a formar uma sociedade de corte.

40 A foto do tilbury está localizada no site inglês Science and Society Picture Library, <http://www.ssplprints.com/>, consulta em 1206/2012. 
O próprio ato da venda e da compra de mercadoria se modificou ao longo do século XIX. Ao rituais de venda e compra tornaram-se rituais de uma nova fase da vida econômica, uma cerimonia, executada com gestos medidos e conhecidos por ambos os lados, os vendedores e os compradores - cada um sabendo seu papel naquele momento específico.

Em Paris trocas incluíam uma decoração cuidada, maneiras corteses, solicitude para com a clientela. Um ritual com uma coreografia regrada como a do balé: designação do vendedor pelo chefe da seção, escolha da mercadoria, clientes acompanhadas pelo vendedor que carrega os pacotes através da loja, pagamento no caixa, etc ${ }^{41}$

\section{Uma rua voltada para o comércio de luxo}

De forma semelhante, surgiu no Rio uma rua que iria agregar esses novos tipos urbanos ligados ao comércio - costureiras especializadas, alfaiates, joalheiros, sapateiros, donos de casas de fazendas, negociantes em rituais de compra e venda. Foi a rua do Ouvidor. "A rua do Ouvidor, a mais passeada e concorrida, e mais leviana, indiscreta, bisbilhoteira, esbanjadora, fútil, noveleira, poliglota e enciclopédica de todas as ruas da cidade do Rio de Janeiro, fala, ocupa-se de tudo; até hoje, porém, ainda não se referiu a quem quer que fosse a sua própria história. ${ }^{42,}$, escreveu Joaquim Manoel de Macedo (1820-1882), autor de A moreninha, sobre a rua de comércio mais conhecida dos cariocas.

Joaquim Manoel de Macedo escreveu as Memórias da rua do Ouvidor em 1878, poucos anos antes de morrer. Na época, escrever as memórias de rua não era comum no Brasil. Mas a rua do Ouvidor tinha um significado especial para a capital do Império.

\footnotetext{
${ }^{41}$ Jeanne Gaillard. "Prefácio" ao livro O paraíso das damas, de Èmile Zola. Trad. port. São Paulo: Estação Liberdade, 2007, p. 14.

${ }^{42}$ Joaquim Manuel de Macedo. Memórias da rua do ouvidor. São Paulo: Saraiva, 1963, p. 3.
} 
Ao longo dos anos, depois de 1822, a rua se tornou o ponto dos elegantes do Rio, o lugar em que ministérios eram feitos e desfeitos, onde as mulheres elegantes compravam seus mimos e as "andorinhas" depenavam seus amantes. Uma rua que significava, claramente, poder e dinheiro de quem a frequentava.

O romântico Joaquim Manuel de Macedo não poderia ter escrito as memórias de qualquer outra rua do país que não a do Ouvidor. Literato, jornalista e preceptor dos filhos da Princesa Isabel, o escritor respirava os ares de seu tempo; seguia o que lia nos livros que chegavam Paris. E os românticos franceses exaltavam Paris, suas vielas, seu comércio pujante, seus pequenos heróis e vilões cotidianos, a antiga cidade que desaparecia sob a batuta de Georges Haussmann (1809-1891), a cidade-luz, que se tornaria símbolo do século XIX.

A rua do Ouvidor parecia ser de fato um oásis no meio de um inferno tropical, se lermos os relatos de cronistas e romancistas da épocas. Mas não era bem assim. Mesmo sendo uma rua dedicada ao comércio de luxo, foram várias as reclamações de vendedoras ou donas de ateliês francesas contra os barris cheios de esgoto, carregados por escravos, que no meio do caminho vazavam ou simplesmente explodiam. Nesta época, a rede de esgoto da cidade ainda não estava montada e a modernidade carioca, descrita por Joaquim Manuel de Macedo, tinha muito de improviso e fantasia.

"Morta é a velha Paris (a forma da cidade/ Muda bem mais que o coração de uma infiel)", escreveu Charles Baudelaire (1821-1867) no poema "O cisne”, que está em As flores do mal. "Paris mudou! Porém minha melancolia/ É sempre igual: torreões, andaimarias, blocos/ arrebaldes em tudo eu vejo alegoria/ Minhas lembranças são mais pesadas que socos.”, escreveu o poeta francês. Aqui nos trópicos, Joaquim Manuel de Macedo se embriagará de Paris. Em suas memórias sobre a rua, escreveu:

No século décimo nono, em um ou dois anos, em 1822, enfim, uma dúzia (nem tanto) de francesas sem peças de artilharia, nem 
espingardas, nem espadas, e apenas com tesoura e agulhas, fundaram suave e naturalmente, e sem oposição nem protestos, a França Antártica no Rio de Janeiro. [...] A França Antártica é a rua do Ouvidor desde a Primeiro de Março até a Praça de S. Francisco. [...] Honra e glória, pois, às modistas francesas, que na sua hégira de 1821 e 1822 se acolharam àquele oásis, àquela predestinada Rua do Ouvidor, da qual fizeram pequena, mas feiticeira filha de Paris, de donde sob o cetro da Moda, puderam logo em 1822, alçar o grito Vive La France! - grito ainda hoje eletricamente correspondido até pelo finadíssimo, mas perpétuo redivivo urso, M. Casse-Majou. ${ }^{43}$

O Rio de Janeiro havia finalmente se tornado francês, ou melhor, havia sido tomado por francesas, que controlavam não apenas o comércio de luxo, mas a confecção de roupas e assessórios para a elite. Os franceses prosperavam na cidade. No mesmo curto espaço de tempo descrito por Joaquim Manuel de Macedo, os franceses de fato tomaram conta do comércio de luxo da capital do império:

[...] sentimo-nos, nós franceses, estranhamente impressionados com o fato de não ver nenhuma senhora, nem nos balcões nem nos passeios. Tivemos [...] que [...] esperar até o dia seguinte, dia de festa, para observar inúmeras nas igrejas. Aí as encontramos com efeito, vestidas de um modo estranhamente rebuscado, com as cores mais alegres e brilhantes, porém obedecendo a uma moda anglo-portuguesa muito pouco graciosa, importada pela corte de Lisboa e na qual há oito anos nada se mudara, como que por apêgo demasiado respeitoso à mãe pátria. Fiz imediatamente um desenho, mas o resultado, pela sua exatidão, foi uma caricatura inútil de reproduzir porque não exprime em absoluto o caráter e o temperamento brasileiro, pois o habitante do Brasil tem-se mostrado, desde então, tão entusiástico apreciador da elegância e da moda francesas que, por ocasião de minha partida, em fins de 1831, a rua do Ouvidor (rue Vivienne, de Paris, no Rio) era

\footnotetext{
${ }^{43}$ Joaquim Manuel de Macedo. Memórias da rua do ouvidor. São Paulo: Saraiva, 1963, p. 97.
} 
quase inteiramente constituída de lojas francesas de todo tipo, mantidas pela prosperidade de seu comércio. ${ }^{44}$

Os franceses, e as francesas, tornaram-se sinônimos de moda e bem vestir. "As francesas dominavam o comércio elegante da cidade e vestiam os salões do império (certas mulheres, em matéria de elegância, só conheciam os figurinos parisienses): ensinavam, inclusive uma nova forma de andar às fluminenses bonitas, com aquele ‘tique-taque' afrancesado a que se referia José Dias, partidário do 'vagar e paciência' que caracterizavam outros tempos". 45

Desta forma, a história da rua do Ouvidor mistura-se à própria história da urbanização do Rio de Janeiro, de cidade colonial à capital do império. Poucos anos após a fundação da cidade de São Sebastião do Rio de Janeiro por Mem de Sá em 1567, ao redor do ano de 1572, alguns colonos portugueses abriram, a poucos metros da rua Direita, uma entrada em ângulo reto, em que pequenas casinhas eram mal e mal erguidas, improvisadas ainda de um traçado urbano organizado. Mas aquela não era ainda propriamente dita uma rua, mas um desvio, um "Desvio do mar" ${ }^{46}$, o primeiro nome da rua Ouvidor.

Em 1590, portanto, ficou decidido que aquela pequena aglomeração de trabalhadores se chamava rua de Aleixo Manuel, que, reza a lenda, era barbeiro e cirurgião. Já para o fim do século XVII, um padre esperto e casamenteiro fez fama no lugar em que morava, justamente na rua Aleixo Manuel. Tanto fizeram as beatas e moças casadoiras, conta Joaquim Manuel de Macedo, que a rua passou a se chamar

\footnotetext{
${ }^{44}$ Jean-Baptiste Debret. Viagem Pitoresca e Histórica ao Brasil. Trad. port. T. I, vol. I e II, São Paulo, Martins Editora, 1940. p. 126

${ }^{45}$ Miécio Táti. O mundo de Machado de Assis. Rio de Janeiro: Livraria São José, 1961, p. 165. Agradeço a Leopoldo Waizbort a indicação o empréstimo do livro.

${ }^{46}$ Joaquim Manuel de Macedo. Memórias da rua do ouvidor. São Paulo: Saraiva, 1963, p. 3.
} 
Padre Homem da Costa. ${ }^{47}$ E assim, ao longo dos anos, a rua continuou chamando-se Padre Homem da Costa até que o Dr. Berquó, um ouvidor da comarca, fixou residência no número 62A, em 1780. A partir daí, dada a importância do ilustre morador, a rua finalmente tomou o nome que lhe deu fama e fortuna, rua do Ouvidor. ${ }^{48}$

Ao escrever sobre da rua mais famosa do Rio de Janeiro, Joaquim Manuel de Macedo não estava apenas fazendo um livro de memórias. Leitor de livros franceses, o escritor brasileiro escrevia "tropicalizando" o tema, um recente gênero literário francês, o de contar como era a vida em cidades, caracterizar tipos ou contar anedotas cotidianas. Walter Benjamin, em seu texto "O flâneur" 49 , vai chamar esse novo tipo de livro de literatura escrita para vender nas ruas de "fisiologias", em que os autores, como Girardin, descreviam tipos anedóticos encontrados em feiras e lugares pitorescos da cidade - da mesma maneira que Joaquim Macedo faria com as personagens de seu livro de memória sobre a rua do Ouvidor. O bêbado, o moço sombrio, a moça melancólica, a prostituta arrependida, o galã cafajeste eram personagens tanto do livro de Macedo como das fisiologias parisienses.

A cidade, e a multidão, eram uma novidade no século XIX e tornaram-se personagens de livros e relatos exóticos. Em 1841, segundo Benjamin, publicaram-se 76 novas fisiologias na França. ${ }^{50}$ Livros como Paris à noite, Paris à mesa, Paris Pitoresca, Paris a cavalo multiplicavam-se e faziam sucesso. "A calma dessas descrições combina com o jeito do flâneur, a fazer botânica no asfalto". ${ }^{51}$ Por aqui temos Joaquim Manuel

\footnotetext{
${ }^{47}$ Joaquim Manuel de Macedo. Memórias da rua do ouvidor. São Paulo: Saraiva, 1963, p. 27.

${ }^{48}$ Joaquim Manuel de Macedo. Memórias da rua do ouvidor. São Paulo: Saraiva, 1963, p. 49.

49 Walter Benjamim. Charles Baudelaire, um lírico no auge do capitalismo. São Paulo: Brasiliense, 2000, p. 33-34.

${ }^{50}$ Walter Benjamim. Charles Baudelaire, um lírico no auge do capitalismo. Trad. port. São Paulo: Brasiliense, 2000, p. 34-35.

${ }^{51}$ Walter Benjamim. Charles Baudelaire, um lírico no auge do capitalismo. Trad. port. São Paulo: Brasiliense, 2000, p. 34.
} 
de Macedo, que escreveu as Memórias da rua do Ouvidor, Um passeio pela cidade do Rio de Janeiro, Labirinto.

Andar pela cidade apreciando tanto as lojas como a multidão de passantes passou a ser uma atividade com um nome e tipo reconhecido em Paris - era um flâneur, que, desocupado, vagava pelas galerias de cristal da cidade-luz. Mas para que o Rio se tornasse uma "pequena feiticeira parisiense", a cidade precisava civilizar-se, "vestir-se", "maquiar-se" para a modernidade. Na foto de Marc Ferrez, a cidade em 1890, com ruas largas, bondes e quiosques, símbolos da modernidade.

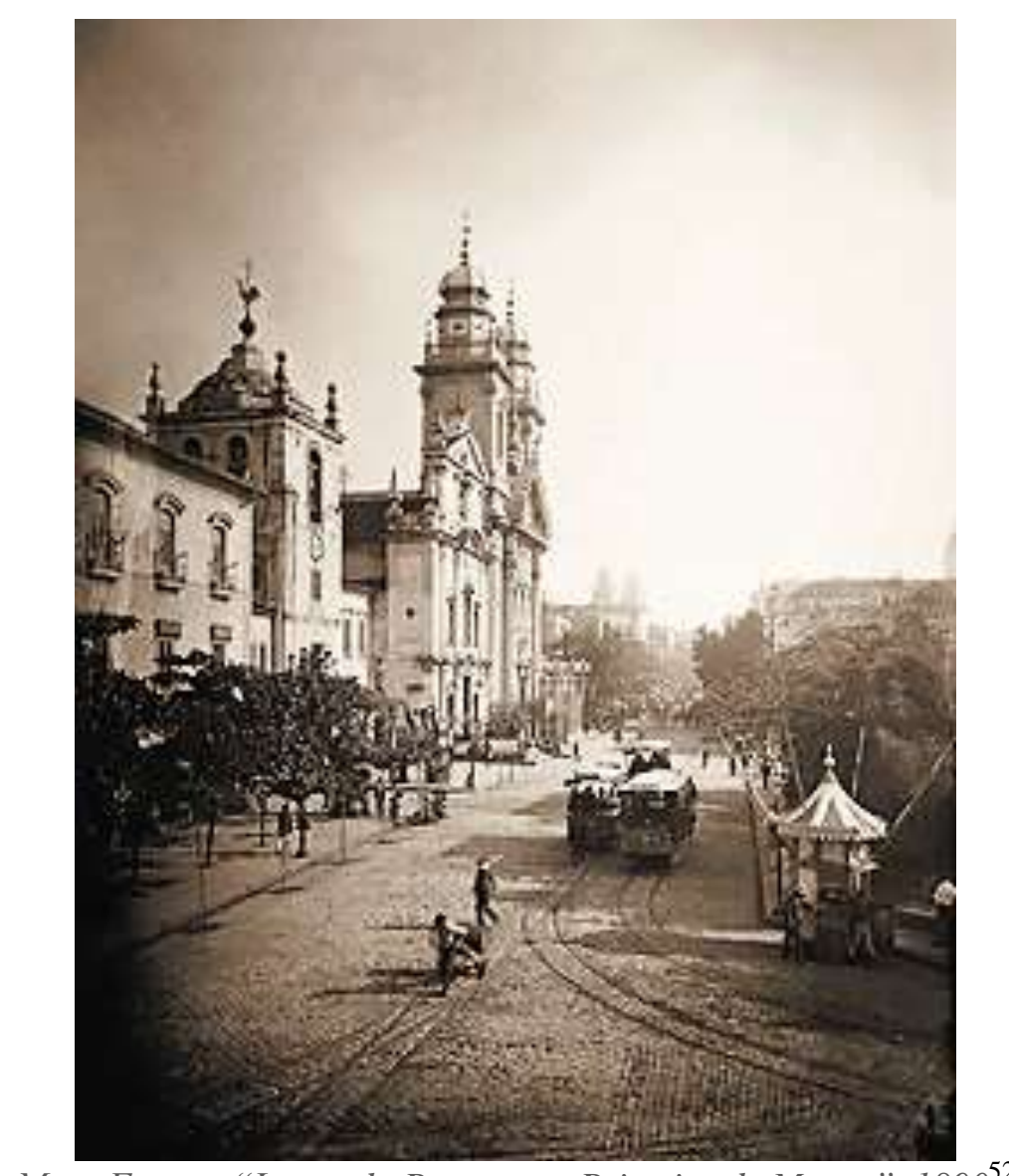

Marc Ferrez: "Largo do Paço e rua Primeiro de Março", $1890^{52}$

52 "Largo do paço e rua primeiro de março", de Marc Ferrez. In: O Brasil de Marc Ferrez. São Paulo: Instituto Moreira Salles, 2004. 
Nas memórias da rua do Ouvidor, são os pequenos gestos do cotidiano que fazem a história da rua, como a paixão de um sapateiro inglês pelo pezinho formoso de uma vendedora francesa, ou os inocentes romances entre estudantes e donzelas, as fugas e os amores proibidos. Nas ruas do Ouvidor, recebia-se a civilização europeia em forma de luvas, chapéus, sapatos, tecidos, ateliês de moda. Itens que traduziam em mercadoria um novo cosmopolitismo burguês que moldava o gosto das cariocas.

Durante todo o segundo império, o comércio em geral, e a rua Ouvidor, em particular, pareciam vibrar com o negócio de itens de moda importados. Mas a grande intensificação nas importações ocorreu na década de 1850, com a Lei Eusébio de Queiroz, complementada pela Lei Nabuco de Araújo, de 1854, que acabava com a polêmica sobre o tráfico negreiro e proibia a entrada de escravos no país.

O fim do tráfico não apenas estimulou a imigração de europeus pobres para o país para trabalharem como mão-de-obra nas fazendas de café - vieram, inclusive, operários qualificados, que fixaram residências em diferentes cidades como artesãos - mas também liberou grande quantidade de capitais que até então eram empregados no comércio de escravos. Foram cerca de 1,9 milhão de libras esterlinas que passaram a entrar por ano na economia brasileira, aquecendo o comércio do Rio, que se transformava numa vitrine de produtos de luxo para as elites carioca e do resto do país. ${ }^{53}$ Os imigrantes, por sua vez, abriram oficinas especializadas, como sapatarias finas, relojoarias, joalherias ou lojas, como a Jouvin, de luvas, localizada na rua do Ouvidor.

"O efeito na balança comercial e na balança de pagamentos do Império é imediato. Comparando-se o quinquênio de 1845-1850 ao de 1850-5 (o ano fiscal corria de julho a junho), constata-se que o valor das importações feitas no Rio de Janeiro

\footnotetext{
${ }^{53}$ Luiz Felipe Alencastro. História da vida privada no Brasil II. São Paulo: Companhia das Letras, 1997, Vol. II, p. 36 e 37.
} 
cresceu uma vez e meia. ${ }^{54,}$ Produtos importados, como tecidos, joias, cavalos, sapatos, chapéus ou móveis, entraram em grande número pelo porto carioca, destinados à nobreza da corte ou aos endinheirados fazendeiros do Vale do Paraíba.

O movimento do comércio e das lojas cariocas não foi fenômeno localizado no Rio de Janeiro nem no Brasil. "Com o advento da empresa capitalista, as formas mais antigas do mercado não desapareceram por completo do mundo ocidental; mas, desde então, ficaram em grande parte restritas aos mercadores de provisões", diz Lewis Mumford, em A cidade na história. ${ }^{55} \mathrm{~A}$ loja ao ar livre, como as retratadas por Debret, com a oficina atrás, por muito tempo permaneceu na paisagem carioca, mas, a partir de meados do século XIX, ela vai dar origem a outro tipo de comércio: lojas com vitrines e também espelhos, candelabros, balcões de mármores, vendedoras simpáticas e arrumadas. A rua do Ouvidor tornou-se o local por excelência do comércio de alto luxo, que acrescentava ao seu glamour uma série de confeitarias e estabelecimentos gastronômicos voltados para a elite.

Ideias e hábitos de uma antiga aristocracia colonial lentamente deram origem a novos modos entre os jovens cariocas - era preciso viver a modernidade conforme os hábitos europeus, especialmente os franceses. Os rapazes, então, discutiam literatura nos cafés, alinhavam-se com escolas literárias, liam jornais estrangeiros e absorviam as novidades do tempo com uma crescente rapidez - na verdade, com a mesma velocidade com que se transformavam os meios de transportes no século XIX, com vapores e trens.

Ao mesmo tempo, o Rio continuava sendo uma cidade cheia de escravos, em que a novidade de hábitos e produtos franceses se misturava com elementos tradicionais. A escravidão na cidade inseria-se em meio a essa modernidade tropical, com escravos e

\footnotetext{
${ }^{54}$ Idem, p. 37.

${ }^{55}$ Lewis Mumford. A cidade na história. Trad. port. São Paulo: Martins Fontes, 2008, p. 517.
} 
escravas de ganho que podiam vender quitutes, abacaxis ou galinhas, ou mesmo alugar "ao dia" suas habilidades de costura ou cozinha.

Uma pintora quase desconhecida da crítica, Abigail de Andrade (1864-1890), aluna e amante de Angelo Agostini, vai mostrar o cotidiano da cidade no quadro A hora do pão. A cidade que se transformava rapidamente, que abria avenidas e importava mercadorias na rua do Ouvidor, ainda vinha carregada de hábitos antigos, com o vendedor de pão oferecendo seus produtos de porta em porta. Uma senhora, em cima de uma janela com um pano vermelho pendurado, dá o dinheiro ao menino ao mesmo tempo em que várias crianças com dinheiro circundam o vendedor à espera do pão. As casas estão desgastadas pelo tempo e têm um jardim tropical à frente - as ruas não têm calçamento e são de terra. Tudo leva a crer que é uma cena de bairro, distante do centro do Rio. 


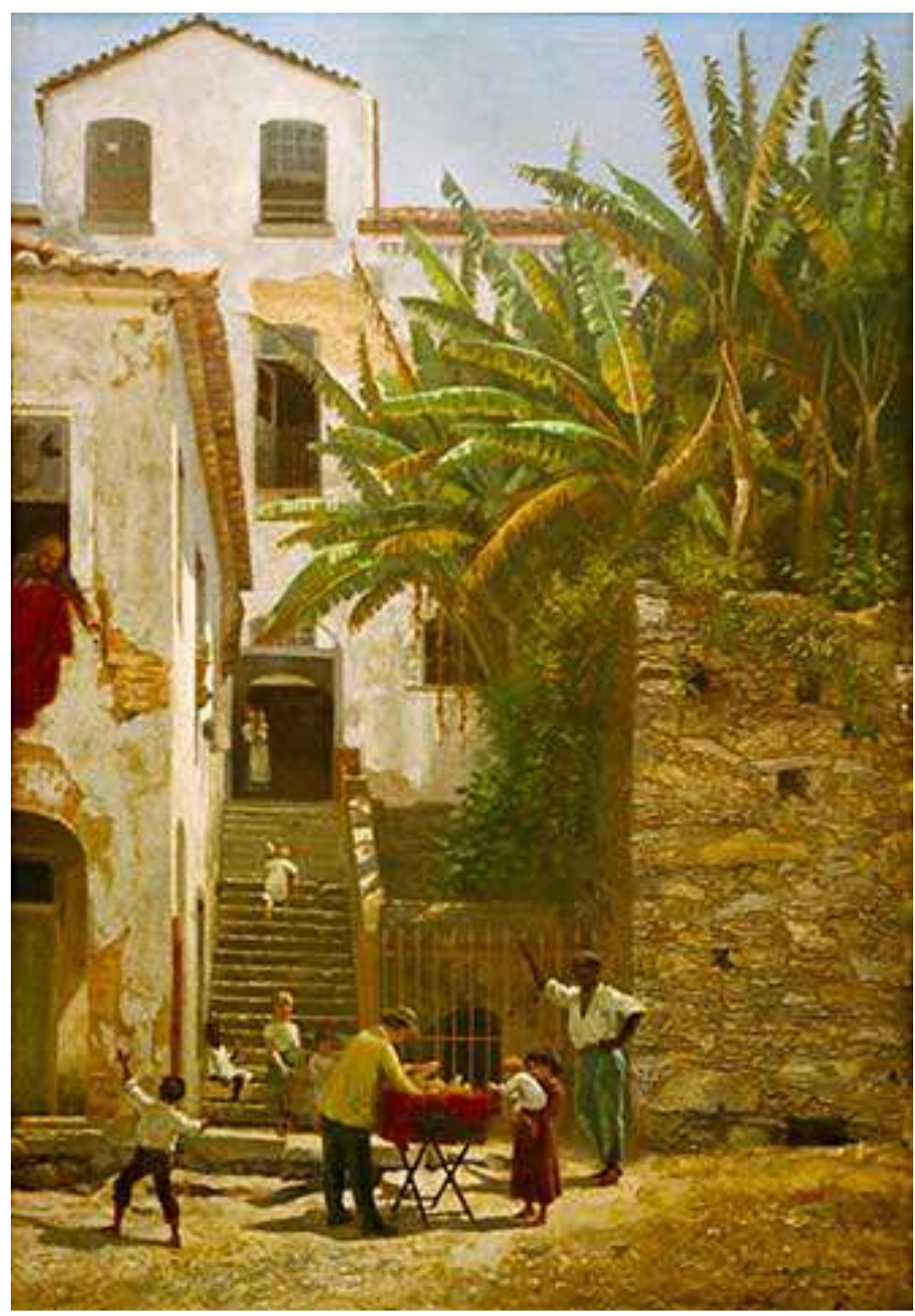

A hora do pão de Abigail de Andrade, de 1889, mostra o cotidiano da cidade em transformação no século XIX $X^{56}$

Usar a moda corretamente fazia todo o sentido para moças e senhoras da elite carioca. Acessórios de moda, como fitas, xales, leques, flores artificiais, chapéus, mantôs ou sapatos, que chegavam em profusão, vinham de diferentes portos do mundo e abasteciam as lojas do comércio carioca. Cada um tinha um significado especial no intrincado código vestuário do século XIX. Para o Jornal das Modas, os acessórios eram itens fundamentais. A moda passava, necessariamente, pelo uso correto dos acessórios.

${ }^{56}$ A hora do pão, de Abigail de Andrade, 1889. Óleo sobre tela, $73.5 \times 50 \mathrm{~cm}$. Coleção Sergio Fadel. 
Mas, para além de seu significativo valor econômico, como podemos perceber nas tabelas de importação, os acessórios de moda também possuíam um importante valor cultural. Os acessórios caracterizavam tipos, classes sociais ou posições de prestígio na corte. No caso dos homens, os acessórios foram essenciais para marcar a riqueza e a posição na sociedade do indivíduo. Dessa forma, a partir do momento em que as roupas masculinas se despiram de ornamentos e tornaram-se basicamente pretas e brancas, foram os acessórios que muitas vezes revelavam o tamanho de uma fortuna. Bengalas importadas, relógios de algibeira, vindos da França ou da Inglaterra, gravatas francesas, sapatos Clark, meias de seda, juntamente com cartolas ou chapéus de castor compunham o guarda-roupa do cavalheiro elegante. Para as mulheres, sombrinhas, luvas, chapéus, joias de todos os tipos distinguiam as moças da boa sociedade. Abaixo, podemos ver os principais acessórios de moda vendidos no comércio carioca e usados no cotidiano dos cidadãos do império.

\section{Em todas as cabeças, chapéus}

Nas tabelas de importação, aparecem em profusão bonets $^{57}$ e barretinas de palha, chapéus de palha, barretes, carapuças, chapéus de lã, de pele e de algodão, chapéus de palha ou de chuva, gorros e chapéus de linho. São tantos os chapéus que os valores das importações para o Brasil denunciavam a importância que esses objetos possuíam no dia a dia. No grande magazine parisiense descrito por Émile Zola em $O$ paraíso das damas, a seção de chapéus era uma das mais movimentadas, recebendo uma infinidade de mulheres atrás das novidades da última moda. Os chapéus eram um item essencial do guarda-roupa, que mudavam a cada estação.

\footnotetext{
${ }^{57}$ Os bonets eram uma espécie de chapéu amarrado com uma fita por baixo do pescoço.
} 
Sair de casa com o chapéu errado, com os ornamentos velhos ou com os mesmos colocados de maneira errada era deselegante, sendo sinal de pobreza, de velhice ou de origem humilde. Saber usar bem um chapéu era sinal de distinção e bom gosto. Mocinhas portavam alegres chapéus de palhas importados, como Amélia, de A pata da gazela, a heroína de Horácio, descrita por José de Alencar: "Por duas vezes avistara a fronte de Amélia coroada com um chapeuzinho de palha da Itália [...]. ${ }^{58,}$

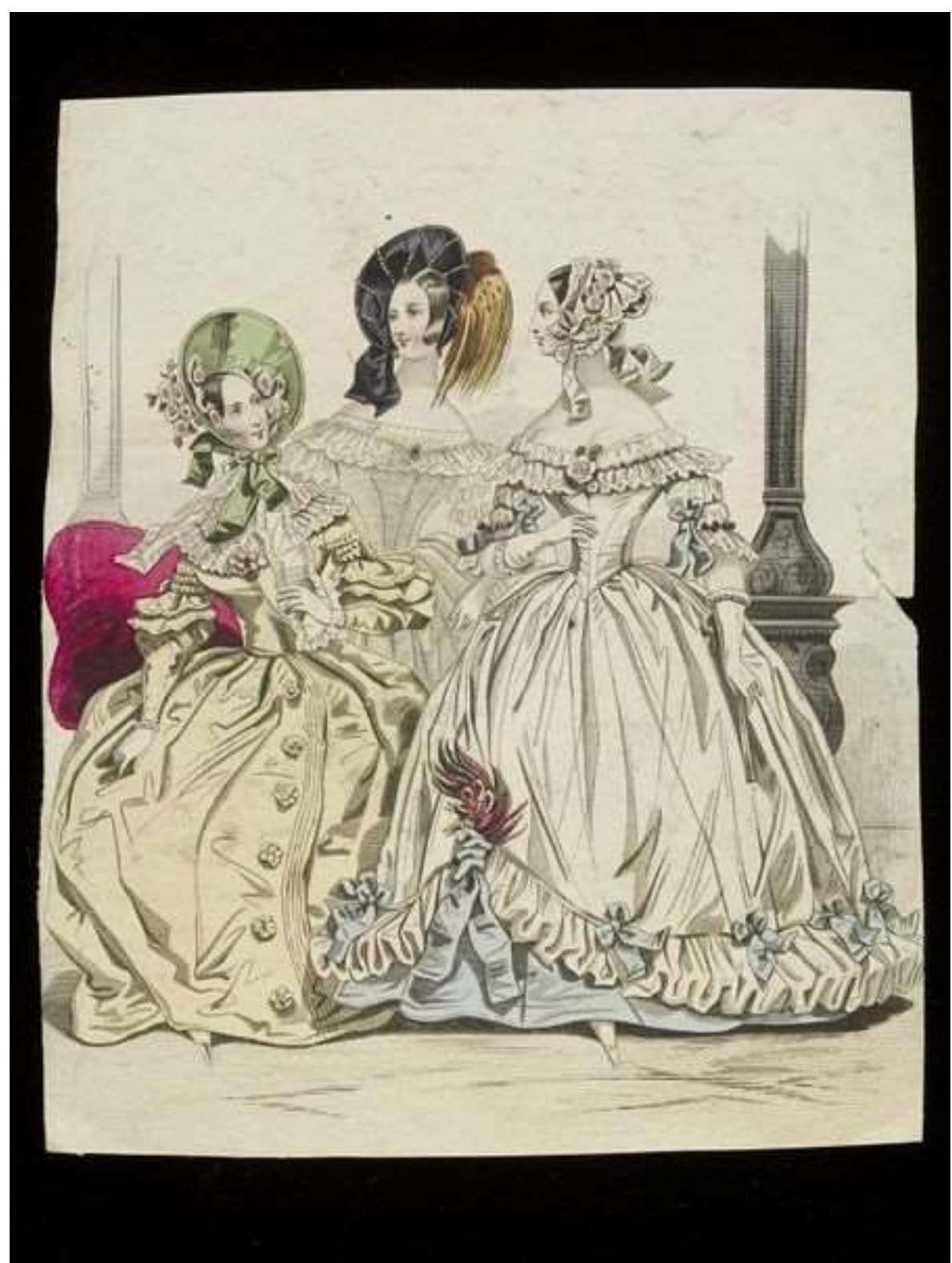

Na gravura de moda da década de 1840, vemos diferentes chapéus em estilo bonnet ${ }^{59}$

${ }^{58}$ José de Alencar. A pata da gazela. São Paulo: Saraiva, 1954, p. 28.

${ }^{59}$ Gravura de moda publicada pela revista francesa Le Bom Ton na década de 1840 por artista desconhecido e pintada à mão. Atualmente, encontra-se no Museu Victoria and Albert, http://collections.vam.ac.uk/item/O576408/fashion-plate-unknown/. 
Ao longo do século, o chapéu foi se tornando item obrigatório - o que também explica a profusão de modelos e preços nas tabelas de importação. Aluísio Azevedo, em Casa de pensão, de 1884, escreveu sobre uma senhora modesta: "vestiu-se para sair, e já de chapéu, a sombrinha na mão, o indispensável enfiado no braço [...]. ${ }^{60,}$

Numa descrição saborosa, os viajantes Daniel Parish Kidder e James Cooley Fletcher flagram o momento em que, em meados dos anos 1850, os chapéus passam a tomar as cabeças das brasileiras e brasileiros:

Sai de casa [...] toda vestida de seda preta, com colo e os braços geralmente descobertos, ou, no máximo, com uma leve mantilha ou capa sobre eles, seus cabelos luxuriantemente belos, bem arranjados e ornamentados, e, às vezes, cobertos por um véu de renda preta [...] É muitas vezes motivo de surpresa para os homens do Norte, a forma pela qual as damas brasileiras podem suportar descobertas os raios do sol, as europeias andam debaixo da proteção de chapéus e de sombrinhas [....] Todavia o chapéu vai se tornando uma moda dominante. $^{61}$

Dessa forma, assim como os sapatos, os chapéus também indicavam a posição social e riqueza de seus portadores. Para mostrar riqueza de uma menina, José de Alencar a descreveu da seguinte maneira: "Para abrigar-se do sol ela trazia apenas um chapéu de palha de abas largas [...]". ${ }^{62}$ Uma moça rica, em roupa de montaria, no romance de José de Alencar, Sonhos d'ouro, vinha trajando: "Um roupão de caxemira verde escura, debruado a cairel ${ }^{63}$ de seda preta, com abotoadura de aço [ ...]. O gracioso

${ }^{60}$ Aluísio Azevedo. Casa de Pensão. São Paulo, Martins Editora, 1960, p. 183.

${ }^{61}$ Daniel Parish Kidder e James Cooley Fletcher. O Brasil e os brasileiros). Trad. port. Vol. 1, São Paulo: Companhia Editora Nacional, 1941, p. 183.

${ }^{62}$ José de Alencar. $O$ tronco do Ipê. Rio de Janeiro: Edições de Ouro, s.d., p. 29.

${ }^{63}$ Cairel é um substantivo masculino que significa fita, galão, para debruar, debrum. 
chapéu de castor cor de pérola [...] pousava como um pombo na rica madeixa negra $[\ldots]^{64 \%}$. Já um jovem pobre, no mesmo livro, O tronco de ipê, é retratado com "o chapéu de feltro escuro e o jaleco de brim [...].",65

Usados em diferentes momentos da convivência social, o chapéu vinha carregado de símbolos de como ser usado e portado, assim como as sombrinhas, bengalas e leques. Cada gesto podia significar uma emoção ou um desejo diferente de seu portador. Em Lucíola, o amante, chateado, conserva seu chapéu na mão para demonstrar tristeza com a protagonista. ${ }^{66}$ Uma jovem rica, em outro livro de José de Alencar, sabia se portar em sociedade e usava, elegantemente, “[...] um vestido de cassa de listras azuis; seu chapéu à pastora ligeiramente pousado sobre os anéis soltos dos cabelos louros e uma bolsa de palha no braço". ${ }^{67}$ Fernando Seixas, o amor de Aurélia, em Senhora, foi assim descrito no romance:

Assim no recosto de uma das velhas cadeiras de jacarandá via-se nesse momento uma casaca preta, que pela fazenda superior, mas, sobretudo, pelo corte elegante e esmero do trabalho, conhecia-se ter o chique da casa Raunier, que já era naquele tempo o alfaiate da moda. Ao lado da casaca estava o resto de um traje de baile [...] finíssimo chapéu claque do melhor fabricante de Paris; luvas de Jouvin cor de palha; e um par de botinas como o Campas só fazia para os seus fregueses prediletos. ${ }^{68}$

\footnotetext{
${ }^{64}$ José de Alencar. Sonhos D'Ouro. T. I, Rio de Janeiro: Livraria Garnier,1872, p. 18-9.

${ }^{65}$ José de Alencar. O tronco do Ipê. Rio de Janeiro: Edições de Ouro, s.d.,p. 34.

${ }^{66}$ José de Alencar. Lucíola. São Paulo: Edições Melhoramentos, s.d., p. 17.

${ }^{67}$ José de Alencar. O tronco do Ipê . Rio de Janeiro: Edições de Ouro, s.d., p. 132-3.

${ }^{68}$ José de Alencar. Senhora. São Paulo: Editora Ática, 1971, p. 29-30.
} 


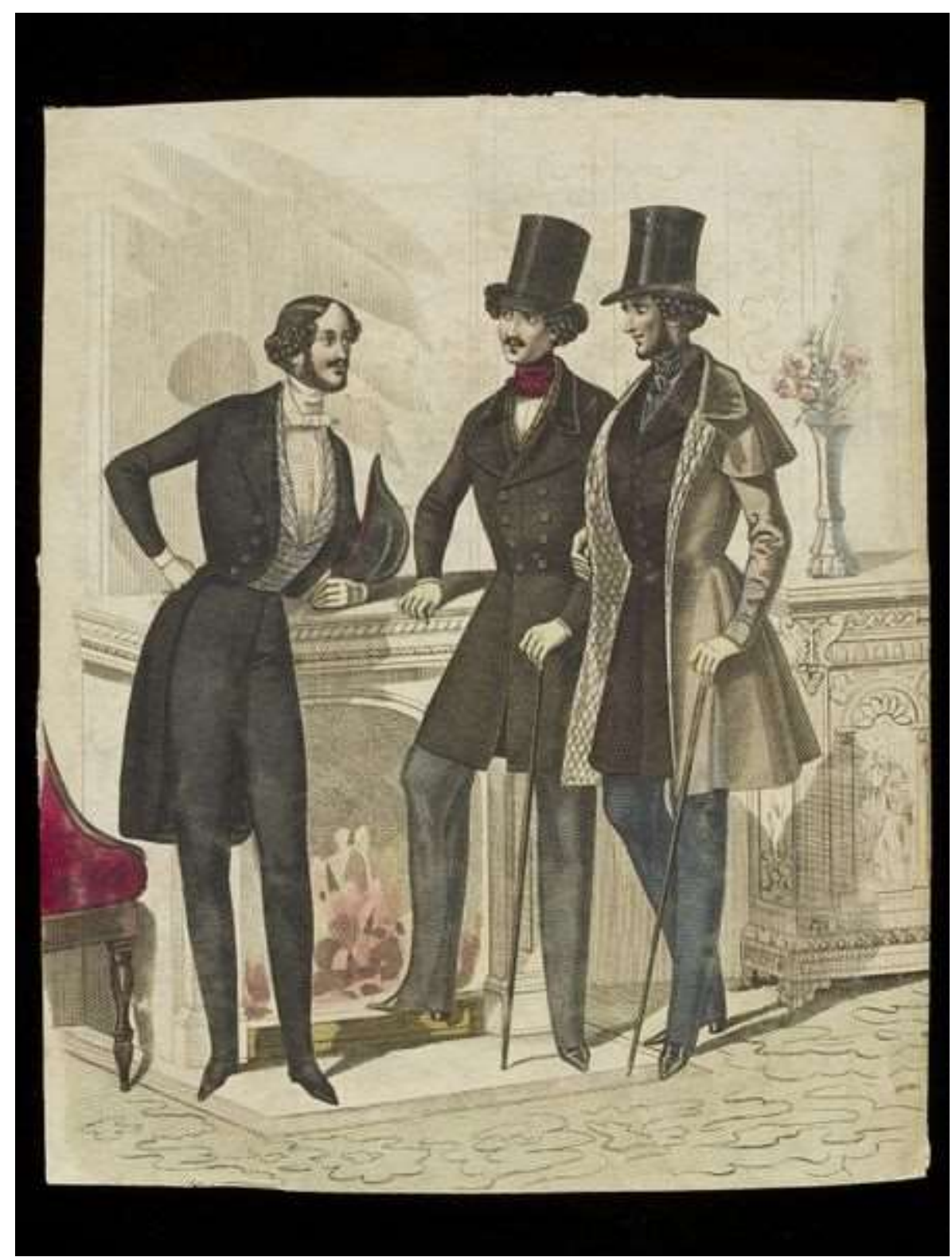

Cavalheiros apresentam diferentes chapéus-claque e um em estilo naval. As bengalas dão o tom de elegância ${ }^{69}$

A casaca preta de corte elegante da casa Reunier, o chapéu claque feito no melhor fabricante de Paris, as luvas Jouvin e as botinas do Campas. Tudo nos trajes de baile de Seixas indicavam seu bom gosto, seu refinamento, seu conhecimento das regras da boa sociedade carioca. O moço investia tempo e dinheiro, muito dinheiro, na arte de se vestir, de estar na moda, de consumir produtos nas melhores lojas carioca. José de

${ }^{69}$ Esta gravura de moda foi publicada na década de 1840. Colorida à mão está no Museu Victoria and Albert, http://collections.vam.ac.uk/item/O576384/fashion-plate-unknown/. 
Alencar, nesta história publicada em 1875, descreve um tipo contemporâneo, mas escreve também sobre a época em que vivia.

Tabelas de importação para os anos de $1871-1872^{70}$ Chapéus, bonets e barrettinas

Bonets e barretinas de palha

\begin{tabular}{|l|r|r|}
\hline País & Quantidade & \multicolumn{1}{|l|}{ Valor } \\
\hline França & 208 & $256 \$ 000$ \\
\hline Grã-Bretanha & 876 & $1: 125 \$ 000$ \\
\hline Portugal & 10 & $4 \$ 000$ \\
\hline Total & 1.094 & $1: 385 \$ 000$ \\
\hline
\end{tabular}

Chapéus de palha

\begin{tabular}{|l|r|r|}
\hline País & Quantidade & Valor \\
\hline Alemanha & 9.825 & $19: 593 \$ 000$ \\
\hline Bélgica & 1.752 & $2: 832 \$ 000$ \\
\hline Chile & 9.451 & $31: 973 \$ 000$ \\
\hline China & 795 & $2: 280 \$ 000$ \\
\hline Conf. Argentina & 722 & $1: 503 \$ 000$ \\
\hline Dinamarca & 534 & $2: 136 \$ 000$ \\
\hline Estado Oriental & 1.078 & $2: 752 \$ 000$ \\
\hline Estados Unidos & 2.960 & $7: 312 \$ 000$ \\
\hline França & 172.747 & $344: 020 \$ 000$ \\
\hline Grã-Bretanha & 149.092 & $254: 802 \$ 000$ \\
\hline Itália & 9.829 & $19: 380 \$ 000$ \\
\hline Peru & 2.345 & $9: 380 \$ 000$ \\
\hline Portugal & 439 & $1: 165 \$ 000$ \\
\hline Indeterminado & 9.057 & $24: 092 \$ 000$ \\
\hline Total & 370.626 & $722: 137 \$ 000$ \\
\hline
\end{tabular}

Barretes, carapuças, bonets, etc.

\begin{tabular}{|l|r|r|}
\hline País & Quantidade & Valor \\
\hline Alemanha & --- & $2: 097 \$ 000$ \\
\hline França & --- & $3: 917 \$ 000$ \\
\hline Grã-Bretanha & --- & $1: 462 \$ 000$ \\
\hline Total & --- & $7: 467 \$ 000$ \\
\hline
\end{tabular}

${ }^{70}$ Tabelas publicadas nas Estatísticas do comércio marítimo do Brasil, exercício de 1871-1872, organizada pela comissão dirigida por D. Sebastião Ferreira Soares. Rio de Janeiro: Typografia acional, 1876. 
Chapéus redondos, chapéus de lã, redondos, de pasta, etc.

\begin{tabular}{|l|r|r|}
\hline País & Quantidade & Valor \\
\hline Alemanha & 3.113 & $3: 677 \$ 000$ \\
\hline Conf. Argentina & 280 & $280 \$ 000$ \\
\hline Estado Oriental & 141 & $315 \$ 000$ \\
\hline França & 43.374 & $78: 052 \$ 000$ \\
\hline Grã-Bretanha & 12.390 & $24: 569 \$ 000$ \\
\hline Portugal & 103 & $377 \$ 000$ \\
\hline Indeterminado & 1.544 & $2: 754 \$ 000$ \\
\hline Total & 60.948 & --- \\
\hline
\end{tabular}

Chapéus de lã, redondos, de pasta, etc

\begin{tabular}{|l|r|r|}
\hline País & Quantidade & \multicolumn{1}{l|}{ Valor } \\
\hline Alemanha & 23.056 & $53: 149 \$ 000$ \\
\hline Bélgica & 156 & $309 \$ 000$ \\
\hline Conf. Argentina & 6.804 & $8: 208 \$ 000$ \\
\hline Estado Oriental & 8.233 & $13: 441 \$ 000$ \\
\hline Estados Unidos & 42 & $82 \$ 000$ \\
\hline França & 151.953 & $293: 143 \$ 000$ \\
\hline Grã-Bretanha & 217.953 & $376: 488 \$ 000$ \\
\hline Itália & 41 & $82 \$ 000$ \\
\hline Paraguai & 296 & $355 \$ 000$ \\
\hline Portugal & 14.283 & $20: 248 \$ 000$ \\
\hline Indeterminado & 5.820 & $2: 754 \$ 000$ \\
\hline Total & & $779: 286 \$ 000$ \\
\hline
\end{tabular}

Chapéus de sol ou de chuva e preparo para os mesmos

\begin{tabular}{|l|r|r|}
\hline País & Quantidade & \multicolumn{1}{|l|}{ Valor } \\
\hline Alemanha & --- & $24: 310 \$ 000$ \\
\hline China & --- & $23 \$ 000$ \\
\hline Estado Oriental & --- & $1: 906 \$ 000$ \\
\hline França & --- & $128: 919 \$ 000$ \\
\hline Grã-Bretanha & --- & $429: 524 \$ 000$ \\
\hline Itália & --- & $18 \$ 000$ \\
\hline Portugal & --- & $412 \$ 000$ \\
\hline Indeterminado & --- & $6: 346 \$ 000$ \\
\hline Total & --- & $591: 460 \$ 000$ \\
\hline
\end{tabular}


Barrets, bonets e gorros de linho

\begin{tabular}{|l|r|r|}
\hline País & Quantidade & \multicolumn{1}{|l|}{ Valor } \\
\hline França & 537 & $432 \$ 000$ \\
\hline Grã-Bretanha & 1.040 & $853 \$ 000$ \\
\hline Total & & $1: 285 \$ 000$ \\
\hline
\end{tabular}

\section{Chapéus de tecido de linho para a cabeça}

\begin{tabular}{|l|r|r|}
\hline País & \multicolumn{1}{|l|}{ Quantidade } & \multicolumn{1}{l|}{ Valor } \\
\hline Alemanha & 295 & $446 \$ 000$ \\
\hline França & 315 & $606 \$ 000$ \\
\hline Grã-Bretanha & 694 & $1: X 92 \$ 000$ \\
\hline Portugal & 56 & $85 \$ 000$ \\
\hline Indeterminado & 312 & $519 \$ 000$ \\
\hline Total & & $2: 748 \$ 000$ \\
\hline
\end{tabular}

\section{O interessante caso dos sapatos ingleses em pés brasileiros}

Os sapatos também representaram um tipo de acessório especial. Indispensável para quem quisesse fazer boa figura quando saísse à rua, proibido para os escravos brasileiros. Produzidos de maneira crescente a partir de meados do século XVIII, a Inglaterra encabeçou o comércio mundial de sapatos ao longo de todo século XIX. Dessa forma, os sapatos saíam de portos como Liverpool e aportavam no Brasil, essencialmente no Rio de Janeiro. Caros e vistosos, os sapatos ingleses representavam uma parte significativa das importações brasileiras do século XIX. Nos mapas de importação dos anos 1871-1872 apareceram, vindos da Grã-Bretanha, 898.116 pares de sapatos ingleses (que podiam incluir sapatos, canhões para botas ou polainas), valendo aproximadamente 1.503:325\$325 (mais de mil, quinhentos e três contos de réis) - o que significa que cada par podia custar cerca de $1 \$ 674$ (mil, seiscentos e setenta e quatro réis). Esse último era o preço de atacado, por par de sapatos, que chegou ao porto do 
Rio de Janeiro. No varejo, o preço do par de sapatos era, quase sempre, de aproximadamente o dobro, ou seja, cerca de $3 \$ 348$ (três mil e trezentos réis). ${ }^{71}$

Para se ter uma ideia do que isso representava, vemos que um administrador da praça do mercado de São Paulo, no mesmo período, ganhava por mês 66\$680 (sessenta e seis mil, seicentos e oitenta réis) e um médico paulista, o Dr. Francisco Honorato de Moura, recebia cerca de $100 \$ 000$ (cem mil réis). ${ }^{72}$ Pode-se também fazer outras comparações de valores já que um terreno em frente à estação de ferro inglesa podia custar 200\$000 (duzentos mil réis) em 1874, em São Paulo, enquanto o aluguel de uma casinha no Belenzinho ficava em cerca de $30 \$ 000$ (trinta mil réis) no mesmo período. ${ }^{73}$ Ou seja, o administrador da praça do mercado de São Paulo podia gastar o equivalente a cerca de uns vinte pares de sapato importados da Inglaterra por mês.

Tabela de importação de sapatos $(1871-1872)^{74}$

Sapatos

\begin{tabular}{|l|r|r|}
\hline País & Quantidade & Valor \\
\hline Grã-Bretanha & 898.116 & $1.503: 325 \$ 325$ \\
\hline Estados Unidos & 6.103 & $3: 793 \$ 800$ \\
\hline França & 714.580 & $914: 976 \$ 800$ \\
\hline Portugal & 326.687 & $225: 254 \$ 175$ \\
\hline $\begin{array}{l}\text { Total (inclui dados de } \\
\text { outros países) }\end{array}$ & & $2.952: 693 \$ 253$ \\
\hline
\end{tabular}

Mas os sapatos também eram fabricados no Brasil, numa enorme variedade de preços, formatos, tamanhos e tipos que podiam ir de chinelas e tamancos às pequenas

\footnotetext{
${ }^{71}$ Veja o anúncio do Almanaque Laemmert de 1870, seção de notabilidades.

${ }^{72}$ Maria Luiza de Oliveira. Entre a casa e o armazém. São Paulo: Alameda Editorial, 2006, p. 299.

${ }^{73}$ Maria Luiza de Oliveira. Entre a casa e o armazém. São Paulo: Alameda Editorial, 2006, p. .326.

${ }^{74}$ As tabelas foram tiradas da publicação Estatísticas do comércio marítimo do Brasil, exercício de 1870-1871, organizada pela comissão dirigida por d. Sebastião Ferreira Soares. Rio de Janeiro: Typografia Nacional, 1876.
} 
sapatilhas de cetim tão citadas por Gilberto Freyre em Sobrados e Mucambos. ${ }^{75}$ Calçarse bem e corretamente fora de casa passava a ser símbolo de distinção social - fato que se estendeu por todo o século XIX e marcou as relações sociais entre as classes. Irônico, Machado de Assis atribuía aos pés e aos sapatos a capacidade de sintetizar a imagem de uma personagem, reforçando a ligação entre pés, sapatos e classes sociais no século XIX. Em Quincas Borba, o escritor descreveu uma cena em que a personagem: "Sentada, via-se-lhe metade do pé, sapato raso, meia de seda, coisas todas que pediam misericórdia e perdão". ${ }^{76}$

Caixeiros portugueses após a Independência, e por muito tempo, iam de casa em casa oferecendo chinelas ou sapatos para vender ou para serem consertados. Portugal, inclusive, possuía uma significativa tradição de confecção de sapatos, cuja importação pela Brasil continua ao longo do século XIX. Apenas no biênio de 1871-1872, vieram para o porto do Rio de Janeiro 326.687 pares, que valiam cerca de 225:254\$175 (duzentos e vinte e cinco mil, duzentos e cinquenta e quatro réis). A profissão de sapateiro por portugueses imigrados para o Brasil continuou a ser exercida por eles durante todo o século XIX. ${ }^{77}$ No anúncio de 1867 do Almanaque Laemmert, veem-se duas casas que vendiam sapatos na rua do Ouvidor, a Dois Irmãos e a Fernandes Braga e Araújo. Ambas vendiam sapatos a pronta entrega e importados.

\footnotetext{
${ }^{75}$ Gilberto Freyre. Sobrados e mucambos. São Paulo: Global, 2003, p. 163.

${ }^{76}$ Machado de Assis. Quincas Borba. São Paulo: Ática, 1987, p. 190.

${ }^{77}$ Gilberto Freyre. Sobrados e mucambos. São Paulo: Global, 2003, p. 524.
} 


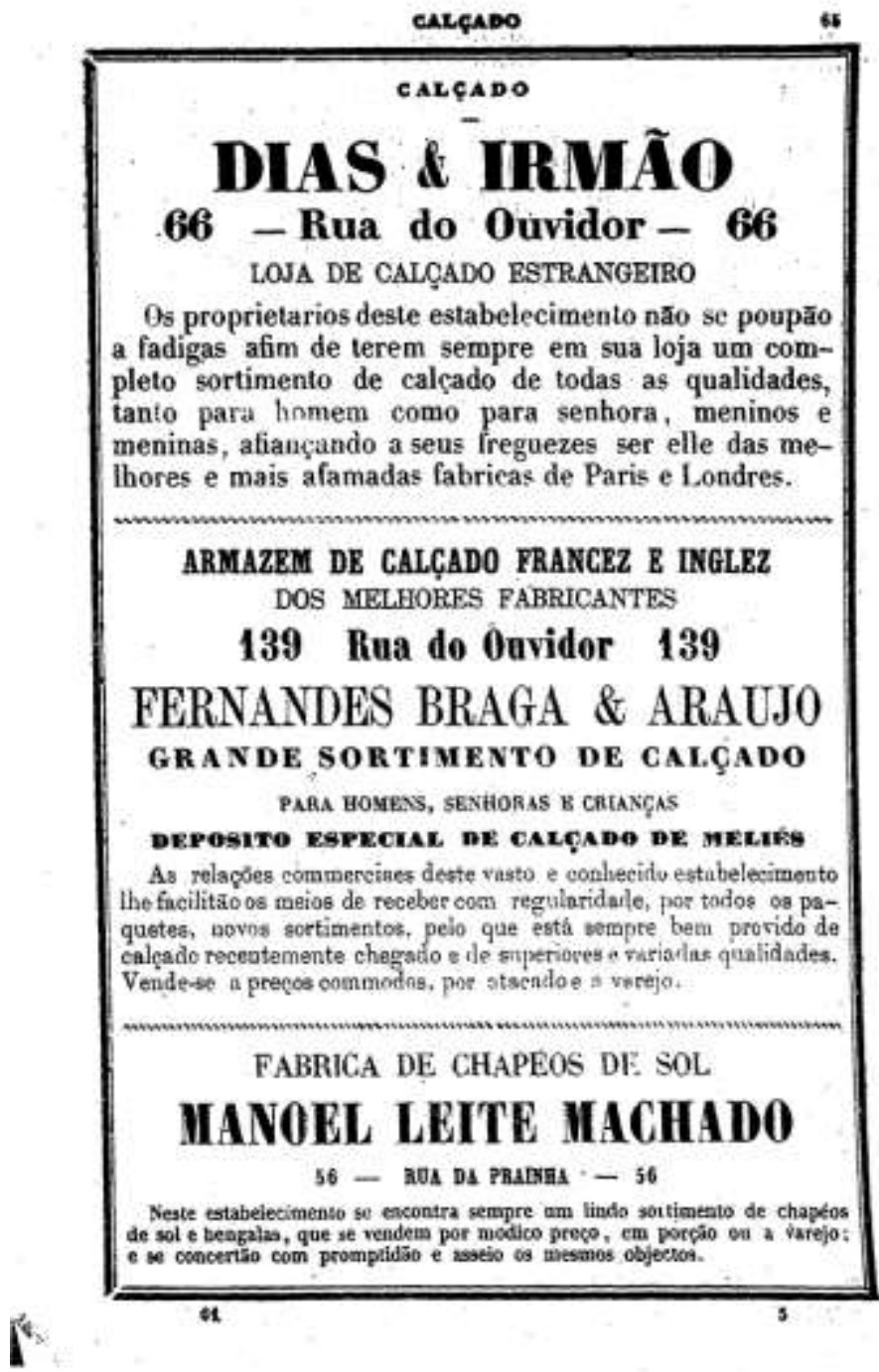

Duas lojas de calçados e um anúncio de chapéus: itens essenciais do vestuário ${ }^{78}$

Por isso, a importação de sapatos pelo Brasil no século XIX constituiu um caso excepcional de um item de consumo em que se misturavam aspectos econômicos e culturais. Os sapatos serem proibidos para os escravos. Proibidos, esses itens tornavamse objetos emblemáticos, que distinguiam classes e separavam os livres dos não-livres, tornando-se assim símbolos de uma vida livre. Numa imagem excepcional, vemos d. Pedro II, em meados do século XIX, rodeado por seus escravos. O homem barbado à sua esquerda, ainda que esteja portando paletó, camisa, gravata e colete, estava descalço, bem como todos seus companheiros de foto, que estão bem vestidos e

\footnotetext{
${ }^{78}$ Almanaque Laemmert de 1861, p. 65 da seção "Notabilidades".
} 
alinhados para a fotografia. A falta de sapatos distinguia os escravos de maneira clara e evidente: "Um escravo de ganho [...] podia ter meios para vestir calças bem-postas, paletó de veludo, portar relógio de algibeira, anel com pedra, chapéu-coco e até fumar charuto em vez de cachimbo. Nem com tamancos, nem com sandálias. De pé no chão. Para deixar bem exposto o estigma indisfarçável do estatuto de cativo", escreveu Luiz Felipe de Alencastro. ${ }^{79}$

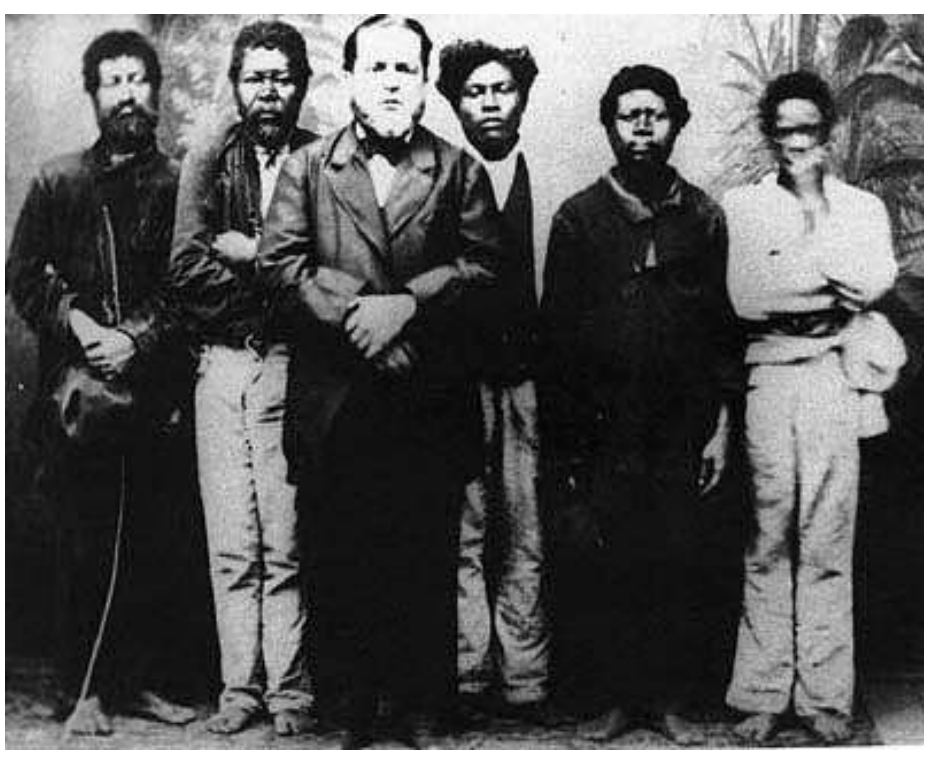

D. Pedro II rodeado por seus escravos descalços numa foto de Militão Augusto de Azevedo ${ }^{80}$

Os sapatos possuíam um valor simbólico fundamental. Pequenas vendas no interior expunham tamancos, chinelos ou sapatos de trabalho, já que esses eram objetos que dignificavam seu usuário. Oscar Canstatt, viajando pelo Brasil em meados do século XIX, observou que: "Só nas localidades mais longínquas é que o sortimento das vendas limita-se aos produtos da terra, materiais para seleiros, ferragens, sapatos e tamancos, aguardente, cerveja inglesa, e as raramente em falta, sardinhas em lata." ${ }^{\prime 1}$ Desta forma, podemos perceber que mesmo nos lugares mais remotos, os sapatos eram

\footnotetext{
${ }^{79}$ Luiz Felipe de Alencastro, "Vida privada e ordem privada no Império". In: História da vida privada no Brasil II. São Paulo: Companhia das Letras, 1997, p. 79.

${ }^{80}$ Foto reproduzida do caderno de imagens (s/ páginas) do livro Lilia Schwarcz. As barbas do imperador. São Paulo: Companhia das Letras, 1998.

${ }^{81}$ Oscar Canstatt. Brasil, a terra e a gente. Trad. port. Rio de Janeiro: Irmãos Pongetti Editores, 1954. p. 302.
} 
itens de primeira necessidade, e figuravam ao lado de importados como a cerveja inglesa e as latas de sardinha e também dos produtos da terra.

Para além da questão sócio-econômica, os sapatos, para as mulheres do século XIX, participavam de um complexo jogo de sedução, em que o mostrar e esconder partes do corpo era fundamental. Com a popularização das crinolinas, o andar ora revelava, ora descobria os pezinhos cobertos por cetim. Segundo Gilda de Mello e Souza, os vestidos criavam "ao rés do chão uma inquietante zona de espera" ${ }^{82}$, com inúmeros exemplos de pés indiscretos e corações apaixonados sendo revelados pela literatura da época. Esta é a história de A pata da gazela, em que Leopoldo se apaixona por uma pequena botina tamanho 29 e corre o Rio de Janeiro em busca de sua amada. Em Senhora, José de Alencar descreve as "fitas azuis do cabelo e do cinto da mocinha, bem como o cetim de um sapato raso, que lhe calçava o pé com o engaste de uma pérola". 83

Em uma de suas melhores peças de teatro, de 1857, José de Alencar exibia em diálogos outro dos fetiches do século XIX, a cintura fina. Em $O$ demônio familiar, uma das personagens, um escravo, dizia: "Moça bonita é Nhanhã Carlotinha! Essa sim! Não tem cá panos, nem pós! Pezinho de menina: cinturinha bem feitinha; não carece apertar! Sapatinho dela parece brinquedo de boneca." ${ }^{84}$

Em A Moreninha, Joaquim Manuel de Macedo repetia um dos clichês sobre as mulheres, a moda e o recato feminino, escrevendo “... que seu pecado contra a modéstia reinante não era senão um meio sutil de que se aproveitava para deixar ver o pezinho mais bem feito e mais pequeno que se pode imaginar." 85 Os pés das mulheres deveriam

\footnotetext{
${ }^{82}$ Gilda de Mello e Souza. O espírito das roupas. A moda no século XIX. São Paulo: Companhia das Letras, 1987, p. 94.

${ }^{83}$ José de Alencar, Senhora. São Paulo: Ática, 1971, p. 180.

${ }^{84}$ José de Alencar. O demônio familiar. São Paulo: Martin Claret, 2002, p. 127.

${ }^{85}$ Joaquim Manuel de Macedo. A moreninha. São Paulo: Martins Editora, 1969.
} 
vir em sapatinhos pequenos, provando seu recato e sua boa índole, como na Cinderela dos irmãos Grimm.

Referindo-se às mulheres pobres ou remediadas, Aluízio Azevedo, às vésperas da abolição da escravatura, escreveu em $O$ homem que uma personagem possuía " os pés

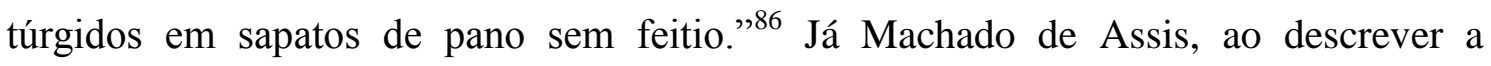
modéstia de Capitu em Dom Casmurro, pouco antes de mencionar seus olhos "oblíquos e dissimulados", acentua-lhe as características descrevendo seus pés e seus calçados. "Não podia tirar os olhos daquela criatura de quatorze anos, alta, forte e cheia, apertada em um vestido de chita [...]. Calçava sapatos de duraque ${ }^{87}$, rasos e velhos, a que ela mesma dera alguns pontos". 88

Pouco antes, no começo dos oitocentos, Jean-Baptiste Debret, atento aos costumes da terra, observou a importância dos sapatos no cotidiano carioca, notando que as senhoras, muitas vezes, mandavam vestir suas escravas preferidas com delicadas sapatilhas de cores pastéis, as mesmas que usavam para ir à igreja ou às visitas. O Rio, descrito por Debret, era cheio de sapatarias. Como podemos observar no trecho abaixo, Debret sabia o que significava para uma cidade na qual cinco sextos da população andava descalço, ou seja, era escrava e não podia usar sapatos:

O europeu que chegasse ao Rio de Janeiro em 1816, mal poderia acreditar, diante do número considerável de sapatarias [...] que esse gênero de indústria se pudesse manter numa cidade em que os cinco sextos da população andam descalços. Compreendia-o entretanto, logo, quando the observavam que as senhoras brasileiras, usando exclusivamente sapatos de seda para andar com qualquer tempo por cima das calçadas de pedras, que esgarçam em pouco instantes o tecido delicado do calçado, não podiam sair mais de dois dias

${ }^{86}$ Aluísio Azevedo. O homem . São Paulo: Martins Editora, 1970, p. 134.

${ }^{87}$ Tecido forte, resistente, próprio para sapatos. Conforme o Dicionário Houaiss.

${ }^{88}$ Joaquim Maria Machado de Assis. Dom Casmurro . São Paulo: Editora Ática, 1974, p. 23. 
seguidos sem renová-los, principalmente para fazer visitas. As únicas cores usadas eram o branco, o rosa e o azul-céu; a partir de 1832 acrescentaram-se o verde e o amarelo, cores imperiais e usadas na corte. Esse luxo, aliás, não é exclusivo aos senhores; ele obriga a brasileira rica a fazer calçarem-se como ela própria, com sapatos de seda, as seis ou sete negras que a acompanham na igreja ou no passeio. A mesma despesa tem a dona de casa menos abastada, com suas três ou quatro filhas e suas duas negras. A mulata sustentada por um branco faz questão também de se calçar com sapatos novos, cada vez que sai e o mesmo ocorre com sua negra e seus filhos. A mulher do pequeno comerciante priva-se de quase todo o necessário para sair com sapato novo e a jovem negra livre arruína seu amante para satisfazer essa despesa por demais renovada. ${ }^{89}$

Debret nota, no saboroso texto acima, que as mulheres faziam dívidas para comprar sapatos ou sair de casa com novos pares - maridos, amantes ou companheiros seriam "arruinados ou privados de outros luxos" para calçarem suas namoradas, mulheres ou amantes. O trecho mostra claramente que os sapatos eram considerados objetos essenciais de distinção social: as mais pobres envergonhando-se de sua condição ao portarem um tamanco, um sapato velho ou de pano; as mais ricas exibindo seus pezinhos em pequenas sapatilhas de seda em tons pastéis. Na gravura abaixo, o exemplo das mulheres bem calçadas de um empregado do governo.

Debret também notou como o Rio de Janeiro era uma cidade de sapatos e sapateiros - e continuou assim por muito tempo, ao longo de todo o século XIX. Na gravura reproduzida abaixo, ainda que o foco principal de atenção seja as relações de trabalho entre escravo e patrão, é numa das inúmeras sapatarias da cidade que a cena, violenta, acontece. Nas vitrines atrás do sapateiro, veem-se as famosas sapatilhas de seda coloridas em tons pastéis, penduradas atrás de vitrines de vidros. As fôrmas ficam

${ }^{89}$ Jean-Baptiste Debret. Viagem pitoresca e histórica ao Brasil . Trad. port. T. I, vol. I e II. São Paulo: Martins Editora, 1940, p. 205. 
no teto, enquanto as botas de homens estão na parede acima do escravo vestido com o avental bege.

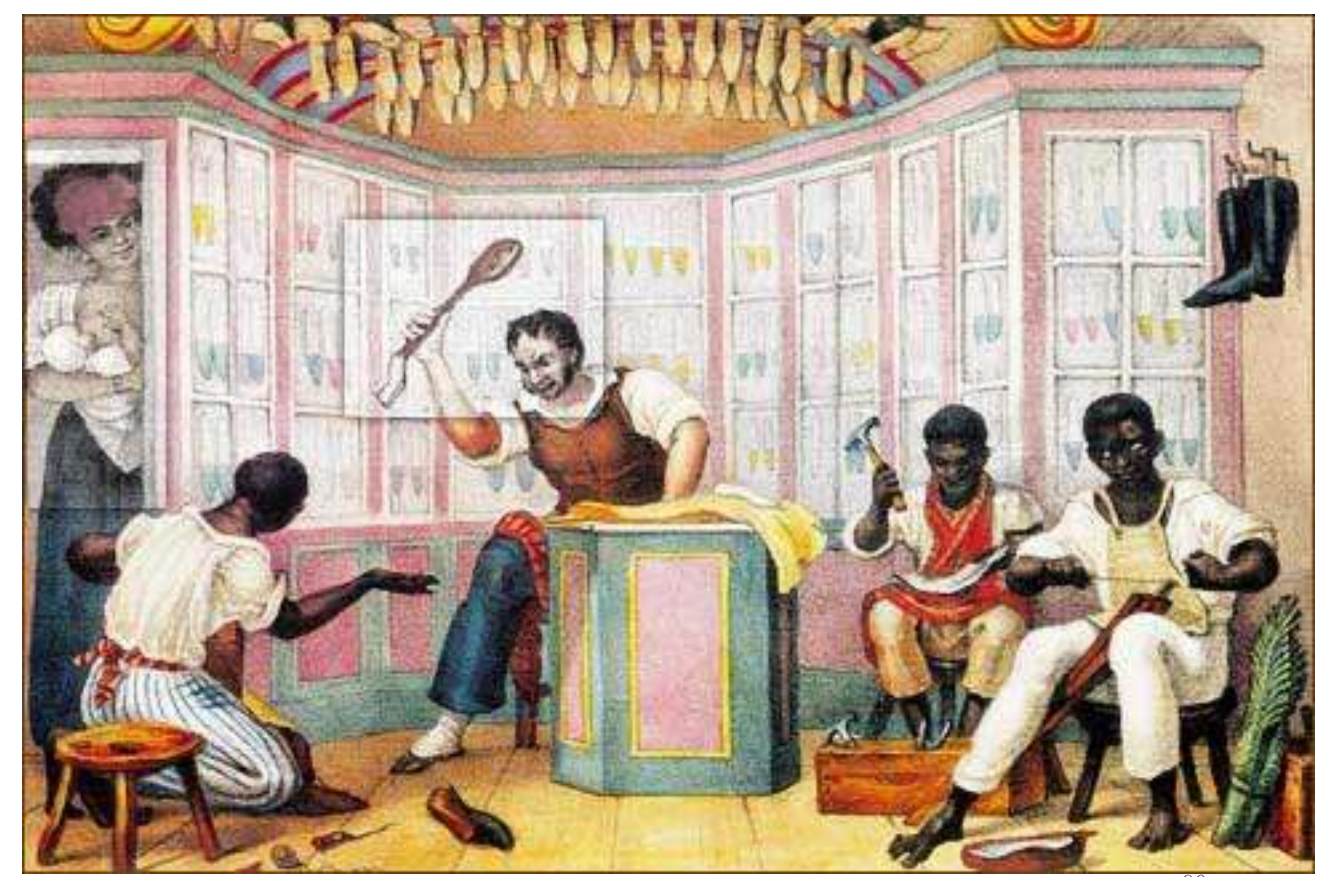

Debret. Reparem nas sapatilhas coloridas atrás do sapateiro (1827)

Os sapatos e os pés, como vimos nos inúmeros exemplos, marcavam as distinções socais. Gilberto Freyre, em Sobrados e mucambos, explorou esta ideia, de que cada camada social calçava-se de acordo com seu poder aquisitivo e que com isso podia-se perceber a qual camada social pertenciam homens e mulheres no século XIX. Dizia ele que: "Os tamancos eram o tipo predominante de calçado urbano entre comerciantes médios portugueses e brasileiros e entre operários, marítimos, negros e pardos livres."91 Distinção social observada nos pés das mulheres também servia aos homens, em sapatos que os marcavam como ricos ou pobres, livres ou não-livres, vaidosos ou não vaidosos, seguidores ou não da última moda. O escritor Aluísio Azevedo, no romance $A$ condessa de Vésper, que se passa no Rio de Janeiro, mais para o fim do século XIX, ao descrever

${ }^{90}$ Julio Bandeira e Pedro Correa do Lago. Debret e o Brasil. Obra completa. Rio de Janeiro: Capivara, 2008, p. 197. È uma gravura.

${ }^{91}$ Gilberto Freyre. Sobrados e mucambos. São Paulo: Global, 2005, p. 382. 
um homem modesto, escreve que: "Fazia má impressão vê-lo com a sobrecasaca puída do uso e das teimosas escoriações, com os seus sapatos remontados, o seu espinhoso colarinho a arrancar-lhe as cordoveias do magro pescoço com as caprichosas franjas dos fiapos do linho [...]." ${ }^{92}$ Em outro livro, Casa de pensão, o desleixo e a pobreza são evidenciados pelos "pés à vontade em sapatos rasos". 93 Dentro de casa a coisa mudava de figura, e podia-se, folgadamente, coçar os bichos de pé, como faz o cavalheiro na gravura abaixo, de Debret.

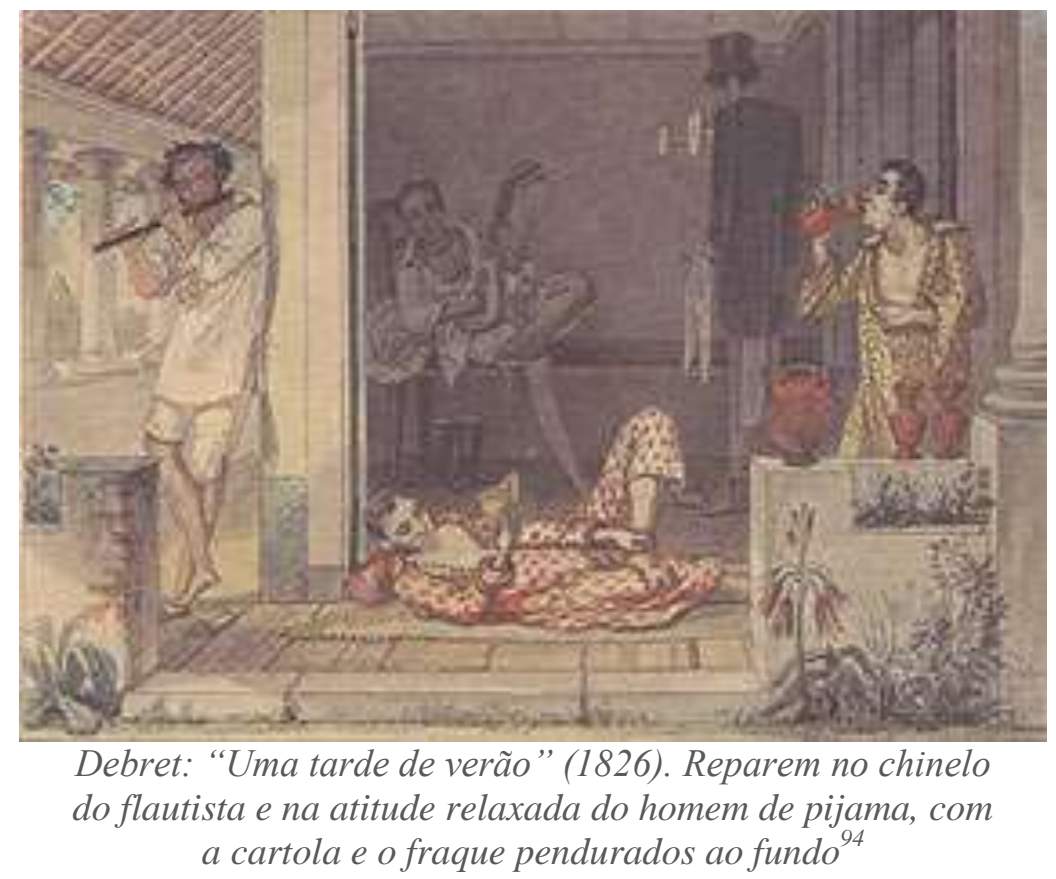

No mesmo Casa de pensão, de 1884, o escritor descreveu com certo sarcasmo um senhor elegante que "parecia eternamente empalhado nos seus fraques irrepreensíveis, nos seus chapéus à moda e nos seus enormes sapatos à inglesa de um elegantismo

${ }^{92}$ Aluísio Azevedo. A condessa Vésper. São Paulo: Martins Editora/ Instituto Nacional do Livro (MEC), 1973, p. 83, 92, 97.

${ }^{93}$ Aluísio Azevedo. Casa de pensão. São Paulo: Martins Editora, 1960, p. 70.

${ }^{94}$ Julio Bandeira e Pedro Correa do Lago. Debret e o Brasil. Obra completa. Rio de Janeiro: Capivara, 2008, p. 211. È uma gravura. 
feroz". ${ }^{95}$ Em Histórias da meia-noite, Machado de Assis, descreve um personagem de classe média da seguinte maneira: "Trajava [...] como é de uso em tais reuniões; e a única coisa verdadeiramente digna de nota eram os seus sapatos ingleses ${ }^{96}$ de apertar no peito do pé por meio de cordões [...] tinha horror às calças compridas [...] apenas se sentou deixou patente a alvura de um fino e imaculado par de meias." ${ }^{, 97}$

A Inglaterra e seus sapatos marcavam a moda e um tipo social peculiar do século XIX, o dândi, o homem que se preocupava em vestir-se e apresentar-se em sociedade, como vimos no capítulo IV. Para o poeta Charles Baudelaire, o dândi preocupava-se com a estética pessoal como uma "religião cotidiana". ${ }^{98}$ Longe da Europa, no Brasil, o dândi e o dandismo arregimentaram seguidores e opositores, entre homens, jornalistas e escritores. Os sapatos, para os dândis, eram itens essenciais de um guarda-roupa elegante, em que se podia notar claramente a classe social de seu portador ou mesmo seu desejo de pertencer a uma classe superior.

Ainda segundo Gilberto Freyre, no Brasil, os pés dos senhores de escravos e fazendeiros os distinguiam das mulheres, dos escravos, dos pobres. Também distinguiam os habitantes das cidades dos do campo, do ato de sair à rua ao de ficar em casa. O sociólogo, comenta que a "ostentação de cabeleira e de pé bem tratado e bem calçado foi refinamento mais da raça branca ou da classe alta, que do belo sexo."99

$\mathrm{Na}$ rua, meias de seda, sapatos ingleses, cavalos, estribos de prata; em casa, chinelos, pés descalços e folgados, como vemos na gravura a seguir, de Debret. ${ }^{100}$

\footnotetext{
95 Aluísio Azevedo. Casa de pensão. São Paulo: Martins Editora, 1960, p. 121.

${ }^{96}$ Grifo meu.

97 Joaquim Maria Machado de Assis. Histórias da meia-noite. (1861-1873). Rio de Janeiro: Livraria Garnier, s.d., p. 92.

${ }^{98}$ Charles Baudelaire. O pintor da vida moderna. In: O elogio da maquiagem. Trad. port. São Paulo: Alameda Editorial, no prelo.

${ }^{99}$ Gilberto Freyre. Sobrados e Mucambos. São Paulo: Global , 2005, p. 100.

${ }^{100}$ Gilberto Freyre. Casa Grande e Senzala. São Paulo: Global, 2005, p. 39.
} 


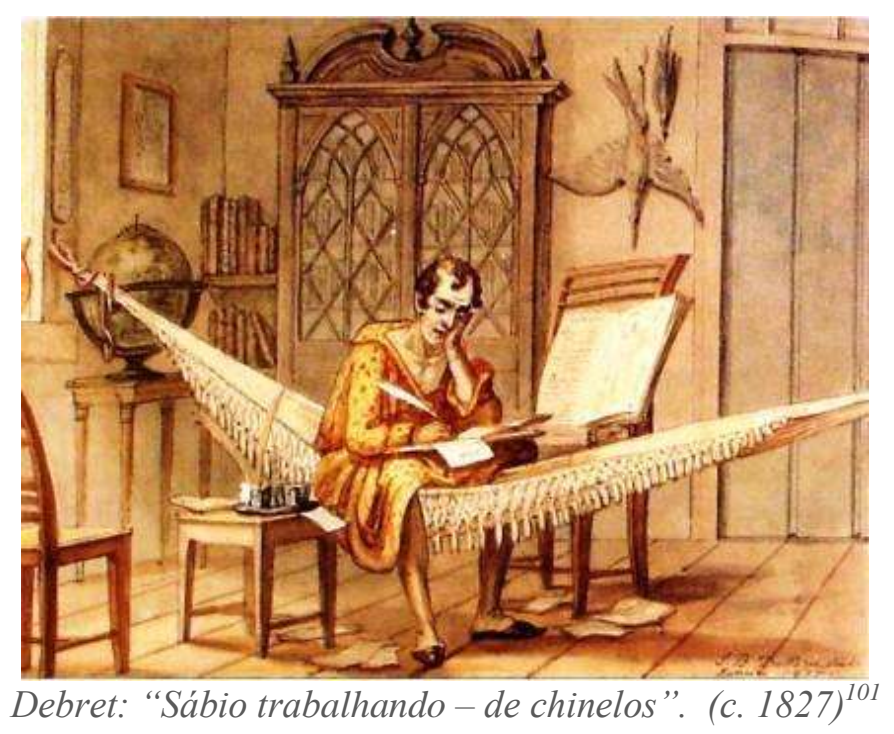

Nas cidades, os sapatos Clark, anunciados nos jornais e almanaques, distinguiam os homens elegantes, os vestidos à inglesa - ou dândis - do restante da população.

Já os calçados Clark, com solas de borracha, distinguiam os ingleses, habitantes abastados da cidade, enquanto as sandálias eram destinadas aos pobres e os matutos do início do século XIX."102 A marca inglesa começou a vender sapatos no Brasil em 1822, com pares importados. Dizem que d. Pedro I recebeu a coroa de imperador com um par de sapatos Clark - os seus prediletos. A primeira loja no Rio de Janeiro foi inaugurada em 1830 na rua do Ouvidor, juntamente com a primeira fábrica de sapatos Clark, logo na casa vizinha. ${ }^{103}$

O Rio, assim como São Paulo, demorou para ter fábricas de sapatos estabelecidas na cidade. Tinha, antes, sapateiros, que funcionavam em pequenas portinhas espalhadas pelos centros das cidades. As fábricas se estabeleceram mais para os meados do século - ainda que a Clark tenha sido uma das pioneiras. Conforme os avanços tecnológicos iam chegando ao Brasil, as fábricas de sapatos os incorporavam, com máquinas a vapor

${ }^{101}$ Julio Bandeira e Pedro Correa do Lago. Debret e o Brasil. Obra completa. Rio de Janeiro: Capivara, 2008, p. 276. È uma gravura.

${ }^{102}$ Gilberto Freyre. Sobrados e mucambos. São Paulo: Global, 2005, p. 382.

${ }^{103}$ The standard guide and handbook of Rio de Janeiro, 1914. s/ed. 
sendo usadas na confecção de calçados, como na Calçados Gravino ou no estabelecimento de Miguel Melillo, chamado de Indústria Paulista. ${ }^{104}$ As fábricas de sapato abrigavam uma mão de obra composta basicamente por imigrantes - orgulhosos de seu ofício (como meu bisavô que veio com a família da Itália para o Brasil, em 1898, para trabalhar numa fábrica de sapatos em São Carlos, interior paulista.).

\section{"Luvas de pelica, camurça e castor. Temos pares para todos os gostos e de todos os preços"}

Luvas foram usadas desde o Egito Antigo ${ }^{105}$ como símbolos de status e de separação de classes. Bordadas, encravadas de joias preciosas e feitas de tecidos nobres, as luvas não apenas protegiam as mãos do frio, mas davam poder e prestígio social para quem as usava. Até meados do século XIX, as luvas eram feitas manualmente, costuradas uma a uma de acordo com o tamanho das mãos, tanto para os homens como para as mulheres. O resultado era irregular, com formatos estranhos que não se ajustavam bem. Assim, da mesma maneira que aconteceu com a invenção da máquina de costura no século XIX, um inventor pensou numa maneira de facilitar o trabalho de se fazer luvas e produzi-las numa escala semi-industrial.

Xavier Jouvin (1800-1844) era um fabricante de luvas em Grenoble, França, quando inventou um método universal de medir as mãos e os dedos para facilitar a fabricação em escala de luvas de todos os tamanhos. Depois de quase cinco anos de pesquisas, Jouvin descobriu um padrão para medir mãos e dedos. As medidas eram tiradas a partir da mão que escrevia, do punho e do tamanho e grossura dos dedos, menos o polegar. Esse tipo de medida foi chamado de peid du roi, e era exatamente $3 / 4$

\footnotetext{
${ }^{104}$ Heloísa Barbuy. A cidade-exposição. São Paulo: Edusp, 2006, p. 202.

105 A primeira luva foi encontrada em 1.370 a.C., segundo consulta ao site $\langle$ http://www.mikeredwood.com/leather_technology/glove_industry_timeline_and_book_list/58 > em 20/6/2011.
} 
de polegada maior que os "pés" ingleses. ${ }^{106}$ As luvas passaram a ter medidas padrão, o que facilitou muito o corte e a fabricação em massa. Dessa forma, o século XIX viu explodir o mercado de luvas no mundo inteiro - e transformaram as luvas em um acessório elegante e essencial, até mesmo em países tropicais como o Brasil.

Dessa maneira, quando sabemos que, em 1870/71, chegaram ao porto do Rio de Janeiro 2.959 pares de luvas de pelica, camurça ou castor vindas da França, podemos entender a preponderância desse país na fabricação e exportação das mesmas, já que Jouvin era francês e a França foi o primeiro país a explorar as possibilidades da fabricação em larga escala de diferentes tipos de luvas. A quantidade equivalia a 39:419\$034 contos de réis. Desta forma percebe-se que o invento de Jouvin proporcionou resultados comerciais bastante expressivos para a França, já que a colocava entre os maiores exportadores de um produto que se tornaria um acessório de moda quase que indispensável. A Inglaterra, seguindo os passos da França, aparece em segundo lugar nas exportações, com 1.751 pares, e Portugal com 1.525.

Entretanto, no calor escaldante do Rio de Janeiro, num país tropical, as luvas não faziam tanto sucesso. A comparação com os sapatos é gritante - no mesmo período em que chegaram quase 3 mil pares de luvas da França, o maior exportador, desembarcam no Rio 898.116 pares de sapatos. Se olharmos atentamente toda a coleção Princesa Isabel, fotografias do século XIX, que está em poder da Biblioteca Nacional, veremos que raras são as fotos em que moças, cavalheiros, damas, senhores e militares estão vestindo luvas. $^{107}$

A coleção, com vários retratos da família real em momentos de intimidade, ou posando para fotógrafos, mostra muitos nobres da corte em diferentes momentos do dia,

\footnotetext{
${ }^{106}$ Um pé inglês corresponde a cerca de 3,48 centímetros.

${ }^{107}$ Para uma ideia mais aproximada do conteúdo da coleção da Biblioteca Nacional, veja a publicação de Pedro e Bia Corrêa do Lago Coleção Princesa Isabel, fotografias do século XIX. Rio de Janeiro: Capivara, 2008.
} 
todos sem luvas. As exceções ficam por conta das viagens ao exterior em que tanto a imperatriz Tereza Cristina como a princesa Isabel usam luvas para se protegerem do frio. $^{108}$

Ainda assim, as luvas aparecem na literatura como exemplos de elegância e beleza. Em A pata da gazela, José de Alencar descreveu Amélia: “A moça tinha um roupão cor de café [...] as luvas eram da mesma cor de cinza das fitas do chapéu de palha [...] pousados na calçada dois pezinhos mimosos que palpitavam dentro das botinas de merino cor de cinza."109

Ao lado dos sapatos, as luvas adquiriam outro sentido, ligado à sexualidade. Sapatos e mãos pequenas realçavam as características femininas desejáveis no século XIX, de recato, modéstia e beleza. Carl Koseritz em sua passagem pelo Rio de Janeiro no começo da década de 1880 notou que: "Uma particularidade louvável têm aqui as senhoras [...] e é a de que, na vida habitual, quase não usam luxo. Vê-se senhoras das melhores e mais ricas famílias, com vestidos de algodão e chapéus muito simples, na rua do Ouvidor. O único verdadeiro luxo são as luvas, [...]"110 O próprio Koseritz disse em outras ocasiões que luvas não faziam muito sucesso por aqui, talvez por causa do calor.

[...] quando vou flanar pela Rua do Ouvidor não me pareço a mim mesmo como um provinciano, e muito menos aos outros. $\mathrm{O}$ estreito chapéu de cano de chaminé que eu tinha trazido da província desapareceu há muito, substituído por uma cartola baixa e de abas largas, que fica a meio termo entre a sombrinha e o chapéu; as luvas (que eu, no meu atraso provinciano, antigamente usava) estão atiradas a um canto, pois aqui se gosta de apertar as suadas mãos

\footnotetext{
${ }^{108}$ Ver o livro de Pedro e Bia Correa do Lago Coleção Princesa Isabel, fotografia do século XIX. Rio de Janeiro: Capivara, 2008.

${ }^{109}$ José de Alencar. A pata da Gazela. São Paulo: Companhia Brasil Editora, 1951. p. 87.

${ }^{110}$ Carl Von Koseritz. Imagens do Brasil. Trad. port. São Paulo, Martins Editora, 1972. p. 42.
} 
desenluvadas, e mesmo na residência do Imperador os mais distintos fluminenses aparecem, sem esta traste que, nos atrasados países da velha Europa, é notoriamente considerado como uso constante. ${ }^{111}$

Ainda assim, as luvas proliferaram-se ao longo do século XIX, sendo encontradas em inúmeros estabelecimentos comerciais cariocas. Jouvin havia se tornado um ícone no que se referia à qualidade das luvas das moças e senhoras. No anúncio de 1861, o estabelecimento A Luva de Ouro anunciava: "Neste estabelecimento há sempre um grande sortimento de luvas de pelica legítimas de Jouvin. Vende-se muito em conta por receber-se diretamente do fabricante de Paris (...)”. O mercado brasileiro para luvas, ainda que pequeno, estava, assim, estabelecido.

${ }^{111}$ Carl Von Koseritz. Imagens do Brasil. Trad. port. São Paulo, Martins Editora, 1972. p. 41. 


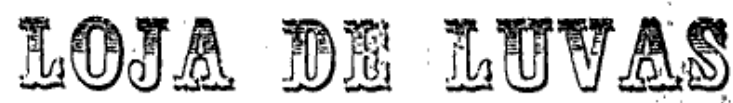

A' LUVA

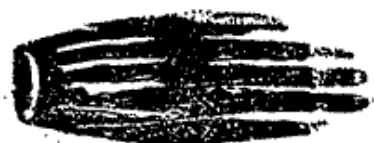

I) $\mathbf{E} \mathbf{O} \mathbf{R O}$

\section{Mme HANRIO'T}

Uuica casa da Luva de Ouro. Neste estabelecimento ha sempre um grande sortimento de luvas de pellica legitimas de Jouvin. Vende-se muito em conta, por motiro de receber-se directamente do fabricante de Paris, livas com enfeites, de casamentos, e de camurça; bem como de todas as onnas qualidades. Na mesma casa ha um grande e variado sortimento de perfumarias de Paris, da sociedade hygienica, Piver, e de Monpelas, o que se vende em porçāo e a varejo.

\section{T. Rua dos burives gat}

LASAS, SEDAS E TODOS OS PEHTENCES PAKA BORDAR

\section{IO BISTIDOR DL BORDIR}

Loja de Lãas, Sedas frouxas, frócòs e aviamentos de bordar.

$$
9: \text { - Rua do Guvidor - 9: }
$$

Me A. C. Favre tem a lonra de praticifar a todos os seus frezuezes a respeitavel Publico, taute nat córte, como nas provincias, que sua casa esta sempre hem sortidit $\mathrm{em}$ tudo o que ha de mais novo em lãas, sedas frouxas, torçaes, fricus. missangas, linhas, algodões, agulhas, crochets, talagarca, papeis picutos. vidrilhos; desenhos e todos os mais aviamentos que sĩo precisos para bordar.

Tudo o que é necessario para costuras.

Tambem tem : fitas, rendas, blondes, gregas, franjas, galões, entremeios de cassa, borlas, botões, barbatanas, luvas de todas as qualidades, e tudo o que se phde desejar de mais molerno e de bom gosto.

$$
95-\text { RUA Do oUvinor }-95
$$

61

Anúncio duplo de 1861 de luvas Jouvin e bastidores para bordar: propagandas para uma nova consumidora ${ }^{112}$

${ }^{112}$ Ver Almanaque Laemmert de 1861, seção de "Notabilidade": 
Tabela de importação de luvas de pelica, camurça, castor (1871-1872)

\begin{tabular}{|l|r|r|}
\hline País & Quantidade & Valor \\
\hline Grã-Bretanha & 1.751 & $19: 453 \$ 299$ \\
\hline Estados Unidos & 1 & $12 \$ 000$ \\
\hline França & 2.959 & $39: 419 \$ 034$ \\
\hline Portugal & 1.525 & $17: 183 \$ 328$ \\
\hline $\begin{array}{l}\text { Total (inclui dados de } \\
\text { outros países) }\end{array}$ & & $112: 670 \$ 328$ \\
\hline
\end{tabular}

\section{Símbolos de distinção para homens e mulheres: joias e relógios}

Machado de Assis descreveu joias inúmeras vezes em seus romances - e estas não apenas adornavam pescoços e dedos de moças e senhoras. As joias mostravam o poderio de quem as dava, como nesta pequena história de Machado, de 1853: “'Comprou-lhe um anel.”, disse o rapaz rico. "'Viu na mesma casa uma joia engraçada, uma meia lua de diamantes para o cabelo, emblema de Diana, que lhe iria muito bem sobre a testa." "113

As joias de ouro ou prata não se destacavam nas tabelas de importação já que possuíamos uma ourivesaria nacional significativa desde os tempos de colônia. No livro Joias de crioula, a pesquisadora Laura Cunha e o fotógrafo Thomas Milz recuperam as maneiras como as escravas usavam cordões ou outros enfeites de ouro. "A cor da pele, muito mais que as posses, determinava a condição social do indivíduo. O negro, à margem da esfera senhorial, não deixava, no entanto, de ostentar uma estética própria, abusando de joias de ouro, diferentes das senhoras brancas, que em geral preferiam peças ricas em diamantes, pérolas e outras gemas." "114 Laura Cunha ainda destaca que as

\footnotetext{
113 José Maria Machado de Assis. Histórias sem data (1883-1906). Rio de Janeiro: Civilização Brasileira, 1977, p. 200.

${ }^{114}$ Agradeço a Mary Lou Paris que gentilmente me cedeu um exemplar do lindo livro por ela editado pela Terceiro Nome. Laura Cunha e Thomas Milz. Joias de crioulas. São Paulo: Terceiro Nome, 2011, p. 45.
} 
senhoras brancas preferiam importar outros tipo de pedras e usar ouro, metal vulgar, que em geral: "era trabalhado nas oficinas das grandes cidades brasileiras". 115

Robert Avé Lallemant, ao viajar pelo país na década de 1850, observou que negras usavam grossas corrente de ouros enfeitando-lhes o colo e o pescoço.

E é genuinamente africano um rico colar de corais, com enfeites de ouro, em volta do pescoço negro dessas mulheres. Muitas trazem grossas correntes de ouro ornando-lhes o colo. Vi uma com um antebraço coberto até o cotovelo de braceletes articulados. Parece-me, todavia, que os maiores cuidados da toilet consistem no enrolar em forma de turbante em volta da cabeça a muito bordada faixa branca, na camisa finamente bordada e na fímbria da saia rodada e franzida. Meias, pareceu-me que nenhuma usava com as leves chinelinhas, como se tivessem estudado a coqueteria da nudez de gracioso pé feminino. ${ }^{116}$

Importavam-se pedras e joias que não se podiam encontrar aqui, como pérolas e corais. No século XIX, a pérola vai ter um papel significativo para a moda, já que simbolizava a pureza de sentimentos das moças e das propostas dos rapazes casadoiros. José de Alencar descreve Lucíola, arrependida de seu passado, vestindo-se castamente com pérolas a adornar o pescoço. "Tudo era branco e resplandecente como a sua fronte serena: por vestes cassas e rendas; por joias somente pérolas." ${ }^{117}$ Em Senhora, Aurélia veste-se de pérolas para o amado: "Aurélia [...] vestiu-se de pérolas e rendas $[\ldots]$ ".. ${ }^{118}$ Em $O$ Homem, de 1887, Aluísio Azevedo retratou uma moça sofrendo por amor. "Foi a partir desse tempo que deu para andar sempre vestida de luto, muito simples, com o cabelo apenas enrodilhado e preso na nuca; um fio de pérolas ao pescoço, sustentando

\footnotetext{
${ }^{115}$ Laura Cunha e Thomas Milz. Joias de crioulas. São Paulo: Terceiro Nome, 2011, p. 46.

${ }^{116}$ Robert Avé-Lallemant. Viagem pelo norte do Brasil no ano de 1859. Trad. port. Vol. I, Rio de Janeiro: Ministério da Educação e Cultura/ Instituto Nacional do Livro, 1961. p. 46.

${ }^{117}$ José de Alencar. Lucíola. São Paulo: Edições Melhoramentos, s.d., p. 123.

${ }^{118}$ José de Alencar. Senhora. São Paulo: Editora Ática, 1971. p. 183.
} 
uma cruz de ouro, e mais nenhuma outra joia."119 As pérolas, brancas e simples, em contraste com o ornamento do vestido preto.

Tabela de importação de joias (1871-1872)

Coral fino, pérolas finas em bruto e em obras

\begin{tabular}{|c|c|c|}
\hline País & Quantidade & Valor \\
\hline Grã-Bretanha & ----------- & 19:936\$000 \\
\hline Estados Unidos & ----------- & 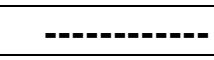 \\
\hline França & ------------ & $21: 407 \$ 000$ \\
\hline Portugal & ------------ & ------------ \\
\hline $\begin{array}{l}\text { Total (inclui dados de } \\
\text { outros países) }\end{array}$ & & $6: 677 \$ 000$ \\
\hline
\end{tabular}

O maior símbolo de poder e dominação do universo masculino no século XIX era o relógio de bolso. Misto de novidade tecnológica e joia, o relógio passou a enfeitar as calças e coletes masculinos como exemplo máximo de distinção, riqueza e poder. Nada lhe superava, nem o sapato inglês, nem o cavalo, nem o chicote, nem todas as joias de sua mulher.

Para o homem modesto, personagem de Aluísio Azevedo em $O$ homem, o relógio significava sua emancipação financeira e sentimental: "Vinte e cinco mil réis para um relógio de prata dourada, dos modernos. Isso era sagrado! Porque ele não admitia que ninguém se casasse sem ter relógio e corrente. Corrente já tinha, cordão de ouro que foi do pai e que vivia fechado na cômoda da tia Zefa ao lado do ouro da família." ${ }^{120}$ E isso porque o relógio nem era de ouro, um simples relógio de prata dourada bastava para dar dignidade e respeito ao homem que se casava.

O relógio e o controle do tempo estavam intimamente ligados à expansão do capitalismo - o relógio vindo a se tornar o símbolo supremo do industrial capitalista.

\footnotetext{
${ }^{119}$ Aluísio Azevedo. O homem. São Paulo: Martins Editora, 1970. p. 70.

${ }^{120}$ Aluísio Azevedo. O homem. São Paulo: Martins Editora, 1970, p. 112.
} 
"Nas regiões industriais, podia-se observá-la [a disciplina] na expansão da disciplina fabril, condicionada pela campainha e pelo relógio, do trabalho às horas de lazer, dos dias úteis ao Sabath, e também nas tentativas de repressão do 'domingo do sapateiro', das feiras e dos feriados tradicionais."121 Ver as horas, contar o tempo, possuí-lo, tornou-se uma obsessão burguesa - os capitalistas sendo os donos do tempo, de trabalho e de lazer, de seus empregados. Pintores e escritores foram pródigos em retratar esse novo símbolo de poder em pinturas ou obras de literatura.

Dom Pedro II usava relógios de bolso e diversas vezes se deixou fotografar com eles. Numa fotografia já do exílio, a corrente com o relógio de bolso era bem nítida e destacava a autoridade do ex-imperador. O relógio é o único símbolo de poder da fotografia, na qual d. Pedro usava paletó escuro e camisa branca, numa simplicidade contida. Os relógios, ao lado os anéis de formatura com pedras preciosas, eram geralmente os únicos ornamentos masculinos. Podiam, quando preciso, virem ao lado de óculos e bengalas.

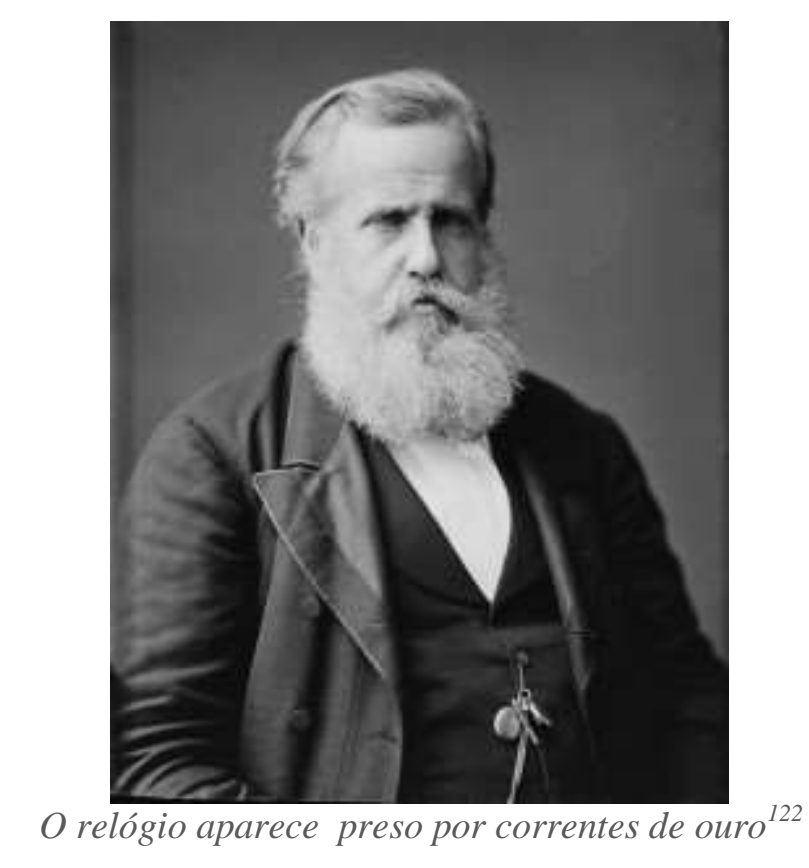

${ }^{121}$ Edward Palmer Thompson. A formação da classe operária inglesa. Trad. port. Vol. II. Rio de Janeiro: Paz e Terra, 1987, p. 294.

${ }^{122}$ x Marcelo de Araújo. D. Pedro II e moda masculina na época vitoriana. São Paulo: Estação das Letras e cores, 2012, p. 78. 
Em dois anúncios da casa de Julio Boulte, de 1862, publicados no Almanaque Lamemmert, veem-se as referências à importação estrangeira e a demanda por novidades tecnológicas: os relógios eram ingleses, premiados na exposição universal de Paris, vendidos em libras. Ambos os anúncios destacam o fabricante, Charles Frodsham Arnolds, cujo nome seria "célebre em sua arte", conforme o anúncio. A família Frodsham Arnolds estava no negócio de fazer relógios desde o século XVIII e Charles havia herdado o negócio, Arnold \& Co, em 1843. Em 1851, participou da Exposição Universal no Palácio de Cristal, em Londres, e recebeu a medalha de ouro pelos seus relógios. A empresa existe até hoje e é a fornecedora oficial de relógios da família real inglesa. ${ }^{123}$

${ }^{123}$ Ver o site oficial dos relógios Frodsham: <http://www.frodsham.com/>, consultado em 23/9/2013. 


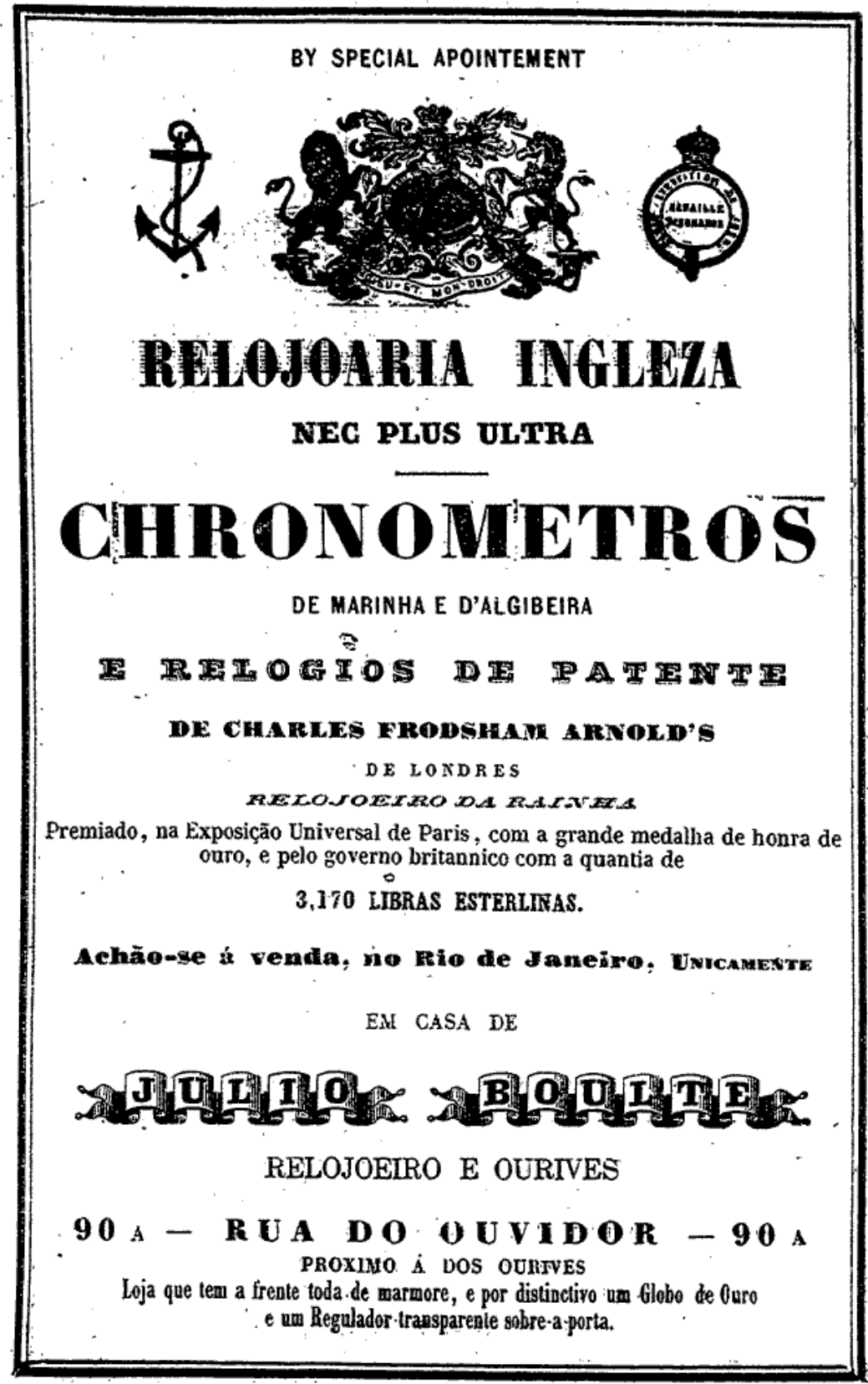

Anúncio de uma relojoaria em 1862, na rua do Ouvidor ${ }^{124}$

${ }^{124}$ Ver Almanaque Laemmert de 1862, seção de "Notabilidades", p. 21. 


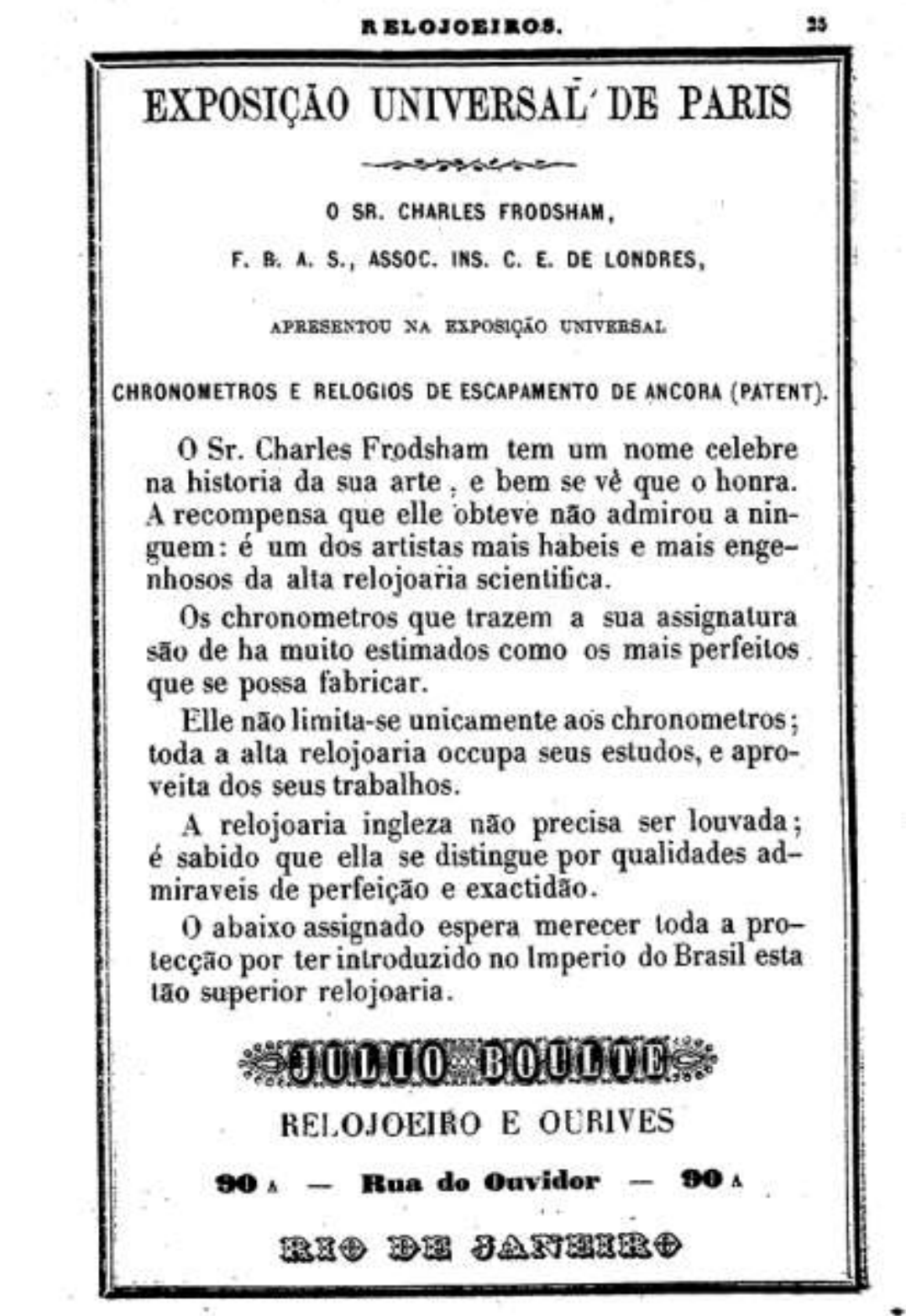

A exposição Universal em relógios no Brasil: propaganda e mística ${ }^{125}$

\section{Vestidos e casacas bailam em festas, saraus e reuniões nos últimos anos do império}

Desde o começo do século XIX, o Rio de Janeiro se aparelhava como capital do Império. Para tanto, a abertura de casas de comércio e outros pequenos negócios ligados

${ }^{125}$ Almanaque Laemmert de 1862, seção de "Notabilidades", p. 25. 
ao vestuário era imprescindível. A importação de itens do vestuário alimentava uma mania, que diziam ser portuguesa, a "anglomania", mas que na verdade, englobava também a França, com uma clara "francomania". Hábitos, modas, jeitos importados eram copiados em sociedade - e vestir-se adequadamente era fundamental. As roupas e acessórios vinham importados, como vimos, mas aos poucos passaram a ser feitos na capital. Debret é testemunho dessa gradual mudança de costumes quando escreve que:

A anglomania portuguesa de alguns cortesãos vindos com o séquito do Rei, e imitada a princípio pelos ricos negociantes do Rio de Janeiro, os levara a mandarem vir os seus calçados de Londres. Mas logo que o Rio se tornou a capital do Reino, aí se instalaram sapateiros e boteiros alemães e franceses, abastecidos com excelentes couros da Europa; como era de esperar, os trabalhadores negros ou mulatos empregados nessas sapatarias logo se tornaram rivais de seus amos e hoje se encontra, nas lojas desses indivíduos de cor, toda espécie de calçados perfeitamente confeccionados. ${ }^{126}$

Nas últimas décadas do século, a cidade parecia oferecer o que havia de mais cosmopolita. Com o imperador já envelhecido, a princesa Isabel fazia política e retomava hábitos tidos com elegantes, como festas, exposições de flores, visitas e teatros. ${ }^{127}$ Até casar a princesa nunca tinha ido a um baile, tamanho era a melancolia da corte de d. Pedro II. Assim que se casou com o conde d'Eu, e mudaram-se para o palácio Guanabara, e a princesa começou a receber convidados para danças, recepções ou palestras.

A coisa era nova. A roda palaciana estranhava: "por mais que faça", escrevia o conde d’Eu, "para animar um pouco a vida social, ela continua forçosamente monótona,

\footnotetext{
${ }^{126}$ Jean-Baptiste Debret. Viagem Pitoresca e Histórica ao Brasil. Trad. port. T. I, vol. I e II, São Paulo: Martins Editora, 1940. p. 206

${ }^{127}$ Wanderley Pinho. Salões e damas do segundo reinado. São Paulo: Livraria Martins Editora. São Paulo: 1970, p. 149-165.
} 
e, por consequência, desde que não chegue ao grau de intimidade, muito penosa para entreter". Afinal, as resistências foram sendo vencidas, e mais tarde, aí pelos últimos meses de 1887, a queixa do príncipe consorte era outra: sentia-se fatigado, o tempo absorvido como pouco agradavelmente em concertos, espetáculos, saraus de todos os gêneros em que fervia então o Rio de Janeiro. ${ }^{128}$

Os vestidos e casacas comprados na rua Ouvidor punham-se a danças em reuniões como as que a princesa Isabel fazia em seu palácio. Diversos salões marcaram o império e deram espaço para que a elite da corte desfilasse um cosmopolitismo aprendido em Paris. A condessa de Barral, preceptora das princesas reais e amante de d. Pedro II, que havia vivido muitos anos em Paris, emprestava seu brilho e cosmopolitismo aos salões imperiais. $^{129}$

Ainda que na maior parte do país as moças vivessem reclusas, saindo de casa apenas para se casarem, no Rio era diferente. As moças começavam cedo a se prepararem para uma vida mundana na corte. A educação nos colégios femininos do segundo Império incluía etiqueta, francês, dança, piano. Nas festas, valsava-se, para desgosto dos conservadores que viam no gesto de dois corpos próximos valsaram pelo salão, sinal de depravação de costumes. ${ }^{130}$ "Nos salões mundanos seguíamos o modelo parisiense: entre os risos, o ruge-ruge das sedas, as tramas políticas articuladas ao pé do ouvido, os namoros e o escândalo das valsas, havia sempre um destaque para artistas e escritores."131

\footnotetext{
${ }^{128}$ Wanderley Pinho. Salões e damas do segundo reinado. São Paulo: Livraria Martins Editora. São Paulo: 1970, p. 150.

${ }^{129}$ Roderick J. Barman. Princesa Isabel do Brasil: gênero e poder no século XIX. Trad. port. São Paulo: Unesp, 2002, p. 37-76.

${ }^{130}$ Ubiratan Machado. A vida literária no Brasil durante o romantismo. Rio de Janeiro: Tinta Negra Bazar Editorial, 2010, p. 164.

${ }^{131}$ Ubiratan Machado. A vida literária no Brasil durante o romantismo. Rio de Janeiro: Tinta Negra Bazar Editorial, 2010, p. 165.
} 
Era o caso da marquesa de Abrantes, com sua residência no Largo da Glória, onde se erguia o palácio da família. Todo ano era feita uma festa em agosto, que saía nos principais jornais da cidade. A de 1849 ficou famosa pelo fausto - tanto da festa como dos convidados, que se esmeraram em vestidos e casacas reluzentes. O jardim era coberto de estátuas, havia espelhos por todas as salas, vastamente iluminadas, com um salão de ceia para mais de 80 pessoas. ${ }^{132}$ Joaquim Nabuco também possuía um salão festejado nos jornais cariocas. Assim como o barão de Cotegipe, com seus jantares de quinta-feira, também faziam reuniões com frequência, a baronesa de Bela Vista, a viscondessa de Cavalcanti ${ }^{133}$ e o comendador Pereira Bahia. ${ }^{134}$

Ainda assim, na visão de estrangeiro de Gastão de Órleans, que chegou ao Rio no dia 2 de setembro de 1864, a corte brasileira apenas começava a engatinhar em matéria de civilidade. O conde reclamou as casas caindo aos pedaços, da população mau vestida, das vendas com bacalhau e cebolas expostas na porta e da feiúra das princesas e da dormência das soirées de d. Pedro II. Mas elogiou alguns sinais de progresso na cidade: os barcos a vapor, constantes e potentes, o gás, o caminho de ferro, os ônibus elegantes, a rua do Ouvidor e as francesas semi-despidas e cantantes do Alcázar, na rua Vala. $^{135}$

Fazia-se fora do palácio real - do paço ou da Boa Vista -, o que d. Pedro II não gostava que se fizesse dentro dos edifícios reais. Conforme se passavam os anos, as festas, reuniões, saraus foram sendo transferidos para a casa de d. Isabel ou para a residência de outros políticos importantes do império. Aos poucos, os rituais imperiais

\footnotetext{
${ }^{132}$ Wanderley Pinho. Salões e damas do segundo reinado. São Paulo: Livraria Martins Editora. São Paulo: 1970, p. 155-159.

${ }^{133}$ Wanderley Pinho. Salóes e damas do segundo reinado. São Paulo: Livraria Martins Editora. São Paulo: 1970, p. 179-262.

${ }^{134}$ O Jornal das Senhoras de 15 de agosto de 1852, p. 33.

${ }^{135}$ Luiz Edmundo. Recordações do Rio Antigo. Rio de Janeiro: Conquista Editorial, 1956, p. 150156.
} 
foram sendo abandonados: já não se fazia o beija-mão, o rei não usava roupas majestáticas, não se douravam as carruagens, os guardas palaciais viviam com uniformes desbotados, os palácios sofriam com a falta constante de manutenção. D. Pedro II havia se tornado um “cidadão".

Com efeito, a partir do retorno da segunda viagem [ao exterior], e a despeito do belo te-déum que comemorou o seu regresso, o imperador mais parecia um estrangeiro em terras próprias. Quase como espectador, observava os movimentos políticos - em especial o crescimento do Partido Republicano e do abolicionismo -, assistia de camarote À demissão do Gabinte Conservador e à subida dos liberais, afastados do poder fazia 10 anos. Os graves problemas que assolavam o país, como o movimento sedicioso ocorrido nas províncias da Paraíba e de Pernambuco, em 1874, apelidado de Quedra-Quilos, ou a terrível seca de 1877 , não pareciam afetá-lo. ${ }^{136}$

A política passou a ser feita fora da monarquia ou, ainda, apesar da monarquia. A quantidade de mercadorias que chegavam aos portos do Rio aumentava a cada ano, apontando para um crescente cosmopolitismo e sociabilidade. ${ }^{137}$ Assim, "nas últimas décadas do século XIX, novo fator viria somar-se aos demais, acentuando as diferenças entre os grandes centros e as cidades interioranas e entre as várias regiões do país: o

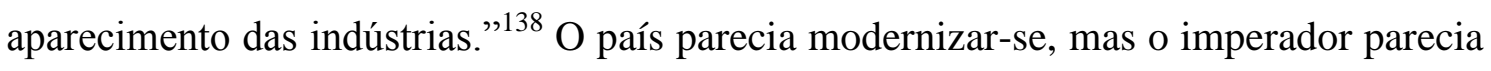
alheio a tudo isso, recluso num palácio cheio de cupins.

\footnotetext{
${ }^{136}$ Lilia Schwarz. As barbas do imperador: d. Pedro II, um monarca nos trópicos. São Paulo: Companhia das Letras, 1998, p. 410.

${ }^{137}$ Emília Viotti da Costa. Da monarquia à República. São Paulo: Editora Unesp, 1998, p. 235271.

${ }^{138}$ Emília Viotti da Costa. Da monarquia à República. São Paulo: Editora Unesp, 1998, p. 261.
} 
O escritor português Ramalho Ortigão, quando escrevia suas cartas à Gazeta de notícias do Rio de Janeiro a partir de julho de $1877^{139}$, lamentava a atitude do imperador. Wanderley Pinho reproduz suas impressões sobre as atitudes de Ortigão.

Não quis ver Ramalho Ortigão esse esforço dos príncipes para corrigir a falta de gosto social de Pedro II. Comunicando em carta a Eduardo Prado as suas impressões de estada no Brasil em 1887 dessangava-se o grande escritor português na veia irônica de uma antiga má vontade ao Imperador. Num exagero caricatural, que deforma a verdade muito menos escandalosa, escreveu que convivência com o espírito e o gênio de Pedro II "vacinara o Rio de Janeiro para resistir vitoriosamente a tudo quanto ofende a delicadeza estética de uma sociedade".

O imperante não cumpria uma missão que lhe cabia; não soubera dirigir na sociedade que governava "a organização dos costumes, no culto da arte, na formação do gosto, na moda da toilette, nas maneiras, nesse conjunto de regras, de convenções, de hábitos nobres e delicados que escapam, pela fina natureza à ação propriamente governativa, de cuja formação resulta, para cada sociedade, o seu nível de atração, de graça, de dignidade, de bem-estar - sua civilização, enfim. Pelo seu exemplo estragou quanto pôde a arte de conversar, a de vestir, a de receber, a de jantar, a de ditar um menu, a de conduzir um cotillon, a de governar um cavalo, a mobiliar um salão, a de edificar uma casa, a de escrever um livro. ${ }^{140}$

O fim das festas, a tristeza das aparições públicas de d. Pedro, envelhecido e doente, a tomar canja no paço, significava o fim da política. Para Norbert Elias, a etiqueta da corte, as festas, rituais e vestimentas não eram acessórios ao regime político

\footnotetext{
${ }^{139}$ Sobre as cartas publicadas na Gazeta de notícias, ver o trabalho de João Carlos Zan. Ramalho Ortigão e o Brasil. Tese de Doutoramento. Faculdade de Filosofia, Letras e Ciências Humanas, Departamento de Letras Clássicas e Vernáculas, 2009.

${ }^{140}$ Wanderley Pinho. Salóes e damas do segundo reinado. São Paulo: Livraria Martins Editora. São Paulo: 1970, p. 154.
} 
imperial - eles eram a própria essência do império. ${ }^{141}$ "Na corte, o valor de um indivíduo se expressa primordialmente nas nuances do convívio social e mundano". ${ }^{142}$

Desta forma, quando o imperador resolveu voluntariamente esquivar-se de sua obrigações, simbolicamente selava o destino da monarquia brasileira. A etiqueta imperial do Brasil, ainda que um pouco estranha às casas europeias, tinha o mesmo significado. Afinal, "era na etiqueta que esse estado de equilíbrio se expressava aos olhos de tosos. Para quem estava envolvido, ela significava uma garantia de sua existência social e de seu prestígio."

Essa associação entre etiqueta e império era bem conhecida dos comandavam os destino do país na época. E não foi à toa que, para fazer com que o império brasileiro brilhasse novamente, resolveu-se fazer um baile, que seria a maior e mais fulgurante festa já vista na corte. Era o primeiro baile do império brasileiro a ser realizado com iluminação elétrica - em homenagem ao navio chileno Almirante Cochrane. Como cenário a Ilha Fiscal, recém-inaugurada. ${ }^{144}$

A necessidade de se possuir um posto de alfândega moderno no porto do Rio era antiga, datava de pelo menos algumas décadas antes de sua construção, no anseio de modernização dos portos do fim do império, que cada dia recebiam mais mercadorias. A ilha ficava bem no meio da Baía de Guanabara, em frente à Praça do Mercado e era conhecida primeiramente como Ilha dos ratos, e já abrigava um posto alfandegário improvisado. ${ }^{145}$ D. Pedro escolheu o Engenheiro-Diretor de Obras do Ministério da Fazenda, Adolpho José Del Vecchio, para construir um edifício em forma de castelo,

\footnotetext{
${ }^{141}$ Norbert Elias. A sociedade de corte. Trad. port. Rio de Janeiro: Zahar Editores, 2001, p. 97131.

${ }^{142}$ Norbert Elias. A sociedade de corte. Trad. port. Rio de Janeiro: Zahar Editores, 2001, p. 108.

${ }^{143}$ Norbert Elias. A sociedade de corte. Trad. port. Rio de Janeiro: Zahar Editores, 2001, p. 105.

${ }^{144}$ Alexandre Campos da Costa e Silva. Dicionário de curiosidades do Rio de Janeiro. Rio de Janeiro: Comércio e Importação de Livros CIL S/D.

${ }^{145}$ Não se sabe bem se pela forma das rochas ou pelos habitantes do lugar.
} 
claramante inspirado em construções românticas francesas. Os recursos foram logo liberados e a obra começou em 16 de novewmbro de $1881 .^{146}$

Adornada de vitrais de cristais ingleses que retratavam a família real, foi construída também uma torre com um relógio alemão de firma Krussamn e Cia. O edifício foi feito inteiramente de pedra vindas do Morro do Pasmado e media sessenta e oito metros de frente, vinte e oito de fundos, e cinquenta e três metros de altura no torreão.

No segundo andar foi feita uma sala, com sacada com vista ao Corcovado e ao Pão-de-Açúcar, destinada ao chefe da aduana, cujo assoalho é ornamentado com madeiras vindas de várias partes do Brasil, como amendoim, pau-brasil, paucetim, peroba-do-campo, tremida, raiz de imbuia e roxinho, jacarandá de vários estados do império. O conjunto, em marchetaria foi feita pela firma Moreira \& Carvalho em formato de uma rosa dos ventos. ${ }^{147}$

Pela delicadeza do conjunto da obra e o sucesso que fez na época, pode-se intuir que a aduana nova não serviria apenas para as funções burocráticas que lhe foram designadas - poderia servir também para festividades imperiais, exatamente como ocorreu em sua inauguração em 27 de abril de 1889, quando o conde d’Eu e o imperador saíram do caís Pharoux na galeota de d. João VI. ${ }^{148}$ Portanto, nada mais natural que usar o mais novo e bonito edifício da corte para um baile que pretendia redimir a monarquia, propagandeá-la e, por fim, salvá-la do possível golpe republicano. O desculpa escolhida para o baile foi uma homenagem ao navio chileno Almirante Cochrane. O simbolismo era evidente. Como vimos, Thomas Cochrane foi uma espécie

\footnotetext{
${ }^{146}$ As informações sobre as características físicas da Ilha Fiscal foram obtidas num tour in loco realizado na Ilha em 18 de junho de 2013.

${ }^{147}$ Idem ibidem.

${ }^{148}$ Alexandre Campos da Costa e Silva. Dicionário de curiosidades do Rio de Janeiro. Rio de Janeiro: Comércio e Importação de Livros CIL S/D, verbete Ilha Fiscal.
} 
de corsário, um oficial escocês contratado pelo governo que combateu tanto pela independência do Brasil como do Chile. ${ }^{149}$ Desta forma, ao homenagear o navio chileno, o governo estava, na verdade, indicando uma clara homenagem à independência brasileira e à casa de Bragança brasileira.

O navio chileno Almirante Cochrane chegou ao Rio de Janeiro no dia 11 de outubro de 1889 , uma sexta-feira. ${ }^{150} \mathrm{Na}$ Gazeta de Notícias de sábado, estampou-se a figura imponente do comandante Bannen, de braços cruzados. O baile na Ilha Fiscal foi apenas uma, dentre as muitas festividades dos eventos que se seguiram à chegada dos chilenos. A visita foi programada nos mínimos detalhes, com organizações e comitivas para cada evento que os tripulantes do navio compareceriam. Nos dia 17 de setembro, por exemplo, reuniu-se uma comitiva para decidir sobre os detalhes da chegada da embarcação. ${ }^{151}$ Ao longo de todo o mês foi publicada uma coluna intitulada "Chile: política, administração e literatura" na Gazeta de Notícias, bem como manifestações sobre como andava a organização para a chegada dos chilenos. ${ }^{152}$ Finalmente no dia 11, 2 dias antes do esperado, atracou no porto do Rio o cruzador chileno capitaneado por Constantino Bannen, que trouxe sua "digníssima esposa". ${ }^{153}$

A Gazeta contou nos mínimos detalhes a visita de Bannen e sua comitiva. Assim que chegaram, seguirem-se vivas de canhões, hasteamento de bandeiras, visita dos chilenos à rua do Ouvidor, enfeitada de bandeiras dos dois países e palmeiras. A tripulação a bordo era de 210 homens, 23 dos quais oficiais. O barco media 210 pés de comprimento e 46 de largura. Durante a viagem, o segundo engenheiro, Saulustio

\footnotetext{
${ }^{149}$ Ver a referência a Thomas Cochrane no capítulo IV desse trabalho.

${ }^{150}$ A Gazeta de Notícias de 12 de outubro de 1889.

${ }^{151}$ A Gazeta de Notícias de 17 de setembro de 1889. O pdf do jornal encontra-se no site da Biblioteca Nacional.

${ }^{152}$ A Gazeta de Notícias de 22, 23, 24, 30 de setembro de 1889.

${ }^{153}$ A Gazeta de Notícias de 12 de outubro de 1889.
} 
Furnas, sofreu um acidente com as máquinas e acabou com as duas mãos decepadas; fora isso, o trajeto foi feito com tranquilidade. ${ }^{154}$

As reuniões, homenagens e visitas foram intensas, culminando no baile do dia 9 de novembro. Os chilenos estiveram na Escola Superior de Guerra, no corpo de bombeiros, num banquete no dia 6 de novembro oferecido pelo príncipe Pedro Augusto, no colégio militar. Em outro momento do dia, a sociedade carioca havia passado pelo convés do navio para brindes, refrescos e sorvetes em vários dias de outubro e novembro. ${ }^{155}$ Finalmente o grande dia do baile oferecido pelo visconde de Ouro Preto havia chegado, e o repórter da Gazeta de Notícias estava a postos, fazendo a descrição do baile e dos salões pouco antes da chegada dos convidados. Chovia, segundo seu relato. $^{156}$

\begin{abstract}
$\mathrm{Na}$ entrada, sobre dois postes, há quatro lâmpadas do força illuminativa só de velas. Seguem-se outros quatro focos iguais no saguão onde vão ser armados dois quadros transparentes, um dos quais alegoria "O Brasil recebendo o Chile. A direita o a esquerda, no primeiro pavimento, são os salões de danças, três do cada lado, o de toilette das senhoras, à esquerda, o da familia imperial à direita. Duas orchestras tocarão nos terraços laterais; uma na sala do bouffet; uma banda ds musica na torre, a do Arsenal de Guerra. ${ }^{157}$
\end{abstract}

Havia o buffet, num pavilhão com duas salas. Na primeira, um mesa disposta em ferradura, com serviço para 450 pessoas. Na segunda sala estaria a mesa destinada à família imperial,consideravelmente menor. Ambas as salas estariam forradas com tapete

\footnotetext{
${ }^{154}$ A Gazeta de Notícias de 12 de outubro de 1889.

${ }^{155}$ A Gazeta de Notícias de 4,5,6, 7 e 8 de novembro de 1889.

${ }^{156}$ A Gazeta de Notícias de 9 de novembro de 1889.

${ }^{157}$ A Gazeta de Notícias de 9 de novembro de 1889.
} 
verdes e as janelas addornadas com cortinas com as cores do Brasil e do Chile. Escudos com bandeiras dos dois países enfeitavam colunas ornamentais. ${ }^{158}$

Os vestidos estavam encomendados fazia tempo nas diversas lojas da rua do Ouvidor. Cabelereiros a postos, joias encomendadas - e o baile começou no horário, com os batelões e suas lanternas à veneziana atravessando a pouca distância que separava o cais Pharoux da Ilha Fiscal. ${ }^{159}$ Jantou-se à farta: 1.300 frangos, 800 quilos de camarão, 500 perus, 20 mil sanduíches, 64 faisões, 14 mil sorvetes, 2900 pratos de doces. Bebeu-se mais 10 mil litros de cerveja e 304 caixas de vinho, mais ou menos 5.000 litros de vinho, champanhe ou licor. ${ }^{160}$ Tudo preparado para receber os 3 mil convidados. É interessante notar que a ilha é pequena e possivelmente os convidados se revezaram na festa durante a noite, pois não caberiam todos ao mesmo tempo.

Durante a festa encontraram-se monarquistas e republicanos, liberais e conservadores, que tomaram sorvetes, beberam cerveja e champanhe, comeram sanduíche e frango. "Não é que só fossem liberais ao baile, também iriam conservadores, e aqui cabia bem o aforismo de D. Cláudia que não é preciso ter as mesmas ideias para dançar a mesma quadrilha."161

D. Pedro II foi de casaca preta folgada, seu traje usual, com a Ordem do Tosão de Ouro na lapela, enquanto a impetriz vestia renda Chantilly preta guarnecidas de vidrilhos. ${ }^{162}$ Dançou-se noite toda - tanto na ilha como no cais, onde uma banda da polícia com farda de gala tocava lundus e fandangos para o povo que havia se reunidos

\footnotetext{
${ }^{158}$ A Gazeta de Notícias de 9 de novembro de 1889.

${ }^{159}$ A Gazeta de Notícias de 9 de novembro de 1889.

160 Encontrei um menu do "último baile" nos documentos referentes à Santos Dumont quando fazia a pesquisa para meu mestrado, no Museu Paulista. Por ter feito o mestrado sobre gastronomia, não resisti a colocar a quantidade de alimentos e bebidas servidas na festa.

161 Machado de Assis. Esaú e Jacó. In: Obras completas. São Paulo: W. M. Jackson Editores, 1942, capítulo XLVIII.

162 Lilia Schwarz. As barbas do imperador: d. Pedro II, um monarca nos trópicos. São Paulo: Companhia das Letras, 1998, p. 455.
} 
para assistir a passagens da aristocracia para Ilha Fiscal de barco. Na mesma noite, Benjamin Constant conspirava contra a monarquia no clube militar. ${ }^{163}$

Nos dias e meses seguintes, correram boatos de que festa havia sido uma orgia, com várias cinta-liga, anquinhas, corpetes e anquinhas encontradas pela ilha. ${ }^{164} \mathrm{Com}$ os anos, criou-se uma espécie de propaganda republicana, de uma festa imperial sem controle, tanto de gastos como de impulsos. Numa ilha pequena, com uma enorme quantidade de convidados, teria sido praticamente impossível ter ocorrido qualquer orgia sexual insinuada pelo jornal. ${ }^{165}$

De fato, este foi o último baile do império. Na metáfora sobre o fim do império, Machado fala sobre o conselheiro Aires e o velho Cusódio, da confeitaria. O confeteiro não sabia o que fazer com uma tabuleta velha, onde estava escitor o nome do estabelecimento, mas encontrava-se atualemente com as letras apagadas. O conselheiro recomenda que a tabuleta seja trocada por uma nova, pois "pintura nova em madeira velha não vale nada". Custódio queria apenas pintar por cima das letras. Ao que respondeu o conselheiro: “agora é receber a nova, e verá como daqui a pouco são amigos". ${ }^{166}$ E assim foi recebida a república, alguns dias depois do baile. Em poucos dias, os jornais davam notícias sobre a família real na Europa como coisa do passado, com ferrenhos monarquistas pouco a pouco apioando o novo governo. Nas propagandas

\footnotetext{
${ }^{163}$ Renato Lemos. Benjamin Constant: vida e história. Rio de Janeiro: Topbooks, 1999, p. 333 a 412.

${ }^{164}$ As peças de roupa íntima foram realmente encontradas na limpeza do local, mas a quantidade de banheiros disponíveis na festa era tão pequena que provavelmente essas peças foram tiradas às pressas para se fazer as necessidades fisiológicas. Na época, a montagem de um vestuário de mulher de festa exigia assistência. Ao vestirem-se sozinhas nos poucos banheiros existentes, muitas mulheres podem ter esquecidos ou prendido mal as peças do seu traje. Também é preciso lembrar que a ilha é pequena para a quantidade gente na festa e era praticamente impossível fazer qualquer espécie de orgia sem que todos vissem.

${ }^{165}$ A propaganda foi tão forte que até hoje nos relatos sobre o baile encontram-se referências às "orgias" dos convidados.

${ }^{166}$ Machado de Assis. Esaú e Jacó. In: Obras completas. São Paulo: W. M. Jackson Editores, 1942, capítulo XLIX.
} 
publicadas, as cahamdas para loterias já não exibiam "apostam na loteria da província da Bahia", mas "Apostem na loteria do Estado de São Paulo". ${ }^{167}$

Os chilenos continuaram no Rio de Janeiro até meados de dezembro. Mesmo depois de proclamada a república, a visita oficial não acabaria - continuavam os bailes, os encontros, os almoços, as inaugurações, como a na Guarnição Fortaleza de Santa Cruz, que havia recebido dinheiro da monarquia para a recepção e junto ao comandante Bannen dava vivas à nova república. ${ }^{168}$ No próprio dia da proclamação, toda a delegação sobe a serra para visitar Petrópolis. ${ }^{169}$ Ao saírem havia foi publicada uma despedida singela pela Academia de Belas Artes no jornal. ${ }^{170}$ Tanta festa ao chilenos tinha um motivo militar forte. O Brasil pretendia mostrar à Argentina (interessada na região de Palmasn entre o Parané e Santa Catarina) seu mais novo aliado nas Américas, o Chile, numa nova composição de forças do continente. ${ }^{171}$

Anos depois de proclamada a República, em 1905,o pintor Francisco Aurélio de Figueredo e Melo (1856-1916), irmão mais novo de Pedro Américo, mostrou ao público seu quando sobre o último baile, "A ilusão do terceiro reinado". Na imagem, vemos os convidados do baile, conversando, as mulheres com leques e decotes, os homens de casa preta e comendas na lapela, como se não se apercebessem que no céu, entre as nuvens estava o macheral Deodoro e sua comitiva de militares, preparados para a acabar com o sonho de d. Pedro de coroar a filha, a princesa Isabel.

\footnotetext{
${ }^{167}$ A Gazeta de Notícias de 20 de novembro de 1889.

${ }^{168}$ A Gazeta de Notícias de 11, 12, 13, 16, 17,19 e 20 de dezembro de 1889.

${ }^{169}$ A Gazeta de Notícias de 16, 17,19 e 20 de dezembro de 1889.

${ }^{170}$ A Gazeta de Notícias de 20 de dezembro de 1889.

171 "O último a sair apague a luz", reportagem de Fabiano Vilaça à Revista de História da Biblioteca Nacional em 1 de junho de 2008.
} 


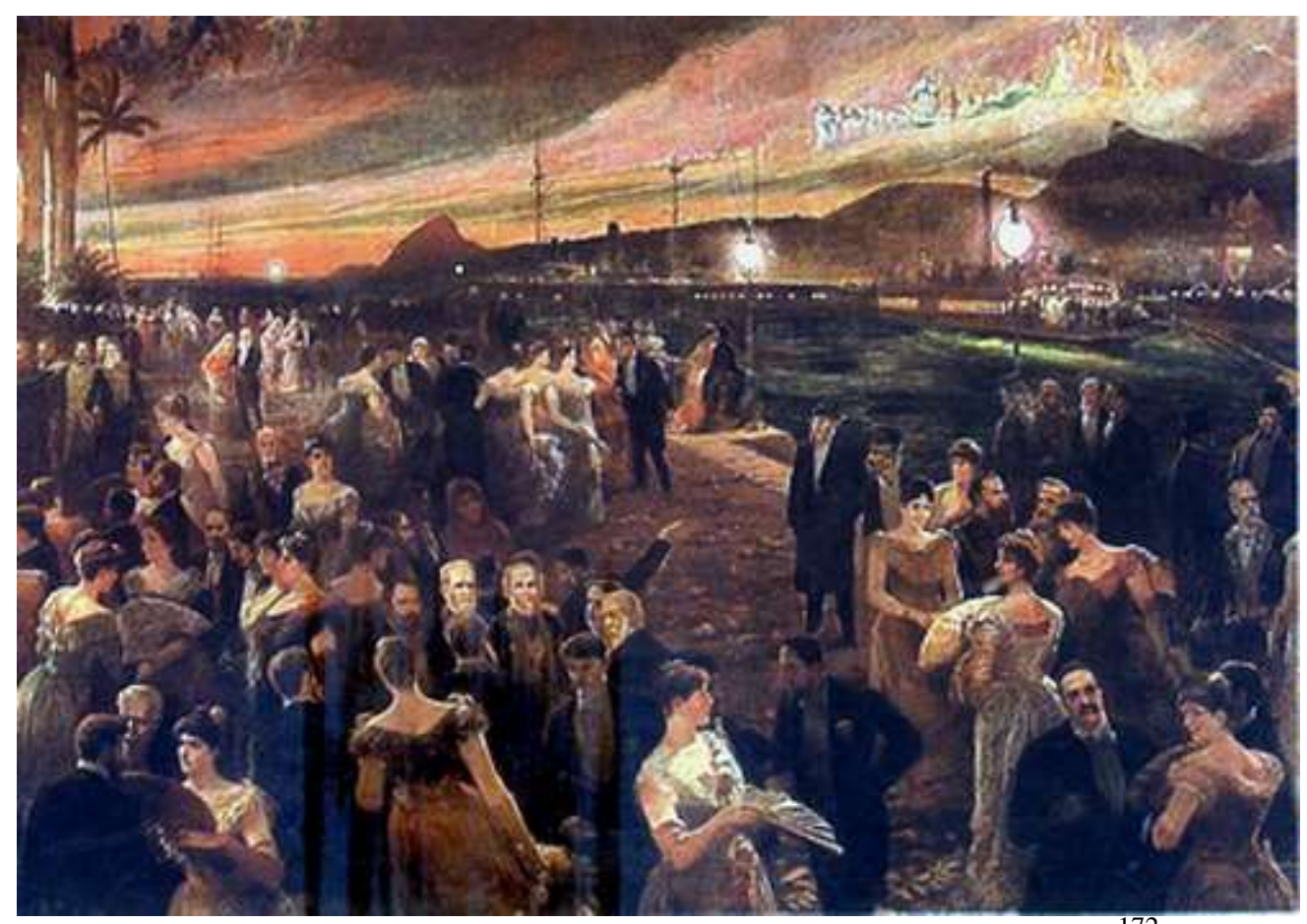

Aurélio de Figueiredo, "A ilusão do terceiro reinado", de $1905^{172}$

${ }^{172}$ Este quadro encontra-se Museu Histórico Nacional. É um óleo sobre tela de $303 \times 708 \mathrm{~cm}$ reproduzido de <http://www.museuhistoriconacional.com.br/>, consultado em 23/9/2013. Uma réplica encontra-se no salão de jantar imperial na Ilha Fiscal. 


\section{Considerações finais}

s transformações econômicas decorrentes do dinamismo das exportações
de café criaram, no Segundo Reinado, condições para a expansão de
valores burgueses. Associada à consolidação do Estado, uma nova maneira de exibir símbolos de distinção e poder construía-se no interior das elites brasileiras. A moda impunha-se e difundia-se pela sociedade, dando sustentação simbólica à expansão do comércio mundial.

O movimento da alfândega carioca mostrava os tecidos e acessórios importados no período. Uma vez no Brasil, eram transformados em roupas, num circuito que envolvia, também, novas produtoras de roupas, as modistas, com suas máquinas de costura, e uma nova maneira de consumi-los, nas lojas da rua do Ouvidor.

No Rio de Janeiro de meados do século XIX, com o dinheiro circulando por causa dos negócios, envolvendo, principalmente, as exportações de café e a administração da corte, o processo de cosmopolitização da elite refletiu-se tanto nas necessidades de remodelação urbana, quanto no estabelecimento de hábitos e costumes e importação de produtos da Europa. Na sociedade da corte, os padrões de consumo intensificaram-se, promovendo a criação de novos negócios, como lojas e ateliês de confecção de roupa.

A utilização da máquina de costura possibilitou que as roupas pudessem ser feitas em menos tempo. Mesmo que o mercado de máquinas tenha se desenvolvido sobretudo nos Estados Unidos, elas chegaram ao Rio de Janeiro em meados do século 
XIX e foram vendidas com sucesso, com inúmeras propagandas em jornais, revistas e almanaques da época.

O cuidado com as roupas envolveu diferentes tipos de trabalhos, a maioria ligada ao universo feminino. Das lavadeiras às costureiras, muitas mulheres eram escravas, trabalhando na cidade em diferentes ocupações ligadas às costuras e às roupas. Ao mesmo tempo, estrangeiras chegavam ao Rio e abriam ateliês de moda. Empregavam tanto mulheres brancas livres, como escravas especializadas, que podiam, com o tempo, comprar a própria liberdade. Novos costumes modificavam antigos hábitos.

Movendo-se junto com a economia do Rio de Janeiro, a moda espelhava especialmente as escolhas da corte. Em um império sem tradição, como o de d. Pedro II, a roupa indicava claramente a posição social do indivíduo. A continuidade da casa de Bragança e do império brasileiro, após a Independência, consolidou uma configuração política em que a presença da família real indicava a formação do Estado nacional. Nesse contexto, o estatuto imperial foi a expressão, não da persistência do Antigo Regime, mas da invenção de uma tradição.

Nesse sentido, embora bem toda a classe dominante estivesse na corte, ela era habilitada a participar da vida no Paço. Ao mesmo tempo, os padrões e hábitos da corte eram a pauta de identificação dessas elites dominantes, que incluía senhores de escravos ambiguamente tocados pelas mercadorias trazidas pela riqueza, fazendeiros modernos oriundos do grande comércio, comerciantes engajados nas redes financeiras. A moda, portanto, configurava-se como elemento de identificação social.

Com a expansão das exportações inglesas de tecidos, resultados dos processos que culminaram na Revolução Industrial, e a abertura dos portos no Rio de Janeiro, uma quantidade cada vez maior de tecidos e acessórios ligados à moda começariam a chegar à cidade. 
Vestir-se bem, ou adequadamente para cada ocasião social, tornou homens e mulheres de elite símbolos de uma nova corte, de um império, inserido nas mudanças econômicas do século XIX. Por meio de vestidos, joias e adornos, poder-se-ia mostrar se determinada dama ou cavalheiro pertencia à nobreza. A moda significou o surgimento de um novo ramo econômico, mas, ao mesmo tempo, exatamente por ser moda e por se pautar por padrões de vestuário, também refletiu as ambiguidades do império. 


\section{Fontes, livros de memória, relatos de viagem e romances}

ALENCAR, José. A pata da gazela. São Paulo: Saraiva, s/d.

ALENCAR, José. Diva. São Paulo: Saraiva, s/d.

ALENCAR, José. Encarnação. São Paulo: Saraiva, s/d.

ALENCAR, José. Lucíola. São Paulo: Saraiva, s/d.

ALENCAR, José de. Lucíola. São Paulo, Edições Melhoramentos, s.d.

ALMEIDA, Guilherme. Cosmópolis. São Paulo: Companhia Editora Nacional, 1962.

ALMEIDA, Júlia. Cruel amor. São Paulo: Saraiva, s/d.

ALMEIDA Julia Lopes de. O livro das noivas. Rio de Janeiro: Castorino Mendes, 1929

AMERICANO, Jorge. São Paulo naquele tempo (1895-1915). São Paulo:

Melhoramentos: 1962.

AMERICANO, Jorge. São Paulo nesse tempo (1915-1935). São Paulo: Melhoramentos, 1962.

AMERICANO, Jorge. São Paulo neste tempo (1935-1960). São Paulo: Melhoramentos, 1962.

ASSIS, Joaquim Maria Machado de. Memórias Póstumas de Brás Cubas (1859-1869).

São Paulo: Editora Ática, s.d. p. 99.

ASSIS, Joaquim Maria Machado de. Obra Completa. Vol II, (Páginas Recolhidas), s. ed., s.d. 
AVE-LALLEMANT, Robert. Viagem pelo sul do Brasil no ano de 1858, vol. I. Rio de Janeiro: Instituto Nacional do Livro/Ministério de Educação e Cultura, 1953.

AZEVEDO, Aluísio. A condessa Vésper (1877-1882). São Paulo: Livraria Martins Editora/Instituto Nacional do Livro (MEC), 1973.

AZEVEDO, Aluísio. Casa de pensão (1884). São Paulo: Livraria Martins Editora, 1960.

AZEVEDO Aluísio. Filomena Borges (1884). São Paulo: Martins Editora, 1960.

AZEVEDO Aluísio. Girândola de Amores (1882). São Paulo: Martins Editora, 1960.

AZEVEDO, Aluísio. O homem. Rio de Janeiro: F. Briguet, 1938.

AZEVEDO, Aluísio. $O$ mulato. São Paulo: Livraria Martins Editora/Instituto Nacional do Livro/MEC, 1975.

BARROS, Maria Paes de. No tempo de dantes. São Paulo: Paz e Terra, 1998.

AVÉ-LALLEMANT, Robert. Viagem pelo norte do Brasil no ano de 1859, vol. I. Rio de Janeiro: Ministério da Educação e Cultura/Instituto Nacional do Livro, 1961.

BATES, Henry Walter. O naturalista no Rio Amazonas (1850-1859), vol. II. São Paulo: Companhia Editora Nacional, 1944.

BAUDELAIRE, Charles. Um comedor de ópio. São Paulo: Clássicos Econômicos Newton, 1996.

BAUDELAIRE, Charles. As flores do mal. Rio de Janeiro: Nova Fronteira, 1985.

BINZER, Ina von. Os meus romanos. São Paulo: Paz e Terra, 2004.

BURTON, Richard. Viagens aos planaltos do Brasil, 3 t. São Paulo: Companhia Editora Nacional, 1983.

CARLOS. "Crônica da quinzena", in: Revista Popular: noticiosa, científica, industrial, histórica, literária, artística, biográfica, anedótica, musical, etc., Rio de Janeiro: B. L. Garnier, 1860 
CARROLL, Lewis. Alice no país das maravilhas. Rio de Janeiro: Objetiva, 2008.

CARROLL, Lewis. Cartas às suas amiguinhas. Rio de Janeiro: Sette Letras.

CARVALHO, Maria Amália Vaz de Carvalho. A arte de viver na sociedade. Lisboa: Parceria Antonio Maria Pereira, 1909.

CARVALHO, Pinto de. Lisboa d'outros tempos, 2 vols. Lisboa: Fenda, 1991.

CÉLINE, Louis-Ferdinand. Voyage au bout de la nuit. Paris: Gallimard, 1952.

CORRESPONDÊNCIA DE RIMBAUD. Porto Alegre: LP\&M, 1983.

CRULS, Gastão. Aparência do Rio de Janeiro. Rio de Janeiro: José Olympio, 1952.

DAVATZ, Thomas. Memórias de um colono no Brasil. São Paulo: Edusp/Biblioteca Histórica Brasileira/Livraria Martins Editora, 1972.

D'ÁVILA, Carmem. Boas maneiras. Rio de Janeiro: Civilização Brasileira, 1949.

DEBRET, Jean-Baptiste. Viagem histórica e pitoresca ao Brasil. Belo Horizonte: Itatiaia, 1989.

DEBRET, Jean-Baptiste. Viagem Pitoresca e Histórica ao Brasil. t. I, vol. I e II, São Paulo: Martins Editora, 1940.

DICKENS, Charles. Oliver Twist. São Paulo: Hedra, 2002.

DINIZ, Firmo de Albuquerque (Június). Notas de viagem. Coleção Paulística, vol. V. São Paulo: Governo do Estado, 1978.

EDMUNDO, Luís. O Rio de Janeiro dos tempos dos vice-reis. Rio de Janeiro: Conquista, 1956.

EDMUNDO, Luís. Recordações do Rio Antigo. Rio de Janeiro: Conquista, 1956.

ENGLES, Friedrich. A situação da classe trabalhadora inglesa. São Paulo: Boitempo editorial, 2007.

FLOREAL, Sylvio. Ronda da meia-noite. São Paulo: Paz e Terra, 2002. 
FREITAS, Afonso A. Tradições e reminiscências paulistanas. Coleção Paulística. São Paulo: Governo do Estado de São Paulo, 1978.

GINZBURG Natalia. Léxico familiar. São Paulo: CosacNaify, 2009.

GRAHAM, Maria. Diário de uma viagem ao Brasil e de uma estada nesse país durante parte dos anos de 1821, 1822, 1823. São Paulo: Companhia Editora Nacional, 1956.

HEGEL Georg W. F. Princípios da filosofia do Direito. São Paulo: Martins Fontes, 2009.

KOSERITZ, Carl von. Imagens do Brasil. São Paulo/Belo Horizonte: Edusp/Itatiaia, 1980.

LOBATO, Monteiro. A barca de Gleyre. Rio de Janeiro: Companhia Nacional, 1944.

KIDDER, Daniel Parish. Reminiscências de viagens e permanência no Brasil, províncias do Norte (1839-1840). São Paulo: EDUSP/ Itatiaia Editora, 1972.

KIDDER, Daniel Parish; FLETCHER, James Cooley. O Brasil e os brasileiros (18511865), vol.1. São Paulo: Companhia Editora Nacional, 1941.

LAGE, Claudia. Mundos de Eufrásia. A história do amor enter a incrível Eufrásia Teixeira Leite e o notável Joaquim Nabuco. Rio de Janeiro: Record, 2009

LUCCOCK, John. Notas sobre o Rio de Janeiro e partes meridionais do Brasil tomadas durante uma estada de dez anos nesse país, de 1808 a 1818. São Paulo: Livraria Martins Editora, 1942.

MACEDO, Joaquim Manuel de. Memórias da rua do Ouvidor. São Paulo: Saraiva, s/d.

MACEDO, Joaquim Manuel de. Um passeio pela cidade do Rio de Janeiro. São Paulo: Planeta, 2004.

MACHADO, Alcântara. Vida e morte do bandeirante. São Paulo: Imprensa Oficial, 2006.

MACHADO, Antonio Alcatara. Brás, Bexiga e Barra Funda. São Paulo: Estadão, 1997. 
MAGALHÃES, José Vieira Couto de. Diário íntimo. Coleção Retrato do Brasil. São Paulo: Companhia das Letras, 1998.

MANET, Edouard. Viagem ao Rio de Janeiro. Rio de Janeiro: José Olympio, 2002.

MANSFIELD, Katherine. Bliss and other stories. Nova York: Penguin, 1962.

MARTINS, Luís. O patriarca e o bacharel. São Paulo: Alameda Casa Editorial, 2008.

MAWE, John. Viagens pelo interior do Brasil, particularmente nos distritos de ouro e diamantes daquele país. Belo Horizonte/São Paulo: Itatiaia/Edusp, 1978.

PINTO, Alfredo Moreira. A cidade de São Paulo em 1900. Coleção Paulística. São Paulo: Governo do Estado de São Paulo, 1979.

POIRET, Paul. King of fashion. The autobiography of Paul Poiret. Londres: V\&A Publishing, 2009.

SPIX Johann Baptiste von e MARTIUS Carl Friedrich Philippe Von. Viagem pelo Brasil (1817-1818). vol. I, Rio de Janeiro: Imprensa Nacional, 1938.

QUEIROZ, Carlota Pereira de. Um fazendeiro paulista no século XIX. São Paulo: Secretaria do Governo, 1965.

QUINCEY, Thomas. Confissões de opiómano inglês. Lisboa: Contexto, 1989.

RANGEL. Alberto. Dom Pedro Primeiro e a Marquesa de Santos. Tours: Typographia de Arrault e Companhia, 1928.

RANGEL. Alberto. No rolar do tempo. Rio de Janeiro: José Olympio, 1937.

REZENDE, Ferreira. Minhas recordações. Rio de Janeiro: José Olympio, 1944.

RIBEIRO, Júlio. A carne. São Paulo: Átiva, 1999.

RIBEYROLLES Charles. Brasil Pitoresco (1858-1860). vol. I, São Paulo: Martins Editora, s.d.

PARTON, James. History of the sewing machine. Coleção: Making America. Carlisle: The University of Michigan, 1872 (edição digital sem data). 
PENTEADO. Jacob do Belenzinho. São Paulo: Livraria Martins Editora, 1962.

SAINT-HILAIRE, Auguste de. Segunda viagem ao Rio de Janeiro, a Minas Gerais e a São Paulo (1822). Belo Horizonte: Itatiaia, 1974.

SAINT-HILAIRE, Auguste de. Viagem à Província de São Paulo. São Paulo: Livraria Martins Editora/Edusp, 1972.

SAINT-HILAIRE, Auguste de. Viagem ao Rio Grande do Sul (1820-1821). São Paulo: Belo Horizonte: Edusp/Itatiaia, 1974.

SAINT-HILAIRE, Auguste de. Viagem pelo distrito dos diamantes e litoral do Brasil (1817-1818). São Paulo/Belo Horizonte: Edusp/Itatiaia Editora, 1974.

SIMMEL, Georg e outros escritos. Filosofia da moda. Lisboa: Edições Textos \&Grafia, 2008.

TÁCITO, Hilário. Madame Pommery. São Paulo, Ática, 1998.

SPIX, Johann Baptiste von; MARTIUS, Carl Friedrich Philippe von. Viagem pelo Brasil (1818-1819), vol. II. Rio de Janeiro: Imprensa Nacional, 1938.

TOUSSAINT-SAMSON, Adéle. Uma parisiense no Brasil. Rio de Janeiro: Capivara, 2003.

TSCHUDI, J. J. Viagem às Províncias do Rio de Janeiro e São Paulo. São Paulo: Comissão do IV Centenário, 1954.

ZOLA, Émile. O paraíso das damas. São Paulo: Estação Liberdade, 2007. 


\section{Referências bibliográficas}

ABREU Marcella dos Santos, "Paquetes, modas e salões: o desejo mimético nas crônicas da Revista popular (1859-1862)”. In: Anais do Seta, vol. 2, 2008, p. 7-12.

APPADURAI, Arjun (ed). The social life of things. Cambridge: Cambridge University Press, 1986.

ARAÚJO, Marcelo de Araújo. Dom Pedro II e a moda masculina na época vitoriana. São Paulo: Estação da Cores e Letras, 2012.

ALENCASTRO Luís Felipe. "Vida Privada e ordem privada no império". In: História da vida privada no Brasil II. São Paulo: Companhia das Letras, 1997

ARAÚJO, Marcelo de. Dom Pedro II e moda masculina na época vitoriana. São Paulo: Estação das letras e cores, 2012.

ARRUDA, José Jobson de. O Brasil do comércio colonial. São Paulo: Ática, 1980.

ARRUDA, Maria Arminda do Nascimento. A embalagem do sistema. A publicidade no capitalismo brasileiro. Bauru: Edusc, 2004.

BARBUY. Heloísa. A cidade-exposição: comércio e cosmopolitismo em São Paulo, 1860-1914. São Paulo: Edusp, 2006.

BARBUY. Heloísa A Exposição Universal de 1889: visão e representação na sociedade industrial. São Paulo: Loyola, 1999.

BARMAN, Roderick. Princesa Isabel do Brasil: gênero e poder no século XIX. São Paulo: Editora Unesp, 2002.

BARTHES, Roland. O sistema da moda. Lisboa: Estampa, 1974.

BAUDOT, François. Moda do século. São Paulo: Cosac Naify, 2002. 
BENJAMIN, Walter. Obras escolhidas I. São Paulo: Brasiliense, 2000.

BENJAMIN, Walter. Obras escolhidas II. São Paulo: Brasileiense, 2001.

BENJAMIN, Walter. Obras escolhidas III. São Paulo: Brasiliense, 2003.

BENJAMIN, Walter. Passagens. Belo Horizonte/ São Paulo: Ed. UFMG/Imprensa Oficial, 2007.

BENJAMIN, Walter. Reflexões sobre a criança, o brinquedo e a educação. São Paulo: Duas Cidades/Editora 34, 2002.

BICALHO, Fernanda. A cidade e o império: o Rio de Janeiro no século XVIII. Rio de Janeiro: Civilização Brasileira, 2003.

BISSELL Don,. The first conglomerate 145 years of the Singer sewing machine company. Edição do autor, 1999.

BOLTON, Sarah Knowles. The story of Elias Howe and the sewing machine. Kindle edition, original de 1885 .

BONADIO, Maria Claudia. Moda e sociabilidade. São Paulo: Senac, 2007.

BORREGO, Maria Aparecida de Menezes. A teia mercantil. Negócios e poderes em São Paulo Colonial (1711-1765). São Paulo: Alameda Casa Editorial, 2010.

BURMEISTER, Hermann. Viagem ao Brasil: através as províncias do Rio de Janeiro e Minas. Belo Horizonte: Itatiaia, 1980.

CANABRAVA, Alice. O desenvolvimento da cultura do algodão na província de São Paulo (1861-1875). São Paulo: Edusp, 2011.

CALANCA, Daniela. História social da moda. São Paulo: Senac, 2008.

CARLSON Laurie. Queen of inventions. How the sewing machine changed the world. Brookfield: The millbrook press, 2003.

CASTARÈDE, Jean. O luxo. Os segredos dos produtos mais desejados do mundo. São Paulo: Barcarola, 2005. 
CERTEAU, Michel; GIARD, Luce; MAYOL, Pierre. A invenção do cotidiano 2. Petrópolis: 1992.

CHARLES-ROUX, Edmond. A era Chanel. São Paulo: Cosac Naify, 2011.

COSTA. Emílio Viotti. Da monarquia à república. São Paulo: Editora Unesp, 1998.

CRANE, Diana. A moda e seu papel social. Classe, gênero e identidade das roupas. São Paulo: Senac, 2006.

CRANE, Diana. Ensaios de moda, arte e globalização. São Paulo: Senac, 2011.

CUNHA, Laura e MILZ, Thomas. Joias de crioula. São Paulo: Terceiro Nome, 2010.

DANTAS, Monica Duarte. Fronteiras movediças: a comarca de Itapicuru e a formação do arraial de Canudos. São Paulo: Hucitec, 2007.

DANTAS, Monica Duarte. Revoltas, motins e revoluções. São Paulo: Alameda Casa Editorial, 2011.

DEVEZA, Guilherme. Um precursor do comércio francês no Brasil. Coleção Brasiliana. São Paulo: Companhia Editora Nacional, 1976.

DOBB, Maurice. A evolução do capitalismo. Rio de Janeiro: Zahar Editores, 1963.

DORATIOTO, Francisco. Maldita Guerra: nova história da guerra do Paraguai. São Paulo: Compnhia das Letras, 2002.

ELIAS, Norbert. A sociedade de corte. Rio de Janeiro: Jorge Zahar, 1990.

ELIAS, Norbert. A sociedade dos indivíduos. Rio de Janeiro: Jorge Zahar, 1994.

ELIAS, Norbert. O processo civilizador. Rio de Janeiro: Jorge Zahar, 1990.

ELIAS, Norbert. Envolvimento e alienação. Rio de Janeiro: Bertrand Brasil, 1983.

EXPILLY, Charles. Mulheres e costumes do Brasil. São Paulo: Companhia Editora Nacional, 1977. 
FEIJÃO, Rosane. Moda e modernidade na belle époque carioca. São Paulo: Estação das Letras, 2011.

FAORO, Raymundo. Machado de Assis: a pirâmide e o trapézio. São Paulo: Globo, 2010.

FERNANDES, Florestan. A revolução burguesa no Brasil. Rio de Janeiro: Jorge Zahar, 1974.

FISHER, Gayle V. Pantaloons and power. A nineteenth-century dress reform in the United States. Kent: The Kent State University Press, 2001.

FRANCO, Carlos. O mobiliário das elites de Lisboa na segunda metade do século XVIII. Lisboa: Livros Horizonte, 2007.

FREITAS, Marcus Vinicius. Hartt: expedições pelo Brasil Imperial, 1865-1878. Rio de Janeiro: MetaLivros, 2001.

FREYRE, Gilberto. Casa Grande e Senzala. São Paulo: Graal, 2005.

FREYRE, Gilberto. Os ingleses no Brasil. São Paulo: Graal, 2006.

FREYRE, Gilberto. Sobrados e mucambos. São Paulo: Graal, 2006.

FREYRE, Gilberto. Modos de homem \& modas de mulher. Rio de Janeiro: Record, 1986.

FREYRE Gilberto. O escravo nos anúncios de jornais brasileiros do século XIX. Cia Editora Nacional, cole. Brasiliana, São Paulo, 1979

FRIEDERICH, Otto. Olympia. Paris in the age of Manet. Nova York: Harper Collins, 1992.

FRY, Roger. Visão e forma. São Paulo: Cosac\&Naify, 2002.

FORDEN, Sara Gay. A casa Gucci. São Paulo: Seoman, 2008.

FURTADO, Celso. Formação econômica do Brasil.São Paulo: Companhia Editora Nacional, 2003. 
GARFIELD, Simon. Mauve: how one man invented a color that changed the world. Nova York/ Londres: W.W. Norton \& Company, 2001.

GERNSHEIM, Alison. Victorian and Edwardian fashion.: a photographic survey. Nova York: Dover, 1981.

GRAHAM, Richard. Grã-Bretanha e o início da modernização no Brasil. São Paulo: Brasiliense, 1973.

GRAHAM, Sandra Lauderdale. Proteção e obediência. Criadas e seus patrões no Rio de Janeiro, 1860-1910. São Paulo: Companhia das Letras, 1992.

GOMES Flavio dos Santos et alii. Cidade negras. São Paulo: Alameda Casa Editorial, 2008.

GRINBERG, Keila; SALLES, Ricardo. O Brasil imperial, vol. III. Rio de Janeiro: Civilização Brasileira, 2009.

GRUMBACH Didier. Histórias da moda. São Paulo: Cosac\&Naify, 2009.

GUIMARÃES. Carlos Gabriel. A presença inglesa nas finanças e no comércio no Brasil imperial. São Paulo: Alameda Casa Editorial, 2012.

HOBSBAWM, Eric. A era do capital, 1848-1875. São Paulo: Paz e Terra, 1996.

HARVEY, John. Homens de preto. São Paulo: Editora da Unesp, 2001.

HESKETT, John. Industrial design. Londres: Penguin, 1980.

HILTON, Timothy. The pre-raphaelits. Londres: Thames\&Hudson, 1995.

HOLLANDER, Anne. O sexo e as roupas. A evolução do traje moderno. Rio de Janeiro: Rocco, 1996.

HOLANDA, Sergio. Capítulos de história do império. São Paulo: Companhia das Letras, 2010.

JENSEN, Joan e DAVIDSON, Sue (orgs.). A needle, a bobbin a strike: womwn needleworkers in America. Filadélfia: Temple university press, 1984.

KLEE, Paul. Sobre arte moderna e outros ensaios. Rio de Janeiro: Jorge Zahar, 2001. 
KÖHLER, Carl. A history of costume. Nova York: Dover Publications, 1963.

LAGO, Pedro; CORREA, Bia. Coleção Princesa Isabel, fotografia do século XIX. Rio de Janeiro: Capivara, 2008.

LANNA, Ana Lúcia Duarte. Uma cidade na transição, Santos, 1870-1913. São Paulo: Hucitec, 1996.

LANDES, David. Prometeu desacorrentado. São Paulo: Campus, 2003.

LEITE, Miriam Moreira. A condição feminina no Rio de Janeiro do século XIX. São Paulo: Hucitec, 1981.

LEVER, James. Costume and fashion: a concise history. Londres: Thames \&Hudson, 1995.

LIMA. Heitor Ferreira. História político-econômica e industrial do Brasil. Coleção Brasiliana. São Paulo: Companhia Editora Nacional, 1970.

LIPOVETSKY, Gilles. O Império do efêmero. São Paulo: Companhia das Letras, 1989.

MACHADO, Ubiratan. A vida lietrária no Brasil durante o Romantismo. Rio de Janeiro: Bazar Editorial, 2010.

MAYER, Arno. A força da tradição. São Paulo: Companhia das Letras, 1990.

MENEZES. Raimundo de. Emílio de Menezes: o último boêmio. São Paulo: Saraiva, s/d.

MONIZ, Heitor. A corte de D. Pedro II. Rio de Janeiro: Livraria Freitas Bastos, 1931.

MORICONI, Martini; GEORGE-HOYAU. Le dictionnaire de la mode contemporaine. Genebra: Minerva, 1999.

NAZZARI. $O$ desaparecimento do dote: mulheres, famílias e mudança social em São Paulo, 1600-1900. São Paulo: Companhia das Letras, 1991.

OLIVEIRA, Sandra Ramalho. Moda também é texto. São Paulo: Rosari, 2007.

PADILHA, Marcia. A cidade como espetáculo: publicidade e vida urbana em São Paulo dos anos 20. São Paulo: Annablume, 2001. 
PEREIRA, Batista. Figuras do império e outros ensaios. Coleção Brasiliana. São Paulo: Companhia Editora Nacional, 1975.

PERLINGERO, Camila. 46 livros de moda que vocês não pode deixar de ler. Rio de Janeiro: Memória Visual., 2007.

PERROT Michelle. Os excluídos da história: operários, mulheres, prisioneiros. São Paulo: Paz e Terra, 1988.

PERROT, Michelle. Mulheres públicas. São Paulo: Editora Unesp, 1997.

PERROT. Michelle As mulheres ou os silêncios da história. Bauru: Edusc, 2005.

PEVSNER, Nikolaus. Os pioneiros do desenho moderno. São Paulo: Martins Fontes, 2002.

RAGO, Margareth. Os prazeres da noite. São Paulo: Paz e Terra, 1991.

ROCHE, Daniel. A cultura das aparências. São Paulo: Senac, 2005.

ROCHE, Daniel. História das coisas banais. Rio de Janeiro: Rocco, 2000.

ROCHE, Daniel. O povo de Paris. São Paulo: Edusp, 2004.

ROSE, Sonya. Gender and class in modern Europe. Ítaca: Cornell University Press, 1996.

ROSSETTI, Ana. Roupas íntimas, o tecido da sedução. São Paulo: Martins Fontes, 1995.

SANT'ANNA, Mara Rúbia. Teoria de moda: sociedade, imagem e consumo. São Paulo: Estação das Letras e Cores, 2009.

SCALERCIO, Marcio. A economia norte-americana no século XIX: um inventário da prosperidade. Rio de Janeiro: Contracapa, 2007.

SCHLERETH, Thomas. Victorian America: transformation in everyday life. Nova York: Harper \& Collins: 1992.

SCOTT Joan W.. A mulher trabalhadora. In: História das mulheres, o século XIXs. Lisboa: Afrontamento, 1994 
SCORCINELLI, Paolo. Estudar a moda: corpos, vesturário, estratégias. São Paulo: 2003.

SCHIMITT, Juliana. Mortes vitorianas: corpos, luto e vestuário. São Paulo: Alameda Casa Editorial, 2010.

SCHWARZ, Lilia Moritz. As barbas do imperador. D. Pedro II, um monarca nos trópicos. São Paulo: Companhia das Letras, 1998.

SILVA, Maria Beatriz Nizza da. Cultura e sociedade no Rio de Janeiro (1808-1821). São Paulo: Companhia Editora Nacional, 1978.

SLEMIAN, Andréia. Vida política em tempo de crise: Rio de Janeiro (1808-1824). São Paulo: Hucitec, 2006.

SMITH, Adam. A riqueza das nações. São Paulo: Martins Fontes, 2003.

SORCINELLI, Paolo. Estudar a moda. Corpos, vestuário, estratégias. São Paulo: Senac, 2003.

SOUZA, Antonio Candido de Mello e. Um funcionário da monarquia: ensaio sobre o segundo reinado. Rio de Janeiro: Ouro sobre azul, 2002.

SOUZA, Gilda de Mello e. O espírito das roupas. São Paulo: Companhia das Letras, 1987.

SUTHERLAND, Daniel E.. The expansion of every day life, 1860-1876. Fayetteville: The university of Arkansas Press, 2000.

STALLYBRASS, Peter. O casaco de Marx: roupas, memória e dor. Coleção Mimo. Belo Horizonte: Autêntica, 2008.

STEIN, Stanley . Grandeza de decadência do café. São Paulo: Brasiliense, 1961.

STEVENSON, N.J. Cronologia da moda: de Maria Antonieta a Alexander McQueen. Rio de Janeiro: Zahar, 2012.

SYLVESTER, David. Sobre arte moderna. São Paulo: Cosac Naify, 2007.

TADEU, Tomaz (org). Baudelaire, Balzac e D’Aurevilly (escritos). Manual do dândi: a vida com estilo. Belo Horizonte: Autêntica, 2009. 
TATI, Miécio. O mundo de Machado de Assis. Rio de Janeiro: Livraria São José, 1961.

THOMPSON E. P. Costumes em comum. São Paulo: Companhia das Letras, 1998.

THOMAS, Dana. Deluxe. Como o luxo perdeu o brilho. São Paulo: Campus, 2008.

TÊXTIL. Guia técnico Ambiental da indústria textil. Série P + L

TOZER, Jane e LEVITT, Sarah. Fabric of society. Londres: Laura Ashley Publication, 1983.

VAUGHAN, Hal. Dormindo com o inimigo. A guerra secreta de Coco Chanel. São Paulo: Companhia das Letras, 2011.

VEILLON, Dominique. Moda e guerra. Rio de Janeiro: Jorge Zahar Editor, 2001.

VINKEN, Barbara. Fashion Zeitgeist. Trends and cycles in the fashion system. Oxford: Grã Bretanha, 2005.

WALKLEY, Christina e FOSTER, Vanda. Crinoline and crimping irons. Londres: Peter Owen, 1978.

WAIZBORT, Leopoldo. As aventuras de George Simmel. São Paulo: Editora 34, 2000.

WEBER, Max. A ética protestante e o espírito do capitalismo. São Paulo: Companhia das Letras, 2009.

WILDE, Oscar; MALLARMÉ, Stéphane. Noblesse de la robe. Paris: Les Belles Lettes, 1997.

XIMENES, Maria Alice. Moda e arte na reinvenção do corpo feminino do século XIX. São Paulo: Estação das letras e cores, 2009.

YÁZIGI. Eduardo. O mundo das calçadas. São Paulo: Imprensa Oficial/ Humanitas/ USP: 2000. 


\title{
Pequeno dicionário histórico de tecidos
}

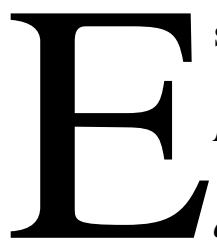

ste pequeno dicionário compilou nomes de tecidos encontrados nos vários Mapas gerais das mercadorias importadas e despachadas para consumo do século XIX, disponíveis no site <http://memoria.nemesis.org.br/>.

Também foram elencados nomes de tecidos descritos em romances e jornais de vão do final do século XVIII a meados do século XX. Ainda que essa abrangência ultrapasse o período estudado, considerei manter os termos anacrônicos aqui, uma vez que eles, de uma forma ou de outra, acabaram participando da reflexão e podem vir a ser úteis para outros pesquisadores. Para a descrição dos tecidos foram usados diversos dicionários, como o Houassis, o Dicionário de Raphael Bluteau de 1728, que está no site do IEB, o Dicionário de língua portugueza Moares e Silva de 1789. Foram consultados também diversos sites de indústrias têxteis para os tecidos mais atuais.

\author{
<http://lojamundonovo.blogspot.com.br/p/promocional.html $>$ \\ $\langle\underline{\text { http://www.casamentoclick.com/report/dicionario-tecidos-.html }}>$ \\ <http://veramonteiro.com.br/dicionario-de-tecidos/> \\ $<\underline{\text { http://manequim.abril.com.br/moda/dicionario-da-moda/> }}$ \\ <http://monopoliodamoda.wordpress.com/dicionario-monopolist/> \\ $<$ http://parkdostecidos.com/showroom/teciteca/>
}


AçORES: Variedade de linho com aspecto rústico.

AdAMASCADO: tecido em seda, linho ou algodão com desenhos brilhantes e opacos contrastantes, muito usado na fabricação de roupas femininas. Os tecidos adamascados são geralmente mais difundidos na moda quando temas como o dandismo e o Oriente servem de inspiração para coleções.

ADATIS: musselina de algodão muito leve fabricada em Bengala na Índia.

AJOUR: palavra francesa para referir-se ao ponto de bordado antigo resultante de uma bainha desfiada e trabalhada com pontinhos. O acabamento com este tipo de ponto é chamado ajouré.

ALBENE: tecido com trama bem fechada e encorpada, com aspecto de seda. Muito usado na década de quarenta do século XX para confecção de ternos masculinos e taillers femininos.

AlCaTIFA: tapete que reveste o chão.

ALPACA: tecido de algodão e/ou viscose que serve como forro em peças de roupa.

ALGODÃo: tecido fabricado com fio de algodão.

AlgOdão EGíPCIO: algodão de fibras longas, de fina qualidade. Principal produto de exportação do Egito, produzido no vale do Nilo.

ALgOdão SEA ISLAND: variedade de fino algodão, que possui fibra têxtil longa e delgada.

AlPaCa: mistura de lã com seda, muito usado na confecção de casaco e forros no século XIX. Tecido brilhoso, que durante o século XX, foi mesclado ao algodão e a fibras artificiais, sendo muito adotado ainda hoje na forração de roupas. Pode também se referir à lã de alpaca, mamífero da mesma família da lhama encontrado na América Latina, mais especificamente no sul do Peru e no oeste da Bolívia. 
ANACOSTE: misto de seda e lã.

ARRASTÃo: tipo de malha com ligamentos bem abertos, semelhante a uma rede de pescador e muito usada em meias femininas.

ASTRACã: refere-se à pele de um cordeiro originário da Ásia Central usada para casacos ou como detalhe de roupas no final do século XIX. No século XX, no final dos anos 1960 e inicio dos anos 1970, foi feita uma imitação de tecido usada para casacos e calças, em cores vivas como roxo-batata.

\section{B}

Baeta OU BAvetTa: tecido felpudo normalmente feito de lã. Pelo dicionário de Raphael Buteau, pano de lã que, com o uso ou com instrumentos, se levanta os pelos.

BARRETINAS: gorros pontudos, como dos gnomos ou do papai Noel.

BAREGE: tecido originário da cidade francesa de Barège, feito de lã, seda ou algodão puros e geralmente usado em roupas femininas.

BONET OU BONNET: Os bonets eram uma espécie de chapéu amarrado com uma fita por baixo do pescoço.

BATISTA: tecido muito fino de fio de algodão e tafetá. Usado em lenços, tecidos do lar, vestidos, camisas, etc.

BATIK: processo de estamparia manual com reserva de tingimento. Coloca-se cera, ou amarra-se com barbante (numa versão mais moderna) as partes do tecido que devem ser reservadas sem tingimento. Pode-se usar várias cores e o batik popularizou-se no final dos anos 1960, início dos 1970, com a cultura hippie.

BARATEA OU GRAin DE POUDRE: em francês poudre significa "pó". É um tipo de tecido feito de lã penteada muito fina, classificada como granitées. Refere-se também às malhas confeccionadas com pontos recolhidos. 
BARbAtANA: as barbatanas de baleia eram muito usadas no fim do século XIX na confecção de espartilhos femininos. Cortadas em pedaços, elas serviam de sustentação à peça que, fechada por cordões, ajudava a delinear o corpo da mulher, formando um "S". As barbatanas de baleia e de outros materiais também foram utilizadas na confecção de crinolinas, armações usadas por baixo das saias femininas que davam a roda e o volume desejados pelas mulheres.. As crinolinas, como podemos ver em filmes como $E$ o vento levou ..., foram muito usadas nas décadas de 1850 e 1860. Já no século XX, barbatanas de nylon passaram a ser inseridas embaixo dos colarinhos de camisas masculinas, não deixando que suas pontas virassem para dar o aspecto firme desejado.

BARROR: pelerine de primeira qualidade, utilizada para ocasiões de luxo.

BELBUTE: tecido de algodão aveludado

BELbUTINA: espécie de belbute aveludado fino com raias paralelas.

Bombasina OU BOMbazine: Tecido de veludo de seda ou algodão com sulcos muito profundos na camada de uso no sentido da teia. Tem muita resistência ao uso e serve para vestuário de homem, senhora e decoração.

BotonÊ: tecido de lã com efeito de coco ralado. É produzido com fios fantasia do mesmo nome e que têm pequenas bolotas de fibras enroladas. Existe hoje um fio para tricô da marca Pinguim que se chama Botonê.

BoUCLÊ: do francês boucler, isto é, encaracolar. É um fio de textura crespa, feito para tricô e muito usado na confecção de malhas.

BRIM: tecido resistente, de algodão ou linho. Atualmente é o mesmo que o jeans, usado em calças, bermudas, etc. Inicialmente feito de linho ou algodão. Mais tarde, no século XIX de fibras mistas ou sintéticas.

BROCADO: vem do francês broucart, que significa ornamentar. Sempre foi o tecido da realeza, em especial da nobreza francesa, sendo inúmeras as leis suntuárias relativas à utilização de brocardo pela nobreza e pela plebe. É o jacquard trabalhado em fios de ouro ou prata. 
BUCARAN: tecido de algodão grosseiro, forte e preparado em ligamento de tafetá. Emprega-se para entretelas, na confeccão de chapéus, cintos e tapeçarias.

C

CАвАM: oleado próprio para fazer capas.

CaIBros: panos compridos a modo de barrotes, pregados nos quatro cantos do tecido.

CAIREL: substantivo masculino que significa fita, galão, para debruar, debrum.

CALA : espaço de entrada dos fios no tear.

Cambraia ou Cambray pano de linho muito fino cuja a origem é a cidade de Cambray, na França. Tecido de algodão ou linho leve, com ligamento tela, para camisas e blusas finas. A cambraia de lã é um tecido mais pesado em ligamento sarja com fios de cores contrastantes no urdume e na trama, usado para ternos.

Canvas: tecido tipo jeans, de algodão pesado.

CANGa: pano grosso com faces com a qual puxam os bois para levar o carro, com os pescoços presos em tarrafas. Pano com que os homens de ganhar levam nos ombros as cargas.

Cangalhos: panos de carga de bois.

CANequiM: pano da Índia. Ex: gibão de canequim fico.

CANilha: canudos de cana delgada em que as tecedeiras enrolam o fio com que tecem e o metem num lançadeira.

CASHMERE: tecido estampado com medalhões de origem indiana. 
Casimira Termo genérico para alguns tipos de tecidos de lã, ou da mistura de lã e poliéster. O tecido geralmente usa ligamento em sarja, possuindo trama fechada e é utilizado para a confecção de ternos, saias ou tailleurs.

CASSA: Tecido fino e transparente, muito parecido com a musselina, muitas vezes usado como sinônimo da musselina.

Cassineta: tecido de lã, fino e leve, geralmente usado em roupas de baixo.

CASTOR: tecido fino e de felpa lisa, como a lã ou a pele do castor, segundo o dicionário de Raphael Buteau. Pode vir associado à palavra droguete, como "droguete castor".

CETIM: tecido liso, macio e brilhante, parecido, mas mais barato, que a seda. $\mathrm{O}$ efeito escorregadio é obtido por meio do desligamento dos fios de trama no direito do tecido.

Chamalote: tecido com efeito de ondas obtidas por meio de calandragem. Neste tecido, a posição do fio produz o efeito ondeado. Originalmente, o chamalote, era feito com lã de pêlo de camelo. Hoje é sintético. Tem outros nomes, como moiré.

\section{Chenille}

Tecido de algodão felpudo, geralmente usado para recobrir sofás ou em colchas e roupões.

\section{Cheviot}

Tecido de lã originário de carneiros da raça de mesmo nome, da Escócia. Estende-se esse nome a outros tecidos de lã com aspecto e toque semelhantes.

\section{Chevron}

Tecido de ligamento espinha de peixe, de origem francesa, que imita o desenho do chevron (divisas militares), muito usado em confecções masculinas.

Chiffon: origina-se na palavra francesa que significa trapo. Trata-se de tecido muito fino e transparente de seda ou de fibras químicas (normalmente poliéster ou poliamida), com fios com grande torção e resistentes. É um tecido aberto, o que lhe 
dá transparência. Utilizam-se fios retorcidos, usualmente dispostos de forma alternada, um fio com torção no sentido $\mathrm{S}$ e outro em sentido $\mathrm{Z}$, tanto no urdume quanto na trama.

Chita: tecido de algodão com desenhos de grandes flores coloridas. O tecido surgiu na Índia e, há tempos, já servia de toalha de mesa em casas de pau-a-pique brasileiras.

CHINT: feito de algodão, muito leve, possui um acabamento firme e brilhante. Muito utilizado em decoração de ambientes.

\section{D}

DAMASCO: tipo de tecido, normalmente com ligamento de cetim ou seda, encorpado, de uma só cor, com fundo fosco e desenhos acetinados, que era usado em trajes de aparato e, atualmente, em estofos de luxo.

DEVORÊ: tecido que apresenta desenhos com efeitos de transparência, produzido a partir de um tecido com fio celulósico binado com um fio de fibras sintéticas, estampado com produto corrosivo que destrói a fibra celulósica.

DAMASQuilho: tecido que imita o damasco.

DELAVÊ: palavra de origem francesa para referir-se ao aspecto desbotado do tecido após lavagens especiais.

DENIM: tecido resistente de algodão em ligamento-sarja. Os denins mais pesados são aplicados na confecção de jeans, enquanto os mais leves destinam-se à outras roupas, como jaquetas, camisas ou saias.

DENIM ÍNDIGo: denim tinto em azul-indigo.

DRAP: feito de lã, que pode ser misturada com seda, é utilizados para ternos, calças, casacos, etc. Semelhante à casimira.

DURAQUE: tecido forte e consistente, espécie de sarja forte, que se aplica especialmente em calçados. 
DROGUETE: tecido ordinário de lã, algodão e seda.

\section{$\mathbf{E}$}

ENDUIT: tecido revestido de material impermeabilizante ou outra substância química.

ENTRETELA: Tecido que se mete entre o forro e a fazenda de uma peça de vestuário, para lhe dar consistência, ou uma boa queda, ou para torná-la armada. Sua aparência é de um morim bastante engomado.

ÉTAMINE: tecido fino e telado, geralmente de algodão, usado em bordados de fios contados, como o ponto cruz.

ESTOPA: parte mais grosseira do linho, com a qual se fabrica o tecido de mesmo nome.

ESCOT: tecido em sarja de algodão com fios singelos, acabamento moleskine brilhante, em geral feito de cor preta, usado antigamente para o luto.

ÉPONGE: tecido leve, solto e macio, feito com fios desiguais.

\section{$\mathbf{F}$}

FAILLE: tecido fino e macio, levemente brilhante, ligamento tafetá, urdume seda, acetato ou poliéster, trama schappe, algodão, lã, sempre mais grossa, para produzir um efeito canelado.

FAILlETTE : tecido feito de fios cardados, ligamento tela, podendo variar em aspecto do brilhante ao opaco. Pelo seu caimento e aspecto é usado como forro de peças na confecção, substituindo o cetim.

FELPA: fibra ou pelo saliente que sai dos fios do tecido, dando aspecto de desfiado. 
FELTRO: material não tecido, feito de lã, pelo de animal ou fibras químicas obtido pela ação conjunta de processos mecânicos, químicos, pressão, umidade e calor.

Feltrado: tecido cuja superfície tem aspecto de feltro.

Flanela: tecido 100\% lã cardada, peso leve a médio, com textura aberta, toque macio, desenho tafetá, com lado "flanelado", aspecto liso ou xadrez, antigamente muito utilizado como roupa íntima masculina e feminina.

FIBRAS ARTIFICIAIS: as fibras artificiais pertencem ao grupo das fibras químicas, mas diferem das sintéticas por serem extraídas de uma matéria prima natural, a celulose. Os tecidos obtidos a partir dessas fibras costumam ser absorventes e confortáveis. O rayon ou viscose e o acetato são dois bons exemplos de fibras artificiais.

FibRAS NATURAIS: as fibras naturais podem ser de origem animal, vegetal e mineral. A seda e a lã são de origem animal, enquanto o algodão, o linho e a juta e outros elementos são de origem vegetal. O amianto é a única fibra mineral com valor comercial, mas seu uso foi condenado por seu potencial cancerígeno.

FibRAS SINTÉTICAS: as fibras sintéticas pertencem ao grupo das fibras químicas, possuem grande diversificação, sendo o acrílico, o náilon (poliamida) e o poliéster as mais conhecidas. A fabricação das fibras sintéticas não são parte de nenhum elemento natural e suas características são leveza, fácil lavagem e tingimento, rápida secagem e boa resistência, tornando-as extremamente atraentes para a produção de alguns tecidos para a indústria.

FIL-À-FIL: tecido de lã, ou algodão, em fios de duas cores alternadas, geralmente uma clara e outra escura.

FILó: tecido transparente, semelhante ao tule, porém mais largo (3,20 m de largura) e mais encorpado, de algodão ou náilon, podendo ser engomado ou não, tramado em forma de rede de furos redondos ou hexagonais, e usado sobretudo para véus, cortinados, vestidos de noite, mosquiteiros, enfeites, etc.

Fio PENTEAdo: é o fio que ficou livre das impurezas naturais remanescentes de outros processos mais básicos por intermédio da limpeza executada pelo equipamento 
denominado penteadeira. A malha confeccionada a partir desse fio é mais resistente, de maior qualidade e praticamente não apresenta a formação de bolinhas. O processo de limpeza da penteadeira aumenta a perda de fibras de algodão, encarecendo o produto final.

Froissé: palavra de origem francesa denominando tecidos de aspecto amassado conferido por um determinado tipo de acabamento.

FUSTÃo: tecido de algodão fino e opaco com listras, riscas ou figuras extravagantes. De fácil tingimento. Acredita-se que os primeiro fustões são indianos e o mesmo passou a ser largamente fabricado na Inglaterra no final do século XVIII, em especial em Lancashire. Primeiro, era usado especialmente para lençóis e cortinas, depois, já no século XIX, passou a ser utilizado como forro para roupas.

\section{G}

GabARDINA: tecido de lã ou de algodão caracterizado pela presença de uma raia diagonal pronunciada. Bem estruturado, em ligamento sarja, é adequado para sobretudos e paletós. Atualmente é produzido com diversos tipos de matéria-prima. O nome gabardina se estende a casaco impermeável, usado como proteção contra fenômenos atmosféricos, confeccionado com esse tecido.

Galatea: tipo de sarja muito resistente, com efeito de superfície em diagonal, usado para roupas femininas e infantis. O tecido foi assim denominado em homenagem ao navio de guerra britânico Galatea.

GAZE: tecido fino e transparente no qual cada fio de trama é circundado por dois fios de urdume, enrolados em torno de si mesmos. Pode ser de seda, algodão, lã ou fibras químicas. A gaze de algodão é geralmente aplicada em uso cirúrgico.

GEORGETTE: tecido de difícil produção, feito basicamente por fios de crepe, o que lhe dá uma superfície acidentada ao toque e que tende a encolher. 
GORGURÃo: tecidos com nervuras na trama, mais acentuadas que as da popelina. O urdume é feito com filamentos de alta densidade, e a trama é um fio cardado. Os filamentos predominam na superfície e no avesso.

GORGURINHO: tecido semelhante ao gorgurão, porém mais leve. Também muito utilizado em decoração, confecção de toalhas de mesa e guardanapos.

GUIPIRE: tipo de renda fina e transparente feita à mão.

\section{$\mathbf{H}$}

HelanCa (Marca Registrada): tecido elástico feito de poliamida texturizada por falsa torção. A helanca, geralmente, tem elasticidade no sentido lateral. Muito usado nas décadas de 1960 e 1970 em roupas esportivas.

HEMP: tecido obtido a partir das fibras da cannabis sativa, a planta da maconha. $\mathrm{O}$ tecido tem aparência de linho, transpira bem e é resistente. Também é conhecido como um tipo de cânhamo.

HIPPIE: tela fina e transparente.

HOPSACK: tecido áspero, de construção frouxa, formado por estrutura panamá. As fibras usadas são variadas, mas originalmente o tecido era fabricado com juta.

\section{I}

ÍNDIGO: corante azul, originalmente obtido de uma planta chamada Indigus a qual continha em sua raiz um corante de coloração natural azul. Hoje, o índigo é preparado por processo sintético, sendo muito utilizado no tingimento de jeans.

INTERPOLA: malha fina especial usada em roupas íntimas, cuja marca mais antiga foi Petit-Besaux (Paris). 
IIRISADA: tecido que apresenta efeito furta-cor sob a incidência de luz, com aspecto semelhante ao arco-íris.

\section{$\mathbf{J}$}

JACQUARD: Joseph Marie Jacquard criou o mecanismo versátil que produz desenhos intricados em tecidos de tear e malha. Atualmente, utilizam-se técnicas que permitem obter motivos muito grandes, além dos tradicionais padrões miúdos. Os novos jacquards em seda, muitas vezes misturados com fios laminados, assemelham-se aos damascos.

JAVANESA: nome comercial de um tecido em ligamento tela com fio de filamento de viscose fiado na trama.

JEANS: sarja com aspecto de algodão fabricada com fios tintos no urdume e fios brancos na trama.

JÉRSEI: tecido de malha circular ou retilínea muito maleável e escorregadio, confeccionado em lã, seda algodão ou fio sintético. Foi originalmente usado na confecção de suéteres dos marinheiros.

JUTA: tipo de fibra natural vegetal extraída da haste da planta. Áspera, barata e abundante, é muito usada para fazer estopa. Chama-se juta também o tecido fabricado com esta fibra, que é usada para revestimento, base para tapete e confecções de aspecto rústico.

$\mathbf{K}$

KALMOUKS: tecido pesado de lã dupla face, usado normalmente para confeccionar cobertores.

KASHa OU CACHA: pano cru, grosseiro, de algodão. 
$\mathbf{L}$

LAISE/LESE: tecido leve de algodão em que pequenos orifícios e pequenos bordados, em forma de flores, galhos etc., são alternados. Foi sempre usado na confecção de roupas femininas, anáguas, camisolas e robes de chambre.

LAMÊ: tecido brilhante, fabricado a partir de seda ou fios sintéticos, usado na confeccção de roupas e forração de acessórios. O lamê pode ser tramado com fios metálicos. Também é usado para fantasias de Carnaval.

LAMINADO: colagem de dois tecidos diferentes com substâncias químicas ou calor.

LÁSTEX: fios de borracha recobertos por outros fios como os de algodão, seda ou rayon. É utilizado na fabricação de peças íntimas femininas, maiôs, cintas e também para dar um efeito franzido e elástico em blusas e partes superiores de saias e vestidos.

LÁTEX: substância líquida obtida a partir da escarificação da seringueira, podendo ser usada em peças de roupas a partir de processos industriais. O latéx é usado em roupas do universo fetichista e em trajes experimentais.

Lã: fibra natural de origem animal, obtida do pelo das ovelhas domésticas e camelos.

LIGANETE: malha de jérsei fria e bem fina.

LINHO: tecido fabricado a partir da fibra extraída da planta da família das lináceas, cultivada há alguns milhares de anos. Usado pelos homens há séculos, possui uma grande variedade de espessuras, apresenta brilho e é muito usado na confeccção de acessórios.

LONITA: tecido consistente de algodão liso, listrado ou xadrez, muito bom na confecção de jaquetas e jogos americanos.

LODEN: tecido resistente semelhante ao feltro.

LONGLOTH: o mesmo que morim. 
LONA: tecido de algodão muito pesado e resistente usado para bolsas, barracas, estofados, encerados e capas diversas.

LYCRA (Marca Registrada): fibra sintética também chamada de elastano. Pode ser esticada de quatro a sete vezes o seu tamanho. Resistente ao sol e água salgada, ela mantém sua característica de comprimento ao passar do tempo.

LUREX: fio de alumínio recoberto de plástico, de aspecto metálico e brilho permanente, em diversas cores.

M

MALiNA: renda muito fina e trabalhada feita na Bélgica.

MADAPOLÃo: tecido de algodão branco entre a chita e o percal.

MADRAS: tecido de seda e algodão quadriculado fabricado, originalmente, na cidade de Madras, na Índia. Este tipo de padrão com infinitas combinações de cores tem sido usado incansavelmente.

MalHA: tecido flexível obtido a partir do entrelaçamento de anéis, laçadas e nós produzidos a partir de um fio têxtil. A malha pode ser tecida manualmente ou à maquina e tem sido uma das matérias primas mais utilizadas na confecção de peças do vestuário masculino, feminino e infantil.

Malha Fria: tecido fabricado a partir dos fios sintéticos, com bom caimento e que passa a sensação de frescor ao ser usado.

MALHA PIQUÊ: tipo de malha usada principalmente na confecção de camisas pólo.

MATELASSÊ: tecido jacquard ou maquinetado, acolchoado, muito usado nas colchas e edredons.

METIN: tecido usado em forros de vestuário no século XIX. 
Microfibra: qualquer fibra sintética mais fina do que a seda. Os tecidos feitos com essa fibra possuem características de leveza e durabilidade. As microfibras podem ser de poliéster, poliamida, acrílico ou viscose.

MODAL: tipo de microfibra produzida a partir de fibras artificiais, conferindo maciez, conforto e alto poder de absorção do suor às malhas utilizadas na confecção de cuecas, calcinhas, blusas e outros artigos do vestuário.

MoIRÉ: diz-se do tecido chamalote ou chamalotado que exibe reflexos e efeitos ondulados em sua superfície a partir de um processo mecânico aplicado geralmente sobre o tafetá. O chamalote é muito usado em roupas de noite e como revestimento de bolsas e sapatos.

MORIM: tecido de algodão inicialmente produzido na Índia e utilizado como forro de roupas e na confecção de roupas de cama e mesa. É algodão cardado de constituição leve, geralmente branco, hoje usado para a confecção de camisetas, camisas e roupas íntimas. Também pode ser chamado de Longloth.

MoLETOM: tipo de malha aflanelada, de lã, algodão ou poliéster misto, feita com entrelaçamentos flutuantes. Usado em peças esportivas, infantis e até mesmo para estofamentos.

MuSSELINA: tecido fino, liso e transparente. O nome é derivado da cidade de Mossul, no Iraque, grande exportadora de musselina. Nas versões de seda, poliéster, algodão e lã, o tecido é aplicado na confecção de camisas, blusas, camisolas, vestidos e em sobreposições.

\section{$\mathbf{N}$}

NÁILON: denominação de diversos materiais sintéticos de poliamida usados na fabricação de fibras, filamentos, cerdas, tecidos e plásticos. 
NAPA: espécie de pelica muito fina e macia empregada na fabricação de bolsas, luvas e acessórios. A napa é feita a partir do couro do carneiro e pode ser encontrada em diversas cores.

\section{$\mathbf{O}$}

ORGANDI: tecido leve e transparente de algodão engomado por processo químico. Semelhante à musselina, só que com acabamento engomado (toque encorpado).

OrganZA: fina e transparente, em geral de fio poliamida, é mais encorpada que o organdi.

OXFORD: tecido originário de Oxford, Inglaterra, feito de algodão, com desenho tafetá, e variações de poliéster.

\section{$\mathbf{P}$}

Patchwork:: tecido de qualquer matéria-prima, composto de vários pedaços de tecidos costurados juntos.

PERCAL: tecido hoje usado em roupas de cama, extremamente macio, feito com fio penteado.

PLuSH: Tecido também conhecido como veludo gratê. Criado sobre malha, que recebe acabamento aflanelado e tem os fios retirados da superfície do tecido. Pode ser chamado de veludo molhado.

PoliéSTER: fibra sintética, também conhecida como tergal. Sua característica é de pouca absorção de umidade.

PoPELINE: feito com um fio de algodão de menor qualidade que o algodão penteado.

Pelúcia: Tecido de veludo felpudo, liso ou estampado, cujo agrupamento de fios lembra o pelo dos animais. 
PiEd-DE-POUle: Padronagem clássica cujo desenho reproduz um pequeno pé de galinha. A versão maior da padronagem é conhecida como peid-de-coq.

\section{$\mathbf{R}$}

RATINA: tecido felpudo de lã. Em francês, ratine.

RISCA DE GIZ: clássico da alfaitaria, esse tecido traz riscas finas, verticais e paralelas, com distâncias regulares, podendo ir no máximo a dois centímetros. Geralmente as riscas são claras sobre um fundo escuro.

RÁFIA: fibra das folhas de um tipo de palmeira de Madagascar, muito usada na fabricação de bolsas e chapéus. Uma de suas versões sintéticas, conhecida por ráfia de sopro, é comercializada em tiras levíssimas e coloridas, sendo muito usadas em trabalhos de crochê.

RAYON: fibra artificial originada a partir da celulose, criada quando pesquisadores tentavam encontrar um substituto para a seda natural. Possui alta absorção de líquidos, facilidade no tingimento, toque e aparência sedosos e um bom caimento nas roupas. $\mathrm{O}$ rayon é utilizado na fabricação de lingerie, forros, gravatas e roupas masculinas e femininas.

RENDA: tecido delicado, confeccionado à mão ou à maquina, constituído por uma trama aberta onde os fios se entrelaçam, criando desenhos. Renda valenciana (muito usada para enfeitar roupinhas de bebê mais tradicionais e camisolas de batismo infantis), renda de bilro, renda labirinto e muitas outras.

\section{$\mathbf{S}$}

SEEERSUCKER: tecido de algodão enrugado em listras. É fácil de lavar e não necessita ser passado. 
SEDA NATURAL: fibra que compõe o casulo que cobre o bicho-da-seda, valiosa por sua utilização em tecidos de alta qualidade. A seda é uma das mais antigas fibras têxteis conhecidas.

SEDA ARTIFICIAL: feita com os fios acetato e viscose.

SARJA: tecido trançado de fio penteado, originariamente feito de seda ou lã. No século XIX, a sarja era utilizada para confeccionar fardas militares e, mais para o final do século, era feita em vários pesos, para vestidos, roupas de banho, e roupas externas. Está muito presente em calças e ternos.

SUEDE: couro acamurçado usado na fabricação de luvas, bolsas, sapatos e cintos.

TAFETÁ: tecido brilhante e nobre fabricado em fios de seda. É aplicado na confecção de roupas mais finas e no revestimento de acessórios femininos.

TARTÃ / TARTAN: Tipo de tecido com trama fechada, cujos padrões diferentes de xadrez eram usados na identificação dos diversos clãs da Escócia.

TENCEL: fibra artificial obtida a partir da celulose, usada em peças de roupas masculinas, femininas e infantis, tendo como algumas de suas características a maciez, o conforto, a resistência e o bom caimento.

TALAGARÇA: tecido de algodão grosso, que apresenta um aspecto furado, próprio para a execução de bordados.

TARTAlana: tecido fino usado em fantasias de carnaval, que lembra o filó. A palavra se popularizou no começo do século XX por causa do conto "O bebê de tarlatana rosa" de João do Rio. Tecido encorpado, de algodão ou de linho, de trama pouco densa, usado, sobretudo, para armar peças de vestuário

TRESSÊ: tipo de efeito ou textura composto pelo entrelaçamento de tiras de couro ou tecido. Bastante usado em bolsas e calçados. 
TRICOLINE: tecido leve de algodão feito com fio penteado, macio e resistente.

TULE: Originariamente feito de gaze ou seda, o tule é um tecido fino de malha hexagonal, utilizado em adornos de vestidos, chapelaria, roupas de bailarinas e vestidos de noiva.

TUSSOR: tecido leve feito com uma variação do fio de seda natural. A lagarta que produz esta seda come somente a folha do carvalho. $\mathrm{O}$ tussor é grosso e brilhante e.

TwEED: acredita-se que a palavra tweed seja uma leitura errônea de tweel, que em escocês significa sarja. O tweed possui uma textura áspera, por ser feito de lã. Muito usado em casacos e ternos.

TwILL: espécie de sarja caracterizada por linhas em diagonal.

TwILl DE SEDA: tecido originário do Japão e da China, utilizado como base para a impressão de estampas nos lenços de seda e gravatas.

$\mathbf{U}$

URDUME: conjunto de fios dispostos no sentido longitudinal do tear pelos quais passam os fios da trama.

\section{$\mathbf{V}$}

VERNIZ: material brilhante e impermeável, usado na fabricação de sapatos, bolsas e cintos. Nos anos 1960, ficou bastante conhecido e ganhou cores vibrantes.

Viscose: fibra química de celulose derivada da polpa de madeira. Tecido com toque macio, sedoso e frio, de caimento pesado. Puro ou com misturas de poliéster, pode ser usado na produção de camisas, vestidos e peças de alfaiataria.

VOAL: tecido leve, transparente feito com algodão de fibra longa. 
XADREZ ESCOCÊS: padrão composto por listras e barras de mesmas cores e tamanhos que, misturados, proporcionam o efeito xadrez com tonalidades diferentes. $\mathrm{O}$ mesmo que tartan.

XANTUNGUE: seda tecida à mão originariamente produzida na província de Shantung, na China. $\mathrm{O}$ xantungue é fino e macio, tecido com fios irregulares, para produzir uma superfície desigual. O xantungue do século XX é geralmente feito de seda misturada a algodão ou rayon, criando um tecido mais pesado que o original, o qual hoje em dia é pouco encontrado.

$\mathbf{Z}$

ZIBELINE: tipo de pele usada em casacos. 